UNIVERSIDADE DE SÃO PAULO

PROGRAMA DE PÓS-GRADUAÇÃO INTERUNIDADES EM MUSEOLOGIA MAE/MAC/MP/MZ-USP

ALICE BEMVENUTI

Gestão de museu: comunicação e público - estudo sobre o Museu do Trem, São Leopoldo, RS (2009-2012). 
ALICE BEMVENUTI

Gestão de museu: comunicação e público - estudo sobre o Museu do Trem, São Leopoldo, RS (2009-2012). 


\section{ALICE BEMVENUTI}

Gestão de museu: comunicação e público - estudo sobre o Museu do Trem, São Leopoldo, RS (2009-2012).

Dissertação apresentada ao Programa de Pós-graduação Interunidades em Museologia da Universidade de São Paulo para obtenção do título de Mestre em Museologia.

Área de Concentração: Museologia

Orientadora: Profa. Dra. Marília Xavier Cury

Linha de Pesquisa: Teoria e Método da gestão patrimonial e dos processos museológicos

Versão original $\left(^{*}\right)$

$\left(^{*}\right)$ A versão original encontra-se disponível no MAE/USP

Versão revisada.

São Paulo 
Nome: BEMVENUTI, Alice

Título: Gestão de museu: comunicação e público - estudo sobre o Museu do Trem, São Leopoldo, RS (2009-2012).

Dissertação apresentada ao Programa de PósGraduação Interunidades em Museologia da Universidade de São Paulo para obtenção do título de Mestre em Museologia

Aprovado em 28 de setembro de 2016.

\section{Banca examinadora}

Profa. Dra. Marília Xavier Cury (orientadora)

Julgamento Assinatura

Profa. Dra. Clarissa Maria Rosa Gagliardi (USP).

Julgamento Assinatura

Dra. Renata Vieira da Motta (Secretaria da Cultura do Estado de São Paulo). Julgamento Assinatura

\section{Suplentes}

Profa. Dra. Maria Cristina Oliveira Bruno (USP).

Julgamento Assinatura

Dra. Cristina Meneguello (Unicamp).

Julgamento Assinatura 
Autorizo a reprodução e divulgação integral ou parcial deste trabalho, por qualquer meio convencional ou eletrônico, para fins de estudo e pesquisa, desde que citada a fonte.

CATALOGAÇÃO NA PUBLICAÇÃO (CIP)

Serviço de Biblioteca e Documentação do

Museu de Arqueologia e Etnologia da Universidade de São Paulo

B455 Bemvenuti, Alice.

Gestão de museu : comunicação e público : estudo sobre o Museu do Trem, São Leopoldo, RS (2009-2012) / Alice

Bemvenuti ; orientadora Marília Xavier Cury. -- São Paulo, 2016.

[286] f. : il. color.

Dissertação (Mestrado) - Universidade de São Paulo, Museu de Arqueologia e Etnologia, Programa de PósGraduação Interunidades em Museologia, 2016.

1. Museu ferroviário. 2. Patrimônio industrial ferroviário. 3. Gestão em museu. 4. Comunicação museológica. 5. Público. I. Cury, Marília Xavier. II. Universidade de São Paulo. Museu de Arqueologia e Etnologia. Programa de Pós-Graduação Interunidades em Museologia. III. Título. 
Para

Aimê

Abel, Anaê e Pablo

Aparecida e Vicente

Heron

Por quem sou, todos os dias.

Pela conivência intensa e perspicaz.

Pela oportunidade de amar e aprender com o amor. 


\section{AGRADECIMENTOS}

São muitos e importantes, pois foram eles fundamentais para que eu realizasse a sonhada pesquisa.

Agradeço à Universidade de São Paulo e ao Programa de Pós-Graduação Interunidades em Museologia.

À minha orientadora Profa. Dra. Marília Xavier Cury, por tantas coisas, por acreditar no meu projeto ainda semente, pelos desafios constantes, pela acolhida em São Paulo e na USP, pela amizade, dedicação, disponibilidade e orientação sempre próxima, mesmo na longa distância, para comigo.

À banca de qualificação e de defesa, pela leitura atenta, observações e contribuições fundamentais: Dra. Renata V. da Motta, Dra. Cristina Meneguello e Dra. Clarissa Rosa Gagliard.

Aos professores da Universidade, Maria Cristina Oliveira Bruno, Paulo César Garcez Marins, Martha Marandino e Bóris Kosoy.

À Biblioteca do MAE, da FAU, da ECA e aos incansáveis: Alberto Bezerra, Ana L. Facini, Eleuza Gouveia, Gilberto Paiva, Hélio R. de Miranda, Washington Marques Jr e Lucila B. Assis.

Ao Serviço do PPG - Karen Ribeiro, Aline, Cleberson Moura e Regina Leopoldo e Silva.

Aos amigos que me auxiliaram com a distância geográfica dos mundos: Viviane Wermelinger Guimarães, Mirian Yagui, Thiago Padovan, Márcia Lourenço, Isabel Corrêa e Reinaldo Meyer.

Ao SEMRS e a Simone Flores Monteiro, por tantas coisas, mas também pela oportunidade de conhecer Maria Célia Santos, Magaly Cabral, Marília Xavier Cury, Noris Leal e Mário Chagas.

A Vicente João Brígido, pela inspiração na Gestão de Qualidade e pelas estatísticas.

Aos estagiários do Educativo e funcionários do Museu do Trem e da SMC de São Leopoldo, e Ary José Vanazzi, Pedro Vasconcellos, Vitor Ortiz, Daniel Martins e Rogério Tosca, que de algum modo foram revisitados nesta pesquisa e, em especial, à minha amiga e parceira na gestão do Museu: Cláudia Koch-Jonhstone, sem os quais a experiência e organização dos dados não teria sido possível.

A Germano Oscar Moehlecke, Márcio Link e Eloisa Capovilla da Luz Ramos, pelo auxilio na pesquisa histórica.

Aos ferroviários: João E. Callegari, Jair Moraes, Dorildes Begnini, Marioni Auler, Manoel Monachesi, Vitor Ferreira (in memoriam), ao SINDIFRGS, Daniel Lena Souto, Roberto A. 
Guedes da Luz; e, em especial, ao incansável Hélio Bueno da Silveira e sua esposa Margarida Margarete.

Pelas contribuições históricas, a Sergio Santos Morais, Telma Lasmar e Ivan Coelho de Sá.

Aos Museus do Trem: Engenho de Dentro, através Bartolomeu Homem d'El-Rei Pinto; do Recife, através de Adriane Alves, e da Cia Paulista de Jundiaí, através de Letícia Borges Schonmaker.

Aos chefes Antônio Luís Tubino Sobral (ULBRA) e Flávio Brecher Muller (EMEB Dr. Liberato S. V. da Cunha), pela compreensão e apoio tão necessários na dupla tarefa de trabalhar e pesquisar; e as Vice-diretoras Márcia, Simone, Mara e Heloisa pela importante acolhida;

À querida Rosella Bruxel de Quadros, pelo reencontro e convivência, troca de figurinhas, ensinamentos, debates qualificados e, principalmente, pela renovação da amizade.

Aos colegas da EMEB Liberato, pela acolhida sempre, em especial aqueles que garantiram a luta e mantem acreditando em um mundo melhor para todos.

À Jeane Piovan, pela revisão e a Mirian Engel Gehrke, pela revisão e formatação.

Ao Sérgio, Adriana e Valter, pela impressão desta pesquisa e demais reproduções.

Às novas amizades que o Programa me proporcionou: Mirela Leite de Araújo, Luiz Mizukami, Maria Paula Pestana Barbosa, Flavia Gama, Janaína Xavier, Karina Alves, Bia Cavalcanti e Adriana de Oliveira.

Às amigas Magali Giordani, Luciene Jardim e Luciana Jacques pela cumplicidade da vida. Aos amigos dinossauros Alberto Coelho e Donald (Goy), Andréa Rodrigues, Nando Clarindo e José, Isabel Marques e Fabio Brasil, e Nei Vargas pela cumplicidade sempre; sem esquecer jamais Mirian Celeste Martins, Paulo Porcella, Marcos Villela, Suzana Vieira da Cunha, Cleusa Peralta, Ivone Richter, Ana Mae Barbosa, Ana Del Tabor e Lucimar Bello Frange que habitam memórias de onde vim e do que sou.

Aos meus médicos incansáveis e amigos: Dra. Alessandra Morelle, Dr. Rodrigo Cericatto, Dra. Fernanda Seelig, Dr. José Indio Alves e Dra.Christiane Ganzo.

À Ediane Borba, pelos cuidados, tão necessários e especiais.

A minha família que de longe ou de perto está sempre perto.

Meus pais e irmãos pela compreensão e suporte em todos os momentos.

Á minha filha Aimê, por renovar a vida em mim a cada dia. 
O Museu de que falo não é o lugar, o templo das musas que gerou a conceituação de museu-depósito de coisas.

O Museu de que falo pensa no sentido das coisas

do mundo e na vida e (re)elabora constantemente a sua missão poética.

Marília Xavier Cury 


\section{RESUMO}

BEMVENUTI, Alice. Gestão de museu: comunicação e público - estudo sobre o Museu do Trem, São Leopoldo, RS (2009-2012). 2016. 286 fl. Dissertação (Mestrado) - Programa de Pós-Graduação Interunidades em Museologia MAE/MAC/MP/MZ, Universidade de São Paulo, São Paulo, 2016.

A pesquisa apresenta estudo de gestão de museu com ênfase na subárea da comunicação e público, a luz de teóricos do campo da museologia, da administração e da educação, com estudo de caso do Museu do Trem de São Leopoldo, entre 2009 a 2012. Apresentando um panorama geral dos museus ferroviários no Brasil, com um relato histórico das iniciativas de criação destes museus, com dados da atuação do PRESERVE/PRESERFE remontados através de entrevistas, além da discussão em torno dos mecanismos de proteção do patrimônio industrial ferroviário. Neste contexto também são mapeadas as instituições museais ferroviárias no Rio Grande do Sul, apresentando a trajetória histórica e cronológica do Museu do Trem de São Leopoldo, desde a criação na década de 1970, o restauro da antiga Estação, as dificuldades com a extinção da RFFSA, as subsequentes reinaugurações até o ano de 2012. A investigação passa por análise quantitativa e qualitativa de aspectos da realidade empírica, encerrando com a reflexão sobre as contribuições desta experiência para a prática da gestão em museus, comunicação e público.

Palavras-chave: Museu ferroviário. Patrimônio industrial ferroviário. Gestão em museu. Comunicação museológica. Público. 


\begin{abstract}
BEMVENUTI, Alice. 2016. Museum management: communication and public - study on the Train Museum, São Leopoldo, RS (2009-2012) $286 \mathrm{fl}$. Dissertação (Mestrado) Programa de Pós-Graduação Interunidades em Museologia MAE/MAC/MP/MZ, Universidade de São Paulo, São Paulo, 2016.

The research presents museum management studies with an emphasis on communication and the public subarea, considering theoreticians in the museology, administration and education fields, with the case study of São Leopoldo's Train Museum from 2009 to 2012. Presenting an overview of the railway museums in Brazil, with a historical account of the creation of such museums, with data from the performance of the PRESERVE/PRESERFE reassembled through interviews, in addition to the discussion of the protection mechanisms of the railway industrial heritage. In this context, the railway museum institutions are also mapped in Rio Grande do Sul, presenting the historical and chronological trajectory of the São Leopoldo's Train Museum, since the creation in the 1970s, restoration of the old station, the difficulties with the extinction of RFFSA, the subsequent reopening until the year 2012. The research involves quantitative and qualitative analysis of aspects of empirical reality, ending with a reflection on the contribution of this experience to the practice of management in museums, communication and public.
\end{abstract}

Keywords: Railway Museum. Railway Industrial Heritage. Museum Management. Museological Communication. Public. 


\section{LISTA DE FIGURAS}

Figura 1 - Estação Ferroviária de São Leopoldo (vista da plataforma). Ano (atribuído): 1874.

Figura 2 - Livro de Registro da abertura do Museu Ferroviário da VFRGS/ RFFSA.......64

Figura 3 - Ficha de funcionária da Nilza Damasceno de Castro.

Figuras 4 e 5 - capa do catálogo do CPHFRS e capa do catálogo do Museu do Trem de Recife.

Figuras 6 e 7 - Capa do catálogo do CPHFRJ e capa do catálogo do Museu Ferroviário de SJDR

Figura 8 - Prédio principal da Estação Ferroviária de São Leopoldo antes da reconstrução. Ano: 1982.

Figura 9 - Prédio do Museu do Trem reinaugurado após a reconstrução. Relatório PRESERVE em álbum fotográfico. Ano: 1985.

Figuras 10 e 11 - Manutenção no interior da rotunda, em 1970. Rotunda abandonada em 1971. .72

Figura 12 - Desenho da rotunda por Sérgio Santos Morais. 72

Figuras 13 e 14 - Rotunda antes do restauro. Ano: 1984. Fonte: Acervo NEOM-ABPF. 73

e Rotunda depois do restauro. Ano: 2008. 73

Figura 15 - Vista aérea do pátio ferroviário com a rotunda ao centro. Ano: $2013 \ldots \ldots \ldots . . .73$

Figuras 16 e 17 - Museu Ferroviário de Curitiba no interior do Shopping Estação. 80

Figuras 18 e 19 - Entrada do prédio e vista da Plataforma da Estação de São Leopoldo. Inauguração do Museu do Trem Data: 26.11.1976.

Figura 20 e 21 - Prédio antes da reconstrução - vista da entrada principal (esquerda) e vista da plataforma (direita). Ano: 1982.

Figuras 22 e 23 - Reconstrução do prédio da Antiga Estação. Relatório PRESERVE em álbum fotográfico. Ano: 1983.

Figuras 24 e 25 - Reconstrução dos arcos e vista geral do Sítio. Relatório PRESERVE em álbum fotográfico. Ano: 1983.

Figura 26 - Clarissa Oliveira de Carvalho mostra exposição a autoridades. Relatório PRESERVE em Álbum Fotográfico. Ano: 1985.

Figuras 27, 28 e 29 - Extintor de incêndio e Furador de Passagens (vista lateral e frente). 
Figuras 33, 34 e 35 - Máquina de escrever de carro grande. Máquina de escrever e Calculadora.

Figuras 36 e 37 - Miniatura Locomotiva (vista de lateral direita e esquerda) 98

Figuras 38, 39 e 40 - Mobiliário Carro Administrativo Bento Gonçalves (mesa, poltrona, vidro) e Mobiliário (mesa de desenho) e Expositor com painel de fotos.

Figuras 41, 42 e 43 - Passagens (Dilermando Aguiar a Santa Maria e Capão do Leão a

Pelotas) e expositor com diversas passagens.

Figuras 44 e 45 - Placas dos Escritórios Administrativos da VFRGS e Placa Informativa do Carro de Passageiro da VFRGS. 99

Figuras 46, 47 e 48 - Relógios de parede e Sino. 99

Figuras 49 e 50 - Telefone e telefone de parede dos escritórios da VFGRS 99

Figuras 51 e 52 - Teodolitos e peças do Telégrafo.

Figuras 53 e 54 - Locomotiva Baldwin, 1896 e Seção de Calderaria em Santa Maria, 1920 (reproduções dos Negativos de Vidro em exposição).

Figura 55 - Reprodução da página 40 Livro de Tombamento do Museu do Trem. Ano: 1985.

Figuras 56 e 57 - Interior do Armazém, equipe em atividades de documentação no Armazém. Período: 1985 ou 1987.

Figuras 58 e 59 - Acervo Documental acondicionado no Armazém. Ano: 2010. 101

Figuras 60 e 61 - Chegada dos carros de passageiro. Álbum Fotográfico - Relatório PRESERVE. Ano:1985.

Figuras 62 e 63 - Chegada da Locomotiva "Maria Fumaça" e do autinho de linha. Ano: 1985.

Figuras 64 e 65 - Locomotiva Baldwin no Sítio Histórico e vista da Plataforma da Estação, Prédio e Carro de Passageiro em exposição. Ano: 1985.

Figuras 66 e 67 - Chegada da segunda locomotiva, Diesel-elétrica, número 6009, e ferroviários alinhando trilhos para a descida da locomotiva. Data: 14.01.1987. Fotografia: Nilson Winter.

Figura 68 - Equipe do Museu do Trem com funcionário da RFFSA, na plataforma da Estação. Ano: 1985.

Figuras 69 e 70 - Exposição no interior do prédio da Estação e expositores acessíveis aos visitantes. Ano: entre 1985 e $1989 .$.

Figuras 71 e 72 - Exposição de longa duração (visão do centro) e funcionária na recepção. Ano atribuído: 1986-7.

Figuras 73 e 74 - Atendimento de escolas no Museu do Trem prela equipe da RFFSA.

Ano atribuído: 1987-8. 
Figura 75 - Reprodução da página 03 do Relatório do PRESERVE sobre os Centros e

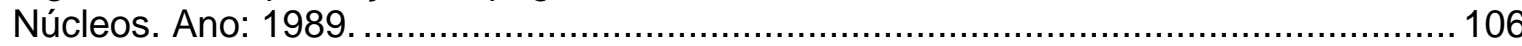

Figura 76 - Sitio Histórico Museu do Trem, delimitação do entorno pelo IPHAE. Ano: 2002.

Figuras 77 e 78 - Reinauguração do Museu do Trem, solenidade em 18 de maio de 1991

Figuras 79 e 80 - Restauro dos Vagões e Carros de Passageiros. Ano: 1996.

Figuras 81 e 82 - Restauro dos Vagões e Carros de Passageiros (parte superior). Ano: 1996.

Figuras 83 e 84 - Museu do Trem. Ano: 1985. Museu do Trem com Estação de São Leopoldo, da TRENSURB, ao fundo. s/data.

Figuras 85 e 86 - Museu do Trem, vista de cima do telhado, sem a Estação de São Leopoldo da TRENSURB. Ano: 1985. Foto à direita: Estação de São Leopoldo TRENSURB e Museu do Trem de São Leopoldo. Ano: 2009.

Figuras 87 e 88 - Atividades no Sítio Histórico em parceria. Ano atribuído: 2000-1.... 113

Figuras 89 e 90 - Atividade cultural com passeio ciclístico. Ano: 2000.

Figura 91 - Reportagem veiculada pelo Jornal Vale dos Sinos, São Leopoldo, capa.

Data:01.05.2009.

Figura 92 - Reportagem veiculada pelo Jornal Vale dos Sinos, São Leopoldo, contracapa. Data: 01.05.2009.

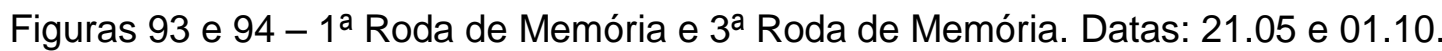
2009, respectivamente.

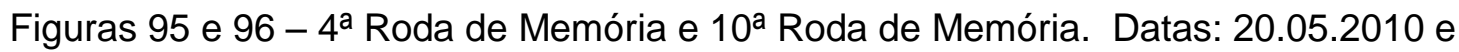
25.05. 2011, respectivamente.

Figuras 97 e 98 - 14를 Roda de Memória em duas atividades, com alunos e com equipe do Museu. Data: 24.05.2012.

Figura 99 - Modelo de um sistema de qualidade baseado em processo..................... 124

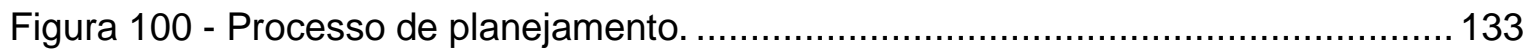

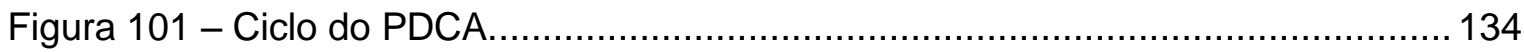

Figura 102 - Estrutura Organizacional Hierárquica. ................................................ 144

Figura 103 - Estrutura Organizacional Horizontal Simplificada. ................................ 145

Figura 104 - Organograma da Diretoria de Patrimônio. Ano: 2009. ............................ 147

Figura 105 - Organograma da Diretoria de Museus. Ano: 2011................................ 149

Figura 106 - Organograma do Museu do Trem. Ano: 2011..................................... 149 
Figura 107 - Organização dos núcleos para o Museu do Trem. Ano: 2012. 150

Figura 108 - imagem aérea (satélite) do Sitio Histórico Museu do Trem e da Estação São Leopoldo, da TRENSURB, com localização das edificações. Ano: 2006. 159

Figura 109 - Logomarca do Museu do Trem, criação de Augusto Bier, 2009. 173

Figura 110 - Crachás padronizados impressos em PVC, 2010. 174

Figuras 111 e 112 - Estagiária em atividade de conservação e funcionária em atividade administrativa com camiseta (uniforme). Ano: 2011.

Figuras 113, 114 e 115 - Equipe em atividades educativas diversas com uniforme de inverno (colete e casaco de moleton) e crachá. Ano: 2011.

Figuras 117 e 118 - Estagiária com público da educação infantil na Oficina de Patrimônio (avental colorido). Ano: 2011.

Figuras 119 e 120 - Selo comemorativo: desenho inicial de Augusto Bier e desenho com acabamento em software, 2011. 175

Figura 121 - Folder institucional do Museu do Trem, parte externa. Ano: 2009. .......... 176

Figura 122 - Folder institucional do Museu do Trem, parte interna. Ano: 2009. 177

Figuras 123, 124 e 125 - Cartazes de atividade cultural, Feira de Trocas, Brique e Encontro de Carros Antigos. Ano: 2012.

Figuras 126 e 127 - Banner da AAMT e Banner alusivo aos 35 anos do Museu. Ano:

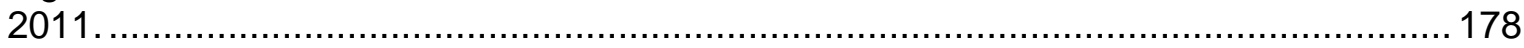

Figura 128 - Gasebo adesivado no jardim. Ano: 2012.

Figura 129 - Faixa Semana de Museu e Feira de Trocas, Brique e Encontro de Carros Antigos, frente do Museu. Ano: 2012.

Figura 130 - Faixa no centro da cidade, rua principal. Ano: 2012. 179

Figuras 131 e 132 - Vistas geral e em detalha de cartaz colado em vitrina exposta para rua, de Livraria parceira do Museu. Rua principal da cidade. Ano: 2012.

Figuras 133 e 134 - Cartaz colado em supermercado de bairro e em padaria no centro da cidade. Ano: 2012.

Figuras 135 e 136 - Cartaz colado em ambiente externo, porta da Escola de Música (localizado na mesma Rua no Museu) e em ambiente interno, parede em Setor Público, Secretaria de Meio Ambiente. Ano: 2012. 180

Figuras 137 e 138 - Cartaz colado em murais interno de instituições universitárias. Ano: 2012.

Figura 139 - Chama de capa, reportagem veiculada pelo Jornal Vale dos Sinos, São Leopoldo. Data: 19.05.2011.

Figura 140 - Reportagem 3ª́Semana de Museus de São Leopoldo, veiculada pelo Jornal Vale dos Sinos, São Leopoldo, página 06, Seção Comunidade. Data: 19.05.2011. ..... 182 
Figura 141 - Artigo publicado pelo Jornal Vale dos Sinos, São Leopoldo, página 09,

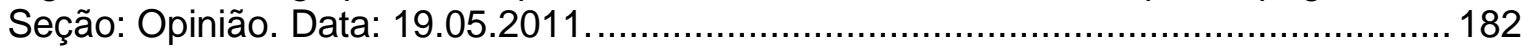

Figuras 142 - Reportagem on-line no site da TRENSURB.................................... 183

Figuras 143 - Reportagem on-line no site da TRENSURB..................................... 184

Figura 144 - Artigo on-line no blog Repensando Museus. ..................................... 184

Figura 145 - Guarita da Guarda Municipal na entrada do Museu, adesivada com

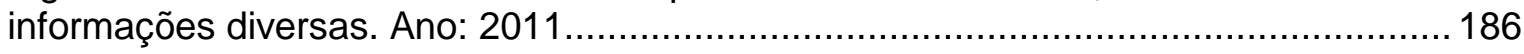

Figuras 146 e 147 - Placas informativas. Ano: 2012 .......................................... 188

Figuras 148 e 149 - Placas informativas. Ano: 2012 ......................................... 188

Figuras 150 e 151 - Material educativo produzido em parceria com a TRENSURB. Anos:

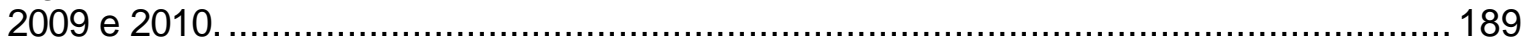

Fig. 152 - Material educativo: verso da capa e páginas 01, 02 e 03. Ano: 2009........... 189

Figura 153 - Material educativo: texto do Setor Educativo, "janela" em cartão preto e

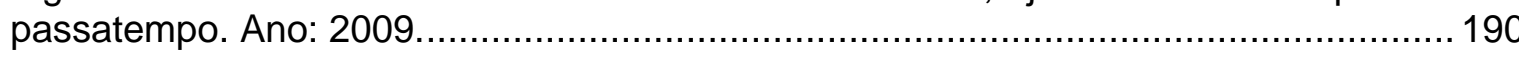

Figuras 154 e 155 - Espaço interno do prédio da Estação com suvenires e cubo impresso com logomarca. Ano: 2011.

Figura 156 - Placa de numeração das bancas da Feira e Trocas e Brique no Museu do Trem. Ano: 2012.

Figuras 157 e 158 - Banca da Associação Amigos do Museu do Trem na Feira de Trocas e Brique no Museu do Trem. Ano: 2012.

Figuras 159 e 160 - Exposição no interior do prédio da Estação, inauguração do CPHFRS. Ano: 1985.

Figuras 161 e 162 - Exposição no interior do prédio da Estação do Museu do Trem. Ano: 2007.

Figura 163 - Desenho do espaço interno do prédio da estação com marcações dos espaços ocupados na exposição. Ano: 2011.

Figuras 164 e 165 - Cubos com logomarca dos apoiadores e selo dos 35 anos do Museu do Trem. Ano: 2011.

Figuras 166 e 167 - Objeto lúdico: quebra-cabeça sobre o suporte em espaço interno e externo. Ano: 2011.

Figuras 168 e 169 - Pai e filho (esquerda) e menina (direita) brincando com quebracabeça. Data: jan.2011.

Figura 170 - Caderninho Sinaleira, capa, apresentação, e páginas 01 e 02. Ano: 2011-2.

Figuras 171 e 172 - Exposição Temporária com acervo do Museu do Trem no interior do Armazém. Ano: 2010. Fotografia: Rogério Tosca. 
Figuras 173 e 174 - Exposição do Instituto de Educação da UFRGS no interior do Armazém. Ano: 2009. Fotografia: Rogério Tosca.

Figuras 175 e 176 - Mostra História do Transporte Rodoviário de Carga do RS no interior do Armazém. Ano: 2012.

Figuras 177 e 178 - Museu de Portão, na Estação Ferroviária, vista frontal, e Exposição Itinerante do Museu do Trem no interior do prédio da Estação de Portão. Ano: 2009 a 2012.

Figura 179 - Exposição Itinerante do Museu do Trem nos Trilhos da Memória, no Memorial do 4으. TRT. Ano: 2009.

Figuras 180 e 181 - Mini locomotiva na Exposição Itinerante "Tempo", Museu C\&T PUC RS (Porto Alegre). Ano: 2010. 203

Fig. 182 e 183 - Participação do Museu do Trem na Feira na Empresa Gerdau (Esteio). Ano: 2010, e participação na Feira do Congresso de Educação (São Leopoldo). Data: 16.10.2010.

Figura 184 - Visita de escolares na exposição de longa duração. Ano: 2011. 208

Figuras 185, 186, 187 e 188 - Visita de escolares e recepção da equipe do Setor Educativo em atividade com uso de recursos pedagógicos. Ano: 2011.

Figuras 189 e 190 - Crianças em atividade na exposição com material confeccionado pelo Setor Educativo. Ano: 2011.

Figuras 191, 192, 193 e 194 - Crianças em atividade de exploração da exposição utilizando recursos pedagógico. Ano: 2011.

Figuras 195 e 196 - Atividade com crianças surdas e sindrômicas, da Escola Cruz Vermelha, de São Leopoldo. A esquerda no interior do Armazém, à direita, na plataforma. Ano: 2011.

Figuras 197, 198, 199 e 200 - Crianças da Escola Municipal Gusmão Maria Brito, de São Leopoldo, em atividade educativa com momentos de caminhada no pátio, conversa na antiga Estação e visitação no interior dos carros de passageiros. Data: 30 abr 2009. Fotógrafo: Thiago.

Figura 201 e 202 - Recepção de jovens com atividade e uso de material pedagógico. Data: 25.11.2011

Figuras 203 e 204 - Visita de escolares (esquerda) e recepção de Grupo de 3aㅗ Idade (direita). Ano: 2012.

Figuras 205 e 206 - Folder da 3a Semana de Museus de São Leopoldo (duas dobras). Parte externa e interna. Ano: 2011. 213

Observação: As figuras de apresentação dos capítulos pertencem ao acervo do Museu do Trem de São Leopoldo e arquivo digital da pesquisadora'.

\footnotetext{
${ }^{1}$ Estas figuras, assim como os anexos, devem ser impressas em folha A3 para manter completa a imagem.
} 


\section{LISTA DE QUADROS}

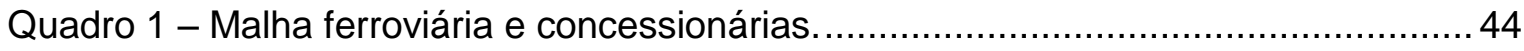

Quadro 2 - Estações ferroviárias tombadas no Rio Grande do Sul. .............................56

Quadro 3 - Centros de Preservação, Núcleos Históricos Ferroviário e Centro Ferroviário

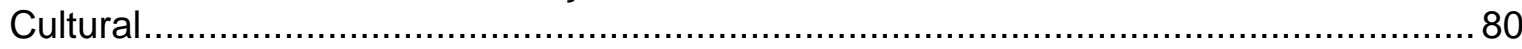

Quadro 4 - Relação dos museus ferroviário ou com patrimônio ferroviário .................... 82

Quadro 5 - Relação de museus com patrimônio ferroviário no Rio Grande do Sul. ........86

Quadro 6 - Documentos referente ao processo de escrita do diagnóstico................... 135

Quadro 7 - Dados do diagnóstico institucional agrupado......................................... 135

Quadro 8 - Documentos referente ao processo de planejamento.............................. 139

Quadro 9 - Documentos da estrutura organizacional ........................................... 146

Quadro 10 - Avaliações diversas com equipe.................................................... 153

Quadro 11 - Itens identificados nas avaliações....................................................... 154

Quadro 12 - Avaliação Anual 2011/2012 …....................................................... 157

Neste momento, o que significa trabalhar no Museu para ti? ................................... 157

Quadro 13 - Avaliação Anual - 2011/2012 ..................................................... 157

Na tua opinião, qual o significado do Museu do Trem para São Leopoldo?................... 157

Quadro 14 - Itens da Planilha para registro do fluxo de público visitante.................... 162

Quadro 15 - Relação de exposições externas itinerante e participações em mostras e feiras 


\section{LISTA DE TABELAS}

Tabela 1 - Avaliação Anual 2009 - O que significa trabalhar no Museu? 155

Tabela 2 - Avaliação Anual 2009 - Qual o significado do Museu do Trem para São Leopoldo? 156

Tabela 3 - Avaliação Anual 2010 - Neste momento, o que significa trabalhar no Museu?

Tabela 4 - Avaliação Anual 2010 - Qual o significado do Museu do Trem para São

Leopoldo? 156

Tabela 5 - Número de visitações espontâneas, planejadas e estimuladas por ano ...... 163

Tabela 6 - Despesa prevista pela Prefeitura Municipal (Planilha A) ............................ 165

Tabela 7 - Receita de doações (valores de mercado (Planilha B) .............................. 166

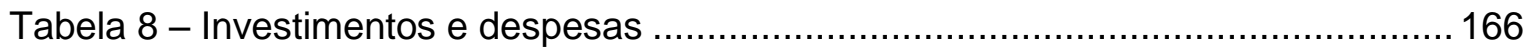

Tabela 9 - Cálculo estatístico participação do público externo ..................................... 169

Tabela 10 - Cálculo per capita - custos e redução de custos .................................... 169

Tabela 11 - Cálculo da média de visitação diária ................................................ 170

Tabela 12 - Clipagem de conteúdos sobre o Museu do Trem veiculados em mídia

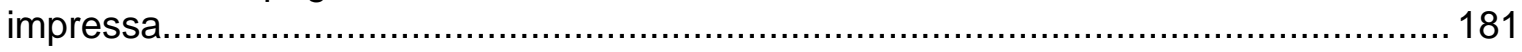

Tabela 13 - Participações da direção do Museu em programas de rádio....................... 185

Tabela 14 - Participações da direção do Museu em programas de TV ......................... 185 


\section{LISTA DE GRÁFICOS}

Gráfico 1 - Público visitante nos meses do ano de 2009........................................ 160

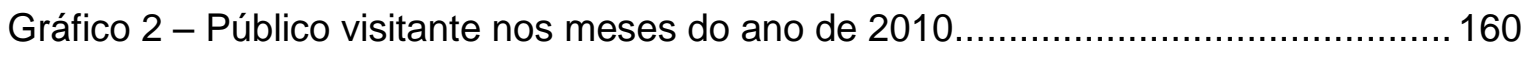

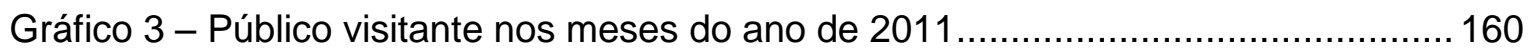

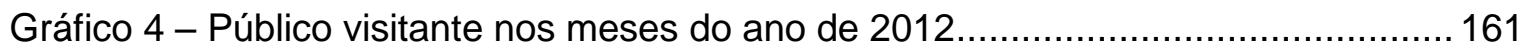

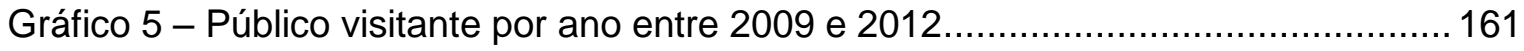

Gráfico 6 - Comparativo das visitações entre 2009 e 2012 ...................................... 163 


\section{LISTA DE ABREVIATURAS E SIGLAS}

\begin{tabular}{|c|c|}
\hline ABOTTC & Associação Brasileira das Operadoras de Trens Turísticos e Culturais \\
\hline ABPF & Associação Brasileira de Preservação Ferroviária \\
\hline AENFER & Associação de Engenheiros Ferroviários \\
\hline AFALA & Associação dos Ferroviários Aposentados da Linha Auxiliar \\
\hline AFL & Academia Ferroviária de Letras \\
\hline AFPF & Associação Fluminense de Preservação Ferroviária \\
\hline ALL & América Latina Logística S.A. \\
\hline ANTPF & Associação Nacional de Preservação Ferroviária \\
\hline ANTT & Agência Nacional de Transporte Terrestre \\
\hline CBTU & Companhia Brasileira de Trens Urbanos \\
\hline CEFEC & Centro Cultural Ferroviário \\
\hline CFVV & Circuito Ferroviário Vale Verde \\
\hline CMBEU & Comissão Mista Brasil-Estados Unidos \\
\hline CPHFRS & Centro de Preservação da História Ferroviária no Rio Grande do Sul \\
\hline CPHFPRSC & $\begin{array}{l}\text { Centro de Preservação da História Ferroviária do Paraná e Santa } \\
\text { Catarina }\end{array}$ \\
\hline CPHFMG & Centro de Preservação da História Ferroviária de Minas Gerais \\
\hline CPHFPE & Centro de Preservação da História Ferroviária de Pernambuco \\
\hline CPHFCE & Centro de Preservação da História Ferroviária do Ceará \\
\hline CPHFRJ & Centro de Preservação da História Ferroviária do Rio de Janeiro \\
\hline CPHFSP & Centro de Preservação da História Ferroviária de São Paulo \\
\hline CPTM & Companhia Paulista de Trens Metropolitanos \\
\hline DTF & Departamento de Transporte Ferroviário \\
\hline DNEF & Departamento Nacional de Estradas de Ferro \\
\hline EFA & Estrada de Ferro do Amapá \\
\hline EFC & Estrada de Ferro Carajás \\
\hline EFCB & Estrada de Ferro Central do Brasil \\
\hline EFCJ & Estrada de Ferro Campos do Jordão \\
\hline EFCP & Estrada de Ferro Central do Paraná \\
\hline EFJ & Estrada de Ferro Jari \\
\hline EFMM & Estrada de Ferro Madeira Mamoré \\
\hline EFNOB & Estrada de Ferro Noroeste do Brasil \\
\hline EFOM & Estrada de Ferro Oeste de Minas \\
\hline
\end{tabular}




$\begin{array}{ll}\text { EFT } & \text { Estrada de Ferro Trombetas } \\ \text { EFVM } & \text { Estrada de Ferro Vitória a Minas } \\ \text { EFPP } & \text { Estrada de Ferro Perus-Pirapora } \\ \text { FCA } & \text { Ferrovia Centro-Atlântica S.A. } \\ \text { FEPASA } & \text { Ferrovia Paulista S.A. } \\ \text { FERROESTE } & \text { Estrada de Ferro Paraná Oeste S.A. } \\ \text { FNS } & \text { Ferrovia Norte-Sul } \\ \text { FNTF } & \text { Federação Nacional dos Trabalhadores Ferroviários (PB) } \\ \text { FSA } & \text { Ferrovia Sul-Atlântico S.A. } \\ \text { FTC } & \text { Ferrovia Tereza Cristina S.A. } \\ \text { FUNALFA } & \text { Fundação Cultural Alfredo Ferreira Lage } \\ \text { IAHPAC } & \text { Instituto dos Amigos do Patrimônio Histórico e Artístico-Cultural e da } \\ & \text { Cidadania } \\ \text { IBRAM } & \text { Instituto Brasileiro de Museus } \\ \text { ICOM } & \text { Internacional Council of Museums } \\ \text { IFPPC } & \text { Instituto de Ferrovias e Preservação do Patrimônio Cultural } \\ \text { IPHAE } & \text { Instituto de Patrimônio Histórico Artístico do Estado } \\ \text { IPHAN } & \text { Instituto de Patrimônio Histórico Artístico Nacional } \\ \text { MHVSL } & \text { Museu Histórico Visconde de São Leopoldo } \\ \text { MinC } & \text { Ministério de Cultura } \\ \text { MMVRB } & \text { Museu Municipal de Visconde de Rio Branco } \\ \text { MPF } & \text { Movimento de Preservação Ferroviária } \\ \text { MRS } & \text { MRS Logística S.A. } \\ \text { MT } & \text { Ministério dos Transportes } \\ \text { MUFER } & \text { Museu Ferroviário de Pires do Rio } \\ \text { NHFBH } & \text { Núcleo Histórico Ferroviário de Belo Horizonte } \\ \text { NHFC } & \text { Núcleo Histórico Ferroviário de Campos } \\ \text { NHFJF } & \text { Núcleo Histórico Ferroviário de Juiz de Fora } \\ \text { NHFMP } & \text { Núcleo Histórico Ferroviário de Miguel Pereira } \\ \text { NHFB } & \text { Núcleo Histórico Ferroviário de Bauru } \\ \text { PAC } & \text { Programa de Aceleração do Crescimento das Cidades } \\ \text { PRESERFE } & \text { Setor de Preservação do Patrimônio Histórico Ferroviário } \\ \text { PRESERVE } & \text { Programa de Preservação do Patrimônio Histórico } \\ \text { RFFSA } & \text { Rede Ferroviária Federal Sociedade Anônima } \\ \text { RMV } & \text { Rede Mineira de Viação } \\ \text { SESEF } & \text { Serviço Social das Estradas de Ferro } \\ & \\ \text { FHe } & \\ \text { FHe } & \end{array}$




$\begin{array}{ll}\text { SJDR } & \text { São João del Rei } \\ \text { SMC } & \text { Secretaria Municipal de Cultura } \\ \text { SEMRS } & \text { Sistema Estadual de Museus do Rio Grande do Sul } \\ \text { SBM } & \text { Sistema Brasileiro de Museus } \\ \text { SR-6 } & \text { Superintendência Regional de Porto Alegre } \\ \text { TLSA } & \text { Transnordestina Logistica S.A. } \\ \text { TICCIH } & \text { The Internacional Committee for the Conservation of the Industrial } \\ & \text { Heritage } \\ \text { UFPel } & \text { Universidade Federal de Pelotas } \\ \text { ULBRA } & \text { Universidade Luterana do Brasil } \\ \text { UNISINOS } & \text { Universidade do Vale dos Sinos } \\ \text { USP } & \text { Universidade de São Paulo } \\ \text { VFCO } & \text { Viação Férrea Centro-Oeste } \\ \text { VFFLB } & \text { Viação Férrea Federal do Leste Brasileiro } \\ \text { VFRGS } & \text { Viação Férrea do Rio Grande do Sul }\end{array}$




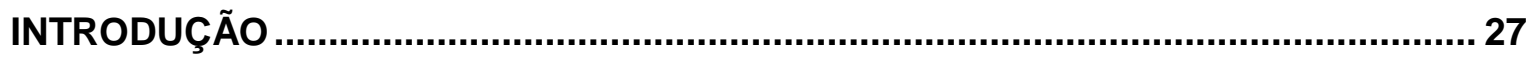

CAPÍTULO 1 - FERROVIA E PATRIMÔNIO ............................................................

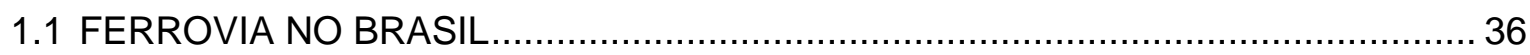

1.2 PATRIMONIO INDUSTRIAL FERROVIÁRIO …………....................................... 44

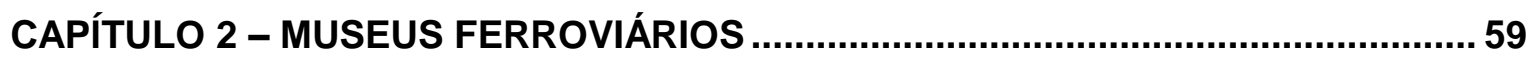

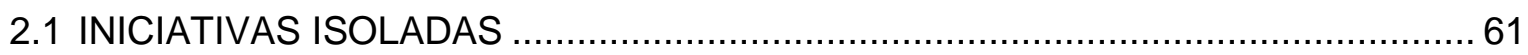

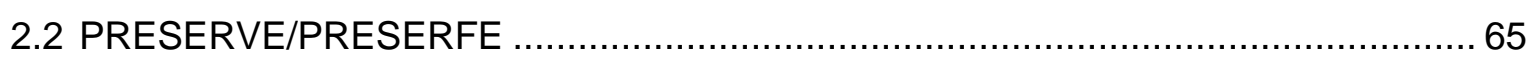

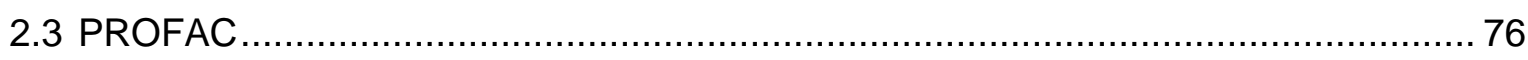

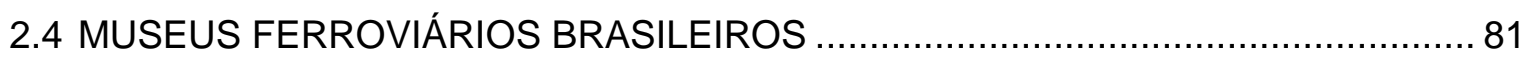

CAPÍTULO 3 - MUSEU DO TREM DE SÃO LEOPOLDO............................................. 88

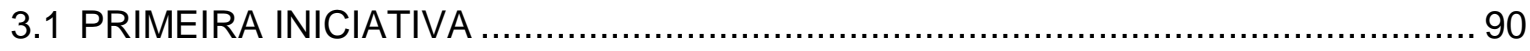

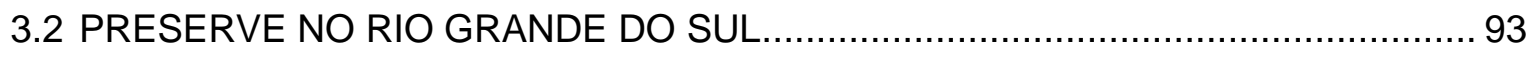

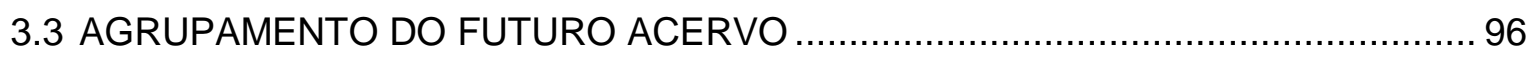

3.4 SETORES: DOCUMENTAÇÃO, COMUNICAÇÃO E EDUCAÇÃO ………….......... 100

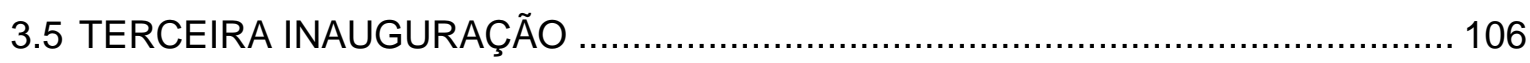

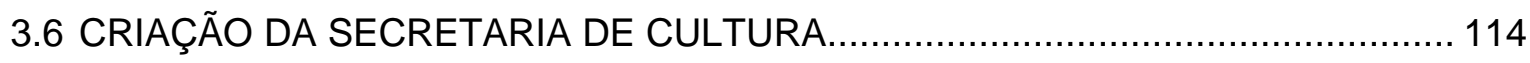

CAPÍTULO 4 - GESTÃO NO MUSEU DO TREM.......................................................119

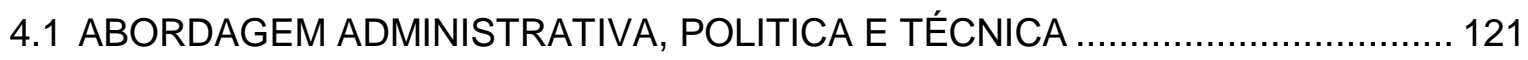

4.2 GESTÃO DE QUALIDADE APLICADA AO MUSEU DO TREM …........................... 132

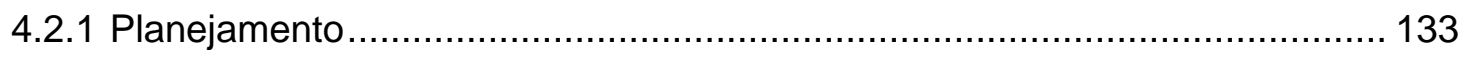

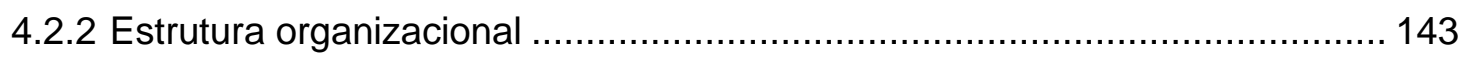

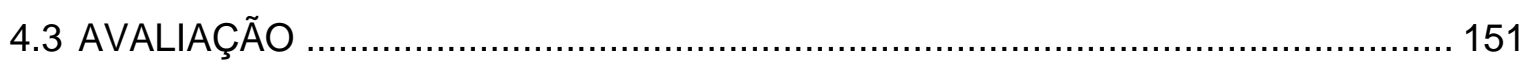

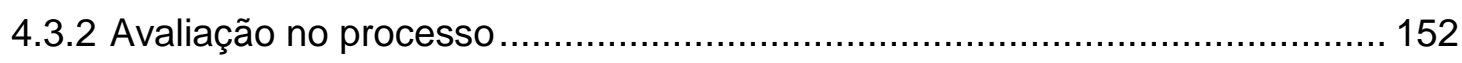

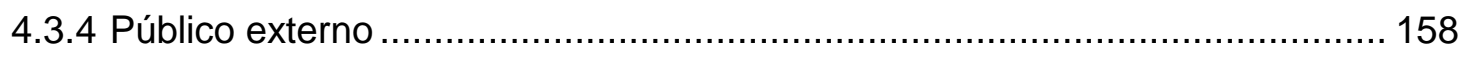

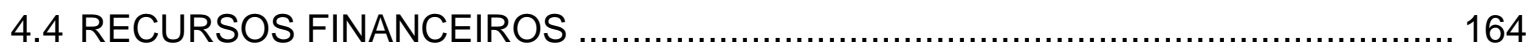

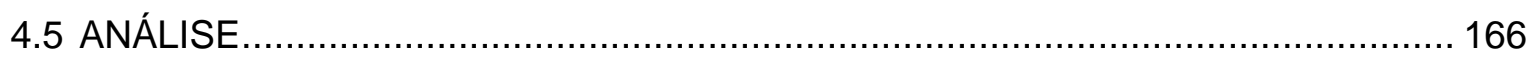

CAPÍTULO 5 - PRÁXIS COMUNICACIONAL NO MUSEU DO TREM........................... 171

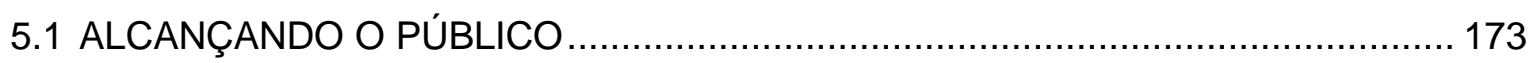

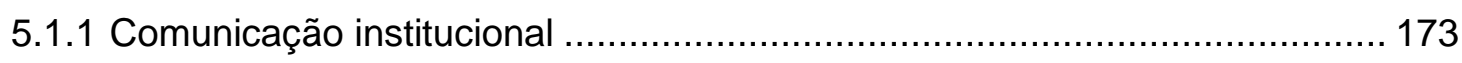




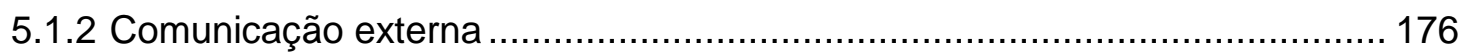

5.1.3 Notícias e artigos na imprensa .......................................................... 180

5.1.4 Organização do espaço de comunicação no pátio ...................................... 185

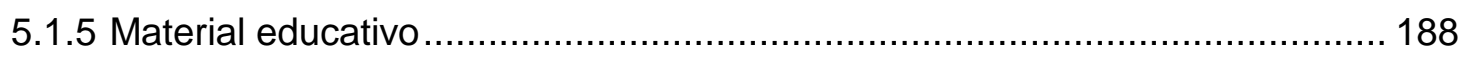

5.1.5 Outros materiais de divulgação ........................................................... 190

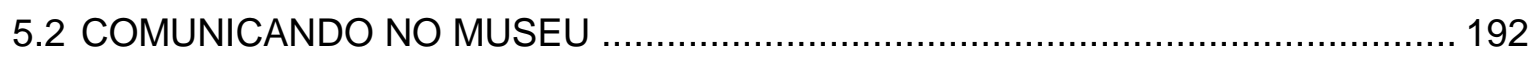

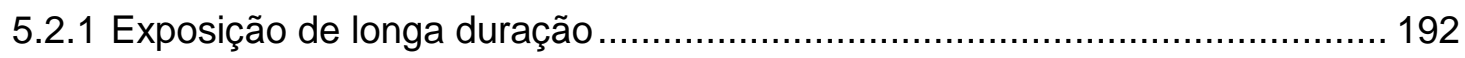

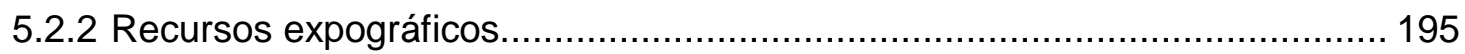

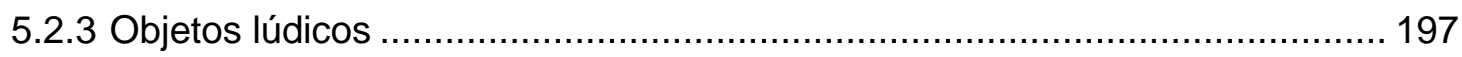

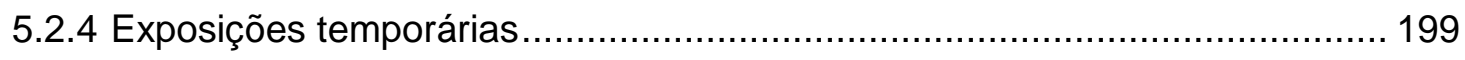

5.2.5 Exposições itinerantes, feiras e eventos externos.................................... 201

5.3 EXPERIMENTANDO UM MUSEU ............................................................. 204

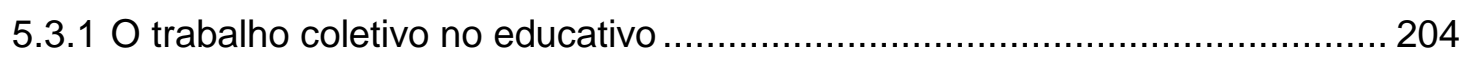

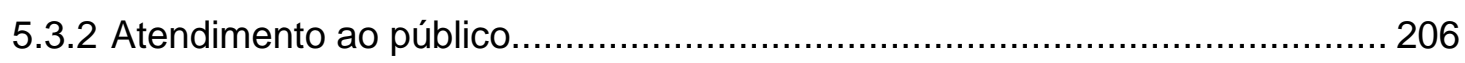

5.3.3 Na relação com outros museus da cidade ............................................ 212

CAPÍTULO 6 - GESTÃO DE MUSEU, COMUNICAÇÃO E PÚBLICO .......................... 215

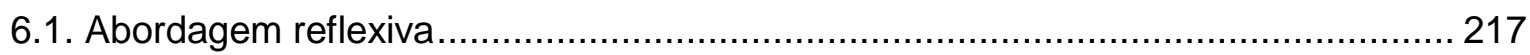

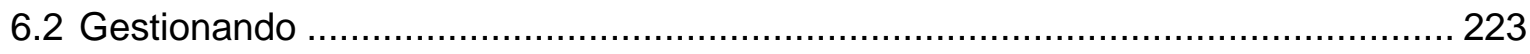

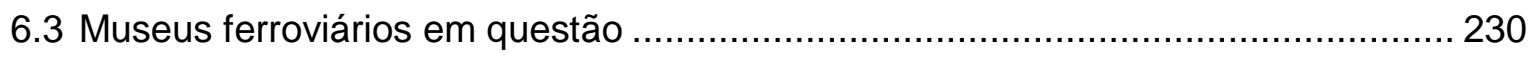

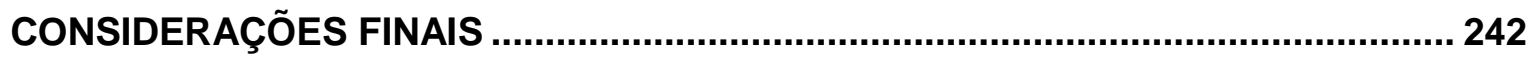

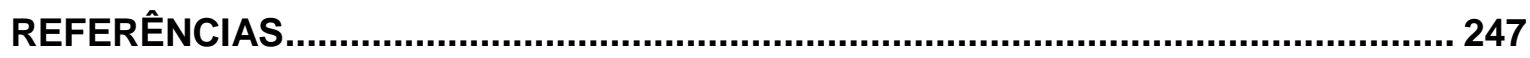

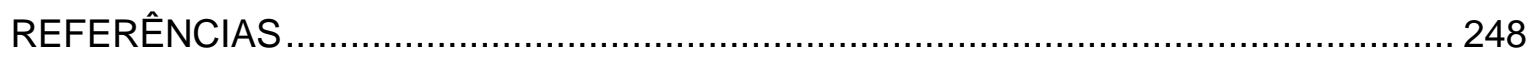

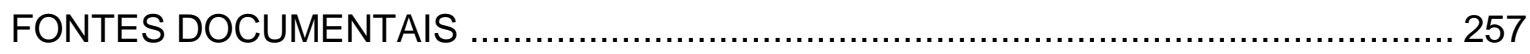

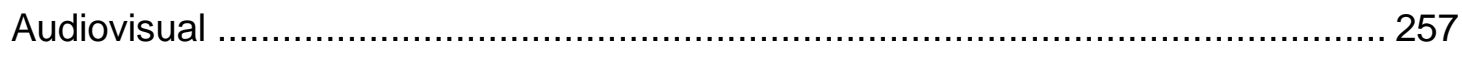

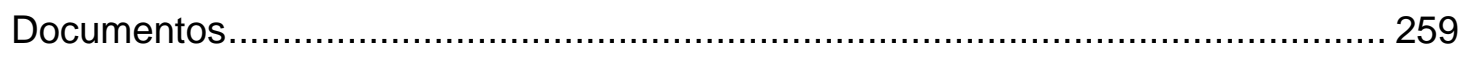

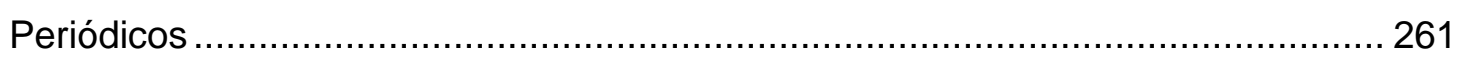

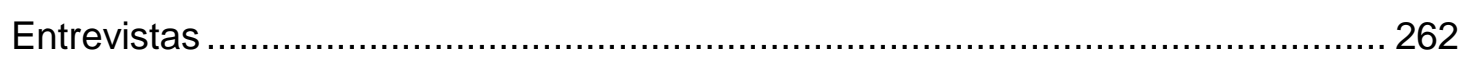

APÊNDICE E ANEXO

APÊNDICE - CORPUS DOCUMENTAL REFERENTE AO MUSEU DO TREM DE SÃO

LEOPOLDO LISTAGEM DE DOCUMENTOS - PERÍODO DE 2009 A 2012........... 264

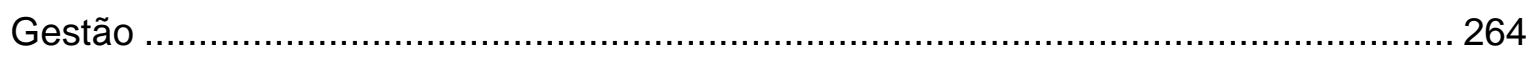

Quadro 1 - Documentos Administrativos ..................................................... 264

Quadro 2 - Documentos iconográficos - diagnóstico e verificação......................... 269

Quadro 3 - Pesquisa de opinião - público externo …........................................ 270 
Quadro 4 - Gestão/Comunicação (avaliação - público interno) ............................ 271

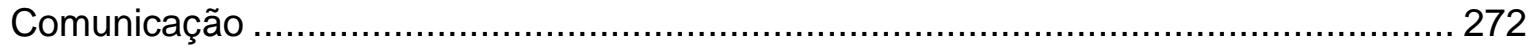

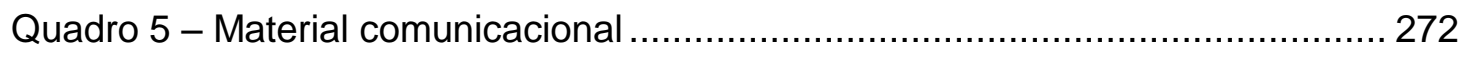

Quadro 6 - Materiais diversos, de apoio, de uso didático, atividades lúdicas. ....... 274

Quadro 7 - Discursos proferidos pela direção do Museu e protocolo dos cerimoniais de eventos comemorativos (Secretaria de Comunicação) ...........................2276

Quadro 8 - Artigos publicados em jornal e revista ........................................... 277

Quadro 9 - Exposição, Reserva Técnica, Documentação (atividades de organização, conservação e afins) ...................................................................... 278

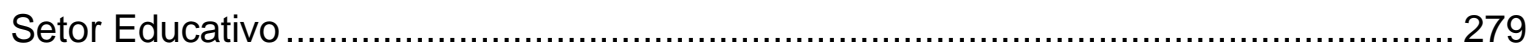

Quadro 10 - Produção escrita da equipe ..................................................... 279

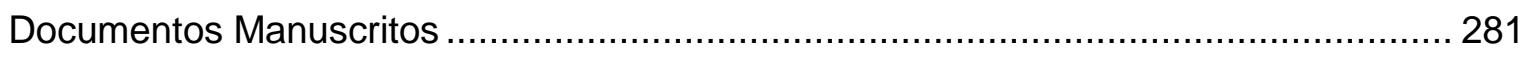

Quadro 11 - Anotações do processo, anotações diversas e sobrepostas de Alice Bemvenuti............................................................................................ 281

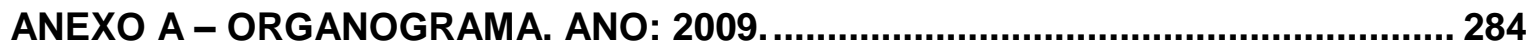

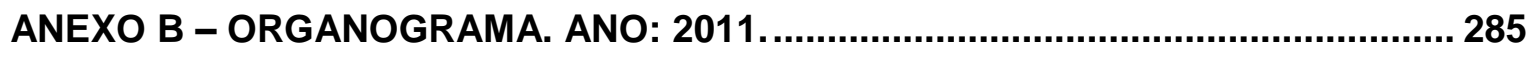

ANEXO C - TEXTO DE PAREDE PARA NOVA EXPOGRAFIA. ANO 2011............... 287 


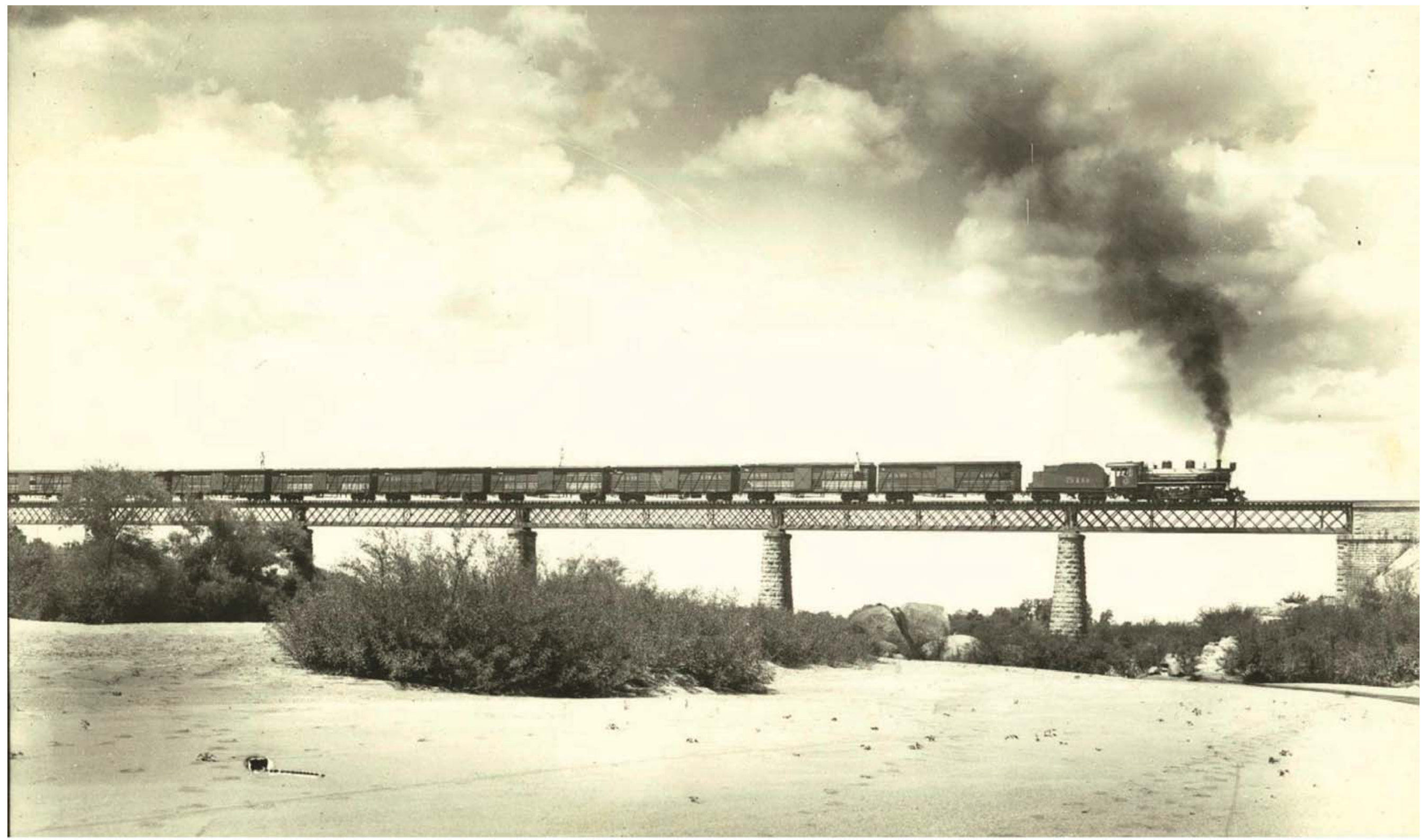


A pesquisa ora apresentada teve por motivação a busca de respostas para indagações que começam a surgir após quatro anos de prática do Museu no Trem de São Leopoldo. Cheguei ao Museu, em 2009, já tendo desenvolvido pesquisa de mestrado² aprofundando questões de história, metodologia e educação em museus, consciente da necessidade de conhecer a história do lugar específico, as práticas museológicas anteriores do Museu do Trem, a composição do acervo e a relação entre ele e a comunidade.

A pesquisa de mestrado é impulsionada, inicialmente, pela inquietação diante das práticas desenvolvidas nesse museu, sob o viés da gestão, considerando os diferentes públicos. Ao escolher padrões estéticos para oferecer a exposição ao público, o museu também informa sua visão comunicacional e sobre essa prática museológica ficam as interrogações: Quais são os motivos que fazem o visitante permanecer mais ou menos tempo dentro do museu? Quais as contribuições visuais e lúdicas na aproximação do público? O que o museu oferece que ora acolhe, ora desafia o público? Em que medida a exposição comunica e impulsiona diferentes interpretações? Nessa perspectiva, com relação ao Museu do Trem, refletir sobre as estruturas e possíveis interações: Qual o alcance social do Museu do Trem? Como o Museu do Trem se define? A que o Museu se propõe? Qual é a dimensão política da instituição? Como realizar uma gestão de museu que permita experimentar o museu como lugar do patrimônio herdado e cultivado, assim como espaço da inovação, da criação e do saber?

O tema gestão em museu foi selecionado para a pesquisa em questão pela motivação do exercício profissional e pelo volume de atividades desenvolvidas no período de quatro anos. A experiência como diretora, envolvida com a rotina do Museu, dificultou inicialmente o distanciamento para uma reflexão acadêmica. De imediato parecendo uma experiência inseparável, pois nela estavam imbricados o olhar e a postura de uma coordenação/gestão que agora ocupava o lugar de pesquisadora/investigadora. Neste sentido, com a preocupação do distanciamento, a pesquisa revê o processo para que, anos depois, possa exercitar a sua teorização a luz da gestão, com ênfase nas ações de comunicação como estratégia de participação do público.

A gestão do Museu do Trem apoiou suas bases na compreensão de um museu como espaço de aprendizagem, educação e possibilidades criativas com o público visitante. Compreender o museu, à medida que se desenvolviam atividades, recepções, Rodas de Memória, impulsionou ao mesmo tempo a compreensão teórico-prática do lugar,

\footnotetext{
2 Dissertação defendida em 2004, na Universidade Federal do Rio Grande do Sul (UFRGS), sob título: Museus e Educação em Museus - História, Metodologias e Projetos, com análises de caso: Museus de Arte Contemporânea de São Paulo, Niterói e Rio Grande do Sul, sob orientação do Prof. Dr. Francisco Marshall.
} 
e oportunizou a participação como um exercício fundante para alcançar a missão, institucional, como lugar público relacionado ao patrimônio.

Segundo Marília Xavier Cury, "o museu se faz nas relações comunicacionais que ele é capaz de estabelecer eficazmente" (2014:65), sendo assim, do modo como o museu faz a oferta, desde a divulgação externa à apresentação dele próprio e da exposição, os recursos e as práticas que envolvem o público, são pontos importantes para discutir sobre o porquê de o visitante permanecer mais ou menos tempo no museu, suas preferências e escolhas. Importa, lembrar que este visitante poderá apresentar um certo estranhamento, que o levará a um afastamento do tema e da situação, por falta de vínculos e/ou de um acolhimento impulsionado pela identificação de algo familiar, ou por uma provocação, ou ainda pelo interesse anterior dos objetos expostos. Neste sentido, o que cabe a gestão impulsionar para que o museu aconteça enquanto instituição museológica? $\mathrm{E}$ considerando a tipologia do Museu que abriga o patrimônio industrial ferroviário, cabe pensar os abandonos recorrentes e os afetos impregnados em uma memória coletiva que ocupa o espaço do Museu do Trem. Segundo Dilma Andrade de Paula,

Há uma estética do abandono; os objetos/lugares abandonados resistem, evocando nostalgias, como se os eventos que haviam anunciado seu fim se tornassem os signos de sua transmutação em símbolos. [...] Os trilhos abandonados e/ou arrancados, os maquinários jogados em algum depósito ou apodrecendo às vistas públicas estimulam a produção de novos símbolos, ou de recordações, na produção de um sentido para o passado (PAULA, 2000:18-19).

O Museu do Trem em sua trajetória é reinaugurado como um dos Centros de Preservação da História da Ferrovia, o que faz pensar as relações institucionais na preservação do patrimônio. Neste caso, considerando-se o grande volume de acervo e lugares, provenientes do espólio não-operacional e operacional da Rede Ferroviária Federal S.A (RFFSA), onde são encontradas estações, acervo de oficinas de locomotivas, objetos provenientes dos setores administrativos e de comunicação telegráfica, além de vasto material rodante, de que maneira o patrimônio ferroviário está sendo preservado? Diante de tantos esquecimentos e algumas parcas confirmações de investimentos, cabe questionar-se também sobre a forma de os poderes públicos, municipal, estadual e federal tratarem as instituições museológicas, em especial o acervo industrial ferroviário e a participação desta no desenvolvimento da cidade.

A investigação passará por uma análise quantitativa e qualitativa, com o intuito de apontar reflexões para a gestão e a subárea de comunicação, a partir das questões: Em que medida a gestão no museu garante e impulsiona a relação entre museu/política/ comunicação/público? Em que medida a gestão de museu compreende a aproximação 
entre público-objeto-museu e proporciona uma experiência para o público? Em que medida os princípios da comunicação museológica e da educação permitem desenvolver uma gestão de qualidade? Teremos, então, o Museu do Trem de São Leopoldo como instituição a ser analisada, para gerar reflexões e conhecimento.

No período dos quatro anos de gestão desse Museu, muitos registros escritos foram realizados relacionados à educação, à rotina, às observações de circulação dos visitantes, sobre as histórias e depoimentos de ferroviários e outros envolvidos, em áudio e audiovisual. Também foram desenvolvidos alguns instrumentos de avaliação, sempre com intuito de subsidiar a gestão e debates, conhecer percursos, redefinir ações e (re)planejar. Os registros analisados foram produzidos no decorrer da gestão que operou de forma participativa com a equipe e revelam-se como conjunto heterogêneo e fragmentário próprio do processo de trabalho como se desenvolveu experimentalmente à época. Sistematizado, o material tornou-se um conjunto denominado de corpus documental para fins de análise, sistematização e fundamentação, que consiste na metodologia desta pesquisa.

Com interesse em usar as fontes documentais, organizou-se uma lista de documentos e evidências, do período de 2009 a 2012, do Museu do Trem. Entendendo por documentos não apenas os documentos em papel com registros escritos de ordem institucional, mas todos aqueles objetos tridimensionais, audiovisuais desenvolvidos e ou utilizados no período já referido, assim como extenso material manuscrito produzido por esta pesquisadora enquanto na função de direção.

A seleção para esta dissertação foi minuciosa, sempre com a atenção em observar o que cada um dos documentos listados poderia informar, de modo legítimo. Percebendo a diversidade e o volume, foi necessário selecionar quais estariam tratando diretamente da relação entre público e museu. Não é a quantidade de documentos em si o interesse, mas a existência dos mesmos, considerando que todos foram desenvolvidos no processo, tanto com objetivo de registrar simplesmente, quanto de ampliar a reflexão sobre as práticas realizadas a medida que se reconhecia os públicos como parte fundamental. Entre as dificuldades distinguir o que constituía como documentos para o objeto de estudo desta pesquisa, centrando o foco na gestão museal, a fim de recuperar evidências e informações de conteúdo para a reflexão desta pesquisa.

Não foram incluindo aqueles pertinentes ao acervo, a Reserva Técnica, Semana de Museus, Rodas de Memória, assim como os de coleta de depoimentos dos ferroviários e de visitas na Vila dos Ferroviários. Também não foram incluídos a clipagem do período que reúne considerável número de materiais publicados em veículos impressos e o 
material com registros escritos produzido pelos estagiário e educadores, pois o excesso nos faria perder o foco.

A listagem sistematizada do corpus documental está disponível no apêndice. Foram agrupados inicialmente em dois grandes blocos: aqueles que se referiam as atividades administrativas e aqueles que se referiam as atividades de comunicação museal. Ao longo da pesquisa novas classificações e agrupamentos foram sendo pensados, então a opção foi criar subgrupos de documentos referentes ao administrativo, à educação, à exposição, e aqueles referentes à divulgação. Essa atividade minuciosa foi importante para compreender os processos e as correlações de cada ação no desdobramento da gestão. A partir do processo de sistematização foi possível descrever e analisar, reconhecendo a concepção de público e a concepção de museu. Outro aspecto metodológico refere-se a levantamento bibliográfico para situar do locus e focus da pesquisa em outros contextos maiores: patrimônio ferroviário e esse espectro do setor industrial musealizado no Brasil.

Para a coleta de dados da trajetória histórica deste Museu e da cronologia da criação dos museus ferroviários no Brasil, incluindo a trajetória do PRESERVE, foram realizadas entrevistas para esse propósito, assim como consultadas fontes audiovisuais realizadas pelo Museu do Trem em 2011. A intenção é situar o Museu do Trem inserido no contexto, assim como a pesquisa, pois o referido museu foi o elemento motivador, mas também e, principalmente, o caso no qual se aprofunda a análise sobre a realidade empírica.

A metodologia apontada foi construída para atingir os seguintes objetivos específicos:

- Apresentar um panorama geral dos museus ferroviários no Brasil, com um relato histórico das iniciativas de criação destes museus, além da discussão em torno dos mecanismos de proteção do patrimônio industrial ferroviário;

- Documentar a gestão do Museu do Trem de São Leopoldo, no período de 2009 a 2012, e recuperar a trajetória histórica da instituição;

- Discutir gestão de museu com ênfase na subárea da comunicação e público, a luz de teóricos do campo da museologia, da administração e da educação, a partir da análise da experiência do referido Museu.

A estrutura da dissertação foi desenvolvida em seis capítulos.

No primeiro capítulo, denominado Ferrovia e Patrimônio, panorama histórico da ferrovia com os desdobramentos decorrentes dos projetos econômicos e políticos do país, desde a criação do primeiro trecho da estrada de ferro até a extinção da Rede Ferroviária 
Federal S.A (RFFSA), com a transferência dos bens patrimoniais de valor histórico para o Instituto de Patrimônio Histórico Artístico Nacional (IPHAN).

No segundo capítulo, os Museu Ferroviários Brasileiros a partir das primeiras iniciativas isoladas nas décadas de 1960 e 1970, seguindo com a atuação do Programa de Preservação do Patrimônio Histórico (PRESERVE) e do Setor de Preservação do Patrimônio Histórico Ferroviário (PRESERFE) com a criação de Centro de Preservação e Núcleos Históricos Ferroviários; e posteriormente com o Programa Ferroviário de Ação Cultural (PROFAC) com os Centros Ferroviários Culturais, recorrendo a utilização de entrevistas para remontar uma trajetória cronológica, mapeando assim os museus existentes, de outras iniciativas. Ao final, dedicando uma atenção ao estado do Rio Grande do Sul para o mapeamento de instituições museais ferroviárias e centros culturais diversos criados em estações espalhadas pelo estado.

No terceiro capítulo aborda o Museu do Trem de São Leopoldo através da trajetória histórica e cronológica dos fatos desde a criação do mesmo na década de 1970 , a reestruturação pelo PRESERVE, detalhando desdobramentos das ações no período. Reconstrução do prédio da Estação de São Leopoldo, organização, registro e acondicionamento do acervo e montagem da exposição e atendimento ao público. Seguido das dificuldades com a extinção da RFFSA, as reinaugurações subsequentes, consequência das tentativas de gerir a instituição, através de coordenações vinculadas à Fundação Cultural e, posteriormente, ao Departamento de Cultura do Município de São Leopoldo. A concessão e o tombamento da Estação Ferroviária de São Leopoldo, juntamente com o pátio e o Armazém, como Sitio Histórico, até a criação da Secretaria Municipal de Cultura e da direção do Museu.

No quarto capítulo a Gestão no Museu do Trem a partir da prática museográfica em um recorte temporal. É um capítulo longo que entrelaça referenciais teóricos da administração e da educação, junto com os princípios da museologia. São apresentados movimentos da gestão envolvendo todos os setores do museu e resultados, sem reduzir a complexa experiência em um relatório de atividades, com dados desde os primeiros movimentos da gestão, diagnóstico, planejamento, ações e desdobramentos da estrutura organizacional.

No quinto capítulo, a Práxis Comunicacional no Museu do Trem apresenta as informações documentais das práticas desenvolvidas nos diferentes setores para 0 entendimento de como o museu atuava comunicacionalmente. A escolha deste formato deu-se pelo volume de informações, que poderão gerar novas análises, reflexões e pesquisas, conferindo ao capítulo um material, inserido na reflexão acadêmica, onde 
apresenta-se desde os processos relacionados ao acervo em exposição, recursos expográficos, objetos lúdicos, exposições temporárias e itinerantes; comunicação institucional, comunicação externa e marketing; e as práticas desenvolvidas com a equipe do Setor Educativo desde a experiência coletiva de formação até a confecção dos materiais educativos com criação de roteiro, as atividades, a rotina e a metodologia na recepção dos diferentes públicos.

O sexto e último capítulo, Gestão de Museu, Comunicação e Público encerra com a reflexão sobre as contribuições da experiência no Museu do Trem para a prática da gestão em museus, comunicação e público. 


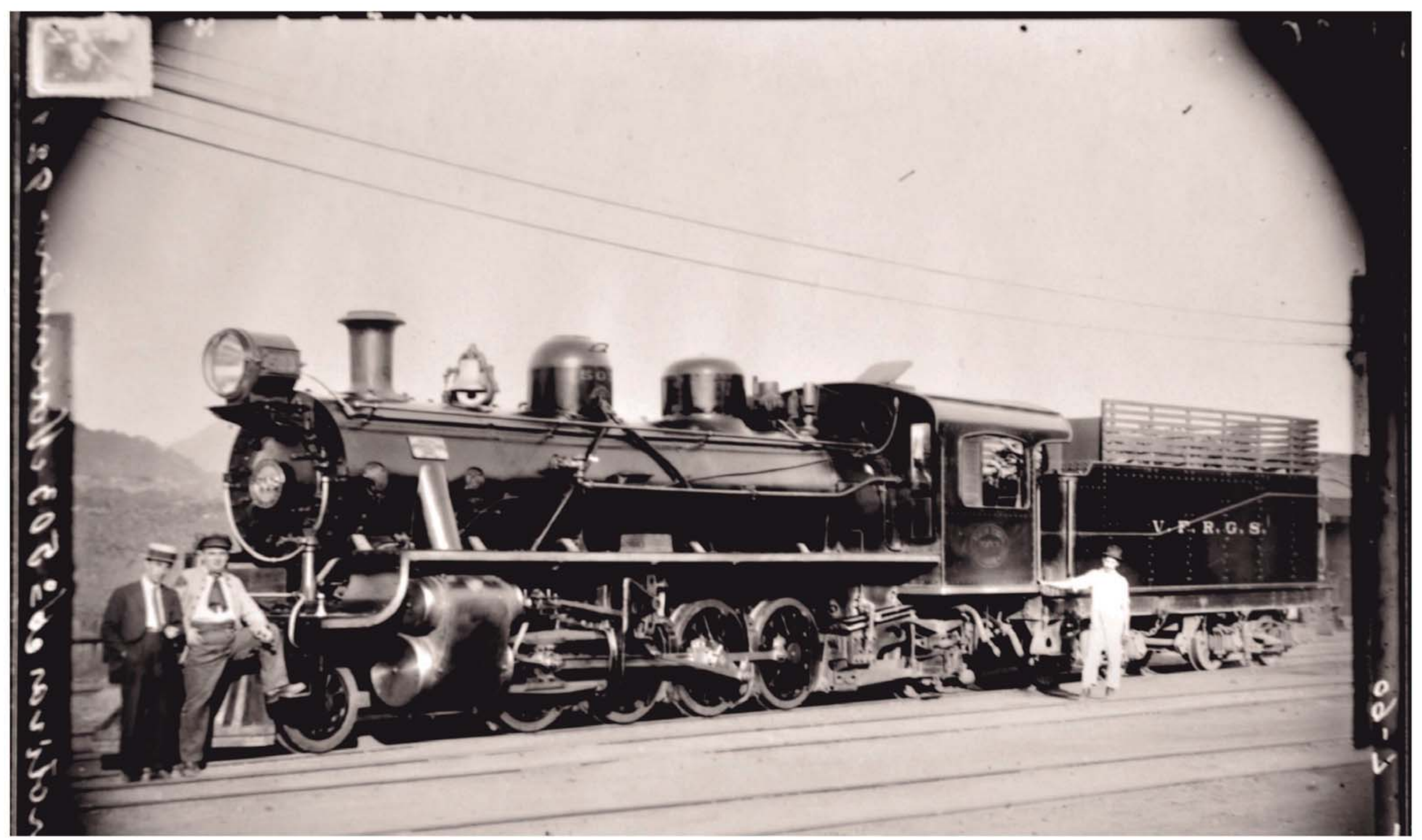

Capítulo 1 
Este capítulo tem por objetivo abordar aspectos em torno dos museus ferroviários brasileiros desde os fatos históricos, aspectos econômicos, políticos e culturais que compreendem o universo de instauração da ferrovia brasileira e os posteriores esvaziamentos a partir dos desdobramentos da erradicação, liquidação e extinção da mesma, a destinação de seus bens patrimoniais, os programas e ferramentas de preservação, salvaguarda e a criação das instituições museais. Períodos que perpassam diferentes governos, avanços tecnológicos que impulsionam novas concepções de mundo e geram mudanças significativas que refletem o País, são questões que fazem parte da discussão desta pesquisa. Para tanto, a partir dos fatos históricos, apresenta-se dados relacionados ao patrimônio industrial ferroviário e as políticas de preservação do mesmo. 


\subsection{FERROVIA NO BRASIL}

A legislação pró-ferrovia, no Império com o Decreto nº 101, de 31 de outubro de 1835, autoriza à concessão para a construção de estradas de ferro da capital do Império até os estados de Minas Gerais, Rio Grande do Sul e Bahia, quando as companhias obtiveram o privilégio de uso por 40 anos para o transporte de carga e de passageiros. A partir de 1850, iniciaram no Rio de Janeiro, o assentamento de dormentes e de trilhos para a construção da primeira estrada de ferro. Anteriormente, o transporte terrestre era realizado por tração de animal e pela força humana, até os centros urbanos ou portos. No Rio Grande do Sul, na mesma ocasião em que foi inaugurada a primeira estrada de ferro brasileira, no Rio de Janeiro, contabilizavam-se 280 lanchões matriculados na capitania dos portos dos rios Cai e Sinos. Dois anos depois se utilizava o vapor para o transporte fluvial e, em 1860, somavam-se quatro linhas, transportando por ano mais de 13.000 passageiros de diferentes cidades até a capital gaúcha.

A construção da ferrovia no Brasil se deu tanto por interesses e investimentos privados, quanto por interesses e investimentos do poder público, vinculados à necessidade de escoamento da produção agrícola e de minérios, em maior escala, e de produtos diversos que abasteciam o comércio e o transporte de passageiros, em menor escala.

No século XIX, a formação de pequenos trechos isolados por setores privados e a aquisição de máquinas importadas de diversos países, é administrada conforme seus interesses, poder aquisitivo e convicções, sendo que são diversos proprietário (público ou privado). Não há deste modo, interligação entre os trechos, nem tão pouca comunicação que possa beneficiar o transporte como um conjunto no extenso espaço geográfico do território brasileiro, pois cada proprietário possui a estrada de ferro nos moldes de suas necessidades de escoamento de rua produção, seja ela agrícola ou de minério.

A historiadora Dilma Andrade de Paula, em sua pesquisa de doutorado, na Universidade Federal Fluminense (UFF), intitulada "Fim de Linha - A extinção dos Ramais da Estrada de Ferro Leopoldina, 1955-1974" nos aponta o jogo de contradições existentes na trama que se constitui a formação do sistema ferroviário. A pesquisadora apresenta dados históricos relativos ao primeiro período demonstrando que os investimentos com o início do tráfego da linha coincidem com o início da decadência da região para o qual ela deveria servir além dos diferentes vínculos trabalhistas adotados para a obtenção de mão de obra, sendo alguns modelos herdados remontam ao período da escravidão no Brasil ainda em transição, e outros já absorvem a mão de obra de imigrantes, já em outro modelo de vínculo. A pesquisadora afirma: 
[...] a história ferroviária no Brasil vitimada pelos contrastes do Brasil "Moderno", atravessado pelo que havia de mais atual em ternos de associação de capital financeiro, as sociedades por ações e, do outro lado, como a outra face da moeda, o trabalho escravo e toda a lógica de funcionamento de uma sociedade escravista (PAULA, 2000:56).

Em 1874, exatamente vinte anos após ter sido realizada a primeira viagem na estrada de ferro brasileira, no trecho que ligava a cidade de Porto de Estrela a Fragoso, no Rio de Janeiro, é que o trecho entre Porto Alegre a São Leopoldo foi aberta ao tráfego no Rio Grande do Sul. No intervalo destes vinte anos, foram também inaugurados nos estados do Recife e do Rio de Janeiro, os trechos da Estrada de Ferro Recife - São Francisco e Dom Pedro II, respectivamente, ambas em 1858. Em São Paulo, foram inaugurados outros importantes trechos, como o da linha de Santos - Jundiaí, em 1864; da Companhia Paulista de Estrada de Ferro, em 1872; e o de Sorocaba, em 1875.

No início do século XX, o governo brasileiro editou leis sobre o investimento de capital estrangeiro no País, oferecendo novamente vantagens a investidores estrangeiros interessados do negócio (FINGER, 2009:39), tendo sido implantadas viações ferroviárias com concessões para empresas belgas, francesas, norte-americanas, entre outras, em vários estados. Este fazia parte do Plano de Viação, criado em 1934, que visava organizar diferentes vias de comunicação, entre elas a ferrovia, a rodovia e a navegação. $O$ debate evoluiu na valorização de outro modal de transporte, contrapondo trilhos $x$ pneus, o que evidenciou diversas fragilidades (PAULA, 2006; OLIVEIRA, 2013).

No Rio Grande do Sul, a inauguração do primeiro trecho ocorreu com a The Porto Alegre \& New Hamburg Brazilian Railway Company, em abril de 1874, e a inauguração dos trechos da Estrada de Ferro Porto Alegre - Uruguaiana e da Estrada de Ferro Rio Grande - Bagé, deu-se em 1884, porém em 15 de março de 1898, foi assinado o contrato de arrendamento das ferrovias federais no Rio Grande do Sul, com a Compagnie Auxiliaire de Chemins de Fer au Bresil. E, em 29 de junho de 1920, a encampação da Compagnie Auxiliaire de Chemins de Fer au Bresil dá início a Viação Férrea do Rio Grande do Sul (VFRGS).

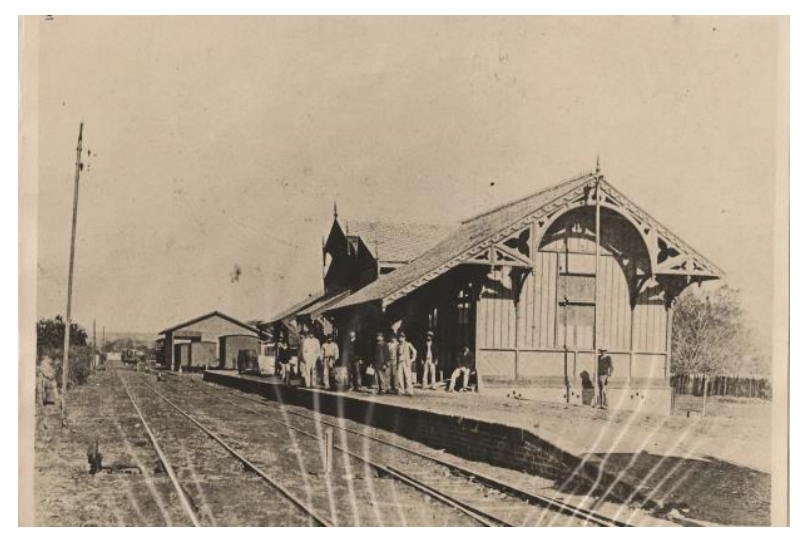

Figura 1 - Estação Ferroviária de São Leopoldo (vista da plataforma). Ano (atribuído): 1874. Fonte: Museu do Trem de São Leopoldo. 
"Governar é abrir estradas", disse o presidente Washington Luís. E conforme a historiadora Dilma Andrade de Paula, logo após a frase, em 13 de maio de 1926, é divulgado pelo Eng. Paulo de Fontin o documento intitulado "Políticas de Viação Brasileira, atuais redes de comunicação, futuras redes" (PAULA, 2000:70), com indicadores do início do interesse pelo transporte rodoviário no Brasil. Em 1927, através do Decreto no 5.141 , de 5 de janeiro, cria-se o Fundo Especial para Construção e Conservação de Estradas de Rodagens Federais, para financiar o desenvolvimento rodoviário do Brasil. E, em 1928, Washington Luís inaugura a rodovia Rio-Petrópolis e termina a Rodovia São Paulo-Rio.

A redução de tempo da viagem de São Paulo ao Rio de Janeiro gera grande impacto, fortalecendo não só os discursos de modernização através da rodovia, mas também o desejo da população brasileira de desfrutar da nova tecnologia que resultava numa dimensão de espaço/tempo diminuída pela velocidade. Assim, a partir do final da década de 1930, o País dispara políticas estatais voltadas para a industrialização, incluindo a construção de rodovias (PAULA, 2000:71), priorizando o transporte vinculado às transformações e ao conforto oferecido pela modernidade automotiva. Reflete Dilma Andrade de Paula:

Todo o aparato administrativo/político formado a partir dos anos 20/30 e atuante no redirecionamento do padrão de transportes "encontrou" uma justificativa naturalizante das "características psicológicas" do povo brasileiro. A modernidade já estaria presente no meio social, como um componente inato, logo, receptivo às transformações (PAULA, 2000:72).

Conforme a autora observa, até a década de 1920, o Estado incentiva e investe em ferrovias, porém a partir dos interesses com a rodovia, inicia-se um processo com consecutivas ações para o início de um pensamento na direção de uma estratégia de desmonte do setor ferroviário. Uma opção que atraía por exigir poucos investimentos iniciais, porém necessitando em longo prazo altos investimentos, demonstrando ser onerosa com o passar do tempo.

A malha ferroviária brasileira cresceu visando à articulação territorial e ao escoamento dos produtos agrícolas das diversas regiões e, num segundo momento, à proteção das fronteiras e agilidade no deslocamento de tropas militares (FINGER, 2009:41-42). Sendo que em 1948 foi realizada a revisão do Plano de Viação de 1934, e novamente em 1952 sendo revisto, culminou com novo projeto incluindo as diretrizes da Comissão Mista Brasil-Estados Unidos (CMBEU).

Em 1951, o governo de Getúlio Vargas, contratava junto ao Banco Mundial um estudo para obter diretrizes norteadoras para administrar a nação. Foi criada, em 19 de julho de 1951, a CMBEU, que realizou um relatório sugerindo diversas ações, entre elas a 
unificação da gestão empresarial das ferrovias controladas pela União (SILVA, 2014). A Comissão Mista utilizou-se de estudo realizadas por missões norte-americanas anteriores, ainda no governo Dutra, sobre o potencial da economia brasileira, sendo esta parte do plano norte-americano de assistência aos países da América Latina.

Da CMBEU resultou a criação, em 1951, do Programa de Reaparelhamento Econômico e do Banco Nacional de Desenvolvimento para administrar os aportes financeiros a partir do reaparelhamento, entre outras ações. Em 1954, o reaparelhamento e as ampliações das vias férreas foram previstas em 137 milhões de dólares e 7 bilhões de cruzeiros, quando seriam então adquiridos materiais rodantes e de tração, construídas pontes e desvios. Conforme aponta o pesquisador Eduardo Romero de Oliveira, que os projetos tiveram dificuldades de serem implantados pela divergência entre dois pontos chaves: a política nacionalista e estatizante de Getúlio Vargas e os órgãos internacionais de investimentos e a diplomacia norte-americana (2007).

O cenário sobrepõe ações políticas, econômicas, mas também é possível identificar o uso de mecanismos de proteção ao patrimônio como parte dos interesses citados. O uso da preservação do patrimônio, e da promoção de eventos comemorativos, como parte do cenário para o fortalecimento da imagem nacionalista, em virtude de justificar as ações políticas e econômicas adotadas no período (OLIVEIRA, 2013). Em dezembro de 1953, a instituição da Comissão para organização dos festejos comemorativos do "Centenário da Estrada de Ferro do Brasil", pelo então Ministro da Viação e Obras Públicas, José Américo de Almeida, que deveria culminar com festejos no dia 30 de abril de 1954.

Composta apenas por engenheiros, a Comissão agregava membros que atuavam em órgãos públicos e mantinham forte vínculo com a Presidência da República (OLIVEIRA, 2007). O calendário das comemorações previa realização de inaugurações de estações, reinauguração de trechos, veiculação matérias em jornal impresso, retomando histórico deste centenário, e um encontro solene para o que os engenheiros proferissem seus discursos ${ }^{3}$ dedicado às vias férreas. Um dos marcos das comemorações foi a viagem organizada por Ruy de Castro e Andrade Pinto, com um comboio composto pelas mais modernas máquinas, intercaladas com locomotivas $n^{\circ} 1^{4}$. O desfile das locomotivas, em 25 de janeiro de 1954, ocorreu também por ocasião do 4º Centenário de São Paulo, tendo

\footnotetext{
${ }^{3}$ Discursos que agrupados foram transformados na publicação especial 'Centenário da Ferrovia' da Revista Brasileira de Geografia, de 1954.

${ }^{4}$ № 1 da Companhia Paulista de Estradas de Ferro, 1867; №1 da Estrada de Ferro Sorocabana, 1873; №1 da Companhia Mogiana, de 1875; e №1 da Estrada de Ferro Noroeste do Brasil, além da "Baroneza" e os dois vagões que conduziram o Presidente Getúlio Vargas e outras autoridades.
} 
sido realizado no trecho de sete quilômetros entre a Estação da Lapa e a de "Presidente Altino". Ao longo do percurso, onde haviam outras máquinas estacionadas, estava a população aguardando para assistir ao desfile. Também como parte estratégica, fora realizada uma declaração como Monumento Nacional, pelo Decreto 35.447-A, de 30 de abril de 1954, assinado pelo Presidente Getúlio Vargas, determinando proteção o primeiro trecho da ferrovia que ligava, em 14 km, Mauá a Fragoso, no Rio de Janeiro 5 .

O historiador, Prof. Dr. Eduardo Romero de Oliveira (UNESP) argumenta sobre questões simbólicas relacionadas ao Centenário das Ferrovias e a produção de sentido com objetivo de fomentar e fortalecer um imaginário positivo, relacionado ao progresso do País (2013). O desfile, com evidência para as primeiras locomotivas, ao lado daquela de última geração, recém adquiridas, opera com o traçado de evolução tecnológica que vai do antigo ao moderno, materializado pela tecnologia atualizada e imponente que possa a ser um dos símbolos do progresso brasileiro, "cujo status é de civilizador dos sertões" (2013:699).

\begin{abstract}
A inclusão das "modernas locomotivas" cria um contraste temporal e desloca o olhar para o presente (as atuais condições da empresa ferroviária). Para entender as particularidades destas celebrações, há de se considerar qual a eficácia simbólica pretendida; isto é, recuperar o programa de celebração, os propósitos que ordenam a realização das solenidades e as questões relevantes no momento do centenário, o que nos leva de volta aos membros da Comissão dos Festejos (OLIVEIRA, 2013:694).
\end{abstract}

Embora o desenvolvimento da ferrovia não tenha acompanhado o crescimento da população no Brasil, a extensão total, incluindo grandes, médias e pequenas ferrovias, no centenário do seu aparecimento, somava um total de 38 mil quilômetros em todo território (SILVA, 1954). Após algumas fusões e incorporações, nesta mesma data, poderiam ser identificadas 41 estradas do sistema ferroviário, subdivididas sem qualquer planejamento de conjunto entre as diferentes regiões, por sua vez concentravam-se ao sul e ao leste e, em menor escala, no nordeste.

Quem tenha sob os olhos uma carta geográfica do Brasil na qual esteja convenientemente representada nossa viação férrea atual, observará, ao primeiro golpe de vista, a desigual distribuição de nossas ferrovias pelo território nacional (SILVA, 1954).

Os discursos e textos dos engenheiros publicados pelo Instituto Brasileiro de Geografia e Estatística (IBGE), em 1954, anunciam a intenção de formação de uma rede

\footnotetext{
${ }^{5}$ Primeiro bem patrimonial ferroviário inscrito no Livro Tombo Histórico do então Departamento do Patrimônio Histórico e Artístico Nacional (DEPHAN).
} 
agrupando em uma única empresa todas as ferrovias. O Congresso Nacional cria uma empresa para centralizar a administração de todas as estradas de ferro, unificando, deste modo, as estradas ferroviárias no País.

Após inúmeros movimentos de aproximação e unificação das ferrovias, foi sancionado pelo Presidente Juscelino Kubitschek, a Lei ํㅜ 3.115, em 16 de março de 1957, criando a empresa estatal denominada de Rede Ferroviária Federal Sociedade Anônima (RFFSA), que entra em funcionamento em 30 de setembro do mesmo ano. Por um lado, com a finalidade de administrar, explorar, conservar, reequipar, ampliar e melhorar o tráfego das estradas de ferro da União, agrupando $80 \%$ das empresas do sistema ferroviário em uma única, por outro lado, a supressão dos ramais chamados de antieconômicos. A Viação Férrea do Rio Grande do Sul (VFRGS) foi incorporada apenas em 1959.

Começava a ser definido um novo papel para as ferrovias brasileiras que priorizava a circulação de cargas em detrimento do transporte ferroviário de longo percurso, com ênfase em atendimento a cargas com volumes superiores a 500 mil toneladas anuais, em distâncias não inferiores a 300 $\mathrm{km}$. Ao transporte de passageiros restaria apenas o atendimento a zonas muito adensadas, em eixos urbanos e metropolitanos, em viagens de curta extensão e grandes volumes de demanda (SILVA, 2014:92).

Em 1969, a RFFSA reorganiza as ferrovias em um sistema regional agrupando os estados em 10 regiões, e em 1976, a RFFSA ampliando para doze as Superintendências Regionais $(\mathrm{SR})^{6}$, determinando que as mesmas passarão a operar na organização administrativa, comercial, operacional, jurídica e de manutenção, orientadas pela Administração Geral, sediada no Rio de Janeiro.

Na década de 1990 dar-se-ia novos rumos a RFFSA que, através do Decreto no 473, de 10 de março de 1992, é incluído no Plano Nacional de Desestatização (PND) desenvolvido pelo governo do Presidente Fernando Henrique Cardoso, estimulando os investimentos da iniciativa privada no setor ferroviário. Assim, os ativos, conforme são denominados os ramais em funcionamento da RFFSA, que constituíam uma malha de 22 mil quilômetros do norte ao sul do País, foram agrupados em seis malhas independentes transferidos, com concessão de uso por 30 anos, ao setor privado através de leilões públicos realizados no período de março de 1995 até junho de 1997. Apenas em 1998, houve a incorporação da Ferrovia Paulista S.A (FEPASA) à RFFSA, seguido da privatização também da referida malha.

\footnotetext{
${ }^{6}$ Superintendência Regional Recife, SR-1; Superintendência Regional Belo Horizonte, SR-2; Superintendência Regional Juiz de Fora, SR-3; Superintendência Regional São Paulo, SR-4; Superintendência Regional Curitiba, SR-5; Superintendência Regional Porto Alegre, SR-6; Superintendência Regional Salvador, SR-7; Superintendência Regional Campos, SR-8; Superintendência Regional Tubarão, SR-9; Superintendência Regional Bauru, SR-10; Superintendência Regional Fortaleza, SR-11; Superintendência Regional São Luiz, SR-12.
} 
A Malha Sul, que agregou a SR5 e a SR6, referente aos estados de Santa Catarina, Paraná e Rio Grande do Sul, e foi leiloada em 13 de dezembro de 1996, tendo sido ganhadora a Ferrovia Sul atlântico S.A (FSA) que alterou sua denominação para América Latina Logística S.A., em 1999.

A decisão do governo brasileiro de erradicar o modal ferroviário e priorizar o transporte rodoviário iniciou na década de 1960, quando há estagnação da ferrovia, impulsionando os primeiros movimentos de retirada de trilhos e desmanche de trechos. Porém são anos seguido por consecutivas etapas até a dissolução operacional da Rede, sua liquidação em leilões e concessões de trechos até sua extinção total em 2007.

São muitos os envolvidos com o encerramento da RFFSA, sendo inumeráveis os processos de desligamento, considerando uma empresa com tamanha estrutura estatal. São inúmeros departamentos e setores em todo o território brasileiro. A cada vinculo encerrado, seja por contrato, acordo, convênio, ou mesmo comodato com os bens patrimoniais operacionais e não operacionais, exige-se a dedicação dos setores encarregados para que o desfecho obtenha sucesso. Sendo necessária a realização das tarefas desde a verificação da natureza do bem, seu histórico de propriedade, sua origem e situação atual. Nesse panorama, compreende-se que a preservação do patrimônio industrial ferroviário requer após a localização de sua guarda nos relatórios e transferências da Inventariança da Extinta Rede o enquadramento da transferência para determinado órgão e a inclusão do mesmo na Listagem que irá protegê-lo.

Os desdobramentos necessários para o Escritório de Inventariança da Extinta RFFSA são minuciosos, não só pelas questões administrativas e jurídicas de sua estrutura, que incluem questões trabalhistas, mas também pelas circunstâncias vinculadas a história do País. Somado ao cenário político e econômico, os fatores socioculturais e psicológicos da população também agregam um valor que dificulta. Lembrando que a maioria dos funcionários foi afastada em um só golpe, quando extintas as atividades laborais e os vínculos com a empresa. Questões essas que apontam valores simbólicos carregado de afetos e histórias de vida. Outra questão a ser aprofundada em pesquisa acadêmica, mas que não será alvo deste trabalho por se tratar de um assunto abrangente e especifico, são as estratégias de interesses políticos e econômicos, que não levam em consideração as reflexões e os desdobramentos do encerramento desta grande empresa (RFFSA) na vida da população brasileira.

$\mathrm{Na}$ medida em que ocorre o desmonte, amplia-se o debate sobre formas de preservação e salvaguarda do acervo material, visto que se acumulavam objetos chamativos como relógios de parede, lanternas, placas, mobiliários, telégrafos e, prioritariamente, as 
locomotivas a vapor. Faziam parte também deste espólio, bens imóveis e edificações, como armazéns, prédios para venda de bilhetes, vilas, casas, oficinas.

Em 1991, no 1ํEncontro Nacional Ferroviário, diagnosticava-se a ausência de uma política nacional de transportes, segundo Dilma Andrade de Paula, tem no Estado o responsável pela política de desmonte do setor ferroviário, pois é o mesmo que opta pela tomada de decisões em função de interesses imediatos (PAULA, 2000), distorcendo o uso da ferrovia, que ao invés de servir para o mercado interno, é direcionado ao serviço de exportação e aos interesses do capital estrangeiro.

Segundo Paula, para além das questões administrativas e jurídicas, a extinção da RFFSA carrega um fardo gigantesco que está relacionado ao impacto gerado na população brasileira, sobretudo dentro das famílias ferroviárias. O modo como a estratégia de desmonte atingiu o universo dos trabalhadores, gerou perdas irreparáveis, sendo ainda possível ouvir em diferentes depoimentos, relatos, entrevistas e rodas de conversas entre ferroviários ativos e ou desligados da extinta RFFSA, questões relativas ao período.

Todavia, a obsolescência dos trens não significou o seu desaparecimento imediato e por inteiro. Os símbolos do que significam as ferrovias estão presentes em vários caminhos da memória, nos quais o passado não está apaziguado (PAULA, 2000:73).

A RFFSA foi dissolvida de acordo com o estabelecido no Decreto no 3.277 , de 7 de dezembro de 1999, alterado pelo Decreto no 4.109, de 30 de janeiro de 2002, pelo Decreto ํo 4.839, de 12 de setembro de 2003, e pelo Decreto no 5.103 , de 11 de junho de 2004 . O processo de liquidação, iniciado em 17 de dezembro de 1999, implicou na realização dos ativos não operacionais e no pagamento de passivos, sendo os ativos operacionais (infraestrutura, locomotivas, vagões e outros bens vinculados) foram arrendados às concessionárias (BRASIL, 1999).

Somavam-se um total de 44 mil empregados. No processo de desestatização foi realizado um programa de demissões voluntárias e posteriormente, transferidos 25 mil funcionários para as concessionárias, que por sua vez demitiram cerca de 9 mil destes funcionários. Somando aqueles que aderiram a demissão voluntária e aos demais demitidos pela RFFSA, permaneceram na RFFSA cerca de 800 empregados distribuídos nas doze SR.

Não nos interessa supervalorizar ou mesmo enaltecer questões relacionadas a nostalgia, a perda de um lugar ou mesmo sublinhar falas porta vozes da saudade. Porém é preciso destacar que os depoimentos apontam repetidamente para uma incompreensão com a extinta da RFFSA. Os aspectos individuais identificados nas falas dos ferroviários 
reproduzem, em pequena escala, questões políticas, econômicas, sociais de uma nação com 204.729.872 habitantes, e representam um desconforto coletivo, que de certo modo, refletem nos mecanismos de preservação do patrimônio ferroviário e no lugar da memória em nossa cultura.

Em 1997, o Governo Federal outorgou à Companhia Vale do Rio Doce a concessão da Estrada de Ferro Vitória e Minas e da Estrada de Ferro Carajás, permanecendo a té os dias de hoje. A composição das concessionárias que arremataram trechos da ferrovia nos leilões, segue no quadro abaixo.

Quadro 1 - Malha ferroviária e concessionárias.

\begin{tabular}{|l|l|l|l|c|}
\hline \multicolumn{1}{|c|}{$\begin{array}{c}\text { Malhas } \\
\text { regionais }\end{array}$} & $\begin{array}{c}\text { Data do } \\
\text { Leilão }\end{array}$ & \multicolumn{1}{|c|}{ Concessionárias } & $\begin{array}{c}\text { Início da } \\
\text { Operação }\end{array}$ & $\begin{array}{c}\text { Extensão } \\
\text { (km) }\end{array}$ \\
\hline Oeste & $05 / 03 / 1996$ & Ferrovia Novoeste S.A. & $01 / 07 / 1996$ & 1.621 \\
\hline Centro-Leste & $14 / 06 / 1996$ & Ferrovia Centro-Atlântica S.A. & $01 / 09 / 1996$ & 7.080 \\
\hline Sudeste & $20 / 09 / 1996$ & MRS Logística S.A. & $01 / 12 / 1996$ & 1.674 \\
\hline Tereza Cristina & $22 / 11 / 1996$ & Ferrovia Tereza Cristina S.A. & $01 / 02 / 1997$ & 164 \\
\hline Nordeste & $18 / 07 / 1997$ & Companhia Ferroviária do Nordeste & $01 / 01 / 1998$ & 4.534 \\
\hline Sul & $13 / 12 / 1996$ & Ferrovia Sul-Atlântico S.A. & $01 / 03 / 1997$ & 6.586 \\
\hline Paulista & $10 / 11 / 1998$ & Ferrovias Bandeirantes S.A. & $01 / 01 / 1999$ & 4.236 \\
\hline
\end{tabular}

Fonte: DNIT, RFFSA, BNDE.

Em 7 de dezembro de 1999, o Governo Federal, com base na Resolução n. 12 , de 11 de novembro de 1999 do Conselho Nacional de Desestatização e por intermédio do Decreto n. 3.277, dissolve, liquida e extingue a RFFSA. O processo iniciado na década de 1990, de liquidação da ferrovia, incluindo os leilões nas diferentes regiões, que só de completa em 2007, com a transferência dos bens patrimoniais histórico, para o IPHAN.

\subsection{PATRIMONIO INDUSTRIAL FERROVIÁRIO}

Para entendimento do termo patrimônio, recorremos à noção do mundo romano como referência ao conjunto de bens transmitidos ao filho pelo pai de família (LIMA, 2012) e ao direito romano, que define o conjunto de bens reunidos pela sucessão de bens que descendem dos pais aos filhos, em oposição aos bens adquiridos (DESVALLÉES; e MAIRESSE, 2013). O pai de família detinha o status social de senhor do patrimônio e, assim, assumia o papel de mantenedor das crenças e tradições (LIMA, 2012).

Importante considerar a noção formada a partir da relação patrimônio e sucessão/herança. Este se torna um instrumento regulador que é associado, segundo Lima, ao 'instituto Preservação', através da permanência e de "sucessão, emprestado ao 
termo Patrimônio, persiste no tempo presente mantendo-se a imagem no conceito de algo transmitido por direito de herança" (LIMA, 2012:34).

A forma e o sentido cultural construídos para criar e estabelecer a ideia
de 'preservação' e de 'transmissão' do bem consolidaram a base do
pensar e do agir que se identifica no conceito de Patrimônio, seja na
condição de elemento musealizável ou quando já se apresenta
musealizado, isto é, sob a forma de Museu (LIMA, 2012:33).

Na Revolução Francesa, com as transformações sociais e políticas é gerada uma nova figura para o Estado francês, a participação do povo. Diferentemente do modelo anterior, se solidifica a figura do cidadão e do coletivo representando a nação, compreendendo a patrimonialização como uma ação de

institucionalização dos bens reais que estabeleceu, alicerçada na noção de tutela com suas regras para a prática da custódia, a legitimação do ato de patrimonializar. Esse procedimento foi seguido durante anos de maneira sistemática pela incorporação nacional dos bens da nobreza, do clero e atendendo a ótica de um Estado laico (LIMA, 2012:34).

O termo 'patrimônio' passa a ser designado como "conjunto de bens imóveis, confundindo-se com a noção de monumentos históricos" (DESVALLÉES; e MAIRESSE, 2013), pois é no seio da Revolução Francesa que ocorrem as discussões com relação a transferências dos bens do clero para a nação além da destruição ideológica. Conforme nos alerta Françoise Choay, a transferência de propriedade que trouxe importante marco para a compreensão de patrimônio, porém também gerou novos problemas para a salvaguarda dos mesmos.

Da noite para o dia, a conservação iconográfica abstrata dos antiquários cedia lugar a uma conservação real. A descrição literária e a prancha gravada apagavam-se diante da materialidade própria dos objetos ou dos edifícios a serem conservados (CHOAY, 2006:96).

Considerando as palavras-chave: herança, sucessão, patrimônio e conservação que transformaram o status das antiguidades nacionais, Françoise Choay (2006) considera que o conceito de patrimônio induz uma homogeneização do sentido e de valores.

O valor primário do tesouro assim devolvido a todo o povo é econômico. Os responsáveis adotam imediatamente, para designá-lo e gerenciá-lo, a metáfora do espólio [...] Integradas aos bens patrimoniais sob o efeito nacionalização, estas se metamorfosearam em valores de troca, em bens materiais que, sob pena de prejuízo financeiro, será preciso preservar e manter. Não dependem mais de uma conservação iconográfica (CHOAY, 2006:98).

A perspectiva do modelo coletivo, impulsionado pelo episódio francês, passa a considerar o sentido de sucessão dado ao Patrimônio chegou até os dias de hoje 
consolidado como transmissão de um valor aplicado aos grupos sociais, a sua vez compreendidos na qualidade de legítimos sucessores de um processo de referências culturais particulares procedentes de seus ascendentes, e que se transmite às gerações futuras (LIMA, 2012:35).

Reunida em Paris, em 1972, a Conferência Geral da Organização das Nações Unidas para a Educação, Ciência e Cultura, diante da constatação que o patrimônio cultural e o patrimônio natural estão ameaçados de destruição, definem como patrimônio cultural:

Os monumentos - obras arquitetônicas, de escultura ou de pintura monumentais, elementos de estruturas de caráter arqueológico, inscrições, grutas e grupos de elementos com valor universal excepcional do ponto de vista da história, da arte ou da ciência;

Os conjuntos - grupos de construções isoladas ou reunidos que, em virtude da sua arquitetura, unidade ou integração na paisagem tem valor universal excepcional do ponto de vista da história, da arte ou da ciência; Os locais de interesse - obras do homem, ou obras conjugadas do homem e da natureza, e as zonas, incluindo os locais de interesse arqueológicos, com um valor universal excepcional do ponto de vista histórico, estético, etnológico ou antropológico. (Carta...1792)

Interessante observar que a partir de então o patrimônio, "inserido na categoria de nacional, tornou-se objeto de inclusão e tratamento em categoria internacional' (LIMA, 2012: 36). Observa-se também que o texto faz menção à ciência, mas não a tecnologia.

Em 2003, na "Convenção para Salvaguarda do Patrimônio Cultural e Imaterial", consolida-se o Patrimônio Intangível, deste modo o texto da Convenção define:

Entende-se por 'patrimônio cultural imaterial' as práticas, representações, expressões, conhecimentos e técnicas - junto com os instrumentos, objetos, artefatos e lugares culturais que lhes são associados - que as comunidades, os grupos e, em alguns casos, os indivíduos reconhecem como parte integrante de seu patrimônio cultural. Este patrimônio cultural imaterial, que se transmite de geração em geração, é constantemente recriado pelas comunidades e grupos em função do seu ambiente, de sua interação com a natureza e de sua história, gerando um sentimento de identidade e continuidade e contribuindo assim para promover o respeito à diversidade cultural e à criatividade humana. Para fins da presente Convenção, será levado em conta apenas o patrimônio cultural imaterial que seja compatível com os instrumentos internacionais de direitos humanos existentes e com os imperativos de respeito mútuo entre comunidades, grupos e indivíduos, e do desenvolvimento sustentável (UNESCO, 2006).

A presença reconhecida dos seres humanos falando de suas comunidades, sua diversidade, destacando o lugar e a experiência individual, "nas suas múltiplas formas de interpretação da realidade, nas suas práticas variadas, nas suas representações pertinentes, vivenciadas e expressas no mundo da materialidade e da intangibilidade" (LIMA, 2012:37). 
Porém, mesmo o reconhecimento do patrimônio imaterial ter impulsionado uma definição mais ampla de patrimônio, muitos conjuntos móveis e imóveis importantes para a identidade das cidades, foram destruídos, pois não considerou utilizar a comunidade como fonte, perdendo referências importantes do modo de produção e da tecnologia.

Entre o século XIX até meados do século $X X$, a seleção para determinar o elemento a ser preservado como Patrimônio ainda lançava mão de parâmetros que não refletiam a história e as atividades de agentes sociais, como, por exemplo, operários, mineiros, oleiros, moleiros, [ferroviários] (LIMA, 2012:37).

A compreensão do patrimônio industrial como memória surge com as exigências impostas pela Revolução Industrial e por acentuadas mudanças decorrente do ritmo da modernização dos setores, que transformam cenários e organizações estruturais das empresas. O que significa que a cada etapa de mudança, ocorrem alterações de ordem técnica, financeira e jurídica, no processo de patrimonialização, sendo que "podem coexistir fases estruturais diferentes, determinadas pelo atraso ou avanço dos setores de produção" (ANDREATTA, 2003:1517).

A preocupação com os processos de industrialização torna-se aparentes a partir de 1960, com o caso de destruição dos edifícios da Bolsa de Carvão e da Estação Euston, em Londres, e do Mercado Central de Paris, nos anos 1970. O patrimônio industrial representa o testemunho das atividades humanas e da construção das cidades. $O$ contexto histórico nos oferece informações importantes para a identificação dos bens relacionados ao cenário industrial que devem ser patrimonializados. A patrimonialização, deste modo, faz-se necessária na integração da memória e da cultura a fim de servir como instrumento de preservação.

As definições englobam também as unidades de produção de energia, a sistematização dos meios de transportes e todo complexo de elementos relacionados à fábrica, e não apenas ao local de produção em si. Isso se dá pelo fato de esses dados serem considerados essenciais para a compreensão do processo de industrialização em sua inteireza, a que almejam os estudos dessa temática (KÜHL, 2010:26-27).

A ação de transformar uma antiga estação ferroviária, que abrange um conjunto de edificações, podendo até chegar a incluir gare, armazéns, carros e vagões, locomotivas, pátio de manobras, residências de ferroviários, oficinas, peças de máquinas, entre outros objetos, requer reconhecer o patrimônio industrial e suas características, pressupondo que estudo dos bens de interesse para a preservação tenha sido realizado e o valor tenha sido identificado (KÜHL, 2010). 
Para cada fábrica é necessário o conhecimento da história industrial, dos seus setores, bem como de sua evolução geral, abrangendo, inclusive, variáveis como capital, o empresário e sua história, ao de obra, a matéria prima utilizada, as condições geográficas e sociais, além de outros fatores que impliquem a análise do conjunto de todos os testemunhos produzidos (ANDREATTA, 2003:1517).

A legislação patrimonial se organiza nas Cartas Patrimoniais escritas após importantes discussões sobre os méritos da questão. Pode-se observar, na Carta de Veneza, de 1964, a Carta de Nizhny Tagil, Rússia, de 2003, preparada pelo The Internacional Committee for the Conservation of the Industrial Heritage (TICCIH), por exemplo, que apresenta definições sobre o que compreende o patrimônio industrial:

Os vestígios da cultural industrial que possuem valor histórico, tecnológico, social, arquitetônico ou científico. Estes vestígios englobam edifícios e maquinarias, oficinas, fábricas, minas e locais de processamento e de refinação, entrepostos e armazéns, centros de produção, transmissão e utilização de energia, meios de transporte e todas as suas estruturas e infraestruturas, assim como os locais onde se desenvolveram atividades sociais relacionadas com a indústria, tais como habitações, locais de culto ou de educação (TICCIH, 2003).

O patrimônio industrial informa sobre a atividade humana. Revelam hábitos, problemáticas sociais, tecnologias, processos de controle do capital intelectual, hierarquização das relações de poder na produção industrial, ou seja, informa sobre o comportamento humano em sociedade.

Marly Rodrigues, da Divisão Técnica do IPHAN, de São Paulo, considera que a não utilização de elementos da unidade fabril na constituição das paisagens local dificultam a constituição de uma representação do processo histórico para fins de perceber o passado como integrante do presente (2010). E indaga se deveríamos esperar a valorização dos espaços fabris através da preservação dos modelos de representação do trabalho organizado em moldes capitalistas, considerando que os mesmos são tidos como menos nobres e revelam práticas de sociabilidade, assim como

os locais de trabalho são lugares de desenvolvimento de identidade profissionais, que concomitantemente, guardam memórias difíceis, como as de cerceamento de vontade, em função da disciplina e eficiência da produção, assédios morais e de tempo roubado ao lazer, à criatividade, enfim, à liberdade de estar solto no mundo (RODRIGUES, 2010:39).

Rodrigues esclarece que no caso específico das ferrovias, o tombamento de estações "revela nitidamente a tendência de consolidar uma imagem nostálgica do passado" (2010: 39), delegando uma conotação de esvaziamento de sentido a respeito dos valores relacionados ao desenvolvimento de identidades, ciclos econômicos, saber-fazer, a herança cultural, 
desviando as possibilidades de problematização "substituindo-se a verdade pela diferença e incluindo-se a subjetividade como elemento constitutivo dos fatos" (2010:34).

Considerando o grande volume de equipamentos e máquinas que se empilhavam nos pátios, a partir do momento que o governo brasileiro decidiu investir no reaparelhamento do sistema ferroviário, substituindo as máquinas a vapor pelas de tração diesel-elétricas, mais modernas e potentes, também se viu o problema de o que fazer com o que se tornava obsoleto. Sem qualquer atribuição de valor histórico e/ou mecanismo de proteção ao patrimônio ferroviário foi descartado de diferentes maneiras, desde a reutilização do material que fora derretido, a venda para outros setores interessados, até o simples abandono. Segundo o historiador Welber Santos, do ponto de vista do patrimônio cultural, a modernização do equipamento da empresa poderia significar o desaparecimento por completo do patrimônio material.

Desde meados da década de 1960, mas principalmente no decorrer da década seguinte, o acervo material desta estrada de ferro, integrante da Rede Ferroviária Federal S.A. desde 1957, era objeto de observação e interesse por parte de um público de âmbito até mesmo internacional. O final de sua operação comercial, ainda em moldes considerados "arcaicos", e, por tal motivo, visto como digno de preservação, por guardar traços em franco desaparecimento, levou ao interesse de entidades preservacionistas inspiradas no modelo europeu de conservação e restauro desse tipo de testemunho do desenvolvimento humano (SANTOS, 2013:04).

Conforme já mencionado, são anos e anos em cada etapa do processo de desfazer a estatal ferroviária. Iniciando pela erradicação dos modais na década de 1960, em função da opção pelas rodovias, e a liquidação desdobrada também em etapas na década de 1990 . Sendo que a extinção legal da RFFSA se dá apenas em 22 de janeiro de 2007, através da Medida Provisória oㅡ 353, posteriormente é convertido na Lei no 11.483/2007, quando são transferidos todos os bens imóveis não-operacionais7, para a União, através da Secretaria de Patrimônio (SPU) e, os bens imóveis operacionais, para a responsabilidade do Departamento Nacional de Infraestrutura e Transporte - DNIT e ao IPHAN. Seguem os artigos:

Art. 20 A partir de 22 de janeiro de 2007:

II - os bens imóveis da extinta RFFSA ficam transferidos para a União, ressalvado o disposto nos incisos I e IV o desta Lei (Redação dada pela Lei no 11.772 , de 2008 do caput do art. 8).

Art. 8 Ficam transferidos ao Departamento Nacional de Infraestrutura de Transportes - DNIT:

I - a propriedade dos bens móveis e imóveis operacionais da extinta RFFSA;

\footnotetext{
${ }^{7}$ Bens não-operacionais são aqueles bens não vinculados a contratos de arrendamento realizados pela extinta RFFSA.
} 
II - os bens móveis não-operacionais utilizados pela Administração Geral e Escritórios Regionais da extinta RFFSA, ressalvados aqueles necessários às atividades da Inventariança;

III - os demais bens móveis não-operacionais, incluindo trilhos, material rodante, peças, partes e componentes, almoxarifados e sucatas, que não tenham sido destinados a outros fins, com base nos demais dispositivos desta Lei.

IV - os bens imóveis não operacionais, com finalidade de constituir reserva técnica necessária à expansão e ao aumento da capacidade de prestação do serviço público de transporte ferroviário, ressalvados os destinados ao FC, devendo a vocação logística desses imóveis ser avaliada em conjunto pelo Ministério dos Transportes e pelo Ministério do Planejamento, Orçamento e Gestão, conforme dispuser ato do Presidente da República (Incluído pela Lei 11.772, de 2008).

O Instituto do Patrimônio Histórico e Artístico Nacional (IPHAN) recebe a responsabilidade de proteger e preservar o patrimônio ferroviário. Como consta no 9ํartigo:

Art. 9o Caberá ao Instituto do Patrimônio Histórico e Artístico Nacional IPHAN receber e administrar os bens móveis e imóveis de valor artístico, histórico e cultural, oriundos da extinta RFFSA, bem como zelar pela sua guarda e manutenção.

$\S 1$ ㄷ Caso o bem seja classificado como operacional, o IPHAN deverá garantir seu compartilhamento para uso ferroviário.

§ 2o A preservação e a difusão da Memória Ferroviária constituída pelo patrimônio artístico, cultural e histórico do setor ferroviário serão promovidas mediante:

I - construção, formação, organização, manutenção, ampliação e equipamento de museus, bibliotecas, arquivos e outras organizações culturais, bem como de suas coleções e acervos;

II - conservação e restauração de prédios, monumentos, logradouros, sítios e demais espaços oriundos da extinta RFFSA.

O Decreto no 6.018, de 22 de janeiro de 2007, por sua vez, regulamenta a Medida Provisória $n^{\circ} 353$, consequentemente regulamentando a Lei $n^{\circ}$ 11.483/2007, que dispõe sobre o término do processo de liquidação e então a extinção da RFFSA neste documento, criam a figura do Inventariante para de tarefa de realizar o prévio inventário dos bens provenientes da extinta RFFSA antes mesmo de sua incorporação ao patrimônio da União. Entre algumas atribuições, consta:

Art. 3 Constituem atribuições do Inventariante:

II - praticar atos de gestão patrimonial, contábil, financeira e administrativa, inclusive de pessoal;

$\mathrm{V}$ - identificar, localizar e relacionar os bens móveis e imóveis, dandoIhes as destinações previstas em lei, podendo, para tanto, designar comissões específicas;

VII - providenciar o tratamento dos acervos técnicos, bibliográficos, documentais e de pessoal, observadas as normas específicas, transferindo-os, mediante termo próprio, ao Arquivo Nacional ou aos órgãos e entidades que tiverem absorvido as correspondentes atribuições da extinta RFFSA;

VIII - providenciar a regularização contábil dos atos administrativos pendentes, inclusive a análise das prestações de contas dos convênios e instrumentos similares da extinta RFFSA, podendo, para tanto, designar comissões específicas; 
A Inventariança é uma organização transitória que terminará logo após o inventário do espólio da Extinta Rede for concluído (LUZ, 2011), porém ainda em 2016 encontra-se em plena atividade, mergulhada em atividades de identificação, definição, inventário, relatórios a fim de enquadrar cada item do bem patrimonial.

Ainda sobre o Decreto ํㅜ 6.018/2007, determina-se a transferência dos bens da extinta RFFSA para diferentes órgãos e destinos, a saber: à Advocacia-Geral da União; à Secretaria do Tesouro Nacional do Ministério da Fazenda; ao Ministério do Planejamento, Orçamento e Gestão; ao Instituto de Patrimônio Histórico e Artístico Nacional (IPHAN); ao Departamento Nacional de Infraestrutura e Transporte (DNIT); à VALEC (Empresa Pública de Engenharia, Construções e Ferrovias S.A.) e à Agência Nacional dos Transportes Terrestres (ANTT). Assim como compete a Secretaria de Patrimônio da União (SPU) do Ministério do Planejamento, Orçamento e Gestão, a subdelegação dos bens repassados, representando a União nos procedimentos de registro cartoriais. Deste modo, delega ao Instituto do Patrimônio Histórico Artístico Nacional (IPHAN) atribuição específica de preservar a memória ferroviária. Diz a Lei nos artigos 5ํㅜ e 7ํㅜㅇ

Art.5 durante o processo de inventariança serão transferidos: IV - ao Instituto do Patrimônio Histórico e Artístico Nacional - IPHAN:

a) os bens móveis de valor artístico, histórico e cultural, oriundos da extinta RFFSA; e

b) os convênios firmados com entidades de direito público ou privado que tenham por objeto a exploração e administração de museus ferroviários e de outros bens de interesse artístico, histórico e cultural;

Art. 7ㅇ O IPHAN deverá solicitar ao Ministério do Planejamento, Orçamento e Gestão a cessão de uso dos imóveis que forem de seu interesse, para o cumprimento do disposto no art. 9ำ da Medida Provisória no 353, de 2007.

Parágrafo único. O IPHAN poderá solicitar a cessão de bens imóveis de valor artístico, histórico e cultural, para utilização por outras entidades de direito público ou privado com o objetivo de perpetuar a memória ferroviária e contribuir para o desenvolvimento da cultura e do turismo.

Segundo a Secretaria de Patrimônio da União (SPU), foram transferidas a União cerca de 52.000 unidades $^{8}$ correspondentes terrenos e edificações não-operacionais, distribuídos em 19 estados brasileiros. Os bens não cadastrados ainda estão sendo inventariados. Tarefa de fôlego que exige desde a vistoria minuciosa dos bens, avaliação, regularização, incorporação até a destinação ao órgão específico. Também publica manual com informações sobre o Programa de Destinação do Patrimônio da Extinta RFFSA para Apoio do Desenvolvimento Local, disponível para consulta no site 9 . O material informa sobre o programa de apoiar ações em áreas de desenvolvimento social, urbano e

\footnotetext{
${ }^{8}$ Dados disponíveis para consulta no site oficial do SPU.

${ }^{9}$ http://www.rffsa.gov.br/principal/Destinacao\%20do\%20Patrimonio\%20da\%20RFFSA.PDF
} 
ambiental mediante a regularização, cessão ou compartilhamento da gestão do imóvel da União oriundos da RFFSA.

A Coordenação Técnica do Patrimônio Ferroviário do IPHAN informa que os dados preliminares da Inventariança da extinta RFFSA, oferecidos no momento de transição das responsabilidades de preservação, afirmavam um universo de bens classificados como históricos. Entre eles:

[...] 31.400 metros lineares de acervo documental, 118.000 desenhos técnicos, 74.000 itens bibliográficos, e um incalculável número de bens móveis espalhados nos escritórios regionais da RFFSA, em almoxarifados, depósitos e pátios. Além destes, também são objeto de análise e avaliação por parte do IPHAN os bens concedidos durante 0 programa de desestatização da RFFSA (CAVALCANTI NETO, CARNEIRO, GIANNECCHINI, 2012).

Importante destacar que o uso da expressão memória ferroviária pela na Lei 6.018/2007, aproxima do ato de preservação do patrimônio material ${ }^{10}$, a compreensão do patrimônio imaterial e a abrangência das implicações para com os envolvidos com a RFFSA. O IPHAN disponibiliza em seu site oficial ${ }^{11}$ verbetes do Dicionário do Patrimônio Cultural, entre eles o de memória ferroviária a seguir:

Formulada dentro do parlamento brasileiro com a intervenção das associações de ferroviários, a categoria memória ferroviária foi aplicada por meio de política pública para agir na preservação do patrimônio ferroviário. Tal como consta na supracitada Lei, o legislador equivaleu a categoria memória ferroviária a patrimônio ferroviário, segundo as práticas históricas de atribuição de valor e proteção que formaram o campo de conhecimento da instituição [...] Pode-se considerar o conceito ou categoria memória ferroviária como fiel à história monumental e tradicional, pois generaliza as especificidades com o objetivo de criar um discurso de unidade sobre um passado que foi heterogêneo, confundindo recordação, que é uma vivência direta e gera uma memória direta, com a imagem do passado, que não possui um testemunho sobre o fato. A generalização sobre 0 conceito de memória ferroviária objetificou uma política de preservação de grande envergadura, que pressupõe haver uma memória ferroviária em todos os lugares e que ela é facilmente associada a quaisquer valores (histórico, artístico, paisagístico, arquitetônico, belas artes, memória etc.) (PROCHNOW, 2015).

Conforme esclarece Lucas Neves Prochnow, em sua pesquisa de mestrado intitulada "O IPHAN e o patrimônio ferroviário: a memória ferroviária como instrumento de preservação", desenvolvida no Programa de Mestrado Profissional Preservação do

\footnotetext{
10 O patrimônio material é composto por um conjunto de bens culturais classificados segundo sua natureza nos quatro Livros Tombo: arqueológico, paisagístico e etnográfico; histórico; belas artes; e das artes aplicadas. O patrimônio imaterial abrange as mais variadas manifestações populares que contribuem para a formação da identidade cultural de um povo registrados em um Livro Tombo específico.

${ }^{11}$ http://portal.iphan.gov.br/dicionarioPatrimonioCultural/detalhes/31/memoria-ferroviaria
} 
Patrimônio Cultural PEP/MP/IPHAN, em 2014, os bens móveis não-operacionais poderão ser declarados de valor histórico, assim como os bens imóveis operacionais, passando deste modo a ser declarado de valor histórico, artístico e/ou cultural, o IPHAN poderá ter gestão total ou compartilhada desses bens com o DNIT (PROCHNOW, 2014).

Cabe destacar aspectos considerados por Marly Rodrigues, tanto quanto a finalidade social da preservação, "antes vista como a constituição de um conjunto simbólico de representação da nação, e hoje percebida como a ação de constituir um conjunto representativo das multiplicidades de memórias presentes na sociedade" (2010:33), concluindo com a relação de acesso a cultura como um direito garantido como dever do Estado, desde 1988, na Constituição Brasileira. Embora, Marly Rodrigues considere que apesar dos avanços, ainda seja necessário superar aspectos da prática preservacionista que valoriza a materialidade e restringe a herança cultural.

A concepção de patrimônio cultural exige ultrapassar a orientação de atribuição de valor aos bens materiais com o uso apenas das disciplinas de Arquitetura e de História, necessitando incluir a "fala dos homens, este sim, os únicos detentores da capacidade de lembrar e de operar memórias" (RODRIGUES, 2010:33).

Com enorme desafio, o IPHAN publica a Portaria n407/2010, instituindo a Lista de Patrimônio Cultural Ferroviário. Como instrumento para as ações de preservação, a Portaria declara como detentores de valor artísticos, histórico e cultural 639 itens, divulgados em 15 de dezembro de 2015 ${ }^{12}$. A Portaria institui ainda uma Comissão de Avaliação do Patrimônio Cultural Ferroviário que terá a função de avaliar e atribuir, ou não valor histórico, aos itens que incluem bens móveis, imóveis, paisagem e cidade, para fins de preservação e salvaguarda.

\begin{abstract}
A preservação do patrimônio ferroviário tem como base os conceitos norteadores da preservação do patrimônio industrial. Tem se buscado a coerência da preservação cultural dos bens ferroviários com as particularidades inerentes às diversas etapas do modo de produção, as referências sócio culturais de cada região onde se insere, a escala que detém e a diversidade apresentada. Entretanto, a representatividade destes bens em âmbito local e/ou regional, e a forte presença do trem na memória e imaginário da população, fez com que o IPHAN estudasse formas de atuação diferenciadas para esse universo, definindo critérios para atribuição de valor cultural aos bens desse conjunto e consequências específicas para essa valoração (CAVALCANTI NETO, CARNEIRO, GIANNECCHINI, 2011).
\end{abstract}

\footnotetext{
${ }^{12}$ Disponível em: http://portal.iphan.gov.br/uploads/ckfinder/arquivos/Lista_patrimonio_cultural_ferrovi\%C3\% A1rio_dez_2015.pdf
} 
Neste processo o IPHAN elabora uma minuta denominada "Parâmetros para declaração de valor histórico, artístico e cultural dos bens móveis e imóveis remanescentes do acervo da extinta Rede Ferroviária S.A." evidenciando a preocupação com o volume gigantesco relativo ao espólio da RFFSA, sendo que o órgão reconhece imediatamente não ter o poder de resolver de modo isolado os problemas relativos ao patrimônio ferroviário (PROCHNOW, 2014).

Cabe destacar itens da Minuta que sugerem considerar o patrimônio ferroviário em suas características físico-espaciais, ambientais, econômicas, sociais, estético/simbólico, histórico/etnográfico e funcionais (PROCHNOW, 2014), de modo a incluir o processo de formação das cidades e sua paisagem coberto pela malha ferroviária, além da vida social desenvolvida a partir daí. São itens da "política nacional de preservação do patrimônio cultural ferroviário":

I. Preservar significa definir as permanências de quê, como e para quem preservar, requerendo coleta e análise de informações capazes de revelar a identidade de sítios, edificações, vias férreas, pontes, túneis, trens, maquinaria, mobiliário e utensílios diversos, obras de arte e acervos documentais bibliográficos e arquivísticos;

II. A estrutura morfológica ou a configuração espacial faz da forma sua principal característica, por meio da qual não apenas se expõe à contemplação e informa sobre a vida social ocorrente, ao mesmo tempo que é uma fonte de entendimento histórico que interage com os que nele se encontram;

III. O estudo da configuração espacial, sob a ótica da preservação cultural, deve considerar a formação histórica do lugar, todos os elementos que compõem sua morfologia, sua função na estrutura regional e da cidade, sua dinâmica de uso, produção e apropriação simbólica por parte da sociedade;

IV. Como portador dessas múltiplas dimensões, demanda conhecimento a partir de categorias de análise e técnicas apropriadas à apreensão dessas dimensões.

Em 2008, o IPHAN cria a Coordenação Técnica do Patrimônio Ferroviário (CTPF), através da Portaria nº 208/2008, subordinada ao Departamento de Patrimônio Material (DEPAM). E, em 2009, o IPHAN realiza o I Seminário Nacional sobre Patrimônio Cultural Ferroviário Brasileiro, em Belo Horizonte (MG), a fim de realizar um fórum de discussão sobre o tema da memória ferroviária, que segundo Cavalcanti Neto requer responsabilidade compartilhada entre órgãos públicos e sociedade civil.

Em 2009, o IPHAN realiza o I Fórum Nacional do Patrimônio Cultural - Sistema Nacional do Patrimônio Cultural - Desafios, Estratégias e Experiências para uma nova gestão, em destaque aqui as duas mesas temáticas com abordagem de conteúdos específicos do patrimônio industrial ferroviário que apresentam na síntese preliminar da discussão, subsídios que refletem sobre os desafios para a formulação da política nacional e para a estruturação de um sistema nacional, destacando potencialidades do Patrimônio 
Cultural Ferroviário e apresentando ações estratégicas a partir de nove objetivos, a destacar os itens que fazem referência ao Instituto Brasileiro de Museus e aos museus de modo geral, a seguir:

d. Efetivação do plano de ação que possibilite a elaboração de estratégias, potencialidades, preservação, destinação e restauro dos bens móveis.

e. Dar continuidade, em parceria com o Instituto Brasileiro de Museus IBRAM, ao mapeamento dos acervos museográficos com temática ferroviária.

f. Dar prosseguimento ao mapeamento dos acervos de documentos ferroviários existentes com vistas à sua catalogação, organização, higienização e destinação.

g. Estabelecer procedimentos metodológicos eficazes para que o patrimônio imaterial ferroviário possa ser preservado.

h. Ampliação da parceria com museus, bibliotecas, e centros de documentação e de referência, com intuito de desenvolver estudos comuns e obter colaboração dos trabalhos realizados pelo IPHAN (IPHAN, 2010).

A necessidade de promover um debate para discutir o cenário atual, os pontos de convergências, dissonâncias e diretrizes para avanços, só seria possível a partir da reunião das autarquias, órgãos e parceiros envolvidos. O Seminário deste modo ao reunir SPU, IPHAN, Inventariança da Extinta RFFSA e DNIT, Agência Nacional de Transportes Terrestres (ANTT), Ministério Público Federal (MPF), Associação Nacional dos Transportadores Ferroviários (ANTF), Associação Brasileira de Trens Turísticos Culturais (ABOTTC), Associação Brasileira de Preservação Ferroviária (ABPF), assim como prefeituras, ONG's e OSCIP's, provocou amplo debate a respeito das atribuições, ações e objetivos dos envolvidos no processo de preservação e salvaguarda da memória ferroviária nacional.

No Rio Grande do Sul, o primeiro órgão voltado à defesa do patrimônio histórico arquitetônico e folclórico, foi criado em 1954, denominado de Divisão de Cultura do Estado. Dez anos mais tarde foi estruturada a Diretoria do Patrimônio Histórico e Artístico do Estado do RG, passando em 1979 a Coordenadoria e, em 1990, através da Portaria nº11/90 constitui-se como Instituto. O então Instituto de Patrimônio Histórico Artístico do Estado (IPHAE) realiza o primeiro tombamento em 1980, em São Leopoldo, sobre a Ponte 25 de Julho.

Como resultado da execução da política de preservação do patrimônio cultural do estado do Rio Grande do Sul, originado pelas inúmeras solicitações de tombamento dos municípios, o IPHAE organiza um Inventário das Estações Ferroviárias do Rio Grande do Sul, publicando em 2002. 
Entre as estações Tombadas no Rio Grande do Sul, tanto através dos mecanismos estaduais, IPHAE, quanto federais, IPHAN, alguns municípios também realizaram a proteção do patrimônio ferroviário através de Lista de Bens e Tombamentos. Ao total são vinte e quatro cidades com estações ferroviárias tombadas no RS, no período entre 1983 a 2011.

Quadro 2 - Estações ferroviárias tombadas no Rio Grande do Sul.

\begin{tabular}{|c|c|c|c|}
\hline Cidade & Bem patrimonial & Órgão & Data \\
\hline Rio Pardo & Estação Ferroviária e 35 bens de valor histórico cultural & Municipal & $?$ \\
\hline Montenegro & Estação Ferroviária & Estadual & 1983 \\
\hline Santo Ângelo & Estação Ferroviária & Municipal & 1984 \\
\hline Rio Grande & $\begin{array}{l}\text { Estação Central, Estação de Vila Siqueiros e Chalé de } \\
\text { Funcionários na Praia do Cassino }\end{array}$ & Municipal & $\begin{array}{c}1986 \text { e } \\
1990\end{array}$ \\
\hline General Câmara & Estação de Santo Amaro - Conjunto Histórico da Vila Santo Amaro & Federal & 1988 \\
\hline São Leopoldo & Estação Ferroviária & Estadual & 1990 \\
\hline Santa Maria & Estação Ferroviária & Estadual & 1990 \\
\hline Passo Fundo & Estação Ferroviária & Municipal & 1991 \\
\hline Santa Maria & Estação Ferroviária & Municipal & 1996 \\
\hline $\begin{array}{l}\text { Várzea Grande- } \\
\text { Gramado }\end{array}$ & Estação Ferroviária & Municipal & 1998 \\
\hline Pelotas & Estação Ferroviária & Municipal & 1998 \\
\hline Marcelino Ramos & Estação Ferroviária & Municipal & 1999 \\
\hline Gaurama & Estação Ferroviária & Municipal & 1999 \\
\hline Uruguaiana & Estação Ferroviária & Municipal & 1999 \\
\hline Carlos Barbosa & Estação Ferroviária & Municipal & 1999 \\
\hline Erechim & Estação Ferroviária & Municipal & 2000 \\
\hline Erebango & Estação Ferroviária & Municipal & 2000 \\
\hline Pedras Altas & Estação Ferroviária & Municipal & 2001 \\
\hline Portão & Estação Ferroviária & Municipal & 2006 \\
\hline Portão & Estação Ferroviária & Federal & 2007 \\
\hline Nova Sardenha & Estação Ferroviária & Municipal & 2007 \\
\hline Cacequi & Estação Ferroviária & Municipal & 2008 \\
\hline Canoas & Estação Ferroviária & Municipal & 2010 \\
\hline Caxias do Sul & Estação Ferroviária & Estadual & 2011 \\
\hline
\end{tabular}

Fonte: elaborado pela autora. 
Apesar dos processos de tombamento, muitos dos referidos edifícios estão sem cuidados, abandonados mesmo na condição de Bem Tombado. Outros estão descaracterizados e poucos se mantêm inserido com oficinas, rotundas, residências, objetos móveis como locomotivas, vagões e carros, ou mesmo em um conjunto de referência restaurado e preservado como o Sítio Histórico do Museu do Trem de São Leopoldo.

O lugar do patrimônio industrial ferroviário ainda é recente, considerando que são inúmeras as questões históricas que se atravessam, em especial, no caso brasileiro. Segundo Rodrigues o traçado ferroviário mapeia a localização das plantas industriais, apesar de ainda pouco se observar com relação à localização das fábricas e o desenho dos bairros e vilas formados a partir desta (2010), porém destaca que o fator "nostalgia" por um lado, impulsiona pedidos de tombamento, e por outro, provoca a resistência ao aprofundamento dos estudos sobre os complexos ferroviários, deixando de esclarecer questões importante econômicas, tecnológicas e sociais, relativas aos setores industriais e ao crescimento das cidades.

No caso específico das ferrovias, o tombamento das estações, cujo papel
só pode ser compreendido no contexto amplo que sustenta funcional e
tecnologicamente o sistema ferroviário, composto de itens como
armazéns, oficinas, residências, instalações mecânicas, revela
nitidamente a tendência de consolidação da imagem nostálgica do
passado e do tratamento unitário de partes, ainda preponderantes sobre
o tratamento dos sistemas industriais (RODRIGUES, 2010:39).

Eduardo Romero de Oliveira reflete a construção da memória a partir de aspectos simbólicos ressaltados pelo significado da ferrovia no desenvolvimento econômico e geográfico de cidades, onde paisagens foram sendo modificadas à medida que o transporte ferroviário crescia, assim como famílias foram sedimentando vínculos e o desenvolvimento foi ofertando uma aproximação rápida com a modernidade. Destaco quatro itens apontados pelo autor, a partir das comemorações do Centenário da Ferrovia, "que extrapola a política institucional de preservação e nos leva a considerar outras formas de elaboração da memória que redundam na valoração patrimonial" (OLIVEIRA, 2013:706) sendo, por sua vez, parte determinante nas ações que objetivam reunir acervos, assim como na formação dos museus ferroviários. São eles: a hiper valorização da imagem nacionalista do Barão de Mauá; narrativas históricas produzidas por engenheiros em vista de identificar a evolução tecnológica; a imagem da degradação do transporte ferroviário $x$ a defesa de sua recomposição como projeto político. "As imagens da perda e do progresso funcionam juntas" (OLIVEIRA, 2013:708). E por último, Oliveira destaca: ferrovia responsável pela expansão político-social, 
a imagem do abandono da ferrovia ganha força como perda do essencial (riqueza e povoamento), assim como a recuperação cobra sua urgência. A celebração traz a imagem de uma integração do espaço nacional promovida pelos transportes ferroviários. Tais elementos recuperam as narrativas históricas das estradas de ferro e reelaboram a memória ferroviária (OLIVEIRA, 2013:709).

Inúmeras estações ferroviárias após o processo de tombamento foram transformadas em centros culturais, museus históricos, espaços expositivos de arte ou com memorial sobre a ferrovia, bibliotecas, ou mesmo utilizada por departamentos de órgão municipais como secretaria de turismo, cultura, educação ou outros setores.

Segundo a arquiteta, Profa.Dra. Beatriz Mugayar Kühl, da Faculdade de Urbanismo e Arquitetura, da Universidade de São Paulo (FAU-USP), as estações ferroviárias são alvo de inúmeras solicitações de estudo para tombamento no estado de São Paulo, apesar de inexpressivas, quanto ao legado ferroviário no estado. Os cuidados posteriores ao tombamento que, na maioria das vezes, além de desrespeitas as características do prédio são isoladas, do contexto ao qual fazem parte, ou mesmo esquecidas e abandonadas (KÜHL, 2010). Questões relacionadas à ocupação das antigas estações e os processos de musealização serão abordadas nos próximos textos. 


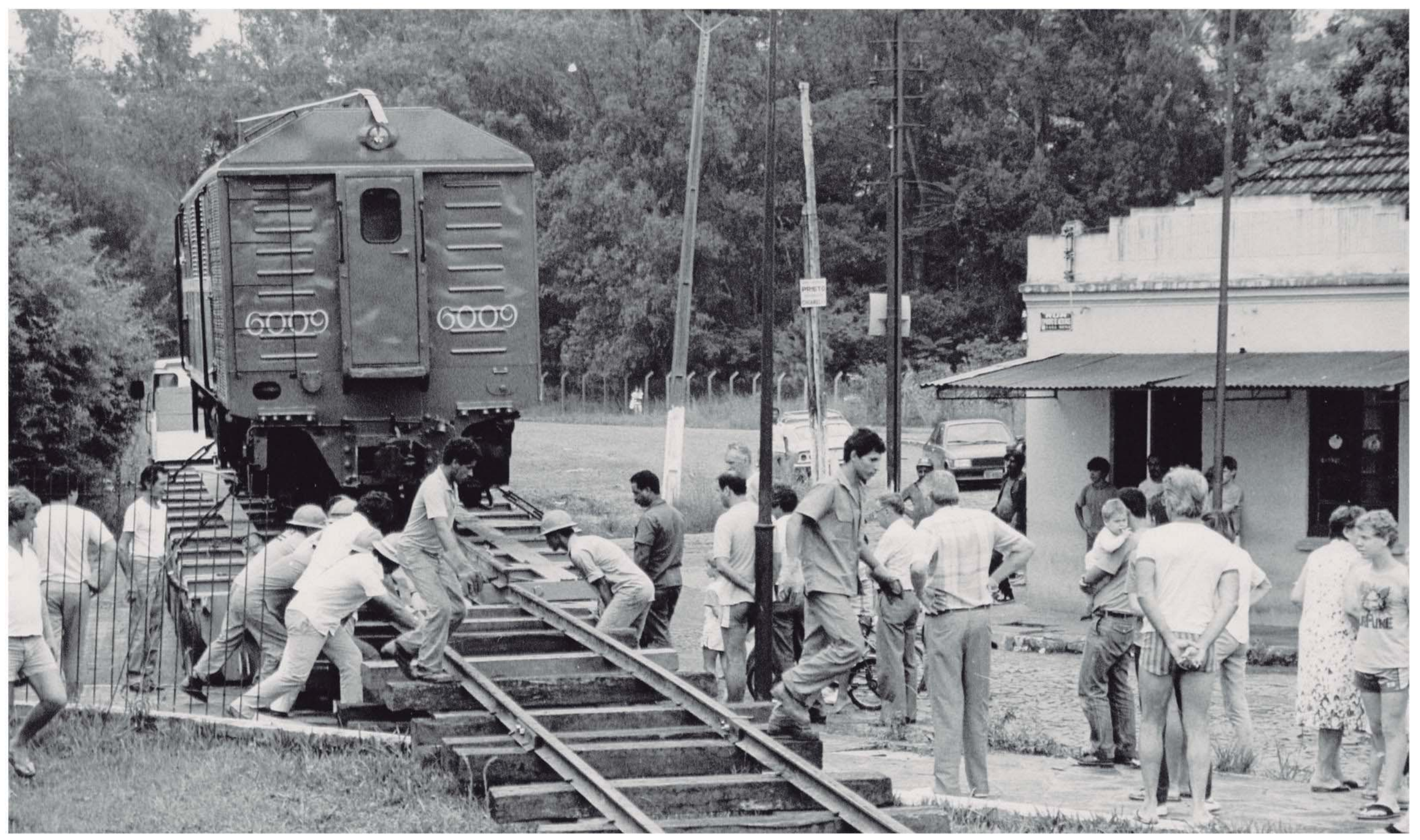

Capítulo 2 
A história da ferrovia se confunde com aspectos da história das instituições museológicas ferroviárias. Faz-se necessário identificar e distinguir da trajetória da ferrovia a história das instituições museológicas, a fim de compreender separadamente cada uma delas. O segundo capítulo se dedica a apresentar as instituições que acolhem o patrimônio industrial ferroviário no Brasil.

A pouca literatura sobre os museus ferroviários, em especial sobre os museus ferroviários brasileiros, e sobretudo, sobre o Museu do Trem de São Leopoldo, motivou a escrita deste capítulo, remontando um relato histórico. A pesquisa sobre a instituição leopoldense impulsionou desvelar um cenário nacional a partir da identificação de iniciativas desde a idealização de um museu do Ministério dos Transportes desdobrada da criação dos Centros de Preservação na qual São Leopoldo está inserido.

Foram realizadas entrevistas ${ }^{13}$ no Grêmio Esportivo Ferrinho, em Porto Alegre, no Museu do Trem do Engenho de Dentro, Rio de Janeiro, além de entrevistas em residências, em 2015, com objetivo específico de coletar informações para esta pesquisa. Assim como formam pesquisadas entrevistas ${ }^{14}$ gravadas pelo Museu do Trem de São Leopoldo, em 2011, com interesse de fazer coletar informações para um breve relato histórico institucional na ocasião dos seus 35 anos.

Foi necessário aproximar informações orais aos dados identificados em documentos históricos. A sistematização cronológica é apresentada em dois capítulos: Museus Ferroviários e Museu do Trem de São Leopoldo. A pesquisa histórica não se encerra aqui, considerando que a sistematização elenca um campo que se amplia, apontando a necessidade de aprofundar as investigações na busca de novas fontes e documentos, talvez ainda desconhecido.

\footnotetext{
${ }^{13}$ Entrevistas realizadas através da disciplina de Fotografia Documental, Universidade Luterana do Brasil, ministrada pela Profa. Me. Alice Bemvenuti, nos anos de 2013 a 2015, em projeto de pesquisa com acadêmicos.

14 Depoimentos colhidos, em 2011, pela equipe do Museu do Trem de São Leopoldo com objetivo de editar um vídeo comemorativo que não foi finalizado. A captação das imagens foi realizada com parcerias, o que também exigiu localizar as cópias originais para utilização nesta pesquisa, tendo sido transcritos em 2015, por esta pesquisadora, parte do material localizado.
} 


\subsection{INICIATIVAS ISOLADAS}

Os processos de investigação e de musealização do patrimônio industrial ferroviário podem ser pensados sob a ótica interdisciplinar (RODRIGUES DA SILVA, 2014). Os campos de conhecimento e os saberes envolvidos determinam parte do universo aparentemente fragmentado e confuso de fatos isolados que sequenciam um conjunto de situações. Para tanto, apenas com a localização e identificação de envolvidos torna-se possível agregar informações que componha um cenário histórico abrangente. Faz-se necessária uma investigação atenta e detalhada. Opta-se aqui pela apresentação cronológica de dados, a partir da pesquisa bibliográfica e de depoimentos orais, que remontam a história ainda não sistematizada. Mesmo sendo esta como uma primeira organização, portanto abrangente, vê nos fatos históricos do conjunto, como fundamentais para a identificação dos altos e baixos na trajetória dos museus ferroviários.

No estado de São Paulo, são duas as iniciativas. A primeira na cidade de Bauru, onde se encontra o entroncamento ferroviário paulista de maior complexidade, com volume de movimentação envolvendo 1.150 funcionários e a manutenção em 134 locomotivas ao ano15. Neste é fundado o Museu Ferroviário, no governo do Dr. Alcides Franciscato, através da Lei ํㅜ 1425. Criado em 11 de julho de 1969, mas sem o registro de atividades. Em 1986, teve seu nome alterado para Museu Ferroviário Regional de Bauru com a intenção de abrigar os acervos provenientes das ferrovias Estrada de Ferro Sorocaba (EFS), Estrada de Ferro Noroeste do Brasil (EFNOV) e Companhia Paulista de Estrada de Ferro (CPEF), e expor objetos de cada ferrovia. Apenas com a ação da RFFSA, através do PRESERVE, em 1989, inauguram neste Museu à primeira exposição de longa duração, com projeto da museóloga Telma Lasmar. Na ocasião adaptaram, o prédio ao lado da Estação Ferroviária, onde se localizavam os escritórios da Diretoria Administrativa da EFNOB, o espaço do Museu. Espaço que foi integrado ao PRESERVE como Núcleo Histórico Ferroviário de Bauru (NHFB). Com relação ao agrupamento e subdivisão do acervo, caberia uma investigação minuciosa.

Na década de 1990 o Governo Federal concede a liberação para uso das linhas para o NHFB que promove excursões e passeis de "Maria Fumaça". O Tombamento foi realizado em 1994, quando o prédio da estação foi desativado. E, em 2005 e 2014, verificam-se atividades de reparos em locomotiva, modificações estruturais no patrimônio

\footnotetext{
${ }^{15}$ Dados apresentados no trabalho de Iniciação Científica é parte do Projeto de Pesquisa: EFNOB/BAURUKM0, vinculado à FAPESP, processo no.: 2011/51014-6, e CONDEPHAAT, processo no.: 2012/50041-2 cujo intuito é o levantamento documental e o inventário do patrimônio ferroviário da EFNOB em Bauru, realizado por Felipe Alves van Ham, com orientação do Prof. Dr. Nilson Ghirardello (UNESP).
} 
edificado, conservação e ampliação de espaços para o uso do Museu. Hoje conhecido como Ferroviário Regional de Bauru (MFRB) e/ou Museu Ferroviário Regional Eng. Cássio Augusto Szeligowski Vilaça, encontra-se aberto a visitação, com atividades educativas, e disponibiliza conteúdos em rede social ${ }^{16}$.

A segunda iniciativa ocorreu na cidade de Jundiaí. Em 1971, foi dirigida ao Diretor de Operações, Eng. Alfredo de Azedo Marques uma carta com manifestação de funcionários que revelavam suas preocupações com o descarte do acervo ferroviário (SCHOENMAKER, 2016; OLIVEIRA, 2010). Em 1979, inauguram o Museu Ferroviário Irineu Evangelista de Souza - Barão de Mauá - subordinado a Ferrovias Paulista S/A (FEPASA) ${ }^{17}$, para ser um centro de referência com intuito de preservar bens de valor histórico das cinco empresas que a constituíam. Em 1995, o Museu Barão de Mauá foi renomeado para Museu da Companhia Paulista. Após a incorporação da FEPASA à RFFSA e sua extinção, decorreu um período de dificuldades de administração e de preservação dos bens ferroviários. Em 2000, um grupo de ex-ferroviários cria a Associação de Preservação da Memória da Companhia Paulista (OLIVEIRA, 2010), impulsionando projetos de restauro, porém atua apenas até 2002. Na sequencia o acervo é desmembrado, sendo parte transferida para o bairro Bom Retiro. Em 2016 o Museu encontra-se aberto, oferecendo atividades educativas, e disponibiliza conteúdo em rede social ${ }^{18}$.

No estado de Pernambuco por iniciativa da RFFSA, a partir da ação coordenada pela 3a Divisão Nordeste, da Rede Ferroviária, juntamente com o Instituto Nabuco de Pesquisas Sociais, fundaram na própria Estação Central, o Museu do Trem de Recife, em 25 de outubro de 1972. Na década de 1980, com o Programa de Preservação do Patrimônio Histórico do Ministério dos Transportes (PRESERVE), o Museu é remodelado e reinaugurado como Centro de Preservação da História Ferroviária de Recife (CPHFR), em 1983. Porém, nesse mesmo ano o Museu precisou ser fechado para a construção do metrô, sendo reaberto dois anos após. A Estação Central Capiba foi desativada nos anos 1990, sendo que o espaço foi reformado para a reinauguração em 2011, quando sua administração passou do Banco do Brasil para a Fundação do Patrimônio Histórico e Artístico de Pernambuco (FUNDARPE). Hoje o Museu encontra-se aberto a visitação, com setor

\footnotetext{
${ }_{16}$ Disponível em http://hotsite.bauru.sp.gov.br/museuferroviario/Sobre.aspx

17 No final da década de 1960 as empresas Estradas de Ferro Sorocabana, Companhia Paulista Estradas de Ferro, Companhia Mogiana de Estradas de Ferro, Estradas de Ferro Araraquara e Estradas de Ferro São Paulo-Minas foram incorporadas e passam para o Governo do Estado de São Paulo formando uma única empresa, Ferrovias Paulista S/A (FEPASA), sendo que na década de 1990 todo o patrimônio da FEPASA é incorporado à Rede Ferroviária Federal S/A (RFFSA).

18 Disponível em http://museudacompanhiapaulista.jundiai.sp.gov.br/
} 
para atividades educativas, e disponibiliza informações em rede social ${ }^{19}$ através da Secretaria de Cultura do Estado.

No estado do Rio Grande do Sul há um fato, aparentemente isolado, que também deve ser considerado. Diz respeito aos documentos localizados ${ }^{20}$ no Museu do Trem de São Leopoldo e que revelam a abertura de um Museu Ferroviário ${ }^{21}$ da Viação Férrea do Rio Grande do Sul (VFRGS), em Porto Alegre, na década de 1960 (figura 01). Entre os documentos localizados estão: um caderno de abertura do Museu Ferroviário da Viação Férrea do Rio Grande do Sul (VFRGS), com data impressa pela VFRGS em 04 de novembro de 1965; texto manuscrito, assinado por Nilza Damasceno de Castro; registro de assinaturas de autoridade e ferroviários presentes em uma cerimônia de fundação do Museu; correspondências institucionais entre diferentes setores da SR6 e a coordenadora do Museu, que datam de 1965 até 1968. Nas correspondências os assuntos: nomeação da funcionária Nilza Damasceno de Castro, então responsável pela Biblioteca Regional da RFFSA de Porto Alegre, para a coordenação do Museu; avaliação de peças para compor o acervo do referido Museu; listagem de patrimonialização de móveis para funções administrativas e peças agrupadas; deslocamento de objetos e avaliação para um possível restauro. A existência de tal fato impulsionou uma busca nos arquivos do Escritório de Inventariança da Extinta Rede 22 . Encontrou-se apenas a ficha de funcionária (fig. 02) da ferroviária Nilza Damasceno de Castro, onde consta sua admissão na Rede como auxiliar de desenhista, em 1944, tendo assumido posteriormente, em 1954, o cargo de copista. Não informando qualquer atividade desenvolvida como bibliotecária e/ou coordenadora do Museu Ferroviário na Regional de Porto Alegre. Também não foi localizado livro tombo ou registro do acervo, assim como nenhuma indicação de transferência de peças pelo referido Museu ao atual Museu do Trem de São Leopoldo.

\footnotetext{
19 Disponível em http://www.cultura.pe.gov.br/pagina/espacosculturais/museudotrem/

20 Documentos localizados em 2010 por ocasião de pesquisas desenvolvidas pela equipe do Museu do Trem de São Leopoldo, com intuito de obter dados da história da instituição para divulgar a comunidade em seu aniversário de 35 anos, a ocorrer em novembro de 2011.

21 Também se identifica a denominação de Museu Histórico da Viação Férrea do Rio Grande do Sul para o mesmo Museu.

22 O Escritório de Inventariança da Extinta Rede Ferroviária Federal S.A. abriga um extenso arquivo com fichas de funcionário com objetivo inicial de ter dados para os desdobramentos jurídicos que ainda estão em andamento. Os arquivos se encontram em segurança, porém os documentos não são considerados arquivos históricos, podendo ser descartado a qualquer momento, à medida que não cumprirem mais com o objetivo de auxiliar em questões administrativas e jurídicas de encerramento da Rede, ou quando o funcionário que de algum modo cuida, for aposentado.
} 


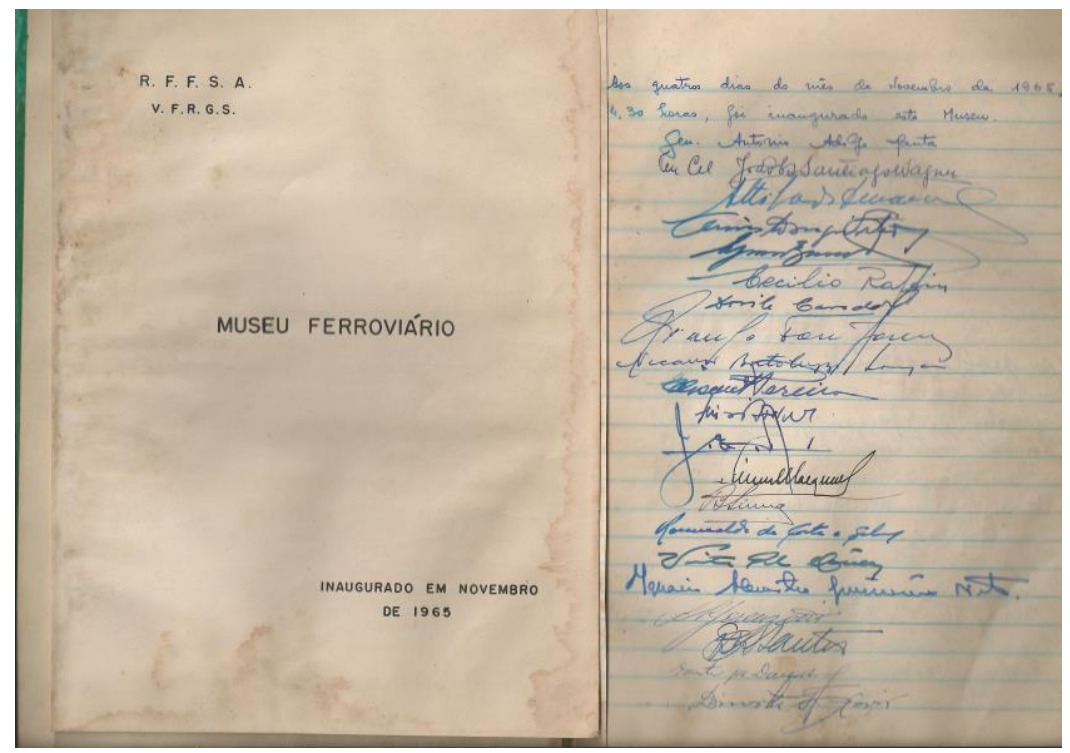

Figura 2 - Livro de Registro da abertura do Museu Ferroviário da VFRGS/ RFFSA. Fonte: Museu do Trem de São Leopoldo.

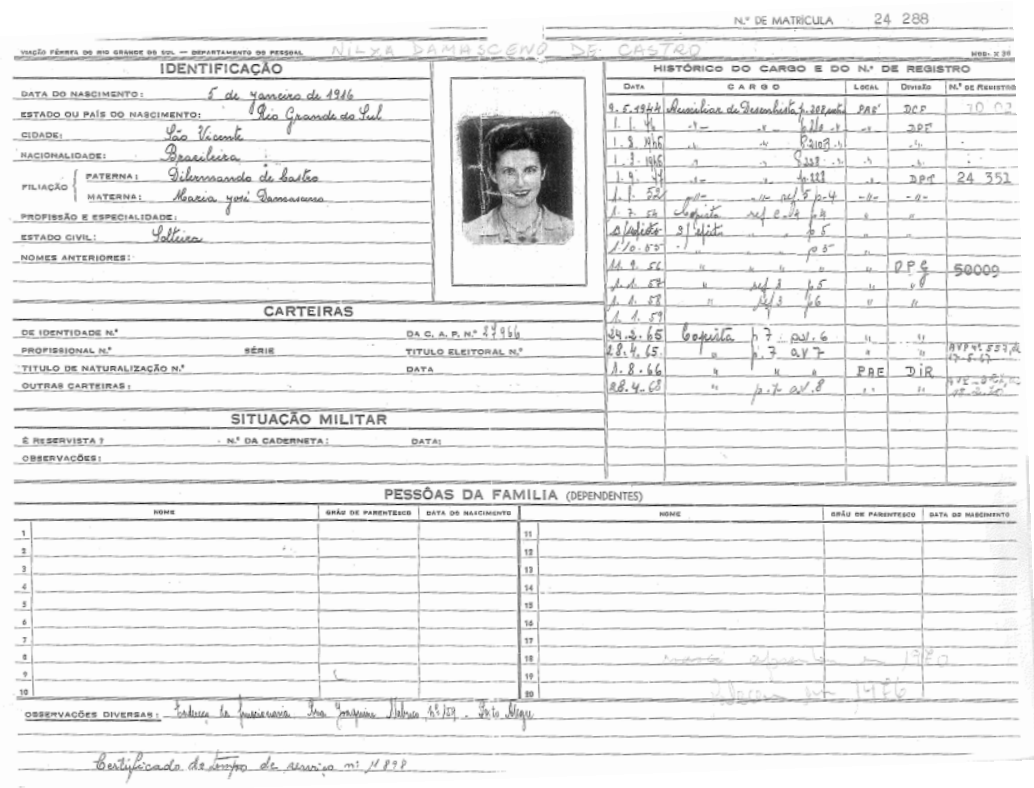

Figura 3 - Ficha de funcionária da Nilza Damasceno de Castro. Fonte: Arquivos da Inventariança da Extinta RFFSA, Porto Alegre

O Governo Brasileiro não era o único a realizar ações de preservação e de organização do acervo ferroviário, porém as ações governamentais, em geral, mantêm algum tipo de registros, seja em relatório ou na veiculação de notícias impressas, o que garante, em parte, a existência do fato, facilitando a investigação e a pesquisa. Mesmo assim, difícil afirmar com exatidão um local e uma data, ou mesmo, uma iniciativa que tenha originado o primeiro museu ferroviário, pois o campo de iniciativas demonstra ser ainda pouco conhecido e, considerando que a investigação possa levar a novas descobertas, o que permite apontar nesta dissertação, não uma iniciativa primeira, mas iniciativas, no plural. 
Em 1976, aparentemente em outro contexto, foi criado o Museu do Trem de São Leopoldo, numa iniciativa em conjunto entre a Prefeitura Municipal, o Museu Histórico Visconde de São Leopoldo (MHVSL) e a RFFSA, através da SR6. É possível detalhar fatos, a partir de novas investigações nas atas o $\mathrm{MHVS}^{23}$.

Ainda no mesmo período, outras iniciativas com interesse preservacionista constituíram-se como a Associação Brasileira de Preservação Ferroviária (ABPF). Preocupada com a recuperação de locomotivas e trechos para fins de viagens em trens turísticos, a ABPF, fundada em 1977, teve papel fundamental na preservação do material rodante e na gestão de museus com trens turísticos, conveniados com administrações públicas. A Associação agrega sócios em Regionais distribuídas nos estados, atuando também com consultoria e estudo de viabilidade de implantação de trens históricos e turísticos, operação de locomotivas, carros, vagões e estações.

As partir destes dados, pode-se dizer, por um lado, que quatro museus marcaram o início da criação das instituições museológicas ferroviárias brasileiras, no período entre o final da década de 1960 e a década de 1970. Por outro lado, considerando as preocupações com os transportes em geral, podemos agregar o Museu Rodoviário de Departamento de Estradas de Rodagem (DNER), criado em 1972.

\subsection{PRESERVE/PRESERFE}

Em 1980, o Ministério dos Transportes cria o Programa de Preservação do Patrimônio Histórico (PRESERVE) através da Portaria nำ292, de 24 de abril de 1980, da Secretaria Geral do Ministério dos Transportes, designando a museóloga Maria Elisa Carrazzoni para coordenar a implantação do Programa.

Com intuito de reunir o ativo histórico das diferentes áreas relacionadas ao transporte (rodoviária, marítima ou ferroviária) planejava-se a criação de Museu Nacional dos Transportes, com sede em Brasília-DF (BUZELIN, 2010; RFFSA, 1982; MORAIS, 2015), para tanto planejava-se identificar material referente ao Ministério dos Transportes, reunir em local apropriado, cuidar, preservar, restaurar e documentar a evolução dos transportes no Brasil (1982).

Mas cada área do transporte se envolveu, de modo diferente, o PRESERVE a RFFSA constitui-se através de Grupo de Trabalho interdisciplinar vinculado diretamente

\footnotetext{
${ }^{23}$ Foram localizados nos livros de Ata n 4 e nำ 7, conteúdo referente a parte das ações realizadas pelo MHVSL na organização do Museu do Trem. O aprofundamento dos documentos deve ser considerado em futuras investigações.
} 
ao Diretor de Patrimônio da Administração Geral e coordenado por um representante da RFFSA junto ao Ministério. Integravam representantes das áreas de Patrimônio, Engenharia, Materiais e Operações, Arquitetos, Desenhistas, estagiários e apoio administrativo. Também foram criados Grupos de Preservação nas Regionais e Divisão Especial Subúrbios do Grande Rio, que trabalhavam em parceria com os órgãos de Comunicação Social. Estavam contemplados os serviços especializados nas áreas da museologia, pesquisa do patrimônio histórico, restauração, fotografia e programação visuais (RFFSA, 1982).

Em 1983, o Ministério dos Transportes lança Portaria nำ126, em 01 de fevereiro, constituindo a Comissão de Coordenação das Atividades do PRESERVE (CCP), com a finalidade de coordenar o planejamento, o desenvolvimento, a implantação e o acompanhamento das atividades do Programa em todas as áreas vinculadas ao Ministério dos Transportes.

O arquiteto Sérgio Santos Morais, primeiro funcionário da Rede a integrar o PRESERVE, atuou nos projetos de restauro em todo País, com destaque para os projetos de restauro do Complexo Ferroviário e da Rotunda de São João Del Rei, inaugurados em 1991 e 1996, respectivamente. Sérgio ingressa na RFFSA em 1976 e se aposenta em 1993. Também participaram da equipe as museólogas Telma Lasmar, Maria Thereza Kahl Fonseca, o arquiteto Claudio Bacalhau, com coordenação geral da museóloga Maria Elisa Carrazzoni.

Para coordenar a equipe do PRESERVE, foi convidada Maria Elisa Carrazzoni, museóloga que havia estado como diretora do Museu Nacional de Belas Artes, no Rio de Janeiro, e acumulava em seu currículo estudos e atividades no Brasil e no exterior. Relata Morais:

\begin{abstract}
Eu fui o primeiro funcionário da Rede a ser escalado para trabalhar no PRESERVE. Isso remonta ao ano de 1980, quando foi instituído o PRESERVE no âmbito do Ministério dos Transportes. E foi, então, designada uma museóloga, Maria Elisa Carrazzoni, renomada na época, porque ela tinha sido diretora do Museu de Belas Artes durante um tempo. Ela estava editando um livro sobre bens tomados, pelo IPHAN, no Brasil. E ela tinha know how muito grande. Ela sempre muito atuante, muito inteligente, muito perspicaz (MORAIS, 2015, entrevista).
\end{abstract}

O PRESERVE realizava ações simultâneas em diferentes estados. Ao mesmo tempo em que desenvolvia pesquisa histórica sobre a ferrovia (com atenção para cada Estrada de Ferro), peças do acervo e edificações, realizava também o levantamento dos locais com diagnósticos, estudos de viabilidade, planos de restauro, estudos de adaptação para remodelar espaço, além de aproximação com prefeituras e demais envolvidas com 
cada região e cada situação em especial. Os projetos envolveram nos primeiros anos recuperação de parte do patrimônio vinculado ao transporte ferroviário, portuário e rodoviário, sendo que o setor ferroviário teve um expressivo envolvimento. Encontram-se convênio entre portos e a RFFSA, onde havia estação em área portuária (PRESERVE, 1984; 1988; 1989).

Conforme relatórios ${ }^{24}$ publicados do PRESERVE, os primeiros trabalhos desenvolvidos com o patrimônio ferroviário foram as pesquisas para um posterior restauro no carro que serviu ao D.Pedro II, denominado Carro do Imperador ${ }^{25}$, e a pesquisa em torno da antiga Estrada de Ferro Oeste de Minas, para posterior implantação do Museu Ferroviário de São João Del Rei.

Em 1981, o PRESERVE inaugura o primeiro Museu Ferroviário de São João Del Rei, Minas Gerais. Nos estudos de viabilidade verificou-se a importância do patrimônio ferroviário da região, e ao mesmo tempo do trecho de bitola $0,76 \mathrm{~cm}$, considerando que este modelo está sendo substituído, com risco de extinção (PRESERVE, 1981), deste modo a recuperação foi subdividida em dois módulos: "o primeiro seria o módulo destinado à informação do público através de documentos e peças e o segundo seria dinâmico, formado pela antiga ferrovia em funcionamento" (CARRAZZONI, 1981). A ação desencadeada envolveu obras de restauro e adaptação no antigo Armazém, na Gare e na Estação. Foram restaurados: Vagão (conhecido como tatu), Locomotiva Baldwin no1, Carro da Administração, Guindaste, Carro Pagador e composição de carros de passageiros,

Com muitas questões polêmicas pelo volume de patrimônio ferroviário depositado, como também pelo estado de abandono, denúncia e disputas políticas, São João Del Rei retrata o cenário que, em maior ou menor proporção, se repete em outras localidades.

O relatório também detalha atividades com a organização da documentação do Carro do Imperador Pedro II, no Rio de Janeiro, a fim de realizar a restauração; estudos para instalação dos Centros de Preservação da História Ferroviária nos estados do Ceará e de Pernambuco.

A experiência com a realização do primeiro museu pelo PRESERVE colaborou com a mudança de rumo do projeto inicial do Ministério, que consistia em criar um Museu Nacional dos Transpores. Em São João Del Rei a equipe do PRESERVE enfrentou

\footnotetext{
24 Foram publicados três relatórios: 1980-84; 1980-1988; 1980-89.

25 O Carro do Imperador foi imunizado contra cupim, sendo a parte interna desmontada e seus acessórios acondicionados (MINISTÉRIO DOS TRANSPORTES, 1982).
} 
inúmeras dificuldades ao retirar a Locomotiva №1, que estava sendo utilizada como objeto decorativo em outro município mineiro (MORAIS, 2015). São João Del Rei, de algum modo, serviu como amostra em escala nacional do que poderia ser enfrentado, caso o projeto de um museu único permanecesse. Além desta questão, chama a atenção à reflexão sobre cuidados com a memória ferroviária, pois conforme Morais haveria esvaziamento de sentido dos objetos ao serem afastados do local de origem, pela perda de referenciais vinculados diretamente com os envolvidos locais, além dos trâmites para permissão dos deslocamentos, que provocariam polêmicas desastrosas na ordem política entre cidades, estados e o Ministério.

O PRESERVE ao invés de dar sequência à institucionalização do Museu dos Transportes, com sede em Brasília, propõe Centros de Preservação da História Ferroviária (CPHF), espalhados nas diferentes regiões e que para isso deveria ter representantes ativos nas Superintendências Regionais. Após inaugurar CPHF de São João Del Rei, realizou-se a instalação de outros Centros de Preservação. Em 1982, os Centros de Preservação da História Ferroviária do Ceará (CPHFC), em Fortaleza; do CPHF de Recife, em Pernambuco; e do CPHF do Paraná e Santa Catarina, em Curitiba. No Rio de Janeiro, seguiram as pesquisas e os registros relativos ao Carro do Imperador, além das pesquisas históricas das Oficinas do Engenho de Dentro. Realizam o Tombamento do acervo existente nas Oficinas e instalam a Reserva Técnica no $2^{\circ}$ andar do prédio. Elaboração do projeto arquitetônico para a formalização do CPHF do Rio de Janeiro, no Engenho de Dentro, e iniciaram as obras de restauro e adaptação do galpão.

No Rio Grande do Sul, em 1982, onde seria instalado o Centro de Preservação da História Ferroviária do Rio Grande do Sul (CPHFRS), restauram o antigo Armazém de carga e organizam a Reserva Técnica, e o prédio principal da Estação de São Leopoldo onde seria posteriormente montada a exposição. Para a cidade de Rio Pardo, no Rio Grande do Sul, também foram desenvolvidos projetos de restauro para a Estação.

Diferentemente dos setores marítimo e rodoviário, o setor ferroviário concretizou, grandes ações na recuperação da memória com o restauro e preservação do patrimônio. Os projetos desenvolvidos pelo PRESERVE chamam a atenção pelo nível técnico qualificado dos profissionais e dos resultados. Observando as datas de criação dos CHPF e dos NHF, fica evidente o grande investimento financeiro realizado pelo Ministério dos Transporte, no Setor do PRESERVE/RFFSA, assim como evidências da dedicação e do comprometimento dos funcionários, quando em pouco espaço de tempo verifica-se a inauguração de mais de um CPHF em estados diferentes. 
A preocupação com a instalação dos Centros de Preservação compreendia um conjunto em todo o País. Conforme Maria Elisa Carrazzoni, Coordenadora do PRESERVE:

Os Centros de Preservação da História Ferroviária que a RFFSA está instalando, têm todos o mesmo objetivo e podem parecer iguais para os que os olharem superficialmente. Para os bons observadores será fácil identificar sua diversidade: cada um deles reflete o desenvolvimento socioeconômico da região em que se encontram; mostram que as diferentes origens do capital que financiava a criação das ferrovias se refletiam no material importado para o funcionamento das mesmas; enfatizam as diversas características da arquitetura ferroviária documentando a influência recebida através do capita I e dos técnicos estrangeiros; preservam e exibem parte da riquíssima documentação fotográfica que fixa os aspectos de cada região, antes e depois da ferrovia, com grande número de projetos de pontes e túneis, alguns já centenários e utilizados para estudos e consulta dos engenheiros, pois ainda estão lá as pontes e os túneis a que precederam (PRESERVE, 1982).

As inaugurações dos CPHF culminavam com um conjunto de entregas a comunidade local, desde os restauros dos prédios com a remodelação dos pátios ferroviários, a organização do museu e com reserva técnica e exposição, a equipe técnica de profissionais, além da publicação de um encarte, com divulgação e informações do novo Centro de Preservação e a publicação de um livro, em formato de catálogo.

Para cada CPHF foi produzido um livro-catálogo iniciando com apresentação de pequenos textos assinados pelos presidentes e diretores do MT, RFFSA e PRESERVE e um texto técnico, de cunho histórico, realizado a partir da pesquisa sobre o patrimônio ferroviário e o acervo local. Deste modo, o material tornava-se rapidamente uma referência para consulta de dados da ferrovia local com fotos históricas e do acervo.
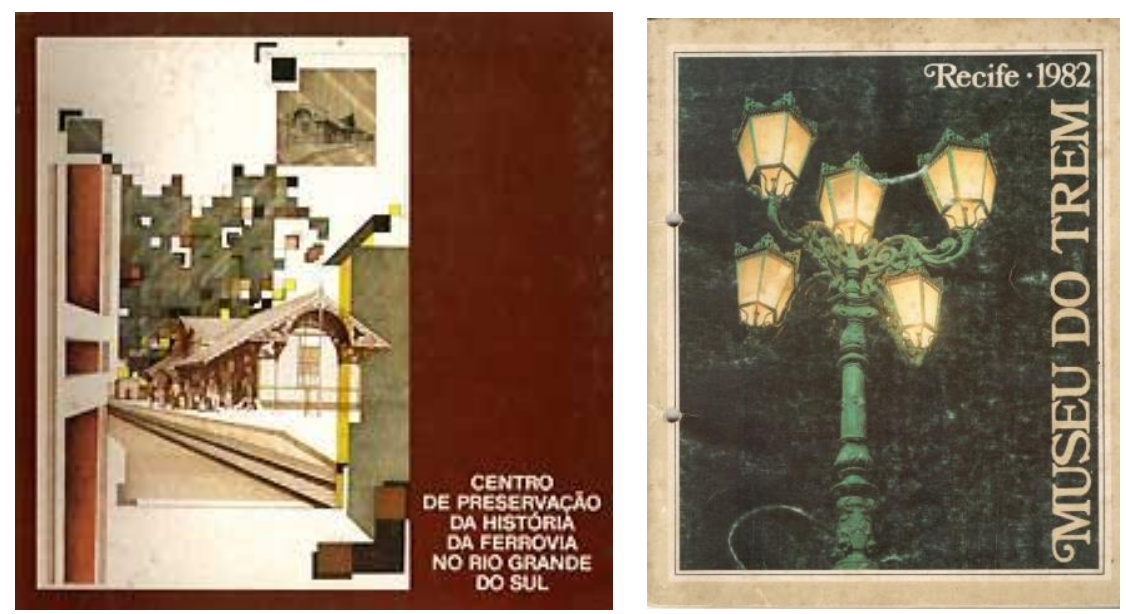

Figuras 4 e 5 - capa do catálogo do CPHFRS e capa do catálogo do Museu do Trem de Recife. Fonte: Museu do Trem de São Leopoldo. 

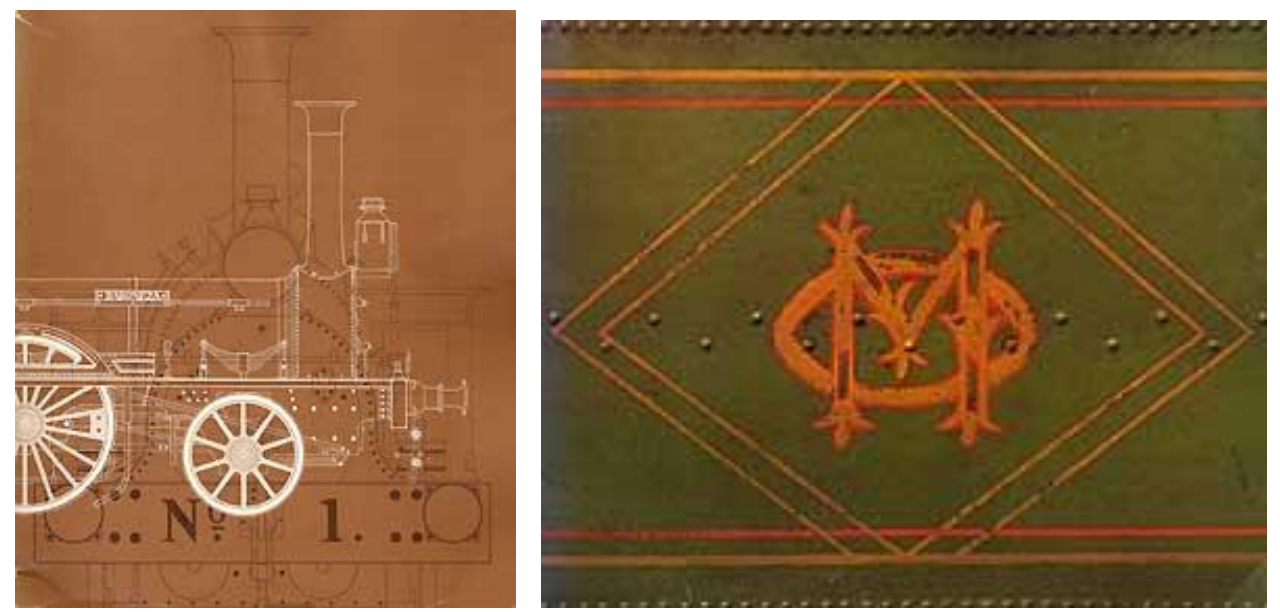

Figuras 6 e 7 - Capa do catálogo do CPHFRJ e capa do catálogo do Museu Ferroviário de SJDR Fonte: Acervo pessoal de Alice Bemvenuti e Acervo Pessoal de Manoel Monascheci

Verifica-se que os conteúdos apresentados são derivados de pesquisas de responsabilidade de diferentes profissionais. Alguns tópicos são semelhantes, outros são relacionados ao contexto da região específica. Entre os assuntos: breves tópicos da história mundial, brasileira e local da ferrovia; a linha do tempo geral; a criação da tecnologia da máquina a vapor no mundo; a classificação das locomotivas; o telégrafo e o código Morse; história e fotografia de objetos do acervo de cada CPHF; carros de passageiros utilizados por autoridades com fotografias dos gabinetes de trabalho e do luxo; entre outros.

Nos referidos catálogos são raros os registros de detalhes e rotina das atividades desenvolvidas pelo PRESERVE. Há ausência de registro dos museus anteriores, salvo o de Recife, mencionado no texto de abertura de Carrazzoni no livro-catálogo. Com relação ao processo em são Leopoldo, localiza-se apenas a foto de número 148, livro-catálogo do CPHFRS, informando processo do restauro da Estação de São Leopoldo. Também são mencionadas por Carrazzoni ações anteriores desenvolvidas pela RFFSA, como por exemplo, as do Setor de Comunicação Social da SR6, no Rio Grande do Sul, com o "Trem da Cultura"; e da SR5, em Curitiba com o "Trem Centenário".

O PRESERVE ao remodelar o espaço e inaugurar o Centro de Preservação da História Ferroviária, renova e amplia o acesso ao público e oferece a oportunidade de contato com o patrimônio ferroviário. Observa-se o resultado comparando as imagens apresentadas da Estação de São Leopoldo, quando inaugurado Museu do Trem, em 1976, e após a intervenção de restauro e remodelação do pátio garantindo o convívio nas dependências museológicas pela população. 


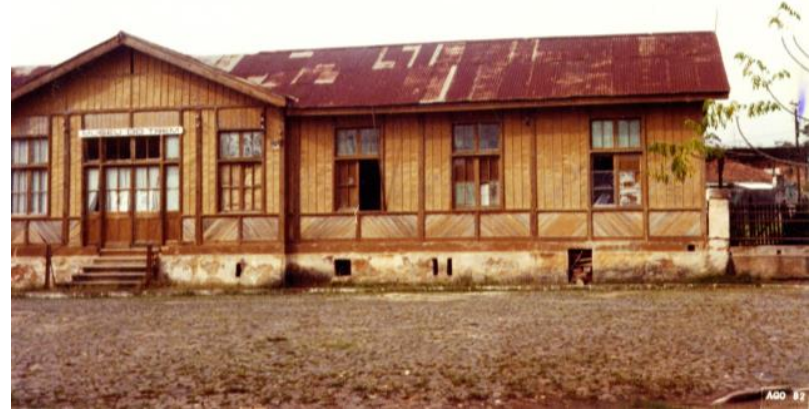

Figura 8 - Prédio principal da Estação Ferroviária de São Leopoldo antes da reconstrução. Ano: 1982. Fonte: Museu do Trem de São Leopoldo.

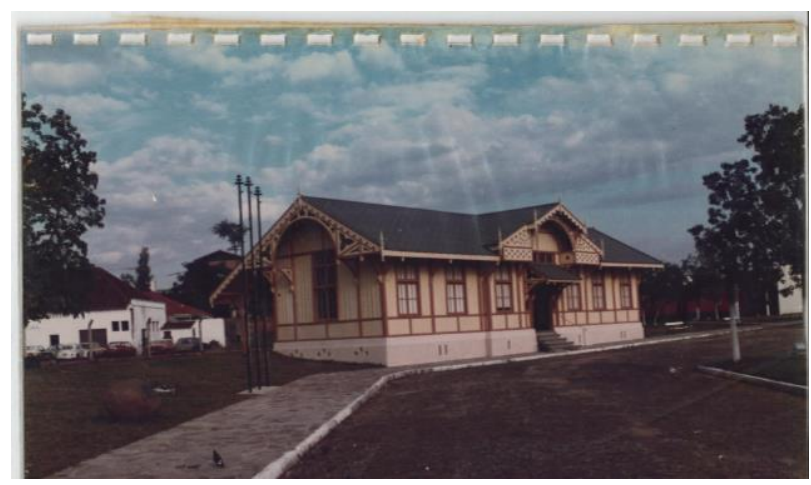

Figura 9 - Prédio do Museu do Trem reinaugurado após a reconstrução. Relatório PRESERVE em álbum fotográfico. Ano: 1985. Fonte: Museu do Trem de São Leopoldo.

Conforme figura 11, verifica-se que o PRESERVE realizou o registro fotográfico do processo dos trabalhos, desde o levantamento e diagnóstico do local, quanto da documentação dos processos de restauro do acervo, edificações propriamente, organização na formação dos sítios históricos, além da exposição, equipe e atendimento ao público. Imagens localizadas em álbum fotográfico que acompanha Relatório do PRESERVE26.

A RFFSA também recuperou trechos ferroviários, locomotivas a vapor e restaurou estações a fim de viabilizar o turismo. Desde modo, em 1986, inaugurou: Curitiba/Lapa(PR), com $85 \mathrm{~km}$; Ouro Preto/Mariana(MG), onde foi instalada uma loja de artesanato e restaurante; Miguel Pereira/Conrado(RJ), com $30 \mathrm{~km}$ de extensão e Bento Gonçalves-Jaboticabal(RS), com 49 km.

Em uma terceira etapa, o PRESERVE realiza entre abril de 1983 e julho de 1984, a reconstrução da rotunda ${ }^{27}$ de São João Del Rei. A decisão de realizar este projeto levou

\footnotetext{
${ }^{26}$ Os álbuns localizados não estão arrolados e não possuem registro no Acervo do Museu do Trem.

${ }_{27}$ No Brasil, no âmbito da RFFSA, existiram 24 rotundas nas cidades de: Natal, Recife, Fortaleza, São Luís, Rosário, são João Del Rei, Ribeirão Vermelho, Sete Lagoas, Cruzeiro, Barra do Piraí, Porto Novo do Cunha, Três Rios, Rio de Janeiro, Bauru, Três Lagoas, Lins, Campo Grande, Curitiba, Cruz alta, Salvador, Alagoinha e Aracaju, sendo que apenas quatro estão desativadas, dez em funcionamento e as demais inexistem (MORAIS, 1987).
} 
em consideração diversos fatores, entre eles ser este "um exemplar arquitetônico significativo com característica peculiares' (MORAIS, 1987). Diferentemente das demais publicações do PRESERVE, o livro-catálogo da Reconstrução da Rotunda de São João Del Rei, assinado pelo arquiteto Sérgio Morais, informa sobre todo o processo realizado, a partir das escolhas técnicas para a intervenção, levando em consideração as condições do patrimônio na ocasião, e descrevendo motivos que levaram a essa ou aquela decisão e os recursos utilizados para a obtenção de um espaço "confortável e atraente [para] uma visita as suas dependências' (MORAIS, 1987).
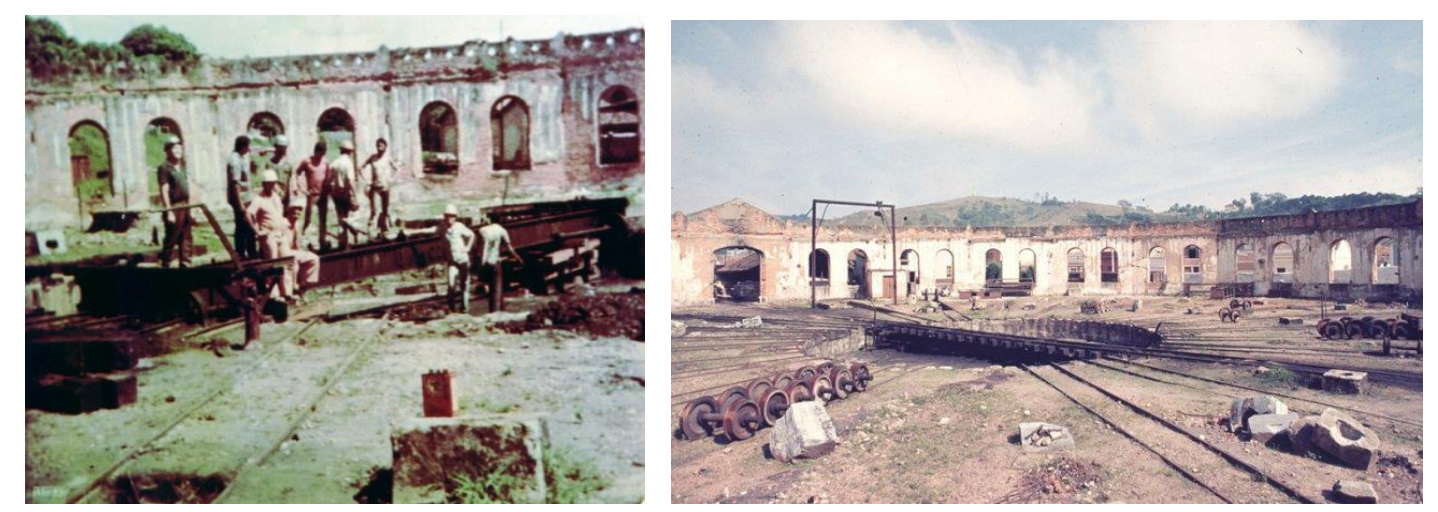

Figuras 10 e 11 - Manutenção no interior da rotunda, em 1970. Rotunda abandonada em 1971. Fonte: Acervo ABPF. Disponível em http://www.estacoesferroviarias.com.br/rotundas/fotos/sjdr9741.jpg

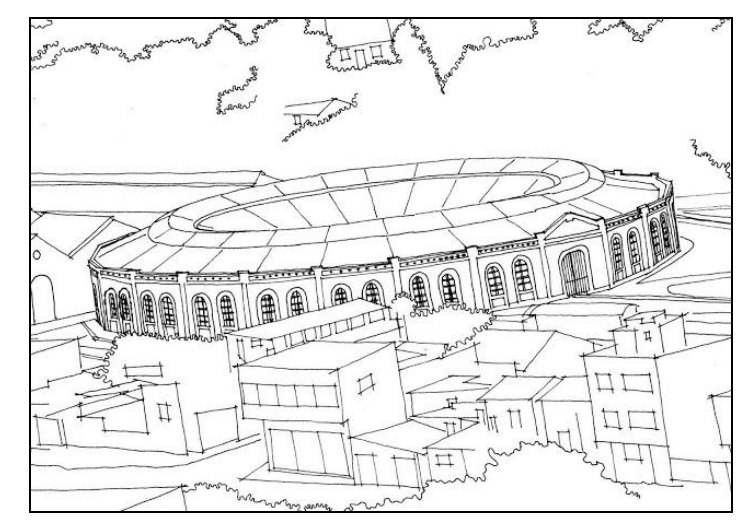

Figura 12 - Desenho da rotunda por Sérgio Santos Morais.

Fonte: Blog Trilhos do Oeste. Disponível em http://trilhosdooeste.blogspot.com.br/2011/10/rotunda.html 

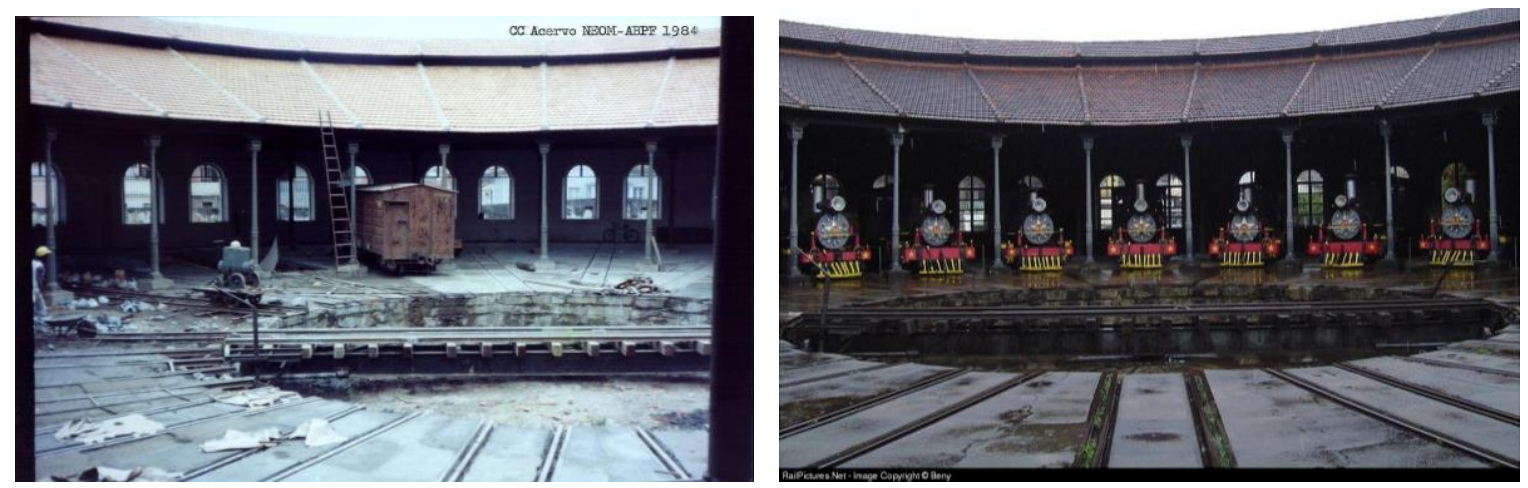

Figuras 13 e 14 - Rotunda antes do restauro. Ano: 1984. Fonte: Acervo NEOM-ABPF. e Rotunda depois do restauro. Ano: 2008.

Fonte: Foto Jonas Augusto Martins de Carvalho. Disponível em: http://tgvbr.org/viewtopic.php?f=70\&t=1142>

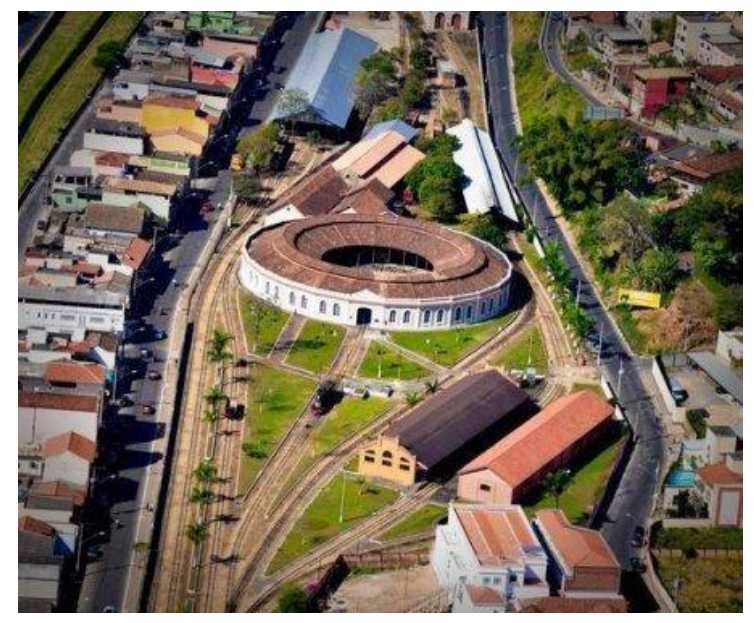

Figura 15 - Vista aérea do pátio ferroviário com a rotunda ao centro. Ano: 2013.

Fonte: http://www.estacoesferroviarias.com.br/rmv_efom/sjdrey.htm

Os relatórios da PRESERVE incluem também os restauros na Estação de Cachoeiro (BA) e projeto previsto de ligação de dois ramais em Bauru, junto ao Núcleo Histórico Ferroviário. E divulga como resultado de nove anos atividades com os setores do transporte, tanto portuário, quanto rodoviário, além do ferroviário. Tendo realizado a criação dos Núcleos da História Portuária nas localidades: Bahia (Salvador); Rio de Janeiro (capital); Belém (Pará); Pernambuco (Recife); além dos Museus do Porto na cidade de Imbituba (Santa Catarina) e de Santos (São Paulo) (PRESERVE, 1989). O Museu Rodoviário do Departamento Nacional de Estradas de Rodagem, inaugurado em 1972, teve intervenção do PRESERVE, com a obra de restauro, a partir de 1989, e projetos de pesquisa e tratamento do acervo, confecção de painéis, vitrinas e montagem de exposição, elaboração de material de apoio como catálogos, folhetos, entre outros (1989).

Quanto à escolha das estações, cidades e estados para a atuação do PRESERVE, havia diversos fatores ponderados. Desde a indicação das SR, até a identificação de problemas com depredação e vandalismo informados através de denúncias; realização de laudos técnicos com levantamento fotográfico para avaliação do bem como histórico. 
Sabe-se que fatores de ordem política e econômica não são facilmente identificados ou compreendidos, porém são parte determinante do contexto. Apesar das inúmeras questões que influenciavam as ações do PRESERVE, fato é que o Programa tinha clareza de sua meta de preservar exemplares significativos e únicos do patrimônio industrial ferroviário espalhado no território nacional, através dos restauros, agrupamento de acervos e criação de instituições museológicas que contemplassem todas as Superintendências Regionais da RFFSA com pelo menos um museu.

Após a definição de cada local, o trabalho consistia em realizar um estudo minucioso de restauro, seguindo princípios e técnicas, para remodelar seja uma estação, escritório, oficina e/ou armazém, para atividades museais, conforme Lasmar.

[Engenho de Dentro] ...naquela Oficina trabalhavam dois mil operários. Era uma Oficina com um movimento enorme. Mas aquele prédio, onde está o Museu, já tinha sido desativado, por isso que o Museu foi instalado ali. Essa é uma característica de todos os museus ferroviários, eles foram instalados em prédios ferroviários que não estavam mais funcionando, como oficinas, rotunda, estação (LASMAR, 2015, entrevista).

O PRESERVE teve uma atuação intensa, porém com uma duração pequena. Intenso, sobretudo no que dizia respeito a RFFSA, o que gerou organizar um programa que abrangesse o setor ferroviário separadamente. Em 1986 criam o Programa de Preservação do Patrimônio Histórico Ferroviário (PRESERFE), com sede no prédio da RFFSA, junto a Administração Geral, no Rio de Janeiro. Os projetos continuaram com objetivos semelhantes, pois o PRESERFE dava continuidade as ações relacionadas exclusivamente ao patrimônio ferroviário, mas que haviam sido iniciadas pelo PRESERVE. Nos primeiros anos do PRESERFE, o arquiteto Cláudio Terêncio M. Bacalhau coordenou a equipe, que contava com os arquitetos Sergio Santos Morais, Marco Motta e Regina de Oliveira; e as museólogas Telma Lasmar e Stella Ladeira.

Em 1987, o PRESERFE cria o Informativo Passado e Presente, com objetivo de informar as atividades realizadas nos diferentes estados. Deste modo, estimulando o vínculo entre os Centros e Núcleos, proporcionado intercâmbio, além da reflexão de temas e questões relacionadas a preservação do patrimônio, pois conforme Sergio Morais, em meio aos funcionários envolvidos, haviam alguns que estranhavam as técnicas e os cuidados com a preservação dos bem quando executavam a mão de obra dos restauros.

[...] a gente resolveu criar um jornalzinho chamado Passado \& Presente era o Informativo do Setor de Preservação do Patrimônio Histórico Ferroviário. Então a gente fazia por trimestres. Isso aí era para a gente distribui para manter a chama acessa. Para tentar sensibilizar de alguma forma o nosso público interno. Esse era o grande problema. Nosso público interno. Sempre achavam que o nosso trabalho era bobagem, 
coisa velha. Era uma batalha. Por que preservar? A gente procurava uns temas assim... e a gente tinha gráfica (MORAIS, 2015, entrevista).

O informativo chegou, em algumas tiragens, ao número de cinco mil exemplares impressos, sob a responsabilidade do Setor de Programação Visual e Gráfica (SEVIG), porém, com última tiragem em 1988/89.

A década de 1990 foi marcada por grandes mudanças decorrentes dos interesses do Plano Nacional de Desestatização (PND) como a extinção da RFFSA. Os recursos financeiros não mais se destinam aos projetos de preservação com a mesma intensidade, assim como ocorre a diminuição dos recursos humanos especializados. A manutenção dos projetos museológicos realizados nos CPHF e dos NHF sofreu com os movimentos relacionados ao enxugamento. Com a saída de Cláudio Bacalhau, o arquiteto Sergio Morais assume a coordenação do PRESERFE.

Com grande preocupação sobre o modo como cada localidade realizava intervenções no patrimônio industrial ferroviário, em 1991, a PRESERFE lança um Manual de Preservação de Edificações Ferroviárias Antigas. De cunho didático, oferece nomenclaturas, definições, termos técnicos, ilustrações a fim de orientar. As tipologias arquitetônicas diversas do patrimônio ferroviário dificultam a intervenção pelas equipes locais. O manual auxilia com instruções de preservação e restauro a partir dos exemplos na Estação do Recife $(\mathrm{PE})$, nas Oficinas de Demósthenes, em Fortaleza (CE), na Estação da Luz, (SP), na Estação de São Leopoldo RS), entre outras. Prefaciado pelo arquiteto Claudio Bacalhau, o Manual possui textos e pesquisa do arquiteto Sérgio Santos Morais, com objetivo de estimular o uso de critério de preservação, com ações menos agressivas e intervenções mais amenas nos cuidados com o patrimônio edificado mesmo que por leigos.

A gente tentou criar normas para a empresa, já que a empresa assumiu ter um setor para a preservação do patrimônio história, a gente tem que criar normas, para instruir. Imagina um cara que está lá no Mato Grosso com o acervo [...] A Rede enquanto existia, ela promovia recuperação de estações, reformas. Então a gente achou que, já que vai reformar, porque não reforma dentro de princípios de preservação. Ao invés de você pegar, por exemplo, uma estação que é de pedra e pintar em cima. O manual dizia assim: não pinte. A pedra, ela tem que ficar ao natural (MORAIS, 2015, entrevista).

Conforme Sérgio, o Manual foi desenvolvido a partir do Projeto do Corredor Cultural do Rio de Janeiro, porém foram inúmeras as dificuldades encontradas para que não alcançassem os resultados conforme planejado. Entre elas as distâncias geográficas, a formação de equipes que produzissem inventários dos bens ferroviários, o volume de material, o que impossibilitou que os Manuais produzissem os efeitos desejados, a falta de política de preservação, entre outros fatores. Comenta: 
Na verdade, a gente nunca conseguiu botar isso em prática. Você para definir o que preservar, você tinha que conhecer. Ou seja, fazer um inventário. A gente chegou a montar uma série de fichas que seriam encaminhadas para todas as Superintendências Regionais, os Setores de Engenharia e Manutenção, solicitando que eles preenchessem alguns dados mínimos. Se tinha planta. Se não tinha planta das Estações. Botar o número. Para a gente ter o universo prá poder analisar e dizer essa tem que ser preservada, pela importância arquitetônica, histórica... e essa nem tanto. Nunca conseguimos (MORAIS, 2015, entrevista).

Datado do mesmo ano, foi localizado um Manual para o Funcionamento dos Centros de Preservação e Núcleos Históricos Ferroviários, com organização e execução de Telma Lasmar, contando com a colaboração de Maria Stella de Paula Ladeira, Maria Tereza Kahl Fonseca e Eliana Coutinho. O Manual oferece detalhadamente um roteiro técnico para a realização de um inventário museológico desde o uso do Livro Tombo, Fichas Técnicas das peças, incluindo classificação de documentos e fotografias, além da manutenção do acervo, organização da Reserva Técnica e Arquivos, Treinamento do Pessoal, Empréstimo de peças, Horários de funcionamento, Pesquisa, Programação e Exposições com visitas programas e ou atendimentos especiais. O oferece ainda com Fichas para todos os itens citados acima.

\subsection{PROFAC}

Com intenção de fomentar projetos culturais em circunstâncias menores e diferentemente dos projetos museológicos anteriores, realizados nos CPHF e dos NHF, a RFFSA cria um novo programa, com nova concepção conceitual, denominado de Programa Ferroviário de Ação Cultural (PROFAC). O PROFAC teve por objetivo realizar convênios com as prefeituras onde havia estações, oficinas ou armazéns ferroviários desativados, a fim de recuperar o patrimônio e utilizá-lo com a função de centro cultural, então denominado Centro Ferroviário de Cultura (CEFEC).

Aí como havia essa demanda muito grande de convênios com as prefeituras, e os convênios às vezes contemplavam não só o prédio, mas como peças também. Como a gente tinha nos acervos, nas Reservas Técnicas muitas peças duplas, vários exemplares. Sinos, telégrafos. A gente juntava um lotezinho, porque a gente gostava de expor nas estações um nucleozinho de exposição com objetos ferroviários. A gente fez vários. Deve ter uma coleção de convênios aí nos arquivos da Rede (MORAIS, 2015, entrevista).

O PROFAC foi coordenado pelo funcionário Victor José Ferreira, então assessor especial da Presidência da RFFSA (BUZELIN, 2009). A implantação do projeto nas edificações ferroviárias criava uma sala de vídeo, uma biblioteca, uma área de exposição contando a história da ferrovia local e uma galeria de arte. A equipe de arquitetos do 
PRESERFE se associou ao PROFAC, passando a realizar os projetos de restauro (MORAIS, 2015). Em 1990 foram criados os Centros Ferroviários de Cultura de Além Paraíba, em Minas Gerais, e de Volta Grande, no Rio de Janeiro; e em 1992, CEFEC em Barbacena, em Minas Gerais; e posteriormente em Itacuruçá, no município de Manguaratiba, e Santos Dumont, no Rio de Janeiro.

Ainda hoje alguns CEFEC estão ativos e oferecem atividades variadas à comunidade, desde oficinas de arte e artesanato, tapeçaria, ballet, ginástica, dança, exposições de fotografias, pinturas, entre outras atividades. Mantidos por prefeituras ou por fundações, realizam feiras diversas, e abrigam arquivo público da cidade.

A privatização da RFFSA requer muita atenção. A complexidade envolvendo um conjunto de situações pré, durante e pós o fato em si, são identificadas em documentos jurídicos e administrativos, notícias de jornais, mas, sobretudo, na experiência de cada envolvido. É preciso enfatizar, o universo que se desdobra com sobreposições, tenciona e dificulta a clareza dos fatos históricos. Com efeito, uma investigação acadêmica profunda no que tange os mecanismos de preservação do patrimônio brasileiro e os museus ferroviários, que por ocasião da privatização destacam um período triste, difícil e de retrocesso.

Fruto do processo de privatização, o descaso com os projetos de preservação do patrimônio, o impactam, geram vazios e ausências. É recorrente entrevistados manifestarem questões sobre esses momentos, assim como abordam o fato da não contemplação de uma política de preservação no período da liquidação da RFFSA tenha acelerado o cenário de abandono.

Foi oferecido aos funcionários de todo território nacional um programa de demissão incentiva ou voluntária, sendo que ciente ou não da situação, em o funcionário não optando por essa alternativa, em segunda instância, ele era demitido. Poucos foram os funcionários que permaneceram. A eles caberiam as atividades de encerrar alguns projetos, 'apagar a e fechar a porta'. A museóloga Telma aderiu ao programa de demissão incentivada e o arquiteto Sergio Morais permaneceu até completar sua aposentadoria. Sendo que ambos revelam mal-estar com a situação enfrentada.

Eu saí na demissão incentivada. Porque eu estava ficando muito doente, com essa destruição, muito doente. E aí eles tinham os planos, era a época do Itamar Franco, primeiro o Collor, depois o Itamar Franco, de demitir funcionário público de enxugar para depois privatizar. E aí eles fizeram a demissão incentivada e eu saí, porque eu não estava aguentando mais (LASMAR, 2015, entrevista).

E aí, depois eu comecei a ficar meio desgostoso, fui me afastando, me afastando. Eu meio que cancelei na minha cabeça. Eu vou ficar com a minha memória do bom. O que eu vivi. O que eu vi (MORAIS, 2015, entrevista). 
As denúncias do vandalismo, gerado a partir do abandono, colaboram para que ações de emergência fossem adotadas. Porém, observa-se que são ações isoladas e sem vínculo com projetos já desenvolvidos ou com a intenção de realizar plano futuro.

O fato da privatização não ter incluído entre os itens do patrimônio a ser leiloado, nem os Centros de Preservação, nem os Núcleos Históricos, nem mesmo o Programa, provoca uma aceleração com o descaso e consequente desmonte das instituições museais, independente de sua localização.

E o pior, Alice, foi o que aconteceu. O pior de tudo isso, foi a privatização. Porque com a privatização, quando o governo resolveu privatizar a ferrovia, ele dividiu o mapa ferroviário em malhas e vendeu essas malhas [...] nós tivemos uma briga enorme porque eles não incluíram nessas malhas, os nossos museus. Eram onze museus. Então quem comprou...não comprou os museus. E com a liquidação da ferrovia, as pessoas jogaram tudo fora. Eu fui recentemente, há uns dois anos a Juiz de Fora, fiquei olha! Tinha uma Biblioteca.......] Pergunta onde estão esses livros? Jogaram tudo fora. Jogaram arquivos, pastas, a memória da ferrovia foi toda para o lixo em alguns lugares (LASMAR, 2015, entrevista).

Com uma reflexão semelhante à de Telma Lasmar, o arquiteto Sérgio Morais identifica na privatização pontos que se desdobram no abandono e apagamento da memora dos projetos de preservação do patrimônio histórico.

Infelizmente o modelo que foi adotado na privatização não contemplava a preservação ferroviária. Não tinha um item que falasse que era obrigado a preservar o que fosse arrendado néh por essas empresas que passaram a operar as diversas linhas, as malhas. Isso não estava contemplado. Lá pelas tantas começou a ter muita denúncia (MORAIS, 2015, entrevista).

Não é um projeto político não, é justamente falta de política. É falta de política mesmo. É falta de uma política de preservação. Porque tudo que a gente fez de 80 a 96, eles destruíram, praticamente, entendeu?! Então, aqui no Rio muita coisa ainda se salvou porque o Sérgio Morais continuou até aposentar. E ele conseguiu salvar muita coisa. Mas nas Regionais prá você ter uma ideia - nosso Museu em Campos, que é aqui no estado do Rio, na Estrada de Ferro Leopoldina. A Leopoldina era uma ferrovia inglesa, tinha porcelana inglesa, faqueiro de prata no carro da chefia, relógio... era uma gracinha. Ficou abandonado. Mendigos quebraram a janela e roubaram tudo. Porque ninguém tava nem aí. Não tinha dono. Quem comprou, não comprou aquilo. E quem era dono daquilo, que era a Rede Ferroviária, não cuidou. Não fiscalizou (LASMAR, 2015, entrevista).

As implicações decorrentes da desestatização e dissolução da RFFSA não contemplaram os programas de preservação, nem mesmo o que dele decorreu. $A$ liquidação que viria a seguir não considera a existência dos CPHF e dos NHF, sendo que as equipes foram destituídas na dissolução da empresa. Observa-se que o abandono e os desdobramentos do mesmo, foram recebidos como atos de violência por aqueles que haviam dedicado não apenas tempo profissional, mas dedicado a desenvolver um projeto inovador que recuperava a memória do País. Comentam: 
Porque a liquidação dessa forma? É o descomprometimento com a história do País, com a memória. Entendeu? As pessoas não acharem que é importante isso aqui, coloca fora. Se tem um arquivo cheio de documentos como esse aqui (LASMAR, 2015, entrevista).

São João Del Rei era para ter sido fechado no dia seguinte à privatização, porque ninguém pensou o que fazer com São João Del Rei. Porque São João Del Rei não era uma ferrovia operacional, era uma ferrovia turística, com trem de passageiros. Como a privatização não contemplava trem de passageiros, ela seria fechada. Só não fechou porque a gente começou a denunciar. Eu me lembro de ter ido ao IPHAN com dossiê [...] e aí conseguiram colocar São João Del Rei como responsabilidade desta nova empresa que ia operar os trens em Minas Gerais, e ele ficou responsável por esse acervo, pelo Museu e pela operação da via turística por um bom período. Não sei. Acho que agora está diferente. Tem um bom tempo. Então, foi graças a isso que não foi fechado. Então, como não existiu essa preocupação, uma cláusula que falasse. Não, existe um patrimônio ferroviário histórico - que a gente trabalhou esses anos todos - tinha que ter uma cláusula! (MORAIS, 2015, entrevista).

O PROFAC não permanece após a saída do professor Victor José Ferreira, porém funcionários que haviam trabalhado no Setor PRESERFE, permaneceram auxiliando em outras tarefas relacionadas ao Setor de Patrimônio, onde estavam localizadas as plantas e dos documentos.

Também como consequência da privatização está a utilização dos espaços por organizações comerciais, como o caso do CPHFPRSC, em Curitiba, que foi conveniado para ser parte de um Shopping, conforme informa Morais.

Um que não escapou foi Curitiba. Curitiba tinha um museu lindo... virou shopping. Eles fizeram um shopping, e o museu foi encolhido. Tinha uma plataforma com locomotivas... tiraram tudo, tudo, tudo, e fizeram um museu, assim, acanhado. Por quê? Porque tinha que fazer o shopping [...] a Estação que é o atrativo do Shopping. Mas não tiveram nenhum respeito com o museu. O museu foi colocado de lado (MORAIS, 2015, entrevista).

Em 1997, o local foi inaugurado como shopping Estação Plaza Show, após reformado, ampliado e rebatizado para Shopping Estação ${ }^{28}$. Hoje além do Museu Ferroviário $^{29}$, o local abriga também o Museu da Farmácia. A inserção desta instituição museológica em um espaço comercial mereceria uma atenção acadêmica para fins de refletir sobre a gestão deste museu, num universo comercial e as implicações decorrentes.

\footnotetext{
28 Shopping oferece cento e cinquenta lojas, dez salas de cinema, dois teatros e dois museus.

29 Disponível em: http://www.curitibacity.com/pt/museus/186-museu-ferroviario-de-curitiba-shoppingestacao.html http://www.curitiba.pr.gov.br/idioma/portugues/linhaturismo/museuferroviario
} 

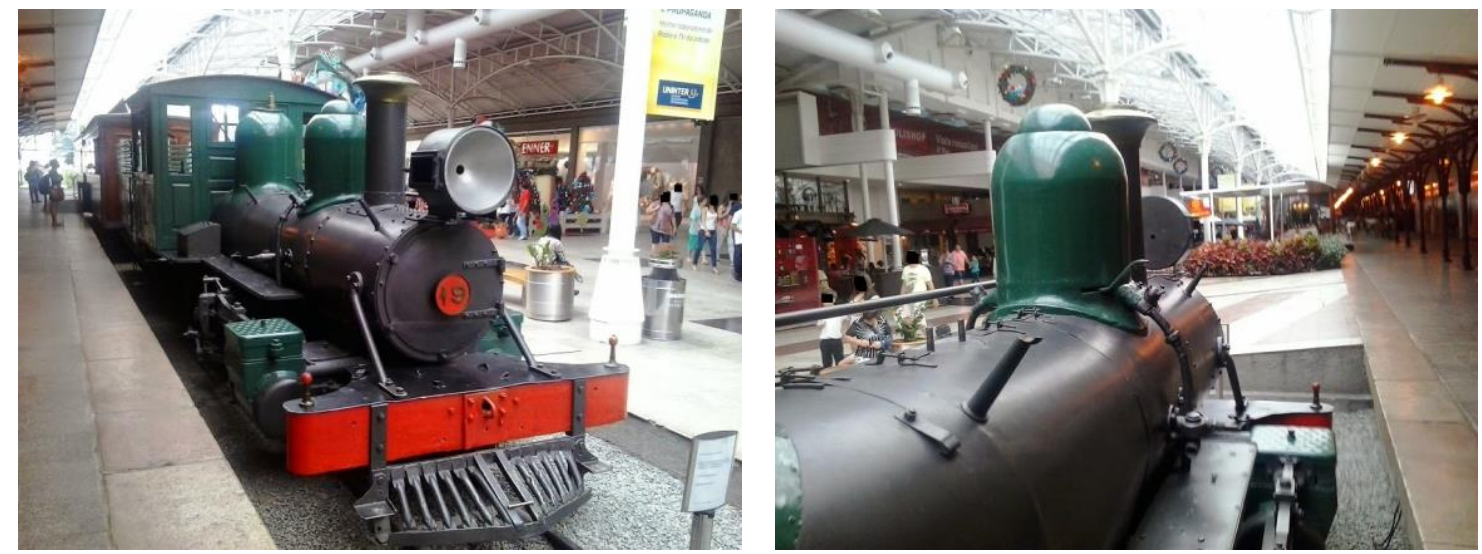

Figuras 16 e 17 - Museu Ferroviário de Curitiba no interior do Shopping Estação.

Fonte: http://datamarcos.blogspot.com.br/2014_12_20_archive.html

A partir das informações reunidas, organizou-se um quadro abaixo com informações da criação das instituições museológicas ferroviárias no período de atuação do PRESERVE, PRESERFE e PROFAC.

\section{Quadro 3 - Centros de Preservação, Núcleos Históricos Ferroviário e Centro Ferroviário Cultural}

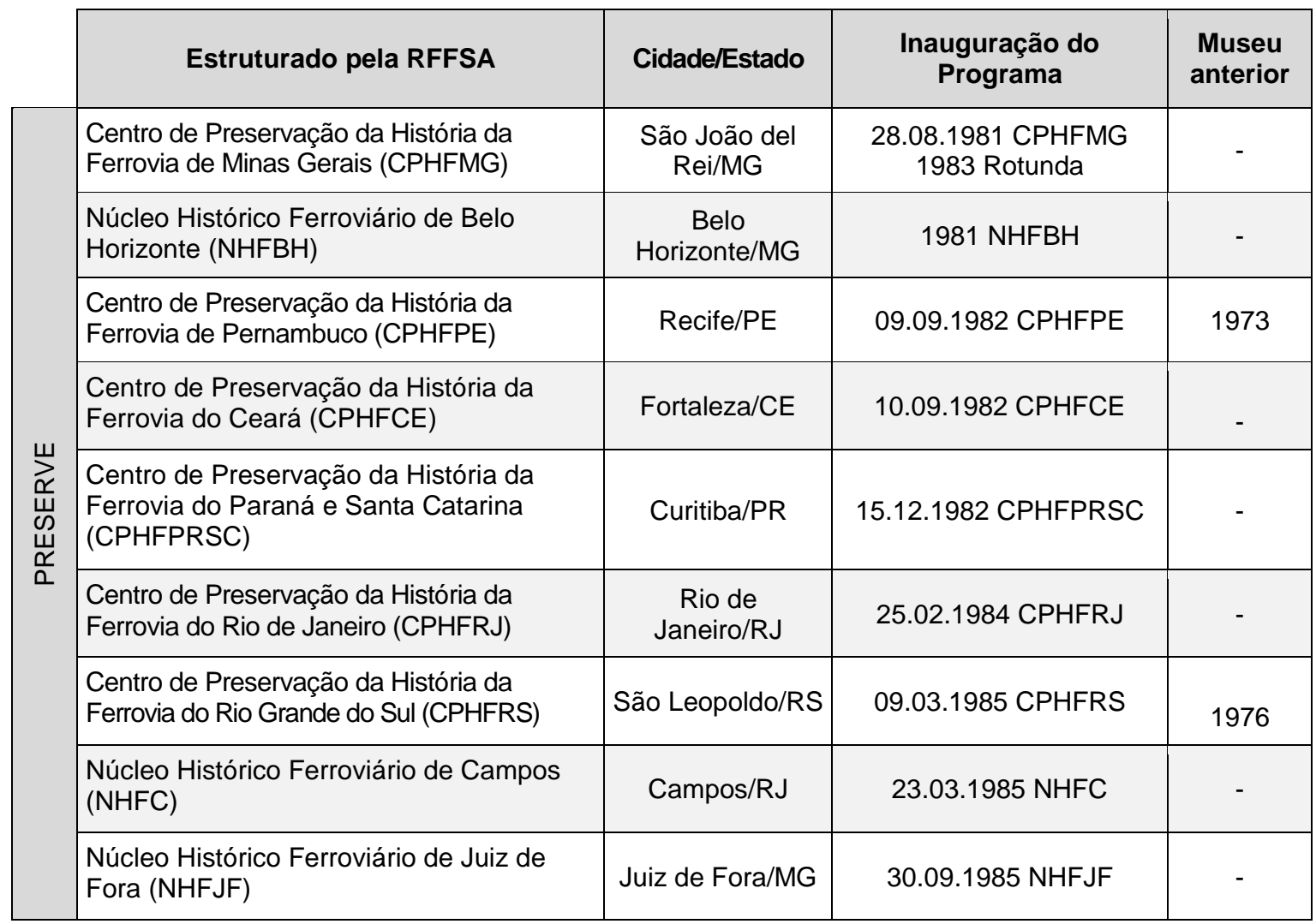




\begin{tabular}{|c|c|c|c|c|}
\hline \multirow{3}{*}{ 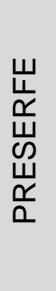 } & $\begin{array}{l}\text { Centro de Preservação da História da } \\
\text { Ferrovia de São Paulo (CPHFSP) }\end{array}$ & $\begin{array}{l}\text { Paranapiacaba/ } \\
\text { SP }\end{array}$ & 30.09.1986 CPHFSP & - \\
\hline & $\begin{array}{l}\text { Núcleo Histórico Ferroviário de Miguel } \\
\text { Pereira (NHFMP) }\end{array}$ & $\begin{array}{l}\text { Miguel } \\
\text { Pereira/RJ }\end{array}$ & 15.08.1987 NHFMP & - \\
\hline & $\begin{array}{l}\text { Núcleo Histórico Ferroviário de Bauru } \\
\text { (NHFB) }\end{array}$ & Bauru/SP & 26.08.1989 NHFB & 1969 \\
\hline \multirow{5}{*}{$\begin{array}{l}\frac{1}{u} \\
\text { O } \\
\frac{\alpha}{a}\end{array}$} & $\begin{array}{l}\text { Centro Ferroviário Cultural de Além } \\
\text { Paraíba (CEFEC) }\end{array}$ & $\begin{array}{c}\text { Além } \\
\text { Paraíba/MG }\end{array}$ & 1990 CEFEC & - \\
\hline & $\begin{array}{l}\text { Centro Ferroviário Cultural de Volta } \\
\text { Grande (CEFEC) }\end{array}$ & Volta Grande/RJ & 1990 CEFEC & - \\
\hline & $\begin{array}{l}\text { Centro Ferroviário Cultural de Barbacena } \\
\text { (CEFEC) }\end{array}$ & Barbacena/MG & 1992 CEFEC & - \\
\hline & $\begin{array}{l}\text { Centro Ferroviário Cultural de Itacuruçá } \\
\text { (CEFEC) }\end{array}$ & Maguaratiba/RJ & $\begin{array}{l}\text { Não localizada data } \\
\text { CEFEC }\end{array}$ & - \\
\hline & $\begin{array}{l}\text { Centro Ferroviário Cultural de Santos } \\
\text { Dumont (CEFEC) }\end{array}$ & $\begin{array}{c}\text { Santos } \\
\text { Dumont/RJ }\end{array}$ & $\begin{array}{l}\text { Não localizada data } \\
\text { CEFEC }\end{array}$ & - \\
\hline
\end{tabular}

Fonte: elaborado pela autora.

\subsection{MUSEUS FERROVIÁRIOS BRASILEIROS}

A fim de obter um panorama abrangente, utilizou-se o Cadastro Nacional de Museus (2010) e os guias de museus brasileiros, listagem de autarquias e organizações associativas de classe interessadas no transporte ferroviário, artigos e notícias.

Nas listagens foram localizadas diversas denominações: museus ferroviários, museus do trem, centros de preservação, núcleos de pesquisa, casas de cultura, espaços culturais e museus dinâmicos. As listagens investigadas ora apresentam cunho histórico, sem qualquer relação ou sistematização com período histórico, ora se cruzam sobrepondo características como centros e espaços de cultura, museus históricos e turismo cultural. Os dados identificados possibilitam visualizar a diversidade e os diversos contextos, inclusive as ações isoladas paralelas.

O agrupamento de museus, centros culturais e acervos permitem mapear o contexto histórico, porém a dificuldade de alinhar as informações ocorre não apenas pela complexidade do cenário, mas pelos dados incompletos.

A partir do cruzamento de informações apresentadas no Guia de Museu (LOUREIRO, 2000); no Cadastro Nacional de Museu $(2011)^{30}$, do Instituto Brasileiro de Museus; no Guia de Museus de SC, do Sistema Estadual de Museus de Santa Catarina

\footnotetext{
30 Disponível em http://www.museus.gov.br/sistemas/cadastro-nacional-de-museus/
} 
(2013); no Cadastro de Museu de SP ${ }^{31}$; no Guia de Museus do RS, Sistema Estadual de Museus do Rio Grande do Sul (2012); na Listagem dos Museus - Trens Turísticos da ABPF ${ }^{32}$; na Listagem de Liberação para utilização de Trens turísticos e comemorativos; nos dados informados no site oficial da ANTP Cultural - Museu de Transporte Público; e na lista de museus organizada pelo ferroviário e Professor Victor José Ferreira e publicada pelo Movimento de Preservação Ferroviária (MPF) e divulgada pelo site da ANFER, em 2011, foi possível comparar e agrupar dados, organizando um panorama geral, ainda inicial, com um universo de museus que incluem: museus com perfil de museus ferroviários, mas também museus que possuem em seu acervo objetos ferroviário, ou mesmo aqueles que fazem uso de edificações ferroviárias. Neste primeiro agrupamento não houve intenção de separar os museus conforme a constituição de cada um, nem mesmo de seu perfil, pois a questão requer uma investigação minuciosa sobre a formação de cada museu listado.

Observa-se maior concentração de museus ferroviários, memoriais, centros culturais, centros de pesquisa e de turismo relacionados ao patrimônio industrial ferroviário nas Regiões Sudeste e Sul, e posição intermediária a Região Centro-Oeste e em menor número a Região Nordeste e Norte. Os números podem ser associados proporcionalmente aos investimentos em malha ferroviária em cada região. Porém, chama a atenção números, que destaco dos estados: São Paulo com 23 instituições; Rio de Janeiro com 17 instituições; Minas Gerais com 17 instituições; Santa Catarina 10 instituições; Paraná 10 instituições; Rondônia com 2 instituições; Mato Grosso do Sul, Goiás, Piauí, Ceará, Pernambuco, Rio Grande do Norte, todos estes estados com apenas 1 instituição. O estado do Rio Grande do Sul será apresentado na sequencia em separado.

Quadro 4 - Relação dos museus ferroviário ou com patrimônio ferroviário ${ }^{33}$

\begin{tabular}{|c|c|c|c|}
\hline \multicolumn{2}{|c|}{$\begin{array}{l}\text { Região/ } \\
\text { Estado }\end{array}$} & \multirow{2}{*}{$\begin{array}{l}\text { Cidade } \\
\text { Parnaíba }\end{array}$} & \multirow{2}{*}{$\begin{array}{c}\text { Museu/Memorial/Centro Cultural/Pesquisa/Turismo } \\
\text { Museu do Trem do Piauí }\end{array}$} \\
\hline \multirow{3}{*}{ 恋 } & $\mathrm{PI}$ & & \\
\hline & \multirow[b]{2}{*}{ RO } & Ji-Paraná & Museu das Comunicações Marechal Rondon \\
\hline & & Porto Velho & $\begin{array}{c}\text { Museu Ferroviário da Estrada de Ferro Madeira - Mamoré } \\
\text { (Complexo Ferroviário EFMM) }\end{array}$ \\
\hline
\end{tabular}

\footnotetext{
31 Disponível em http://www.sisemsp.org.br/index.php/sisem

32 Disponível em http://www.abpf.com.br/trens-da-abpf/

${ }^{33}$ Levantamento nas Regiões Norte, Nordeste, Centro-Oeste, Sudeste e Sul, sem incluir o estado do Rio Grande do Sul que será apresentado separadamente.
} 


\begin{tabular}{|c|c|c|c|}
\hline \multirow{3}{*}{$\begin{array}{l}\frac{0}{10} \\
\frac{1}{0} \\
\frac{0}{2} \\
z\end{array}$} & $\mathrm{CE}$ & Fortaleza - CE & Museu Ferroviário de Fortaleza \\
\hline & $\mathrm{PE}$ & Recife - PE & Museu do Trem do Recife - Estação Central \\
\hline & $\mathrm{RN}$ & Ceará Mirim - RN & Museu Ferroviário Manoel Tomé de Souza \\
\hline \multirow{17}{*}{ 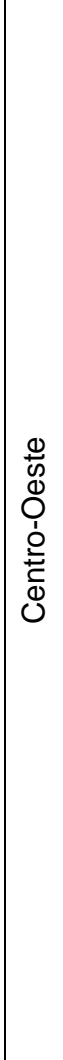 } & GO & Pires do Rio & Museu Ferroviário de Pires do Rio - MUFER \\
\hline & \multirow{16}{*}{ 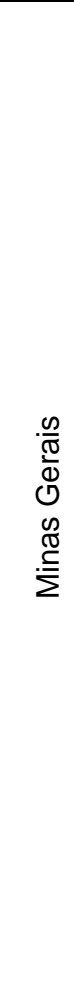 } & Além Paraíba & Centro Ferroviário de Cultura - CEFEC (Porto Novo) \\
\hline & & Araguari & Museu dos Ferroviários - Palácio dos Ferroviários \\
\hline & & Barbacena & Centro Ferroviário de Cultura - CEFEC \\
\hline & & Bom Despacho & Museu Ferroviário de Bom Despacho - Praça da Estação \\
\hline & & Conselheiro Lafaiete & Museu Ferroviário de Conselheiro Lafaiete \\
\hline & & Juiz de Fora & $\begin{array}{l}\text { Museu Ferroviário de Juiz de Fora (FUNALFA) } \\
\text { Estação Ferroviária (EF Leopoldina) }\end{array}$ \\
\hline & & Ouro Preto & Programa de Educação Patrimonial Trem da Vale \\
\hline & & Ouro Preto & Projeto Estação Cultura - Estação de Miguel Burnier \\
\hline & & Passa Quatro & Museu Estação Coronel Fulgêncio \\
\hline & & Recreio & Museu Ferroviário de Recreio - Estação Ferroviária \\
\hline & & São João Del Rei & Núcleo de Estudos da Oeste de Minas (Museu Virtual) \\
\hline & & São João Del Rei & Museu Ferroviário de São João Del Rei - Estação da EFOM \\
\hline & & Sarzedo & $\begin{array}{l}\text { Museu da Ferrovia - Estação Sarzedo / Plataforma de } \\
\text { Cultura (Museu da Mineração e da Ferrovia) }\end{array}$ \\
\hline & & Sete Lagoas & Museu Ferroviário de Sete Lagoas \\
\hline & & Soledade de Minas & Museu Ferroviário de Soledade de Minas \\
\hline & & Volta Grande & Centro Ferroviário de Cultura de Volta Grande - CEFEC \\
\hline \multirow{18}{*}{ 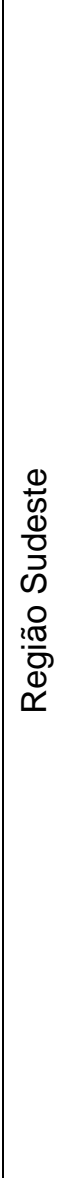 } & \multirow{4}{*}{ 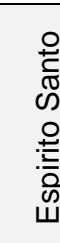 } & Alfredo Chaves & Estação Ferroviária de Matilde \\
\hline & & Cachoeiro de Itapemirim & Museu Ferroviário de Cachoeiro de Itapemirim \\
\hline & & João Neiva & Museu Ferroviário de João Neiva \\
\hline & & Vila Velha & Museu Vale \\
\hline & \multirow{14}{*}{ 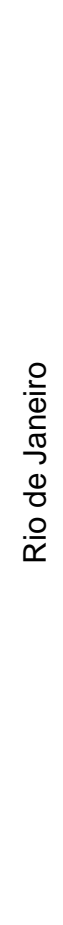 } & Carmo & Memórias de Carmo \\
\hline & & Magé & Estação Guia de Pacobaíba \\
\hline & & Manguaratiba & $\begin{array}{l}\text { Centro Ferroviário de Cultura Odjaime de } \\
\text { Hollanda Ferreira de Itacuruçá (CEFEC) }\end{array}$ \\
\hline & & Miguel Pereira & $\begin{array}{c}\text { Museu Ferroviário de Governador Portela (AFALA) } \\
\text { Estação de Governador Portela }\end{array}$ \\
\hline & & Paraíba do Sul & Museu Ferroviário José Pereira Palhares \\
\hline & & Petrópolis & Centro Cultural Estação Nogueira \\
\hline & & Petrópolis & Museu Imperial de Petrópolis \\
\hline & & Rio das Ostras & Centro Ferroviário de Cultura de Rocha Leão \\
\hline & & Rio de Janeiro & Academia Ferroviária de Letras(AFL)-Trem do Corcovado \\
\hline & & Rio de Janeiro & Museu do Trem do Rio de Janeiro - Engenho de Dentro \\
\hline & & Rio de Janeiro & Museu do Bonde- Santa Teresa \\
\hline & & Rio de Janeiro & Espaço Cultural do Trem do Corcovado \\
\hline & & Rio de Janeiro & Espaço Cultural Carlos Lange de Lima - AENFER \\
\hline & & Rio de Janeiro & Museu de Sinalização Ferroviária(MUSIFE) - EFCB \\
\hline
\end{tabular}




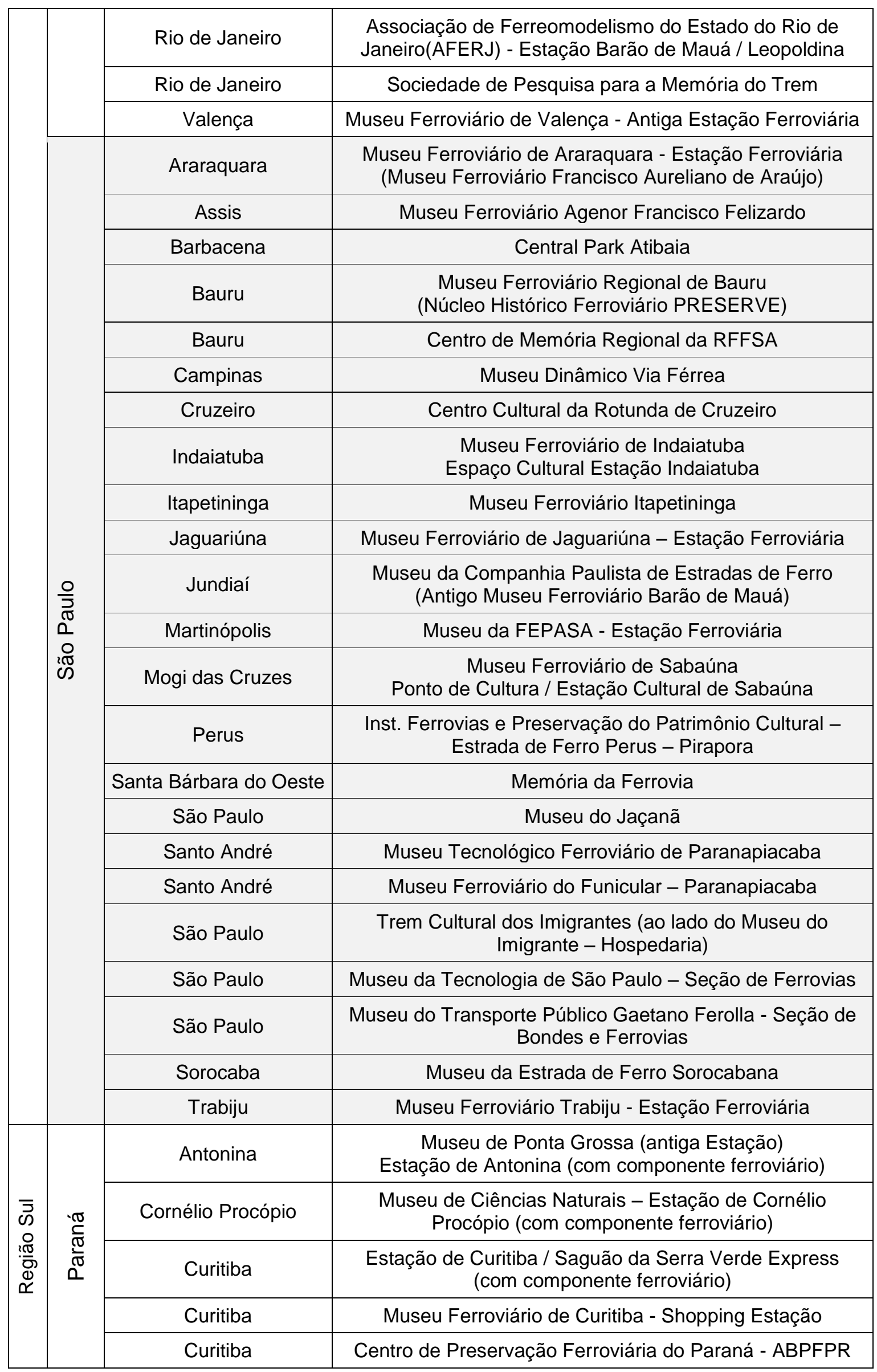




\begin{tabular}{|c|c|c|}
\hline & Jaguariúna & Museu Ferroviário Palacete Conde Francisco Matarazzo \\
\hline & Londrina & Museu Histórico de Londrina - Antiga Estação Ferroviária \\
\hline & Paranaguá & $\begin{array}{l}\text { Museu Ferroviário e Marítimo de Paranaguá (em } \\
\text { organização) (com componente ferroviário) }\end{array}$ \\
\hline & União da Vitoria & Museu de Arapoti (com componente ferroviário) \\
\hline & União da Vitória & Museu de União da Vitória (com componente ferroviário) \\
\hline \multirow{10}{*}{ 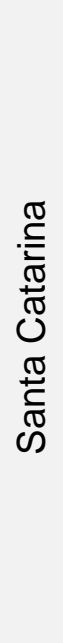 } & Criciúma & Memorial Casa do Agente Ferroviário Mário Ghizi \\
\hline & Içara & Museu Ferroviário Anselmo Cargnin \\
\hline & Jaguaruna & Museu Municipal Ferroviário Silvestre Ernesto da Silva \\
\hline & Joinville & Estação da Memória \\
\hline & Lages & Museu Ferroviário do $10^{\circ}$ Batalhão de Engenharia de Construção \\
\hline & Pirituba & Museu Ferroviário de Pirituba - Trem Turístico \\
\hline & Rio do Sul & $\begin{array}{l}\text { Museu Histórico Cultural de Rio do Sul - } \\
\text { Antiga Estação Ferroviária }\end{array}$ \\
\hline & Rio Negrinho & Museu Ferroviário ABPFSC - Trem Turístico \\
\hline & Tubarão & Museu Ferroviário de Tubarão - Antiga Estação e Oficinas \\
\hline & Videira - Contestado & Museu Ferroviário do Contestado - Trem Turístico \\
\hline
\end{tabular}

Fonte: elaborado pela autora.

Observando o quadro acima é possível identificar: museus ferroviários, memoriais, centros culturais, entre outras denominações, ao lado dos centros de preservação (CPH), núcleos históricos ferroviários (NHF) e Centro Ferroviário de Cultura (CEFEC), criados pelo PRESERVE/PRESERFE/PROFAC.

O levantamento realizado no estado do Rio Grande do Sul incluiu o detalhamento das instituições diferenciando-as em museus ferroviários, para aquelas instituições que assumem a denominação e abrigam acervo com patrimônio industrial ferroviário; museus de tipologias diversas, em sua maioria museus históricos, museus de arte que possuem componentes ferroviários no acervo ou estão abrigados em estações ferroviárias, algumas tombadas; os centro culturais que possuem diversas características, entre elas aqueles que utilizam vagões para atividades, aqueles que foram organizados por sindicatos, organizações não-governamentais ou mesmo associação de ferroviários aposentados; os trens turísticos que oferecem a experiência do turismo cultural, em sua maioria possuem ambiente com objetos ferroviários em salas especiais ou próximo das bilheterias; e outras atividades, onde identificou-se estações com usos diversos como restaurantes, setores públicos de diferentes áreas, pontos de saúde, entre outros. As estações ferroviárias que sendo utilizadas apenas por outras atividades, sem qualquer ambiente com exposição de acervo, como as utilizadas por corpo de bombeiros, polícia, prefeituras, não foram incluídas na listagem apresentada a seguir. 
Quadro 5 - Relação de museus com patrimônio ferroviário no Rio Grande do Sul.

Legenda: MF - Museu Ferroviário MD - Museu tipologia diversa CC - Centro Cultural TT - Trem Turístico

\begin{tabular}{|c|c|c|c|c|c|c|}
\hline Cidade & M. & $\begin{array}{l}\text { M. } \\
\text { D. }\end{array}$ & $\begin{array}{l}\text { C. } \\
\text { C. }\end{array}$ & $\begin{array}{l}\text { T. } \\
\text { T. }\end{array}$ & Instituição & Criação da Instituição \\
\hline $\begin{array}{c}\text { Bento } \\
\text { Gonçalves }\end{array}$ & $x$ & & & $X$ & $\begin{array}{c}\text { Ferrovia do Vinho- trecho Bento } \\
\text { Gonçalves-Garibaldi-Carlos Barbosa }\end{array}$ & Inaugurado em 17.11.1992 \\
\hline Cacequi & $X$ & & & & $\begin{array}{c}\text { Museu de Memória Ferroviária de } \\
\text { Cacequi }\end{array}$ & $\begin{array}{c}\text { Inaugurado em 27.12.2001 } \\
\text { reetruturação em } 2015\end{array}$ \\
\hline $\begin{array}{l}\text { Cachoeira } \\
\text { do Sul }\end{array}$ & & $x$ & & & Museu Histórico Edyr Lima & Não localizada data \\
\hline Canela & $x$ & & & $x$ & $\begin{array}{c}\text { Fundação Cultural } \\
\text { Mundo a Vapor (Parque Temático) }\end{array}$ & Inaugurado em 1991 \\
\hline Canoas & & & $X$ & & Fundação Cultural de Canoas & $\begin{array}{c}\text { Recuperada em } 2003 \\
\text { pela TRENSURB }\end{array}$ \\
\hline Canoas & & $\mathrm{X}$ & & & \begin{tabular}{|} 
Museu da Tecnologia da ULBRA \\
(Museu do Automóvel) contendo \\
replica de estação e duas locomotivas
\end{tabular} & $\begin{array}{l}\text { Inaugurado em 20.08.2002 } \\
\text { Extinto e leiloado em } 2009\end{array}$ \\
\hline Caxias do Sul & $x$ & & & & Museu Ferroviário & Inaugurado em 17.04.2013 \\
\hline Cruz Alta & & $\mathrm{X}$ & & & Museu Histórico Municipal de Cruz Alta & Não localizado \\
\hline Erebango & & $x$ & & & Museu Histórico Municipal & Reformado em 2012 \\
\hline Erechim & & $x$ & & & $\begin{array}{c}\text { Centro Cultural - Arquivo Histórico } \\
\text { Estação Ferroviária }\end{array}$ & Inaugurado em 18.11.1980 \\
\hline Gaurama & & $\mathrm{X}$ & & & $\begin{array}{l}\text { Museu Municipal Irmã Celina } \\
\text { Schardong }\end{array}$ & $\begin{array}{l}2015 \text { projeto de } \\
\text { iluminação para o museu }\end{array}$ \\
\hline $\begin{array}{l}\text { Marcelino } \\
\text { Ramos }\end{array}$ & $X$ & & & $x$ & $\begin{array}{c}\text { Trem das Termas - Ação de } \\
\text { Associação Amigos de Ferroviários }\end{array}$ & $\begin{array}{l}1996 \text { projeto para } \\
\text { recuperação }\end{array}$ \\
\hline Montenegro & & $\mathrm{X}$ & & & $\begin{array}{c}\text { Museu Histórico, Pinacoteca Pública } \\
\text { Ênio Pinalli e Atelier Livre }\end{array}$ & Inaugurado em nov.2006 \\
\hline Osório & $X$ & & & & Museu da Via Férrea & $\begin{array}{c}\text { Construída réplica e } \\
\text { Inaugurado em 19.05.2008 }\end{array}$ \\
\hline Parobé & & $x$ & & & Museu Histórico & Inaugurado em 2002 \\
\hline Pelotas & $x$ & & & & Memorial Ferroviário & $\begin{array}{c}\text { Restaurada em } 2014 \\
\text { memorial em andamento }\end{array}$ \\
\hline Portão & $X$ & $x$ & & & Memorial Histórico de Portão & Não localizada data \\
\hline Porto Alegre & & & $X$ & & $\begin{array}{c}\text { Espaço Cultural Grêmio Esportivo } \\
\text { Ferrinho }{ }^{34}\end{array}$ & Inaugurado em 1963 \\
\hline Porto Alegre & $x$ & & $x$ & & Espaço Cultural Júlio Enes Araújo & Inaugurado em 2011 \\
\hline Porto Alegre & $X$ & & & & $\begin{array}{c}\text { Saguão escritório } \\
\text { da Inventariança da Extinta RFFSA }\end{array}$ & Inaugurado em 2000 \\
\hline Rio Grande & $x$ & & & & Projeto para museu ferroviário & Não localizada data \\
\hline Santa Maria & & $X$ & & & Museu Comunitário 13 de Maio & Inaugurado em 2001 \\
\hline
\end{tabular}

${ }^{34}$ Contemplado como Ponto de Cultura em 2016. 


\begin{tabular}{|c|c|c|c|c|c|}
\hline Santa Maria & $x$ & & & $\begin{array}{l}\text { Associação Amigos do Museu } \\
\text { Ferroviário de Santa Maria }\end{array}$ & Fundado em 31.10 .2003 \\
\hline Santa Rosa & & $x$ & & Museu Municipal e Biblioteca Pública & Inaugurado em 07.08.2003 \\
\hline $\begin{array}{l}\text { Santana do } \\
\text { Livramento }\end{array}$ & $x$ & & & $\begin{array}{l}\text { Museu - Cine Estação } \\
\text { Instituto Educação ALL }\end{array}$ & $\begin{array}{l}\text { Restaurada em } 2012 \mathrm{e} \\
\text { Inaugurado em } 17.01 .2013\end{array}$ \\
\hline Santiago & $x$ & & & $\begin{array}{l}\text { Estação do conhecimento } \\
\text { Memória Ferroviário de Santiago }\end{array}$ & $\begin{array}{l}\text { Restaurada em 2009/11 } \\
\text { Inaugurado em 03.01.2011 }\end{array}$ \\
\hline Santo Ângelo & $x$ & & & $\begin{array}{c}\text { Anexo ao Memorial Coluna Prestes - } \\
\text { o Museu Ferroviário. }\end{array}$ & $\begin{array}{c}\text { Restauro - data? } \\
\text { Inaugurado em dez } 1996\end{array}$ \\
\hline São Borja & & $x$ & $x$ & $\begin{array}{c}\text { Arquivo Histórico Municipal e Centro } \\
\text { Cultural }\end{array}$ & $\begin{array}{l}\text { Inaugurado em } 2013 \text { ainda } \\
\text { em situação de abandono }\end{array}$ \\
\hline São Gabriel & & $x$ & & $\begin{array}{l}\text { Museu Gaúcho da FEB - Forças } \\
\text { Expedicionárias Brasileiras }\end{array}$ & \begin{tabular}{|l} 
Fundado em 12.01 .1978 \\
Vai para Estação em 1980
\end{tabular} \\
\hline São Leopoldo & $x$ & & & $\begin{array}{l}\text { Museu do Trem de São Leopoldo - } \\
\text { (CPHFRS/PRESERVE) }\end{array}$ & \begin{tabular}{|c|} 
Inaugurado em 26.11 .1976 \\
Reconstruído 1984 \\
Reinaugurado em 1985 \\
\end{tabular} \\
\hline Sapiranga & & $X$ & & $\begin{array}{l}\text { Museu Municipal Adolfo Evaldo } \\
\text { Lindenmeyer }\end{array}$ & Inaugurado em 1996 \\
\hline $\begin{array}{c}\text { Várzea Grande } \\
\text { (Gramado) }\end{array}$ & $x$ & & $x$ & $\begin{array}{l}\text { Espaço Cultural Estação Férrea } \\
\text { Várzea Grande }\end{array}$ & $\begin{array}{l}\text { Inaugurado em } 16.05 .2008 \\
\text { reformado em } 2009\end{array}$ \\
\hline
\end{tabular}

Fonte: elaborado pela autora

Visualizar o panorama dos museus ferroviário brasileiros possibilita refletir sobre tópicos específicos da formação de cada museu e do agrupamento de cada coleção. São muitas lacunas ainda abertas para compreender as diferentes iniciativas e a relação entre elas. Comparar os quadros acima instiga novos questionamentos quanto a concentração dos museus em determinados estados e regiões; as coleções que acolhem; ao funcionamento e gestores; além do possível desconhecimento que cada instituição elencada possa ter do cenário em que estão inseridas. Futuras pesquisas poderão explorar essas e outras questões. 


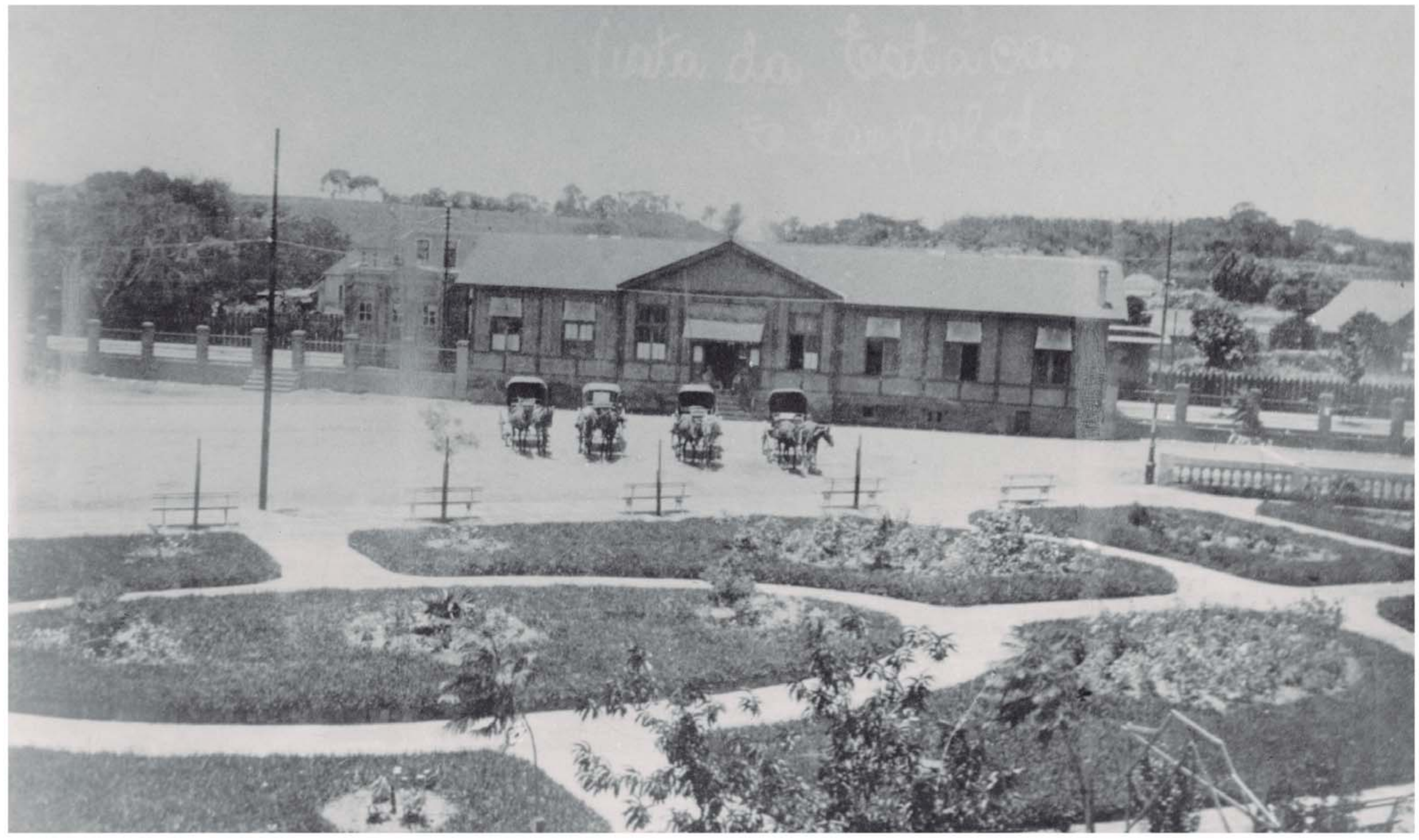

Capítulo 3

MUSEU DO TREM DE SÃO LEOPOLDO 
São Leopoldo tem em sua história a passagem de portugueses, africanos, alemães, italianos, entre outros. A cidade destaca a colonização alemã e os avanços decorrentes do período da chegada destes colonizadores. Interessada em preservar a história, a cidade providencia mecanismos de valorização atrelados aos aspectos da modernidade e economia local decorrentes da ocupação do território. A criação do Museu do Trem no mesmo local em que foi inaugurada a primeira estação férrea gaúcha demonstra parte dos interesses na preservação do patrimônio e na história da cidade. 


\subsection{PRIMEIRA INICIATIVA}

O Museu do Trem de São Leopoldo não é um fato isolado. O cenário museal e cultural apresenta, por um lado, a criação de museus ferroviários nos estados de São Paulo e Pernambuco; por outro a inauguração na cidade de São Leopoldo, da Biblioteca Pública Municipal, em 1941; do Museu Histórico Visconde de São Leopoldo (MHVSL), em 1959; e do Museu de Arqueologia e Etnologia ${ }^{35}$, em 1983-4.

A história da criação do Museu do Trem de São Leopoldo não é linear, a começar pelos interesses simultâneos em pontos diferentes. A inquietação frente ao acúmulo do patrimônio, incluindo estações desativadas, despertou atenção da população e do poder público. Algumas ideias convergiam em iniciativas positivas, outras em discursos pesarosos e derrotistas, sem qualquer ação. Tanto nas cidades do interior, como na capital gaúcha, a RFFSA agrupa em almoxarifados máquinas, relógios, bancos, mobiliários, telégrafos, peças de toda ordem, principalmente da antiga VFRGS, que eram substituídas por outras mais modernas. Já as estações erradicadas, ficavam perdidas muitas vezes em pontos geográficos inacessíveis, passando a serem vistas como monumentos, que rememoravam um passado nostálgico, porém de difícil acesso, ficando abandonadas.

Em São Leopoldo, a comunidade participa na formalização do museu ferroviário, porém havia planos de um complexo museológico para a cidade, agrupando os museus já existentes, Museu Histórico Visconde de São Leopoldo (MHVSL) e a Casa do Imigrante, e o futuro Museu do Trem, (PRIETO, 2011; MOEHLECKE, 2011; BEMVENUTI, 2012a). Em paralelo, se verifica as preocupações com patrimônio ferroviário pela RFFSA, que mais tarde vai ao encontro a iniciativa da cidade.

A escolha para a formalização do Museu do Trem em São Leopoldo perpassa diversas questões: (1) a Antiga Estação de São Leopoldo obter uma área ferroviária generosa com patrimônio histórico edificado; (2) ser o primeiro trecho ferroviário inaugurado no RS; (3) Estação São Leopoldo da Empresa de Trens Urbanos de Porto Alegre (TRENSURB) ao lado; (4) interesse e organização da cidade na implantação do Museu do Trem. Outro fator apontado pelo engenheiro Roberto Guedes Albuquerque da $\mathrm{Luz}^{36}$, é o fato da Estação de Santa Maria, importante entroncamento ferroviário, também

\footnotetext{
35 Segundo Pe. Ignácio Schimitz, herdou do Seminário Nossa Senhora da Conceição o acervo que já vinha agregando objetos há décadas, inaugurado na cidade, aos cuidados do Instituto Anchietano de Pesquisa.

${ }^{36}$ Engenheiro Roberto Guedes Albuquerque da Luz é admitido na RFFSA em dezembro de 1978 e permanece até a liquidação em fevereiro de 2007, tendo sido um dos poucos ferroviários a ser realocado para a empregadora VALEC Engenharia, Construções e Ferrovias S.A., passando a realizar atividades na
} 
cogitado para abrigar o Museu do Trem do RS, estar com o ramal em pleno funcionamento com atividades da ALL, que é a concessionária.

Conforme ata de reunião da diretoria do MHVSL, de abril de 1975, consta o pedido de permissão de uso da antiga estação de São Leopoldo, para diretoria da SR6; solicitação ao Prefeito Municipal, da cedência de uma professora para trabalhar no futuro Museu do Trem (MOEHLECKE, 2011). Mais tarde, sob a responsabilidade do MHVSL, confirma-se a ida da professora Eliane Klumb ${ }^{37}$, designada para a função de abrir o Museu para o público, receber escolas e zelar pelo local.

A RFFSA fez-se presente, através do representante Dr. Plauto Adroaldo dos Santos Facin, Superintendente da SR6, no dia 26 de novembro de 1976, no ato de inauguração do Museu do Trem de São Leopoldo, com parceria entre o MHVSL, a Prefeitura de São Leopoldo e a RFFSA. A data escolhida para o ato de inauguração do Museu do Trem de São Leopoldo foi especialmente por ser o aniversário de cem anos do lançamento da pedra fundamental, que marca para a construção da ferrovia no século $\mathrm{XIX}$, no mesmo local.

O último trem de passageiro a trafegar em São Leopoldo foi o trem operário, sendo que, na ocasião da criação do Museu circulavam apenas trens de carga. A Estação de São Leopoldo foi desativada por completo apenas na década de 1980. Para comportar o Museu, o prédio, que ainda era usado para a função de controle de passagem dos trens de carga e moradia do Agente de Estação, foi subdividido. Uma parte para organização do espaço do Museu, com exposição de objetos; a outra parte, para uso da ferrovia (PRIETO, 2011). Organizou-se uma mostra com peças emprestadas do acervo do MHVSL e outras trazidas da SR6, de Porto Alegre, e abriu-se um livro ${ }^{38}$ para registros de assinaturas com texto inicial assinado pelo Prof. Telmo Lauro Müller.

No referido livro de registros constam 63 assinaturas $^{39}$ de visitantes presentes, entre elas: Carlos Mac Ginity ${ }^{40}$, Ana Maria Cabral e Maria Margarida Lemos de Carvalho (Museu Júlio de Castilhos - Porto Alegre), Professor Arnildo Hoppen (Colégio Sinodal -

\footnotetext{
Inventariança da Extinta RFFSA até janeiro de 2013, quando cedido para o DNIT, onde ainda hoje realiza atividades vinculadas aos inventários.

${ }^{37}$ Filha do Prof. Telmo Lauro Muller, então diretor do MHVSL.

38 Também se lê uma anotação de autoria do Prof.Telmo Lauro Muller ao final do texto, entre parênteses, registrando que, na ocasião, o dia estava ensolarado com céu azul.

39 Entre as pessoas presentes foi possível localizar nome para as entrevistas relativas a busca de dados históricos no Projeto de 35 anos do Museu do Trem, em 2011.

40 Descendente de John Mac Giniy (responsável pela construção do trecho).
} 
São Leopoldo), Astrogildo Fernandes (UFRGS - Porto Alegre), Hélio Bueno da Silveira (Ferroviário), Ana Winter (TV Gaúcha) (BEMVENUTI, 2012a). Havia representantes do poder público, instituições museológicas e da própria RFFSA, sendo possível verificar o volume expressivo de pessoas presentes no evento (ver figura 19).
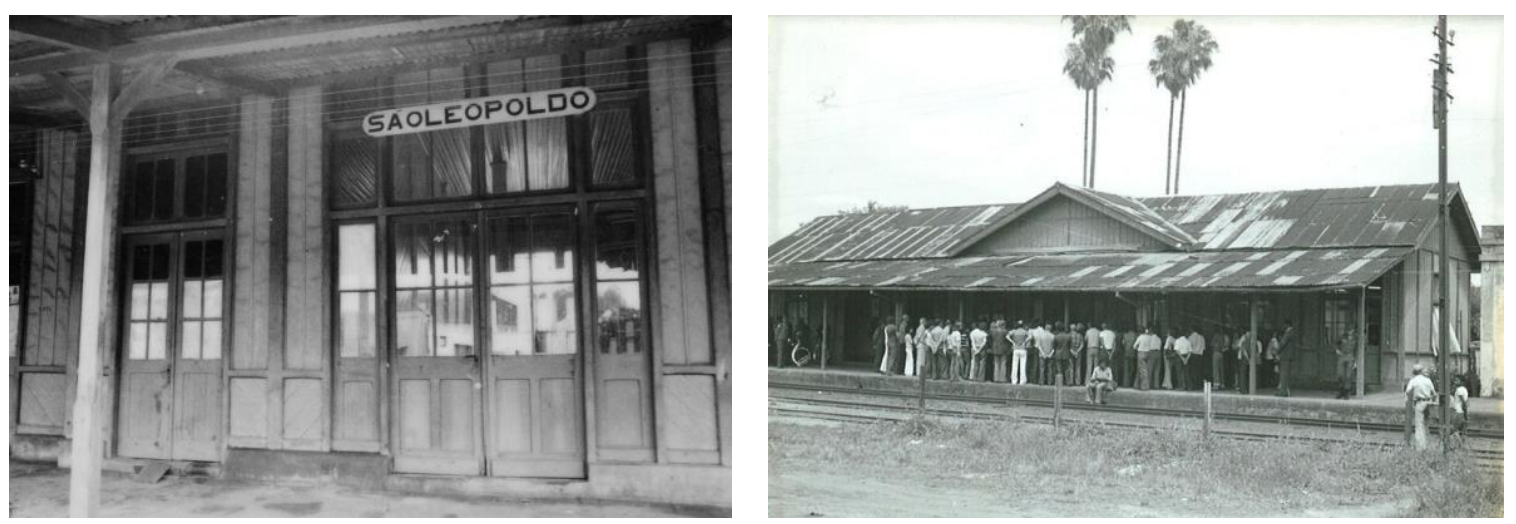

Figuras 18 e 19 - Entrada do prédio e vista da Plataforma da Estação de São Leopoldo. Inauguração do Museu do Trem Data: 26.11.1976.

Fonte: Museu do Trem de São Leopoldo.

No discurso ${ }^{41}$ proferido pelo Prof. Telmo Lauro Müller, então diretor do MHVSL, são mencionados: fatos históricos da ferrovia; trechos da passagem do viajante inglês Michael George Mulhall, em 1871, quando no lançamento da pedra fundamental; a edificação préfabricada trazida da Inglaterra com uma proteção de zinco ${ }^{42}$; cita personagens e políticos importantes que chegaram a São Leopoldo de trem; e por fim, faz referência ao trem do futuro, o trem elétrico. Müller destaca também as parcerias entre a Prefeitura Municipal, MHVSL e a SR-6 e encerra o discurso com as mudanças do transporte de massa e a necessidade da nova tecnologia modernizada pelo trem elétrico e, finaliza anunciando projetos do complexo museológico para a cidade, a citar:

Pelo comodato assinado com a RFF, o Museu Histórico "Visconde de São Leopoldo" será responsável pelo Museu do Trem que hoje entregamos ao público apenas parte, pois o aproveitamento total da estação depende da implantação do novo sistema de trens elétricos. É o começo. Um grande e animador começo (MULLER,1976:09).

Estudos desenvolvidos pelo Grupo Executivo de Integração das Políticas de Transportes da Empresa Brasileira de Planejamento de Transportes (GEIPOT) também marcam o ano de 1976 no setor do transporte ferroviário, pois apontam para a criação da empresa de Trens Urbanos de Porto Alegre (TRENSURB). Fato que iriam gerar grandes

\footnotetext{
41 Publicado na integra pela Revista Rua Grande, de São Leopoldo, em 26 fev. 1985.

${ }^{42} \mathrm{~A}$ Estação pré-moldada recoberta de zinco que tinha função de proteger de possíveis ataques de indígenas e de flechas incendiárias. Este é um aspecto repetido pela população da cidade.
} 
mudanças no cenário gaúcho, mas que ainda não era possível dimensionar os desdobramentos e, sobretudo, quais poderiam atingir o Museu do Trem.

Nos primeiros anos ${ }^{43}$ o Museu do Trem recebe escolas no turno da tarde, das $14 \mathrm{~h}$ às $17 \mathrm{~h} 30 \mathrm{~min}$, de terças-feiras a sábados, oferecendo exposição com objetos em duas salas. A professora responsável Eliane Klumb permanece no Museu por um período aproximado de dois anos (KLUMB, 2011).

\subsection{PRESERVE NO RIO GRANDE DO SUL}

Em 1982, a RFFSA se aproxima do espaço do Museu do Trem com a finalidade de desenvolver as atividades de restauro, remodelando a Estação para a criação de um Centro de Preservação da História da Ferrovia do Rio Grande do Sul (CPHFRS).

O processo de reconstrução do prédio da Antiga Estação em São Leopoldo inicia com o estudo das fotografias da estação de Porto Alegre, pois eram muitas as alterações que a descaracterizavam do original. Foram necessárias pesquisas aprofundadas, a fim de obter parâmetro para a reconstrução da antiga Estação, pois não fora localizado o projeto arquitetônico original.

$\mathrm{Na}$ reconstrução, foram dois anos de pesquisa, conforme Marioni Auler ${ }^{44}$, os detalhes foram estudados para que o projeto original fosse recuperado. O engenheiro Nelson Palmer, responsável pela coordenação da pesquisa e execução do trabalho, desenvolveu a tarefa envolvendo inúmeros profissionais, desde arquitetos, marceneiros, pedreiros e ferroviários, junto à equipe do PRESERVE que trabalhava paralelamente em pesquisa histórica, iconográfica, arquitetônica, além do estudo museográfico.

Houve toda uma preocupação de refazer cada pedaço de madeira, que hoje você enxerga aí na Estação...em cima, no teto, exatamente igual aos originais. Se pegou fotografias da época (AULER, 2011).

\footnotetext{
${ }^{43}$ Não foram localizados documentos sobre o período exato em que o Museu esteve aberto ao público nos seus primeiros anos.

44 Jornalista, funcionária aposentada da RFFSA, SR6, em Porto Alegre, tendo permanecido 30 anos na empresa, desde estagiária até chefe do Departamento de Comunicação Social, depois Comunicação Empresarial. Cabe destacar que a mesma foi a responsável por organizar os setores após as demissões. Auler acompanhou a trajetória do Museu do Trem, tendo participado dos diferentes momentos.
} 

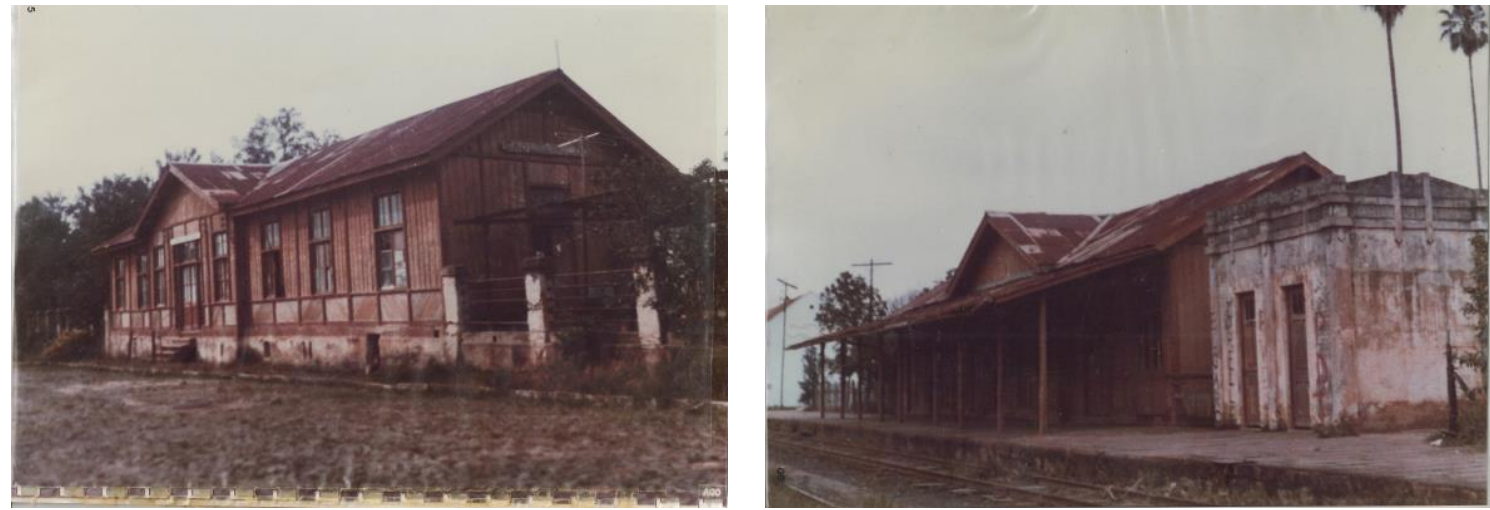

Figura 20 e 21 - Prédio antes da reconstrução - vista da entrada principal (esquerda) e vista da plataforma (direita). Ano: 1982.

Fonte: Museu do Trem de São Leopoldo
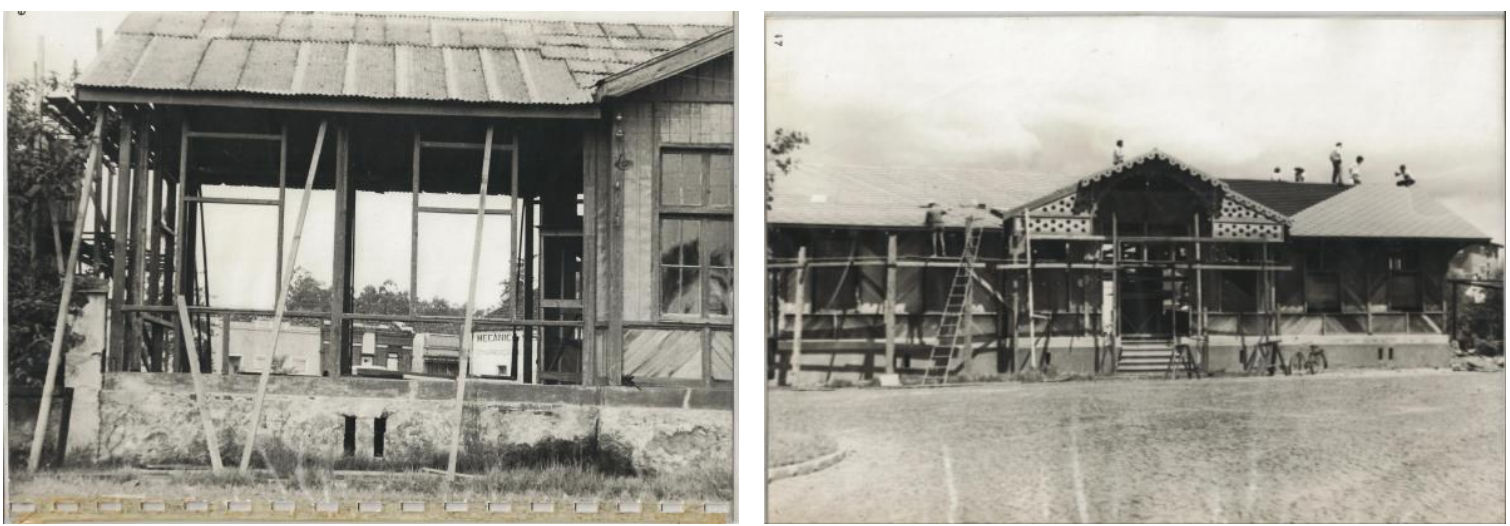

Figuras 22 e 23 - Reconstrução do prédio da Antiga Estação. Relatório PRESERVE em álbum fotográfico. Ano: 1983. Fonte: Museu do Trem de São Leopoldo.
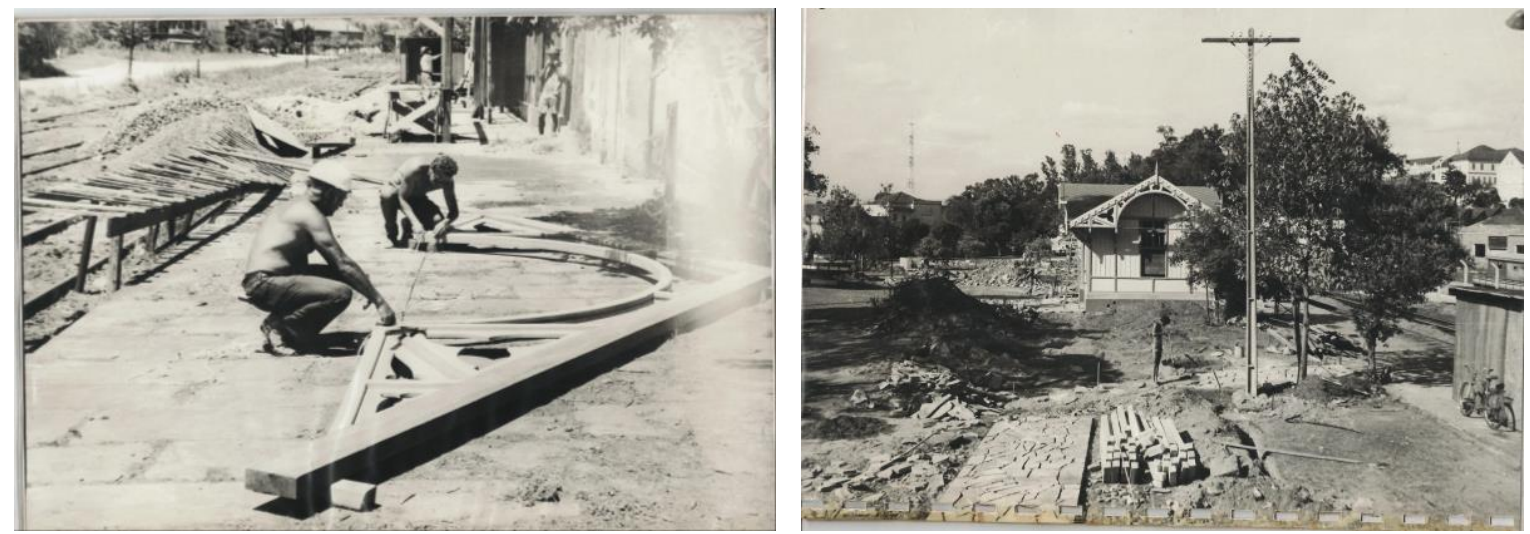

Figuras 24 e 25 - Reconstrução dos arcos e vista geral do Sítio. Relatório PRESERVE em álbum fotográfico. Ano: 1983.

Fonte: Museu do Trem de São Leopoldo.

Após o extenso trabalho de reconstrução do prédio da Antiga Estação, do Armazém de carga e o pátio remodelado como Sitio Histórico, o local é reinaugurado 
em 09 de março de $1985^{45}$. O ato solene contou com autoridades da cidade, assim como com o Ministro dos Transportes, Cloraldino Severo, e o Superintendente da SR6, Antônio Carlos Vidal de Oliveira. Na ocasião da inauguração, o Jornal Vale dos $\operatorname{Sinos}^{46}$ e a Revista Rua Grande noticiaram com encartes especiais, divulgando o novo Museu, agora Centro de Preservação da História Ferroviária do Rio Grande do Sul (CPFHRS).

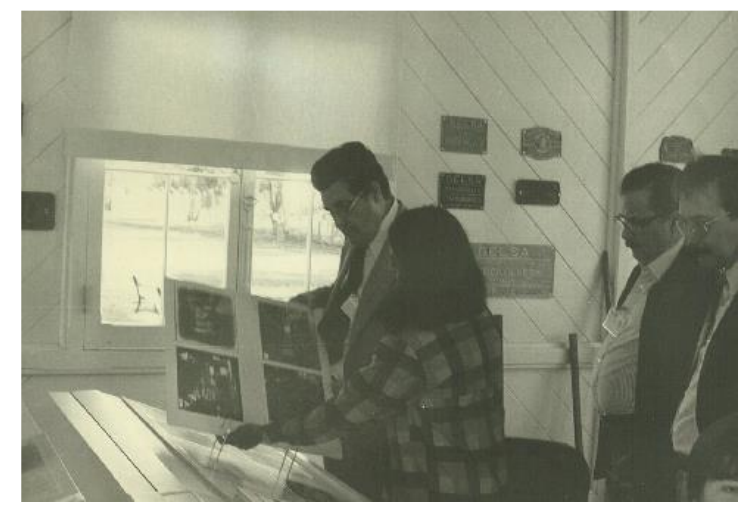

Figura 26 - Clarissa Oliveira de Carvalho mostra exposição a autoridades. Relatório PRESERVE em Álbum Fotográfico. Ano: 1985. Fonte: Museu do Trem de São Leopoldo.

Foi estruturada uma equipe com funcionários da RFFSA para as atividades de organização e preservação do acervo e também para as de recepção de visitantes. Entre os integrantes: Clarissa Oliveira de Carvalho, Isabel Cristina Flores Fernandes, Rejane Costa da Silva, Maria Trindade Mercker. Outros ferroviários, como Marioni Auler e Hélio Bueno da Silveira, trabalhavam em parceria com o Museu, mas estavam lotados em outro Setor da SR6.

Conforme o padrão do PRESERVE-RFFSA, na inauguração também era lançado um livro-catálogo do Centro de Preservação da História da Ferrovia. Em São Leopoldo, o livro-catálogo da CPHFRS possuía 115 páginas, 158 figuras, ficha técnica com nominata dos profissionais responsáveis pelo restauro e instalação do Centro de Preservação. O mesmo permaneceu disponível para a venda no Museu do Trem durante alguns anos, até esgotar.

A atuação do PRESERVE/PRESERFE provoca interrogações quanto a gerenciamento dos Centros e Núcleos nas cidades. É nitidamente uma unidade entre os trabalhos desenvolvidos em todo território nacional, mas até que ponto o Museu do Trem, por exemplo, possuía autonomia na gestão administrativa, na gestão de acervo e no educativo? Que concepção de museus o PRESERVE/PRESERFE fomentava? De que

\footnotetext{
45 Porém as atividades de montagem da exposição com objetos no pátio foram concluídas apenas em dezembro daquele ano.

${ }^{46}$ Encarte especial Museu do Trem veiculado em 26 de fevereiro de 1985.
} 
maneira os projetos museográficos foram discutidos com a cidade? De que maneira o PRESERVE absorveu as iniciativas do município de São Leopoldo?

\subsection{AGRUPAMENTO DO FUTURO ACERVO}

O Acervo do Museu do Trem tem registro de procedência de apenas parte dos objetos. Os bens transferidos para o Museu vieram de procedência diversa. Conforme o Engenheiro Roberto Albuquerque Guedes da $\mathrm{Luz}^{47}$ houve um trabalho importante da Superintendência do recolhimento e seleção inicial dos objetos que formariam posteriormente o acervo do Museu do Trem de São Leopoldo.

Tiveram origens diversas. Porque a Rede Ferroviária, ela tinha diversas instalações esparramadas no Rio Grande do Sul. Então ela tinha que ter instalação de Oficinas, para a manutenção dos vagões e das locomotivas. Ela tinha que ter instalação prá manutenção de outro tipo de máquinas. Então ela sempre teve, normalmente, em alguns Núcleos importantes, ela tinha em Rio Grande, Cruz Alta, Cacequi, Porto Alegre. Santa Maria foi um centro ferroviário importantíssimo, com oficinas de vagões grandes, e junto as oficinas e, as instalações importantes, tinham os almoxarifados. Então esses materiais que a medida foi avançando, e alguma modernização acontecendo na ferrovia, eles foram se tornando obsoletos, sem utilização. Eles então precisavam ser recolhidos. Eles eram recolhidos inicialmente para os almoxarifados. E esses almoxarifados eram descentralizados, tinham almoxarifados em várias cidades do Rio Grande do Sul [...] um trabalho de seleção nos almoxarifados e, como em Porto Alegre tinha um almoxarifado muito grande e muito importante, se concentrou aqui em Porto Alegre e com o que tinha no almoxarifado em Porto Alegre, se fez uma seleção para se montar o acervo do Museu [...] (LUZ, 2011).

Conforme a jornalista Marioni Auler, desde meados da década de 1970 a SR6 já pensava na possibilidade de transferir para São Leopoldo as peças obsoletas da VFRGS que se acumulavam em depósitos. Auler relembra do impacto ao se deparar com uma sala repleta de objetos da Viação no Edifício Sede, em Porto Alegre, ainda no início da carreira:

[...] o nosso acervo era imenso. Eu lembro que quando eu entrei para a ferrovia em 75, logo que eu entrei para essa área de Comunicação, dentro do edifício sede, que era na rua Voluntários da Pátria, 1358, em Porto Alegre, e que hoje esse edifício sede pertence a Secretaria Estadual de Segurança, existia uma sala específica, que era abarrotada de objetos, em que quando aquilo era desativado...um telefone, até um banco de estação, qualquer objeto...se colocava naquela sala. E, eu entrei naquela época naquela sala, e fiquei impressionadíssima. Eu era uma menina, nunca tinha visto algo assim...tantos objetos que eu considerava [importante] sempre gostei de coisas antigas, objetos antigos. E eram telefones, telégrafos, enfim materiais de escritórios, abarrotados, apinhados. Em cima um do outro, cadeiras [...] e começou-se a modernizar a ferrovia no Estado todo e tinha coisas que começaram a ser desativadas. No caso os telefones,

\footnotetext{
${ }^{47}$ Desenvolveu atividade na Inventariança da Extinta RFFSA, no período da entrevista. Mas seu vínculo com a empresa foi transferido para o DNIT.
} 
os telégrafos, máquinas de escrever e por aí a fora [...] Essa salinha ainda não era museu, não era nada. Era uma sala de depósito (AULER, 2011).

Sabe-se que através da campanha da RFFSA, para que ferroviários levassem as peças guardadas em casa, foram recolhidas também diversas peças. Os ferroviários guardavam objetos trazidos do local de trabalho, pois no encerramento das atividades lhes foi dito pela chefia imediata que escolhe algo para levar de lembrança. Essa situação é repetida naturalmente por ferroviários em diferentes lugares. Outro exemplo foi o caso vivido pelo ferroviário Hélio Bueno da Silveira, que salvou do fogo algumas peças que estavam sendo descartadas pela empresa que havia ganhado a concessão, e que numa ação de limpeza e organizar, esvaziou salas e queimou o que considerava velho e sem serventia ${ }^{48}$.

Com o Plano Nacional de Desestatização, foram leiloados objetos materiais diversos, estações, armazéns, etc. o Museu do Trem recebeu dois lotes de objetos para integrar o acervo, que foram retirados dos bens que iriam a leilão nos dias 22 de outubro e 05 de dezembro de 1996. Conforme nos relata a jornalista Marioni Auler, o acervo veio em etapas para o Museu.
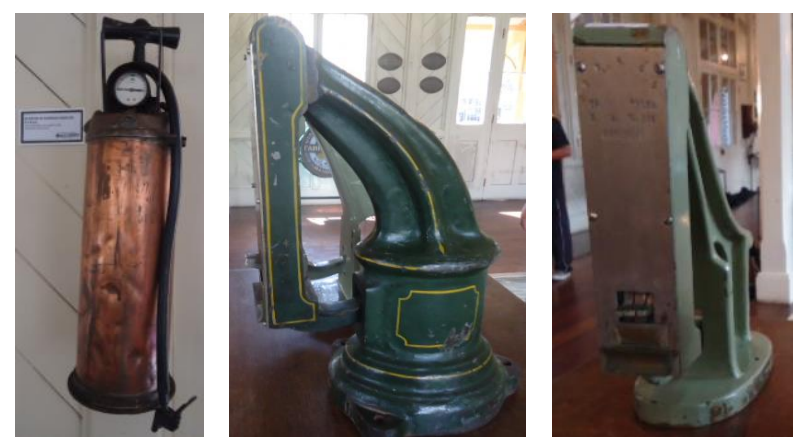

Figuras 27, 28 e 29 - Extintor de incêndio e Furador de Passagens (vista lateral e frente). Fonte: Museu do Trem de São Leopoldo
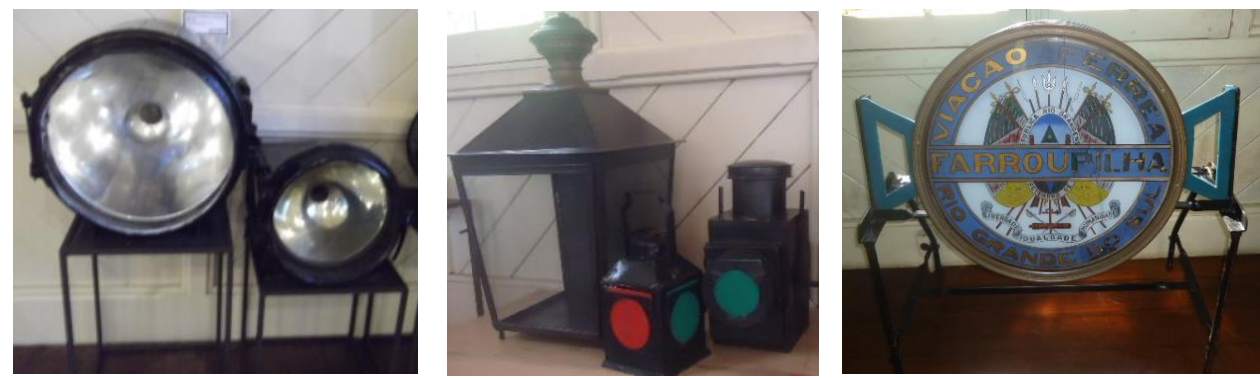

Figuras 30, 31 e 32 - Farol, Lanternas e Lanterna Farroupilha Fonte: Museu do Trem de São Leopoldo

\footnotetext{
${ }^{48}$ No desespero, retirava do fogo e arrastava os objetos, mobilizado pela angustia de ver a sua história e a história do país apagada. Seu Helinho, como é chamado, escondeu os objetos e os tem até hoje sob sua guarda, porém junto, guarda também o medo de que os mesmos ainda possam ser reivindicados por alguém que não preserve o patrimônio.
} 

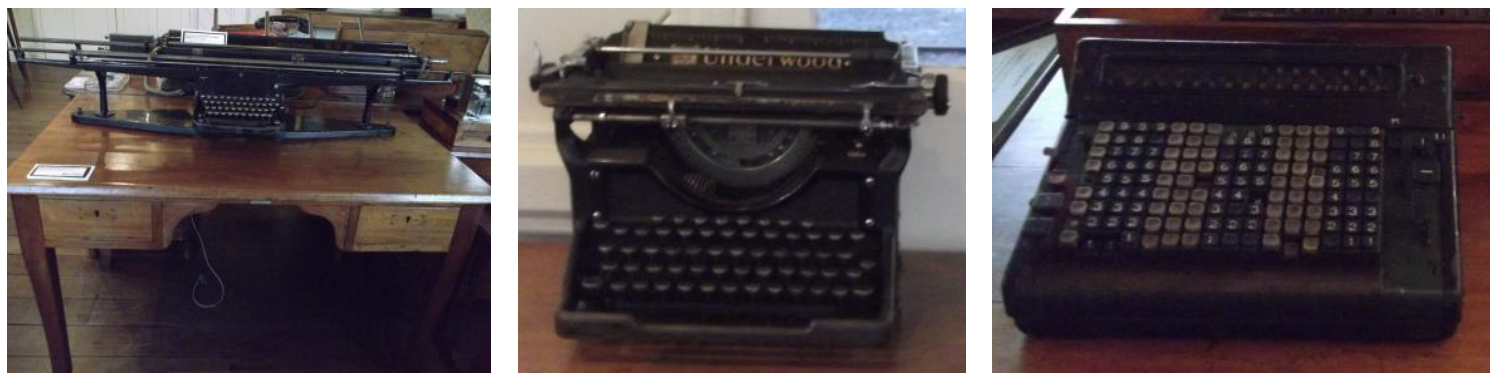

Figuras 33, 34 e 35 - Máquina de escrever de carro grande. Máquina de escrever e Calculadora. Fonte: Museu do Trem de São Leopoldo
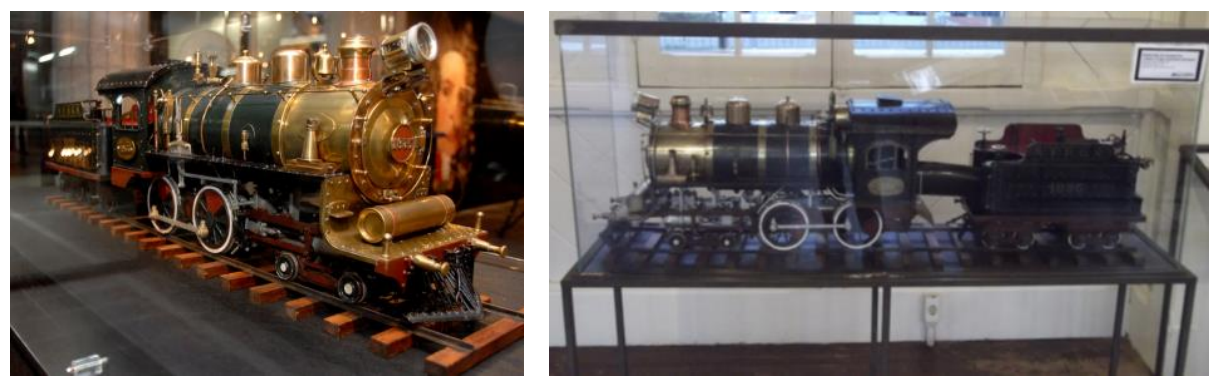

Figuras 36 e 37 - Miniatura Locomotiva (vista de lateral direita e esquerda) Fonte: Museu do Trem de São Leopoldo
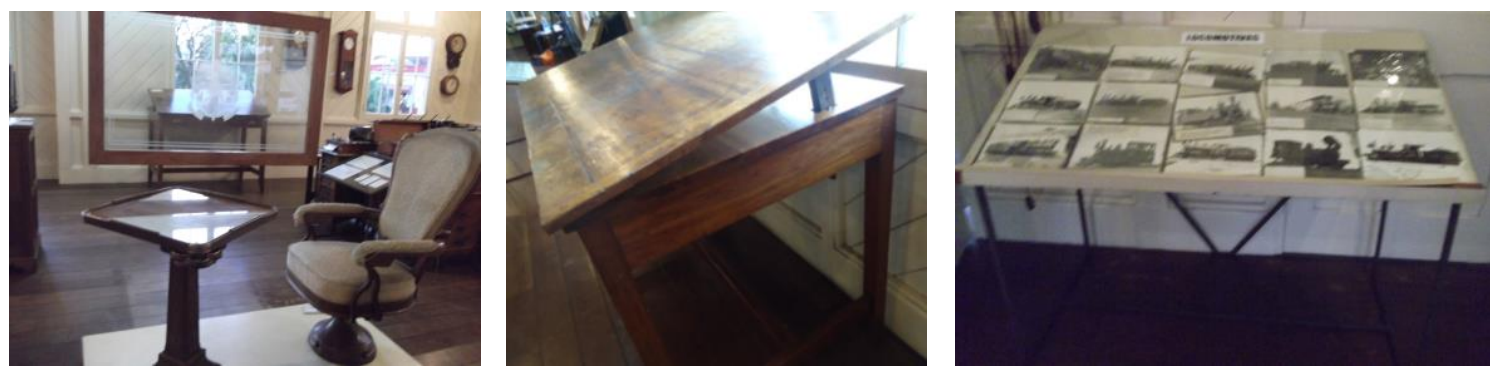

Figuras 38, 39 e 40 - Mobiliário Carro Administrativo Bento Gonçalves (mesa, poltrona, vidro) e Mobiliário (mesa de desenho) e Expositor com painel de fotos. Fonte: Museu do Trem de São Leopoldo
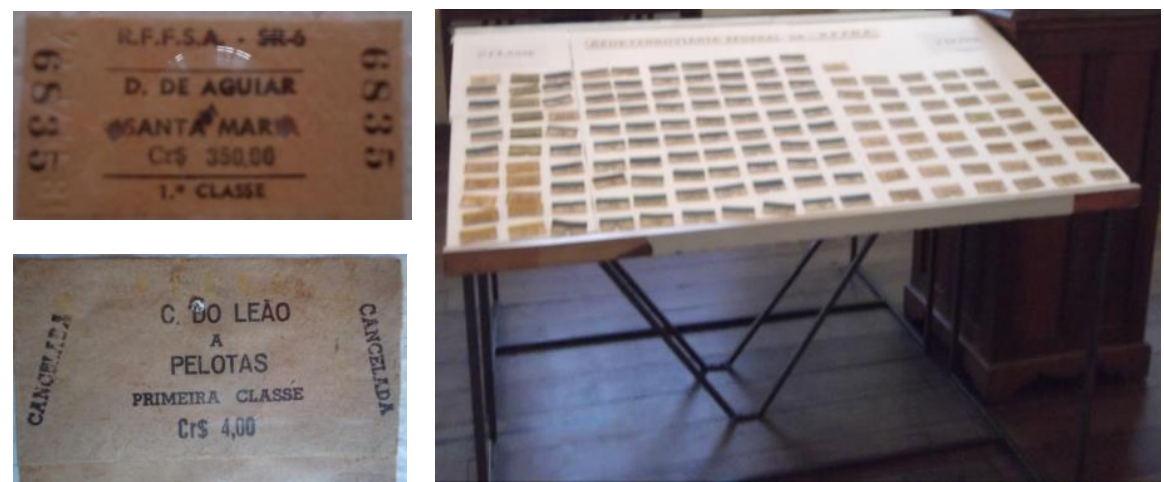

Figuras 41, 42 e 43 - Passagens (Dilermando Aguiar a Santa Maria e Capão do Leão a Pelotas) e expositor com diversas passagens.

Fonte: Museu do Trem de São Leopoldo 

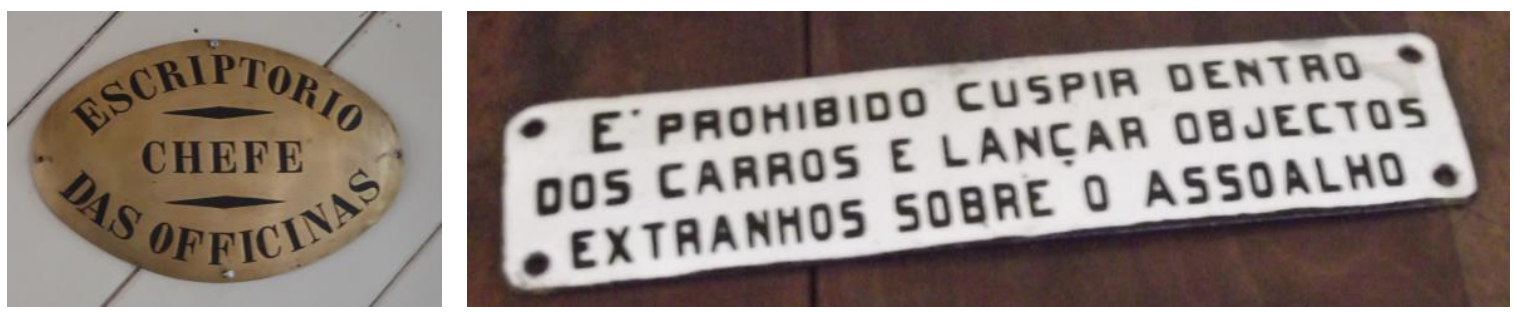

Figuras 44 e 45 - Placas dos Escritórios Administrativos da VFRGS e Placa Informativa do Carro de Passageiro da VFRGS.

Fonte: Museu do Trem de São Leopoldo.
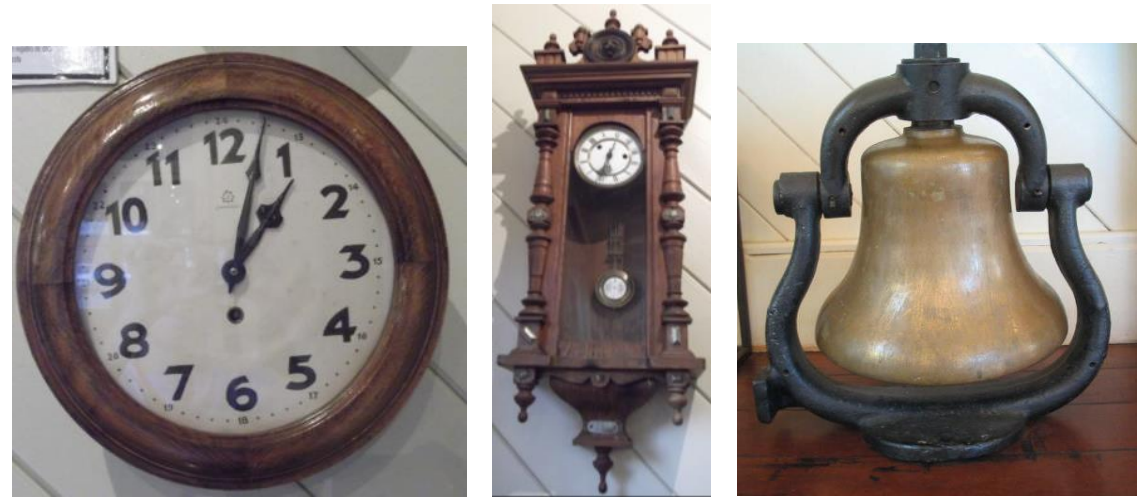

Figuras 46, 47 e 48 - Relógios de parede e Sino. Fonte: Museu do Trem de São Leopoldo.
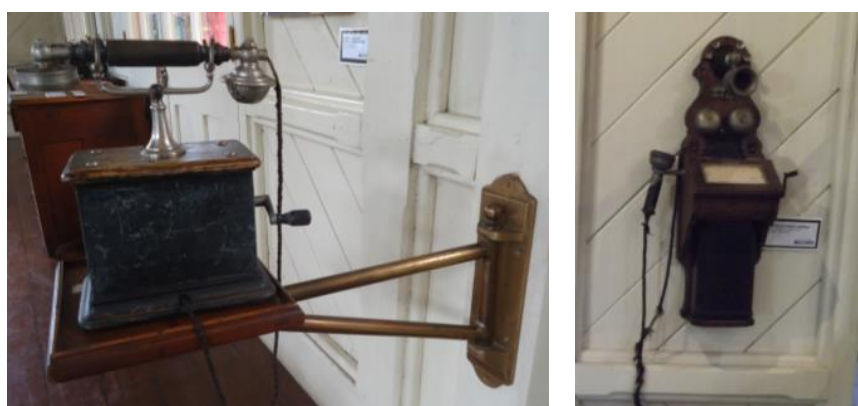

Figuras 49 e 50 - Telefone e telefone de parede dos escritórios da VFGRS. Fonte: Museu do Trem de São Leopoldo
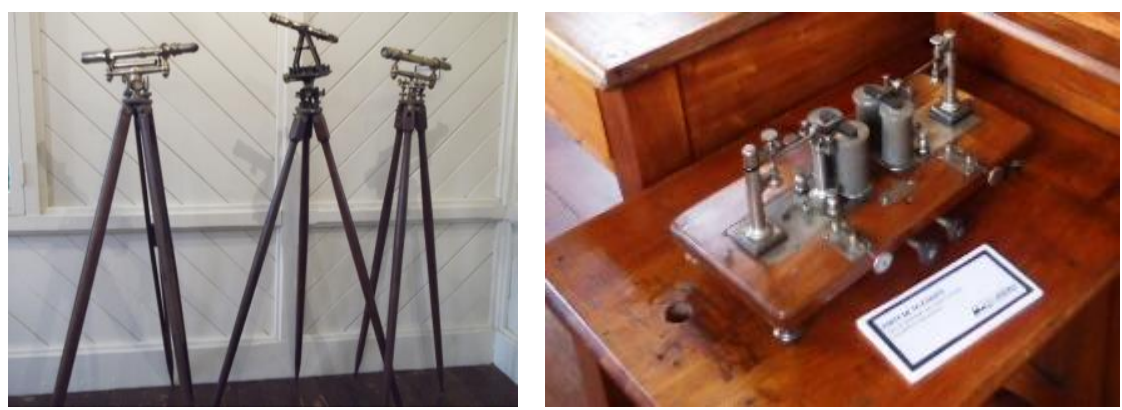

Figuras 51 e 52 - Teodolitos e peças do Telégrafo. Fonte: Museu do Trem de São Leopoldo 

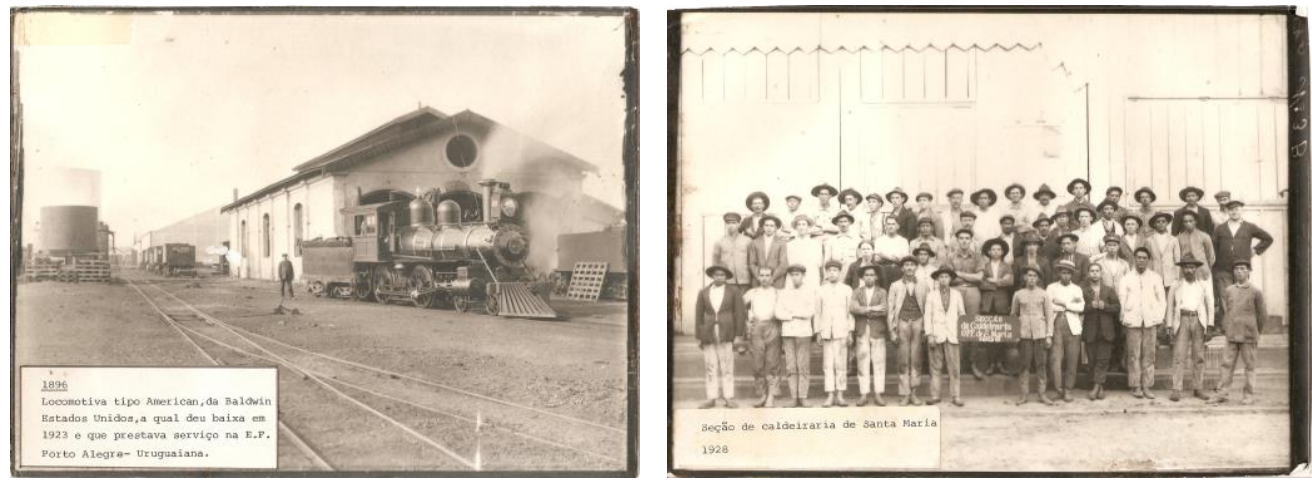

Figuras 53 e 54 - Locomotiva Baldwin, 1896 e Seção de Calderaria em Santa Maria, 1920 (reproduções dos Negativos de Vidro em exposição). Fonte: Museu do Trem de São Leopoldo.

\subsection{SETORES: DOCUMENTAÇÃO, COMUNICAÇÃO E EDUCAÇÃO}

O Armazém de cargas do Museu do Trem abrigava setores e acervo, onde foi organizada a Reserva Técnica. A realização do registro dos objetos tridimensionais foi coordenada inicialmente pela Maria Thereza Kahl Fonseca e posteriormente por Clarissa Oliveira de Carvalho ${ }^{49}$. Três livros de Tombamento, capa dura azul, padrão impresso com logomarca da RFFSA: primeiro foi aberto em 18 de dezembro de 1984, antes ainda da inauguração do CPHFRS; os outros dois foram abertos nos mesmos moldes, em 03 de setembro de 1985 e 24 de agosto de 1988, respectivamente. Na página ao lado do termo de abertura encontram-se instruções para o registro sob o título de esclarecimento. Lê-se:

O número de registro de cada peça é composto de três elementos, sendo o primeiro o número de ordem da entrada da peça no Museu, seguindo de ponto e segundo elemento é o ano de entrada da peça, também seguindo de ponto. $O$ terceiro se compõe de uma letra maiúscula referente a inicial da coleção (p. ex. coleção de relógios, Letra $R$ ) segundo o número da peça na referida coleção (MUSEU DO TREM,1984).

Tanto os registros de Tombamento das peças para o acervo, quanto as fichas catalográficas, foram organizadas no período entre 1984 a 1989, aproximadamente, seguindo critérios orientados pelo PRESERVE.

\footnotetext{
${ }^{49}$ Clarissa de Oliveira Carvalho era licenciada em História e foi admitida na RFFSA para realizadas atividades no Museu. Em 1983-84 a mesma realiza formação "Ação Educativa em Museu", entre 1983 e 1984, que permite que a RFFSA ao criar o cargo de museólogo, possa inseri-la. Recebe carta com a função de museóloga na Rede em 19.09.1988.
} 


\begin{tabular}{|c|c|c|c|c|c|c|c|}
\hline N* REGISTRO & PE C A & $\begin{array}{c}\text { VALOR } \\
\text { APROX. (aftual) }\end{array}$ & INCORPORAÇAO & PROCEDENCIA & EST. CONSERVAÇAO & DATA & OBSERVAÇAO \\
\hline M71.969 Eax & Rele de Telégrato & $\checkmark$ & hranguênua & vfrges & grive & 280489 & \\
\hline 1722 geg Pl 122 & Placin de canstrulecis de bocomotiva & $v_{v}$ & tramateréncro & RFrSA & bom & ze res & \\
\hline 1979929 A179 & Cankio & 1 & tranifiènus: & Refiat & exceiente & 28 oies & \\
\hline$(124 . * 6) \varepsilon 38(6)$ & Nivel d'aigua & $\gamma$ & brenikrânia & RFFSA & razoaivel & $280+.69$ & \\
\hline i175.989 E375 & Nivel d'aguia & 8 & hronserénus. & RfFSA & eccelente & relones & \\
\hline imb.989 E350(c) & Nivel d'aiguen. & 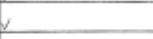 & bronsterencia & RfFia & razorivel & 28,0469 & \\
\hline$m \infty 00, E 381$ & Nuvel diägura & 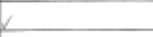 & tramplerêncus & RFASA & exvelente. & 2804.89 & \\
\hline wregeg.c382 & Nivel diágua & 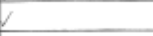 & Frangerêncas & Refeser & han & $280 \mathrm{as}$ & \\
\hline $42989 P_{123}$ & Placa de estacicio & $v_{v}$ & honsteressuce. & RfFAs & razparel & 28 का ह9 & \\
\hline 116090981124 & Pacai de estaúio & v & tromperencua & RFFIA & razodrel & $280<89$ & \\
\hline $1181989 \mathrm{TH}$ & Teietone de telex & 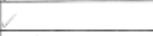 & tromiterérusa & RFGAA & bo in & zeoisen & \\
\hline 1182989 Tuz & Parke de telex & 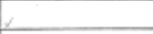 & Jramikiênuna & Rffers & boin & 280400 & \\
\hline \multirow[t]{7}{*}{$483909, T 118$} & Barte de teler & $\gamma$ & tronafiènua & pressa & bin & zacmes & \\
\hline & & & & & & & \\
\hline & & & & & & 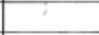 & \\
\hline & & & & & & & \\
\hline & & & & & & & \\
\hline & & & & & & & \\
\hline & & & & & & & \\
\hline & & & & & & & \\
\hline
\end{tabular}

Figura 55 - Reprodução da página 40 Livro de Tombamento do Museu do Trem. Ano: 1985. Fonte: Museu do Trem de São Leopoldo.
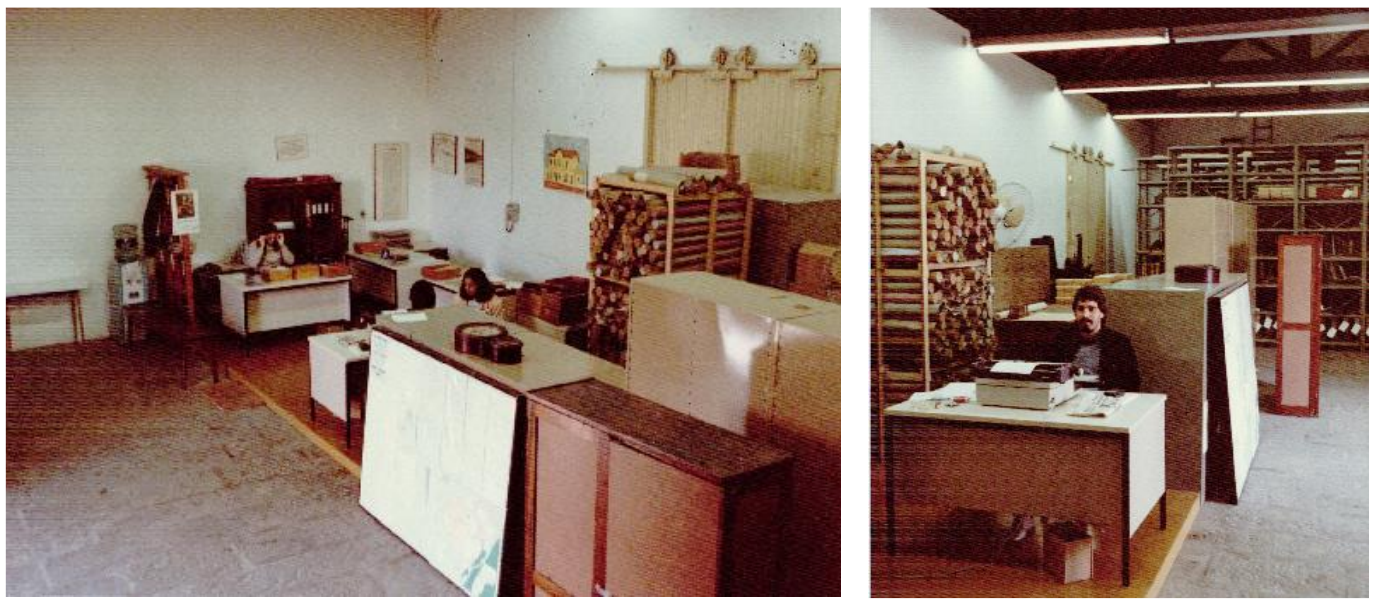

Figuras 56 e 57 - Interior do Armazém, equipe em atividades de documentação no Armazém. Período: 1985 ou 1987.

Fonte: Museu do Trem de São Leopoldo.
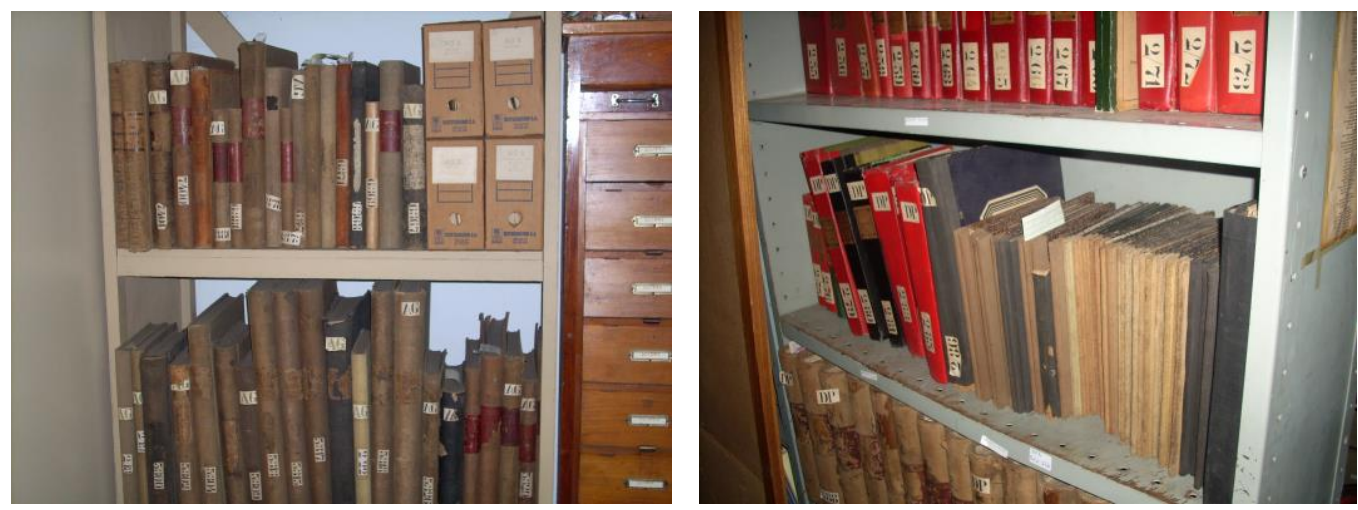

Figuras 58 e 59 - Acervo Documental acondicionado no Armazém. Ano: 2010. Fonte: Arquivo digital do Museu do Trem de São Leopoldo.

A exposição planejada pelo PRESERVE abrange todo Sítio Histórico Museu do Trem. No pátio expostos os objetos de grande porte, inicialmente, com a Locomotiva a Vapor Baldwin ํㅜ11, o autinho de linha, os carros de passageiros de $1^{\underline{a}}$ e $2^{\underline{a}}$ classe, os 
vagões, o carro leiteiro, a bicicleta, o rema-rema, o trole, exemplares de trilhos para diferentes bitolas e dormentes. A locomotiva Diesel-elétrica GM Tipo B12, no 6009, chegou posteriormente, em 1987.
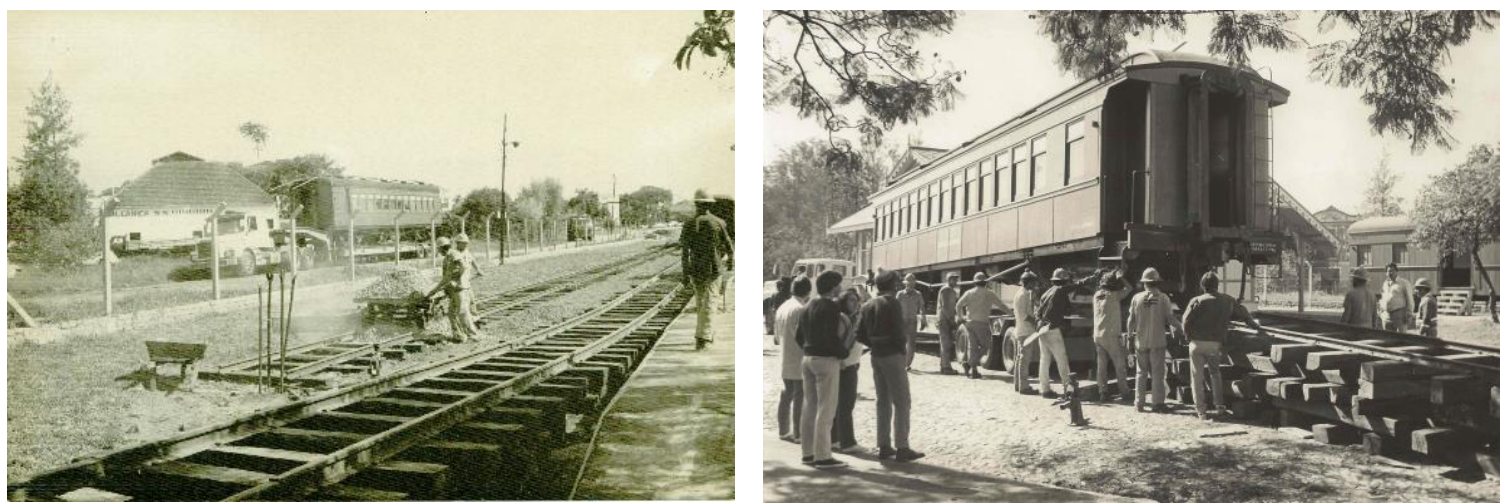

Figuras 60 e 61 - Chegada dos carros de passageiro. Álbum Fotográfico -

Relatório PRESERVE. Ano:1985.

Fonte: Museu do Trem de São Leopoldo.
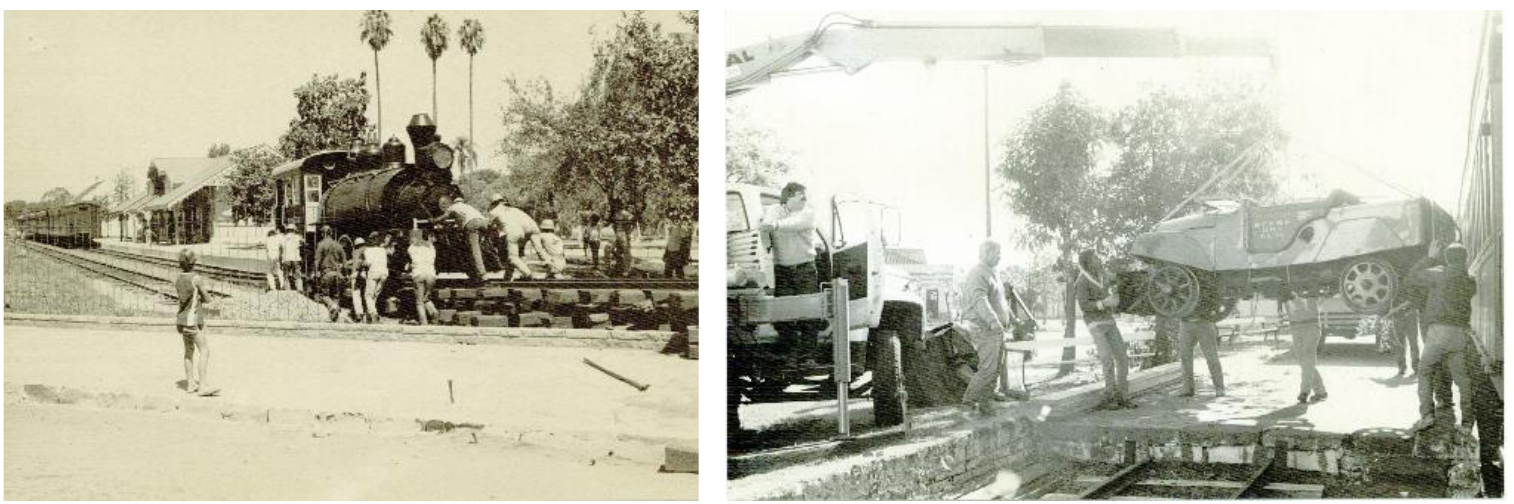

Figuras 62 e 63 - Chegada da Locomotiva "Maria Fumaça" e do autinho de linha. Ano: 1985. Fonte: Museu do Trem de São Leopoldo.
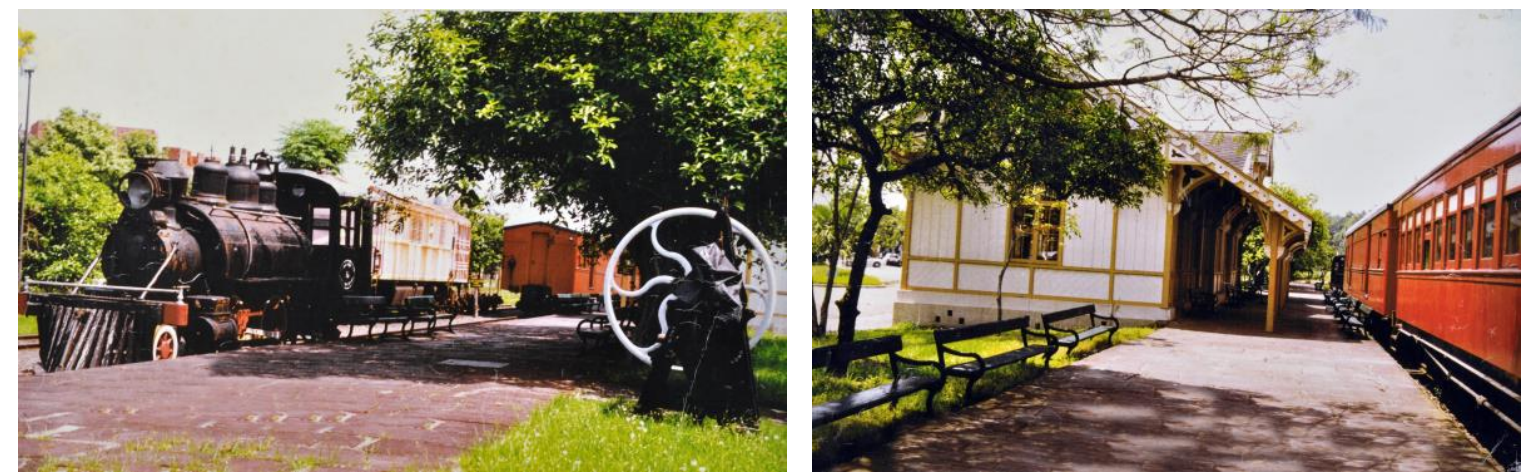

Figuras 64 e 65 - Locomotiva Baldwin no Sítio Histórico e vista da Plataforma da Estação, Prédio e Carro de Passageiro em exposição. Ano: 1985.

Fonte: Museu do Trem de São Leopoldo. 

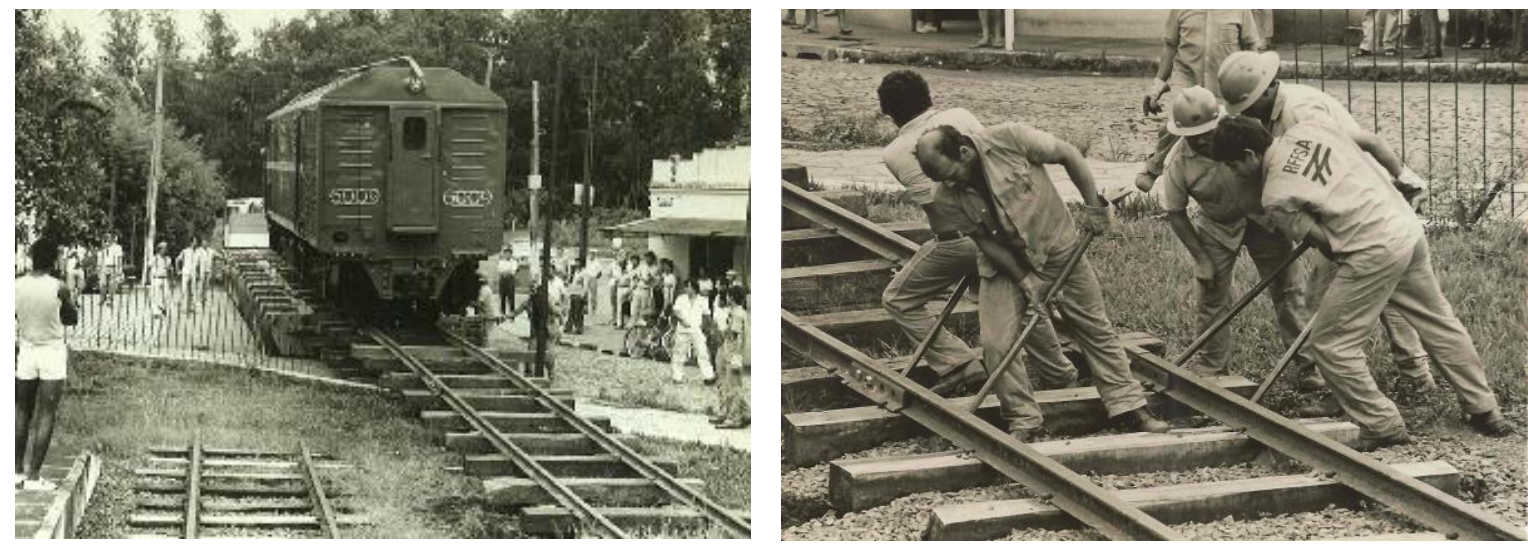

Figuras 66 e 67 - Chegada da segunda locomotiva, Diesel-elétrica, número 6009, e ferroviários alinhando trilhos para a descida da locomotiva. Data: 14.01.1987. Fotografia: Nilson Winter.

Fonte: Museu do Trem de São Leopoldo.

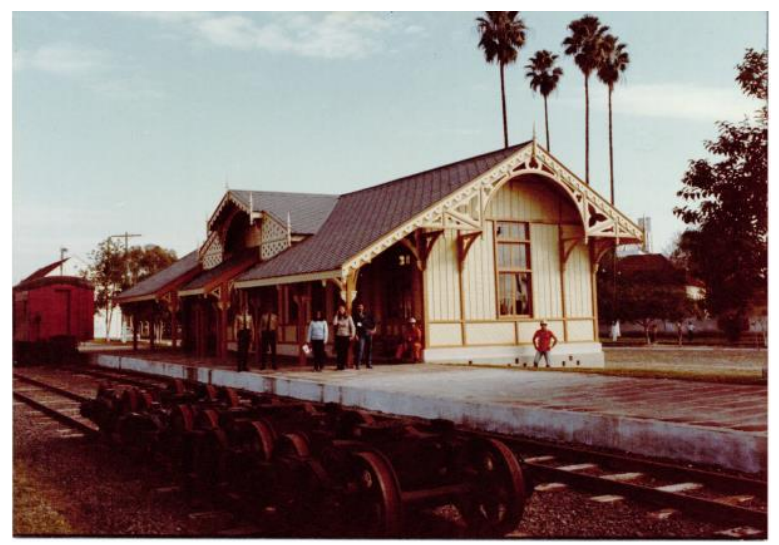

Figura 68 - Equipe do Museu do Trem com funcionário da RFFSA, na plataforma da Estação. Ano: 1985.

Fonte: Museu do Trem de São Leopoldo.

No interior do prédio reconstruído foram expostos objetos diversos: mobiliários dos setores administrativos da VFRGS, telégrafos, sinos, lanternas, farol Farroupilha Comemoração 110 anos, teodolitos, ferramentas da Via Permanente, telefones, máquinas de escrever, calculadoras, placas, fotografias ampliadas dos negativos de vidro, entre outros.

Os objetos dispostos em suportes de madeira e/ou metal ou em vitrinas, com etiquetas individuais. Painéis com vidro para exposição de fotografias, entre outros recursos expográficos, forma projetados especialmente para o Museu do Trem de São Leopoldo, como também fora desenvolvido um plano de iluminação para o ambiente. Verifica-se objetos suspensos por fios do teto, com apoio especial, na altura dos olhos dos visitantes. Conforme o arquiteto Sérgio Morais, responsável pela museografia, houve uma preocupação em explora a transparência, a fim de respeitar as informações visuais que a antiga Estação oferecia ao visitante. 

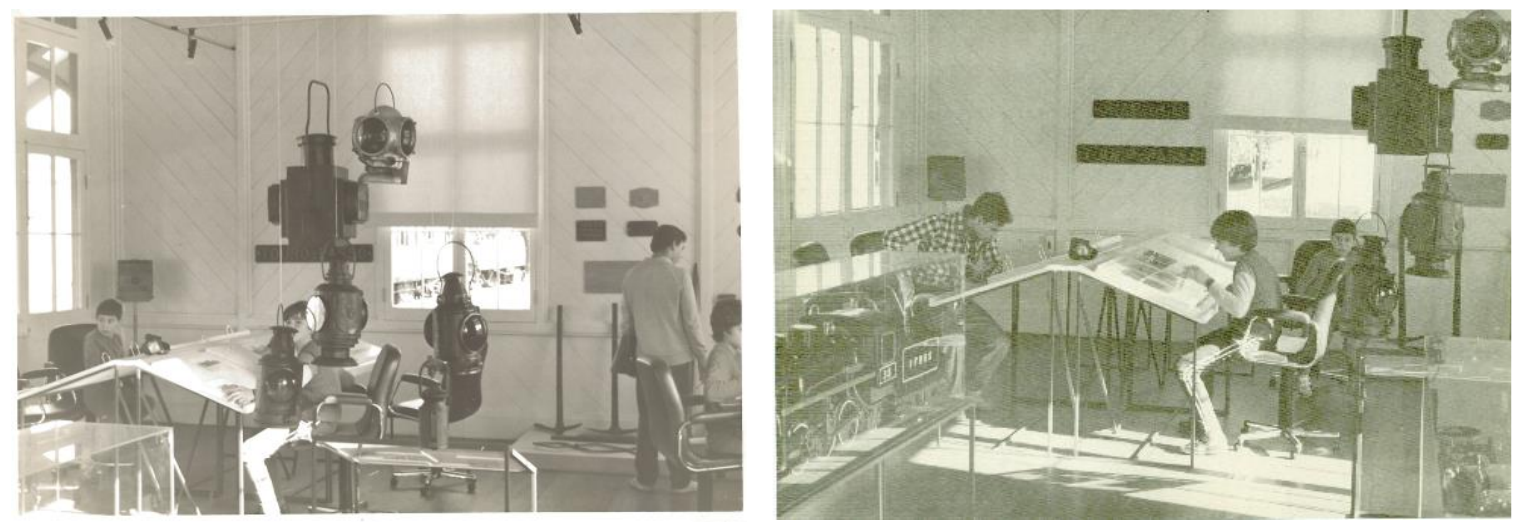

Figuras 69 e 70 - Exposição no interior do prédio da Estação e expositores acessíveis aos visitantes. Ano: entre 1985 e 1989.

Fonte: Museu do Trem de São Leopoldo.
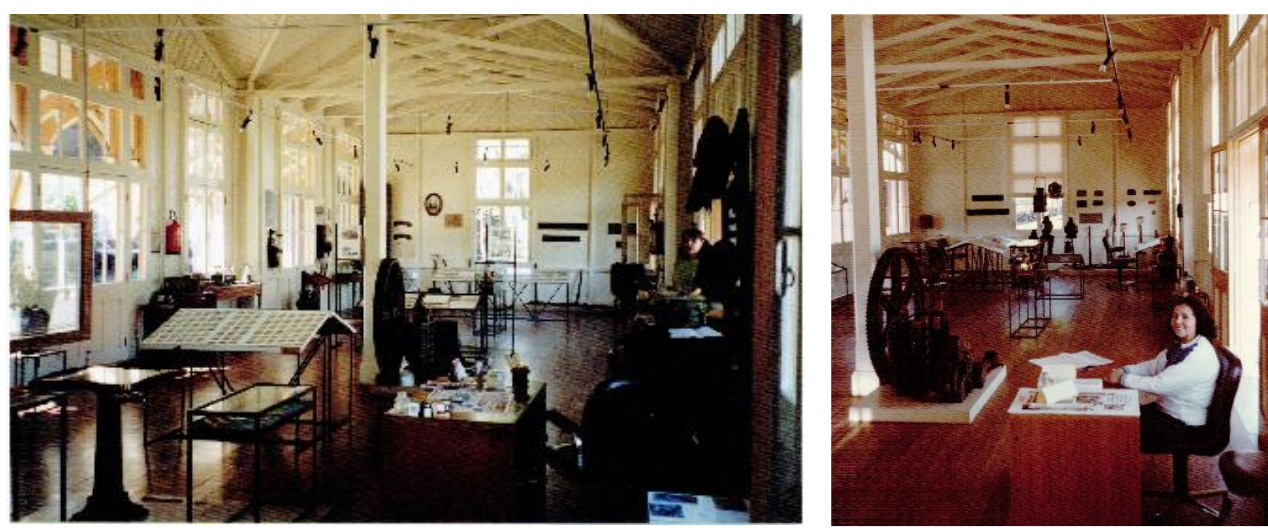

Figuras 71 e 72 - Exposição de longa duração (visão do centro) e funcionária na recepção. Ano atribuído: 1986-7.

Fonte: Museu do Trem de São Leopoldo.

Existiam normas de instalação das exposições, incluindo: estrutura física, uso de cores, sinalização, iluminação, espaço expositivo, ventilação, valorização das peças e circulação de público. A museóloga Telma Lasmar ${ }^{50}$ relata sobre a preocupação quanto ao padrão dos museus seguindo uma organização de três temas, a fim de dar sequência narrativa à exposição.

[...] tínhamos um padrão de museu ferroviário. E nesse padrão os museus tinham todos há mesma narrativa. Como que a ferrovia surgiu? Como que a ferrovia surgiu no Brasil? Como que a ferrovia chegou naquela região? Cada núcleo desses contava essa história introdutória, da locomotiva, locomotiva no Brasil, Barão de Mauá, etc. e depois ingressava na região (LASMAR, 2015 entrevista).

\footnotetext{
${ }^{50}$ Museóloga integrante da equipe do PRESERVE e posteriormente do PRESERFE, responsável pela escrita de materiais que foram distribuídos nos estados. O trabalho de Telma não incluía atividades junto à equipe em São Leopoldo.
} 
A museóloga relembra uma das dificuldades nesse processo, que era quanto ao registro de origem das peças.

[...] os próprios funcionários, os aposentados, saiam catando. E não tinha uma preocupação de naquela época, de anotar procedência data, quem foi...não tinha. Muitas coisas a gente não sabe mesmo a procedência. Quando a gente chegava para montar o museu, já tinha aquele tanto de coisa. Um monte de sino, um monte de apito, pedaço de trilho, já tinha um monte de coisa. Então a gente não sabia mesmo. E aí, porque também a história contada nos museus ferroviários, em grande parte, ela é a história oral. Em grande parte... com depoimentos do que as pessoas faziam (LASMAR, 2015 entrevista).

O PRESERVE/PRESERFE oferece diretrizes para que os processos museológicos sejam realizados, não só com relações a montagem da Reserva Técnica; registros em Livro Tombo; Fichas catalográficas; acondicionamento, organização e manuseio, mas também orientações para funcionamento, recepção dos visitantes, horário de atendimento, equipes especializadas e segurança adequada. Também foram localizados alguns materiais impressos: formulários em papel timbrado da RFFSA, para fins de relatório; Projeto do Setor Educativo e Plano de Visita Orientada para Monitores, de 1987; e Museu como Instrumento de Educação, de 1992, entre outros.
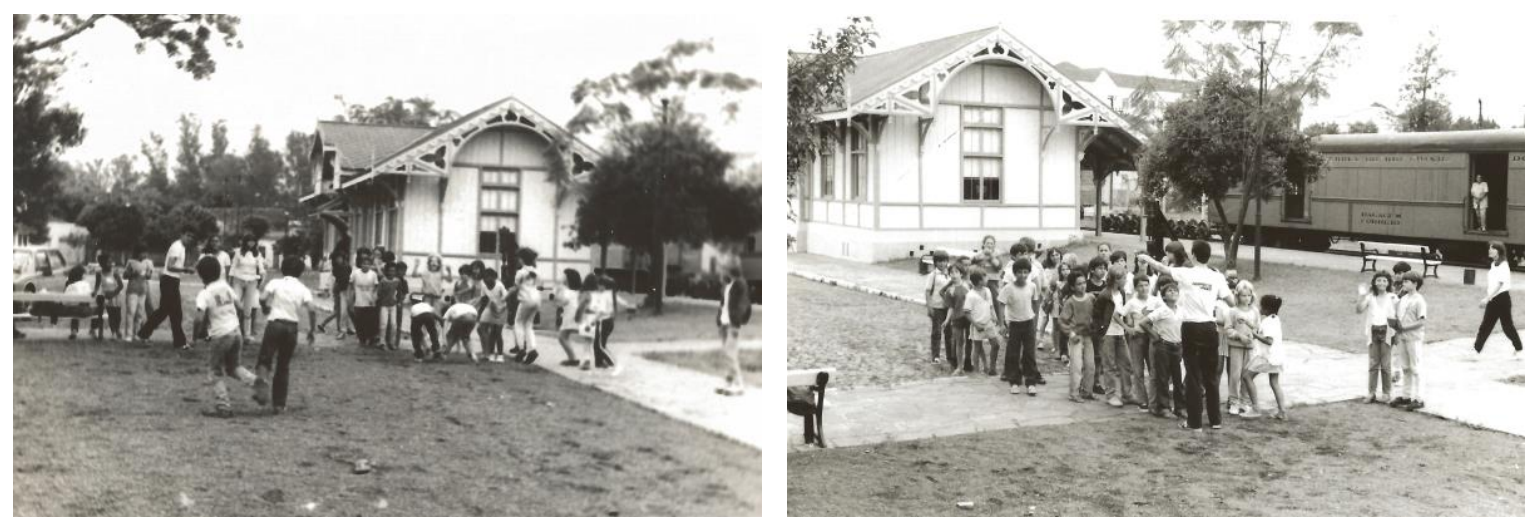

Figuras 73 e 74 - Atendimento de escolas no Museu do Trem prela equipe da RFFSA. Ano atribuído: 1987-8.

Fonte: Museu do Trem de São Leopoldo

O atendimento ao público era realizado pela equipe, recebendo escolas e visitantes, em geral, com visitas acompanhadas pela exposição em todo o Sítio Histórico e atividades diversas, além de exposições temporárias nos vagões. Observa-se adesão de público, tanto por relatos, fotografias, como pelo relatório sistematizado pela coordenação do PRESERVE e publicado em 1989. A seguir: 


\section{8 - Desempenho dos Centros de Preservação e Núcleos Históricos}

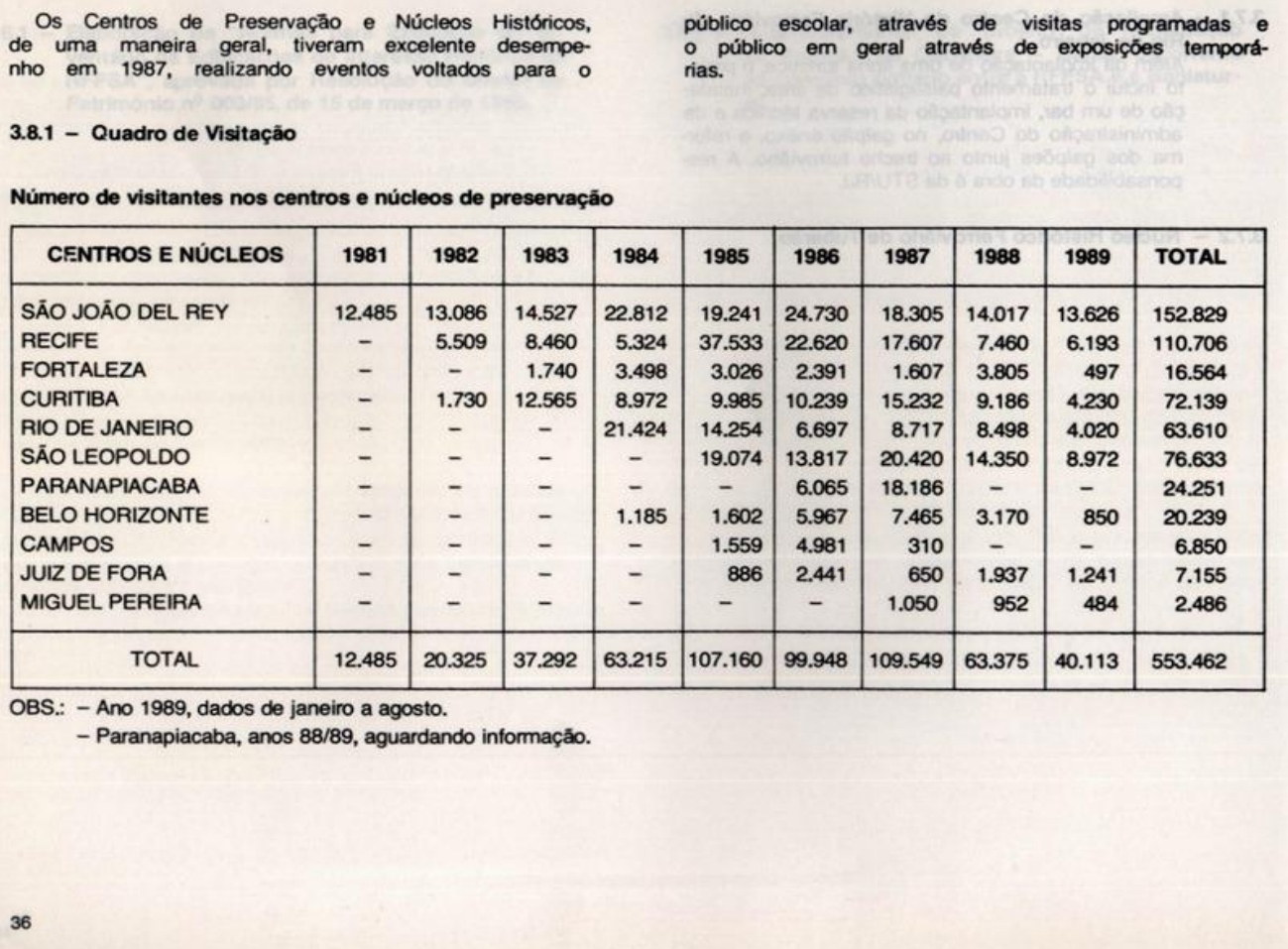

Figura 75 - Reprodução da página 03 do Relatório do PRESERVE sobre os Centros e Núcleos. Ano: 1989. Fonte: NUMEMUS - UNIRIO

Assim como em todo o Brasil, São Leopoldo sofre com o fechamento da RFFSA. O Museu fecha as portas e são encerradas atividade, seguidas de demissão dos funcionários que compunham a equipe: uma museóloga, cinco funcionários administrativos, serviços gerais e seguranças. Permaneceram no Museu apenas a funcionária Maria Mercker e um segurança (RAMOS, 2011; BEMVENUTI, 2012c). Nas entrevistas os depoimentos revelam ser este um momento traumático, delicado, carregado de vazios e de saudades, gerado pelo luto que se sucedeu ${ }^{51}$. Período que merece ser investigado com mais aprofundamento.

\subsection{TERCEIRA INAUGURAÇÃO}

A década de 1990 foi marcada por uma nova luta para a preservação do patrimônio ferroviário em São Leopoldo. A situação envolvia outros fatores, além daqueles gerados pelo fechamento do Museu. O que estava em discussão agora era a permanência do Museu

\footnotetext{
51 A cidade de São Leopoldo vive um luto duplo com o fechamento do Museu e falecimento da funcionária Clarissa Oliveira de Carvalho.
} 
no local, em virtude da construção da nova Estação de São Leopoldo, pela empresa de Trens Urbanos de Porto Alegre S.A (TRENSURB). A proposta inicialmente era ocupar o sítio do Museu para a Estação nova, neste caso, sendo necessário derrubar o mesmo.

A comunidade participava na defesa e permanência do Museu na cidade. Segundo o historiador Márcio Linck ${ }^{52}$, um grupo de estudantes do Curso de História da Universidade do Vale dos Sinos (UNISINOS), por exemplo, propunha que a nova estação fosse construída na Av. Mauá, em frente ao Colégio São José e ao BIG, pois, além da preocupação com a possível transferência do Museu para outra localidade, caso a TRENSURB seguisse o projeto original que planejava utilizar exatamente o espaço do Museu para construir suas instalações; chamavam a atenção para os impactos ambientais que poderia atingir o Sítio Histórico, caso a Estação da TRENSURB fosse construída próxima do Museu, como ocorreu. A proposta não vingou, mas gerou resultados, pois

o Ministério Público então chamou o TRENSURB, nos chamou, enquanto sociedade civil, [a Prefeitura Municipal e a RFFSA] para fazer então um acordo, um termo de ajustamento, onde como forma de compensação ao impacto da obra do TRENSURB, conseguiu-se: o recuo da Estação, em 52 metros; a cobertura dos vagões, em termos de proteção; e a própria reforma, das dependências do Museu do Trem e das locomotivas, que elas receberam pintura nova, tratamento para ferrugem, e o estofamento. Tudo, mais ou menos restaurado. Foi o último grande investimento que ocorreu em função da conservação e recuperação deste patrimônio (LINCK, 2011).

Outro grupo reunia os moradores do Bairro São José, ao lado do Museu (PRIETO, 2011; ROESLLER, 2011). Estes criaram uma Associação para defender a manutenção do Museu no local. A organização, a presença constante nas recorrentes reuniões, ou seja, a pressão exercida pela comunidade, de algum modo, acelerou (RAMOS: 2011) atitude do poder público na solução do problema.

Quando a comunidade de São Leopoldo começa a se reunir em vários locais. Eu ia com a Profa. Mirian Blauth Rossi, Dona Lilian Rossi. Paulo Koch. Henrique Prieto, em alguns momentos. Prof.Telmo Lauro Muller. E muitas outras pessoas. Nós nos reunimos pra pensar o que fazer, porque a comunidade queria a reabertura do Museu do Trem. A comunidade pedia. A comunidade se reunia e indicava ao Prefeito da época, Olimpio Albrecht, que queria essa reabertura. Houve uma mobilização, foi crescente (RAMOS, 2011).

Segundo reportagem ${ }^{53}$ veiculada em jornal local na época, também fora organizada um Comissão pró-permanência do Museu, com finalidade de buscar recursos para o Museu do Trem, com reuniões nas dependências da Associação Comercial e Industrial de

\footnotetext{
52 No qual ele mesmo era um dos estudantes do Curso de História na ocasião.

53 Jornal Vale dos Sinos, 19 de setembro de 1990.
} 
São Leopoldo (ACl-SL), com coordenação de Paulo Koch (Paulão) e relator, Prof. Léo Verbist, representante da Fundação Cultural.

A Prefeitura Municipal de São Leopoldo encaminha para o IPHAE o pedido de Tombamento do Sítio Histórico Museu do Trem, que foi realizado através da portaria ํo 17/90, datada de 02 de outubro de 1990.

Segundo o Instituto de Patrimônio Histórico e Artístico do Estado (IPHAE) na Rua Lindolfo Collor, onde se situa a entrada do Museu, possui casa com características do início do Século XX, que estavam incluídas na Listagem de Bens de Interesse Histórico de São Leopoldo. Com o Tombamento do Sítio Histórico, as construções que estiverem incluídas na poligonal de entorno (ver figura 76) do Museu passariam a ser incluídas nas diretrizes estipuladas pelo IPHAE desde as novas construções, reformas, demolições, assim como quaisquer outras intervenções em edificações. O que incluía a construção da nova Estação pela TRENSURB, que precisou ser avaliada quanto ao impacto de vizinhança.

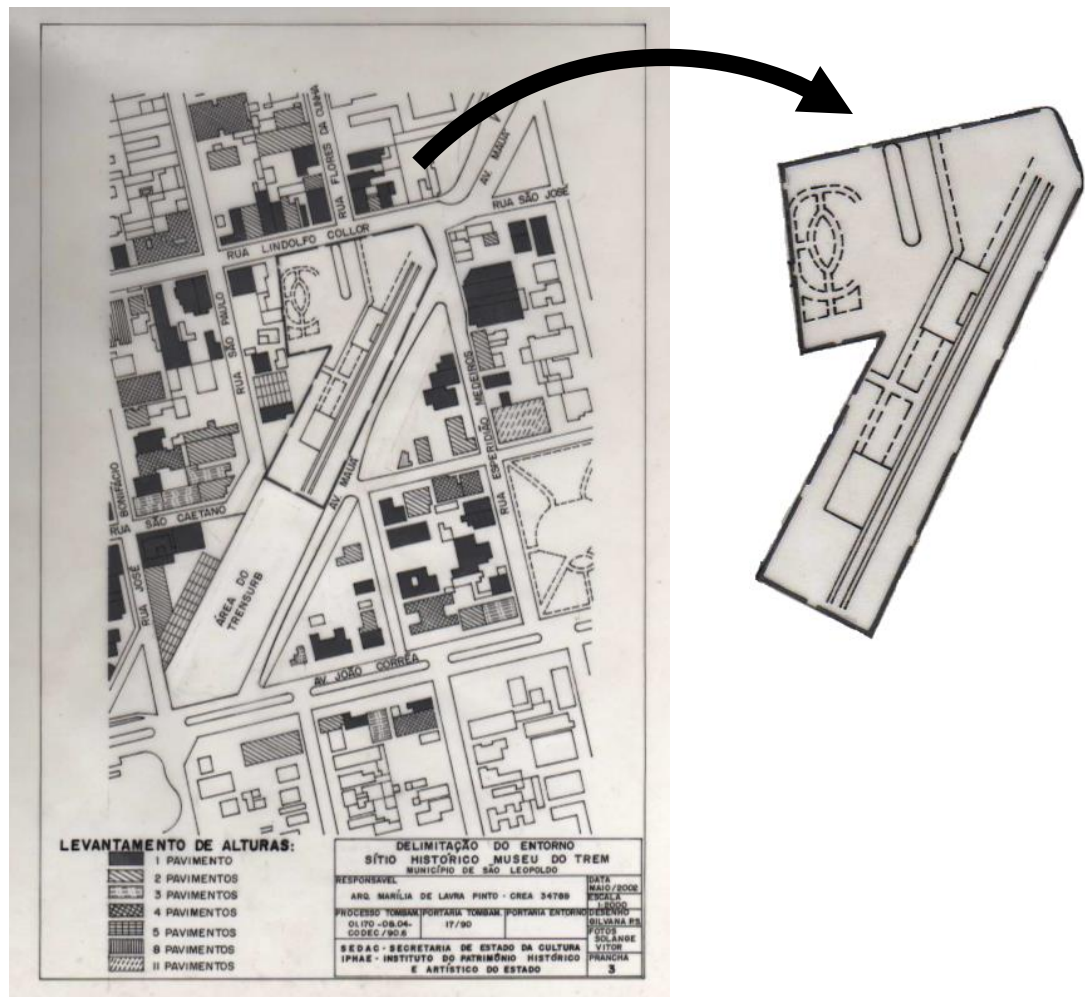

Figura 76 - Sitio Histórico Museu do Trem, delimitação do entorno pelo IPHAE. Ano: 2002. Fonte: IPHAE.

Segundo parecer do IPHAE, a implantação da Estação São Leopoldo, da TRENSURB, junto ao Museu do Trem, onde está localizada à Antiga Estação ferroviária e instalações afins, "causa impacto no local, devido às escalas das estruturas da TRENSURB, assim como a proximidade às edificações ferroviárias do Século XIX" (IPHAE, 2002). 
Ao final, foi realizado um acordo entre Ministério Público, RFFSA, TRENSURB, Prefeitura Municipal e apoio da comunidade ${ }^{54}$ garantindo a permanência do Museu do Trem em São Leopoldo.

Em janeiro de 1991, é assinado o Termo de Permissão de Uso entre a RFFSA, através da SR6, e a Prefeitura de São Leopoldo, selando acordo na administração, manutenção e preservação do acervo deste Museu. Neste acordo também estava o ônus do aluguel de 100BTN mensais, pagos para a Rede ${ }^{55}$.

O Decreto Municipal delegava a responsabilidade da gestão à Fundação Cultural que contava com Marlene Petersen, como Presidente; Maria Luiza Roessler, como Diretora Cultural; Antenor Dutra, Diretor Administrativo, e Prof. Léo Verbist, como Presidente do Conselho.
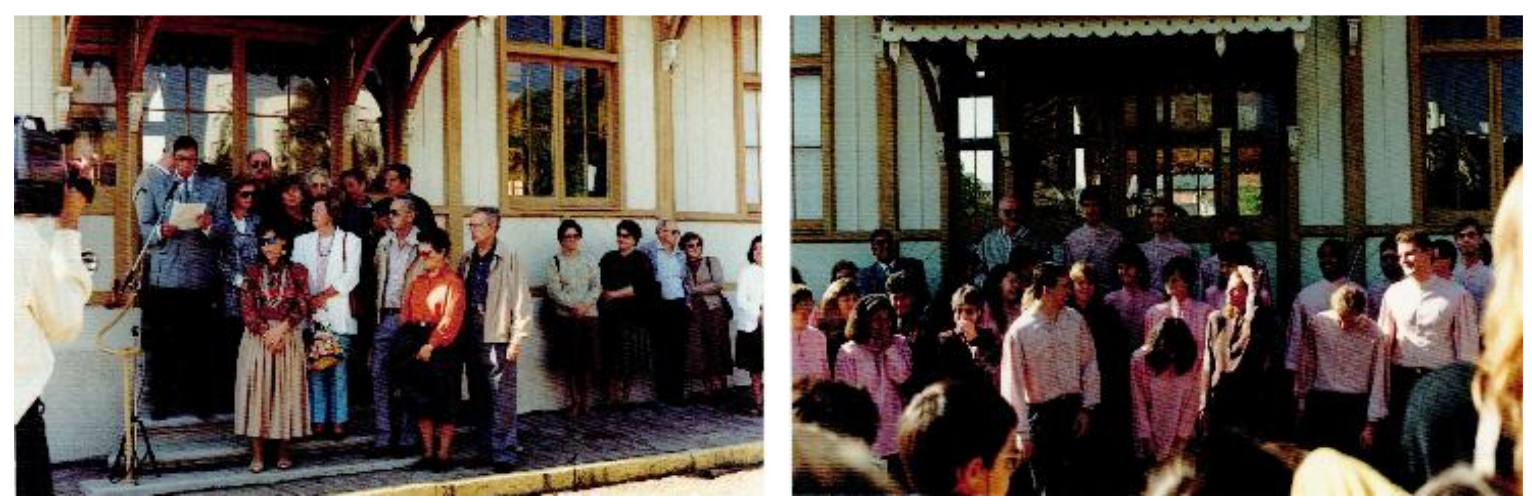

Figuras 77 e 78 - Reinauguração do Museu do Trem, solenidade em 18 de maio de 1991 Fonte: Museu do Trem de São Leopoldo.

O Museu do Trem é reinaugurado pela terceira vez na manhã de 18 de maio de 1991.

É possível encontrar reportagens do período em tom comemorativo com a reabertura. A Revista Rua Grande e o Jornal VS noticiam os esforços da Fundação para receber a população abrindo em finais de semanas alternados, assim como em readequar o Museu às necessidades básicas de limpeza e manutenção, uma vez que a Prefeitura alegava não poder despender recursos. Nos meses de junho e julho foram inúmeras atividades envolvendo exposição de fotos, oficina de teatro e de máscara, coral, Escoteiros do Grupo Cruzeiro do Sul em atividade colaborativa e também atividades com os artistas Fábio Fansere e Luis Brasil (BEMVENUTI, 2012c).

\footnotetext{
${ }^{54}$ Moradores do Bairro São José, que faz divisa com o Museu do Trem, criaram uma Associação de Amigos do Bairro com intuito de lutar pela permanência do Museu em São Leopoldo. Também houve um movimento organizado de estudantes em defesa da mesma causa.

55 Sergio Santos Morais e Roberto Albuquerque Guedes da Luz, entrevistados em diferentes momentos, falam de momentos em que a RFFSA buscava alternativas de captação de recursos, entre ele o aluguel dos locais para as Prefeituras, que tinham o ônus dobrado, considerando que passavam a administrar o local também.
} 
No período a professora e historiadora Eloisa Helena Capovilla da Luz Ramos ${ }^{56}$, cedida pela Secretaria de Estado da Educação, integrou como coordenadora do Museu do Trem, tendo realizado diferentes atividades, entre elas as de atendimento as escolas e ao público espontâneo, juntamente com Dona Maria Mercker. Ramos também estabelece uma importante parceria com o Curso de História da Universidade do Vale dos Sinos (UNISINOS), através da Professora Marluza Harres, para fins de inventariar o acervo documental, pois conforme Ramos, o Tombo realizado pelo PRESERVE estava concentrado nas peças tridimensionais. Os documentos, apesar de organizados em mapotecas e em armários por grupos, não haviam sido arranjados através de inventário (RAMOS, 2011).

O projeto museográfico, estruturado pelo PRESERVE, permanece quase intacto no local.

[...] momento em que houve a inauguração. A exposição foi rearranjada, mas no mesmo modelo que havia antes. Foi limpa. A exposição se manteve a mesma exposição, que o pessoal da Rede, que tinha vindo do Rio de Janeiro, o Claudio Bacalhau e um pessoal, tinha vindo e montado. A exposição era deles, nós não fizemos trabalho de museografia. Não houve. Isso estava pronto e montado pelo pessoal da Rede e permaneceu (RAMOS, 2011).

O contexto apresentava-se contraditório. Por um lado, a preservação da história ferroviária e, por outro, o abandono da mesma. No mesmo ano que o Governo Federal promove o leilão da RFFSA e vende o patrimônio, o Museu do Trem de São Leopoldo consegue sensibilizar a TRENSURB e, através do Ministério dos Transportes, recebe verba para o restauro dos carros de passageiros.
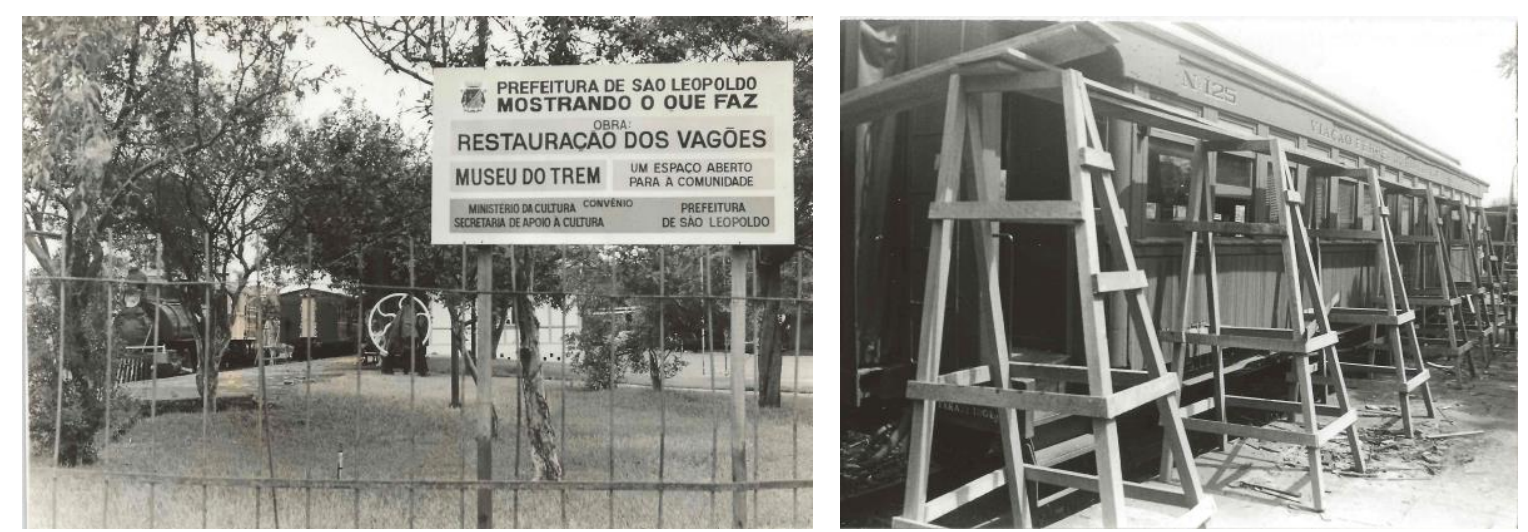

Figuras 79 e 80 - Restauro dos Vagões e Carros de Passageiros. Ano: 1996. Fonte: Museu do Trem de São Leopoldo.

56 Também professora do Curso de Graduação de História da UNISINOS. 

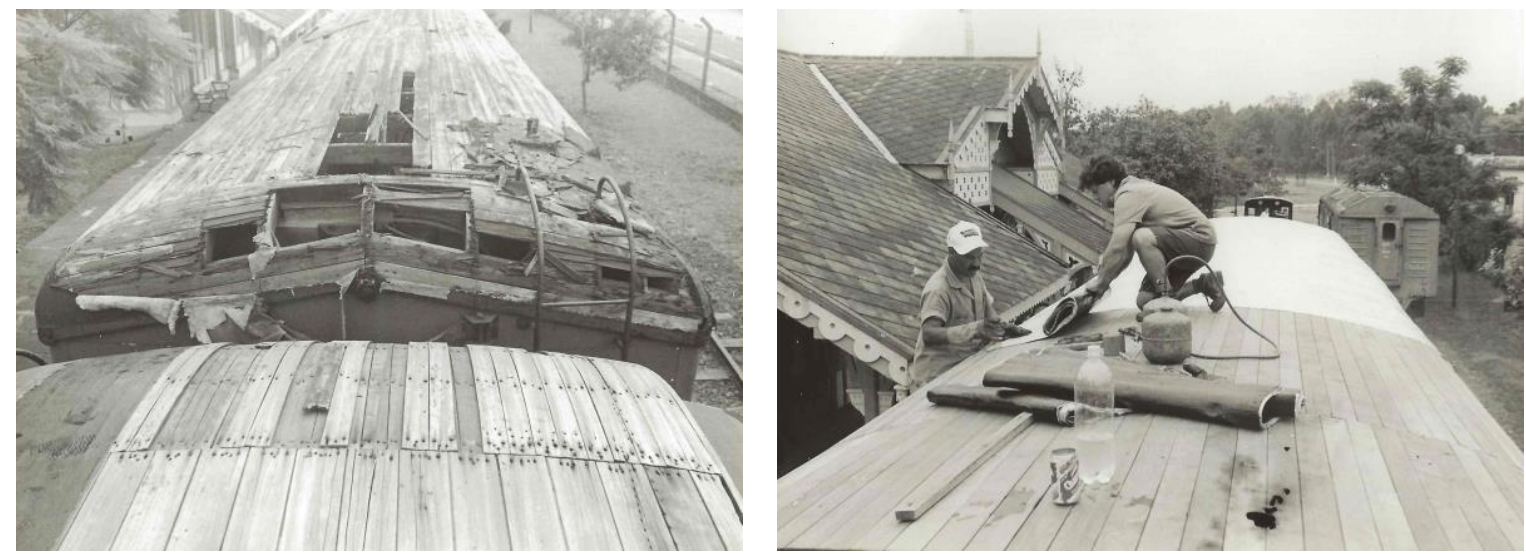

Figuras 81 e 82 - Restauro dos Vagões e Carros de Passageiros (parte superior). Ano: 1996. Fonte: Museu do Trem de São Leopoldo.

Não conseguindo manter a Fundação Cultural, a mesma é encerrada e tempo após o Governo Municipal cria um Departamento de Cultura, vinculado à Secretaria Municipal de Educação, da mesma forma como ocorre em muitas cidades pequenas no interior.

O ex-presidente do MHVSL e um dos fundadores do Museu do Trem, Germano Oscar Moehlecke ${ }^{57}$, aos 70 anos de idade, aceita o convite de trabalhar no Museu do Trem, passando a desenvolver atividades diversas: pesquisa da ferrovia e do acervo do Museu de São Leopoldo; atendimento as escolas e pesquisadores; organização de exposições itinerantes (MOEHLECKE, 2011). Neste período também foram desenvolvidos projetos em parceria com o ator Marcelo Schneider, com o Grupo Teatro Geração Bugiganga (TGB) que realizava atividades nas escolas onde as exposições itinerantes eram levadas.

Em 1999 foi realizada nova reunião entre a Prefeitura Municipal, a Construtora SULTEPA, a TRENSURB e a RFFSA, a fim de realizar a adaptação de três carros musealizados para a realização de atividades culturais. No ano seguinte foram adaptados os carros de $2^{\underline{a}}$ classe em: Vagão Biblioteca Infantil, Vagão Arquivo e Vagão Atelier.

Em abril de 1999, o Jornal Zero Hora, de Porto Alegre, informa sobre as coberturas para o acervo ao ar livre do Museu do Trem e, em 2000, é inaugurada a cobertura na mesma data que a Estação São Leopoldo da TRENSURB é aberta ao público usuário, inaugurando o novo trecho até Sapucaia do Sul, da linha originária de Porto Alegre.

\footnotetext{
57 Comerciante aposentado.
} 

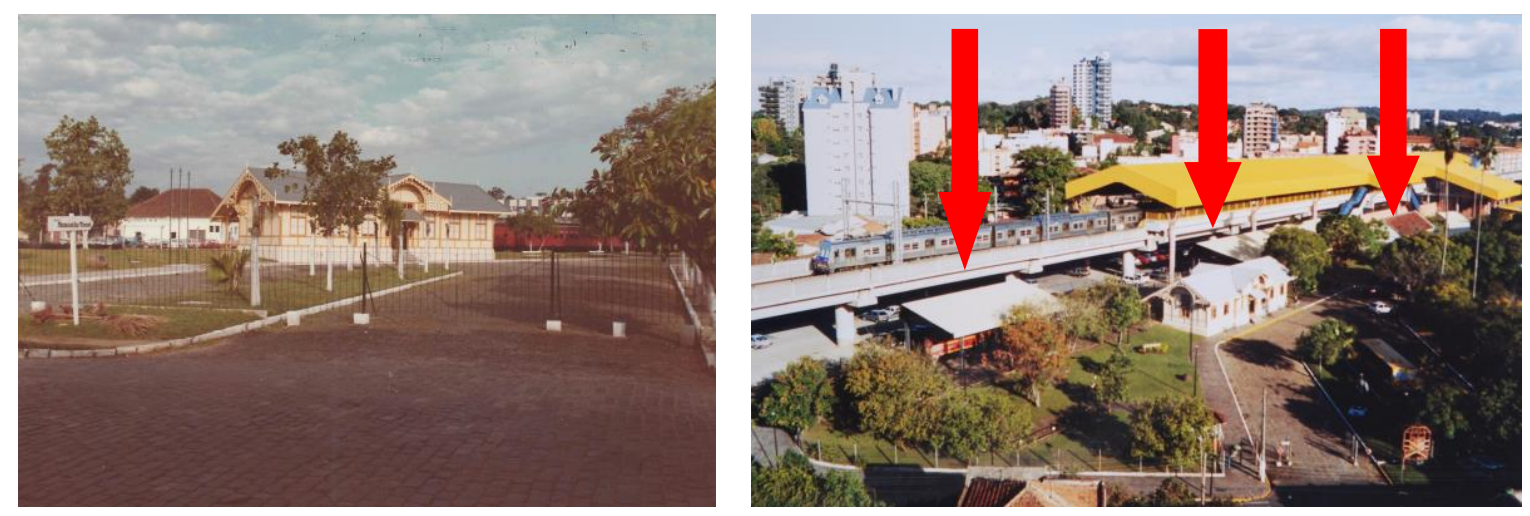

Figuras 83 e 84 - Museu do Trem. Ano: 1985. Museu do Trem com Estação de São Leopoldo, da TRENSURB, ao fundo. s/data. Fonte: Museu do Trem de São Leopoldo.
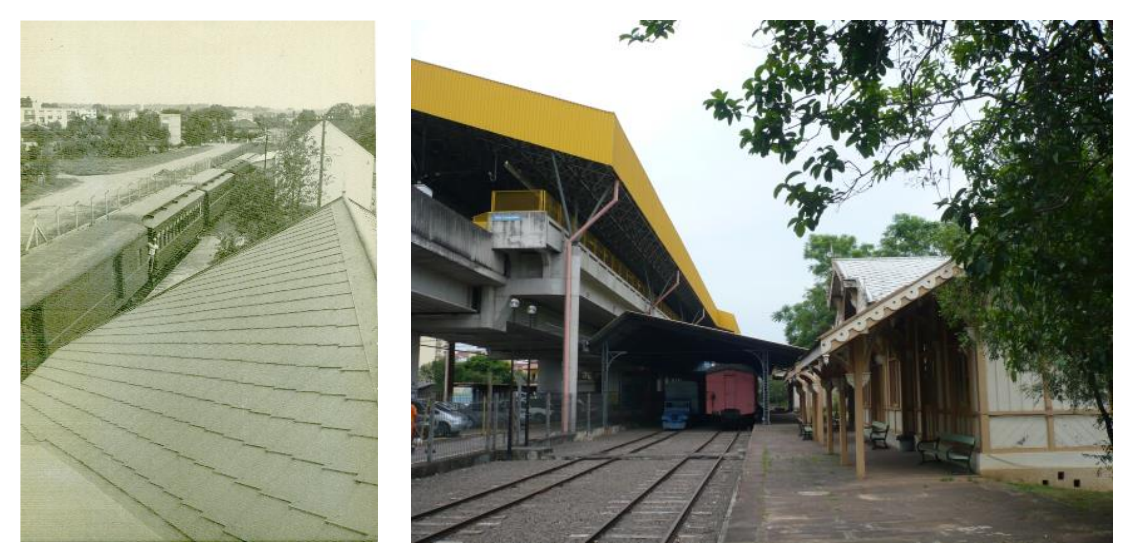

Figuras 85 e 86 - Museu do Trem, vista de cima do telhado, sem a Estação de São Leopoldo da TRENSURB. Ano: 1985. Foto à direita: Estação de São Leopoldo TRENSURB e Museu do Trem de São Leopoldo. Ano: 2009.

Fonte: Museu do Trem de São Leopoldo

Sobre a paisagem da cidade, cabe destacar o contraste arquitetônico gerado pelas construções de séculos e estilos formais diferentes: a Antiga Estação, ao lado do moderno prédio da Estação São Leopoldo da TRENSURB, no mínimo chama a atenção para quem passa.

[...] é interessante também eles terem essa estação moderna deles aqui, ao lado dessa estação antiga. É um referencial muito importante para a história da Viação Férrea, que culmina com essa questão do antigo com o trem moderno, que está se expandindo, está indo até Novo Hamburgo, enfim. Meio que, de certa forma, repetindo o que no passado ocorreu quando o trem se instalou em São Leopoldo e, dois anos após ter se instalado, chegou a Novo Hamburgo, permitindo ali o desenvolvimento da cidade, [...] (LINCK, 2011).

Desde meados da década de 1990 até o ano de 2004, o Departamento de Cultura manteve sua sede nas dependências do Museu do Trem. Em meados dos anos 1990, Rose Miranda esteve responsável pelo Museu. Após assume o Museu, a convite do Prefeito Ronaldo Ribas, o jornalista Alejandro Mallo. Também estavam no Museu os funcionários: 
Alcemir Lopes Fogaça, Gilberto Antônio Ferreira, além de Germano Moehlecke. Período em que foram desenvolvidas atividades de Exposição Itinerante em cidade da Serra e a Exposição de 125 anos da Viação no Shopping Iguatemi, na capital gaúcha. Os primeiros anos do século XXI, o Departamento de Cultura ficou sob a direção de Andréa Guedes, juntamente com Marta Regina Vargas de Farias e as professoras Lisiane Bauermann e Zuleika Pinheiro, cedidas pela Secretaria Municipal de Educação.

Da gestão de Guedes há registros sistematizados e relatórios anuais com dados de frequência de público escolar, pesquisadores, visitas programadas, entre outros dados. É possível verificar a realização de atividades com participação de comunidade local e com parceiros, como o SESC de São Leopoldo e o 19ํㅡㄹ Batalhão de Infantaria Motorizada, o Passeio Ciclístico e o Projeto Estação da Cultura, desenvolvido em bairros e escolas.
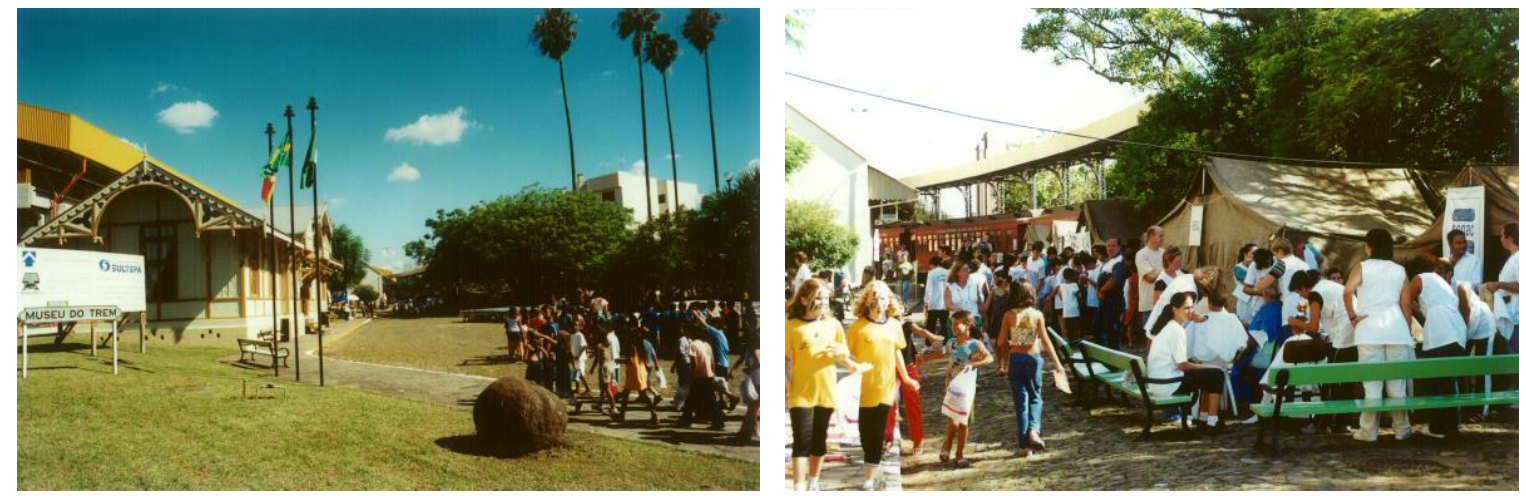

Figuras 87 e 88 - Atividades no Sítio Histórico em parceria. Ano atribuído: 2000-1. Fonte: Museu do Trem de São Leopoldo.
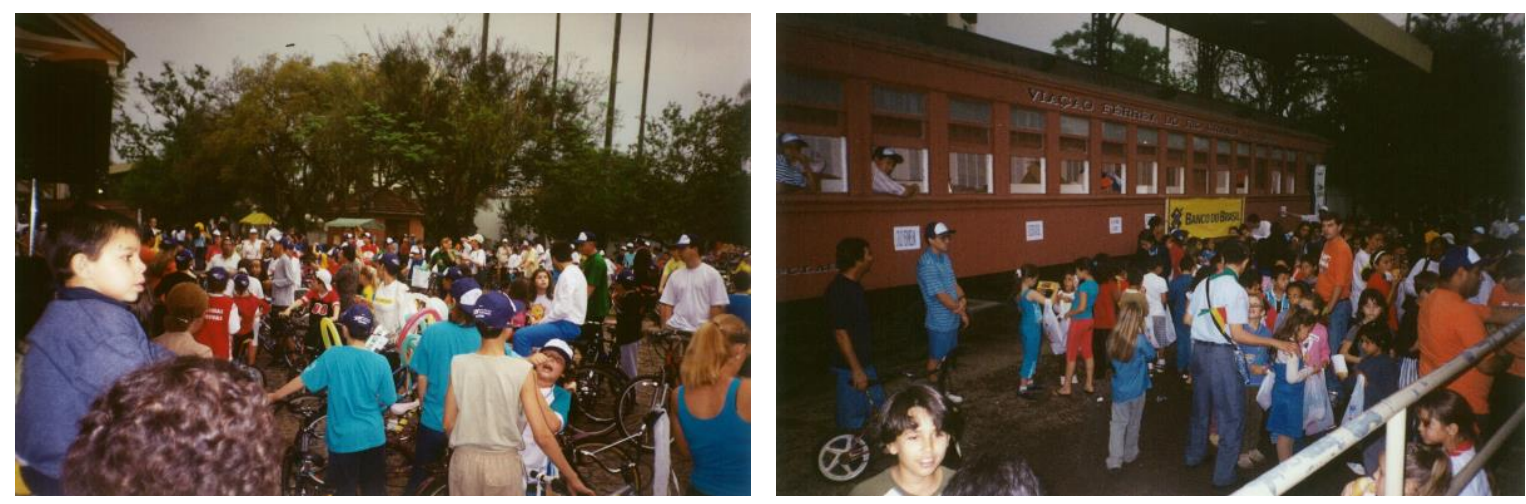

Figuras 89 e 90 - Atividade cultural com passeio ciclístico. Ano: 2000. Fonte: Museu do Trem de São Leopoldo.

Mesmo já extinto o Setor PRESERVE, foram localizados no Museu do Trem formulários intitulados Relatório Mensal do Centro de Preservação da História Ferroviária - PRESERVE. Os mesmos estavam preenchidos demonstrando terem sido encaminhados à RFFSA. O formulário, de papel timbrado, possuía campos para serem preenchidos com: Situação do prédio (troca de lâmpadas, pintura interna, pintura 
externa, áreas e jardins); Situação do Acervo (estado das peças, limpeza, estado dos painéis fotográficos); Novas aquisições e doações (tipo do objeto, doador, como foi adquirido); Estatística Mensal: Visitação (número de pessoas, maior fluxo, dia e horário), Visitação Programadas (número de ordem, número de pessoas, entidade que solicitou); Venda de material de divulgação (cartazes e catálogos); Pessoal lotado no Museu (nome, classe, função); Ocorrências (roubo, acidentes, quebra de peças, etc.); divulgação (pela imprensa local ou área de comunicação social); Programação extra; Reclamações; Observações; Data; Assinatura do Responsável; Responsável pelo PRESERVE.

\subsection{CRIAÇÃO DA SECRETARIA DE CULTURA}

Em 2005, o Governo Municipal cria a Secretaria Municipal de Cultura (SMC), tendo como primeiro Secretário o artista plástico e músico, José Carlos Martins. Na ocasião, a Professora Me. Alice Bemvenuti e o arquiteto Daniel Reisewitz Martins são convidados para a coordenação do Museu do Trem, sendo que apenas Martins assume o cargo. A SMC instala-se com sua equipe administrativa no Armazém do Museu do Trem, seguindo o uso que o antigo Departamento de Cultura fazia do Museu. Apenas em 2006 a SMC é transferida para outro endereço no centro da cidade.

Sob direção de Daniel Martins, o Museu do Trem de São Leopoldo realizou atividades diversas e em parceria como Aldeia SESC Capilé, Reuniões com a $1^{\text {a }}$ Região do Sistema Estadual de Museus (SEMRS), Música no Museu, exposições itinerantes no interior do estado, em diversas cidades, entre elas: Canoas, Campo Bom e Santiago. Também estavam no Museu do Trem os funcionários municipais Alexandre Ferreira, Zelaine e Tânia Maria Nascimento, e os estagiários de História, da UNISINOS, Marlon Luiz Correa e Fabiano Queiroz.

$\mathrm{Na}$ ocasião o Museu do Trem de São Leopoldo recebe uma equipe da Inventariança da Extinta RFFSA, composta por funcionário dos escritórios de Porto Alegre e do Rio de Janeiro, para realizar o inventário do acervo do Museu. Com intenção de arrolar todos os objetos musealizados, entre tridimensionais, documentos e fotografias, e gerar um relatório completo do patrimônio salvaguardado pela instituição, que até o presente momento, não detinha de um documento contendo todos os itens do acervo. $O$ inventário cumpria parte do protocolo de entrega do acervo ao IPHAN, a quem era determinada a responsabilidade da guarda através da Lei $n$ ํ 11.483/2007, regulamentada pelo Decreto no 6.018/22.11.2007, conforme detalhado no Capítulo 1 desta pesquisa.

Em 2009, a convite do Prefeito Ary José Vanazzi (já no segundo mandato) o jornalista Vitor Ortiz assume a Secretaria de Cultura. O convite para Alice Bemvenuti gerir o Museu do Trem veio através de Vitor Ortiz. Bemvenuti assume a direção e compõe uma 
equipe incluindo cargos técnicos e professoras cedidas da Secretaria de Educação. Iniciam-se um período de gestão preocupada em aproximação com os diferentes públicos, sobretudo, os ferroviários.

Em abril de 2009 é lançado o Programa de Ação Educativa, com material educativo impresso e extensa programação para os diversos públicos. Integram a equipe a professora Claudia Koch-Jonhstone e a professora Gilda Prass, através de cedência da Secretaria Municipal de Educação. Através de uma seleção pública foram escolhidos os primeiros nomes para a função de estagiários ${ }^{58}$, Alexandre Lucas, Ana Paula Pinto Viegas, Gisele Bauermann e Sabrina Esmeris, que formaram a equipe do educativo. Também recebia estagiários de ensino médio para auxiliar em atividades menos complexas, através do Programa Jovem Aprendiz.

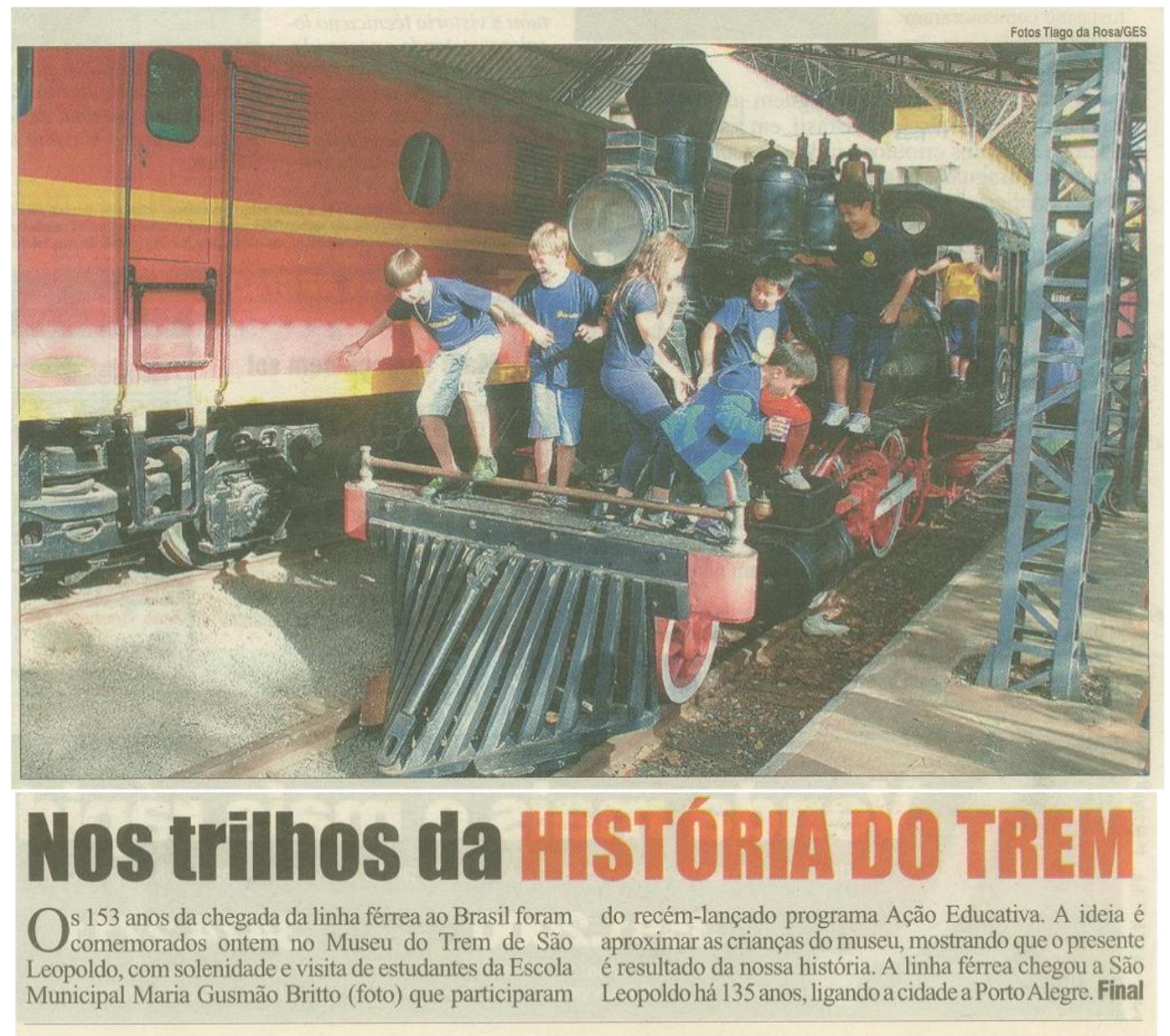

Figura 91 - Reportagem veiculada pelo Jornal Vale dos Sinos, São Leopoldo, capa. Data:01.05.2009. Fonte: Museu do Trem de São Leopoldo

\footnotetext{
${ }^{58} \mathrm{O}$ processo de seleção foi instaurado com critérios informados publicamente. Três etapas: apresentação de currículo; apresentação de um percurso no Museu para atender determinado público, a escolher, para uma Comissão composta por integrantes de outros museus (incluindo São Leopoldo e Porto Alegre); entrevista coletiva.
} 


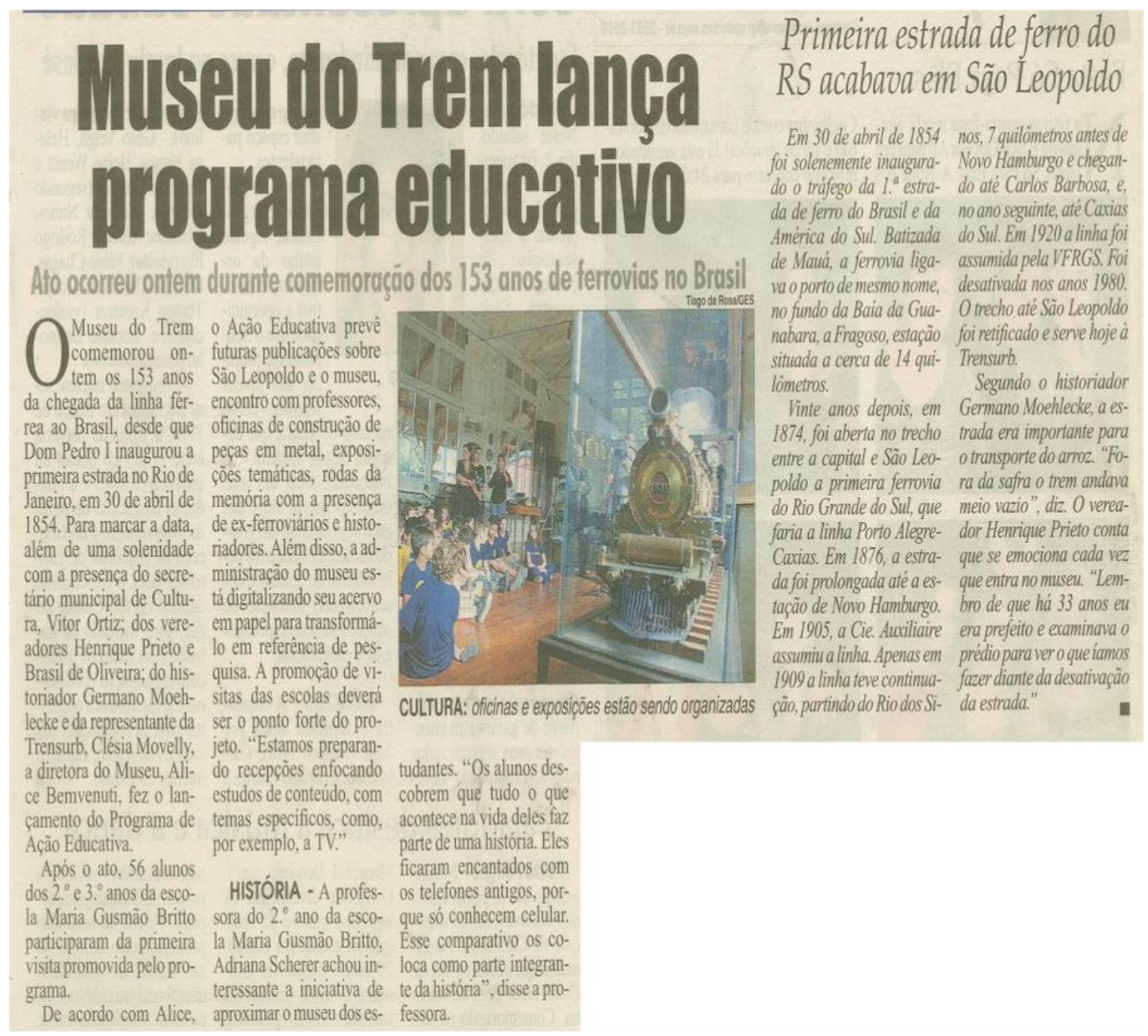

Figura 92 - Reportagem veiculada pelo Jornal Vale dos Sinos, São Leopoldo, contracapa. Data: 01.05.2009. Fonte: Museu do Trem - São Leopoldo

Também em 2009 inicia-se uma aproximação com os museus da cidade. A iniciativa realizou quatro Semanas de Museus de São Leopoldo, paralelas à Semana Nacional de Museus, divulgando através de um único material impresso, a programação dos diferentes museus, incluindo atividades de troca de experiência entre os museus envolvidos. Entre os parceiros estavam as Universidades e alguns museus da capital.

Com organização da sociedade civil e parceria de museus do estado, em 2010, cria-se a Associação Amigos do Museu do Trem (AAMT), com a finalidade de auxiliar na gestão do Museu. Através da AAMT desenvolveu-se um programa de estágios voluntários, com parceria com as Universidades. Como primeira Presidente, a arte-educadora Andréa Rodrigues da Silva, juntamente com os ferroviários aposentados Hélio Bueno da Silveira e Dorildes Begnini. 
Ainda no mesmo ano são realizadas as Feiras de Trocas e os Briques no Museu, uma vez por mês, aos sábados, coincidindo propositalmente com o encontro de carros antigos $^{59}$ que tem o Sitio Histórico como ponto de encontro.

Em 2011, assume pasta da Cultura, Pedro Vasconcellos. Novos investimentos são realizados no Museu incluindo a pintura dos prédios. No mesmo ano, a Prefeitura abre vagas para compor um corpo técnico específico para o Museu. Karina dos Reis Kerpen é a primeira historiadora concursada a integrar a equipe. No mesmo ano, o Museu do Trem foi contemplado com $\mathrm{R} \$ 50.000,00^{60}$ pelo Edital referente ao Prêmio de Modernização de Museus, categoria de Microprojetos, com projeto intitulado "Patrimônio do Museu do Trem: aplicabilidade do processo de conservação", com participação da museóloga Daniela Schmitt.
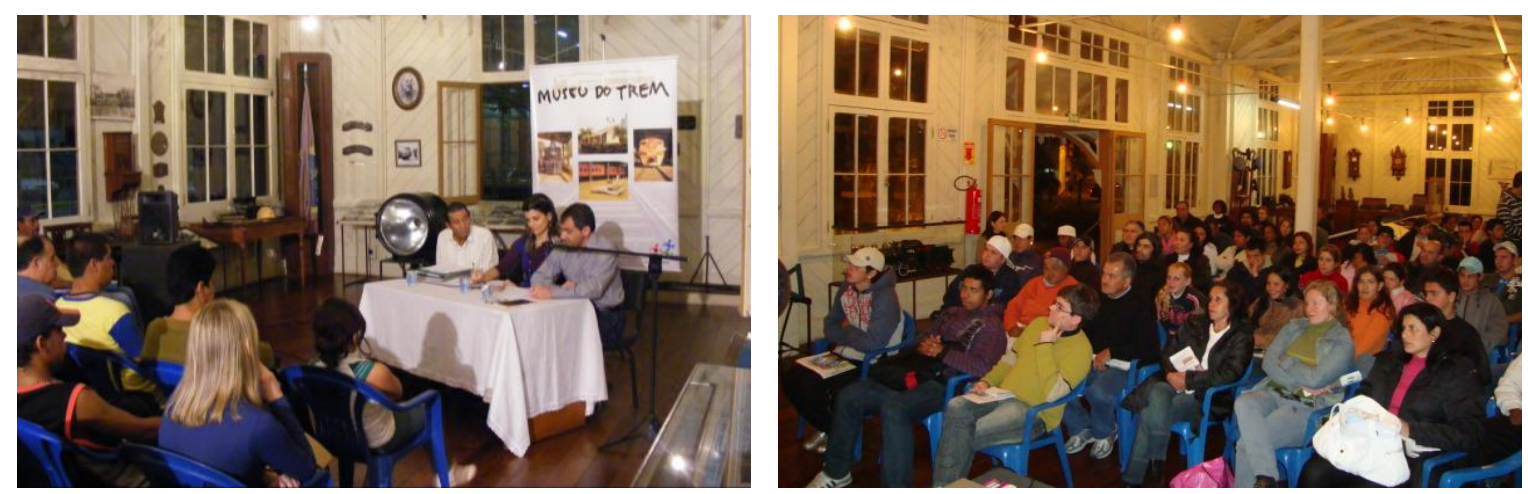

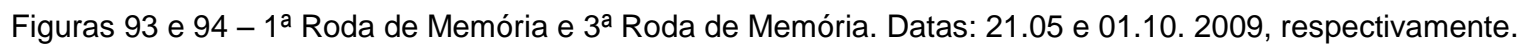
Fonte: Arquivo digital da autora.

59 O encontro de carros antigos se realizada desde os anos 2000 , aproximadamente, sendo que os organizadores não se integram com o Museu, nem mesmo combinam ou informam a instituição suas atividades. Ocupam o Sítio Histórico impondo regras de uso do espaço. A realização da Feira e do Brique no mesmo dia gerou diversas dificuldades, porém também permitiram estabelecer novos modos de uso do Museu, respeitando a instituição e o acervo.

60 Depósito apenas em outubro de 2012 para o Município desenvolver o Projeto. 

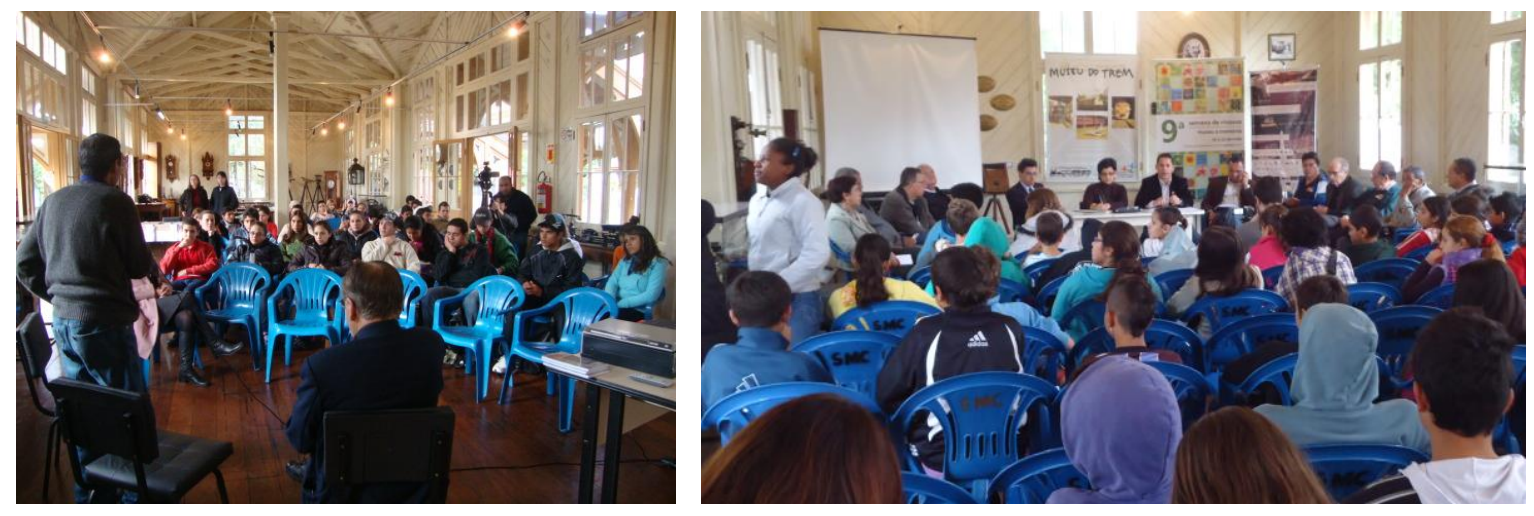

Figuras 95 e 96 - 4ํㅡㄹ Roda de Memória e 10 ${ }^{\underline{a}}$ Roda de Memória.

Datas: 20.05.2010 e 25.05. 2011, respectivamente.

Fonte: Arquivo digital da autora.
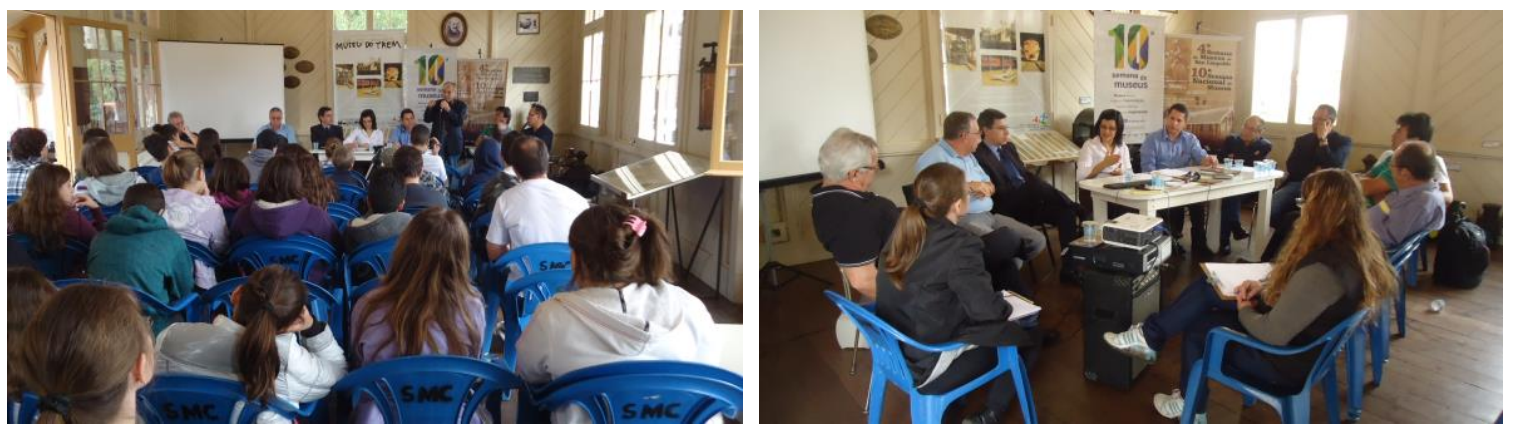

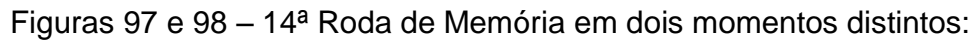
com alunos e com equipe do Museu. Data: 24.05.2012.

Fonte: Arquivo digital da autora.

Ao longo dos quatro anos desta gestão, foram realizadas inúmeras atividades entre elas aquelas com a participação de ferroviários, moradores da cidade e escolas, a exemplo das Rodas de Memória. Foram vinte edições das Rodas de Memória, tendo sido registradas ou em fotos, em audiovisual ou áudio, sempre com a presença de ferroviários, moradores de São Leopoldo e ou passageiros do antigo trem. Os registro por terem sido capturados em parcerias, em parte não foram localizados posteriormente.

Foram também realizados seminários, formações diversas, roteiros planejados de visita, entrevistas e pesquisas, parcerias com outras instituições de ensino e museológicas, parcerias com outros setores e atividades culturais como: edições do evento Aldeia SESC Capilé, Ensaio aberto de Chorinho com o Grupo Buquezeiros, Oficinas de Ferromodelismo (membro da ABPF). As Oficinas de Conservação de Peças em Metal ministrada pela historiadora Jussara Prates desencadearam-se através de um projeto de cooperação (convênio) entre Prefeituras, São Leopoldo e Portão, através do Museu Histórico Municipal situado na Estação Ferroviária da cidade, o Arquivo Histórico de Portão, o Museu do Trem de São Leopoldo e o projeto educativo com jovens coordenado pelo Quartel 16 BIM. 


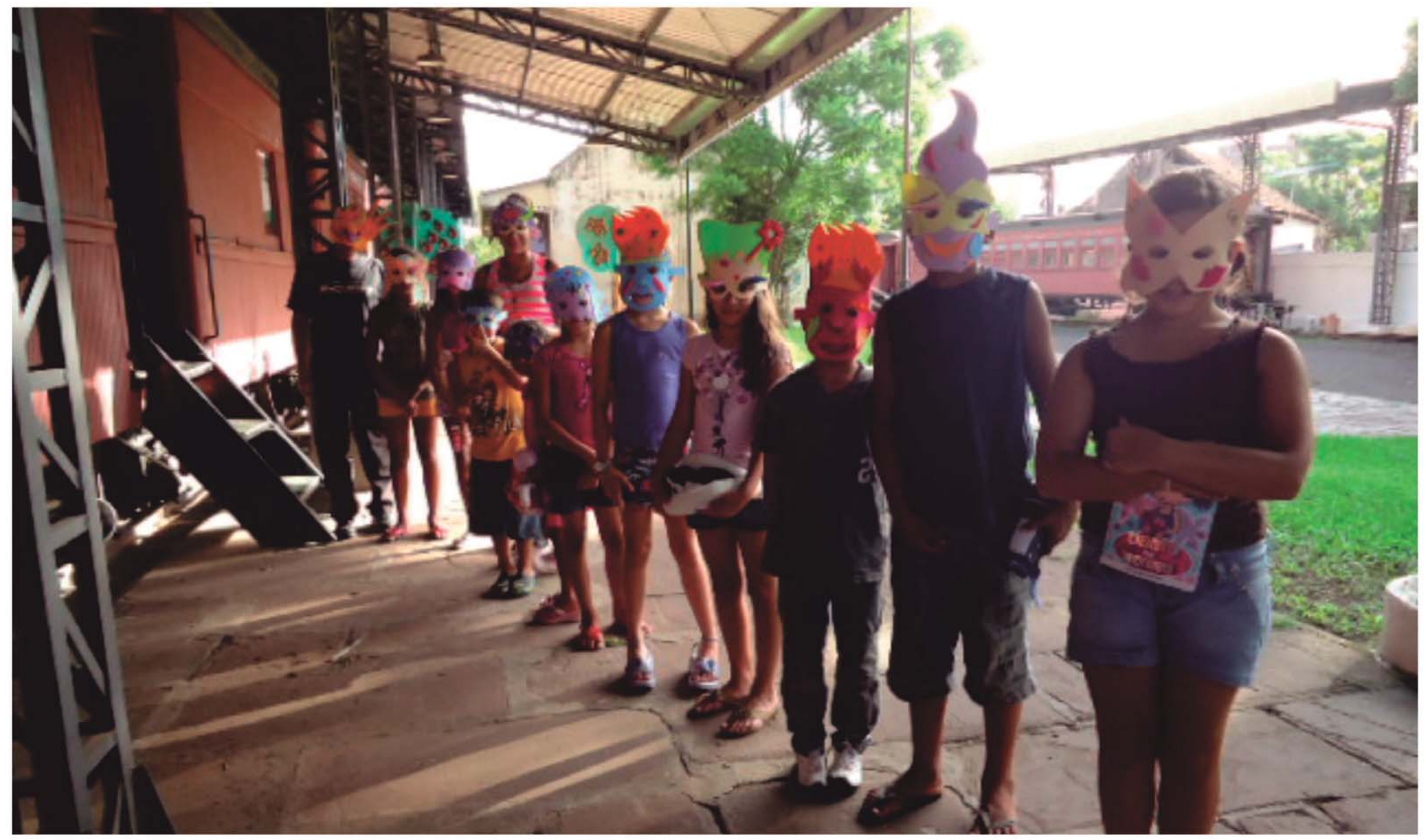

Capítulo 4 
Com uma introdução teórica, o capítulo a seguir apresentação os mecanismos da gestão de qualidade, o uso do PDCA ${ }^{61}$; detalhando os documentos de diagnóstico, planejamento, organização da estrutura institucional e sucessivas avaliações; sistematizando dados e resultados obtidos com investimentos; público visitante e, ao final, análise da experiência utilizando a ferramenta com estrutura SWOT ${ }^{62}$. O capítulo aproxima campos teóricos com referenciais da administração, em especial da Gestão de Qualidade, e da educação, em especial da concepção democrática de educação, e da museologia, com ênfase na comunicação, público e gestão.

Aproximar da museologia aspectos referentes ao campo da administração e da educação permite compreender algumas escolhas da gestão realizada no Museu do Trem. Com risco de ao descrever as atividades e seus desdobramentos, reduzir a experiência da gestão a um relatório, transformando o complexo processo da práxis museográfica em uma apresentação restrita a planos, metas e realizações, opta-se em apresentar em dois capítulos o exercício da gestão realizada do período em questão. Primeiramente a reflexão teórica com abordagem política, administrativa e técnica, seguindo com apresentação da Práxis Comunicacional e com dados documentais do processo da gestão.

\footnotetext{
61 Ferramenta de planejamento que orientar programas de Qualidade.

62 Ferramenta de avaliação contínua.
} 


\subsection{ABORDAGEM ADMINISTRATIVA, POLITICA E TÉCNICA}

Gestão é o gerenciamento e a administração de algo. Para gerir é preciso que haja quem, ou o quê, será gerido. Neste caso podendo ser uma empresa, uma entidade social, uma instituição envolvendo pessoas ou recursos. A gestão surge após a revolução industrial, quando profissionais preocupados com os problemas advindo decorrente da indústria, buscar soluções e experimentam métodos e técnicas administrativas.

Os sistemas e as abordagens disponíveis hoje são resultado proveniente da demanda da pós-industrialização, configuradas a partir das mudanças no campo do conhecimento e do crescimento das organizações, provocadas, por sua vez, pela explosão populacional e tecnológica. Neste cenário encontra-se também a instituição museal.

Segundo a museóloga e Profa. Dra. Maria Cristina Oliveira Bruno, da Universidade de São Paulo, "a partir dos anos de 1930, as ações museológicas passaram a fazer parte de políticas do estado" (2014:103), experimentando distintos modelos de gestão nas diversas regiões do país. Então no século XXI o país "assisti à implantação da Política Nacional de Museus e a criação do Instituto Brasileiro de Museus no âmbito do Ministério da Cultura" (2014:103). A atenção dada a gestão de museus impulsiona inquietações interdisciplinares sobre os processos museológicos e "direciona nosso olhar para a compreensão de que museus são instituições do presente e do futuro" (BRUNO, 2014:104).

Para a autora, a gestão de museus está relacionada a trajetória dos processos museológicos que permeiam "a manutenção de tradições e a proposição de rupturas" (2014:101) sendo necessário debruçarmos nossa atenção para os desdobramentos e desafios. Requer destacar que

direcionarmos nosso olhar para o passado, verificamos que, ao longo dos
séculos, os museus têm ampliado suas características enquanto
instituições comprometidas com a herança cultural e em dar sentido
atualizado para os bens patrimoniais (BRUNO, 2014:101).

Bruno aponta que os processos museológicos por sua vez abrangem os seguintes movimentos: a) Hierarquia dos sentidos e significados patrimoniais: a especialização dos museus; b) Diversidade dos sentidos e significados patrimoniais: a tipologia museológica; c) Reflexos das rupturas nos espaços e na organização dos museus; e d) Gestão museológica: princípios e procedimentos (2014).

Neste sentido, destaco os tópicos trazidos pela autora no item d.

d) Gestão museológica: princípios e procedimentos.

- Complexidade em relação a diferentes modelos de gestão;

- Identificação de atividades-meio e atividades-fim;

- Valorização da perspectiva de qualidade e avaliação (BRUNO, 2014:102). 
A gestão museológica experimenta modelos de organização das distintas instâncias: comunicação e salvaguarda. Uns mais, outros menos, os modelos em curso exigem mecanismos de transmissão e interação do público, porém cada vez mais o alvo está sendo disputado entre museu e convites apelativos para consumo. A saber o conceito de museu de acordo com o Conselho Internacional de Museu (ICOM):

Um museu é uma instituição permanente, sem fins lucrativos, a serviço da sociedade e de seu desenvolvimento, aberta ao público, que adquire, conserva, pesquisa, divulga e expõe, para fins de estudo, educação e lazer, testemunhos materiais e imateriais dos povos e seu ambiente (Código de Ética para Museus, 2004).

Os itens contemplados nesta definição são identificados nos desdobramentos das ações do planejamento na instituição museal. Segundo Marília Xavier Cury, um museu é um sistema (2005). Sendo que poderá estar também dentro de um outro sistema, como as universidades, as prefeituras, as empresas privadas. Estando, segundo Cury, a comunicação museológica operando como um sistema dentro do próprio sistema museu, ou seja, um subsistema. Neste caso, confere ao sistema museu os processos que nele estão imbricados.

Os sistemas são hierárquicos ou piramidais. São constituídos de sistemas ou de subsistemas relacionados entre si por um processo ou padrão de interação. O próprio universo é um sistema constituído por uma infinidade de sistemas e subsistemas intimamente relacionados entre si (CHIAVENATO, 1977:439).

Nos processos museológicos, cabe destacar as opções metodológicas correspondentes ao contexto institucional (CURY, 2005) que

o meio ambiente, enquanto condicionante do sistema, tenderá a influenciar as suas expectativas de qualidade. O equilíbrio dependerá dá capacidade do sistema de adaptar-se às exigências externas ou inverter o jogo influenciando o exterior, sempre com ações conscientes da qualidade. A qualidade não é uma abstração, mas é construída no domínio da situação (CURY, 2005:13-14).

Generalizando as questões básicas do processo e não cada um dos seus passos separadamente (CURY, 2005), pensar os sistemas dentro do sistema museu, permite pensar os processos administrativos em sua totalidade.

O museu como um sistema é o conjunto de procedimentos metodológicos, infraestrutura, recursos humanos e materiais, técnicas, tecnologias, políticas, informações, procedimentos e experiências necessárias para o desenvolvimento de processos museais (CURY, 2009:30). 
Do ponto de vista da abordagem clássica, os princípios da Administração passam pela departamentalização, racionalização do trabalho, estrutura linear ou funcional, sendo estes tópicos nunca totalmente substituídos. Conforme Idalberto Chiavenato, a teoria Clássica torna-se presente em todas as teorias administrativas (1997).

Embora existam vários métodos de gerenciamento opta-se aqui pelos pilares da Gestão da Qualidade ${ }^{63}$, a partir dos amplos estudos da administração empresaria, e nele observa-se dois acessos: a teoria da gestão da qualidade e a prática com a certificação da qualidade, através do selo ISO $9000^{64}$. Ambos nos oferecem dados sobre conceitos, características e implicações.

Segundo Paladini, o termo qualidade é utilizado erroneamente como sinônimo de perfeição, gosto e preferências, sinônimo de sofisticação, luxo e variedade. Sendo que o problema não reside propriamente conceituação equivocada de qualidade, mas nos reflexos críticos desses equívocos no processo de gestão [...] pois o impacto do equívoco, assim, parece ser o maior nos reflexos gerados do que na ocorrência em si (2009:20).

Os conceitos da Qualidade seguem as definições: "Qualidade é a condição necessária de aptidão para o fim a que se destina." (Organização Europeia de Controle de Qualidade - EOQC, 1972); "Qualidade é adequação ao uso." (JUAN e GRYNA, 1991); e "Qualidade é o grau de ajuste de um produto à demanda que pretende satisfazer." (JENKINS, 1971).

O referencial da Gestão da Qualidade aponta dois indicativos que demonstram a obtenção de êxito: grau de fidelidade do consumidor e a possibilidade de transformar clientes em consumidores; e "adequação ao uso" por todos os setores, áreas, pessoas, envolvida direta ou indiretamente (PALADINI, 2009), com foco na melhoria contínua do processo.

Processo composto por um conjunto de ações que direcionam os recursos para a transformação das entradas (necessidades dos clientes) em saídas, produtos ou serviços. Este modelo é representado na figura 99, a seguir:

\footnotetext{
63 Os sistemas de gestão da Qualidade aparecem inicialmente desenvolvidos para a indústria.

${ }^{64}$ Que abrange o ISO 9000, que descreve os fundamentos se sistemas de gestão da qualidade e estabelece a terminologia para esses sistemas; ISO 9001, que especifica requisitos para um Sistema de Gestão de Qualidade, estabelecendo que uma organização precisa demonstrar sua capacidade para fornecer produtos que atendam aos requisitos do cliente e aos requisitos aplicáveis, além de objetivar o aumento da satisfação do cliente; ISO 9004, que fornece as diretrizes que consideram tanto a eficácia como a eficiência do sistema de gestão da qualidade e que tem como objetivo melhorar o desempenho da organização e a satisfação dos clientes e das partes interessadas.
} 


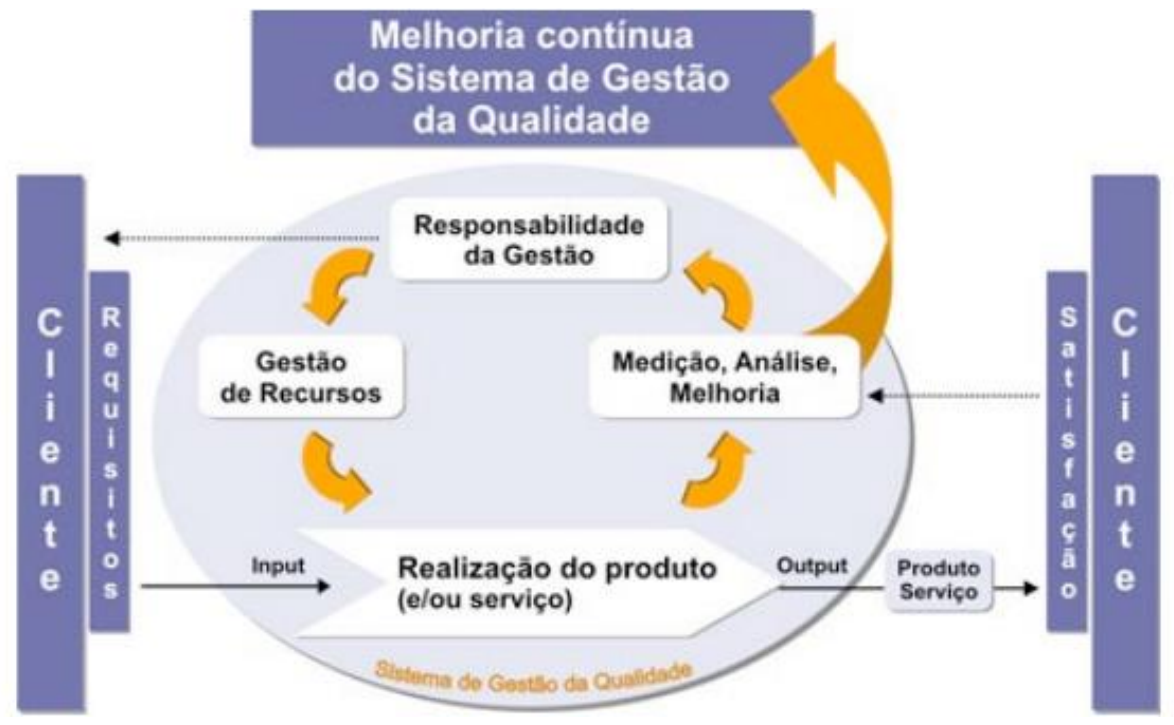

Figura 99 - Modelo de um sistema de qualidade baseado em processo.

Fonte: http://www.nitmantiqueira.org.br/portal/images/pdf/ documentacao/cit-orientacoes-sistema-gestao-qualidade.pdf

O processo de melhoria contínua deve identificar as necessidades dos clientes (interno e externo) e a partir delas estabelecer ações com objetivo de satisfazer as necessidades identificadas. O cliente como um consumidor que diante do conhecimento de como o produto é realizado e oferecido, resolve adquiri-lo (PALADINI, 2009). O cliente é o motivo da existência da instituição, o que faz que a satisfação do cliente seja ponto fundamental e determinante no processo.

No contexto apresentado nesta pesquisa, o cliente será compreendido como público. Conforme aponta Cury, para os museus e para a museologia a participação do público nos processos museológicos é um tema em pauta constantemente (2009:57). A autora enfatiza ainda o papel do público visitante na existência da instituição museal.

Falar de público significa discutir finalidade dos museus e o seu papel social e sobretudo a democratização dessas instituições. Falar de público, no âmbito dos museus e da museologia, significa atribuir um sentido social ao ato de preservar. Falar de público significa considerá-lo a partir de suas expectativas, códigos culturais e esquemas mentais ao elaborar programas de comunicação [programas de gestão] (CURY, 2005:57, grifos meus).

Para os administradores de empresa, sob os fundamentos da Gestão de Qualidade, a pergunta básica seria: o que o consumidor considera na hora de adquirir um bem ou um serviço? Uma questão para o qual se tem procurado resposta continuamente. Considerando o Museu do Trem de São Leopoldo, a pergunta é readequada para: o que o público leva em consideração na hora de escolher visitar (ou não) o Museu do Trem de São Leopoldo?

Na prática, as interpretações sobre quais "razões de consumo" levam a escolha deste ou daquele produto, torna-se o ponto básico para que David Garvin desenvolva um 
conjunto de ênfases (PALADINI, 2009) que permitem refletir sobre os elementos que levam a decisão do consumidor não incluir o museu em sua lista de prioridades.

Para responder à pergunta: por que o consumidor adquire determinado produto? David Garvin aponta cinco abordagens (apud PALADINI, 2009): 1) confiança no processo do produto; 2) aceitação do produto; 3) valor associado ao produto; 4) confiança na imagem ou na marca; e 5) adequação ao usuário.

São muitas as variáveis, que o consumidor considera quando decide adquirir um produto ou utilizar um serviço. Considerar essas variáveis, assim, tem impacto estratégico sobre a organização. De fato, o consumidor seleciona um produto ou um serviço pelas características que eles têm, mas a seleção de quais dessas características (ou de outras) estarão presentes nesse produto ou serviço é uma decisão da empresa (PALADINI, 2009: 72).

A atividade do planejamento, na perspectiva deste mecanismo de gestão, é fundamental para atingir a qualidade. Segundo Paladini, gerenciar é tomar decisões, do mesmo modo que tomar decisões a partir do planejamento pode significar escolher a melhor forma de fazer as coisas.

E planejar significa exatamente tomar decisões sem as pressões que a urgência do momento requer, ou seja, toma-se decisões com certa folga em relação ao momento em que se deverão ser implantadas. Isso, obviamente, gera decisões tomadas com maior tempo de análise, maior segurança para decidir o que fazer, avaliação mais cuidadosa sobre os possíveis efeitos (PALADINI, 2009:105).

Para tanto planejar é a ação chave do desenvolvimento do circuito da Qualidade. Porém, ao mesmo tempo, planejar deve ainda ser o ponto de maior dificuldade para muitas empresas na implementação do sistema.

Planejar não significar planejar algo que não irá conter defeitos ou gerar algum erro. Obviamente esse é o ponto que se quer eliminar, mas planejar é um exercício e exige dirimir ações improvisadas, com base intuitiva e subjetivas. Este no que tange o museu, de modo geral, pode ser uma contradição, porém não iremos fazer digressões a respeito, apenas assinalar. Retornando ao planejamento, cabe destacar que este aspecto pode nos levar a pensar um comparativo com a natureza da instituição museal. Caberia sim uma análise com relação ao uso de potencialidades humanas, que podem incorrer em uma qualidade sem mensuração imediata, como os resultados da educação de qualidade. Este é um dos tópicos, dentre tanto outros que tangenciam a questão.

Cabe aqui atentar para as fases do planejamento: política de qualidade; diagnóstico; organização e administração; planejamento propriamente dito; implantação; e avaliação (PALADINI, 2009: 106-107). 
O Museu do Trem de São Leopoldo, assim como grande parte dos museus, tem os aspectos legais e financeiros de responsabilidade do poder público, o que pressupõem, segundo o casal canadenses Gail e Barry Lord, autores do Manual of Museum Managent ${ }^{65}$ considerar, em primeiro lugar, as três funções fundamentais vinculadas aos encargos de dirigir, gestionar e fazer funcionar o museu (2010) respectivamente com encarregados na posição de governo, na equipe do museu e nas parcerias diversas.

Segundo Lord e Lord são quatro formas principais de relação entre museus e administração pública. Dependência orgânica; Dependência com autonomia de gestão; Organização sem fins lucrativos e Entidade Privada. O Museu do Trem inserido na situação de dependência orgânica requer compreender as bases do governo, a fim de ajustar melhor suas necessidades.

Y los que son responsables de museos que funcionan desde hace tempo también deberían tener muy em cuenta los problemas que se derivam de la forma de governo de la institución, porque la forma de gobierno que em su dia establecieron puede que hoy dia ya no se ala más apropriada (LORD, LORD: 2010:27-28).

Inserido na Administração pública, os funcionários pertencem ao organismo, assim como o diretor do museu é nomeado por autoridades governamentais, diferentemente de uma empresa ou museu privado, ou seja,

em cualquier caso, el gobierno de los museos de dependência orgânica se integra em uma estrutura de gobierno mayor. Los museos de dependencia orgânica se financian fundamentalmente mediante asignaciones procedentes de los presupuestos de la organización de la que dependen (LORD, LORD: 2010:28).

O caso do Museu do Trem possui características próprias, não apenas pela natureza da instituição, mas também pela característica marcante atual de estar inserida em uma sociedade de organizações, segundo Peter Drucker, referindo-se as tarefas sociais desenvolvidas por governos, universidades, sindicatos e empresas.

A sociedade de organizações tende a um pluralismo de objetivos, a uma diversidade de instituições e a uma difusão do poder. Essas organizações agem entre si e, embora sejam interdependentes, elas têm de viver e trabalhar juntas. Nenhuma das organizações existe por si só (DRUCKER apud CHIAVENATO, 1997:334).

Observa-se nos processos museológicos e na trajetória do Museu do Trem, elementos importantes da relação entre o Museu e a Secretaria Municipal de Cultura

65 Traduzido para o espanhol e publicado na Espanha. 
(SMC) ao qual estava vinculado. A saber, relatórios e documentos da SMC apresenta itens como a democratização do acesso à cultura, refletindo sobre o papel do Museu do Trem na cidade.

O Plano Diretor do Museu do Trem apresenta três eixos vinculando questões subjetivas vinculadas ao patrimônio material e imaterial, e questões vinculadas a preservação e acesso a este patrimônio musealizado. Lê-se:

Com intuito de implantar um Projeto de Gestão em Museu e um Programa de Ação Educativa, organizou-se um plano de trabalho com os seguintes eixos estruturantes: MEMÓRIA e PRESENTE; IDENTIDADE e PERTENCIMENTO; PRESERVAÇÃO e ACESSIBILIDADE. Assim, com a meta de adequar o Museu do Trem ao Estatuto dos Museus lei federal, ao código de Ética do ICOM e aos demais regulamentos de cadastramento e atualização do Museu, apresentamos neste projeto os objetivos, metas e ações que reestruturam e intensificam a relação do Museu com a comunidade (MUSEU DO TREM, 2009).

O Projeto de Governo para a cidade de São Leopoldo, no mesmo período, inclui itens envolvendo os demais museus da cidade. Ficando evidente que a atenção para com os museus é parte das ações prioritárias deste Governo. Lê-se na proposta do Programa de Ação Educativa:

A Prefeitura Municipal de São Leopoldo, através da Secretaria Municipal
de Cultura desenvolve um Projeto de Gestão em Museu e um Programa
de Ação Educativa no Museu do Trem com intuito de promover o
conhecimento, salvaguardar o acervo histórico da R.F.F.S.A (Rede
Ferroviária Federal Sociedade Anônima) e do Sítio Histórico, promove a
qualificação da relação dos escolares, pesquisadores, famílias
leopoldenses e turistas, com a história da R.F.F.S.A. no Rio Grande do
Sul, com a história de São Leopoldo e as mudanças econômicas, políticas e
sociais a partir do transporte ferroviário, propiciando assim o fortalecimento
e a manifestação das identidades dos usuários do trem, dos ferroviários
e famílias e ex-ferroviários, convidando a todos a aventurarem-se como
aprendiz dentro do Museu (MUSEU DO TREM, 2010).

Do mesmo modo, identifica-se relação com autarquias na utilização do Estatuto de Museus, Lei $n^{\circ} 11.904$, de 14 de janeiro de 2009, em especial aos artigos $1^{\circ}, 2^{\circ}$ e $3^{\circ}$, relacionados aos princípios fundamentais e características, e $28^{\circ}, 29^{\circ}$ e $30^{\circ}$, relacionados ao estudo, pesquisa e ação educativa; e o Plano Nacional de Cultura, Lei no 12.343, de 02 de dezembro de 2010, nos itens relacionados às diretrizes de acesso, preservação e comunicação, referente ao Instituto Brasileiro de Museus (IBRAM) e Ministério da Cultura (MinC), conforme segue:

AMPLIAR E PERMITIR O ACESSO compreendendo a cultura a partir da ótica dos direitos e liberdades do cidadão, sendo o Estado um instrumento para efetivação desses direitos e garantia de igualdade de condições, promovendo a universalização do acesso aos meios de produção e 
fruição cultural, fazendo equilibrar a oferta e a demanda cultural, apoiando a implantação dos equipamentos culturais e financiando a programação regular destes.

PRESERVAR O PATRIMÔNIO MATERIAL E IMATERIAL, resguardando bens, documentos, acervos, artefatos, vestígios e sítios, assim como as atividades, técnicas, saberes, linguagens e tradições que não encontram amparo na sociedade e no mercado, permitindo a todos o cultivo da memória comum, da história e dos testemunhos do passado.

AMPLIAR A COMUNICAÇÃO E POSSIBILITAR A TROCA ENTRE OS DIVERSOS AGENTES CULTURAIS, criando espaços, dispositivos e condições para iniciativas compartilhadas, o intercâmbio e a cooperação, aprofundando o processo de integração nacional, absorvendo os recursos tecnológicos, garantindo as conexões locais com os fluxos culturais contemporâneos e centros culturais internacionais, estabelecendo parâmetros para a globalização da cultura (PLANO NACIONAL DE CULTURA, 2010).

A gestão do Museu articula entre os diferentes setores e propõe parceria tanto com público externo, quanto com público interno. O Museu ouve os públicos através de diversos instrumentos, como por exemplo, os integrantes da equipe participam de reuniões, conversas e realizam relatórios e registros em instrumentos de avaliação. Identifica-se neste aspecto o entrelaçamento da postura administrativa e política, a partir da concepção de educação como postura política e processo de qualidade, conforme Madalena Freire:

Qualidade da educação; educação para a qualidade; educação e qualidade de vida, não importa em que enunciado se encontrem, educação e qualidade são sempre uma questão política, fora de cuja reflexão, se cuja compreensão não nos é possível entender nem uma nem outra. Não há, finalmente, educação neutra nem qualidade por que lutar no sentido de reorientar a educação que não implique uma opção política e não demande uma decisão, também política de materializá-la (FREIRE, 1993: 44).

Cabe destacar que a escolha de aproximar os fundamentos da Gestão de Qualidade com os pressupostos dos Instrumentos Metodológicos (FREIRE, 1995; FREIRE, 1997), se dá pelo modo como estes se estruturam e pelos pontos que fundamentam a metodologia de ação do Museu.

São identificados inúmeros desafios na escolha dos fundamentos da gestão do Museu do Trem, tanto no que tange aos itens da Gestão de Qualidade, como ao aporte dos Instrumentos Metodológicos ${ }^{66}$. Ambos apresentam cinco ações que seguem uma sequência na direção do movimento que se retroalimenta. Os Instrumentos Metodológicos subdividido em dois grupos apresentar as ações: 1) observação, registro, reflexão; 2)

\footnotetext{
66 Instrumentos Metodológicos I e II são publicações elaboradas a partir da atividade do grupo interdisciplinar constituído por Madalena Freire, Mirian Celeste Martins, Juliana Davini e Fátima Camargo, no Espaço Pedagógico, que durante quase duas décadas realizou formação de profissionais de diversas áreas em práticas com metodologia de concepção democrática.
} 
avaliação e planejamento. O planejamento orientado pela ferramenta de qualidade, por sua vez, requer cinco momentos em movimento.

Iniciando pela coleta de dados através de instrumentos de avaliação, o Museu segue a ferramenta da qualidade denominada PDCA ${ }^{67}$, identificando inicialmente o cenário interno e externo. O segundo movimento é o levantamento de hipóteses do planejamento, onde deverão ser especificados os objetivos gerais e específicos das atividades (FREIRE, 1997:56) a serem realizadas, com previsão dos recursos materiais, do tempo e do espaço necessário. O terceiro momento é o acompanhamento da ação planejada, que deverá ser registrado a partir de pontos de observação, seguidos do quarto momento que é a avaliação reflexiva do produto conquistado. O quinto momento é o replanejamento, que ao mesmo tempo que atinge o último estágio, reinicia o movimento pois este deverá orientar os passos a seguir dentro do planejamento.

Portanto, na concepção democrática de educação o ato de planejar não é meramente fabricar planos; ele é o processo ininterrupto, permanente, cujo desafio é lançar-se na reelaboração diário de novos planejamentos. Neste sentido 0 ato de planejar é processual, onde avaliação e planejamento constroem o produto. Essa reelaboração viva do planejamento está centrada na reflexão, no pensar da ação cotidiana. Nesse pensar temos momentos que, dentro do processo de planejar, intercomunicam-se (FREIRE, 1997: 57).

Outro ponto diz respeito ao grupo. A equipe e o exercício de aprender no processo coletivo. O grupo, considerando a especificidade do museu, pode ser pensando no plural: grupos - referindo-se aos públicos. Pensar os movimentos na construção de um grupo e pensar os movimentos na construção de públicos, com certeza caracteriza-se âmbitos diferentes. Cabe então pensar em que momento os movimentos de grupo são presentes e fortalecem a instituição.

A participação da equipe como sujeito que deseja, estuda e produz hipóteses, requer aceitar o lugar de participante ativo, que por sua vez, requer disponibilidade. A tarefa não é fácil, pois exige paciência, flexibilidade, reflexão, estudo, disciplina intelectual (FREIRE, 1995), generosidade para compartilhar, amorosidade para estar junto, questionamento, humildade para ouvir e falar, aprendizagem com o outro, coragem para propor, experimentar hipóteses, fazer, refazer e refazer-se na ação.

Se defendemos e fundamentamos, que para construção do conhecimento é necessário a presença de um educador, é crucial a presença de um coordenador no subgrupo. Se conhecimento envolve interação com os outros para o enfrentamento de problemas, conflitos (cognitivos, sociais e afetivos), a proposta do trabalho de subgrupo terá que levar em conta

67 O PDCA será detalhado no próximo subitem. 
para sua composição: - Que hipóteses diferenciadas e conflitantes entre si existem? - Que hipóteses e de quem desestabilizam? Qual? Quem? Que papéis mesclara? (Falantes, resistentes, silenciosos) - Quem ampara, limita, norteia quem? No quê? (FREIRE, 1993:57).

Segundo a autora, a reflexão possibilita aos envolvidos diferentes deslocamentos, que podem inclusive gerar mal-estar. Freire enfatiza a reflexão que rompe com a anestesia do que anteriormente estava acomodado, passivo, cego, e "constatar quais são as contradições entre o pensar teórico e a prática" (1995:54), do mesmo modo possibilita "o distanciamento necessário para tomar consciência de que se sabe (e pensa que não sabia) e do que ainda não se conhece" (Idem). O exercício aqui requer uma atenção sensível para o exercício do refletir de modo sistemático. A reflexão impulsiona dar-se conta, mas em alguns casos também, impulsiona o reconhecimento dos próprios limites frente a proposta estabelecida, a elucidação da correlação da ação e do que ela representa para a instituição. No grupo, reconhecer-se sobre o pensar-fazer elucida também a opção pedagógica e política, segundo a autora.

Um grupo se constrói no espaço heterogêneo das diferenças entre cada participante: da timidez de um; do afobamento do outro; da serenidade de um da explosão do outro; do pânico velado de um; da sensatez do outro; da seriedade desconfiada de um, do afobamento do outro; da seriedade desconfiada de um, da ousadia do risco do outro; da mudez de um, da tagarelice de outro; do riso fechado de um, gargalhada debochada de outro; da lividez do rosto de um, do encarnado o risco do outro (FREIRE, 1993:23).

O grupo para constituir-se como tal necessita de uma coordenação (FREIRE, 1993; 1995). A coordenação, na proposição do movimento dos Instrumentos Metodológicos, tem papel fundamental. Enquanto coordena, deverá dispor-se a aprender, "trabalhando os ranços autoritários e espontaneístas na tentativa, na busca da construção de uma relação democrática" (FREIRE, 1995:54). Esse exercício de aprender deverá ser cercado pelos mesmo movimentos de observação, registro e reflexão, para posterior ação, avaliação e replanejamento. Freire defende que a coordenação deverá ter a perspicácia de intervir no processo, a fim de orientar a condução do grupo. Apesar do termo intervenção estar vinculado a uma ação de imposição, diferentemente da atitude autoritária, Freire propõe que o coordenador exerça o lugar de autoridade, coordenando o processo, no qual está inserido no grupo, ao contrário da postura autoritária de delegar ao gruo mantendo-se fora dele, sem participar dos movimentos de dificuldade durante 0 processo, que carregam inseguranças, angustias e ansiedade, necessidade de manter a persistência e até a conquista e a euforia.

Em todos esses movimentos, a presença do educador é indispensável. Como mediador que instiga, limita e acompanha (intervindo, encaminhando, 
devolvendo) os passos desse processo. Nenhum grupo sobrevive a ausência do educador. Todo grupo depende de uma autoridade para a construção de seu exercício democrático (FREIRE, 1993:30).

Identificar, reconhecer, ter ciência, tomar conhecimento ainda são os verbos que melhor definem o caminho que leva as melhores escolhas. Enfrentar alguma dificuldade administrativa junto a equipe, em qualquer que seja o setor, exige da coordenação a responsabilidade de decisão sobre qual o melhor caminho a seguir para a solução do problema.

Para Gary Edson, diretor executivo do Museu da Universidade Técnica do Texas, o sucesso contínuo da gestão do museu concentra-se com grande força no que chama de uma equipe que adere e é eficaz (2004). Destacando para o fato de que sustentar as relações e vínculos com a equipe requer liderança (EDSON, 2004).

A gestão eficaz do museu é uma responsabilidade que envolve todos os recursos e as atividades museológicas e todo o pessoal. É um elemento necessário do desenvolvimento e progresso do museu. Sem gestão própria, o museu não pode providenciar a preservação e utilização adequada do acervo, nem pode manter e apoiar uma exposição e um programa educativo eficaz. Sem uma gestão qualificada, pode perder-se o interesse e a confiança pública e o reconhecimento e o valor do museu, como instituição ao servidor da sociedade, pode ser posto em perigo. Necessita de ser uma reflexão a um alto nível de desenvolvimento social com pessoal com várias competências educativas de tomada de decisão (EDSON, 2004:146).

O lugar do gestor exige, não apenas o conhecimento dos fatos e a liderança no grupo, mas a capacidade de reconhecer de que maneira a situação ecoa em si como sujeito da ação. Qualquer que seja a situação, ao ecoar das questões institucionais no coordenador, impulsiona uma atitude enérgica ou ponderada, ou mesmo, o engessamento diante do fato, pela incapacidade de decisão momentânea. Diante disto, os verbos indicados listam possíveis caminhos para a coordenação obter ferramentas para tomadas de decisões. Sejam elas micro decisões, ou grandes decisões, o exercício da reflexão a partir do reconhecimento das características individuais na função, auxilia a solução de problemas, através de encaminhamentos plausíveis. No exercício democrático da gestão, não há como negar os movimentos individuais potencializados pelos movimentos do grupo.

Na junção dos fatores: instituição com gestão pública com instituição museológica, encontra-se, por sua vez, uma somatória de questões, dada a natureza dos dois fatores, que desconhecem a possibilidade de tal exercício. Primeiramente, se considerarmos a gestão pública, onde os envolvidos, na maioria das vezes são indicados como cargos de confiança política, não estando preparados para desenvolver a função na qual foi 
responsabilizado. Em segundo lugar, e não menos importante, é o lugar da instituição museológica na cultura do país. Preconizado como lugar de coisas velhas, o museu para desprender-se dessa imagem, desta identificação com um depósito de coisas em desuso, obsoletas, que não se sabe bem para qual finalidade servem, necessita conceber-se como espaços de produção de saber, de criação, de inovação, de encontros com o desconhecido e, portanto, novo.

\subsection{GESTÃO DE QUALIDADE APLICADA AO MUSEU DO TREM}

Os processos de gestão no exercício da Gestão de Qualidade se estruturam sobre um movimento que requer presença ativa de todos os envolvidos. O movimento do exercício da Gestão de Qualidade é impulsionado pelo diagnóstico que se realiza na identificação do cenário (interno e externo) através de observação pautadas por tópicos orientadores $^{68}$. A escrita do plano de ação inicial ocorre após o diagnóstico, sendo este o planejamento que dará direcionamento para as ações seguintes que, por sua vez, também serão observadas à medida que são executadas, a fim de manter sequência ao movimento circular $^{69}$ proposto pela metodologia da Qualidade.

Avaliar é um modo de obter dados do contexto real para direcionar as ações subsequentes. O avaliar torna-se uma constante e tem a função de identificar, provocar reflexão, orientar mudanças, retomar estratégias, redefinir rumos, como também, afirmar escolhas.

O movimento é um processo contínuo do exercício de observação e planejamento, passando ser fundamental o acompanhamento constante dos processos. A arteeducadora e Profa. Dra. Miram Celeste Martins (Mackenzie), defende a forma espiralada para visualizar esse movimento contínuo. Porém isso tudo só fará sentido se estiver a serviço da Missão do Museu. A saber:

Missão: Assegurar a dimensão do Museu como território de salvaguarda e difusão da história da RFFSA, no Rio Grande do Sul. E o objetivo geral: Compreender o papel do Museu do Trem na sociedade local, estadual e federal e ampliar a participação do Museu na vida da cidade e a comunidade leopoldense na vida do Museu, um Museu para Todos (MUSEU DO TREM, 2012).

\footnotetext{
68 Essa mesma estrutura é utilizada por Madalena Freire e Mirian Celeste Martins, denominada de Ponto de Observação (PO), Instrumentos Metodológicos, e que foi utilizada com o Setor Educativo para orientar os registros escritos a partir da observação da prática.

${ }^{69}$ Conforme já apresentado na figura da seção anterior.
} 
Stuart Davies ao detalhar como se realiza um Plano Diretor, na Série Museologia Roteiros Práticos, publicado pela USP em parceira com a Fundação Vitae, apresenta o seguinte desenho:

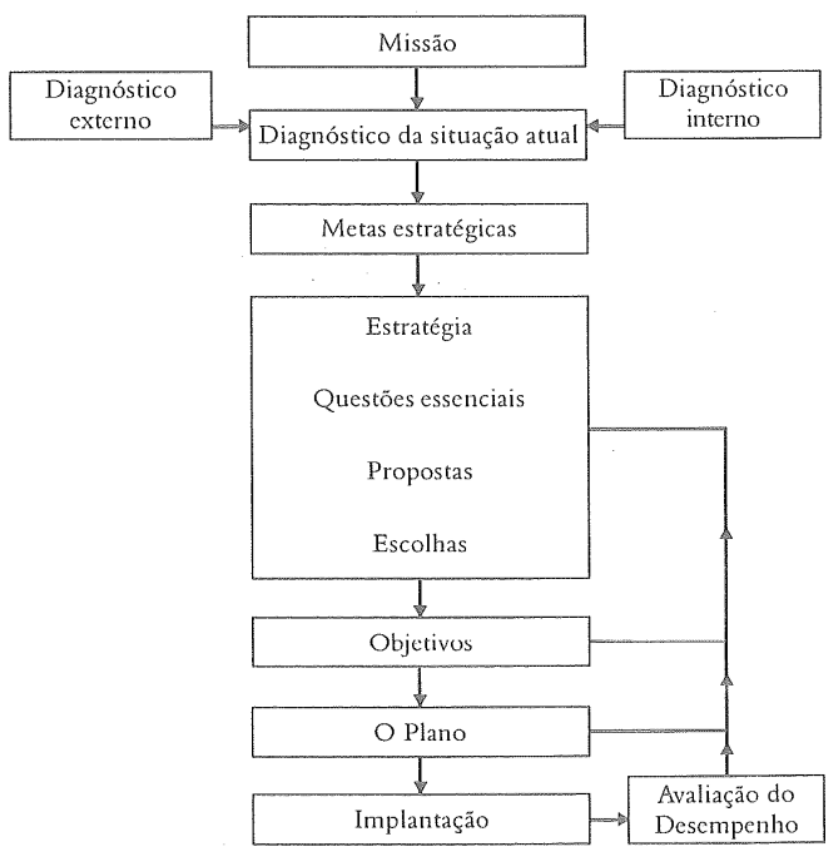

Figura 100 - Processo de planejamento.

Fonte: Stuart Davies, 2001: 25

Davies sugere seguir a ordem conforme apontam as setas. No topo do processo está a Missão do museu (DAVIES, 2001 :31), considerando que a mesma deve responder a cinco perguntas: Para que existimos (finalidade); em que acreditamos (valores); o que queremos alcançar (metas); o que fazemos (função); e, para quem o fazemos (público/parceiros). O autor reforça a importância da escrita da missão em um processo metódico, entendendo que a partir destas perguntas cruciais terão que ser feitas $e$ discutidas (DAVIES, 2001:32).

\subsubsection{Planejamento}

A ferramenta utilizada para orientar o movimento contínuo do planejar (planejaravaliar-(re)planejar), foi o PDCA $^{70}$ (figura 101). A estrutura da ferramenta auxiliou na visualização de cada item em cada fase facilitando a tomada de decisões pelo gestor. O ciclo PDCA é assim chamado devido às iniciais dos termos correspondentes em inglês: P: plan (planejar); D: do (fazer); C: chec (verificar); A: action (ação), conforme figura a seguir:

${ }^{70}$ A origem do PDCA se deu a partir do ciclo de Walter Andrew Shewhart, engenheiro americano e que inicia o uso do controle estatístico para o controle da qualidade. 


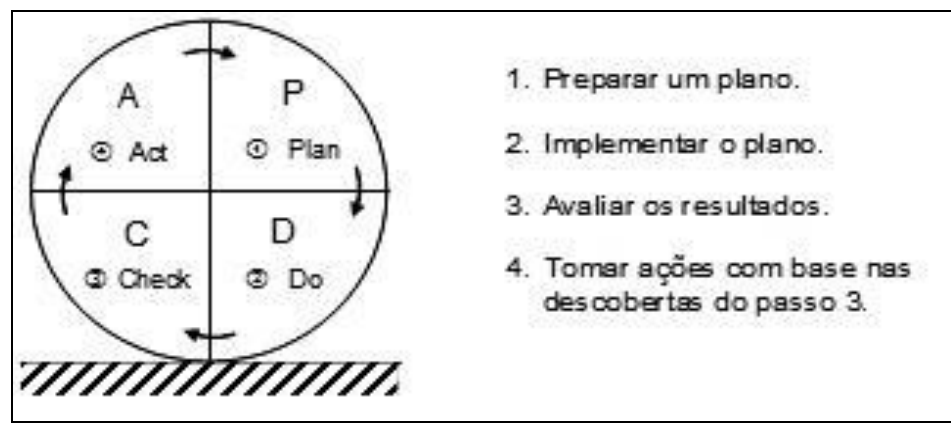

Figura 101 - Ciclo do PDCA.

Fonte: http://www.qualypro.com.br/artigos/pdca-origem-conceitos-e-variantes-dessa-ideia-de-70-anos

Nas etapas, a letra $\mathrm{P}$, do termo plan, caracteriza-se pela ação inicial de identificar o problema, políticas e equipamentos; verificar os pontos fortes, pontos fracos, as oportunidades e as ameaças ${ }^{71}$, observar e analisar a fim de elaborar um Plano de Ação, que deve ter na sua estrutura a eliminação dos problemas identificados, o bloqueio das ameaças, o aproveitamento dos pontos fortes na estrutura interna e das oportunidades externas. A letra $\mathrm{D}$, do termo $\mathrm{DO}$, ou fazer, concentra-se em executar passo a passo o planejado, ciente da necessidade de capacitar os envolvidos. A letra $\mathrm{C}$, do termo Chec, verificar, refere-se à avaliação em processo, onde poderão ser revistas ações estratégias em andamento, caso elas sejam identificadas como ponto fraco ou ameaça a estrutura. $A$ letra A, refere-se ao termo Action, ação, que diz respeito aos resultados, que ao serem avaliados poderão seguir, chegando ao padrão de qualidade almejado, ou corrigir, retornando para nova estratégia de ação. $O$ ciclo é contínuo não se fechando. $O$ movimento gerado nas avaliações e nos replanejamentos, permite adequar, integrar, corrigir, refazer, aprimorando, sendo a experiência acumulada parte constituinte do sistema como um todo.

O Museu do Trem realizou um planejamento seguindo cada passo do PDCA., tendo iniciado pela sistematização de um amplo diagnóstico, através do registro escritos e fotográfico, incluindo dados provenientes da opinião individual dos integrantes equipe composta por funcionários, estagiários e contratados. Os diferentes documentos ${ }^{72}$ identificados como parte do diagnóstico estão apresentados no quadro abaixo.

\footnotetext{
71 A sistematização dos pontos forte/oportunidades e pontos fracos/ameaças será apresentada através da análise com estrutura SWOT ao final deste capítulo.

72 Os documentos fazem parte do corpus documental organizado para esta pesquisa que está disponível no Apêndice.
} 
Quadro 6 - Documentos referente ao processo de escrita do diagnóstico.

\begin{tabular}{|l|c|c|}
\hline \multicolumn{1}{|c|}{ Descrição } & Período & Características \\
\hline Diagnóstico preliminar (02 folhas) & Jan/mar. 2009 & Anotações iniciais \\
\hline $\begin{array}{l}\text { Anotações de cinco funcionários a partir de roteiro } \\
\text { pré-estabelecido (13 folhas) }\end{array}$ & 2009 & Fichas \\
\hline Diagnóstico (sistematização em reunião) (4 folhas) & 12 ago. 2009 & Ata \\
\hline $\begin{array}{l}\text { Diagnóstico sistematizado da Estação para Projeto de } \\
\text { Restauro (12 folhas) }\end{array}$ & Jun. 2010 & Dados sistematizados \\
\hline $\begin{array}{l}\text { Diagnóstico para fins da escrita do Plano } \\
\text { Museológico. Dados agrupados e reescritos. }\end{array}$ & Jan. 2011 & Revisão \\
\hline
\end{tabular}

Fonte: elaborado pela autora.

Para o Museu do Trem o ponto de partida foi a descrição dos itens quanto ao Sítio Histórico Museu do Trem de São Leopoldo de modo geral. Desde os espaço físico externo, pátio e praça; o funcionamento, horários e segurança; acervo em exposição e Reserva Técnica, organização, acondicionamento e conservação; comunicação, em especial: comunicação visual, sinalização, circulação, panfletos e divulgação; serviços de atendimento ao público e relação com a comunidade; e à imagem da instituição para público interno e externo.

O diagnóstico prioriza uma atenção especifica ao lugar do qual se observa, gerando identificação, conhecimento, reconhecimento, reflexão e posterior projeção de ações. $O$ Museu do Trem realizou o diagnóstico através de várias etapas sempre utilizando a participação de diferentes pessoas da equipe e o registro escrito. Os documentos apresentados no quadro $\mathrm{n}^{\circ} 07$ possibilitam verificar o conjunto de informações agrupadas, desde a identidade da instituição e as responsabilidades de cada um, até a localização das peças com avarias, as necessidades emergenciais e as potencialidades.

Os dados reunidos pelo Museu foram sistematizados sempre a partir do instrumento utilizado na situação observada, ou seja, separadamente, a partir dos itens pré-estabelecidos. O quadro a seguir dispõe de uma nova sistematização dos dados coletados pelo Museu na ocasião. São apresentados aqui agrupados, em um único quadro, as diferentes anotações localizadas nos diferentes momentos.

\section{Quadro 7 - Dados do diagnóstico institucional agrupado.}

\begin{tabular}{|l|l|}
\hline & $\begin{array}{l}\text { - Funcionamento de terça a sexta-feira, as 9h as 18h. Sábado e domingos das } 14 \mathrm{~h} \\
\text { às } 18 \mathrm{~h} .\end{array}$ \\
Funcionamento & $\begin{array}{l}\text { Portões de folha dupla com apenas uma lateral aberta (deixando dúvida se o local } \\
\text { geral }\end{array}$ \\
& $\begin{array}{l}\text { estaria ou não aberto ao público). } \\
\text { - Falta setores ou divisões museológicas. }\end{array}$ \\
\hline
\end{tabular}




\begin{tabular}{|c|c|}
\hline & $\begin{array}{l}\text { - Falta lojinha para venda de souvenirs. } \\
\text { - Falta envolvimento com o Turismo. }\end{array}$ \\
\hline Segurança & $\begin{array}{l}\text { - Realizada pela Guarda Municipal. Não são funcionários do Museu. Cumprem os } \\
\text { plantões com escalas de trabalho de } 12 \text { por } 36 \text { horas, com a responsabilidade de } \\
\text { zelar e manter a ordem do lugar. Pouca comunicação entre a corporação e o } \\
\text { Museu. A maioria deles não conhece o Museu, nem a exposição localizada na parte } \\
\text { da Estação do Museu do Trem, nem o que significa uma instituição museal. Guarita } \\
\text { de alvenaria com vidros ao redor. Sendo que os mesmos são tapados por pedaços } \\
\text { de caixa de papelão, para impedir que o interior da peça seja visto pelo lado de fora. } \\
\text { Localizada na entrada do Museu, é utilizada para diversas funções: guardar } \\
\text { pertences, descanso, local de refeições, passar o tempo, olhar televisão. Dispõe de } \\
\text { um fogão, uma geladeira, armários com seis nichos, uma televisão, um botijão de } \\
\text { gás, uma escrivaninha, uma cadeira. Paredes úmidas e frias, com infiltração no solo } \\
\text { e com cheiro desagradável. } \\
\text { - Câmeras de segurança desativadas. } \\
\text { - Os roubos de lâmpadas são frequentes, inclusive, durante o dia enquanto a equipe } \\
\text { está trabalhando. }\end{array}$ \\
\hline $\begin{array}{l}\text { Edificações e } \\
\text { espaços físicos }\end{array}$ & $\begin{array}{l}\text { - Antiga Estação: avarias presente na parte externa (ornamentos da madeira } \\
\text { quebrados, apodrecidos e sujos). Na parte interna, mofo e manchas de umidade no } \\
\text { teto, lâmpadas queimadas, vidros quebrados e pintura descascada. Portas que } \\
\text { possuem apenas uma fechadura antiga (do tempo em que a Estação foi montada, } \\
\text { no final do Século XIX). } \\
\text { - Sanitário público é o único para uso tanto dos funcionários, quanto do público } \\
\text { externo. Os azulejos caindo, sujos, vazamentos. Falta privacidade. } \\
\text { - Armazém: infiltrações no telhado, goteira, calhas enferrujadas e furadas, manchas } \\
\text { de umidade nas paredes, pintura descascada. Espaço com divisórias de madeira e com } \\
\text { divisórias com armários e prateleiras. O espaço distribuído inclui copa, administrativo, } \\
\text { pesquisa e Reserva Técnica, biblioteca, serviços gerais. O ambiente é frio e úmido. } \\
\text { - Falta armários e ambiente reservado para funcionários. } \\
\text { - Existe um telefone fixo para ligações externas. }\end{array}$ \\
\hline Pátio & $\begin{array}{l}\text { - Lixo no pátio e junto aos vagões (baganas de cigarro, sacos plásticos, pacotes de } \\
\text { - Jalgadinho, etc.). } \\
\text { - Jardins descuidados (mato alto, capim entre os trilhos e passeio público, grama } \\
\text { alta, inço, falta de podas em árvores e retirada de galhos secos). } \\
\text { - Passeio público quebrado, com buracos e raízes de árvores } \\
\text { - Iluminação externa apagada } \\
\text { - Falta sinalização para chegar até o local } \\
\text { - Inexistem placas sinalização que identifiquem, na parte de circulação do Sítio } \\
\text { - Histórico, sanitários, acessos, salas, exposições, lixeiras, ou de qualquer restrição } \\
\text { - Falta quadro de avisos ou informativos públicos } \\
\text { - Acessibilidade para cadeirantes é insuficiente }\end{array}$ \\
\hline Comunicação & $\begin{array}{l}\text { - Falta folder institucional impressos ou digital. } \\
\text { - Falta material educativo de apoio para professores e ou alunos. } \\
\text { - Falta divulgação impressa de programação. } \\
\text { - Falta informativos eletrônicos ou participação em mídias sociais. } \\
\text { - Existe um postal impresso, com a divulgação de horários e com algumas imagens } \\
\text { históricas, confeccionado em parceria com a Empresa TRENSURB. } \\
\text { - Falta logomarca, impressos em papelaria para uso administrativo, de modo geral. } \\
\text { - Falta identificação ou uniformes para funcionários (crachás, camisetas, coletes ou } \\
\text { outro tipo de identificação). } \\
\text { - Falta plano de marketing. } \\
\text { - Falta um projeto expográfico atualizado. }\end{array}$ \\
\hline
\end{tabular}




\begin{tabular}{|c|c|}
\hline $\begin{array}{l}\text { Acervo em } \\
\text { exposição }\end{array}$ & $\begin{array}{l}\text { - Acervo exposto na parte externa apresenta avarias: partes quebradas, faltando } \\
\text { partes, ferrugem, poeira e manchas de mofo e pragas. Necessita reparos, limpeza, } \\
\text { restauro e conservação preventivas. Vagões e carros de passageiros permanecem } \\
\text { fechados, mesmo em dias de visitação, apenas sendo aberto através de solicitação } \\
\text { do visitante. Alguns vagões utilizados como depósitos (objetos de decoração do } \\
\text { Carnaval, do Natal e da Festa da Colonização Alemã) outros com vestígios de } \\
\text { moradia de mendigos. } \\
\text { - A exposição na parte interna do prédio da antiga estação apresenta ainda o projeto } \\
\text { da primeira montagem, realizada em } 1985 \text { pelo PRESERVE. Etiquetas estão } \\
\text { desbotadas e manchadas. Não há textos ou títulos explicativos. Observa-se } \\
\text { acúmulo de objetos em excesso. Alguns objetos estão com avarias como a } \\
\text { Bandeira do Brasil desbotada (mesmo dentro da vitrina). Falta cortinas para } \\
\text { proteção da luz solar. Vidros quebrados, painéis com avarias, fotos desbotadas. } \\
\text { Etiquetas grudadas machucando o acervo (informando um ok, utilizadas no } \\
\text { arrolamento do inventário realizado em 2008). Algumas fotografias possuem } \\
\text { etiquetas com informações datilografadas, coladas sobre as mesmas. }\end{array}$ \\
\hline $\begin{array}{l}\text { Reserva } \\
\text { Técnica }\end{array}$ & $\begin{array}{l}\text { - Abrigado no mesmo espaço de outros setores, inclusive da copa, não há controle } \\
\text { de umidade, temperatura. O local é úmido. Alguns objetos do acervo estão sendo } \\
\text { utilizados pelo setor administrativo (mesa de escritório, cadeiras, banco, armários). } \\
\text { - Acervo documental, fotográfico, tridimensional agrupado. } \\
\text { - Falta sistemas de segurança. Acesso restrito. Extintores com prazos de validade } \\
\text { vencidos. } \\
\text { - Acervo organizado prateleiras de metal identificadas e agrupados por semelhança. } \\
\text { As peças sem proteção ou acondicionamento. Peças com avarias e maltratadas } \\
\text { (ferrugem, quebradas, cupim, apodrecimentos). } \\
\text { - Acervo bibliográfico acondicionados em armários de metal com portas. Nível de } \\
\text { conservação razoável. Fitas cassete, filmes de rolo, negativos de vidro, embalados } \\
\text { e protegidos. Algumas peças tridimensionais em armários de madeira do próprio } \\
\text { acervo. As plantas e projetos de engenharia organizada em mapotecas de metal. } \\
\text { - O acervo tridimensional está registrado em Livro de Tombamento, pelas museólogas } \\
\text { Maria Thereza Kahl Fonseca e Clarissa Oliveira de Carvalho (PRESERVE). Não } \\
\text { foram localizados registros sistematizados de alguns grupos do acervo documental, } \\
\text { como mapas, fotografias, filmes, diapositivos, plantas, entre outros. }\end{array}$ \\
\hline $\begin{array}{l}\text { Públicos e } \\
\text { parceiros }\end{array}$ & $\begin{array}{l}\text { - Presença do público é esporádica. Famílias utilizam os espaços abertos para nele } \\
\text { passear; muitos casais de namorados também aproveitam os bancos da Praça e a } \\
\text { tranquilidade do lugar; as escolas agendam visitas por telefone sendo atendidas } \\
\text { pelos estagiários. Aos finais de semana, identifica se a presença de amantes da } \\
\text { ferrovia que trazem familiares para visitar o acervo exposto. Há um livro para } \\
\text { registro de assinaturas do público, na entrada da exposição. } \\
\text { - Falta recursos e apoio para deficientes visuais e ou auditivos. } \\
\text { - Vizinhos jogam lixo doméstico por cima do muro (carcaça de galinha, caixas de } \\
\text { cereais, de leite, esponjas de louça, etc.). } \\
\text { - Parceria com a TRENSURB. } \\
\text { - Falta parceria institucional com Universidade, Secretarias Municipais e ou ONGs. } \\
\text { - A visitação é esparsa e eventual. Há procura de escola e de pesquisadores, porém } \\
\text { não em grande volume. } \\
\text { - Comentários dos visitantes, destacados pela equipe: } \\
\text { "Antigamente o Museu do Trem tinha bastante procura". } \\
\text { "Que tristeza! Que abandono! Ninguém valoriza isso". } \\
\text { "A exposição é sempre igual? Viu uma vez não precisa voltar". } \\
\text { "Eu gosto de vir aqui. Sempre trago meus familiares quando me visitam". } \\
\text { - Comentário nostálgico e de rememoração do passado se repete entre os visitantes, } \\
\text { ferroviários, ou profissionais que participaram na reconstrução da Estação e mesmo } \\
\text { de ferroviários. Reclamações sobre a falta de cuidados e o abandono do lugar } \\
\text { também são frequentes. } \\
\text { - Impressões dos funcionários: desânimo, baixa estima, pouca motivação, ausência } \\
\text { de perspectivas de mudança ou melhora, conformismo com o abandono e a falta } \\
\text { de cuidados. Conhecem muito pouco do acervo. } \\
\text { - Falta parceria com pares da área museológica. }\end{array}$ \\
\hline $\begin{array}{l}\text { Recursos } \\
\text { humanos }\end{array}$ & $\begin{array}{l}\text { - Composição do quadro: um agente administrativo, dois serviços gerais e dois } \\
\text { estagiários, mais dois guardas municipais. O tempo de serviço deste grupo varia de } 13 \\
\text { anos até } 6 \text { meses. Concursados e estagiários (são graduandos do Curso de História) } \\
\text { cumprem carga horário de } 30 \mathrm{~h} \text { semanais. Guardas cumprem uma escala de } 12 / 36 \mathrm{~h}\end{array}$ \\
\hline
\end{tabular}




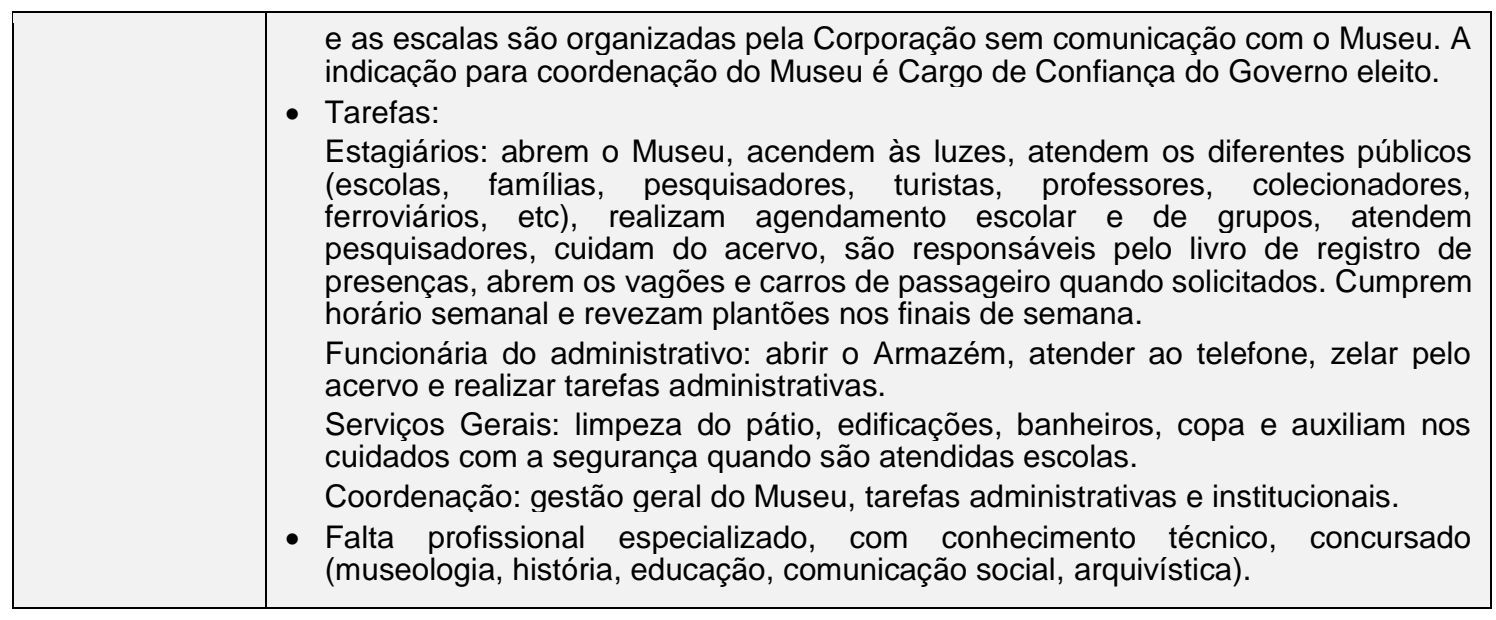

Fonte: elaborado pela autora.

A identificação do cenário interno e do contexto possibilita ao Museu encontrar respostas a questões básicas e iniciais como: quem eram os funcionários e os estagiários; motivos que o levam a escolha deste trabalho; formação; rotina e atividades desempenhavam, o que pensavam sobre a instituição; sobre um museu inserido em um Sítio Histórico; tipos de abordagem do público pelos seguranças; visão dos seguranças sobre o Museu do Trem e se os mesmos já haviam visitado a exposição dentro da Estação; horários e procedimentos da ronda noturna. Ou seja, o Museu do Trem inicia a partir do diagnóstico um pensar sobre si.

Segundo Timothy Mason, na gestão três são os princípios chaves: 1. Estabelecer uma visão clara; 2. Para onde o museu está se dirigindo; 3. Como chegar lá. Defende que o primeiro princípio envolve um processo de consulta dentro e fora do museu sobre o direcionamento do mesmo, o que para ele agrega elementos para a definição de uma missão. O segundo princípio resume-se em estabelecer objetivos, metas de curto e médio prazo, e o terceiro princípio se caracterizam pelo como se irá fazer, ou seja, as estratégias que irão oportunizar atingir as metas estabelecidas anteriormente (2004).

- Planejamento ajuda a garantir a proteção dos acervos a longo prazo;

- Todos (dentro e fora do museu) são esclarecidos sobre a finalidade do museu;

- Todos sabem como cada um se encaixa nos objetivos estratégicos e específicos deste;

- Leva a um uso mais eficaz dos recursos;

- Integra todas as partes da operação do museu num único sistema de gerenciamento;

- Estabelece uma estrutura dentro da qual as decisões estratégicas podem ser tomadas;

- Funciona como uma referência para todos os parceiros do museu (MASON, 2004: 48).

Mason enfatiza o planejamento como uma atividade fundamental, afirmando ser esta também uma "segurança do futuro dos museus" (2004:46), sendo que para o diretor, 
o planejamento não se caracteriza por um processo rápido, exigindo envolvimento e investimento de tempo.

O próprio processo de pensar sobre o museu pretende realizar e como está tentando fazê-lo pode, de fato, ser muito mais valioso. O planejamento faz as pessoas pensarem sobre qual é o propósito do museu e como ele pode ser devidamente cumprido. O plano é um meio prático de se resumir os resultados dessas considerações e apresentar uma declaração sobre o propósito e as metas do museu para o mundo exterior (MASON, 2004: 48).

Entre os documentos de planejamento ${ }^{73}$ do Museu do Trem, elaborados ao longo dos quatro anos, elenca-se aqueles relacionados como planejamento institucional geral e parcial, quando sobre programas e projetos específicos, e ao (re)planejamento. A saber:

Quadro 8 - Documentos referente ao processo de planejamento.

\begin{tabular}{|l|c|l|}
\hline \multicolumn{1}{|c|}{ Descrição } & Período & \multicolumn{1}{|c|}{ Características } \\
\hline $\begin{array}{l}\text { Organizando possibilidades para o Museu do } \\
\text { Trem (roteiro de ideias) (04 folhas) }\end{array}$ & Fev. 2009 & $\begin{array}{l}\text { Planejamento Institucional (geral) } \\
\text { Museu do Trem. }\end{array}$ \\
\hline Plano Diretor (incompleto) (05 folhas) & Mar. 2009 & $\begin{array}{l}\text { Planejamento Institucional (geral) } \\
\text { Museu do Trem. }\end{array}$ \\
\hline $\begin{array}{l}\text { Proposta Inicial para debate - Diretoria de } \\
\text { Patrimônio (06 folhas) }\end{array}$ & Mar. 2009 & $\begin{array}{l}\text { Planejamento Institucional } \\
\text { Diretoria de Patrimônio. }\end{array}$ \\
\hline $\begin{array}{l}\text { Planejamento Estratégico para quatro anos } \\
\text { (10 folhas) }\end{array}$ & 2009 & $\begin{array}{l}\text { Planejamento Institucional (geral) } \\
\text { Museu do Trem. }\end{array}$ \\
\hline $\begin{array}{l}\text { Programa de Ação Educativa - Institucional } \\
\text { (08 folhas) }\end{array}$ & 2010 & $\begin{array}{l}\text { Planejamento Institucional } \\
\text { (parcial) (Programa). }\end{array}$ \\
\hline $\begin{array}{l}\text { Lista açães e planejando o ano de 2011 } \\
\text { (03 folhas) }\end{array}$ & 2011 & $\begin{array}{l}\text { Planejamento Institucional } \\
\text { (parcial). }\end{array}$ \\
\hline $\begin{array}{l}\text { Programa e Projetos - Institucional } \\
\text { (07 folhas) }\end{array}$ & Abril 2011 & $\begin{array}{l}\text { Apresentação Institucional (geral) } \\
\text { Museu do Trem. }\end{array}$ \\
\hline $\begin{array}{l}\text { Museu para Todos - Institucional } \\
\text { (11 folhas) }\end{array}$ & 01.04 .2011 Meramento Institucional \\
\hline $\begin{array}{l}\text { Museu Inclusivo - Institucional } \\
\text { (04 folhas) }\end{array}$ & $\begin{array}{l}\text { Planejamento Institucional } \\
\text { (parcial) (Projeto). }\end{array}$ \\
\hline $\begin{array}{l}\text { Proposta Gestão (atualização do Plano Diretor } \\
\text { 2009). } \\
\text { (07 folhas) }\end{array}$ & 2011 & $\begin{array}{l}\text { (re) Planejamento Institucional } \\
\text { (geral) Museu do Trem. }\end{array}$ \\
\hline $\begin{array}{l}\text { Planejamento Estratégico para 2012 } \\
\text { (atualização e reescrita). } \\
\text { (14 folhas) }\end{array}$ & $\begin{array}{l}\text { (re) Planejamento Institucional } \\
\text { (geral) Museu do Trem. }\end{array}$ \\
\hline
\end{tabular}

Fonte: elaborado pela autora.

${ }^{73}$ Este levantamento é parte do corpus documental organizado para esta pesquisa, disponível no Apêndice. 
Foram identificados também documentos de estudo de necessidades ${ }^{74}$ relacionados as demandas enfrentadas e os problemas identificados no diagnóstico. Entre os estudos de necessidade estão os projetos para buscar recursos através de leis de incentivo e projetos para justificar e comprovar as necessidades de uso dos recursos públicos. Ao total foram identificados dezenove documentos abrangendo desde estudo arquitetônico para banheiros novos, estudo para projetos museográfico e expográficos, até projetos de manutenção, pintura, publicação, climatização, restauro, acessibilidades, entre outros.

Nesta pesquisa, entre os documentos referente a escrita do planejamento, serão detalhados apenas aqueles que em sua característica referem-se a escrita institucional de questões gerais do Museu do Trem (ver quadro no 08 ). Os referidos documentos deram origem ao (re) planejamento subsequente, sendo eles:

1. Organizando possibilidades para o Museu do Trem (roteiro de ideias) - 2009;

2. Plano Diretor - 2009;

3. Planejamento Estratégico - 2009;

4. Museu para Todos - 2011;

5. Proposta Gestão (atualização do Plano Diretor de 2009) - 2011;

6. Planejamento Estratégico (atualização e reescrita) - 2012.

Ainda nessa seção serão abordados os organogramas elaborados no processo de planejamento e (re) planejamento.

As anotações iniciais, referente aos primeiros meses, intitulada Organizando possibilidades para o Museu do Trem (roteiro de ideias) abrange os tópicos: Estratégias para turistas e souvenir, Infraestrutura (espaço físico); Ação Educativa; Programação/ eventos; Marketing; Equipe; Publicações; Relações institucionais; Projeto Museográfico, Site e Patrimônio Cultural.

Decorrente das primeiras anotações, a elaboração do, Plano Diretor, ainda em 2009, com Estudo para debate (pensando Projeto Museológico e Museográfico), apresentado a partir de diretrizes. Diretrizes da Secretaria Municipal de Cultura (SMC). São os tópicos: Revitalizar o patrimônio cultural da cidade de São Leopoldo. Diretrizes do Museu: Revitalizar o Museu do Trem; sentir-se parte da história de São Leopoldo - relação de pertencimento; Valorização da própria história - identificação; e Construção da cidadania. Apresenta as seguintes metas e estratégias, seguindo o modelo do PDCA na organizacional administrativa:

\footnotetext{
74 Detalhados no Corpus Documental - Apêndice desta pesquisa.
} 
1. Proposta de Estrutura Organizacional;

2. Gerir o Museu;

3. Projeto de Integração e Inclusão Social;

4. Projeto de sustentabilidade e Meio ambiente;

5. Ação de Marketing Cultural;

6. Adequar estrutura física;

7. Ação Educativa;

8. Segurança;

9. Projeto Museológico e Museográfico.

Terceiro documento com características gerais foi escrito como Planejamento Estratégico, datado também de 2009, apresenta dez grandes prioridades para as ações que envolvem diversas questões do patrimônio cultural da cidade e que ficam sob a responsabilidade da Diretoria de Patrimônio Histórico-Artístico-Cultural ${ }^{75}$. Três prioridades são de interesse específico do Museu do Trem: Projeto Museológico; Programa de Ação Educativa; e Projeto Museográfico ${ }^{76}$. O Programa de Ação Educativa é inaugurado em abril de 2009, sendo prioridade, além de ocupar o lugar de eixo estrutural no planejamento e, consequentemente, no desenvolvimento de outras ações e setores do Museu.

Em 2010, Projeto Museu para Todos e, em 2011, a Proposta de Gestão para o Museu do Trem (atualização do Plano Diretor) e Planejamento Estratégico para 2012 (atualização e reescrita). Os documentos apresentam textos com trechos repetidos dos documentos elaborados em 2009, porém mostrando serem desdobramentos amadurecidos na prática da gestão museológica e o movimento proposto pela gestão de qualidade de avaliar e (re) planejar sem descartar os pontos fortes. Destaque aos objetivos elencados, a saber:

01. Assegurar que o Museu do Trem seja território de salvaguarda e difusão da história da R.F.F.S.A (Rede Ferroviária Federal Sociedade Anônima) no Rio Grande do Sul, propiciando o fortalecimento e a manifestação das identidades, a percepção crítica e reflexiva da contemporaneidade, a produção de conhecimento, a promoção da dignidade humana e a oportunidade de lazer.

02. Garantir a preservação do patrimônio da R.F.F.S.A (Rede Ferroviária Federal Sociedade Anônima) no Rio Grande do Sul e o cumprimento das leis de proteção do acervo de valor histórico e cultural.

03. Implantar Projeto de Gestão em Museu e do Programa de Ação Educativa;

04. Desenvolver e implantar Plano Museológico e Museográfico.

\footnotetext{
75 Nos anos de 2009 e 2010 o Museu do Trem esteve ligado a SMC através da Diretoria de Patrimônio Histórico-Artístico-Cultural, sendo que apenas em janeiro de 2011 foi separada a Diretoria de Patrimônio Cultural da direção do Museu do Trem.

${ }^{76}$ A Secretaria Municipal de Educação contratou o arquiteto Marcelo Ferraz para desenvolver um estudo de revitalização de espaços na cidade, incluindo o Museu do Trem, chamado de Projeto REVITA. Em parceria com a Universidade Vale do Rio dos Sinos (UNISINOS), foi desenvolvido estudo, porém não foi implantado.
} 
05. Preservar, catalogar, organizar e disponibilizar para ao público o acervo documental, museológico/tridimensional, fotográfico e audiovisual, bibliográfico.

06. Viabilizar que os projetos desenvolvidos e o acervo possam ser apresentados em exposições itinerantes por diferentes cidades, assim como em Congressos, Fóruns e eventos afins.

07. Promover projetos em parcerias com diferentes instituições, entre elas: rede de ensino fundamental e médio, ensino superior, rede municipal de saúde e de assistência social, turismo, meio ambiente e empresas da comunidade leopoldense.

08. Criar rede de intercâmbio e parcerias com os órgãos municipais, estaduais e federais, relacionados a preservação, memória, educação e patrimônio cultural, entre eles: IPHAN, IPHAE, ICOM, IBRAM, SEM/RS, ABM, FAEB, AGA e Universidades.

09. Participar e compor com as políticas de gestão cultural da Secretaria Municipal de Cultura de São Leopoldo.

10. Garantir a manutenção do Sítio Histórico que agrega o Museu do Trem, Estação Antiga, Armazém, o acervo ao ar livre e a Praça Mac Ginity.

11. Dar o acesso e acessibilidade aos diferentes públicos para conhecer o Acervo, o Sítio Histórico e o Programa de Ação Educativa.

12. Criar Setor de Documentação e Pesquisa disponibilizando novas formas de acesso (MUSEU DO TREM, 2010).

\section{E para o (re) planejamento:}

Formação de quadro de funcionários para o Museu: abertura de concurso para vaga de: arquivista, educador em museus, historiador e museólogo; ampliação do número de estagiários, oportunizando a participação das diferes áreas do conhecimento, entre elas os cursos de licenciatura: letras, história, artes para a diversidade, artes visuais, música, artes cênicas, audiovisual, filosofia, sociologia e também: pedagogia, turismo, jornalismo, relações públicas e museologia; funcionários preparados para recepção de públicos diversos (turistas, deficientes, escolares, famílias, pesquisadores, etc.); qualificação de funcionários e estagiários.

Produção de material impresso: reimpressão da caderneta de anotações para distribuição aos escolares; impressão de folder em 4 línguas diferentes para público em geral; elaboração de revista (didática) para crianças da rede municipal; elaboração de revista (didática) para público jovem com temática abordando a história, a arte, a sociologia e o urbanismo; criação de materiais didáticos para brincadeiras; elaboração de jogos didáticos relacionando diferentes áreas do conhecimento.

Readequação do espaço físico, Manutenção e Restauro: recuperação do telhado do Armazém; restauração da Estação Antiga; reforma nos banheiros; construção de cozinha, almoxarifado e ambiente para vestiário dos funcionários; criação de ambiente lúdico para recepção de escolares, crianças e famílias; construção de mini-auditório e espaço para formação; readequação das divisórias do armazém para organizar ambiente para reuniões administrativas, pedagógicas e pesquisa.

Buscar recursos financeiros para preservação e recuperação do acervo: recursos financeiros para todos os itens acima detalhado mais os itens abaixo; higienização, catalogação do acervo documental; higienização, catalogação do acervo tridimensional/museológico; higienização, catalogação do acervo fotográfico e audiovisual (MUSEU DO TREM, 2010). 
As etapas do diagnóstico permitem impulsionar ações, correlacionar observações dos cenários interno e externo e realizar o desdobramento em ações. Neste caso, o Museu do Trem elabora o planejamento e executa o trabalho sempre direcionado pelas observações. O diagnóstico também auxilia na distinção das ações emergentes, oferecendo dados para a escolha de prioridades e determinação de quais ações serão imediatas e quais serão de médio e longo prazo. Entre as ações emergentes estiveram: a limpeza geral do local, a ampliação e capacitação de uma equipe e da identidade visual; entre as de médio prazo estiveram: a aprovação de dois cargos técnicos, historiador e arquivista, para composição da equipe, através de concurso; reorganização e manutenção dos espaços físicos; aproximação com parceiros entre eles os ferroviários e o apoio para a criação de uma associação de amigos de museu. Entre as ações de longo prazo, estiveram: projetos diversos para captura de recurso para os diferentes setores referentes as questões de salvaguarda e comunicação de modo geral. Registra-se que o Museu do Trem foi contemplado com o Prêmio do IBRAM de Microprojetos ${ }^{77}$, com recursos para ações com o acervo.

Pressupondo que "a gestão museológica organiza a práxis formando o cotidiano institucional que opera no tempo" (CURY, 2009:30), estar com o museu aberto ao público exigem mais que apenas simplesmente abrir os cadeados e os portões. É necessário enfrentar os tempos relativos a burocracia e trabalhar com a ideia de conjunto. Tornar o Museu do Trem acessível depende de planejamento e organização da gestão, de recursos disponíveis, de vontade política e persistência, durante o encaminhamento das ações e dos processos que se desdobram continuamente.

No caso de São Leopoldo, o Museu não é separado do sistema organizacional da Administra Pública, o que demanda sintonia entre as partes envolvidas para que o Museu aconteça como instituição a partir dos princípios da museologia.

\subsubsection{Estrutura organizacional}

Um quadro organizacional com um desenho dos setores, estruturas e áreas, pode ser utilizado para demonstrar os vínculos entre os serviços, as funções e responsabilidades, com clareza. A maioria dos museus tem uma estrutura de gestão que inclui: gestão, curadoria e atividades (EDSON, 2004:147). O modo como estão vinculadas depende dos

\footnotetext{
77 Projeto intitulado: Patrimônio Museu do Trem: aplicabilidade do processo de conservação, através do Edital com Prêmio, de Microprojeto do IBRAM, em 2011.
} 
princípios e da estrutura organizacional. Na planificação da estrutura em desenho, as linhas de autoridade e trocas de informação (idem) tornam clara a estrutura que se quer realizar.

A questão importante é ter uma estrutura claramente definida com linhas de comunicação estabelecidas. Todo o pessoal do museu deve saber onde se encaixam na organização e um simples diagrama pode mostrar a relação deles com os outros membros do pessoal. $O$ quadro organizacional é um mapa que define o sistema e descreve o fluxo de trabalho no museu e demonstra a atitude organizacional da instituição (EDSON, 2004:148).

Para Edson, é fundamental na gestão do museu:

(1) selecionar o pessoal certo para trabalhar;

(2) determinar o trabalho a ser feito;

(3) decidir o método de trabalho a ser realizado;

(4) gerir a relação entre as pessoas que fazem parte o trabalho e os outros elementos do museu (EDSON, 2004:147).

As estruturas apresentadas por Gary Edson mostram dois modelos. O primeiro (figura o102), determina a autoridade máxima no topo, seguida do diretor/gestor, separado do restante do pessoal que está agrupado conforme a relação com as divisões primárias. Denominada como estrutura hierárquica, resulta em uma abordagem autoritária ou vertical da gestão institucional. O contato do pessoal com o diretor/gestor é dado apenas através de duas posições, consideradas como posições médias, permanecendo os demais com distanciamento. A segunda estrutura (figura №103), denominada de estrutura horizontal, oferece uma abrangência de contato entre diretor/gestor e pessoal responsável pelas áreas. Aumentando o número de pessoas na posição média de gestão (2004).

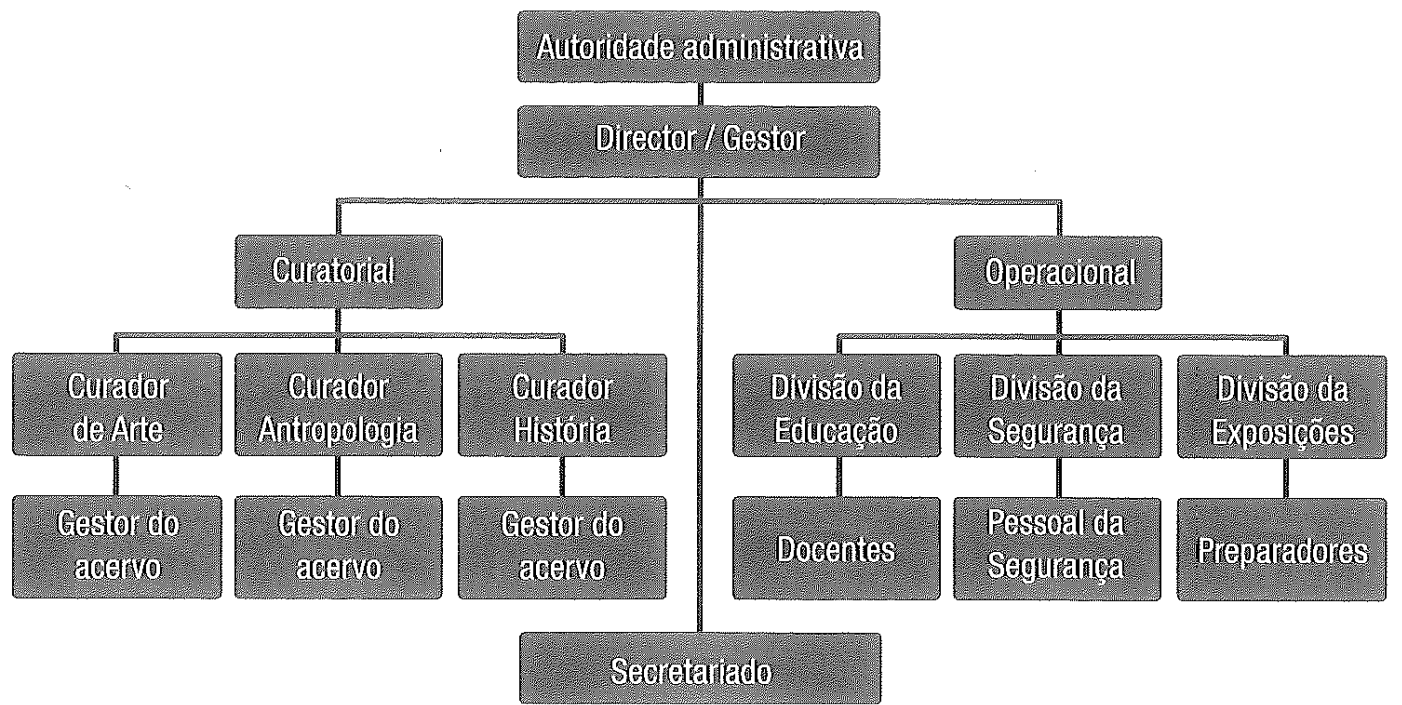

Figura 102 - Estrutura Organizacional Hierárquica.

Fonte: Gary Edson, 2004. 


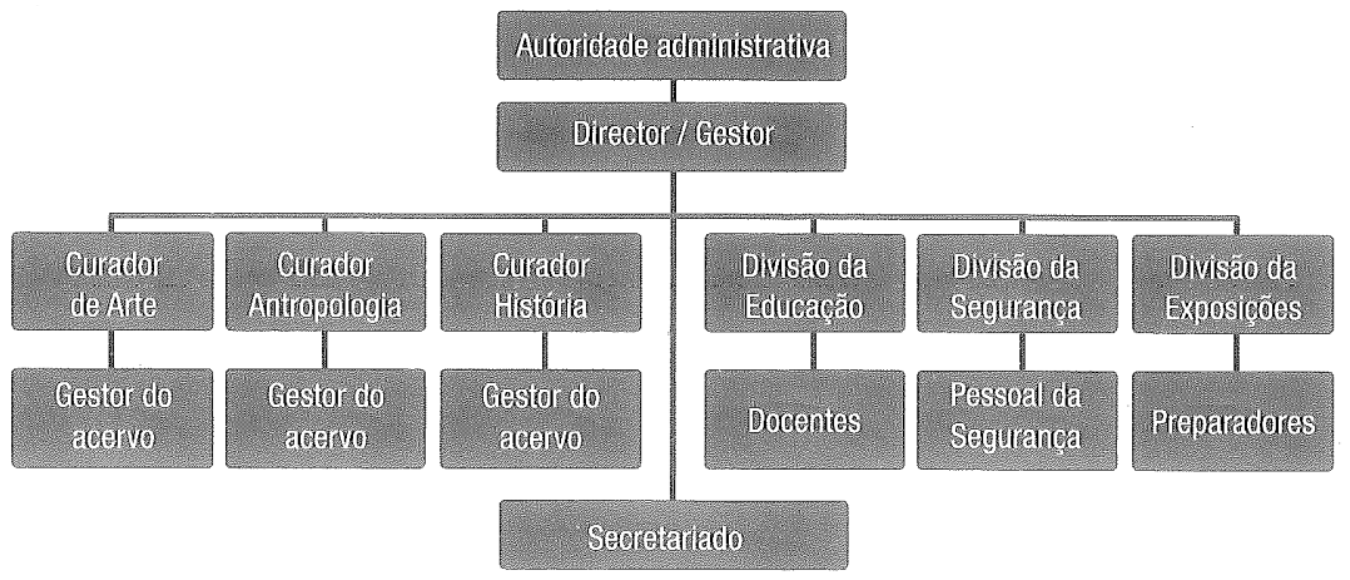

Figura 103 - Estrutura Organizacional Horizontal Simplificada. Fonte: Gary Edson, 2004.

A terceira estrutura apresentada por Edson, denominada estrutura matriz, atribuí responsabilidade vertical ao pessoal do topo, porém a relação deve atravessar todas, ou quase todas, estruturas do museu. As tarefas são também determinadas por temas que devem ser solucionados por comissões, sendo que ao final todos os elementos convergem para o diretor/gestor.

Um modo para promover esta troca é ter um comitê de aconselhamento de gestão. Isso permitirá aos membros do pessoal reunirem-se regularmente, com o diretor e outros gestores do topo, para discutirem assuntos relacionados com as atividades operacionais (EDSON, 2004:149).

Exige-se normalmente que funcione de acordo com o sistema de gestão do órgão administrativo.

Alguns diretores têm a autoridade para tomar decisões operacionais do dia-a-dia, incluindo a contratação e disciplina do pessoal, enquanto sob outros sistemas de responsabilidade pertence ao serviço de pessoal do governo ou da cidade (EDSON, 2004: 145).

O Museu do Trem elabora cinco documentos com desenhos de organogramas que apresentam modificações significativas. Os organogramas identificados com características de organograma informativo, vertical, funcional e radial, disponibilizam elementos que revelam a trajetória no período. 
Quadro 9 - Documentos da estrutura organizacional

\begin{tabular}{|l|c|c|}
\hline \multicolumn{1}{|c|}{ Descrição } & Ano & Características \\
\hline $\begin{array}{l}\text { Diretoria de Patrimônio Histórico-Artístico-Cultural } \\
\text { - objetivos, envolvidos, eixos estruturadores, projetos, parcerias, } \\
\text { temas transversais (01 folha) }\end{array}$ & 2009 & $\begin{array}{c}\text { Organograma } \\
\text { Informativo }\end{array}$ \\
\hline $\begin{array}{l}\text { Diretoria de Museu } \\
\text { - pressupostos, embasamento Plano Nacional de Cultura, } \\
\text { envolvidos, eixos estruturadores, projetos e atividades (01 folha) }\end{array}$ & 2011 & $\begin{array}{c}\text { Organograma } \\
\text { Informativo }\end{array}$ \\
\hline $\begin{array}{l}\text { Equipe do Museu do Trem } \\
\text { - funções hierárquicas com nome dos envolvidos em cada setor } \\
\text { (01 folha) }\end{array}$ & 2011 & $\begin{array}{l}\text { Organograma } \\
\text { vertical }\end{array}$ \\
\hline $\begin{array}{l}\text { Estrutura Organizacional } \\
\text { - funções hierárquicas interligadas por setores, distribuídos em } \\
\text { três patamares: grupo estratégico, grupo tático, grupo } \\
\text { operacional (01 folha) }\end{array}$ & 2011 & $\begin{array}{c}\text { Organograma } \\
\text { funcional }\end{array}$ \\
\hline $\begin{array}{l}\text { Estrutura em Setores e Áreas (Estudo para Regimento Interno). } \\
\text { - setores e áreas apresentados interligado em um sistema, sem } \\
\text { posicionamento hierárquico (01 folha) }\end{array}$ & 2012 & $\begin{array}{c}\text { Organograma } \\
\text { radial }\end{array}$ \\
\hline
\end{tabular}

Fonte: elaborado pela autora.

A estrutura organizacional desenhada como organograma integra princípios, objetivos, recursos humanos e funções. O desenho das estruturas em cada etapa revela a ação contínua de refletir sobre o modo como a instituição estava funcionando. A primeira figura corresponde à estrutura do Museu inserida na Diretoria de Patrimônio HistóricoArtístico-Cultural da Secretaria Municipal de Cultura (SMC) (figura 104).

O organograma elaborado em $2009^{78}$ apresenta características informativas, com uma síntese envolvendo desde os objetivos que abrangem o interesse em:

1. Integrar programa cultura-educação-turismo-desenvolvimento econômico;

2. revitalizar o patrimônio (cultural grifos meus) da cidade;

3. criar programas de educação patrimonial.

A Diretoria de Patrimônio Histórico-Artístico-Cultural tem o Museu do Trem como principal ação, porém não é a única. O desenho informa ainda sobre os envolvidos, os projetos, os parceiros, além dos eixos centrais estruturados e transversalidades.

78 Organograma de 2009 (figura 104) encontra-se também no Anexo A, e de 2011 (figura 105) no Anexo B. 


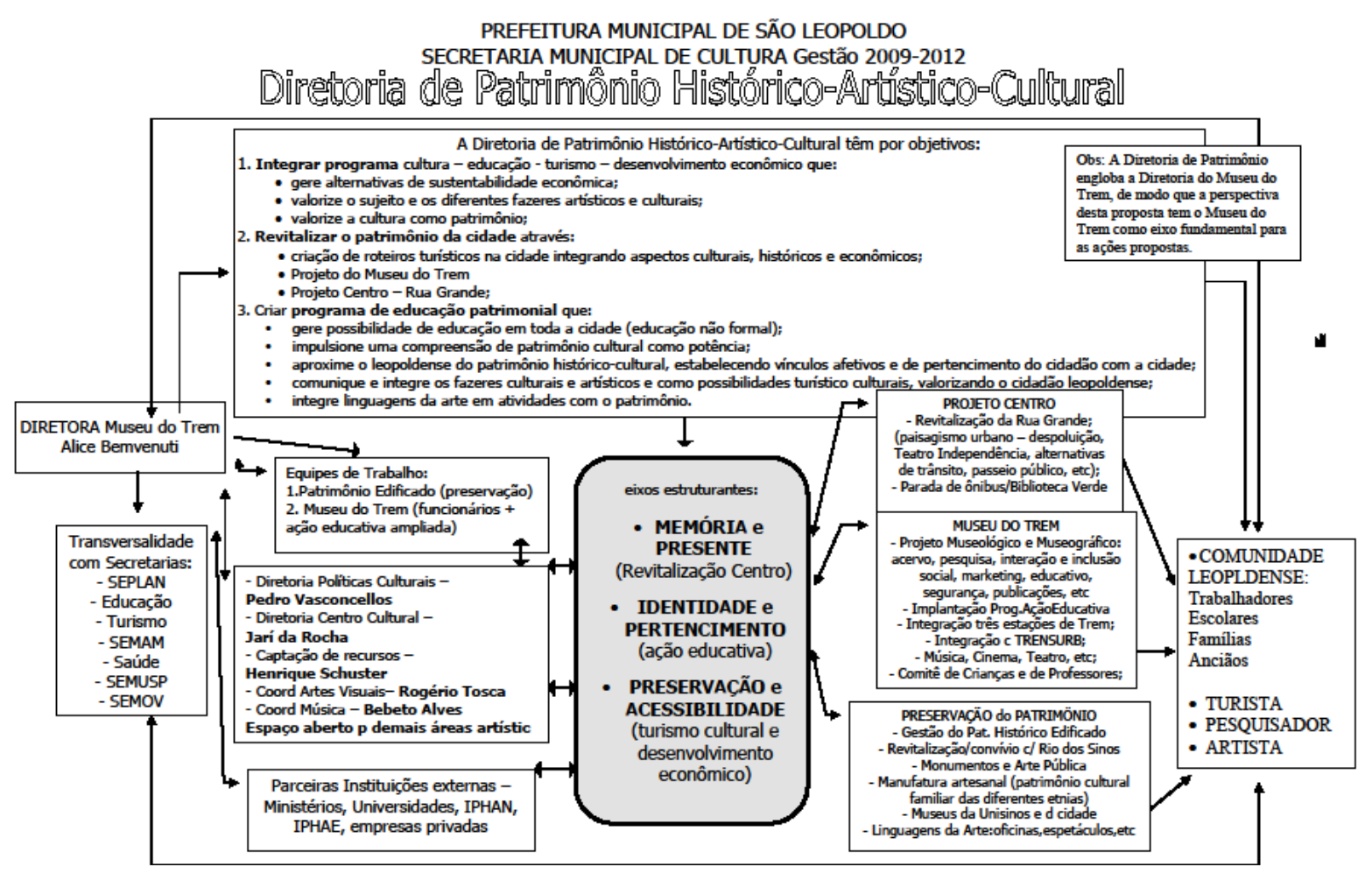

Figura 104 - Organograma da Diretoria de Patrimônio. Ano: 2009. Fonte: Museu do Trem de São Leopoldo.

A elaboração de políticas relativas a temas específicos, auxilia na tomada de decisões e na definição do curso das ações (EDSON, 2004) para o museu. Segundo Gary Edson, os museus devem formular três tipos de políticas.

a) Política filosófica (que dirigem aos assuntos éticos;

b) Política de desenvolvimento de recursos: que definem a distribuição de recursos principais;

c) Procedimentos do trabalho: que se preocupam com os assuntos operacionais (EDSON, 2004:152).

Em 2011 ocorrem mudanças na SMC com Pedro Vasconcellos assumindo a pasta. Ainda em janeiro, realizam um Seminário de Cultura a fim de discutir, avaliar e redirecionar os projetos e equipamentos culturais sob sua responsabilidade. No grupo de trabalho Patrimônio Cultural, do referido Seminário, são aprofundadas questões sobre: patrimônio, memória e museus, e definidas alterações Diretoria de Patrimônio Histórico-ArtísticoCultural, desvinculando o Museu do Trem de sua responsabilidade. Aventa-se a possibilidades de o Município estruturar uma Diretoria de Museus, interligando diferente instituições e organizações museais da cidade, tendo sido já identificado: museus, 
memoriais e acervos salvaguardados ${ }^{79}$, mas sem estrutura técnica implantada. A partir destas questões, é redesenhado o organograma ${ }^{80}$ (figura $\mathrm{n}^{0}$ 105). Entre os pressupostos vinculados a SMC e a Diretoria de Museus, são destacados os seguintes itens:

\section{Cidadania Cultural, Direito e Acesso a Bens e Produção Cultural}

- Identificar e valorizar a compreensão de patrimônio cultural como parte da história da cidade;

- Valorizar o sujeito e os diferentes fazeres e manifestações artísticoculturais salvaguardados em objetos históricos no Museu;

- Projetos integrados com outras Secretarias Municipais da cidade, com outros Municípios e Museus, com outras instituições que possa compor projeto de interesse comum.

- Gestão do acervo, pesquisa e produção de conhecimento.

\section{Economia de Cultura}

- Em parceira com o turismo, compor roteiros turísticos na cidade integrando aspectos culturais, históricos e econômicos;

- Programa de Ação Educativa como um todo nas diversas atividades que desenvolve;

- Gerar alternativas de sustentabilidade econômica através das oficinas diversas (Conservação, Ferromodelismo, Patrimônio, etc.) assim como pelas possibilidades turistas que o local sugere.

\section{Estética}

- Programa de Ação Educativa na perspectiva de produção de conhecimento em diversas instâncias e com diversos públicos;

- Ampliar a noção de preservação e conservação de patrimônio a partir da identificação e da noção de pertencimento desenvolvido pelo Programa de Ação Educativa - um Museu para Todos!;

- Reconceituar a função do museu e da salvaguarda dos objetos;

- Aproximar o leopoldense do patrimônio histórico-cultural, estabelecendo vínculos afetivos e de pertencimento do cidadão com a cidade (MUSEU DO TREM, 2011).

A Administração Pública em São Leopoldo acolhe a discussão sobre mecanismos de salvaguarda e comunicação no Museu do Trem, de modo geral, mesmo que em um ritmo diferente da necessidade apresentada.

\footnotetext{
79 Realizado levantamento dos museus, memoriais e acervos salvaguardados no Município, tomou-se a iniciativa de aproximar as diferentes instituições, porém a iniciativa pareceu ousada, tendo realizado algumas reuniões, mas enfrentando dificuldades de manter as aproximações.

80 Organograma de 2011 apresentado na figura 105 está também no Anexo B.
} 
PREFEITURA MUNICIPAL DE SÃO LEOPOLDO

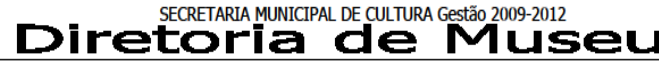

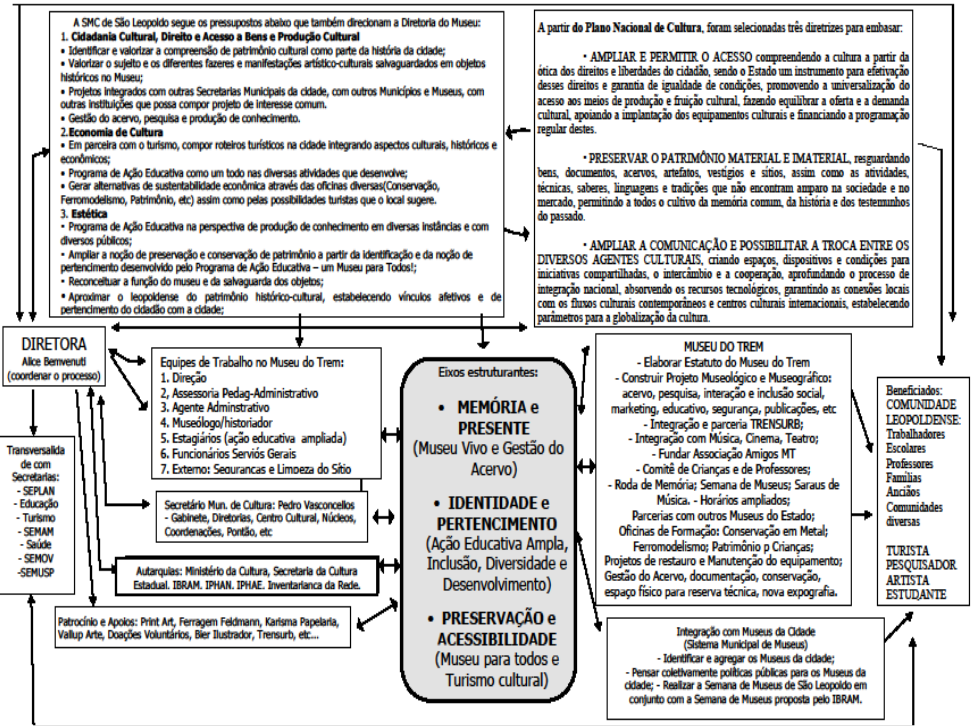

Figura 105 - Organograma da Diretoria de Museus. Ano: 2011. Fonte: Museu do Trem de São Leopoldo.

Também 2011, com a entrada de cargos técnicos concursados, redefiniu-se a estrutura da equipe (figura 106), dispondo função e responsabilidade dos diferentes cargos a partir do grupo estratégico, do grupo tático e do grupo operacional.

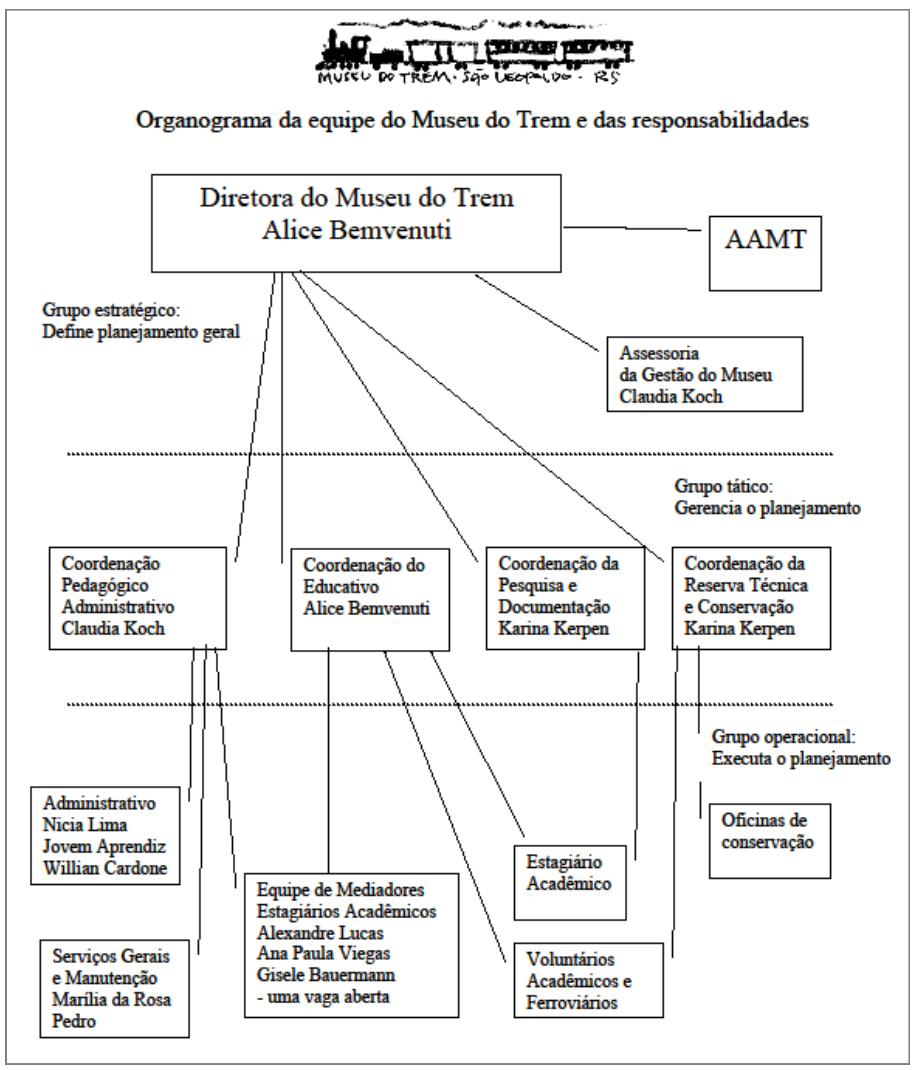

Figura 106 - Organograma do Museu do Trem. Ano: 2011. Fonte: Museu do Trem de São Leopoldo. 
Em 2012, por ocasião do 2ํ Curso de Verão com atividades de formação interna, o Museu realiza a escrita coletiva de um Regimento Interno. Entre os itens desenvolvidos, estiveram: à missão da instituição, às políticas de relacionamento, de acervo, de comunicação e gestão. O Regimento Interno ${ }^{81}$ foi escrito por doze participantes do Curso de Verão, entre eles a equipe do Museu e dois convidados.

O Regimento previu uma estrutura com Núcleo Administrativo, Núcleo Educativo, Núcleo Histórico, Núcleo Museológico e uma grande área de Comunicação, Marketing e Relacionamento. Além da escrita do texto para o Regimento, o Museu reorganiza o desenho do organograma envolvendo os setores a partir da compreensão de um sistema por conjuntos. Sendo nítida há compreensão da necessidade de os setores estarem relacionados entre si, configurando o museu como um todo (figura 107).

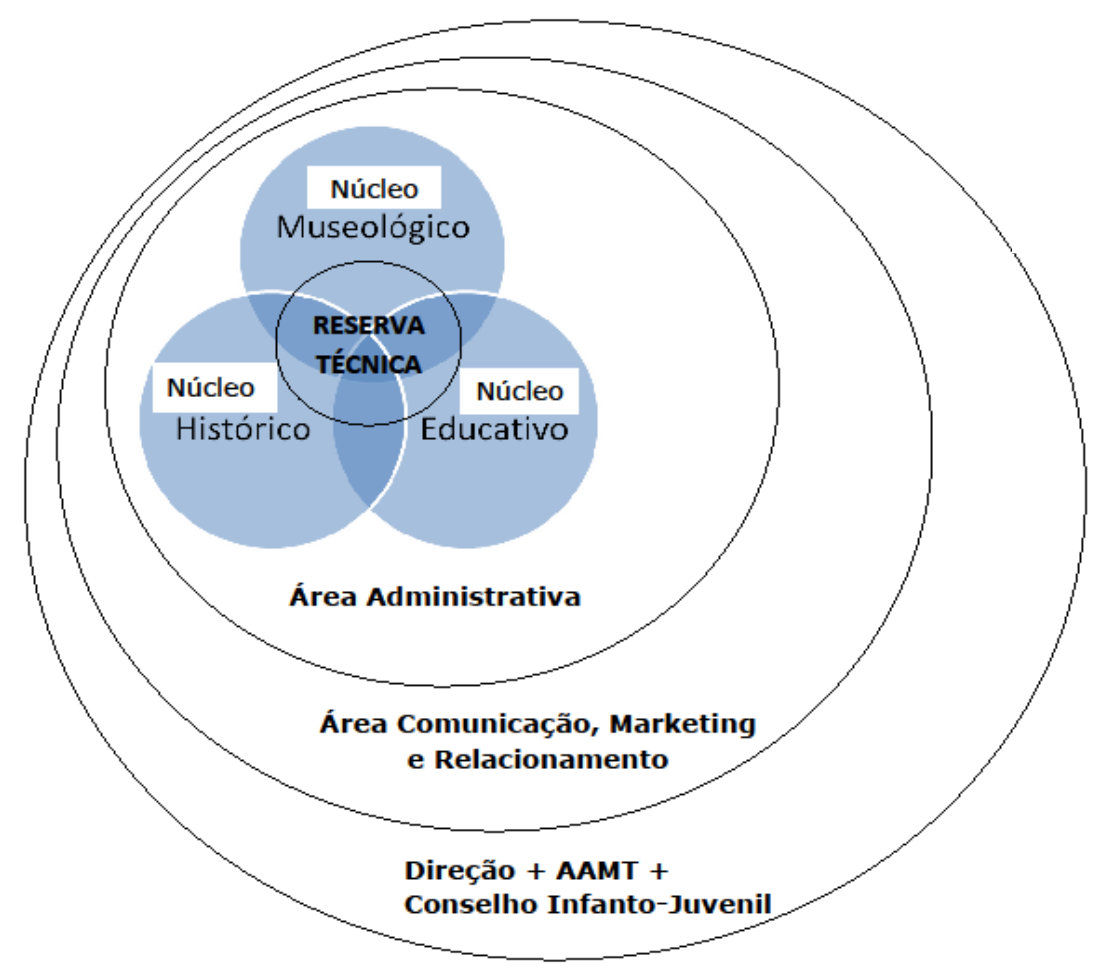

Figura 107 - Organização dos núcleos para o Museu do Trem. Ano: 2012. Fonte: Museu do Trem de São Leopoldo.

É importante observar como a Associação Amigos do Museu do Trem (AAMT) ${ }^{82}$ foi colocada em ponto estratégico junto a direção do Museu. No desenho apresentado (figura 107), observa-se também ao lado da direção e o Conselho Infanto-Juvenil83.

\footnotetext{
81 O Regimento Interno não foi levado para a aprovação da Câmara dos Vereadores, ficando esta tarefa para quem assumisse a gestão seguinte.

82 Criada em 2010, a AAMT é assim constituída por Assembleia Geral, Diretoria, Conselho Consultivo e Conselho Fiscal. Qualquer pessoa física ou jurídica, brasileiro, em acordo com o Estatuto, poderá se associar. 83 Não foi implantado.
} 
Aproximar os organogramas e comparar os desenhos, que por sua vez apresentam as prioridades, permite perceber como durante a gestão o Museu compreendeu com maior clareza a sua natureza. E são nas estruturas definidas que o Museu do Trem realiza mudanças na rotina, a partir dos objetivos e metas que o leva a optar por essa ou aquela prioridade a partir da necessidade, emergência e demanda priorizada.

\title{
4.3 AVALIAÇÃO
}

Avaliação é um tema complexo e abrangente que permitem sua utilização com diferentes finalidades e de distintas maneiras. Avaliação pode ser uma ferramenta utilizada pela gestão com enfoque no público externo, no público interno, nos processos em geral. O instrumento de avaliação, por um lado, possibilita aos envolvidos uma aproximação com a coordenação/gestão da instituição, por outro, permite que a coordenação/gestão possa identificar tópicos relevantes para orientar tomadas de decisão.

\begin{abstract}
Avaliação, antes de tudo, é uma postura profissional que busca o aperfeiçoamento e o domínio de nosso ofício. A avaliação é uma ferramenta para aprofundar a nossa compreensão do trabalho que desenvolvemos. É um meio para o refinamento profissional - e, consequentemente, institucional - seja dos processos de trabalho, seja dos produtos que idealizamos e concretizamos. A avaliação é um meio para um fim (CURY, 2005: 124).
\end{abstract}

A qualidade em uma gestão pode ser identificada sob diversos aspectos, entre eles através da verificação e análise de dados. Sem qualquer intenção de obter uma certificação ${ }^{84}$, o Museu do Trem faz uso da avaliação com frequência, reunindo dados sobre as suas ações no período entre 2009 a 2012.

Segundo Cury, avaliação como uma maneira de se estabelecer diálogos com a realidade e um meio para transformá-la” (CURY, 2005:123). Avaliar permite constatar, aproximar, verificar, refletir. No caso do Museu do Trem, permite que possam sem ouvidas as diferentes vozes daqueles que integram a equipe e que são responsáveis por diferentes funções. Inicialmente o instrumento de avaliação permite identificar as atividades realizadas e constatar de modo breve itens relacionados a satisfação dos envolvidos, sejam eles público interno ou externo.

${ }^{84}$ A certificação é conferida as empresas que são enquadradas nos padrões definidos e publicados pela ABNT, ISO 9000. 


\subsubsection{Avaliação no processo}

Uma ferramenta utilizada pela coordenação/gestão do Museu do Trem para a tomada de decisões foram as avaliações realizadas ao longo dos quatro anos. Sem um padrão intencional, as avaliações obedecem a uma lógica de verificação através do registro individual e coletivo, desde as expectativas iniciais do trabalho, atividades desenvolvidas, auto avaliação, convivência no grupo, perspectivas futuras e sugestões para o Museu.

Com diversos formatos, desde formulários, questionários, textos, as avaliações tornam-se instrumentos facilitadores da escuta das diferentes vozes dos diferentes envolvidos. O Museu reuniu informações significativas abrangendo os setores em diferentes períodos e atividades, revelando conflitos, interesses, faltas, excessos, ponderações, satisfações, conquistas e sugestões sobre diferentes aspectos.

Inicialmente desenvolvidos para obter dados da rotina do Museu e manter a prática do registro escrito ${ }^{85}$, as avaliações ${ }^{86}$ ofereceram a coordenação/gestão conteúdos sobre as práticas dos diferentes setores no contexto de instituição pública. Os dados compõem o rol de informações sobre o cenário interno e externo, necessários para a realização do planejamento e do contínuo (re)planejamento. Para os envolvidos é um constante detectar, apurar, refletir, orientar, voltar atrás, ampliar, restringir, revelar, aplicar, alterar, reforçar. Do mesmo modo, observa-se, ao longo das respostas, a construção de alguns conceitos específicos sobre questões museológicas, antes desconhecidas, como à concepção de museu, identificação e reconhecimento das funções e responsabilidades individuais, conhecimento e vínculos com o acervo ferroviário, entre outros. Para Cury,

[...] a avaliação da educação em museus está ligada às condições de produção - desenvolvimento do processo educacional. Abrange o modo de utilização dos recursos disponíveis, a eficiência dos processos, os esforços da equipe e procedimentos adotados (CURY, 2014:61).

Entre funcionários, estagiários, contratados e voluntários, constata-se que 56 pessoas participaram da equipe do Museu do Trem ao longo dos quatro anos.

O Museu do Trem ao realizar as avaliações em diferentes momentos, estabelece uma importante ferramenta de comunicação interna. Assim, coleta opiniões sobre o

\footnotetext{
85 Intencionalmente se arquivou cópias, a fim de produzir informações sobre a história institucional deste Museu.

86 Os instrumentos desenvolvidos permitem aprofundar estudos de avaliação em categorias distintas: diagnóstico, formativa (DIAMOND, 1999), de processo e somativa (CURY, 2005), porém não serão abordados os dados sobre este aspecto.
} 
processo e a experiência de participante envolvido diretamente, como também se utiliza desta alternativa de comunicação, para visualizar pontos desapercebidos. No referido período, foram identificadas ao todo 84 avaliações respondidas em um universo de 13 avaliações diferentes.

Observa-se uma padronização na estrutura, essencialmente por pergunta abertas e algumas com questões fechadas, que utiliza de uma linguagem próxima do leitor que irá responder. $O$ instrumento é aplicado tanto para fins de avaliação de período e planejamento, como para a avaliação de eventos específicos. Sendo, a primeira avaliação realizada como sondagem, no período de chegada da coordenação/gestão ao Museu. Os documentos em ordem cronológica estão apresentados no quadro a seguir.

Quadro 10 - Avaliações diversas com equipe.

\begin{tabular}{|l|c|c|c|}
\hline \multicolumn{1}{|c|}{ Descrição } & Período & Quantidade & Característica \\
\hline $\begin{array}{l}\text { Expectativas para o trabalho (início do período } \\
\text { da Gestão no Museu) }\end{array}$ & 10.02 .2009 & 06 & Diagnóstico \\
\hline Tarefas e Responsabilidades & Abr. 2010 & 09 & Processo \\
\hline Avaliação de 2010 e planejamento de 201188 & Dez.2010 & 09 & $\begin{array}{c}\text { Processo e } \\
\text { autoavaliação }\end{array}$ \\
\hline 1º Curso de Formação de Verão & Jan. 2011 & 06 & $\begin{array}{c}\text { Processo e } \\
\text { autoavaliação }\end{array}$ \\
\hline $\begin{array}{l}\text { 3a Semana de Museus de São Leopoldo/ 9a } \\
\text { Semana Nacional de Museus }\end{array}$ & Mai. 2011 & 08 & Somativa \\
\hline Entrada de novos integrantes na equipe & Ago. a dez. 2011 & 03 & Diagnóstico \\
\hline Avaliação de 2011 e planejamento de 201289 & $2011 / 2011$ & 09 & $\begin{array}{c}\text { Somativa e } \\
\text { autoavaliação }\end{array}$ \\
\hline $\begin{array}{l}\text { 2o Curso de Formação de Verão } \\
\text { (reflexão parcial) }\end{array}$ & Jan. 2012 & 07 & Processo \\
\hline $\begin{array}{l}\text { 2o Curso de Formação de Verão } \\
\text { (formulário) }\end{array}$ & Jan. 2012 & 09 & Processo \\
\hline Entrada de novos integrantes na equipe & Ago. 2012 & 06 & Diagnóstico \\
\hline $\begin{array}{l}\text { Avaliação semestral - encerramento de período } \\
\text { de estagiário (para renovação) }\end{array}$ & Ao longo de 2012 & 07 & Autoavaliação \\
\hline Avaliação final (período de término do estágio) & 2012 & 04 & Autoavaliação \\
\hline Avaliação (término do estágio Jovem Aprendiz) & 2012 & 01 & Autoavaliação \\
\hline
\end{tabular}

Fonte: elaborado pela autora.

\footnotetext{
${ }^{87}$ Questões selecionadas desta avaliação para tabulação das respostas.

${ }^{88}$ (Idem).

${ }^{89}$ (Idem).
} 
Inicialmente, para fins desta pesquisa, os documentos foram agrupados cronologicamente, e posteriormente, por característica do mesmo. Define-se uma subdivisão: diagnóstico, processo e somativa (CURY, 2005), em um total de: 15 avaliações num contexto de diagnóstico, em momentos distintos entre 2009 e 2011; 25 avaliações do processo, incluindo registro sobre tarefas, responsabilidades, planejamentos realizados e avaliação de atividade e evento, no período entre 2010 a 2012; 08 avaliações somativa, que apresentam avaliações de fechamento de atividade e evento, no período de $2011 ; 12$ auto avaliações, fechamento de período, avaliação semestral/anual e reflexões, ao longo de 2012; 15 avaliações mistas processo e auto avaliação, período de 2010; e 09 avaliações mistas somativa e auto avaliação, período de 2011/2012.

\section{Quadro 11 - Itens identificados nas avaliações}

\begin{tabular}{|c|c|c|c|c|c|c|c|c|c|c|c|c|}
\hline \multirow[b]{2}{*}{ Característica } & \multirow[b]{2}{*}{ Descrição } & \multirow[b]{2}{*}{ Ano } & \multicolumn{10}{|c|}{ Inclui questão referente ao item abaixo } \\
\hline & & & 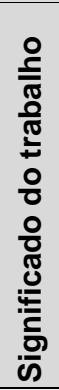 & 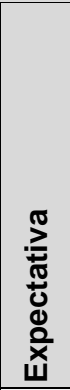 & 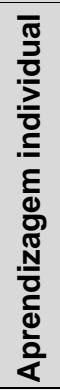 & $\begin{array}{l}\stackrel{0}{\bar{z}} \\
\text { 훔 }\end{array}$ & 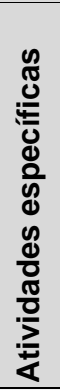 & 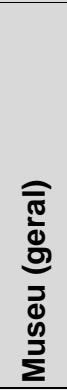 & 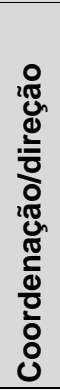 & 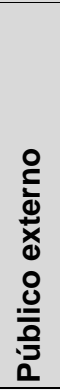 & 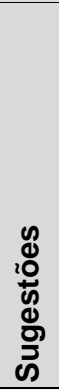 & 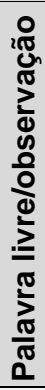 \\
\hline \multirow{3}{*}{ Diagnóstico } & $\begin{array}{l}\text { Expectativas para o trabalho } \\
\text { (início da Gestão) }\end{array}$ & 2009 & $X$ & $\mathrm{X}$ & & & & $\mathrm{X}$ & & & $X$ & \\
\hline & $\begin{array}{l}\text { Entrada de novos integrantes } \\
\text { na equipe }\end{array}$ & 2011 & $x$ & $x$ & & & & $\mathrm{x}$ & & & $\mathrm{X}$ & \\
\hline & $\begin{array}{l}\text { Entrada de novos integrantes } \\
\text { na equipe }\end{array}$ & 2012 & $X$ & $\mathrm{X}$ & & & & $x$ & & & $x$ & \\
\hline \multirow{3}{*}{ Processo } & Tarefas e Responsabilidades & 2010 & & & & $\mathrm{X}$ & & $\mathrm{x}$ & $\mathrm{x}$ & & $\mathrm{X}$ & $x$ \\
\hline & $\begin{array}{l}\text { 2 Curso de Formação de } \\
\text { Verão (reflexão parcial) }\end{array}$ & 2012 & & $\mathrm{X}$ & $x$ & & $x$ & & & & $x$ & $x$ \\
\hline & $\begin{array}{l}2^{\circ} \text { Curso de Formação de } \\
\text { Verão (formulário) }\end{array}$ & 2012 & & $X$ & $\mathrm{X}$ & & $x$ & & $x$ & & $\mathrm{X}$ & $x$ \\
\hline \multirow{2}{*}{$\begin{array}{l}\text { Processo e } \\
\text { autoavaliação }\end{array}$} & $\begin{array}{l}\text { Avaliação de } 2010 \text { e } \\
\text { planejamento } 2011\end{array}$ & 2010 & $x$ & & $\mathrm{X}$ & $\mathrm{X}$ & $\mathrm{X}$ & $X$ & $\mathrm{X}$ & & $\mathrm{X}$ & $x$ \\
\hline & $\begin{array}{l}11^{\circ} \text { Curso de Formação de } \\
\text { Verão }\end{array}$ & 2011 & & & $x$ & $\mathrm{x}$ & $x$ & & & & $x$ & $\mathrm{x}$ \\
\hline Somativa & $\begin{array}{l}\text { 3"a Semana de Museus de SL/ } \\
9^{a} \text { Semana Nac.de Museus }\end{array}$ & 2011 & & & $x$ & $\mathrm{X}$ & $x$ & & $X$ & $x$ & $x$ & \\
\hline $\begin{array}{l}\text { Somativa e } \\
\text { autoavaliação }\end{array}$ & $\begin{array}{l}\text { Avaliação de } 2011 \text { e } \\
\text { planejamento de } 2012\end{array}$ & $\begin{array}{l}2011 \\
2012\end{array}$ & $\mathrm{X}$ & & $\mathrm{X}$ & $\mathrm{X}$ & $x$ & & $\mathrm{X}$ & & $\mathrm{X}$ & $\mathrm{x}$ \\
\hline \multirow{3}{*}{ Autoavaliação } & $\begin{array}{l}\text { Avaliação semestral - } \\
\text { encerramento período estágio }\end{array}$ & 2012 & $x$ & & $\mathrm{X}$ & $\mathrm{X}$ & $\mathrm{X}$ & & $\mathrm{X}$ & & & \\
\hline & $\begin{array}{l}\text { Avaliação final (período de } \\
\text { término do estágio) }\end{array}$ & 2012 & $\mathrm{X}$ & & $x$ & $\mathrm{X}$ & $\mathrm{X}$ & & $X$ & & $\mathrm{X}$ & $x$ \\
\hline & $\begin{array}{l}\text { Avaliação (término do estágio } \\
\text { Jovem Aprendiz) }\end{array}$ & 2012 & & $\mathrm{X}$ & $x$ & & $\mathrm{X}$ & & & & & \\
\hline \multicolumn{2}{|l|}{ Total } & & 7 & 6 & 8 & 7 & 7 & 6 & 7 & 1 & 11 & 7 \\
\hline
\end{tabular}

Fonte: elaborado pela autora. 
Aspecto importante a verificar nesse cenário, considerando a utilização do instrumento como forma de obter informações diversas, é quanto as questões elencadas. É possível identificar a repetição de questões em diferentes períodos, verificando que questões relativas ao processo estiveram presente em quase todos os instrumentos, porém a observação do público externo surge apenas em um instrumento.

\subsubsection{Público Interno}

Em uma amostra, serão apresentadas respostas da equipe. Foram selecionados itens que se repetem em diferentes avaliações para que se faça um comparativo. A estrutura das perguntas nem sempre foi objetiva e fechada, de modo que as respostas também informam, de modo subjetivo e aberto, sobre os tópicos avaliados, o que merece maior aprofundamento e reflexão.

O item priorizado para a reflexão desta seção diz respeito às questões:

- O que significa trabalhar no Museu [do Trem] para ti?

- Na tua opinião, qual o significado do Museu do Trem para São Leopoldo?

As questões acima fazem parte dos seguintes documentos, que terão suas respostas tabuladas:

- Expectativas iniciais, 2009, com 14 questionários respondidos, referente ao diagnóstico;

- Avaliação Anual, 2010, com 9 questionários respondidos, referente ao processo;

- Avaliação Anual, 2011/2012, com 9 questionários, referente a avaliação somativa;

Tabela 1 - Avaliação Anual 2009 - 0 que significa trabalhar no Museu?

\begin{tabular}{|c|c|c|c|}
\hline Palavras extraídas das respostas & $\%$ & Itens agrupados & $\%$ \\
\hline Bom/gosto & 21,40 & \multirow{3}{*}{ Satisfação } & \multirow{3}{*}{42,80} \\
\hline Ótimo & 14,30 & & \\
\hline Especial & 7,15 & & \\
\hline Aprender & 14,30 & \multirow{3}{*}{ Oportunidade } & \multirow{3}{*}{57,20} \\
\hline Chance de participar/experiência & 35,70 & & \\
\hline Vínculo afetivo com acervo & 7,15 & & \\
\hline Soma total & 100,00 & & 100,00 \\
\hline
\end{tabular}

Fonte: elaborado pela autora. 
Tabela 2 - Avaliação Anual 2009 - Qual o significado do Museu do Trem para São Leopoldo?

\begin{tabular}{|c|c|c|c|}
\hline Palavras extraídas das respostas & $\%$ & Relacionado & $\%$ \\
\hline Turismo, crescimento econômico & 21,40 & \multirow{3}{*}{ Cidade } & \multirow{3}{*}{78,55} \\
\hline História, patrimônio histórico, identidade & 50,00 & & \\
\hline Museu municipal & 7,15 & & \\
\hline Memória ferroviária & 14,30 & Ferrovia & 14,30 \\
\hline Especial para as crianças & 7,15 & Educação & 7,15 \\
\hline Soma total & 100,00 & & 100,00 \\
\hline
\end{tabular}

Fonte: elaborado pela autora.

Tabela 3 - Avaliação Anual 2010 - Neste momento, o que significa trabalhar no Museu?

\begin{tabular}{|c|c|c|c|}
\hline Palavras extraídas das respostas & $\%$ & Itens agrupados & $\%$ \\
\hline Lucidez, compreensão do processo no qual se inserem & 11,11 & \multirow{3}{*}{$\begin{array}{c}\text { Satisfação positiva } \\
\text { (ênfase na } \\
\text { experiência } \\
\text { significativa) }\end{array}$} & \multirow{3}{*}{44,44} \\
\hline Conhecimento, aprendizagem, crescimento. & 22,22 & & \\
\hline Cumprir obrigações & 11,11 & & \\
\hline No grupo e profissional & 11,11 & \multirow{5}{*}{ Oportunidade } & \multirow{5}{*}{55,56} \\
\hline Colaborando na preservação da própria história & 11,11 & & \\
\hline Nunca pensei que trabalharia em museu & 11,11 & & \\
\hline Fazer parte do município e da história & 11,11 & & \\
\hline Desafio: traduzir a história para o agora & 11,11 & & \\
\hline Soma total & 100,00 & & 100,00 \\
\hline
\end{tabular}

Fonte: elaborado pela autora.

Tabela 4 - Avaliação Anual 2010 - Qual o significado do Museu do Trem para São Leopoldo?

\begin{tabular}{l|c|c|c}
\multicolumn{1}{c|}{ Palavras extraídas das respostas } & $\%$ & relacionado & $\%$ \\
\hline Aprendizagem & 11,11 & Educação & 11,11 \\
\hline População vai conhecer a história do trem & 11,11 & Ferrovia & 11,11 \\
\hline Memória da cidade, história da cidade. & 22,22 & & \multirow{2}{*}{ Cidade } \\
\hline Turismo, crescimento econômico & 11,11 & & 77,78 \\
\hline História, contribuição histórica, identidade & 33,33 & & \\
\hline Significado histórico cultural & 11,11 & & 100,00 \\
\hline
\end{tabular}

Fonte: elaborado pela autora.

Sendo que na primeira questão da fase diagnóstica, verifica-se tópicos relacionados a itens de satisfação e de oportunidade (aprender, chance de participar, experiência de troca e vínculo afetivo com o acervo). E na segunda questão, verifica-se termos relacionados à história, patrimônio e identidade; turismo e crescimento econômico; 
memória ferroviária; museu municipal; lugar especial para crianças. É possível verificar a transformação dos dados na fase formativa.

A comparação possibilita identificar conceitos relativos à concepção de museu, compreensão das funções e responsabilidades no trabalho, assim como refletir sobre movimentos do grupo, estratégias e práticas no contato com o público externo, compreensão de conceitos e novos vínculos (BEMVENUTI, 2014).

\section{Quadro 12 - Avaliação Anual 2011/2012}

\section{Neste momento, o que significa trabalhar no Museu para ti?}

Um sonho que se realizou em um momento que eu achava que trabalhar dentro de um Museu eu teria que ser formada, tive essa grande oportunidade. É muito bom trabalhar com que se gosta. Tenho muitas oportunidades de aprendizado, aperfeiçoamento. Faz muito mais sentido o que estou aprendendo na Universidade.

Neste momento significa estar inserida em um espaço privilegiado de cultura, memória e educação.

Hoje deposito minha vontade em crescer juntamente com o museu e a equipe. Acredito que através do nosso trabalho é possível trazer boas mudanças. Criando novos diálogos com a comunidade.

${ }^{*}$ Neste optou-se pelo destaque da resposta na íntegra.

Fonte: elaborado pela autora.

É possível identificar respostas com ênfase em aprendizados, em oportunidades em convivência com o grupo. E manifestações que reforçam um sentimento de pertencimento em um coletivo.

Quadro 13 - Avaliação Anual - 2011/2012

Na tua opinião, qual o significado do Museu do Trem para São Leopoldo?

Um lugar de acolhimento para a cidade, onde guarda grande parte da história e memória da cidade de São Leopoldo. Também sendo um local de referência na questão do patrimônio.

Acredito que o trem é uma referência das reminiscências das pessoas que usufruíram ou trabalharam nele. O museu tem a função de lembrar, para não cairmos no esquecimento. O museu contribui ainda para a afirmação da identidade do lugar onde está inserido.

O Museu do Trem é um equipamento cultural e turístico, contribui trazendo dignidade e preservação de uma história, também como pólo de cultura, lazer, arte e educação.

${ }^{\star}$ Neste optou-se pelo destaque da resposta na íntegra.

Fonte: elaborado pela autora.

Sobre o significado do Museu do Trem para a cidade e para o crescimento da cidade. É possível verificar anotações que abordam sobre importância da preservação da história da ferrovia, um símbolo, assim como do museu como local de memória, acolhimento da história da cidade e como um indutor para o turismo, afirmação da identidade do lugar. 
Os registros e as reflexões apresentadas pelo grupo envolvido, ao revelarem sobre o aprendizado obtido, as oportunidades de convivência em grupo, o sentimento de pertencimento em um coletivo na equipe do Museu, informam também os pontos fortes resultantes da gestão de qualidade.

Outro aspecto é identificação de novos vocabulários e de conceitos relativos à concepção de museu, compreensão das funções e responsabilidades no trabalho, assim como refletir sobre movimentos do grupo, estratégias e práticas no contato com o público externo, compreensão de conceitos e novos vínculos.

Outras questões referentes a gestão, as funções/tarefas/responsabilidades, ao público externo, ao Museu de modo geral, ainda poderão ser aprofundadas em investigação futura.

Foram identificadas ainda as avaliações relativas a opinião de público. Entre os documentos ${ }^{90}$ estavam aqueles relacionados a diferentes atividades, tanto com público infantil, quanto com público adulto, com dados a partir de 2010, e também e-mail com avaliações de parceiros datado de 2012, porém estas não serão explorados nessa pesquisa.

\subsubsection{Público externo}

A reflexão sobre os públicos no Museu do Trem passa pela identificação de quem são as pessoas que frequentam o Museu, assim como daquelas que não visitam o Museu. As possibilidades com relação ao estudo de público são inúmeras, porém aqui o destaque é para os dados apresentados em relatório pela gestão do Museus ao final do período.

O Museu do Trem possui livro de registro para as assinaturas dos visitantes. Sendo esta uma ferramenta importante para contagem e verificação de dados como, por exemplo, a presença (ou não) de ferroviários como visitantes do Museu. Porém, com a necessidade de obter maior aproximação o número real de visitação, o Museu utiliza outros métodos de contagem e de registro.

Para a visualização do espaço e das condições de circulação de público, opta-se por apresentar um mapa. Na figura que segue, serão marcados e identificados os espaços de circulação e os prédios do Sítio Histórico.

\footnotetext{
90 Estão elencados no Corpus Documental, disponível no Apêndice.
} 

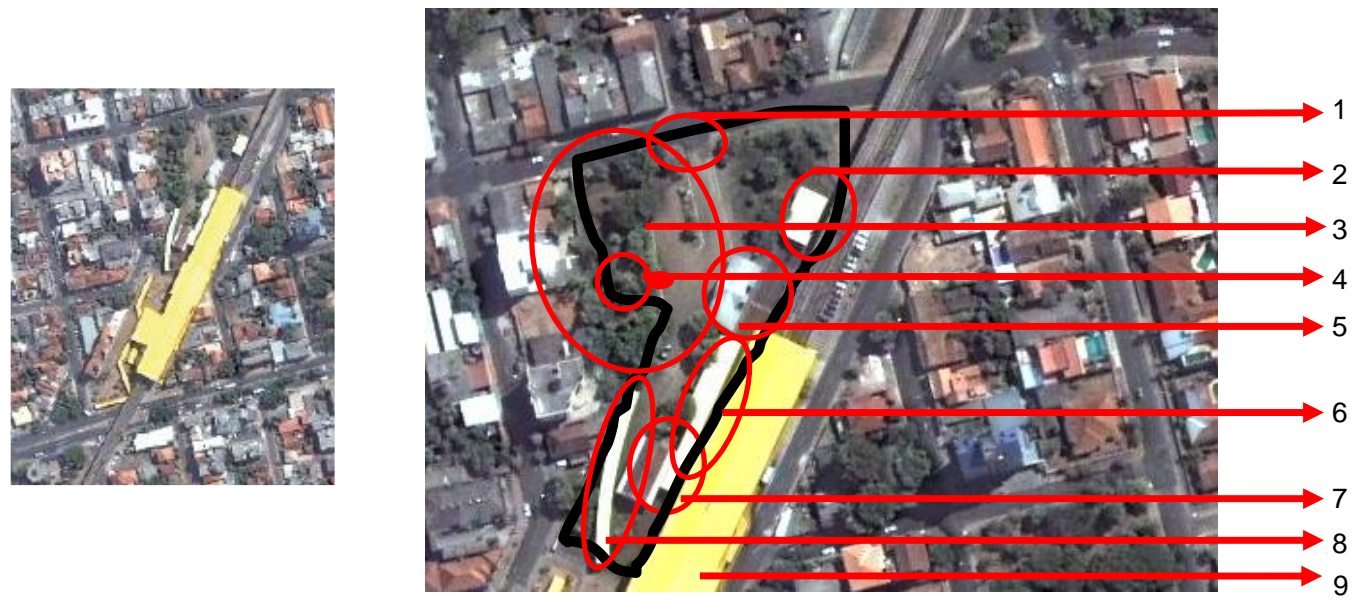

Legenda

1. Entrada pela Rua Lindolfo Collor.

2. Cobertura das locomotivas.

3. Praça Mac Ginity, rua e estacionamento.

4. Sanitário público.

5. Prédio da Antiga Estação.

6. Cobertura dos Vagões, Carros de $1^{\underline{a}}$ e $2^{\mathrm{a}}$ Classe, Trole e Autinho de Linha.

7. Prédio do Armazém de Carga.

8. Cobertura dos carros de $2^{\mathrm{a}}$ classe adaptados para atividades com crianças.

9. Estação São Leopoldo, da TRENSURB.

Figura 108 - imagem aérea (satélite) do Sitio Histórico Museu do Trem e da Estação São Leopoldo, da TRENSURB, com localização das edificações. Ano: 2006.

Fonte: SEPLAN/Google Maps.

O Museu do Trem é visitado pela população local, por escolas, pesquisadora, curiosos e turistas. Além da exposição, o local oferece um amplo espaço de verde (item 2 e 3) com bancos e sombra, o que atrai muitos casais de namorados e famílias. A localização central e de fácil acesso, proporciona condições para que o visitante retorne com frequência. Não há passagem de acesso entre o Museu e a Estação São Leopoldo da TRENSURB (item 9), sendo a única entrada para o Museu se dá pela Rua Lindolfo Collor (item 1). O Sítio Histórico inclui o prédio da antiga estação do trem de ferro (item 5), o armazém de carga (item 7), o sanitário público (item 4), a praça (item 3), o pátio de circulação, a antiga linha férrea com trilhos, a guarita da Guarda Municipal na entrada (item 1), uma rua com canteiro (item 3) utilizada para acesso e estacionamento e três coberturas com estruturas de ferro das locomotivas, carros de passageiros e vagões (item 6). Ao lado, a Estação São Leopoldo, da TRENSURB (item 9), que pode ser visualizada com facilidade em imagem aérea de satélite, pela cor amarela. O espaço é amplo e permite a circulação de grande número de pessoas e realização de diferentes atividades ao mesmo. 
Gráfico 1 - Público visitante nos meses do ano de 2009

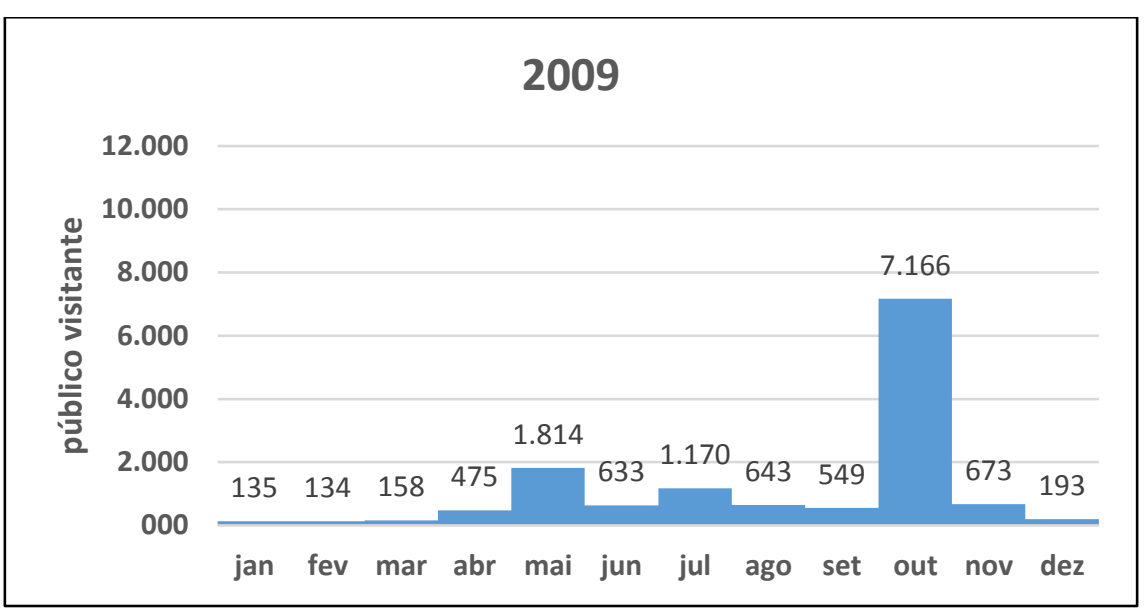

Fonte: Relatório Museu do Trem de São Leopoldo, 2012.

Gráfico 2 - Público visitante nos meses do ano de 2010

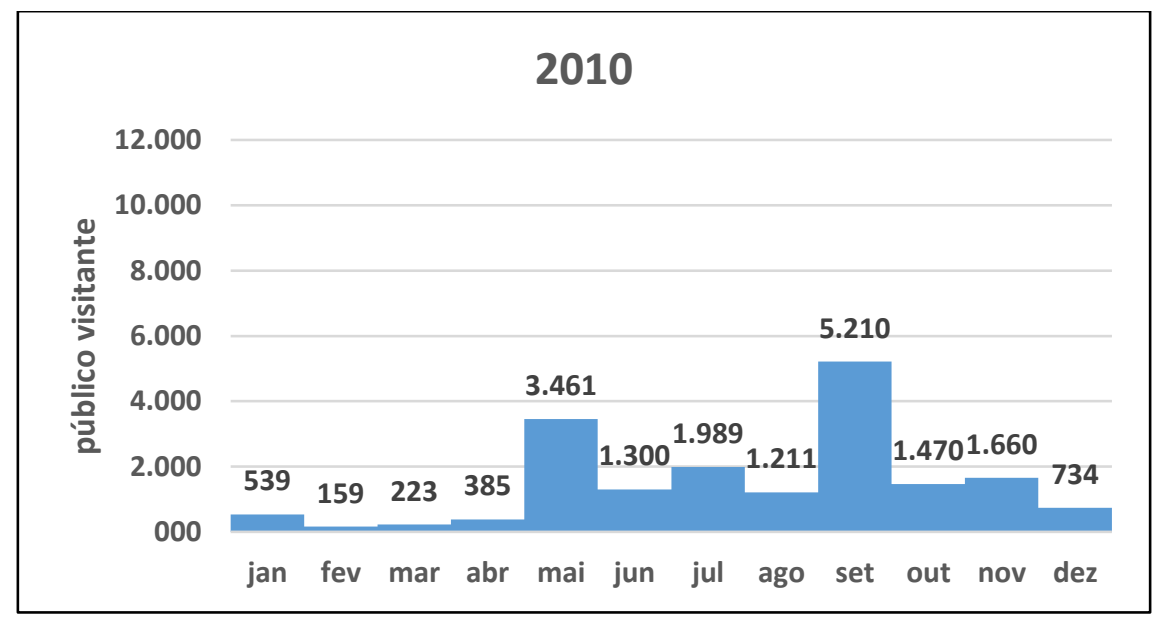

Fonte: Relatório Museu do Trem de São Leopoldo, 2012.

Gráfico 3 - Público visitante nos meses do ano de 2011

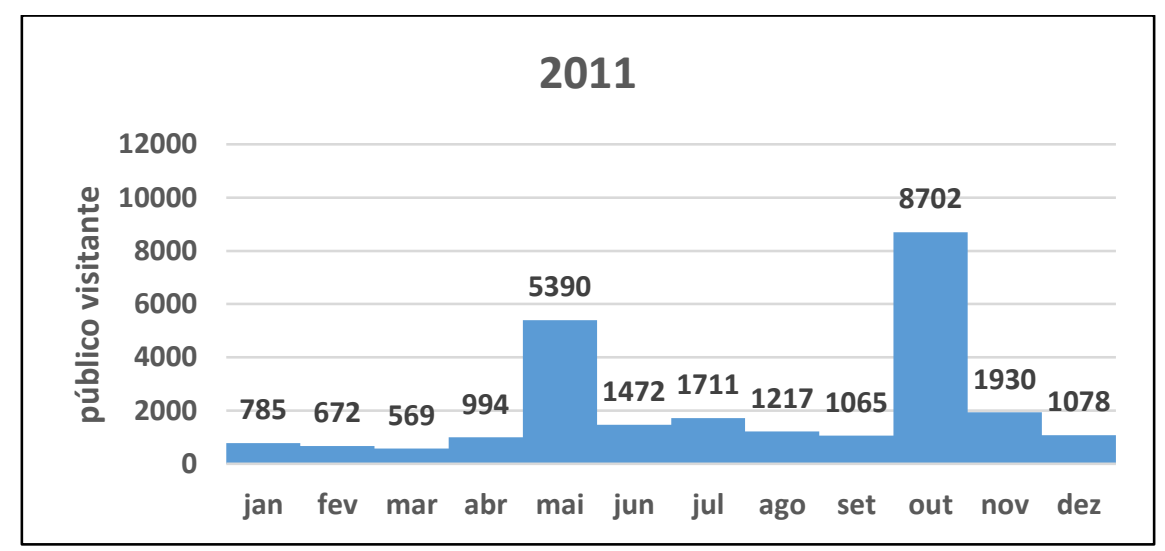

Fonte: Relatório Museu do Trem de São Leopoldo, 2012. 
Gráfico 4 - Público visitante nos meses do ano de 2012

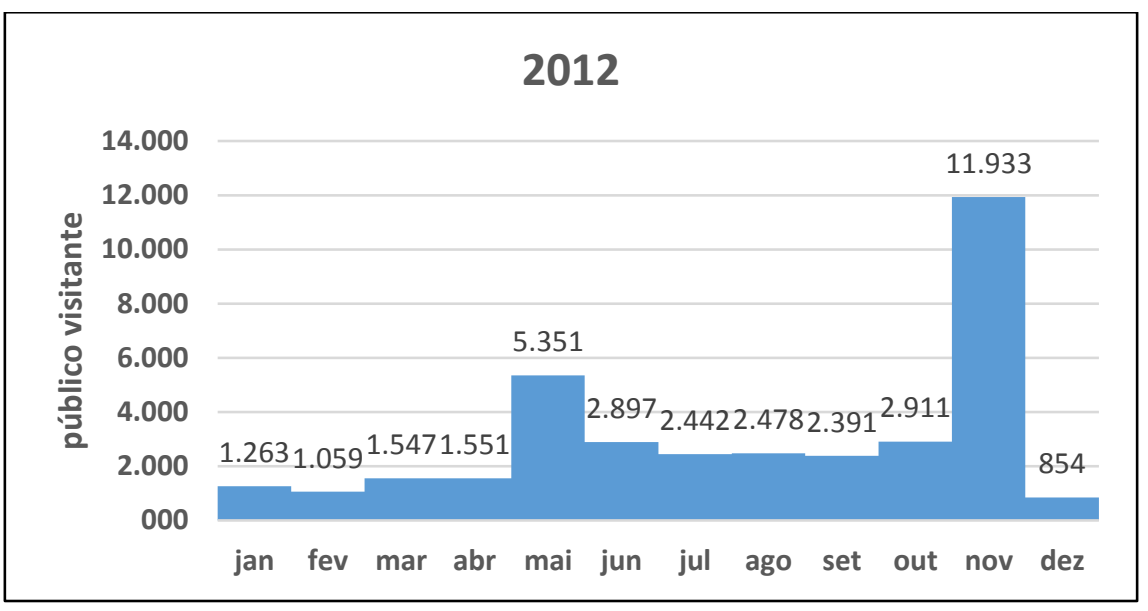

Fonte: Relatório Museu do Trem de São Leopoldo, 2012.

Gráfico 5 - Público visitante por ano entre 2009 e 2012

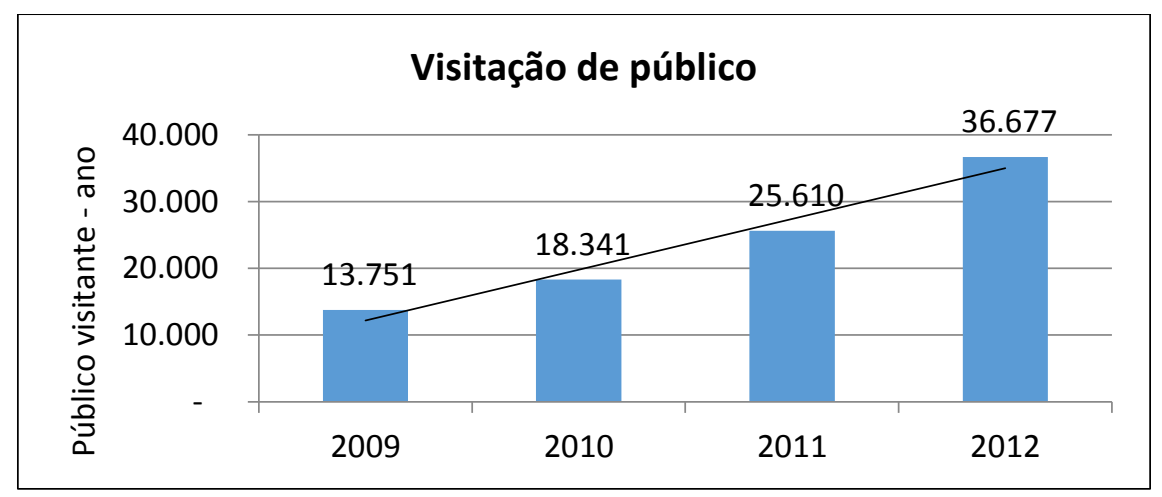

Fonte: Relatório Museu do Trem de São Leopoldo, 2012.

Os gráficos apresentados nessa seção facilitam nossa observação quantos aos meses de maior interesse pelo público externo. Cabe correlacionar os números com as atividades desenvolvidas pelo Museu nesse ou naquele período. Mas o que chama a atenção é o crescimento da procura de modo crescente entre os anos de 2009 e 2012. Para fim de aprofundamento e prioridade de metas e estratégias, o Museu possui importante material para orientar, visto os disponíveis aqui.

Ao identificar os públicos e desenvolver uma metodologia para o registro do fluxo, - Museu adota subdivisões a partir de movimentos espontâneos, planejados e estimulados, adaptado dos termos: audiência espontânea, audiência planejada e audiência estimulada ${ }^{91}$ (CAZELLI e COIMBRA, 2012).

\footnotetext{
91 Apresentados por Sibele Cazelli no $1^{\circ}$ Workshop Internacional de Pesquisa em Educação em Museus, São Paulo, dezembro de 2012, e publicado juntamente com Carlos Alberto Quadros Coimbra nos Anais do evento sobre o título de Pesquisas Educacionais em Museus: Desafios colocados por diferentes audiências.
} 
Quadro 14 - Itens da Planilha para registro do fluxo de público visitante.

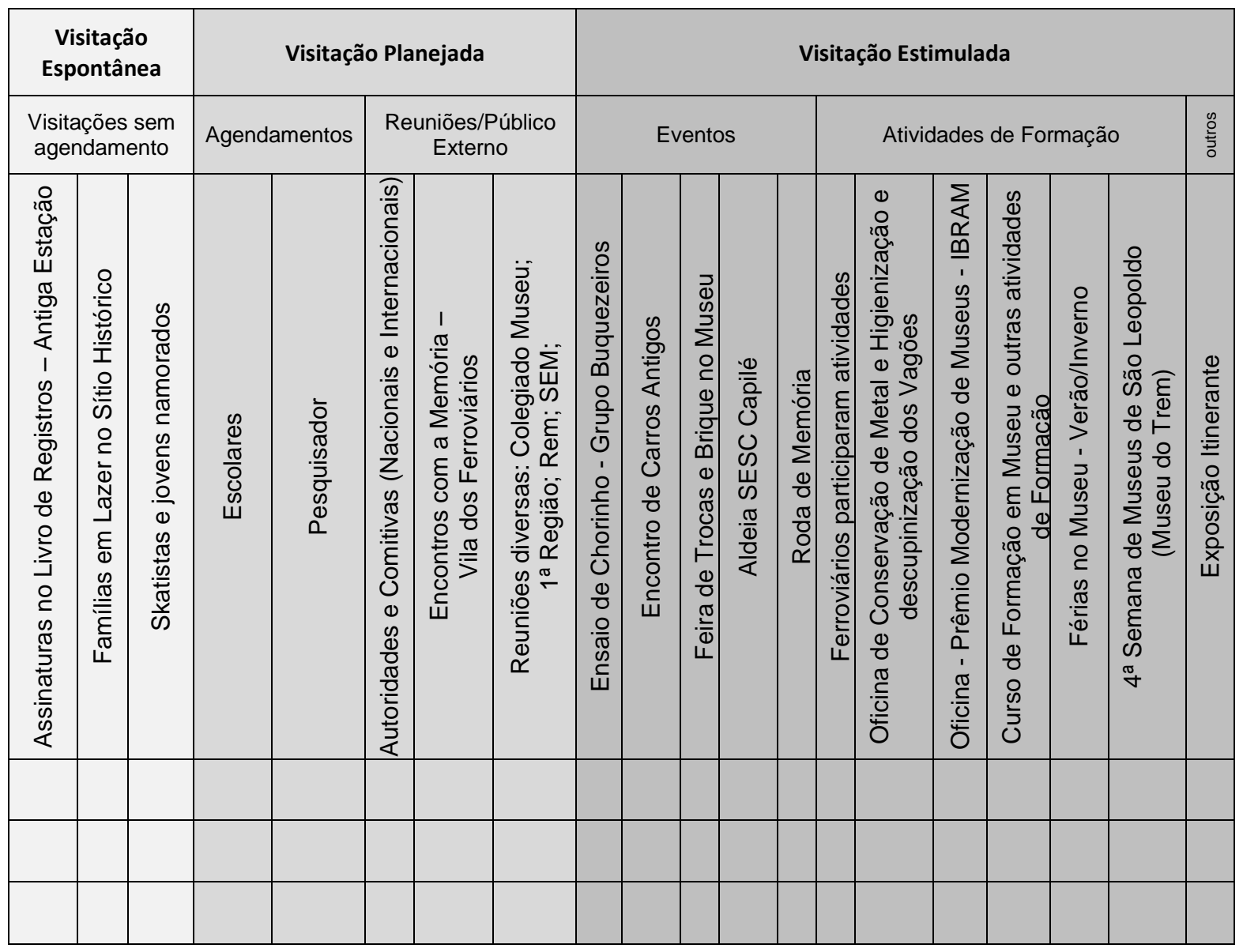

Fonte: Relatório Museu do Trem de São Leopoldo, 2012.

No item visitação espontâneas, o Museu agrupou o número de assinaturas do Livro e o número de visitantes do Sítio Histórico, utilizando uma formula de porcentagem a partir do número de assinaturas mensais no Livro de registro. Assim, calculando o número de famílias e multiplicando cada família por três. Posteriormente, verificou-se que a formula resultava em um número distante (aquém) do volume de visitantes que transitavam pelo Sítio Histórico e visitam a exposição sem registrar sua assinatura no Livro. O Museu deste modo aumenta as ferramentas para contagem, determinando para os finais de semana a contagem manual de público visitante em horários alternados pré-fixados, registrando assim em um formulário para Relatório de Finas de Semana.

Entre a visitação planejadas foram agrupados números de visitantes a partir de dois subgrupos, Agendamentos (atividades agendadas tanto por escolas, pesquisadores e ou grupos diversos, como de empresas ou de outras cidades) e reuniões com público externo. E, para a visitação estimuladas, foi identificada três subdivisões: eventos (Ensaio de Chorinho com Grupo de Música Buquezeiros, Encontro de Carros Antigos, Feira de Troca e Brique, Aldeia SESC Capilé); Atividades de formação (Roda de Memória, participação de ferroviários, cursos, oficinas, incluindo as Férias no Museu e Semana de Museus) e outros (exposições itinerantes). 
A soma dos públicos por interesse informa sobre as preferências e sobre a movimentação entre as atividades ofertadas pelo Museu. No quadro a seguir, é possível identificar o crescente na visitação.

Tabela 5 - Número de visitações espontâneas, planejadas e estimuladas por ano

\begin{tabular}{c|r|r|r|r}
\hline Ano & $\begin{array}{c}\text { Visitação } \\
\text { espontânea }\end{array}$ & $\begin{array}{c}\text { Visitação } \\
\text { planejada }\end{array}$ & $\begin{array}{c}\text { Visitação } \\
\text { estimulada }\end{array}$ & Soma por ano \\
\hline 2009 & 3.942 & 2.100 & 7.709 & 13.751 \\
\hline 2010 & 9.084 & 2.702 & 6.555 & 18.341 \\
\hline 2011 & 10.749 & 3.286 & 11.575 & 25.610 \\
\hline 2012 & 15.361 & 5.565 & 15.751 & 36.677 \\
\hline \multicolumn{5}{r}{}
\end{tabular}

Fonte: Relatório Museu do Trem de São Leopoldo, 2012

A comparação entre os dados de ano a ano, pode ser observada nos quadros apresentados a seguir:

Gráfico 6 - Comparativo das visitações entre 2009 e 2012.

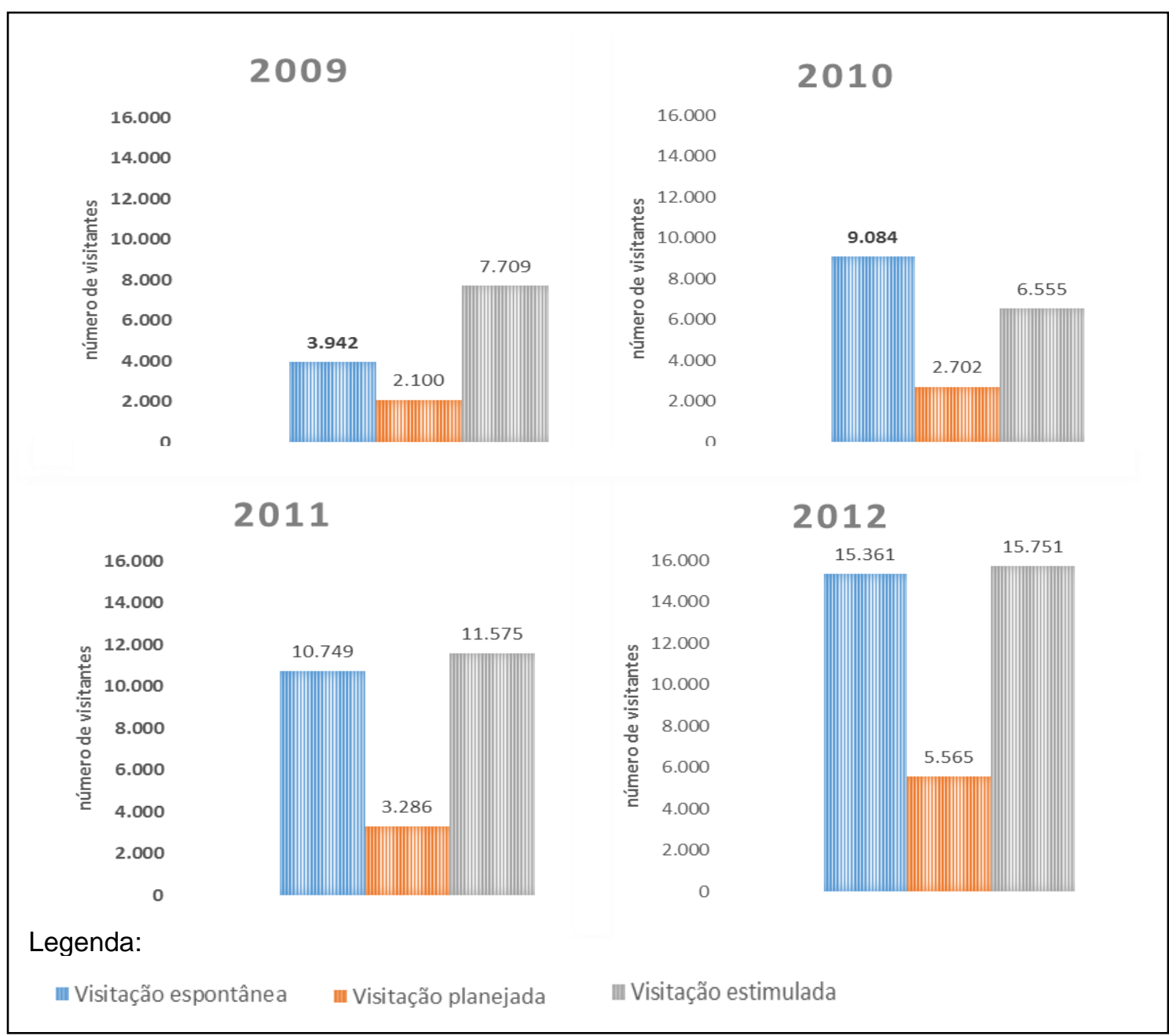

Fonte: Relatório Museu do Trem de São Leopoldo, 2012. 


\subsection{RECURSOS FINANCEIROS}

Perguntas como "O orçamento do museu tem crescido, ou, em termos reais (levando em conta a inflação), está diminuindo? Você tem como prever se os orçamentos para os próximos anos serão suficientes para manter suas atividades/serviços atuais?" (DAVIES, 2001: 35) no item Finanças, realizadas por Stuart Davies, demonstram algumas das fragilidades enfrentadas pelos museus brasileiros.

Diante das restrições orçamentárias foram definidas duas grandes estratégias: escrita de Projetos a partir dos estudos de necessidades, para disputar recursos em Editais Nacionais e Estaduais, oferecido prioritariamente pelos órgãos de cultura; e a formação de parcerias para apoio em recursos materiais.

Os parceiros ${ }^{92}$ que colaboram a partir de patrocínios e apoio institucional tornaramse fundamentais para a realização de ações no âmbito da divulgação, conservação, reprodução e digitalização de fotografias do acervo, transporte para escolares, estrutura para recepção em datas comemorativas, atividades com famílias e feiras, em impressos e banners e outros materiais de divulgação, como em impressões de materiais educativos e materiais lúdicos. Em contrapartida o Museu oferece divulgar a marca em alguns panfletos e também em dispositivo junto a exposição (cubos de papel adesivado ${ }^{93}$ ).

Apesar dos recursos restritos e da falta de autonomia financeira, o Museu do Trem, como qualquer outra instituição de sua natureza, tem um custo permanente aos cofres públicos que são responsáveis pela conservação e manutenção do patrimônio histórico como o em questão.

Assim, com a intenção de compreender os custos institucionais, advindo dos benefícios financeiros e administrativos, o Museu do Trem mensurou as despesas, a partir dos gastos públicos, e os investimentos realizados através de doações de materiais e serviços, a partir da atribuição de valor de mercado, gerando assim o custo anual da instituição.

Os custos de responsabilidade da Administração Pública envolveram despesas administrativas incluindo folha de pagamento de funcionários, estagiários; despesas com

\footnotetext{
92 Empresa citadas: TRENSURB, Print \& Art Gráfica, A\&C Cópias, Vallup Artes Gráficas, Ferragem Feldmann, Livraria Karisma, Livraria Steigleder, Foto Roma, Pizzaria Buccadisantantonio, Restaurante Caçarola, Jornal Vale dos Sinos, Revista Rua Grande, Ilustrador Augusto Bier, Loja do Peixe, Grêmio Esportivo Ferrinho, SINDIFERGS e Secretarias da Prefeitura de São Leopoldo como: SEMAE, SEMOV, Secretaria de Saúde, SEMUSP, SMED, Secretaria da Mulher, Diretoria de Mobilidade Urbana, Diretoria da Juventude, Universidades (UNISINOS, ULBRA, UFRGS, UFPel e FEEVALE), ONGs e o Quartel Militar 16ํIM.

93 Detalhado no próximo capítulo.
} 
materiais e manutenção geral e de recuperação, além da água, luz e serviços. A tabela n6 apresenta valores de custo apresentados no Relatório de Gestão 2009-2012, onde é possível verificar as despesas do equipamento ao cofre público.

Tabela 6 - Despesa prevista pela Prefeitura Municipal (Planilha A)

\begin{tabular}{c|c|c|c|c|c}
\hline \multicolumn{6}{|c}{ Planilha de Custos - Desempenho do Setor (Museu do Trem) } \\
\hline \multirow{2}{*}{ Ano } & $\begin{array}{c}\text { Despesa com } \\
\text { recursos } \\
\text { humanos }\end{array}$ & $\begin{array}{c}\text { Despesa com } \\
\text { materiais de } \\
\text { expediente }\end{array}$ & $\begin{array}{c}\text { Despesas } \\
\text { orçamentárias } \\
\text { (manutenção } \\
\text { geral) }\end{array}$ & $\begin{array}{c}\text { Despesas com } \\
\text { parcerias } \\
\text { (SEMAE, IEE) }\end{array}$ & Total parcial (A) \\
\cline { 2 - 6 } & $\mathbf{R} \$$ & $\mathbf{R} \$$ & $\mathbf{R} \$$ & $\mathbf{R} \$$ & $\mathbf{R} \$$ \\
\hline 2009 & $228.154,39$ & $2.385,62$ & $12.891,62$ & $2.275,24$ & $245.706,87$ \\
\hline 2010 & $244.093,04$ & $1.700,13$ & $6.550,68$ & 223,60 & $252.567,45$ \\
\hline 2011 & $226.277,90$ & $1.557,97$ & $48.108,00$ & $2.247,28$ & $278.191,15$ \\
\hline 2012 & $267.723,39$ & 890,75 & $12.439,83$ & $4.187,74$ & $285.241,71$ \\
\hline
\end{tabular}

Fonte: Relatório Museu do Trem de São Leopoldo, 2012.

Ademais, na tabela n7 são apresentados os valores relativos aos recursos materiais, obtidos através de convênios, parcerias e doações, que incluíram recursos materiais desde gimo cupim, cadeados, mangueira, escada, adesivos para a exposição, materiais para oficinas, lixeiras, serviços prestados, além dos mencionados anteriormente relativos a materiais comunicacionais.

Destaca-se que a previsão orçamentária anual é fundamental em qualquer situação, sendo este "uma ferramenta de gestão e um documento do planejamento" (EDSON, 2004). Para Gary Edson, é importante destacar que o orçamento para a previsão, planejamento e organização dos recursos financeiros, não deve ser uma atividade esparsa. Sendo assim necessário seguir seis regras para planejar o orçamento. São elas: 1) ter especificidade; 2) excesso de otimismo pode prejudicar; 3) refazer orçamento avaliando dados da realidade; 4) estabelecer orçamentos interno mínimos; 5) distinguir entre: custos fixo e orçamentos de programas e projetos; 6) não subestimar as despesas extras (2004).

Como alternativa para suprir as necessidades relativas a valores menor, geralmente apresentados como demandas urgentes, o Museu conta com a provisão da Associação Amigos do Museu do Trem (AAMT). A soma dos valores administrados pela AAMT apresenta importante participação no processo. 
Tabela 7 - Receita de doações (valores de mercado (Planilha B)

\begin{tabular}{r|r|r}
\hline \multicolumn{3}{|c}{ Planilha de Custos - Desempenho do Setor (Museu do Trem) } \\
\hline $\begin{array}{c}\text { Doações de materiais } \\
\text { recebida através de parcerias }\end{array}$ & $\begin{array}{c}\text { Advindo de anuidades e } \\
\text { doações da AAMT }\end{array}$ & Total parcial (B) \\
\hline $\mathbf{R} \$$ & $\mathbf{R \$}$ & $\mathbf{R} \$$ \\
\hline $5.651,00$ & 00,00 & $5.651,00$ \\
\hline $6.694,60$ & 50,00 & $6.744,60$ \\
\hline $5.838,46$ & 510,00 & $6.348,46$ \\
\hline $7.638,86$ & $1.327,00$ & $8.965,86$ \\
\hline
\end{tabular}

Fonte: Relatório Museu do Trem de São Leopoldo, 2012.

A seguir um quadro com os valores anuais, na soma dos quadros apresentados anteriormente. Constata-se um crescendo, mesmo que tímido.

Tabela 8 - Investimentos e despesas

\begin{tabular}{r|r|r}
\hline \multicolumn{1}{c|}{ Tabela A } & Tabela B & Total geral \\
\hline $\mathbf{R} \$$ & $\mathbf{R} \$$ & $\mathbf{R} \$$ \\
\hline $245.706,87$ & $5.651,00$ & $251.357,87$ \\
\hline $252.567,45$ & $6.744,60$ & $259.262,50$ \\
\hline $278.191,15$ & $6.348,46$ & $284.539,61$ \\
\hline $285.241,71$ & $8.965,86$ & $294.207,57$ \\
\hline
\end{tabular}

Fonte: Relatório Museu do Trem de São Leopoldo, 2012.

Nos dados apresentados não foram contabilizados os custos referentes ao uso transporte e combustível para produção de exposições e eventos, formações e capacitações diversas, e espaços em meios de comunicação (impresso, rádio e TV).

\subsection{ANÁLISE}

Em função da quantidade e diversidade dos itens apresentados, da amplitude do tema discutido, parece evidente que o caso apresentado nos leve a reflexão da prática museológica nos quesitos relacionados a gestão de museu, comunicação museológica e educação. Porém este tópico será discutido e aprofundado no próximo capítulo.

Para Edson Pacheco Paladini, o exercício de análise deve ser contínuo, sendo "o estudo do processo de gestão é um desafio permanente" (PALADINI, 2004:329), sobretudo considerando estar a instituição museológica em questão, inserida em um

\footnotetext{
${ }^{94}$ Associação Amigos Museu do Trem.
} 
contexto externo carregado de adversidades relativas ao patrimônio industrial ferroviário e ao público. Cabe neste sentido destacar a importância de rever itens do cenário interno e externo a partir da ferramenta de análise SWOT ${ }^{95}$.

Análise SWOT é considerado um sistema simples que possibilita a verificação da posição estratégica da empresa, sendo o termo uma sigla oriunda do idioma inglês: S - strengths; $\mathrm{W}$ - weaknesses; O - opportunities; T - threats; que em português também é denominado como análise FOFA, proveniente das mesmas palavras em português: $\mathrm{F}$-força (strengths); O - oportunidade (opportunities); F - fraquezas (weaknesses); A - ameaças (threats).

A análise com a estrutura SWOT possibilita destacar itens em diferentes instâncias, com diferentes abrangências, mas que estão num mesmo contexto e participam de um mesmo sistema. Os itens que auxiliam e os itens que atrapalham participam do mesmo contexto e encontram-se lada a lado, deixando uma membrana apenas de separação entre os pontos, porém, mas que evidenciadas em ação, demonstram diferenças substanciais que definem a qualidade dos resultados.

Autores como Gary Edson (2004) e Stuart Davies (2001) fazem referência ao uso da ferramenta de Análise SWTO como um método para analisar a instituição a partir das informações do processo. Destaca que "sem um programa de planejamento e avaliação contínuo, o esforço do museu será negligenciado" (EDSON, 2004:158).

O exercício de análise converge para "os estudos sobre a função social de pertencimento, a singularidade da ressignificação museológica dos bens culturais e a necessidade da educação da memória" (BRUNO, 2006:10-11). Estão também presentes as dimensões museológicas relacionadas ao que foi sonhado e ao que foi realizado no Museu do Trem de São Leopoldo.

A partir dos itens considerados como forças/oportunidades e fraquezas/ameaças, como resultado de ações realizadas que geraram melhorias, assim como resultado de ações não realizadas, ou que tiveram insucesso, ou mesmo que nem foram contempladas nas prioridades. Entre os itens elencados a seguir estão contemplados aqueles que dizem respeito a Salvaguarda (Acervo, Reserva Técnica, edificações e Pátio); a Comunicação (Exposição; Educação); e a Gestão (Funcionamento Geral; Comunicação Externa/Interna; Público Externo; Setores e Recursos Humanos).

95 Desenvolvida por Albert Humphrey, em projeto de pesquisa na Universidade de Stanford (EUA) nas décadas de 1960 e 1970. 
Entre os pontos que podem ser agrupados como benefícios, inclui-se aqueles referentes ao operacional: organização interna; redução de desperdício; redução de retrabalho; melhoria da imagem do Museu; definição clara de responsabilidades; aumento da produtividade; aumento do fluxo de visitação; elevação de nível de satisfação. Referente aos benefícios financeiros/administrativos: relacionados ao público interno e externo; aumento de visitação; aumento da satisfação dos públicos; melhoria da imagem da instituição; aumento de segurança; maior investimento da administração. Àqueles relacionado aos funcionários: aumento da conscientização da importância do Museu; aumento da qualificação da equipe; melhoria da comunicação interna; aumento de produtividade; aumento de satisfação com o trabalho; aumento de participação nos processos e sugestões para os diferentes setores.

Entre as dificuldades, observa-se o que segue:

- Com relação à equipe: a resistência a mudança, inconstância com postura de ética e a morosidade e descomprometimento com as tarefas aliado a cultura organizacional do funcionalismo público; dificuldade da permanência dos profissionais nos setores técnicos pelo vínculo profissional de contrato; falta de profissionais da área da museologia; ansiedade por desenvolver atividades; acumulo de funções e responsabilidades potencializado pelo aumento de visitação; baixos salários e falta de plano de carreira.

- Com relação à administração ser vinculada ao poder público: ainda ocorre a falta de autonomia política/administrativa; morosidade para solucionar emergências estruturais; descontinuidade de projetos iniciados; falta de recursos financeiros e autonomia para geri-los; cultura tradicional de descaso à coisa pública. Dependência das autarquias: demora para repasse de recurso recebido através de Edital de Prémio; parceiros externos tímidos; morosidade na transferência dos bens patrimoniais para o IPHAN.

- Com relação à prática da gestão e ao funcionamento de modo geral, observa-se que o impacto positivo gerando novas demandas, ultrapassam as previsões iniciais; impacto negativo pela não execução do novo banheiro; a não execução da construção da Reserva Técnica; excesso de exposição na mídia; disputa de uso do espaço do Museu por grupo externo; investimento do setor inferir ao aumento da demanda; competitividade externa. Ainda: falta de sistema de comunicação interno; falta de cumprimento legal de implantação de projeto de acessibilidade.

Outro dado importante para análise é resultado da compreensão estatística dos números entre os investimentos realizados e número total de público visitante no mesmo período. Observa-se: 
Tabela 9 - Cálculo estatístico participação do público externo

\begin{tabular}{|c|c|c|c|}
\hline Ano & Número visitantes & $\begin{array}{c}\text { Crescimento } \\
\%\end{array}$ & $\begin{array}{l}\text { Média anual de visitação } \\
\text { entre } 2009 \text { e } 2012\end{array}$ \\
\hline 2009 & 13.743 & 1 & \multirow{4}{*}{23.586 visitantes/ano } \\
\hline 2010 & 18.341 & 33 & \\
\hline 2011 & 25.585 & 86 & \\
\hline 2012 & 36.677 & 167 & \\
\hline
\end{tabular}

Fonte: elaborado pela autora.

Chama a atenção os dados percentuais de crescimento anual de visitação dos diferentes públicos. Considerando a média de visitação ao ano, o Museu do Trem se aproxima dos números apresentados pelo Instituto Brasileiro de Museus, na publicação Museus em Números, que divulga média de visitação anual ${ }^{96}$ em 2009, com o resultado de 22.327 visitantes anuais por museu.

Tabela 10 - Cálculo per capita - custos e redução de custos

\begin{tabular}{c|c|c|c|c|c}
\multirow{2}{*}{ Ano } & $\begin{array}{c}\text { Investimentos } \mathbf{n} \\
\text { despesas }\end{array}$ & \multirow{2}{*}{$\begin{array}{c}\text { Número de } \\
\text { visitantes }\end{array}$} & Custo per capita & $\begin{array}{c}\text { Redução } \\
\text { relativa }\end{array}$ & $\begin{array}{c}\text { Média de } \\
\text { redução } \\
\text { per capita }\end{array}$ \\
\cline { 2 - 5 } & $\mathbf{R} \$$ & 13.743 & 18,28 & 100 & \\
\hline 2009 & $251.357,87$ & 18.341 & 14,63 & -23 & \multirow{2}{*}{0,30} \\
\hline 2010 & $259.262,50$ & 25.585 & 11,12 & -39 & \\
\hline 2011 & $284.539,61$ & 36.677 & 8,05 & -56 & \\
\hline 2012 & $294.207,57$ & & & \\
\hline
\end{tabular}

Fonte: elaborado pela autora.

A verificação permite identificar um aumento de recursos financeiros investidos no Museu, ainda que de modo tímido, ao mesmo tempo que um aumento na visitação do público, de modo geral. A divisão dos investimentos pelo número de visitantes, irá gerar um custo per capita, conforme apresentado no quadro acima.

Outro dado importante é quanto a redução de custo e a média para essa redução. Observação média de redução do custo per capito de 0,30\%. Novamente confere-se um resultado positivo, quando, proporcionalmente, verifica-se uma queda de valor do custo de cada visitante.

\footnotetext{
${ }^{96}$ Calculada considerando apenas aqueles museus que responderam a solicitação da pesquisa.
} 
Tabela 11 - Cálculo da média de visitação diária

\begin{tabular}{c|c|c|c|c}
\hline Ano & Soma anual & $\begin{array}{c}365 \text { dias do ano } \\
-70 \text { dias Museu não abriu }\end{array}$ & $\begin{array}{c}\text { Média de visitação } \\
\text { diária }\end{array}$ & $\begin{array}{c}\text { Crescimento diário } \\
\text { por ano } \\
\%\end{array}$ \\
\hline 2009 & 13.743 & 295 dias/ano & 7 pessoas/dia & 1 \\
\hline 2010 & 18.341 & 295 dias/ano & 9 pessoas/dia & 33 \\
\hline 2011 & 25.585 & 295 dias/ano & 13 pessoas/dia & 40 \\
\hline 2012 & 36.677 & 295 dias/ano & 18 pessoas/dia & 56 \\
\hline Total & 94.379 & \multicolumn{5}{|c}{ Fonte: elaborado pela autora. }
\end{tabular}

Fonte: elaborado pela autora.

A soma dos números de visitação anual ao ser divido pelo total de dias em que o Museu esteve aberto ao ano, resulta em uma média diária de visitação, há cada um dos anos separadamente. O crescimento da médica diária é um dado importante com relação aos resultados. A quantificação desses dados nos possibilita prever necessidades de recursos humanos e financeiros futuros.

Avaliação de desempenho do Museu do Trem no período desta pesquisa revela importante resultado considerando os números apresentados, porém outros dados ainda poderão ser analisados a partir do exposto nesta seção. 


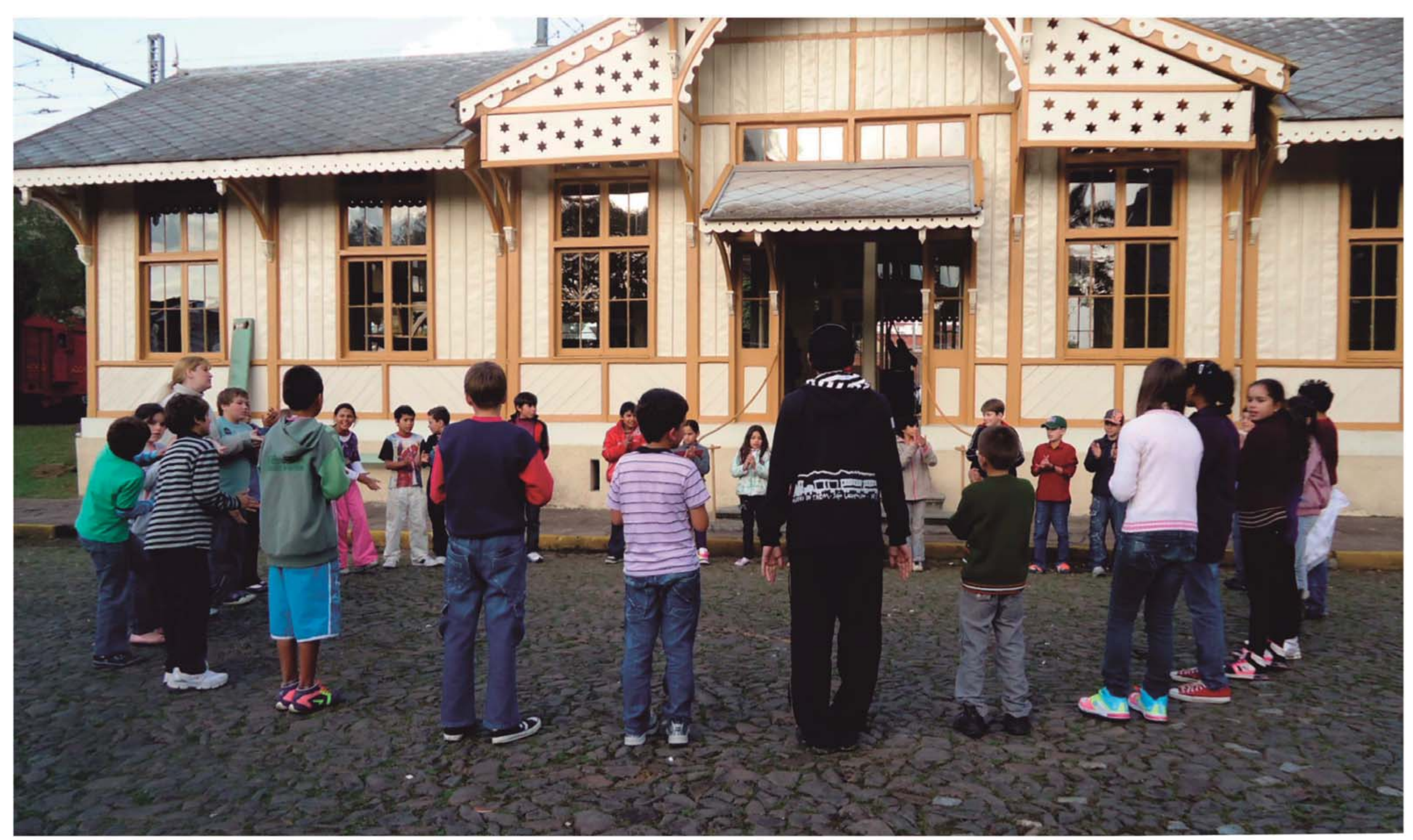

Capítulo 5 
A experiência no museu possibilita inúmeras ações, entre elas, as definidas pelos verbos: entrar, encontrar, ocupar, estar lá, respirar, sentir, cheirar, vislumbrar-se, estranhar, envolver-se, ignorar, dar meia volta, retornar. A experiência no museu pode ser sutil, tranquila, mediana, por um lado, ou intrigante, provocativa e avassaladora, por outro. Mas, independentemente de qual esteja ao alcance do sujeito. Adentrar o museu é uma opção e uma ação acompanhada de uma predisposição anterior, quando ao planejar a visita, o sujeito organiza sua agenda para que em determinado dia e horário irá até o local, com intenção de ocupar seu tempo naquele espaço e com aquele assunto. Apesar do ambiente, do acervo, do cenário, do prédio e do cheiro estimularem interesses completamente diferentes de um museu para o outro, a disponibilidade, a organização e o planejamento do visitante para estar lá e ver o que o espaço oferece pressupõem um gesto fundamental. O que vai acontecer no encontro com o museu irá depender não só do que está exposto, mas do modo como está sendo comunicado, além dos estados psicológicos, do humor de quem chega, entre outros pontos da subjetividade humana.

Cabe destacar que estamos em um campo complexo, que envolve a significação da mensagem e as práticas de comunicação em um espaço específico, o museu - campo esse que pressupõe uma gestão integrada com o todo. Assim, torna-se imprescindível refletir sobre como a mensagem museológica age e como ocorre a interação entre museu e público através do modo como ele é oferecido. Nesse caso, os verbos relativos à experiência, a partir do ponto de vista do próprio museu, incluiriam: mostrar, alcançar, comunicar, oferecer, provocar, ocupar, acolher, intrigar, mobilizar, envolver. Desse modo, o capítulo apresenta a práxis comunicacional do Museu do Trem desde a comunicação institucional, interna e externa, passando pelo marketing, e chegando a exposição de longa duração, temporária e itinerante, bem como às atividades culturais e ao setor educativo. 


\subsection{ALCANÇANDO O PÚBLICO}

\subsubsection{Comunicação institucional}

No início de 2009, foi criada logomarca para o Museu do Trem, com objetivo de dar visibilidade e chamar a atenção para o seu novo momento. Utilizada em materiais de expediente, na rotina do dia a dia, e em eventos e atividades especiais, a mesma foi desenvolvida pelo ilustrador Augusto Bier. Trata-se de trem em movimento, desenhado com pincel e tinta preta, com traço espontâneo e impreciso, sem acabamento, deixando visível a presença do gesto.

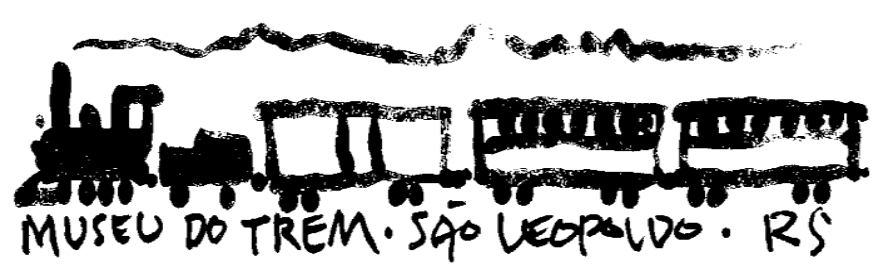

Figura 109 - Logomarca do Museu do Trem, criação de Augusto Bier, 2009. Fonte: arquivo digital Museu do Trem de São Leopoldo

Fica evidente a importância da logomarca como elemento que pode evocar todo um contexto de qualidade e confiabilidade no público, além da sua função básica de identificar e diferenciar um produto ou serviço (AAKER, 2007). O trenzinho em movimento, como se estivesse andando sobre os trilhos, destaca uma intencionalidade lúdica do Museu do Trem: o interesse em acolher, através do afeto, os visitantes - o que fica demonstrado pela ferrovia.

O desenho, além de informar um novo projeto em curso no Museu, informa também sobre a oferta de serviços de qualidade, confiança e eficiência profissional. Identifica-se no uso constante da logomarca a renovação de interesses pelo Museu do Trem, contrariando o estigma de abandono e de lugar velho e desatualizado.

Os uniformes utilizam as cores preto e branco, sendo oferecidas opções para clima e atividades diferentes - há peças de vestuário tanto para inverno quanto verão, como camisetas, casacos de moletons, casacos de tactel e coletes. Também há um avental única peça colorida, em amarelo - com a logomarca do Museu na altura do peito, para uso em Oficinas de Patrimônio ${ }^{97}$ com público infantil. Porém, observa-se que esse avental

\footnotetext{
${ }^{97}$ Oficinas de Patrimônio foras atividades planejadas com objetivo de explorar exercícios de interpretação do patrimônio, assim como exercícios lúdicos com recursos confeccionados especialmente para este fim. As Oficinas de Patrimônio formam desenvolvidas pela equipe durante dos anos de 2011 e 2012.
} 
não obteve boa adesão da equipe. Os uniformes têm concepção estética atual e são confeccionados com materiais confortáveis e de qualidade. Têm impacto visual, fixando a marca e ajudando a reforçar a percepção do Museu do Trem como lugar de qualidade.

Os crachás apresentam o nome do funcionário bem visível e uma foto do Museu do Trem, seguida das logomarcas do Museu, da Secretaria de Cultura e da Prefeitura Municipal (ver Figura 110).
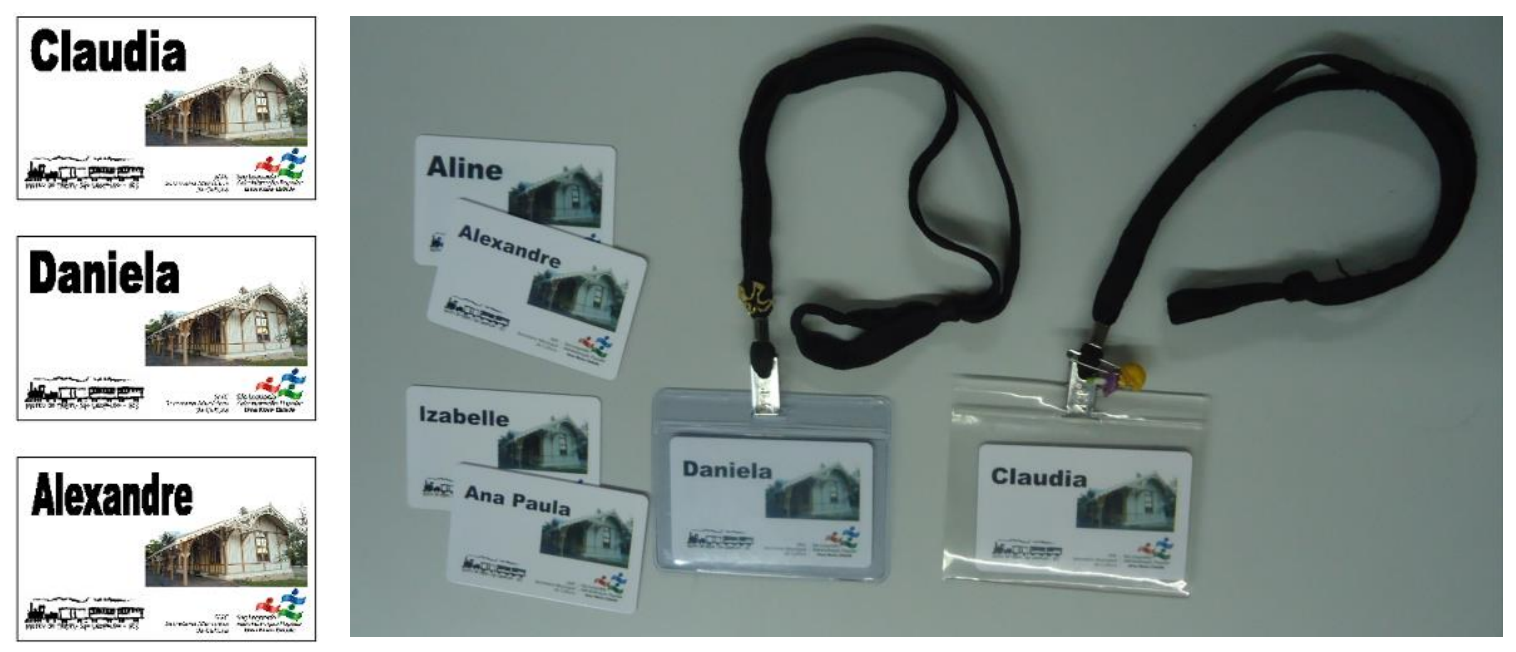

Figura 110 - Crachás padronizados impressos em PVC, 2010.

Fonte: Museu do Trem de São Leopoldo

O crachá não informa à função desenvolvida pelo portador do mesmo. Por trás dessa decisão, houve intenção de reforçar a unidade da equipe e a responsabilidade de todos de cuidar do espaço e atender bem ao público externo, sem distinção hierárquica. Os cordões para pendurar os crachás foram recebidos de doação, sendo que não havia número suficiente da mesma cor para toda a equipe. Deste modo, a cor vermelha é utilizada para estagiários em geral e serviços gerais e a cor preta para funções especializadas e direção - o que diferencia responsabilidades e serviços oferecidos.
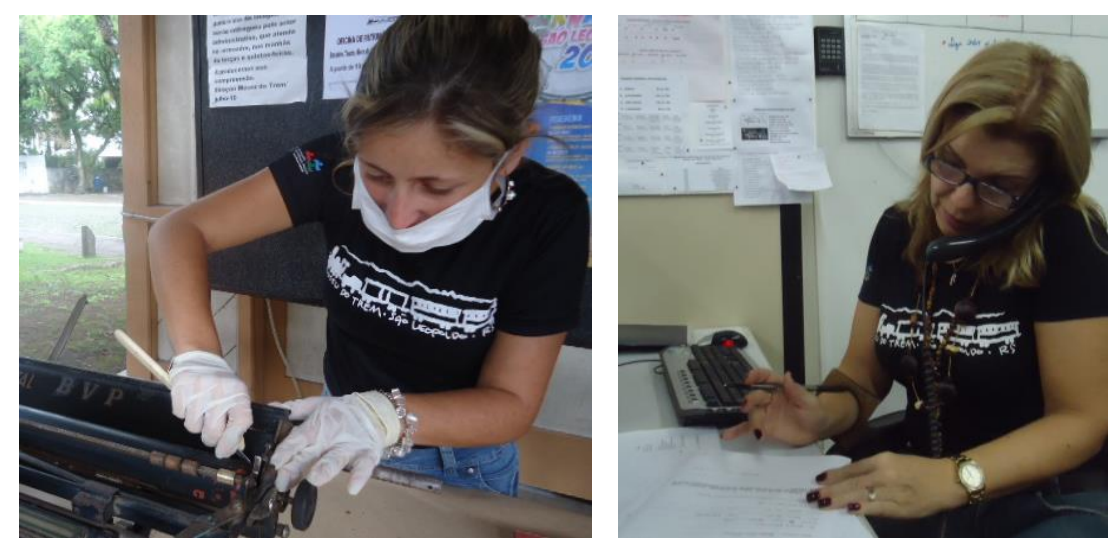

Figuras 111 e 112 - Estagiária em atividade de conservação e funcionária em atividade administrativa com camiseta (uniforme). Ano: 2011.

Fonte: arquivo digital da autora. 

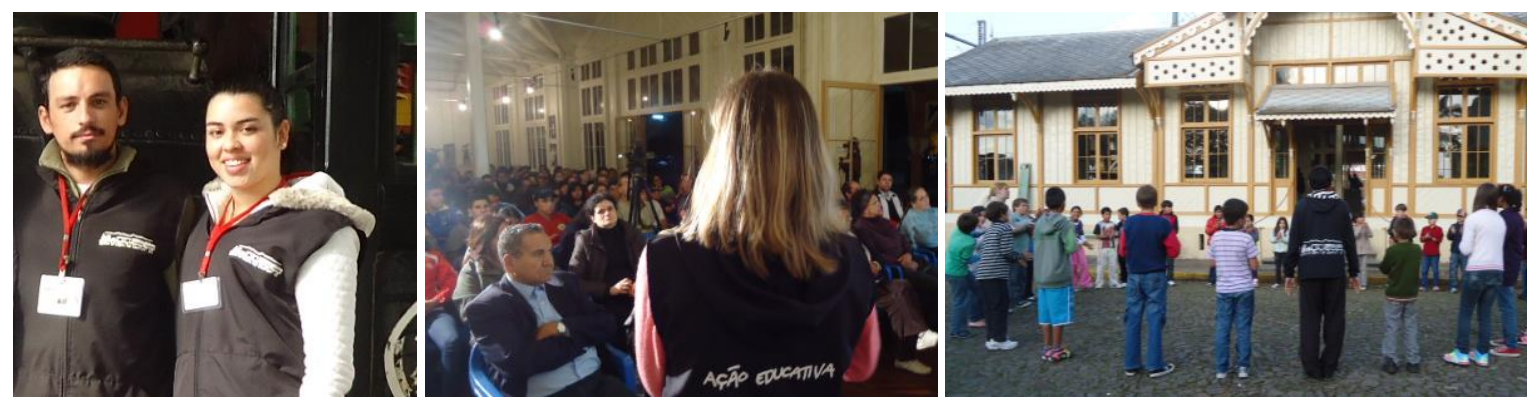

Figuras 113, 114 e 115 - Equipe em atividades educativas diversas com uniforme de inverno (colete e casaco de moleton) e crachá. Ano: 2011. Fonte: arquivo digital da autora.
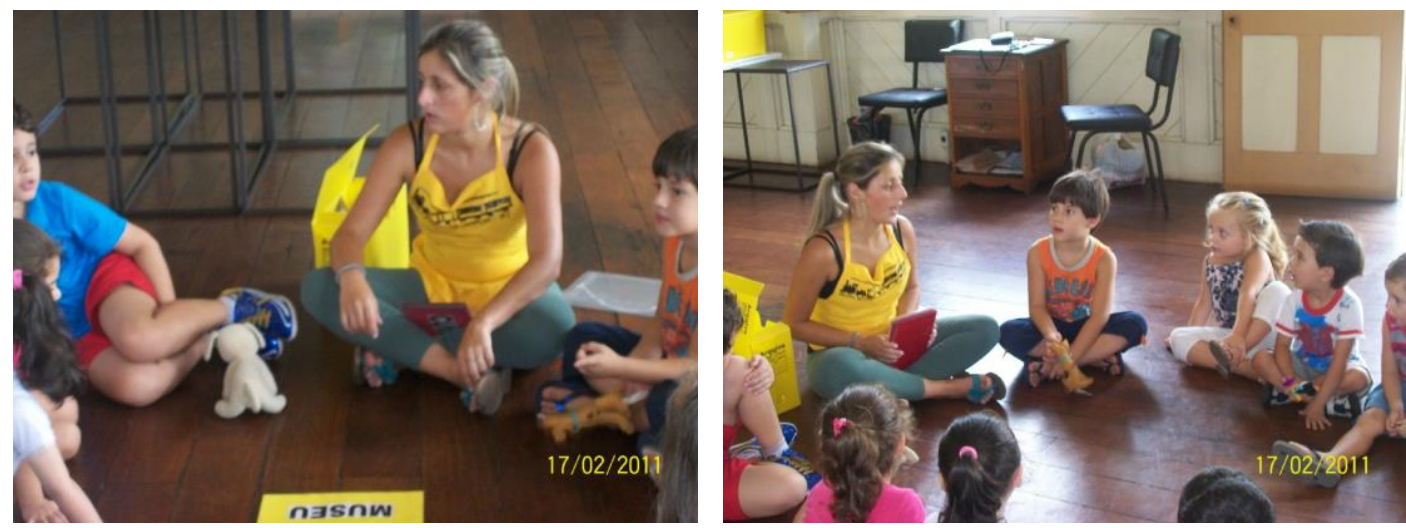

Figuras 117 e 118 - Estagiária com público da educação infantil na Oficina de Patrimônio (avental colorido). Ano: 2011. Fonte: arquivo digital da autora.

Foi desenvolvida, em parceira com empresa gráfica, folhetaria para uso em ocasiões especiais, como convites, agradecimentos, cartão de Natal.

No ano em que o Museu completou 35 anos, foi criado um selo comemorativo, também desenvolvido pelo ilustrador Augusto Bier, seguindo referências da logomarca, porém com acabamento feito em software de desenho. $O$ selo foi utilizado durante todo o ano de aniversário, de 26 de novembro de 2011 a 26 de novembro de 2012, em cartazes, marcador de página, imãs de geladeira, canecas, camisetas, entre outros materiais.
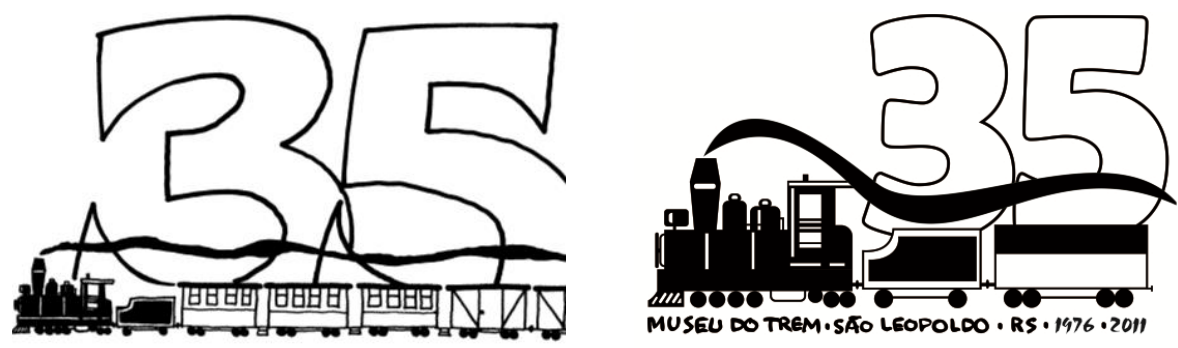

Figuras 119 e 120 - Selo comemorativo: desenho inicial de Augusto Bier e desenho com acabamento em software, 2011.

Fonte: Museu do Trem de São Leopoldo. 


\subsubsection{Comunicação externa}

A logomarca foi amplamente utilizada em cartazes e folhetos impressos de diferentes padrões e formatos, para distribuição de divulgação das atividades. O material com enfoque publicitário inicialmente foi desenvolvido pela equipe do Museu, de modo amador, com reprodução em folhas de ofício brancas. Posteriormente, passaram a ser desenvolvidos por profissionais com conhecimentos técnicos - tanto publicitários da Secretaria Municipal de Comunicação (SECOM), quanto designers e publicitários da equipe da Print Art ${ }^{98}$, que ora criavam a arte, ora forneciam o material impresso. Outros materiais ainda foram desenvolvidos por empresa contratada pela Prefeitura. Além de papel e papelão, foram utilizados diversos materiais como suporte para as impressões: Iona, PVC, tecido e aço.

Entre as peças desenvolvidas, encontram-se: folder institucional, flyers relativos a atividades específicas, cartazes de eventos e campanhas, banners e faixas de uso interno e externo, camisetas, texto de parede ${ }^{99}$, placas externas de metal, placas externas de PVC e impressão em gazebo.

Os materiais incluíram banner da Associação de Amigos do Museu, banner do dia do Maquinista, banner Institucional, placa das bancas da Feira de Trocas e Brique, divulgação de evento de Férias no Museu, entre outros, demonstrando a amplitude e a diversidade no uso de instrumentos de comunicação. Alguns deles podem ser conferidos na sequência.

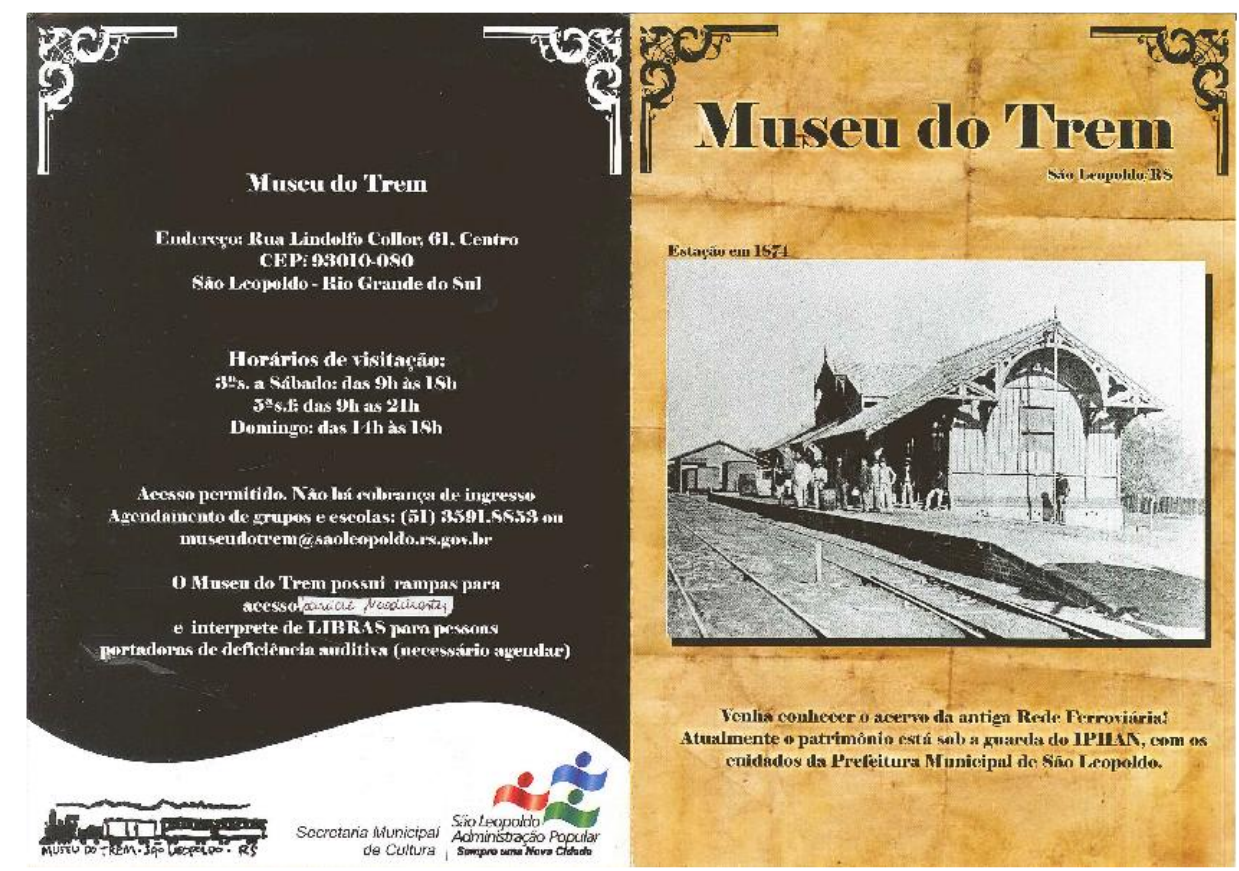

Figura 121 - Folder institucional do Museu do Trem, parte externa. Ano: 2009. Fonte: Museu do Trem de São Leopoldo.

\footnotetext{
98 A empresa Print Art Plotagem e Impressões, de São Leopoldo, foi uma das maiores apoiadoras das atividades do Museu.

99 Texto de parede é a denominação para a lona adesivada com conteúdo histórico e informativo que acompanha uma exposição.
} 


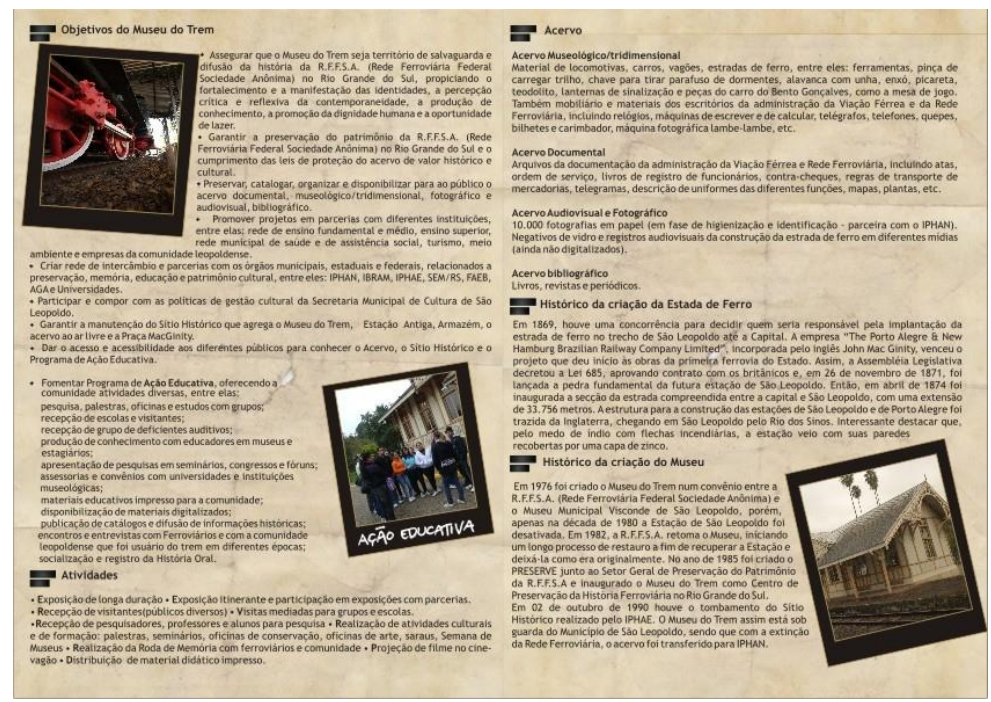

Figura 122 - Folder institucional do Museu do Trem, parte interna. Ano: 2009. Fonte: Museu do Trem do São Leopoldo.
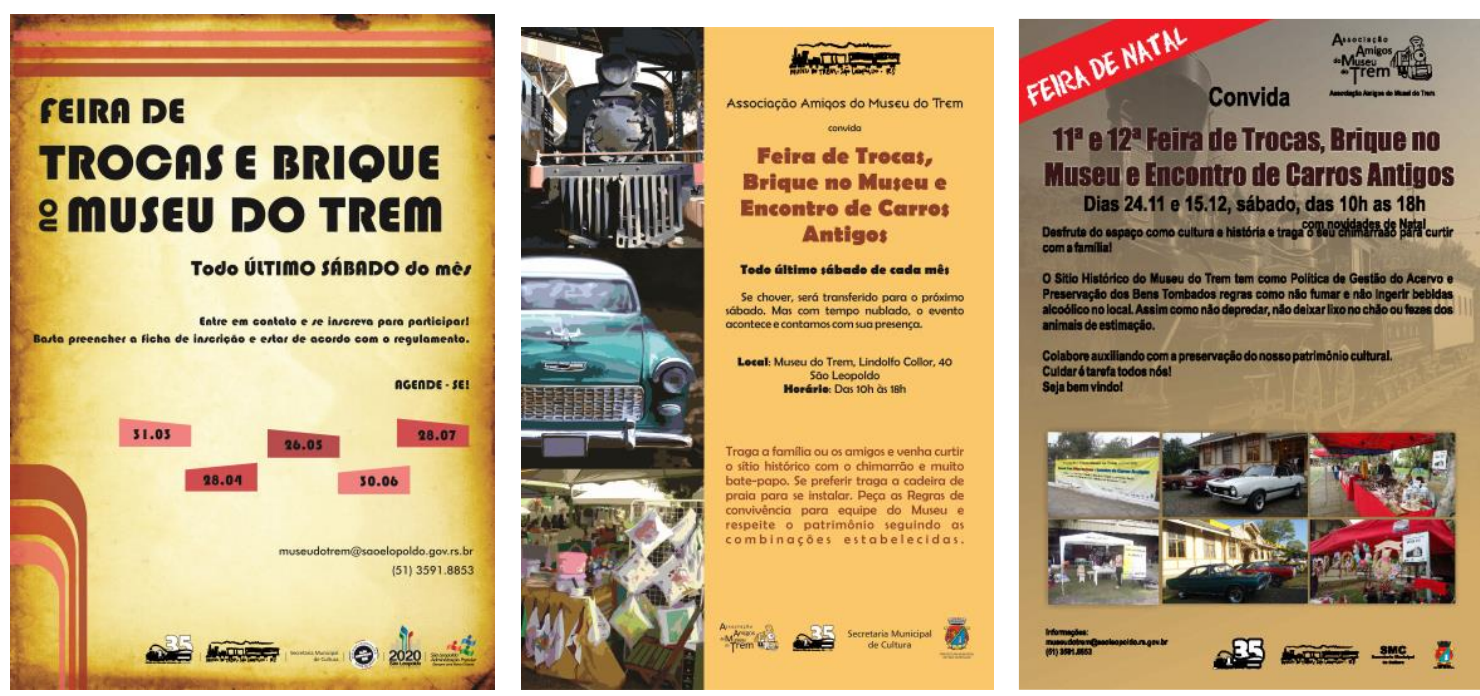

Figuras 123, 124 e 125 - Cartazes de atividade cultural, Feira de Trocas, Brique e Encontro de Carros Antigos. Ano: 2012. Fonte: Museu do Trem do São Leopoldo. 

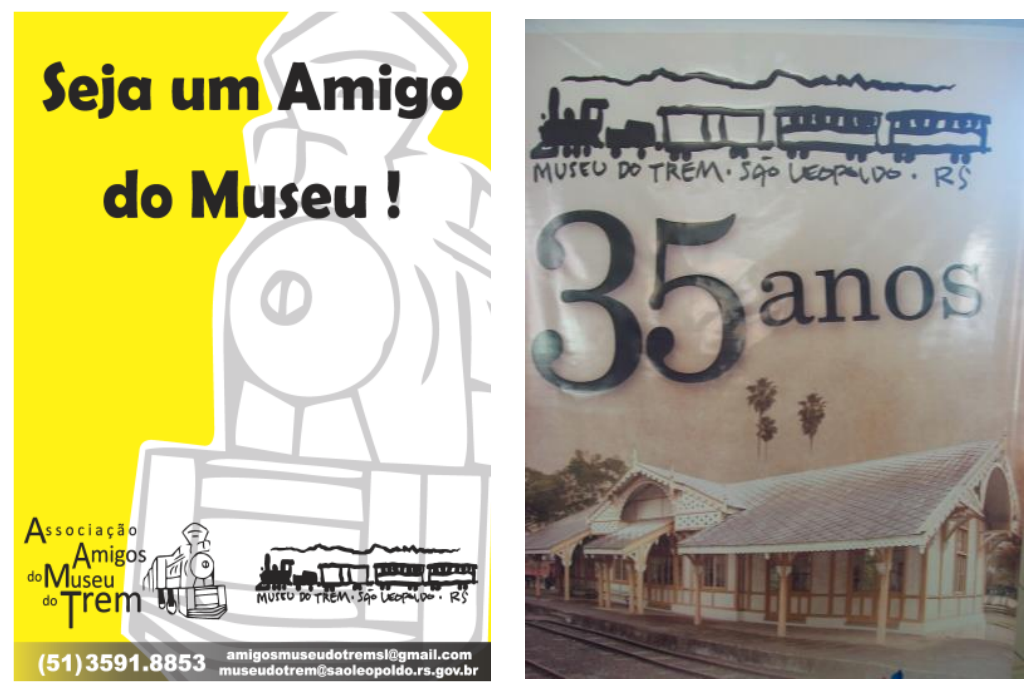

Figuras 126 e 127 - Banner da AAMT e Banner alusivo aos 35 anos do Museu. Ano: 2011. Fonte: PRINT Art Impressões - São Leopoldo

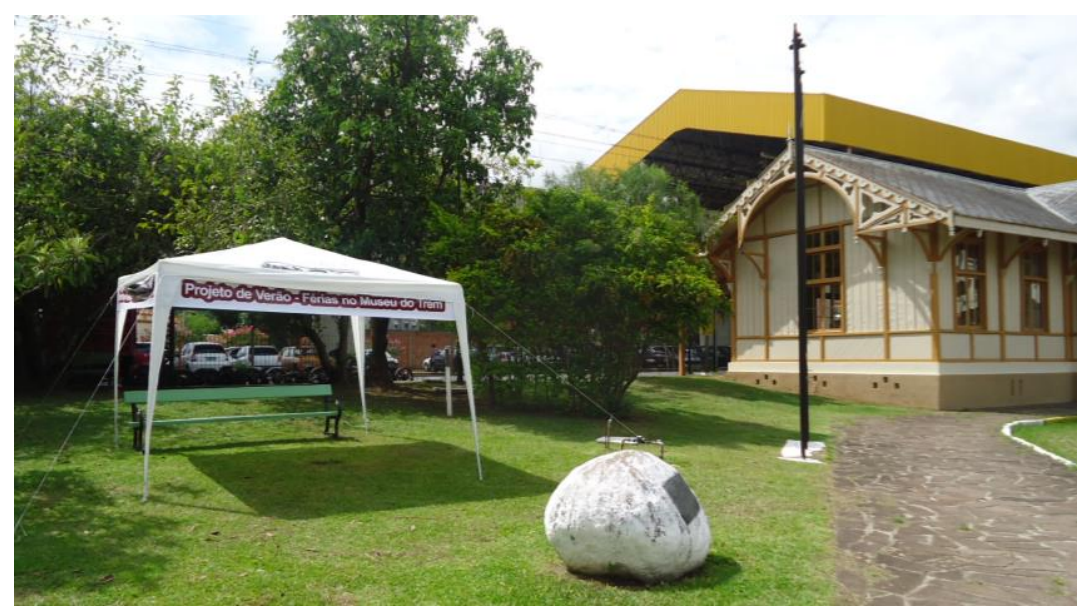

Figura 128 - Gasebo adesivado no jardim. Ano: 2012. Fonte: arquivo digital da autora.

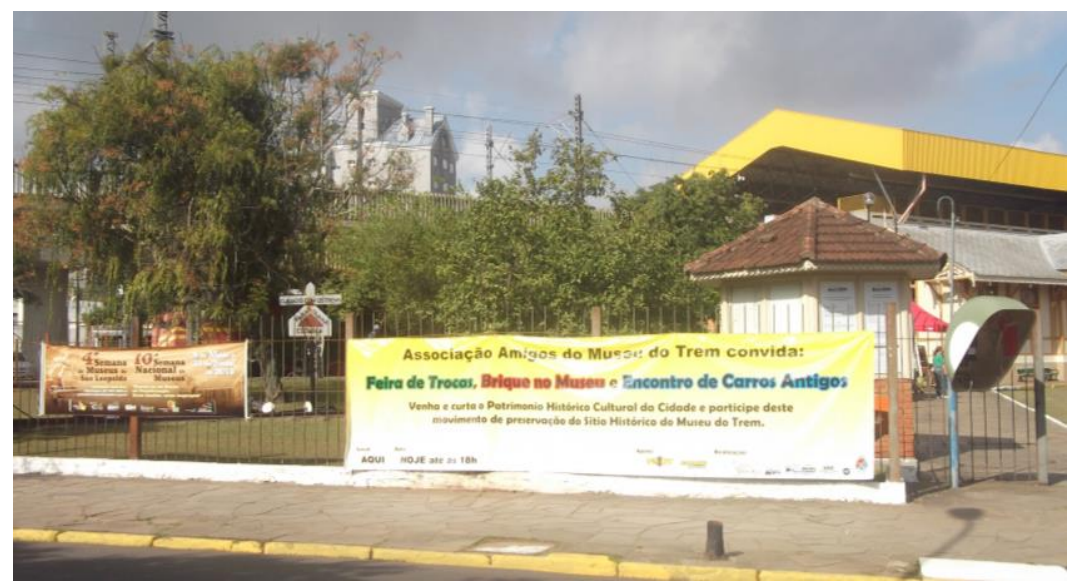

Figura 129 - Faixa Semana de Museu e Feira de Trocas, Brique e Encontro de Carros Antigos, frente do Museu. Ano: 2012. Fonte: arquivo digital da autora.

Cabe destacar o uso do material de divulgação principalmente em cenas externas, quando se confirma a publicidade da informação e integração das atividades do Museu 
com a cidade. As imagens a seguir mostram os diferentes lugares onde se observou a divulgação do Museu integrada.

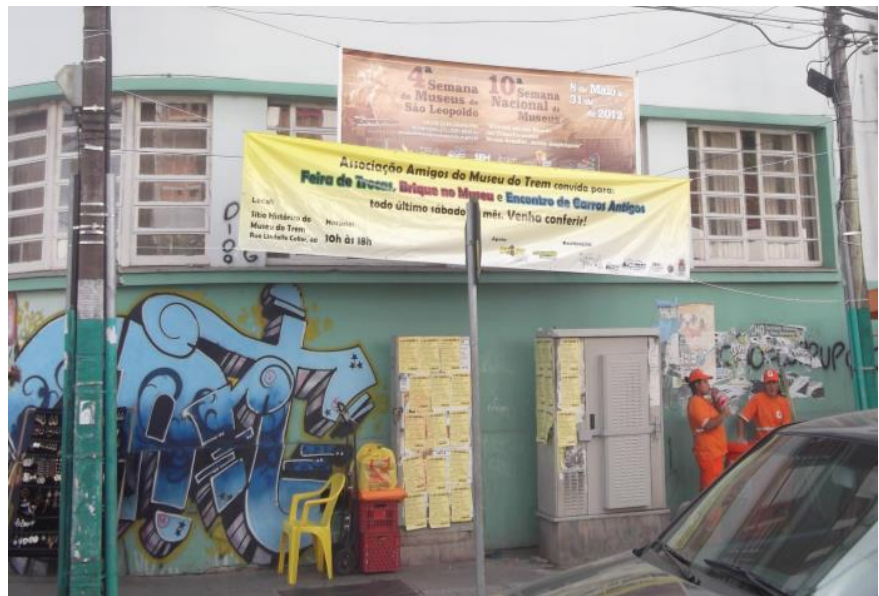

Figura 130 - Faixa no centro da cidade, rua principal. Ano: 2012. Fonte: arquivo digital da autora.
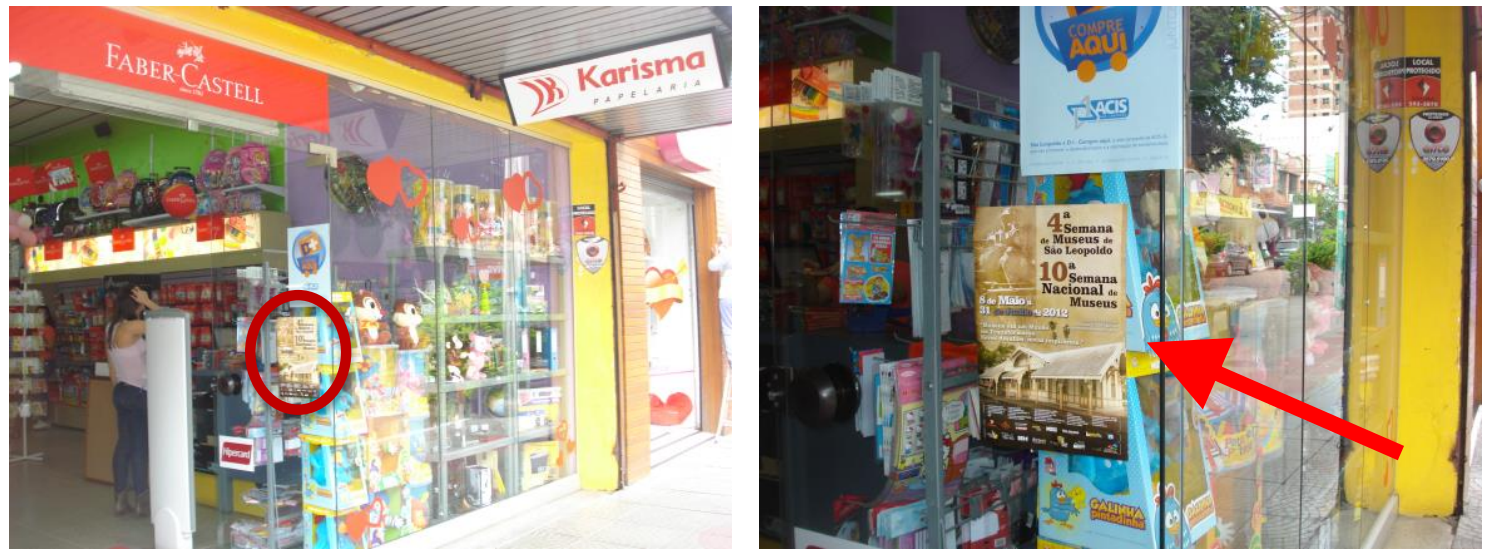

Figuras 131 e 132 - Vistas geral e em detalha de cartaz colado em vitrina exposta para rua, de Livraria parceira do Museu. Rua principal da cidade. Ano: 2012.

Fonte: arquivo digital da autora.
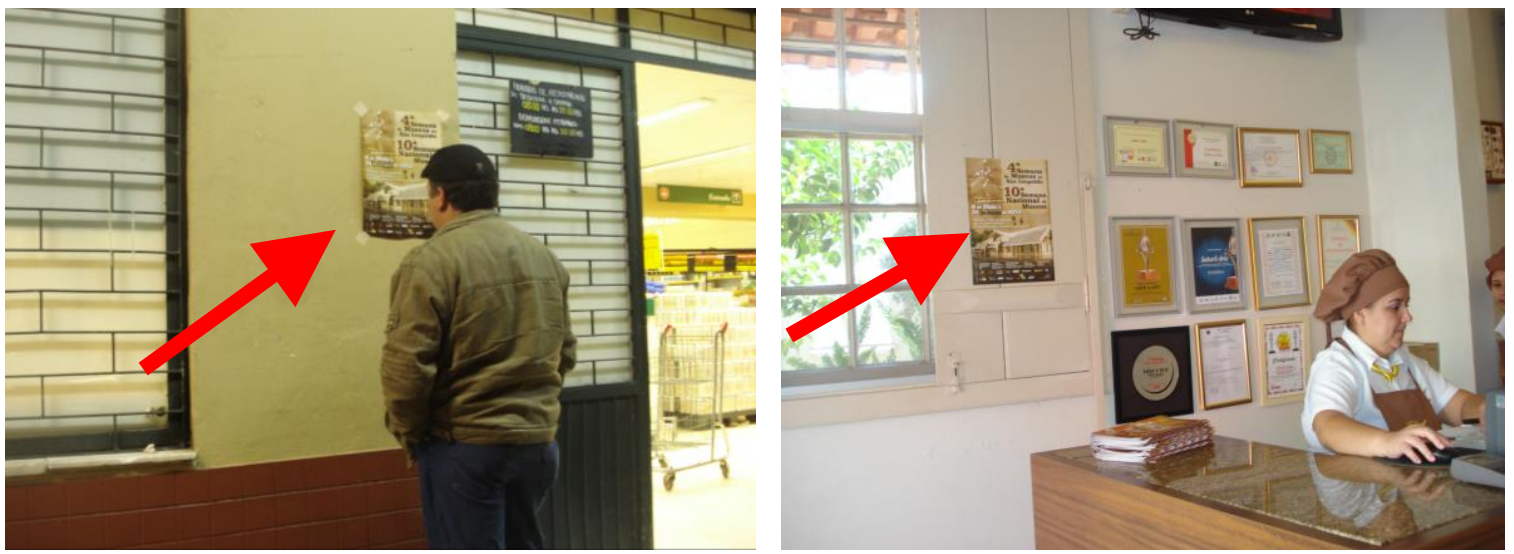

Figuras 133 e 134 - Cartaz colado em supermercado de bairro e em padaria no centro da cidade. Ano: 2012. Fonte: arquivo digital da autora. 

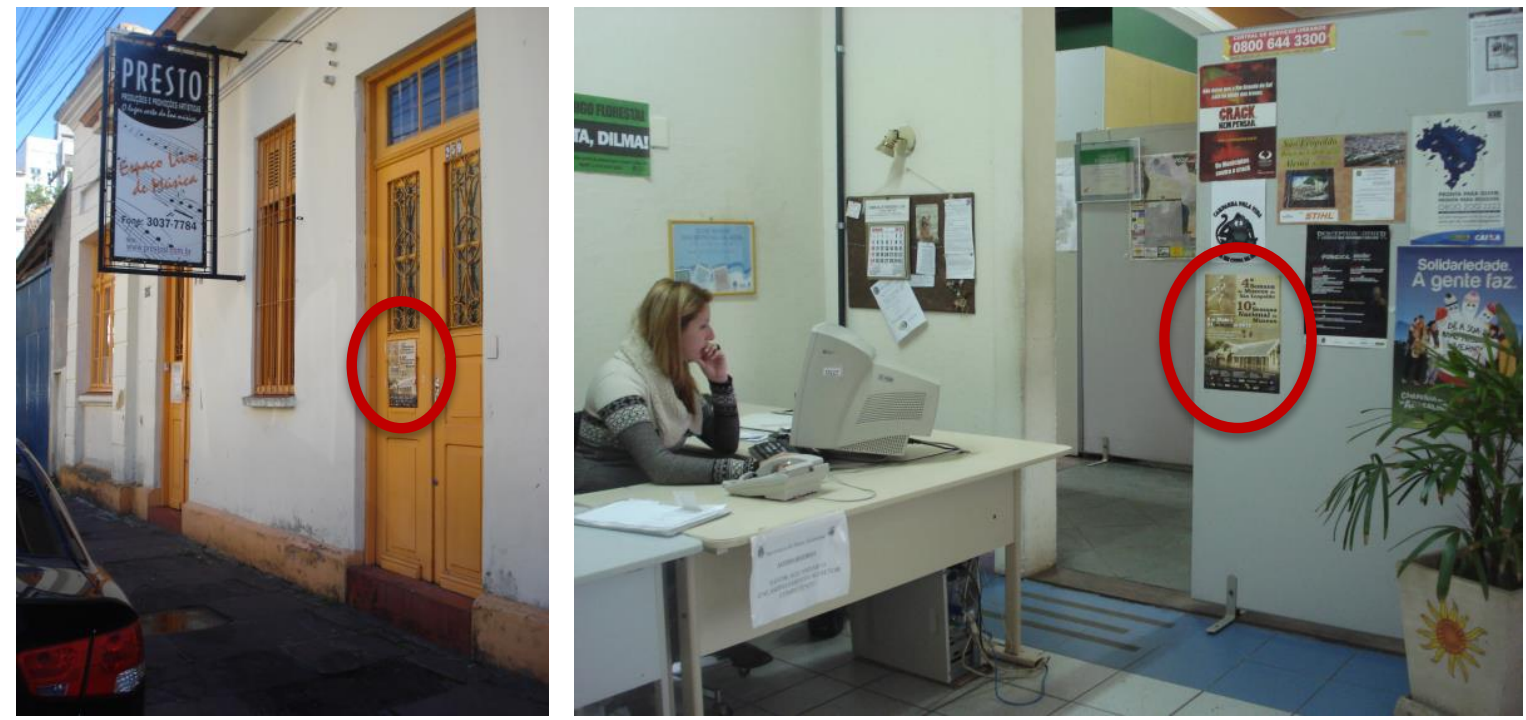

Figuras 135 e 136 - Cartaz colado em ambiente externo, porta da Escola de Música (localizado na mesma Rua no Museu) e em ambiente interno, parede em Setor Público, Secretaria de Meio Ambiente. Ano: 2012. Fonte: arquivo digital da autora.
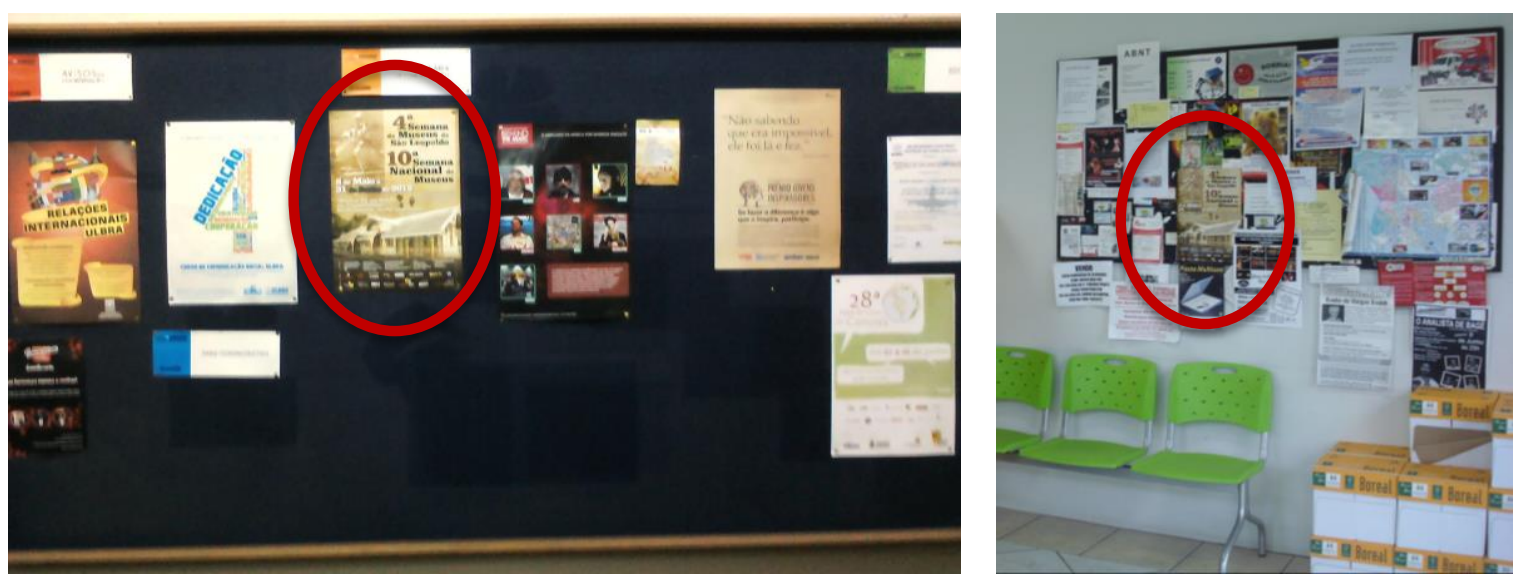

Figuras 137 e 138 - Cartaz colado em murais interno de instituições universitárias. Ano: 2012. Fonte: arquivo digital da autora.

\subsubsection{Notícias e artigos na imprensa}

Foram veiculadas reportagens sobre eventos e ações nos diferentes setores do Museu e artigos de autoria da direção do Museu, com reflexões, informações históricas e de divulgação das atividades desenvolvidas.

No período de quatro anos, o relatório da gestão informa a clipagem de $90 \%$ do material, que revela os seguintes números: 
Tabela 12 - Clipagem de conteúdos sobre o Museu do Trem veiculados em mídia impressa.

\begin{tabular}{c|c|c|c|c|c|c|c}
\hline \multirow{2}{*}{ Ano } & \multicolumn{2}{|c|}{ Jornal VS } & $\begin{array}{c}\text { Porto } \\
\text { Alegre } \\
\text { e outras } \\
\text { cidades }\end{array}$ & $\begin{array}{c}\text { Revista } \\
\text { Rua } \\
\text { Grande }\end{array}$ & $\begin{array}{c}\text { Artigos } \\
\text { da direção } \\
\text { do Museu }\end{array}$ & $\begin{array}{c}\text { Área total } \\
\text { incluindo todos os } \\
\text { vaículos impres- } \\
\text { sos (em cm2) }\end{array}$ & $\begin{array}{c}\text { Total de } \\
\text { itens } \\
\text { veiculados }\end{array}$ \\
\hline 2009 & 3 & 6 & 6 & $7 ?$ & 7 & $11.637,75$ & 55 \\
\hline 2010 & 3 & 9 & $2 ?$ & 5 & 2 & $6.905,82$ & 45 \\
\hline 2011 & 8 & 20 & 12 & 6 & 1 & $18.049,81$ & 82 \\
\hline 2012 & 8 & 26 & 16 & 2 & 5 & $22.649,69$ & 157 \\
\hline Total & $\mathbf{2 4}$ & $\mathbf{6 1}$ & $\mathbf{3 6}$ & $\mathbf{2 0}$ & $\mathbf{1 5}$ & $\mathbf{5 9 . 2 4 3 , 0 7}$ & $\mathbf{3 3 9}$ \\
\hline
\end{tabular}

Fonte: Elaborado pela autora.

As informações publicizadas pelo Jornal Vale dos Sinos ocupam a capa do periódico dia após o início da Semana de Museus. Na mesma data, ainda é publicado artigo da direção do Museu (figuras 139, 140 e 141).

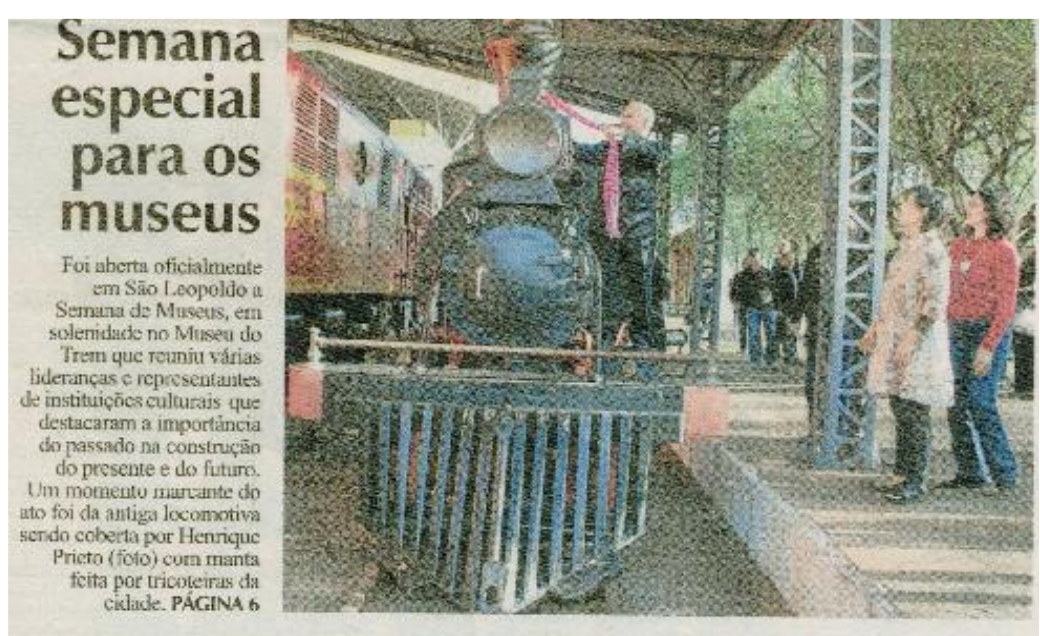

Figura 139 - Chama de capa, reportagem veiculada pelo Jornal Vale dos Sinos, São Leopoldo. Data: 19.05.2011. Fonte: Museu do Trem de São Leopoldo. 


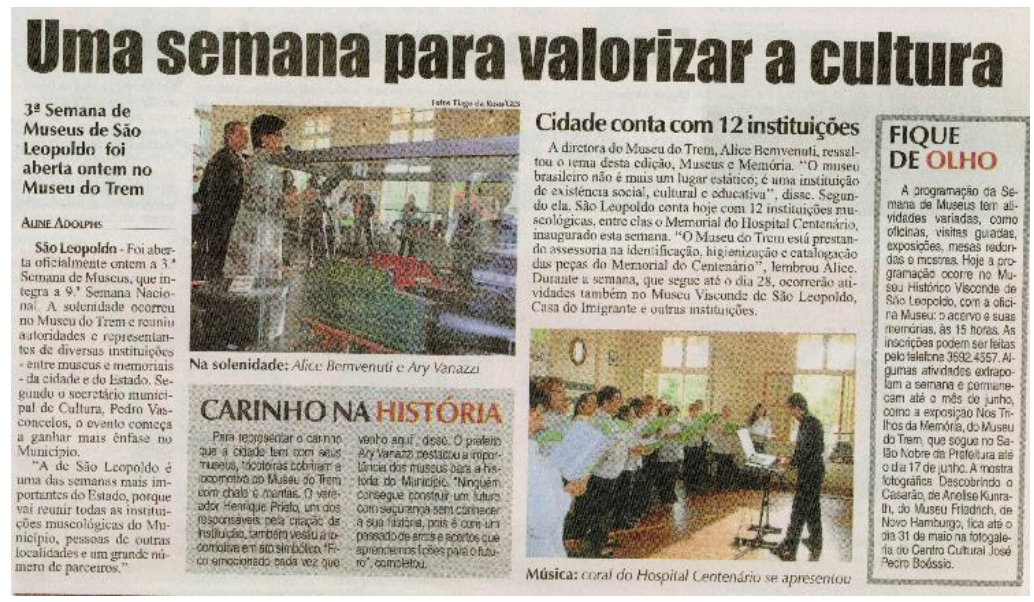

Figura 140 - Reportagem 3ª Semana de Museus de São Leopoldo, veiculada pelo Jornal Vale dos Sinos, São Leopoldo, página 06, Seção Comunidade. Data: 19.05.2011. Fonte: Museu do Trem de São Leopoldo

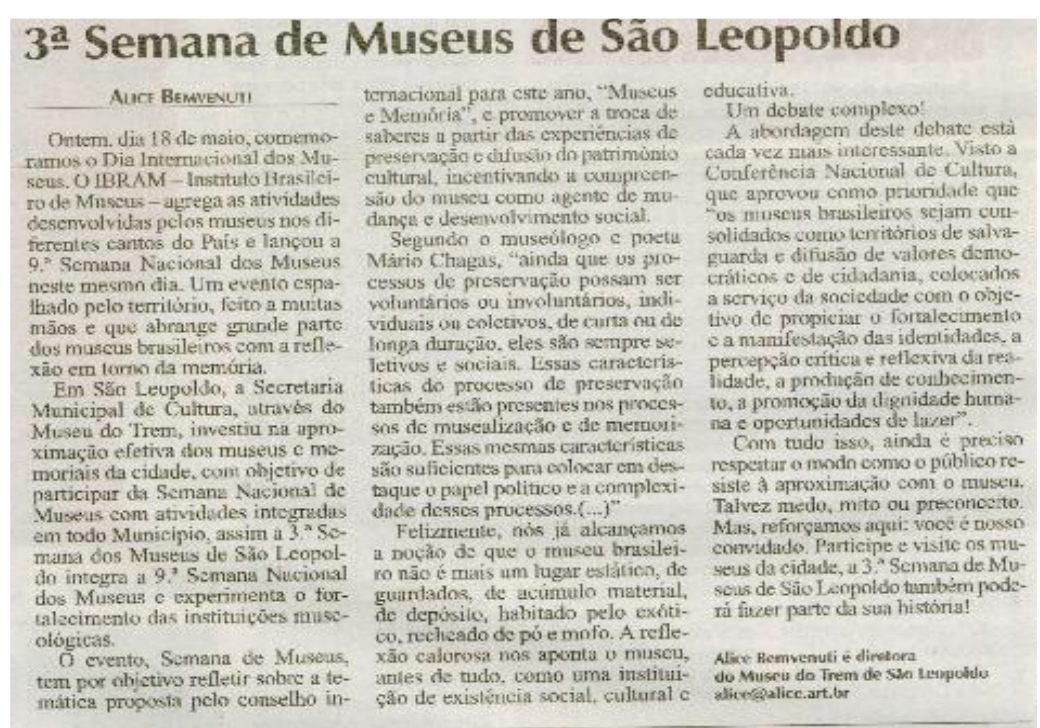

Figura 141 - Artigo publicado pelo Jornal Vale dos Sinos,

São Leopoldo, página 09, Seção: Opinião. Data: 19.05.2011.

Fonte: Museu do Trem de São Leopoldo

A Prefeitura Municipal de São Leopoldo, através do seu site institucional, oferece informações sobre o Museu do Trem. Utilizando poucas imagens, divulga a composição da diretoria, horários de funcionamento, aspectos relacionados ao histórico e ao acervo. Poucas atividades e eventos foram incluídas nesse site, entre elas: $3^{\text {a }}$ Semana Nacional de Museus, divulgada separadamente em uma página associada ao site principal, com informações da programação e contatos para o público fazer a inscrição. O site possui uma seção relacionada às notícias, mas não divulga atividades do Museu.

Pode-se verificar, também, a divulgação de conteúdos relacionados à programação cultural e ações do Museu em outros sites, como os do TRENSURB, da revista Quatro 
Rodas e do Almanaque Gaúcho ${ }^{100}$ assim como em blogs gerenciados por pesquisadores e/ou envolvidos na área de museus, como: DEFENDER, Blog Repensando Museus, Blog do Curso de História da UNISINOS.

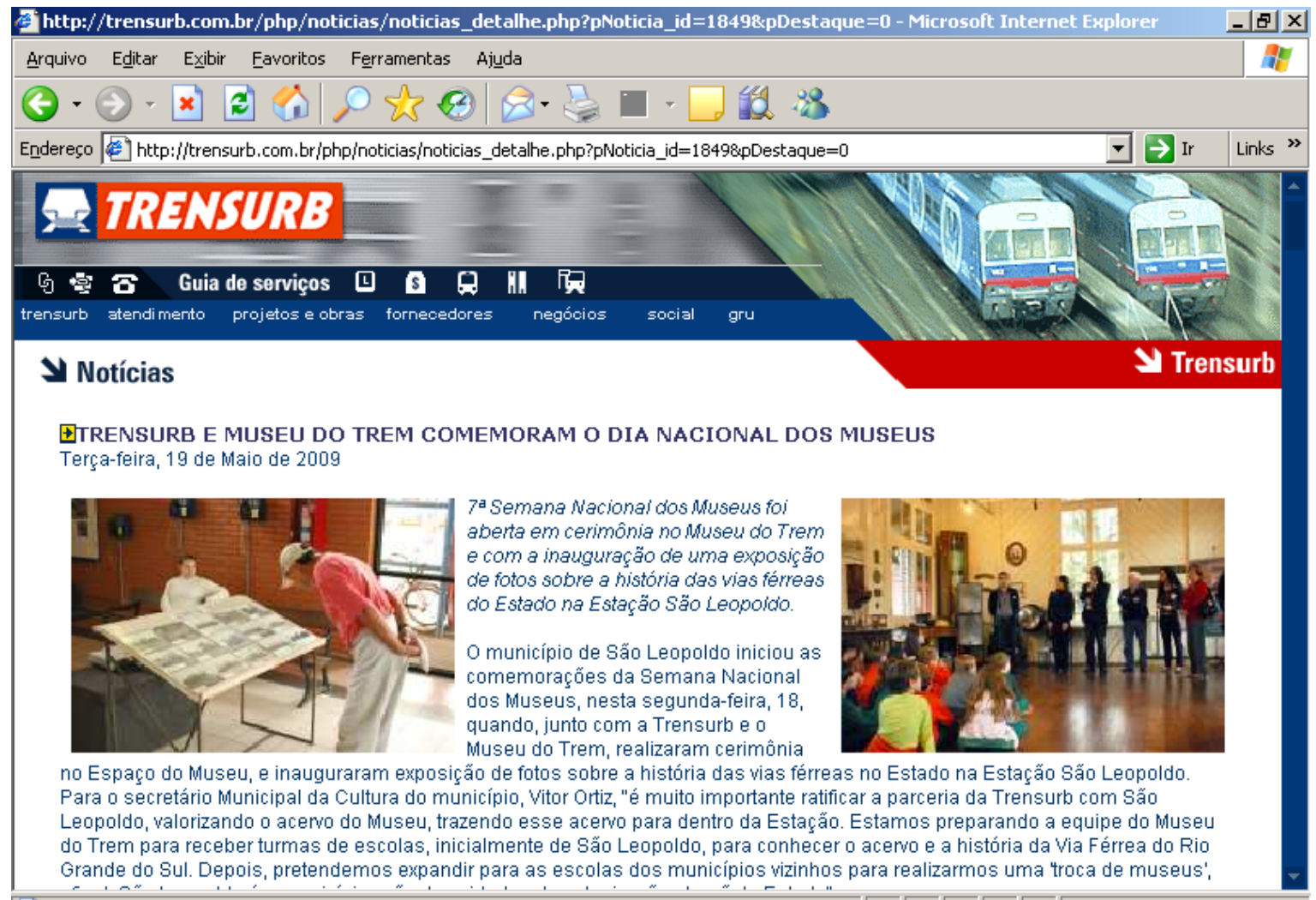

Figuras 142 - Reportagem on-line no site da TRENSURB.

Fonte: disponível em <http://trensurb.gov.br>. Acesso em: 13 fev. 2011.

${ }^{100}$ Editoria do jornal Zero Hora, Porto Alegre. 


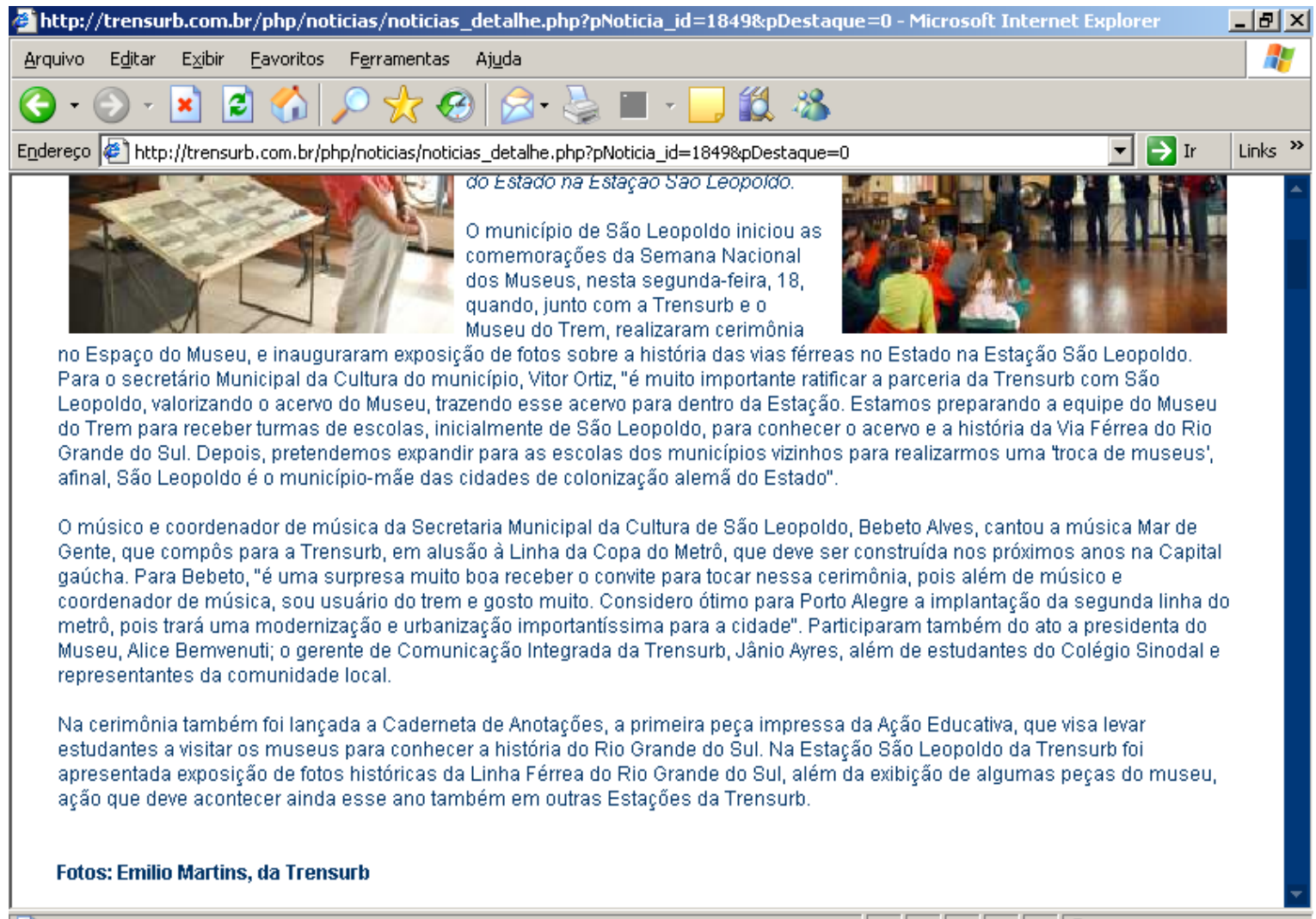

Figuras 143 - Reportagem on-line no site da TRENSURB.

Fonte: disponível em <http://trensurb.gov.br>. Acesso em: 13 fev. 2011

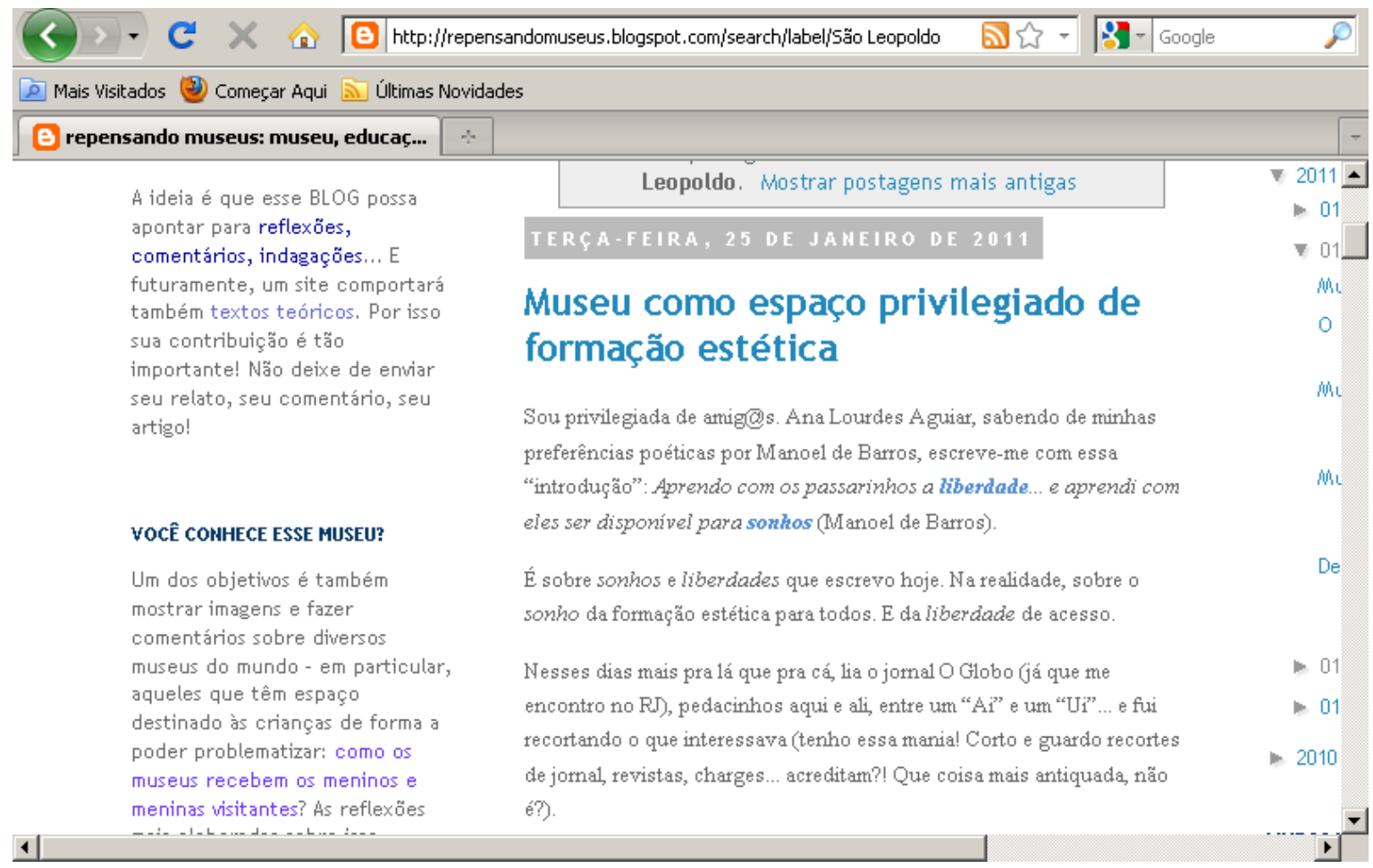

Figura 144 - Artigo on-line no blog Repensando Museus.

Fonte: disponível em <http://repensandomuseus.blogspot.com.br/search/label/S\%C3\%A3oLeopoldo>. Acesso em: 06 fev. 2011. 
Durante o ano de 2011, o Museu do Trem aderiu à utilização do Facebook. É possível observar a divulgação de diversas ações, seguidas de fotos e de comentários, porém não se enfatizou o acervo e a exposição de longa duração como uma atração.

Também são informados em relatório de gestão dados referentes à participação da direção em emissoras de rádio e TV, com os seguintes dados:

Tabela 13 - Participações da direção do Museu em programas de rádio

\begin{tabular}{c|c|c|c|c}
\hline Veículos & $\mathbf{2 0 0 9}$ & $\mathbf{2 0 1 0}$ & $\mathbf{2 0 1 1}$ & $\mathbf{2 0 1 2}$ \\
\hline Rádio UNISINOS & 2 & 1 & 1 & 1 \\
\hline Rádio Progresso & 2 & 2 & 2 & 1 \\
\hline Rádio ABC & 1 & 2 & 1 & 1 \\
\hline Total & $\mathbf{5}$ & $\mathbf{5}$ & $\mathbf{4}$ & $\mathbf{3}$ \\
\hline
\end{tabular}

Fonte: elaborado pela autora.

Tabela 14 - Participações da direção do Museu em programas de TV

\begin{tabular}{c|c|c|c|c}
\hline Veículos & $\mathbf{2 0 0 9}$ & $\mathbf{2 0 1 0}$ & $\mathbf{2 0 1 1}$ & $\mathbf{2 0 1 2}$ \\
\hline TV Unisinos & 2 & 2 & 1 & 3 \\
\hline UlbraTV & - & - & 3 & 1 \\
\hline TVCom & 1 & - & 1 & - \\
\hline TV Feevale & 1 & 1 & 1 & - \\
\hline Total & $\mathbf{4}$ & $\mathbf{3}$ & $\mathbf{6}$ & $\mathbf{4}$ \\
\hline
\end{tabular}

Fonte: elaborado pela autora.

Os dados informam a presença do Museu em diversos veículos da cidade de São Leopoldo, cidades vizinhas (Canoas, com UlbraTV, e Novo Hamburgo, com TV Feevale) e capital (TVCom), revelando que notícias sobre o Museu do Trem ultrapassaram metas iniciais de atingir a cidade.

\subsubsection{Organização do espaço de comunicação no pátio}

O visitante pode entrar no Museu do Trem vindo pela Rua Lindolfo Collor. Há acesso para automóveis e para pedestres. $\mathrm{Na}$ entrada, a guarita da segurança pública. $\mathrm{O}$ espaço externo da guarita foi adesivado com informações, passando a servir como mural público. A solução resolve, ao mesmo tempo, o problema de excesso de exposição do guarda, quando no interior do prédio, e do fornecimento de informações ao público sobre o Museu, horários e programações. 


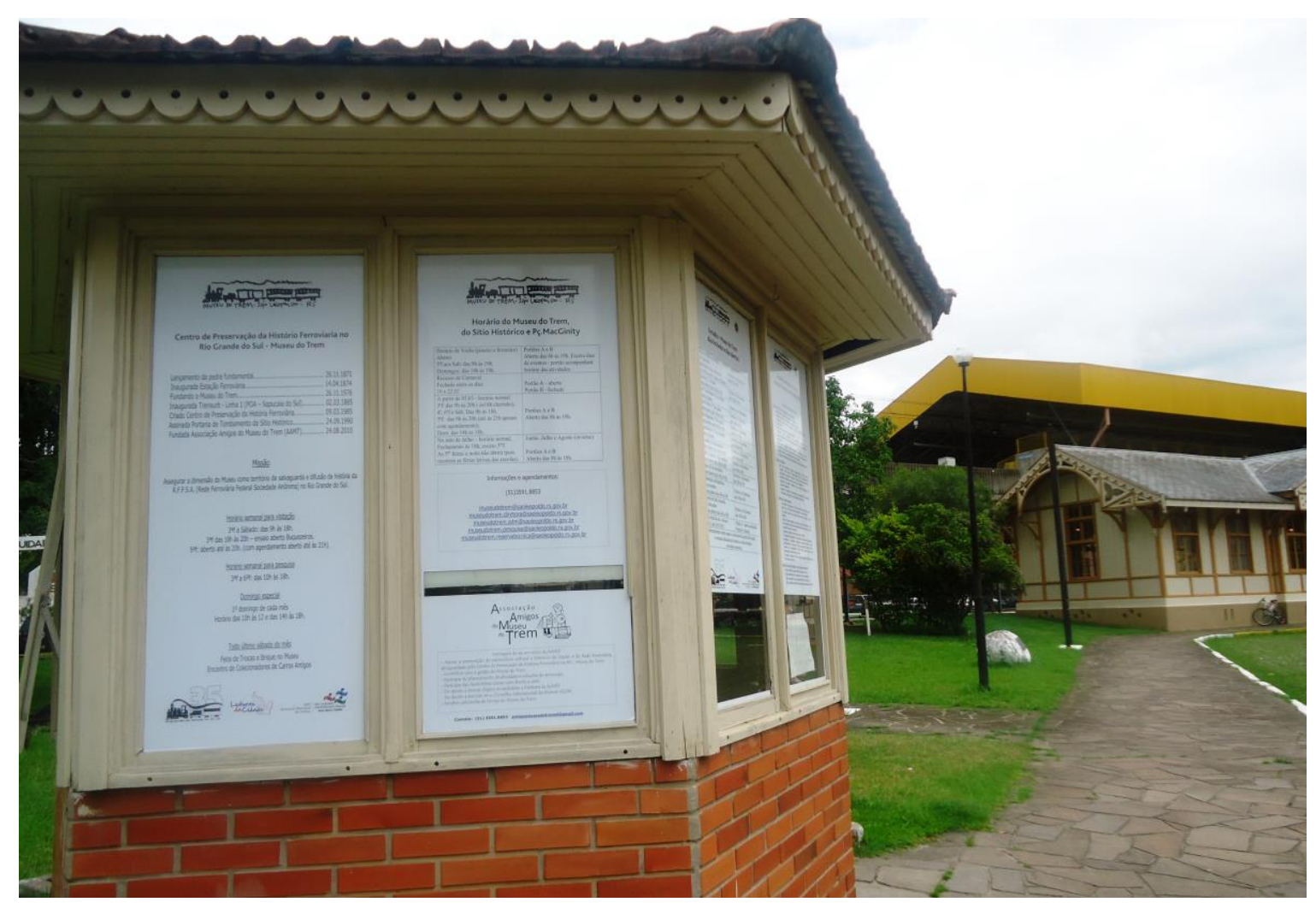

Figura 145 - Guarita da Guarda Municipal na entrada do Museu, adesivada com informações diversas. Ano: 2011.

Fonte: arquivo digital da autora.

Os adesivos foram colados sobre os vidros, seguindo um padrão: no alto um cabeçalho com o nome - Centro de Preservação da História da Ferrovia do Rio Grande do Sul - Museu do Trem - e a logomarca em preto; abaixo, dados e informações variados. Entre eles, lê-se no primeiro vidro, da esquerda para a direita: a Missão do Museu, datas importantes que informam desde o lançamento da pedra fundamental, em 1871, até a fundação da Associação de Amigos do Museu do Trem, em 2010. Informa os horários abertos para a visitação, detalhando o horário semanal, de feriados, domingos especiais, horários para a pesquisa e Feira de Trocas e Brique no Museu, juntamente com o Encontro de Carros Antigos, no último sábado de cada mês.

No segundo vidro encontra-se um calendário com dias e horários especiais de verão (janeiro e fevereiro), o normalizado de março até julho, especificando horários em que os portões ficam abertos independentes do Museu. Divulgação também dos contatos: telefone e e-mails. Na parte inferior, há informações referentes à Associação dos Amigos, logomarca da AAMT e sete itens de vantagens de ser um associado.

O terceiro vidro oferece informações detalhadas da abertura dos portões $A$ e B, referindo-se às entradas para os carros, para os feriados que vão da Páscoa, em abril, até o recesso de Natal e Ano Novo de 2013. 
No quarto vidro, as informações oferecidas são referentes à política de convivência no local. O texto é apresentado em tópicos, o primeiro bloco sobre o que o Museu do Trem oferece aos visitantes, como segue:

- Atendimento acolhedor, informativo e hospitaleiro.

- Ambiente interno limpo, arejado, organizado e seguro.

- Dispositivo para receber sugestões, críticas construtivas e/ou reclamações.

- Sitio histórico preservado e salvaguardado.

- Ambiente para pesquisa de documentos históricos do acervo (pesquisador deverá utilizar, obrigatoriamente, luvas, na prática da pesquisa).

- Meios para reproduzir imagens digitais e impressas do acervo museológico, desde que com autorização prévia, através dos termos de cessão previstos no Regimento Interno deste Museu.

- Programa de Ação Educativa na perspectiva de um "Museu para Todos!".

No segundo bloco são relacionados itens referentes ao que o Museu considera ser de responsabilidade do visitante, deixando claro que é esperado deste um papel ativo:

- Zelar pelo patrimônio municipal salvaguardado no Sítio Histórico (compõe o Sítio Histórico: Museu (Estação de 1874), Armazém (Setor Administrativo, Espaço da Reserva Técnica, Núcleos: Museológico, Educativo e Histórico), Acervo ao Ar Livre, Pç. Mac Ginity).

- Descartar lixo pessoal e dejetos de seu animal de estimação nos coletores adequados.

- Respeitar as políticas de conservação, de preservação, de reprodução de imagens, de segurança e relacionamento deste Museu.

No terceiro bloco de itens, o texto tem como subtítulo Política de Relacionamento, no qual são estabelecidas regras de segurança, de respeito e preservação do local, com o seguinte texto:

- É permitido fumar apenas na Pç. John Mac Ginity (distante 50 metros do acervo ao ar livre, do acervo em exposição e da reserva técnica).

- É proibido consumir e/ou portar drogas ilícitas e álcool no Sítio Histórico.

- Cabe ao visitante respeitar o convívio social e familiar previsto em Lei da Constituição da República Federativa do Brasil, observando as ações de atentado ao pudor e violência.

- É vedado ao visitante ouvir som alto (acima de $60 \mathrm{db}$ ).

- É necessário aos fotógrafos e cinegrafistas (profissionais e amadores), acadêmicos e estudantes, solicitarem autorização prévia no Setor Administrativo do Museu do Trem para capturar imagens no Sítio Histórico. $\mathrm{Na}$ inexistência de taxa, serão aceitas doações para manutenção e conservação do acervo.

- O acesso a Reserva Técnica e espaço funcional são restritos aos funcionários e técnicos. 
No último bloco, são informados quatro itens que determinam o que não é permitido dentro do Museu e nos espaços expositivos, lembrando que o local tem acervo museológico exposto, tanto dentro da Estação e do Armazém quanto na rua, dentro do Sítio Histórico. Os itens são os seguintes:

- Não é permitido consumir bebidas, alimentos e fumar.

- Não é permitido tocar nas peças do acervo museológico.

- Não é permitido correr nos espaços internos e expositivos.

- Não é permitido usar flash ou iluminação direcionada no acervo.

As informações apresentadas neste último espaço, também foram impressas em folha sulfite branca, tamanho A5, e distribuídas para os visitantes ao longo do ano de 2012.
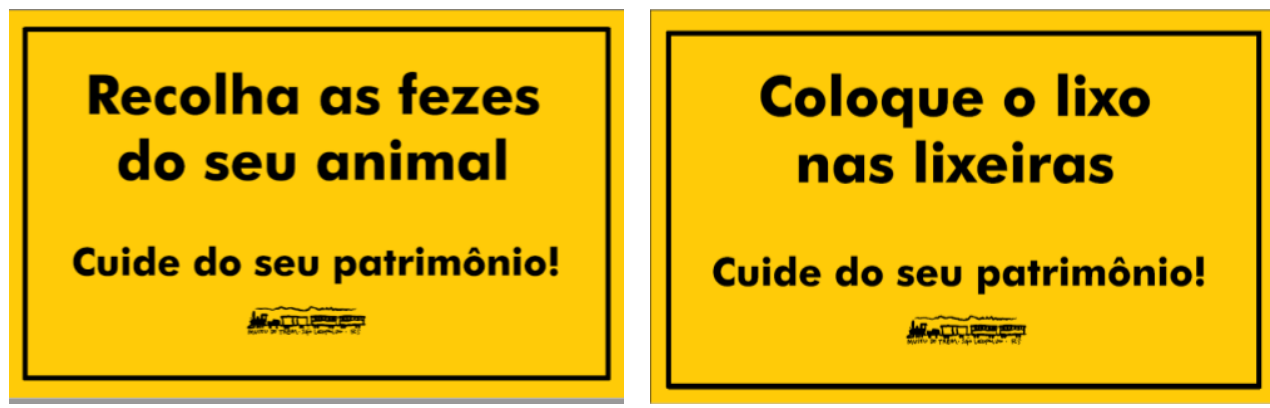

Figuras 146 e 147 - Placas informativas. Ano: 2012. Fonte: PRINT Art Impressões - São Leopoldo
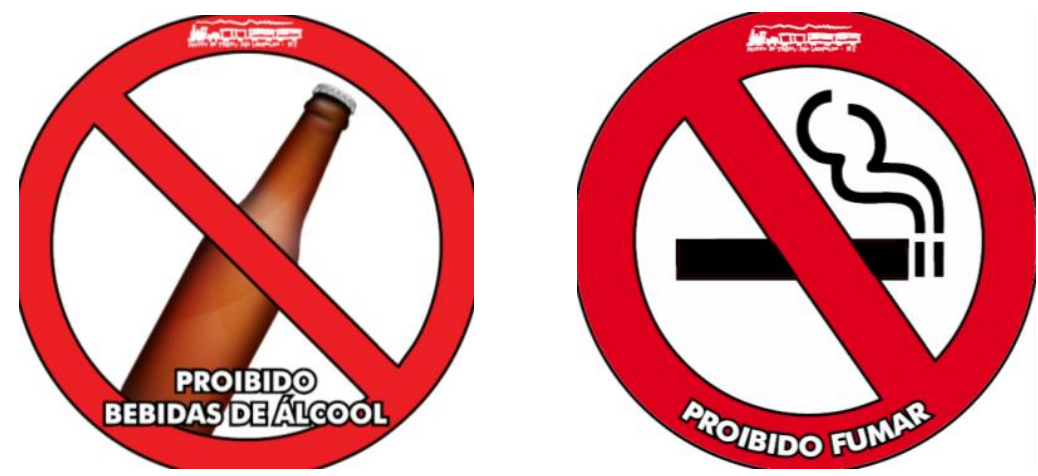

Figuras 148 e 149 - Placas informativas. Ano: 2012. Fonte: PRINT Art Impressões - São Leopoldo

\subsubsection{Material educativo}

Foram desenvolvidas cadernetas ${ }^{101}$ para distribuição gratuita após a visita no Museu. Com um perfil não só informativo, mas educativo e lúdico, a caderneta tem páginas com texto sobre a história da ferrovia, fotografias do acervo fotográfico, uma página sobre

\footnotetext{
101 O recurso foi inspirado em cadernetas, em semelhante tamanho e proposta, distribuídas pelo Museu lberê Camargo, em Porto Alegre.
} 
a ação educativa no Museu do Trem, folhas em branco para uso de anotações diversas, duas páginas com desenho para colorir e passatempo e uma página com o expediente. A última folha, de papel cartão com gramatura espessa, preta, com um furo retangular ao centro, serve para atividade educativa. Como uma provocação, a folha cartão preta é uma moldura e pode ser utilizada para olhar os espaços do Museu. Ou seja, serve para olhar através. Nas atividades educativas, convida-se o visitante a olhar o Museu pela "janela", fazendo menção à janela do trem. Todas as ilustrações e os títulos possuem a grafia do ilustrador Augusto Bier. Foram impressas duas tiragens, apenas com a capa diferente na segunda.
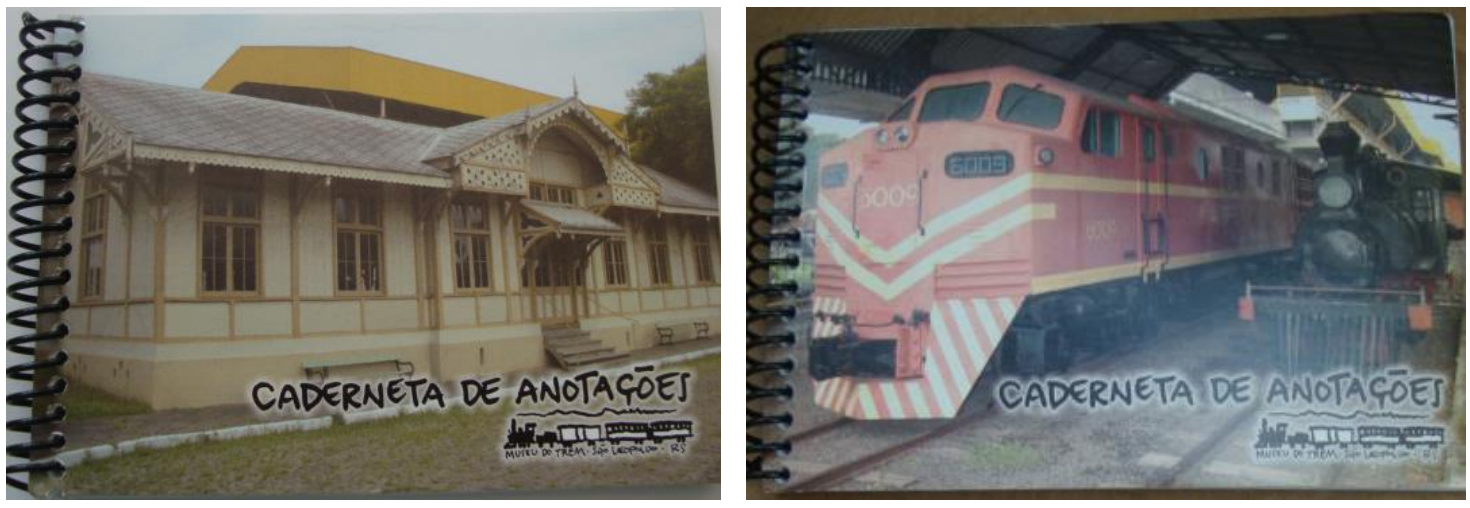

Figuras 150 e 151 - Material educativo produzido em parceria com a TRENSURB. Anos: 2009 e 2010. Fonte: acervo da autora.

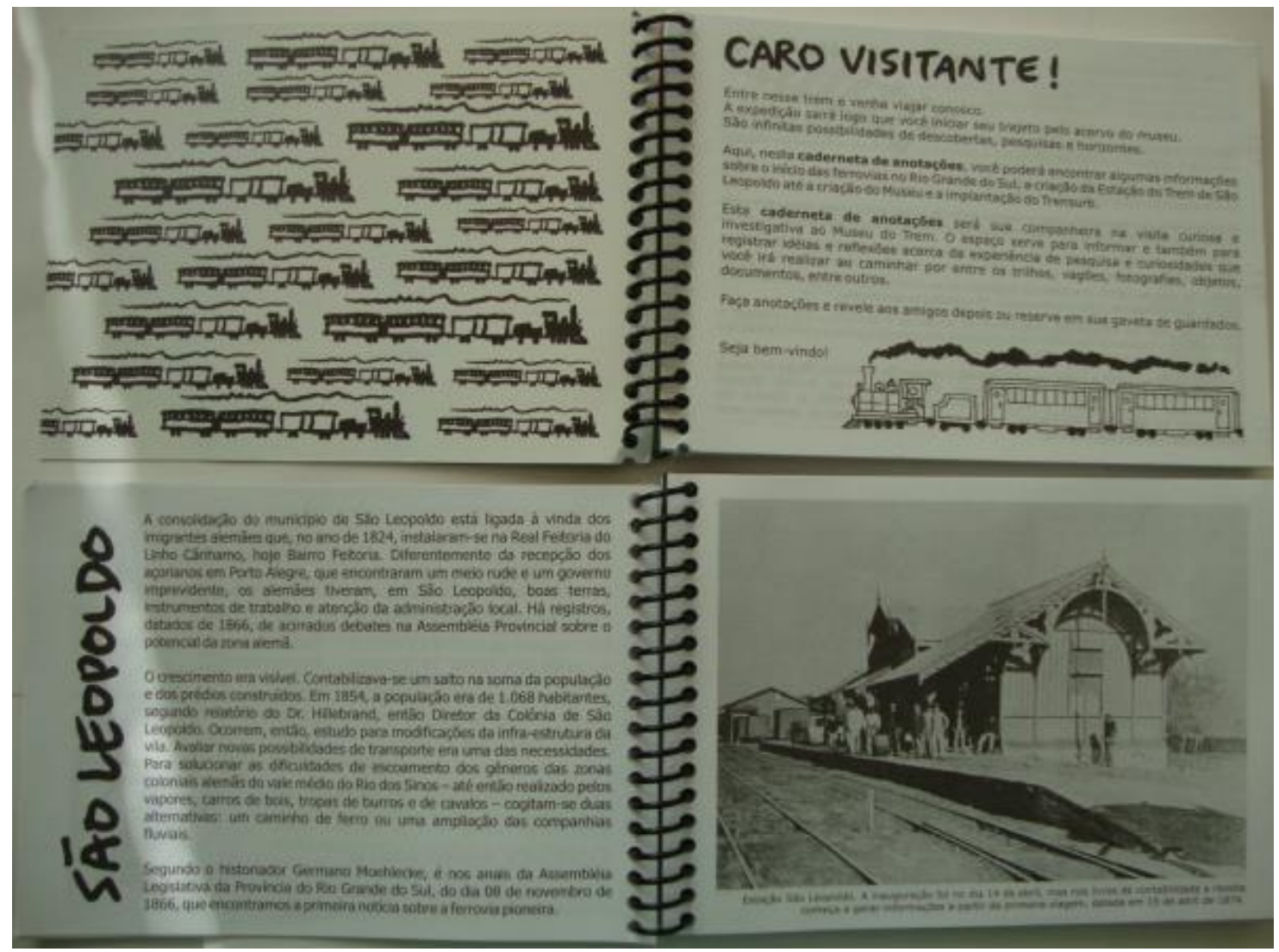

Fig. 152 - Material educativo: verso da capa e páginas 01, 02 e 03. Ano: 2009. Fonte: acervo da autora. 


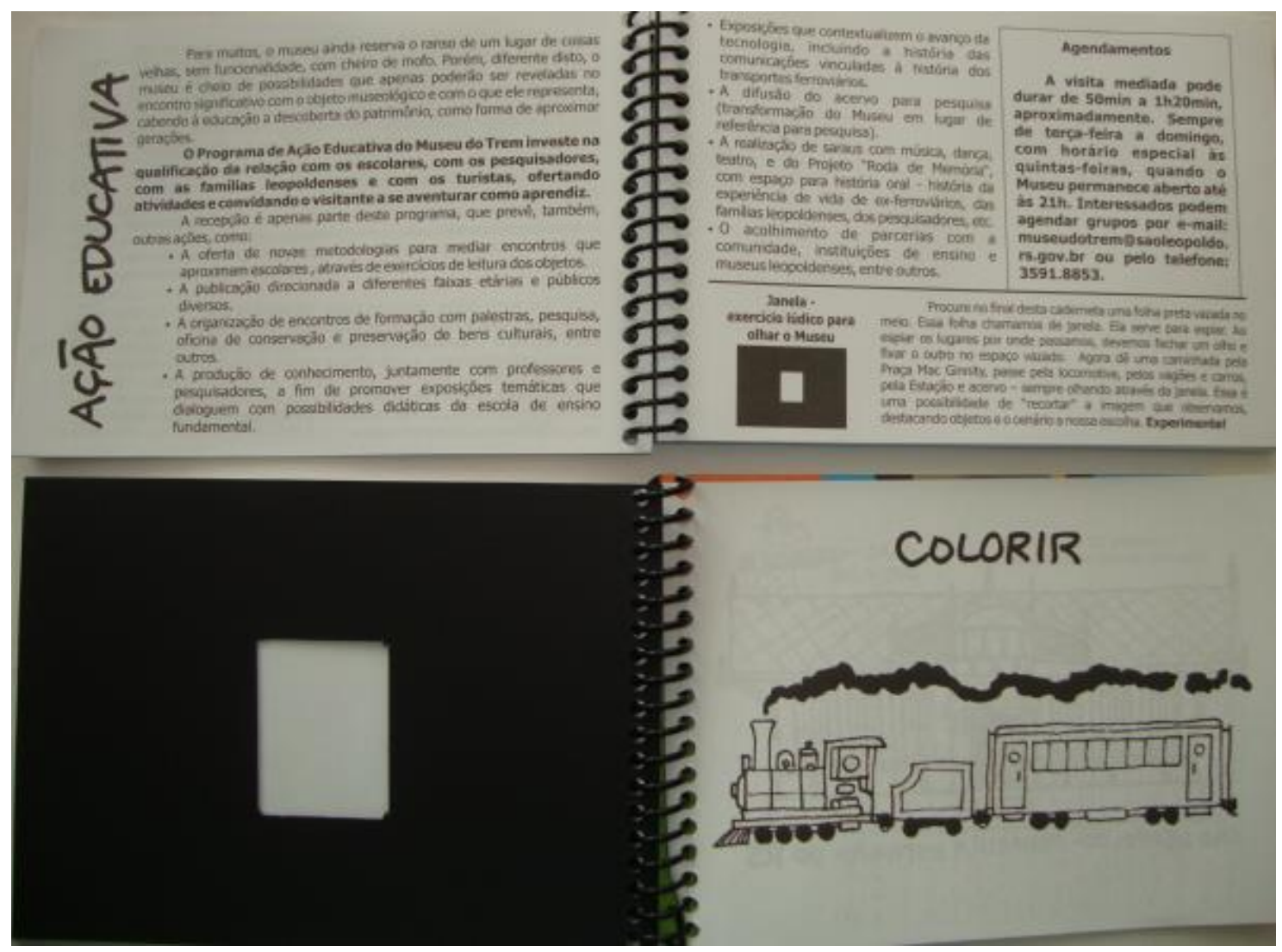

Figura 153 - Material educativo: texto do Setor Educativo, "janela" em cartão preto e passatempo. Ano: 2009.

Fonte: acervo da autora.

\subsubsection{Outros materiais de divulgação}

Foi reservado, no interior do prédio da Estação, junto à exposição, um local para a comercialização de produtos, como camisetas e suvenires, através da Associação de Amigos do Museu do Trem (AAMT). Os produtos se destacam, pois, possuem bom acabamento e reproduzem imagens do acervo, além do selo comemorativo de 35 anos do Museu do Trem. Entre os suvenires estão canecas, canetas, apoio para laptop e mini quebra-cabeças. As camisetas, em diferentes cores e tamanhos, ficam expostas em cabides presos a uma arara de metal.

A iniciativa encanta alguns visitantes mais envolvidos com a temática. Muitos compram produtos com intuito de auxiliar a AAMT; outros veem ali uma oportunidade de ter uma recordação do Museu. Tanto um quanto outro ajudam o Museu a divulgar sua proposta. Porém, a iniciativa não teve continuidade, devido a diversas carências: de local adequado, de vitrinas para demonstração dos objetos, de pessoal para ficar disponível para atender eventuais interessados, de prática em administrar um espaço comercial dentro do museu, de profissional para contatar empresas que produzem os suvenires, selecionar e cotar preços, de modo a apresentar um produto de qualidade estética que impulsione o consumo. 
Os quesitos que envolvem a lojinha e a divulgação do Museu através de suvenires sugere uma ampla discussão, tanto com relação à espetacularização do Museu, quanto desta alternativa como meio de gestão, porém essa é uma questão que não será aprofundada na presente pesquisa.
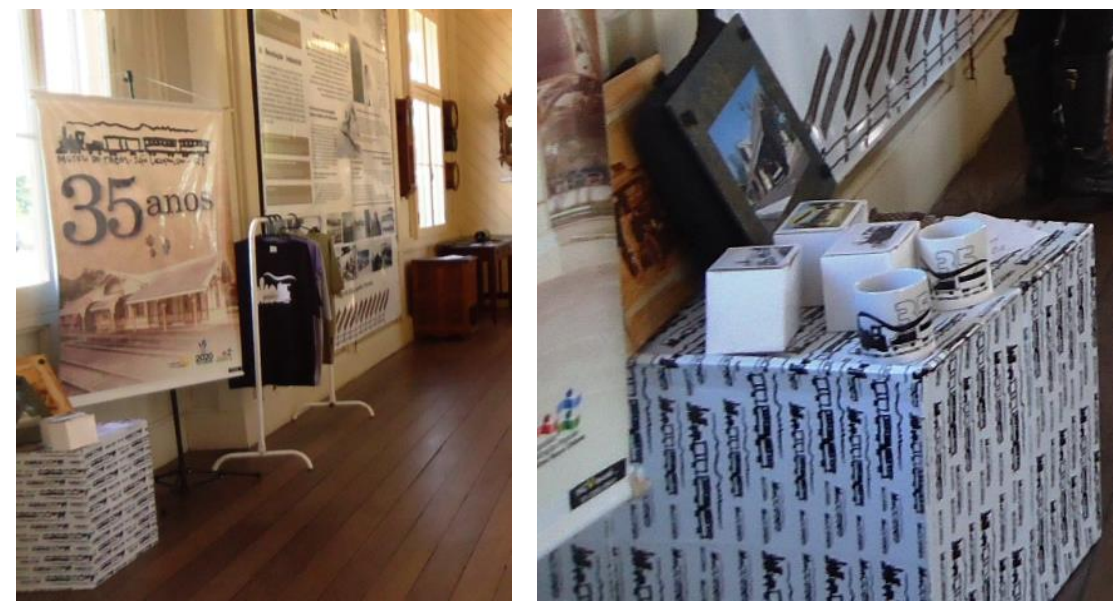

Figuras 154 e 155 - Espaço interno do prédio da Estação com suvenires e cubo impresso com logomarca. Ano: 2011. Fonte: arquivo digital da autora.

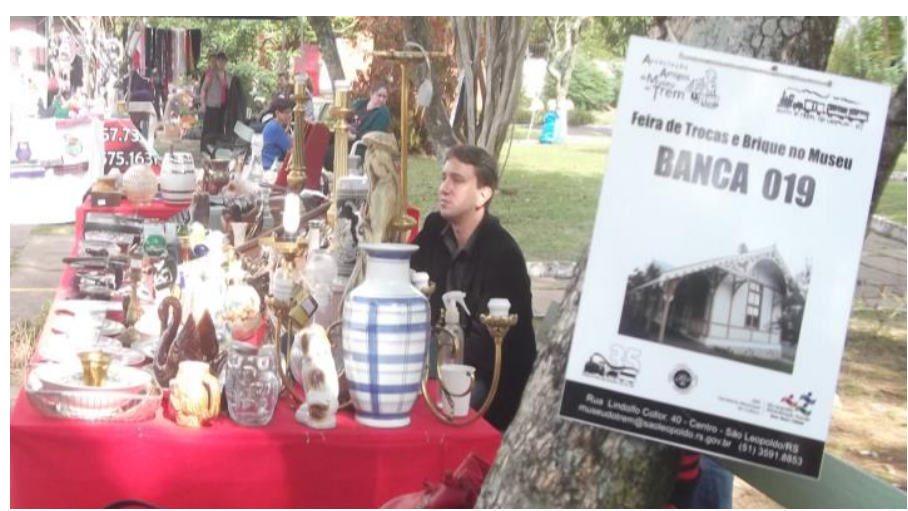

Figura 156 - Placa de numeração das bancas da Feira e Trocas e Brique no Museu do Trem. Ano: 2012.

Fonte: arquivo digital da autora.
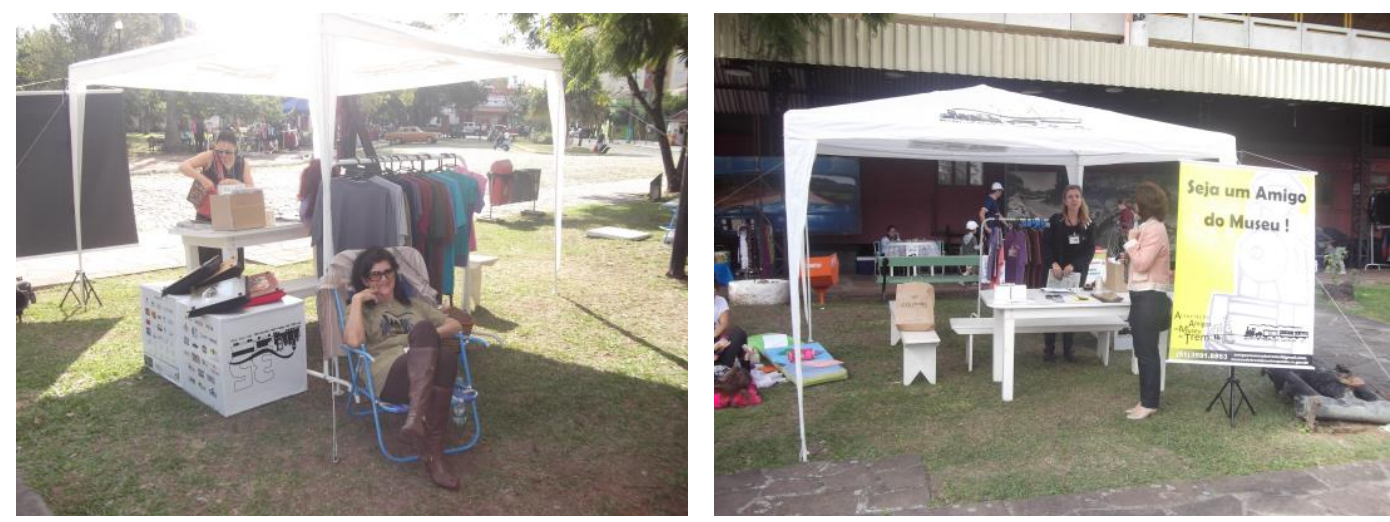

Figuras 157 e 158 - Banca da Associação Amigos do Museu do Trem na Feira de Trocas e Brique no Museu do Trem. Ano: 2012. Fonte: arquivo digital da autora. 


\subsection{COMUNICANDO NO MUSEU}

\subsubsection{Exposição de longa duração}

A exposição concebida pelo arquiteto Sérgio Santos Morais (PRESERVE) para o prédio reconstruído da Estação foi inaugurada em meados da década de 1980, permanecendo como a principal exposição do Museu do Trem de São Leopoldo por trinta e cinco anos. Com poucas alterações a exposição apresenta a mesma disposição, vitrinas, organização espacial, espaços de circulação e objetos expostos.
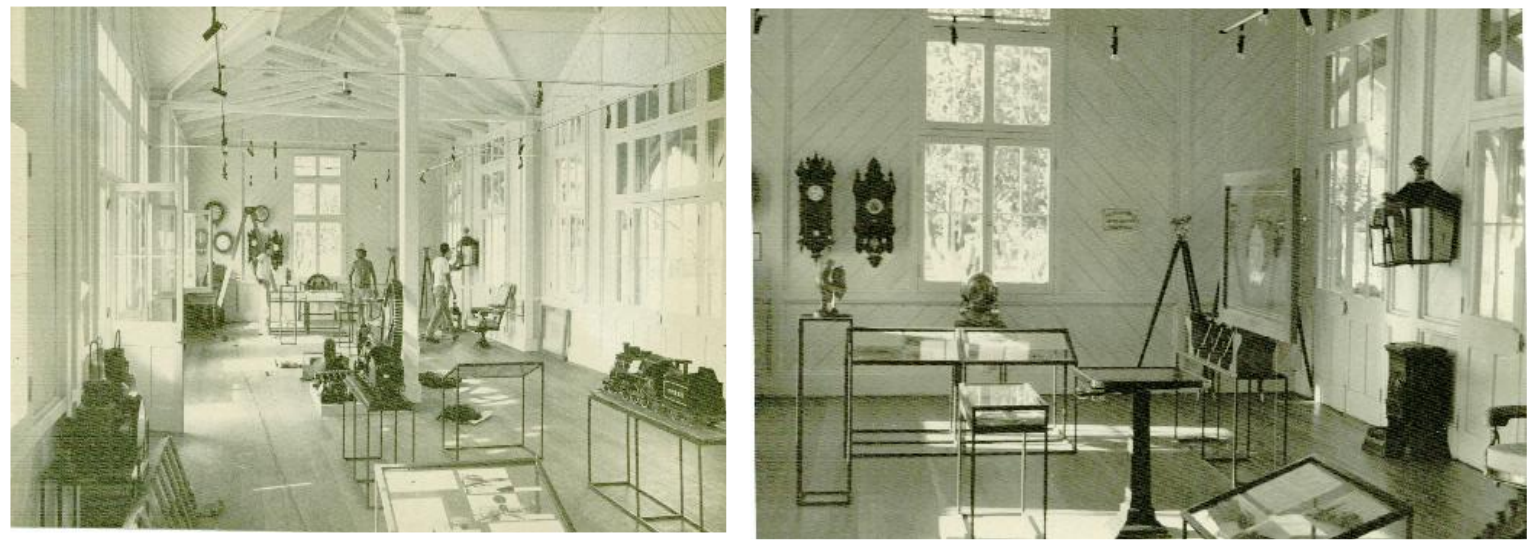

Figuras 159 e 160 - Exposição no interior do prédio da

Estação, inauguração do CPHFRS. Ano: 1985.

Fonte: Museu do Trem de São Leopoldo.
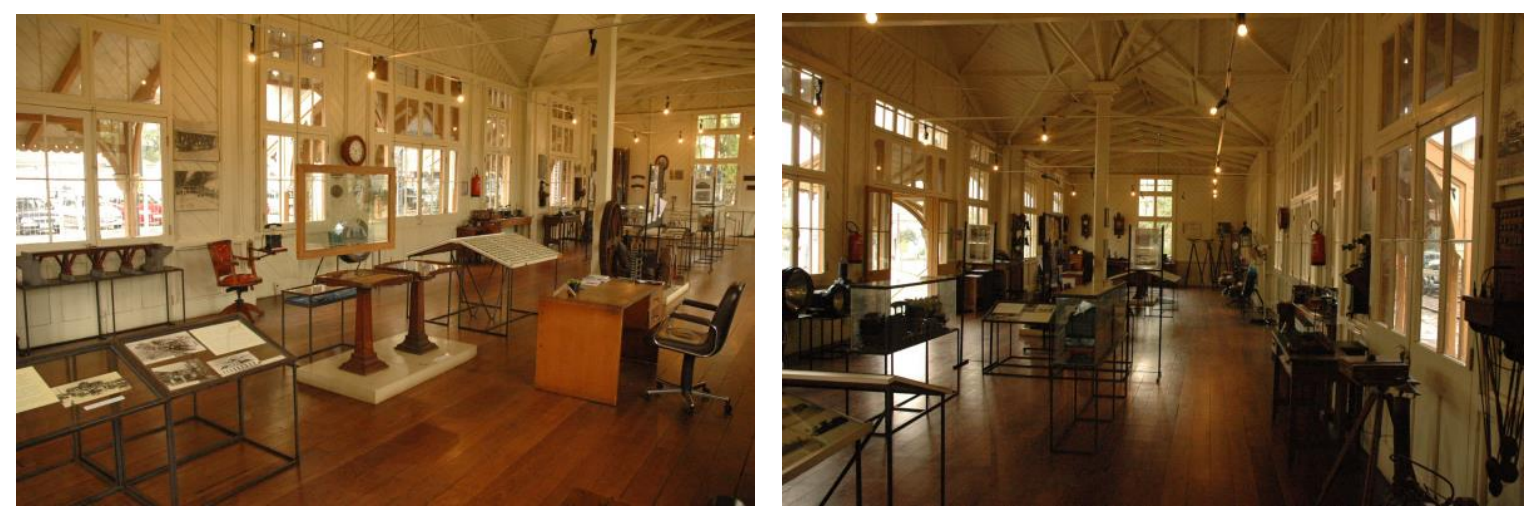

Figuras 161 e 162 - Exposição no interior do prédio da Estação do Museu do Trem. Ano: 2007. Fonte: Museu do Trem de São Leopoldo

Considerando a não existência de previsão orçamentária para realizar um projeto de expografia, a gestão do Museu propõe duas frentes de ação: a escrita de projeto, com intuito de disputar editais de incentivo (estaduais e federais), e a capacitação da equipe do Museu para, através dela, realizar ações possíveis de atualização da exposição existente. 
Entre as ações de capacitação, em 2009, o Museu estimulou que sua equipe frequentasse a Oficina de Expografia ${ }^{102}$, ministrada pela museóloga Profa. Dra. Marília Xavier Cury (USP), no Museu da Universidade Federal do Rio Grande do Sul, em Porto Alegre. Essa oficina foi seguida de dois encontros, quando houve a assessoria de Cury no próprio Museu do Trem, em São Leopoldo, com objetivo de desenvolver estudo de novo projeto expográfico in loco. Em 2011, o Museu realizou Oficina de Expografia com a arquiteta Profa. Dra. Jeniffer Cuty (UFRGS), com estudo e prática, então reorganizando a exposição.

Inicialmente contextualizando o espaço estruturado existente, Cuty propõe debate e reflexão a respeito do impacto das mudanças pretendidas e o exercício de conceber um novo espaço a partir da disponibilidade de peças, do espaço e dos recursos - os quais, neste caso, se restringiam aos recursos humanos, impressão de etiquetas e, posteriormente, à impressão de textos e imagens em uma lona vinilica (Anexo $\mathrm{C}$ ), afixada em uma parede.

No processo, foram retiradas peças com avarias, vários objetos foram deslocados e reagrupados, criando novos espaços de circulação e outra narrativa expositiva. É importante destacar aqui a opção da direção em provocador, ao mesmo tempo, um estudo sobre as questões museológicas e museográficas, no próprio ambiente do Museu do Trem, como também de realizar a revitalização com os recursos existentes.

Entre os objetivos da concepção de uma nova apresentação do espaço expositivo, estavam: a) estimular novas possibilidades de encontro como o acervo, ressignificando o espaço para as atividades educativas e de conversas como a exposição; b) renovar o ambiente com baixo custo; c) atualizar a exposição para que o público encontre novidades ao visitar o Museu; d) redimensionar o espaço, despoluindo e gerando espaços de circulação; e) identificar possíveis avarias, necessidades de higienização e limpeza de peças, assim como de conservação preventiva e/ou substituição; f) refazer as etiquetas; g) criar um novo layout e experimentar um texto de parede utilizando lona (banner gigante) a fim de ofertar pequenos textos informativos e históricos para que o público possa ter acesso às informações independentemente da recepção da equipe; h) criar novos roteiros e narrativas para o público; i) gerar a reflexão sobre o lugar da exposição e o papel do museu junto aos diferentes públicos.

O fato de uma nova exposição ter sido planejada, estruturada, debatida e concebida pela equipe do Museu, através de um exercício de estudo assessorado,

\footnotetext{
102 Organizado pelo Sistema Estadual de Museus do Rio Grande do Sul (SEM-RS) para os museus da

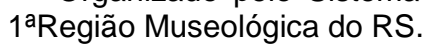


permitindo a prática museológica, gerou resultados positivos não só quanto ao local, mas também quanto à sua utilização.

Com relação ao papel da equipe na execução das decisões, ações e estratégias que geram mudanças no Museu, fica evidente que participar do processo oportuniza, inclusive, a revisão da metodologia de trabalho. Observa-se que a exposição, anteriormente tratada como uma relíquia intocável, como um relicário (MENESES, 1994) detentora de memórias do passado ${ }^{103}$, é ressignificada em novas abordagens e narrativas oferecidas a partir de então.

A equipe, como um todo, assume o papel de planejadora, executora e beneficiária: toma decisões estratégicas e táticas e assume as consequências dessas decisões e, ainda, se beneficia por estar sendo respeitado e valorizado na sua dimensão humana (CURY, 2005, p. 91).

Cury, no Relatório Revisão Museológica e Museográfica do Museu Histórico de São Francisco do Sul, enfatiza os resultados obtidos a partir de práticas com a participação da equipe no processo de gestão dos espaços museológicos:

Entendendo desta maneira, o partido expográfico atenderá aos requisitos abaixo:

- inteligibilidade, para que a exposição possa ser "lida" pelo visitante. A exposição deve dar conta de si mesma, deve suportar-se;

- participação interpretativa e elaborativa pelo público, considerando que a retórica abre espaço para que o visitante complete a mensagem expositiva;

- possibilidade de aproximação das pessoas entre si, entre sujeitos que dialogam em torno do patrimônio, uma vez que a interação humana no contexto museal enriquece a experiência do público;

- exposição como unidade conceitual e visual, dividida em módulos, como forma de organização e apropriação pelo visitante;

- ambiente com tradição e renovação tecnológica, considerando que a dicotomia entre o novo e o antigo é artificial;

- ambiência (ambiente ressignificado) por meio de iluminação, cores e materiais, para que o visitante sinta-se vivenciando uma experiência integral (física, cognitiva, afetiva, emocional, psicomotora, etc.);

- fuga da fetichização dos objetos: supervalorização dos objetos descontextualizados, considerando que o centro do museu são as pessoas, do passado, do presente e do futuro. O objeto é uma forma de apreensão do mundo e de relacionamento das pessoas entre si (CURY, 2006b, p. 8).

A nova expografia privilegiou mais de cem peças do acervo no interior do prédio da Estação, com tridimensionais e fotografias agrupados em ilhas, ao centro, e encostado

\footnotetext{
103 "Lugar do passado", aqui, está se referindo à instituição museal e sua história e não propriamente ao acervo exposto e à memória evocada pelo patrimônio material.
} 
nas paredes, conforme esquema apresentado na Figura 163. Também foi criado um novo espaço expositivo no interior do Armazém, junto ao setor Administrativo e Reserva Técnica.

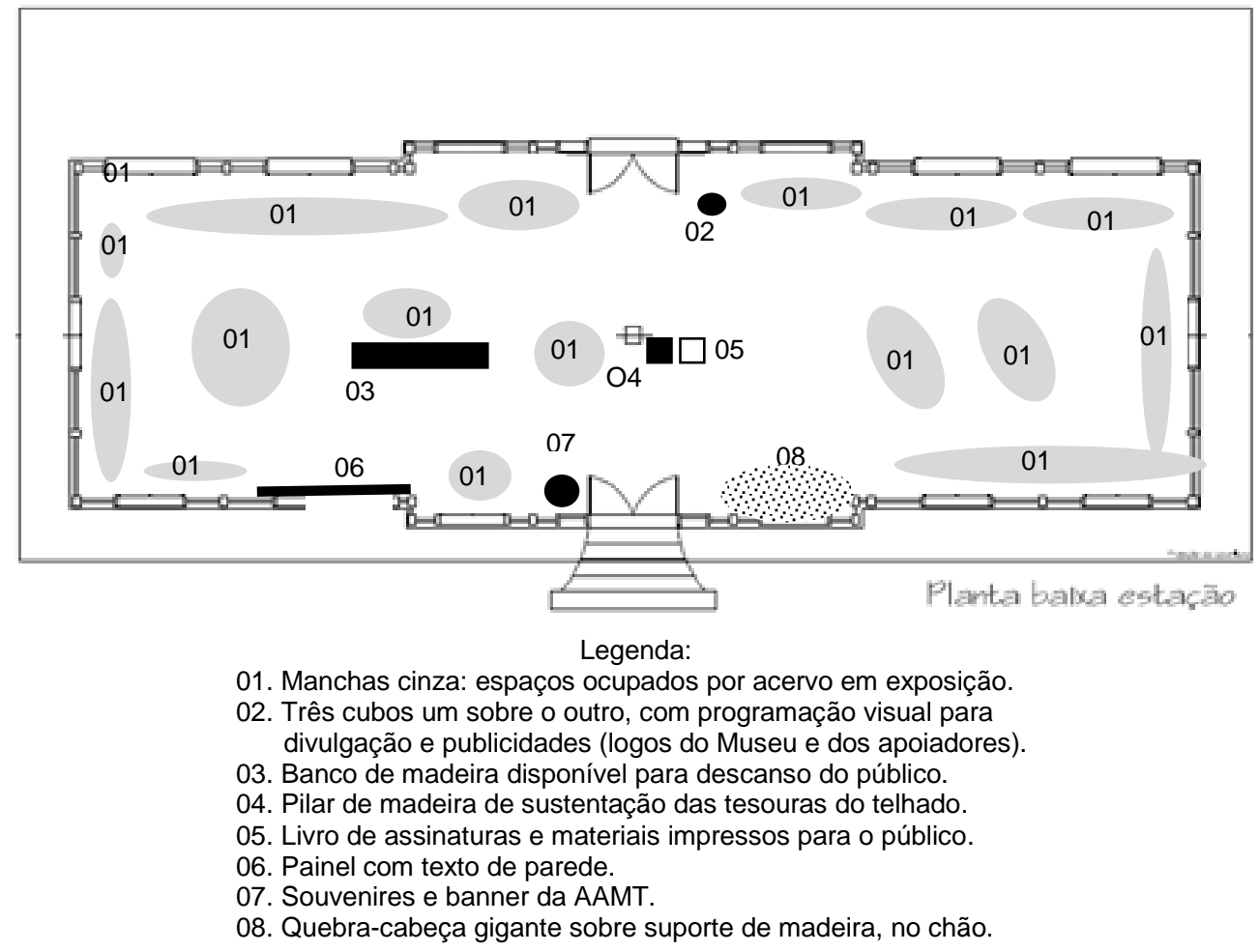

Figura 163 - Desenho do espaço interno do prédio da estação com marcações dos espaços ocupados na exposição. Ano: 2011. Fonte: elaborado pela autora.

\subsubsection{Recursos expográficos}

Com a preocupação de não agredir o patrimônio e respeitar as informações apresentadas pelo acervo exposto, a nova expografia contou com materiais gráficos, entre eles: etiquetas, texto informativo de parede, recurso publicitário para veiculação de marcas e logomarca de parceiros, recursos pedagógicos e objetos lúdicos.

As etiquetas foram desenvolvidas em um padrão, tamanho $16 \mathrm{~cm} \times 5 \mathrm{~cm}$, fonte preta, com margem preta, impressas sobre fundo branco, coladas sobre foan. Entre as informações apresentadas estão o nome da peça, escrito em negrito na parte superior esquerda da etiqueta, seguido pela data de fabricação e procedência do objeto, que, em sua maioria, é desconhecida. Na parte inferior, à direita, a logomarca do Museu do Trem. Todas as etiquetas foram plastificadas com papel Contact.

O texto de parede consiste em um painel de $3 \mathrm{~m} \times 3,5 \mathrm{~m}$, impresso em lona vinílica com ilhoses, fixado na parede com parafusos, cobrindo uma das janelas (verificar Anexo C). O painel apresenta dezesseis pequenos textos, cada um com uma fonte diferente, articulados por imagens e/ou datas. O título geral, na parte superior, à esquerda, diz: São 
Leopoldo e a Ferrovia. Ao fundo, na lateral direita, uma imagem da própria Estação, em cores, suavizada nas bordas com diluição e transparência. Os textos são pequenos com os seguintes títulos:

- A formação do núcleo de São Leopoldo;

- Real Feitoria do Linho Cânhamo;

- 1824: a vila denominada Colônia Alemã de São Leopoldo;

- 1846: colônia elevada à categoria de Vila;

- 1864: Revolução Industrial - O trem: representante da modernidade;

- 1919: o primeiro automóvel em São Leopoldo;

- João Correa;

- O início da estrada de ferro;

- A instalação da 1aㅡ linha férrea no RS - com imagens reproduzidas do John Mac Ginity e da pá que fez o corte para a pedra fundamental no ato de lançamento;

- A disputa pela concessão da primeira ferrovia do Rio Grande do Sul;

- A ferrovia em mãos estrangeiras: ingleses, belgas e norte-americanos;

- 1920: a encampação pelo Governo Estadual e o nascimento da VFRGS;

- 1959: a transformação em uma única empresa RFFSA e as novas medidas;

- Dos anos 1990 a 2000: da liquidação à extinção da Rede.

Na parte inferior da grande lona, duas fileiras com imagens reproduzidas do acervo fotográfico e de documentos do acervo documental. Ao todo, são 23 fotografias apresentadas; entre elas: as oficinas da ferrovia; locomotivas da Viação; trabalhadores e artífices ferroviários; pontes; a estação, na década de 20, com táxis charretes estacionadas; e a imagem do primeiro automóvel de São Leopoldo. Não há legendas nas fotos. Por fim, há uma "Linha do tempo de São Leopoldo/Ferrovia", com datas desde a instalação da Real Feitoria do Linho Cânhamo, em 1788, até a extinção da Rede Ferroviária Federal, em 2007.

As logomarcas dos apoiadores e do Museu do Trem aparecem adesivadas em três cubos $^{104}$ de papel, com $50 \mathrm{~cm}$ nas arestas, fundo branco. Os cubos podem ser empilhados um sobre o outro, como um totem, e ser deslocados para diferentes ambientes. Cada um apresenta conteúdo diferente: um traz os apoiadores que realizaram doações; outro, parceiros internos e externos; o último apresenta proposta lúdica, com a impressão de locomotivas, parte da logomarca do Museu. Todos demonstram vínculos com o Museu do Trem, ora através do selo de 35 anos, ora com a logomarca (ver figuras 164 e 165).

\footnotetext{
104 Os cubos de papel foram reaproveitados de atividade desenvolvida pelo SESC São Leopoldo no Museu.
} 

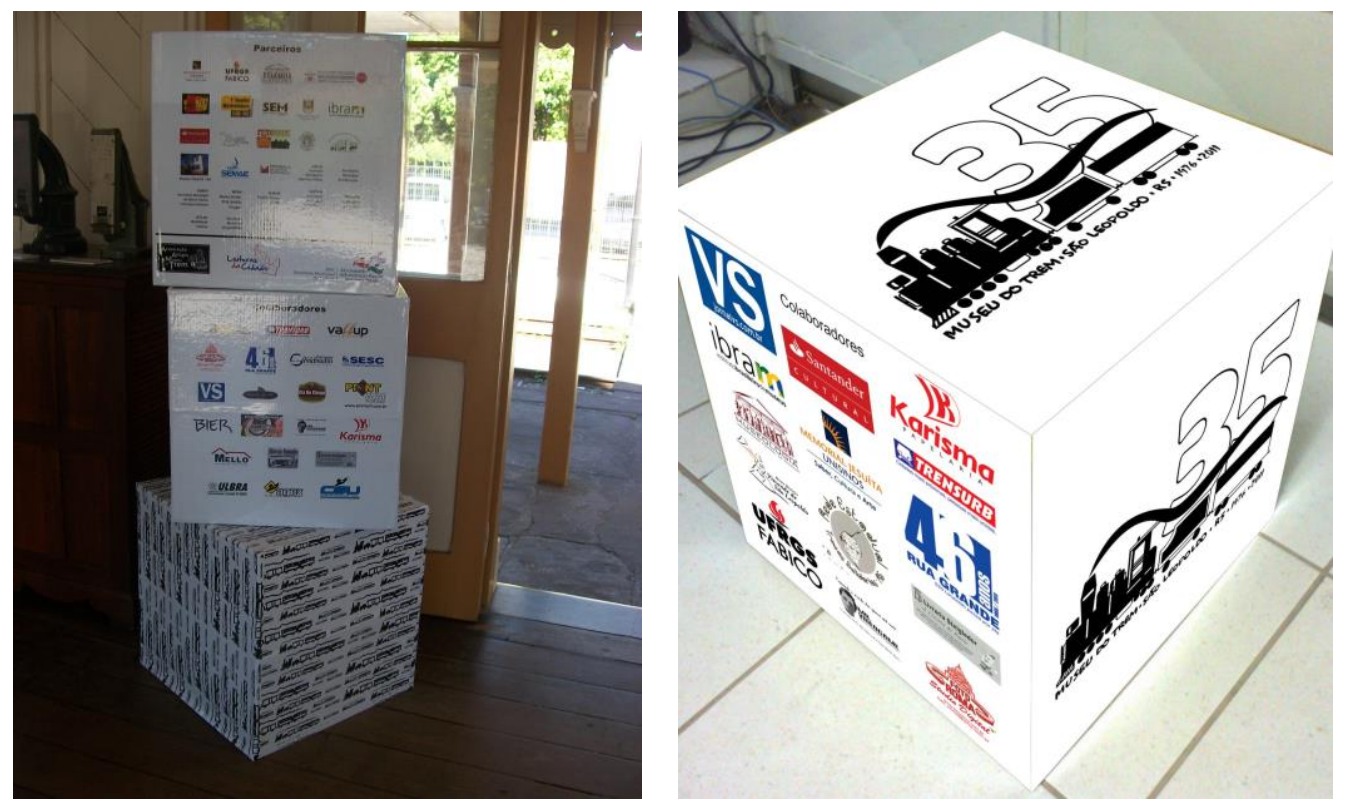

Figuras 164 e 165 - Cubos com logomarca dos apoiadores e selo dos 35 anos do Museu do Trem. Ano: 2011.

Fonte: arquivo digital da autora.

\subsubsection{Objetos lúdicos}

Os objetos lúdicos: quebra-cabeça gigante ${ }^{105}$ de cubos de madeira. São doze peças, cada uma com $23 \mathrm{~cm}$ de aresta, sobre um tablado de madeira. O quebra-cabeça possui imagens de seis locomotivas - fotografias do acervo do Museu - e está disponível para o público dentro da Estação, porém pode ser deslocado para qualquer ambiente.
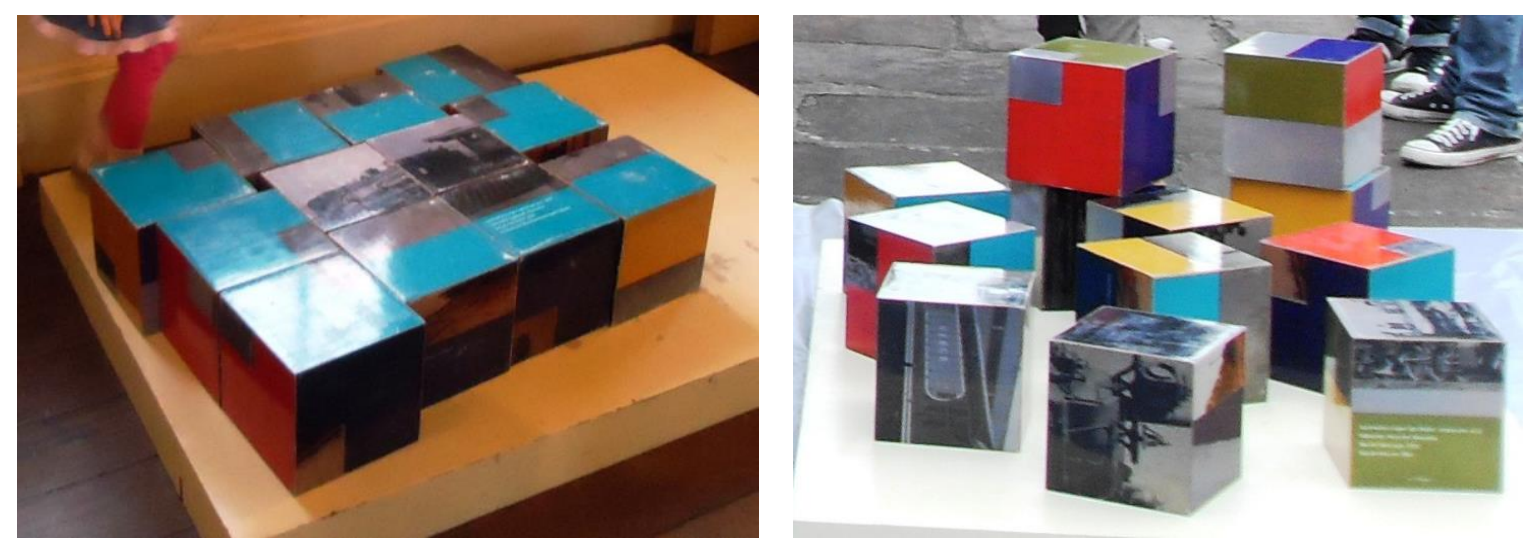

Figuras 166 e 167 - Objeto lúdico: quebra-cabeça sobre o suporte em espaço interno e externo. Ano: 2011. Fonte: arquivo digital da autora.

105 Quebra-cabeça gigante foi resultado da parceria estabelecida com o Memorial do 4ำ Tribunal Regional do Trabalho, de Porto Alegre. 
Observa-se, na exposição, a integração do público com os recursos educativos, tanto o quebra-cabeça gigante, de fácil acesso para as crianças pequenas, quanto as peças do acervo. Com relação às famílias, percebe-se que as crianças e os pais aproveitam quando descobrem o quebra-cabeça, pois muitas vezes ele serve como alternativa para o toque físico com os objetos, considerando que, no interior do prédio da Estação, não é permitido tocar no acervo museológico.
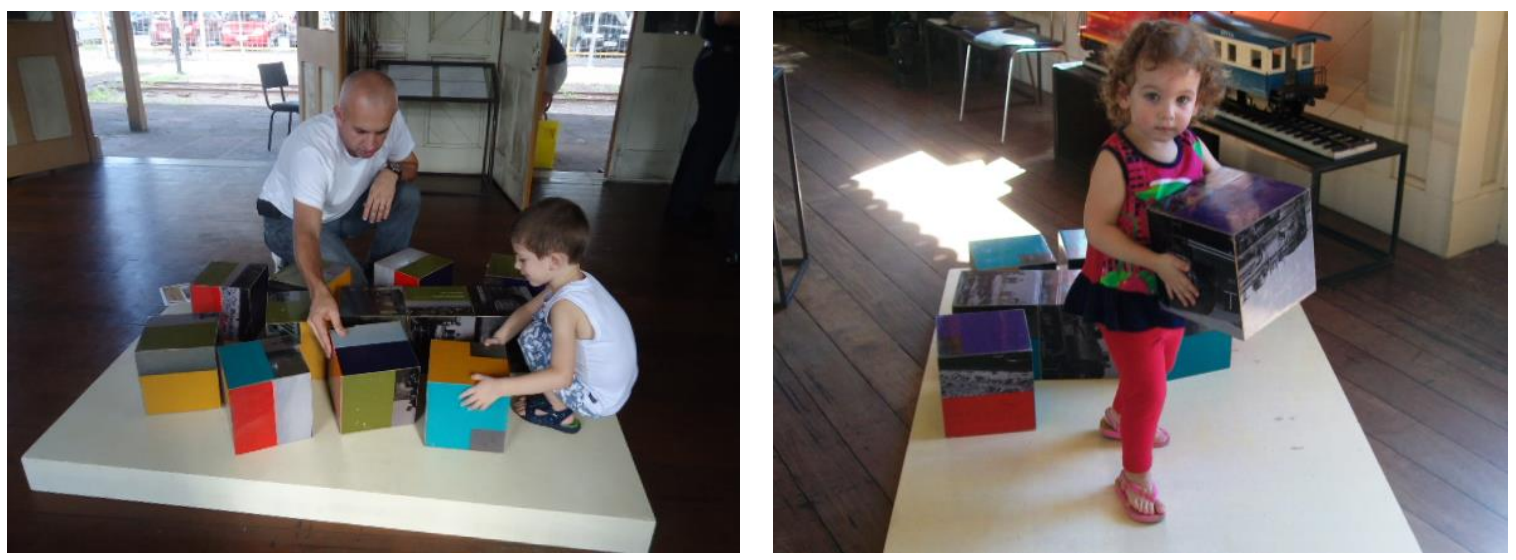

Figuras 168 e 169 - Pai e filho (esquerda) e menina (direita) brincando com quebra-cabeça. Data: jan.2011.

Fonte: arquivo digital da autora.

Caderninho Sinaleira: tamanho $15 \mathrm{~cm} \times 21 \mathrm{~cm}$, folhas plastificadas e encadernadas em espiral, impresso com fonte preta sobre fundo colorido (verde, amarelo, vermelho), com diversos tamanhos e estilo de fontes, sempre em caixa alta, para atingir público em processo de alfabetização. Apresenta informações seguindo a lógica da sinalização de trânsito em semáforos, relacionando o conteúdo à ação de avançar (cor verde), atenção (cor amarela) e parar (cor vermelha). As folhas verdes apresentam texto de introdução a questões relacionadas ao Museu, em especial ao Museu do Trem, e convida o leitor a pensar o museu como uma "caixinha de surpresas" a ser descoberta. As folhas amarelas chamam a atenção para cuidados que o visitante deve ter em relação ao acervo e as vermelhas informam o que é proibido, como por exemplo, comer, entrar com animais, tocar nos objetos e usar flash em fotografias.

O Caderninho Sinaleira é utilizado com objetivo de informar o que pode e o que não pode ser feito dentro do espaço interno da Estação. O mesmo fica disponível ao público sobre um banco de madeira, em frente ao texto de parede. Os estagiários estimulam que as famílias tomem conhecimento do material durante a visita. 

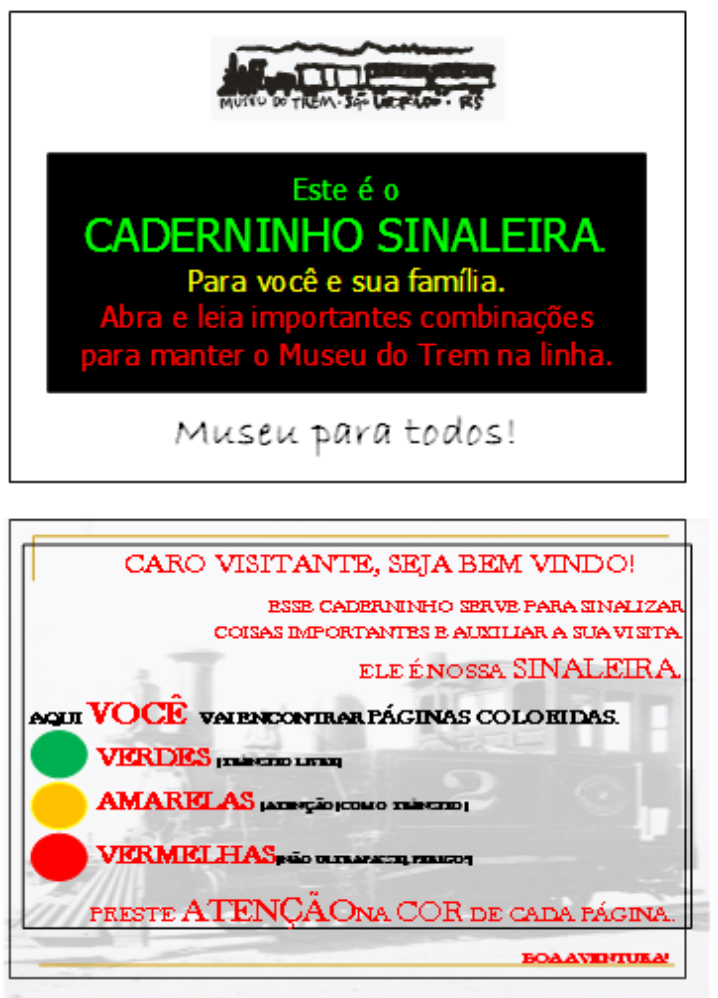

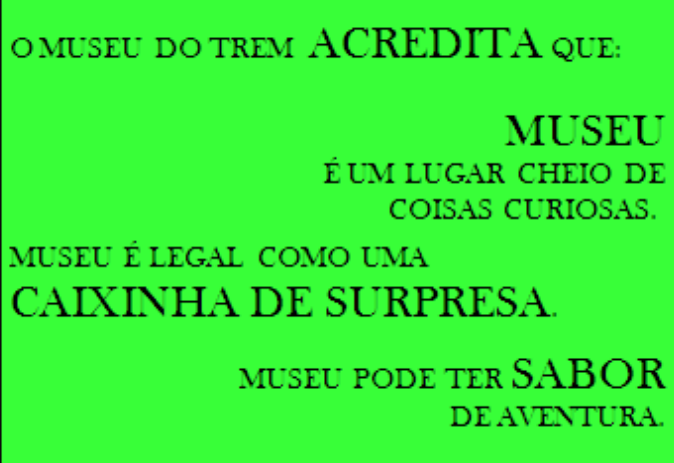

\section{- MUSEU DO TREM TEM}

ACERTO MUSEOLÓGICO TRIDIMENSIONAL (OBJETOS DE MADEIRA, FERRO, BRONZE, TECIDO) ACERVO AO AR LIVRE (I OGOMORDLA GARRODE PASSAGEIRO, BAIANCA, TROLE, ETC) ACERVO ALDIOVISLAL E FOTOGRÁFICO (FILMES DIIRSOS E FOTOGRAFLAS, NEGATNOS DE VIDRO)

ACERVO BIBLIOGRAFICO (LIMROS E REVISTAS)

ACERVO DOCLMENTAL DOCLMENTOS DAXFB.GS I DARERAA

Figura 170 - Caderninho Sinaleira, capa, apresentação, e páginas 01 e 02. Ano: 2011-2. Fonte Arquivo digital da autora.

Painéis móveis de ferro e vidro, utilizados com folhas tamanho $30 \mathrm{~cm} \times 20 \mathrm{~cm}$, impressas com fonte preta, apresentam a trajetória do Museu do Trem de São Leopoldo, desde sua criação, com datas e tópicos dos diferentes períodos. Esses elementos destoam da exposição em si ao abordar um tema que não está nela.

\subsubsection{Exposições temporárias}

Durante o processo das Oficinas de Expografia, foi rearranjado um espaço físico no interior do Armazém, anteriormente utilizado como depósito, que passou a ser aproveitado para exposições temporárias - tanto do acervo próprio, quanto de instituições convidadas - e atividades de formação.

As exposições temporárias que foram montadas no local, na maioria das vezes, culminaram com a programação da Semana Nacional de Museus, realizada pelo Museu do Trem. A citar:

- em 2009, a exposição do processo de restauro das obras de arte, realização do Instituto de Educação da Universidade Federal do Rio Grande do Sul, UFRGS, com curadoria de Nei Vargas da Rosa; 
- em 2010, exposição da vida e obra do Pe. Orestes João Estraglioto, com curadoria do Pe. Édson Thomassim, da Associação de Difusão do Evangelho e Promoção Humana (ADEPH), juntamente com a programação da $2^{a}$ Semana de Museus de São Leopoldo; - em 2012, mostra História do Transporte Rodoviário de Carga no Rio Grande do Sul, com concepção e organização do Sindicato dos Transportes Rodoviários de Carga, tendo a museóloga Cristina Pons como responsável pela pesquisa, também por ocasião da programação da $4^{a}$ Semana de Museus de São Leopoldo.

A exposição temporária com acervo do próprio Museu do Trem apresentava objetos selecionados de atividade específica na via permanente e nas oficinas. Outros objetos, como mobiliário ${ }^{106}$, foram agregados ao local a partir da desativação do seu uso no setor administrativo. Armários de portas de vidro, por exemplo, foram usados para guardar quepes de maquinistas e guarda-chaves, a fim de que não sofressem com deformações e poeira, pois antes eram expostos pendurados em porta chapéus de madeira, com ganchos de ferro e um espelho ao centro e, pela posição desprotegida em que se encontravam, eram manuseados pelo público ${ }^{107}$.

Além das exposições, o local também foi utilizado para formações de professores, reuniões, oficinas, entre outras atividades. A seguir, as exposições realizadas no espaço do Armazém.
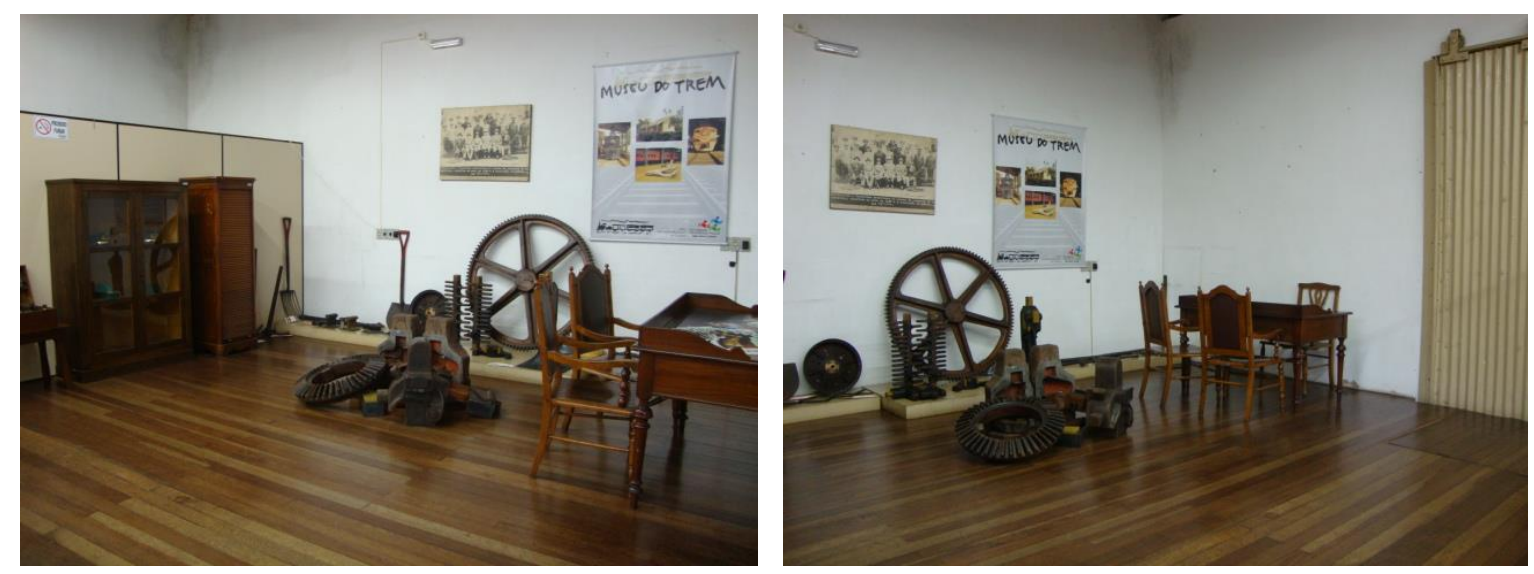

Figuras 171 e 172 - Exposição Temporária com acervo do Museu do Trem no interior do Armazém. Ano: 2010. Fotografia: Rogério Tosca.

Fonte: arquivo digital da autora.

\footnotetext{
106 Mobiliário utilizado pelo setor administrativo do Museu foi deslocado para integrar o acervo tridimensional. 107 Inúmeras vezes foram necessárias intervenções, pois o público experimentava os quepes do acervo, com uma naturalidade de quem está em um provador de loja.
} 

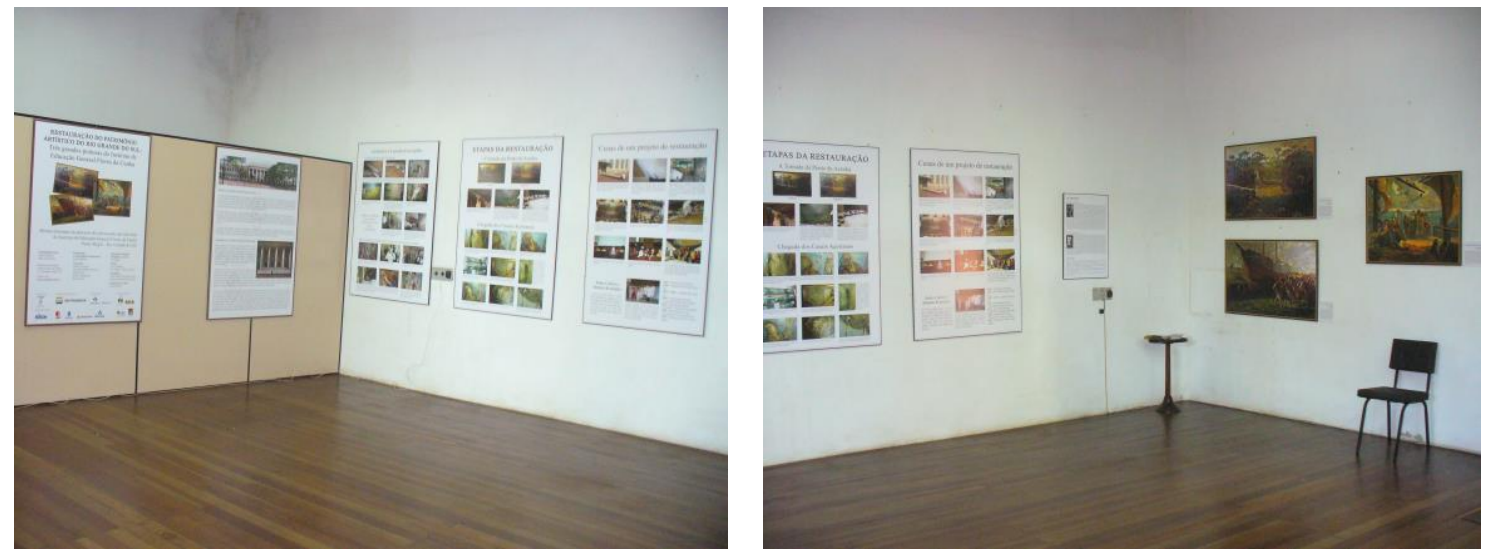

Figuras 173 e 174 - Exposição do Instituto de Educação da UFRGS no interior do Armazém. Ano: 2009. Fotografia: Rogério Tosca. Fonte: arquivo digital da autora.
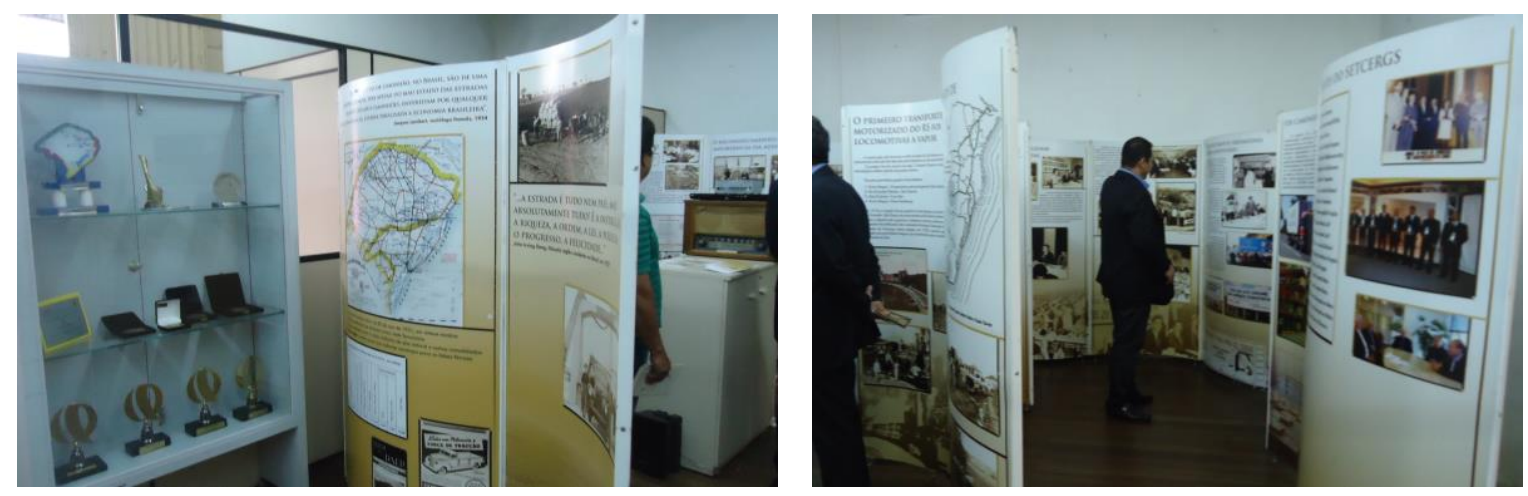

Figuras 175 e 176 - Mostra História do Transporte Rodoviário de Carga do RS no interior do Armazém. Ano: 2012. Fonte: arquivo digital da autora.

\subsubsection{Exposições itinerantes, feiras e eventos externos}

Foram realizadas exposições itinerantes com o acervo selecionado da Reserva Técnica, em parceria com outros órgãos públicos ou Secretarias de Cultura de outros municípios. A exposição mais longa foi na cidade de Portão, tendo como parceiro o Arquivo Histórico Municipal, que permaneceu aberta durante quatro anos, período em que, como contrapartida, foi realizada oficina de conservação de peças de metal do Museu do Trem, ministrada pela historiadora Jussara Prates. Todas as demais exposições para as quais foi emprestado acervo tiveram contrapartida com doações de materiais necessários para a conservação ou com recursos humanos, como assessorias e auxilio técnico. Tais exposições itinerantes são listadas no quadro a seguir: 


\section{Quadro 15 - Relação de exposições externas itinerante e participações em mostras e feiras}

\begin{tabular}{|c|c|c|c|c|}
\hline Atividade & Período & Local & Convênio/parceria & Peças \\
\hline $\begin{array}{l}\text { Exposição Itinerante } \\
\text { no Museu de Portão }\end{array}$ & 2009 a 2012 & $\begin{array}{l}\text { Museu de Portão - } \\
\text { Estação Férrea }\end{array}$ & $\begin{array}{l}\text { Municípios de Portão e } \\
\text { São Leopoldo }\end{array}$ & 155 objetos \\
\hline $\begin{array}{c}\text { Exposição Itinerante: } \\
\text { Nos Trilhos da } \\
\text { Memória }\end{array}$ & $\begin{array}{l}25.06 .2009 \\
\text { até } 2010\end{array}$ & $\begin{array}{c}\text { Saguão do } 4^{\circ} \text { Tribunal } \\
\text { Regional do Trabalho, Av. } \\
\text { Praia de Belas, Porto } \\
\text { Alegre }\end{array}$ & $\begin{array}{l}\text { Memorial do } 4 \text { TRT, } \\
\text { Porto Alegre }\end{array}$ & 112 objetos \\
\hline $\begin{array}{l}\text { São Leopoldo Fest - } \\
\text { Seminário de } \\
\text { Patrimônio }\end{array}$ & $\begin{array}{l}16 \text { a } 27 \text { de } \\
\text { julho } 2009\end{array}$ & $\begin{array}{l}\text { São Leopoldo Fest, no } \\
\text { ginásio Celso Morbach, } \\
\text { São Leopoldo }\end{array}$ & $\begin{array}{l}\text { Secretaria Municipal } \\
\text { de Cultura }\end{array}$ & $\begin{array}{l}\text { Objetos e } \\
\text { banner }\end{array}$ \\
\hline Exposição Itinerante & $\begin{array}{l}\text { Novembro de } \\
2009\end{array}$ & Salvador do Sul & $\begin{array}{l}\text { Prefeitura Salvador do } \\
\text { Sul }\end{array}$ & 44 objetos \\
\hline $\begin{array}{c}\text { Exposição Itinerante: } \\
\text { Nos Trilhos da } \\
\text { Memória }\end{array}$ & 2010 & $\begin{array}{l}\text { Espaço Cultural } \\
\text { Santa Maria }\end{array}$ & $\begin{array}{l}\text { Memorial do } 4 \text { TRT, } \\
\text { Porto Alegre }\end{array}$ & 112 objetos \\
\hline $\begin{array}{c}\text { Feira para } \\
\text { funcionários na } \\
\text { empresa Gerdau }\end{array}$ & 07.07 .2010 & $\begin{array}{l}\text { Empresa Gerdau, } \\
\text { Sapucaia do Sul }\end{array}$ & Empresa Gerdau & 10 objetos \\
\hline $\begin{array}{c}\text { Exposição Coletiva } \\
\text { Tempo }\end{array}$ & 2010 a 2011 & $\begin{array}{l}\text { Museu de Ciências \& } \\
\text { Tecnologia da PUC RS, } \\
\text { Porto Alegre }\end{array}$ & $\begin{array}{l}\text { 1ㄹ Região Museo- } \\
\text { lógica e Museu de } \\
\text { Ciências \& Tecno- } \\
\text { logia da PUC RS }\end{array}$ & $\begin{array}{c}\text { Mini } \\
\text { Locomotiva }\end{array}$ \\
\hline $\begin{array}{c}\text { Exposição/Mostra do } \\
\text { Museu do Trem }\end{array}$ & 2010 & $\begin{array}{c}\text { Fundação Cultural de } \\
\text { Canoas - Estação } \\
\text { Ferroviária }\end{array}$ & $\begin{array}{c}\text { Departamento } \\
\text { Municipal de Cultura } \\
\text { de Canoas }\end{array}$ & $\begin{array}{l}\text { Objetos e } \\
\text { banner }\end{array}$ \\
\hline $\begin{array}{c}\text { Mostra do Museu do } \\
\text { Trem }\end{array}$ & $\begin{array}{l}\text { Outubro de } \\
2010\end{array}$ & $\begin{array}{l}\text { Ginásio Celso Morback, } \\
\text { São Leopoldo }\end{array}$ & $\begin{array}{l}\text { Congresso de Educação, } \\
\text { organização Secretaria } \\
\text { Municipal de Educação }\end{array}$ & 5 banners \\
\hline $\begin{array}{c}\text { Exposição de Objeto } \\
\text { do Museu do Trem }\end{array}$ & $\begin{array}{c}09 \text { a } 27 \text { de } \\
\text { maio de } 2012\end{array}$ & $\begin{array}{l}\text { Saguão da Biblioteca } \\
\text { Pública - Centro Cultural } \\
\text { José Pedro Boéssio }\end{array}$ & $\begin{array}{c}\text { Secretaria Municipal } \\
\text { de Cultura de São } \\
\text { Leopoldo }\end{array}$ & $\begin{array}{c}\text { Mini } \\
\text { Locomotiva }\end{array}$ \\
\hline $\begin{array}{c}\text { Exposição Itinerante } \\
\text { Nos Trilhos da } \\
\text { Memória }\end{array}$ & Maio 2011 & $\begin{array}{l}\text { Saguão da Prefeitura } \\
\text { Municipal de São } \\
\text { Leopoldo }\end{array}$ & $\begin{array}{l}\text { Memorial do } 4^{\circ} \text { TRT, } \\
\text { Porto Alegre }\end{array}$ & 112 objetos \\
\hline $\begin{array}{l}\text { Exposição de } \\
\text { Banners }\end{array}$ & $\begin{array}{l}\text { Maio e junho } \\
2011\end{array}$ & $\begin{array}{l}\text { Restaurante Caçarola, } \\
\text { Centro, São Leopoldo }\end{array}$ & Restaurante Caçarola & 5 banners \\
\hline $\begin{array}{l}\text { Exposição Mostra do } \\
\text { Museu do Trem }\end{array}$ & $\begin{array}{c}02.11 .2011 \text { ou } \\
2012 ?\end{array}$ & $\begin{array}{c}\text { Parque Ecumênico, São } \\
\text { Leopoldo }\end{array}$ & Parque Ecumênico & $\begin{array}{l}\text { Objetos e } \\
\text { banners }\end{array}$ \\
\hline
\end{tabular}

Fonte: elaborado pela autora. 

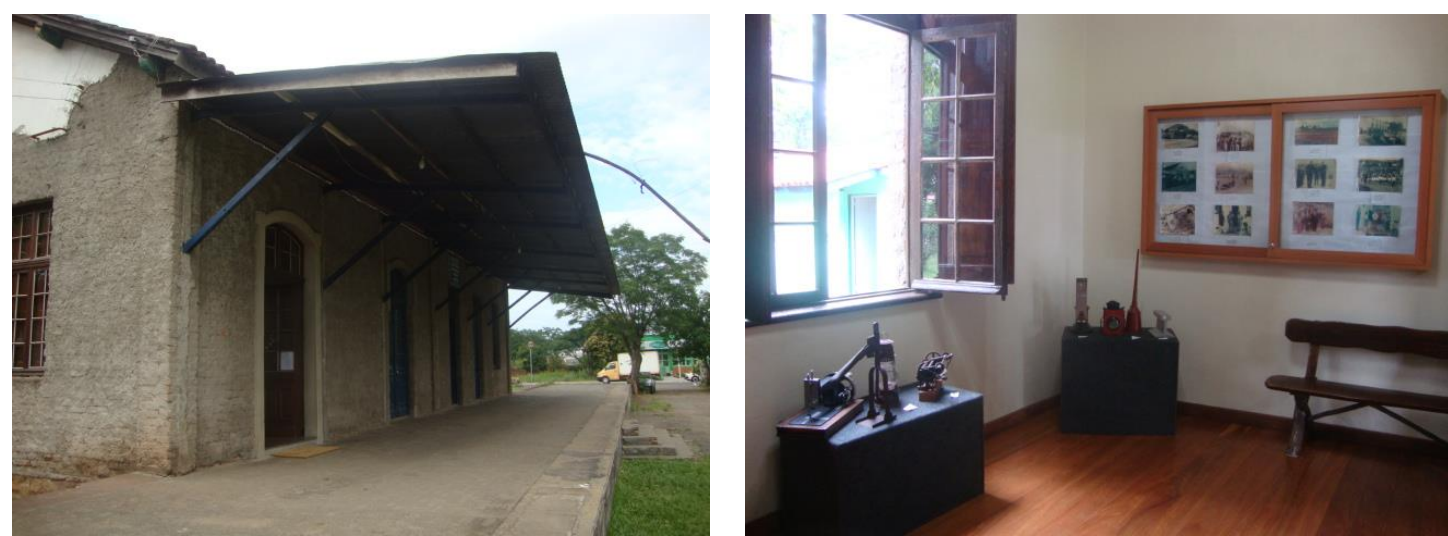

Figuras 177 e 178 - Museu de Portão, na Estação Ferroviária, vista frontal, e Exposição Itinerante do Museu do Trem no interior do prédio da Estação de Portão. Ano: 2009 a 2012.

Fonte: arquivo digital da autora.

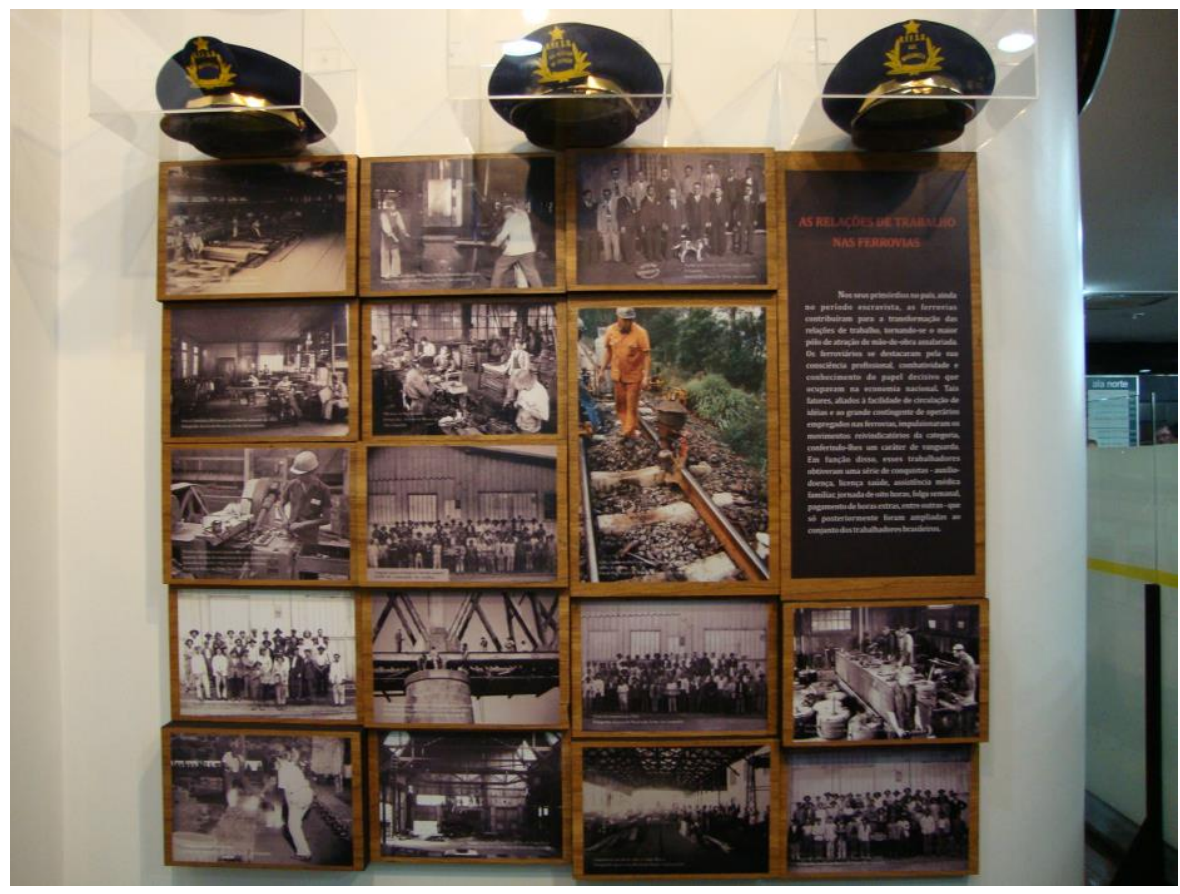

Figura 179 - Exposição Itinerante do Museu do Trem nos Trilhos da Memória, no Memorial do 4ํTRT. Ano: 2009.

Fonte: arquivo digital da autora.
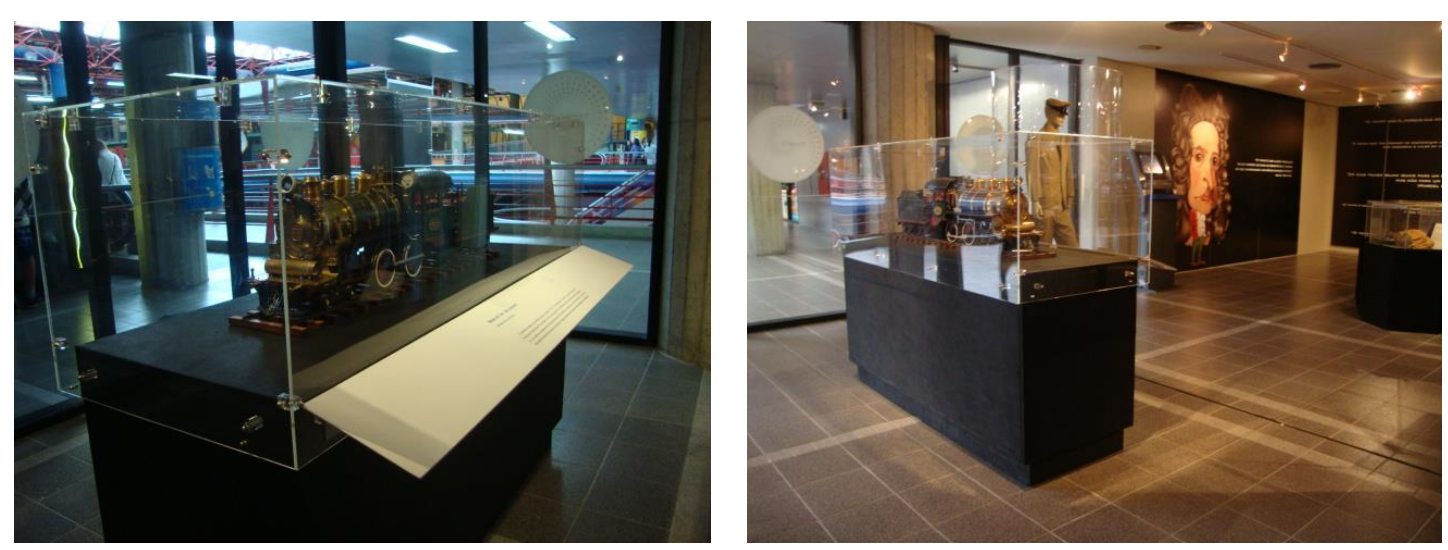

Figuras 180 e 181 - Mini locomotiva na Exposição Itinerante "Tempo", Museu C\&T PUC RS (Porto Alegre). Ano: 2010.

Fonte: arquivo digital da autora. 

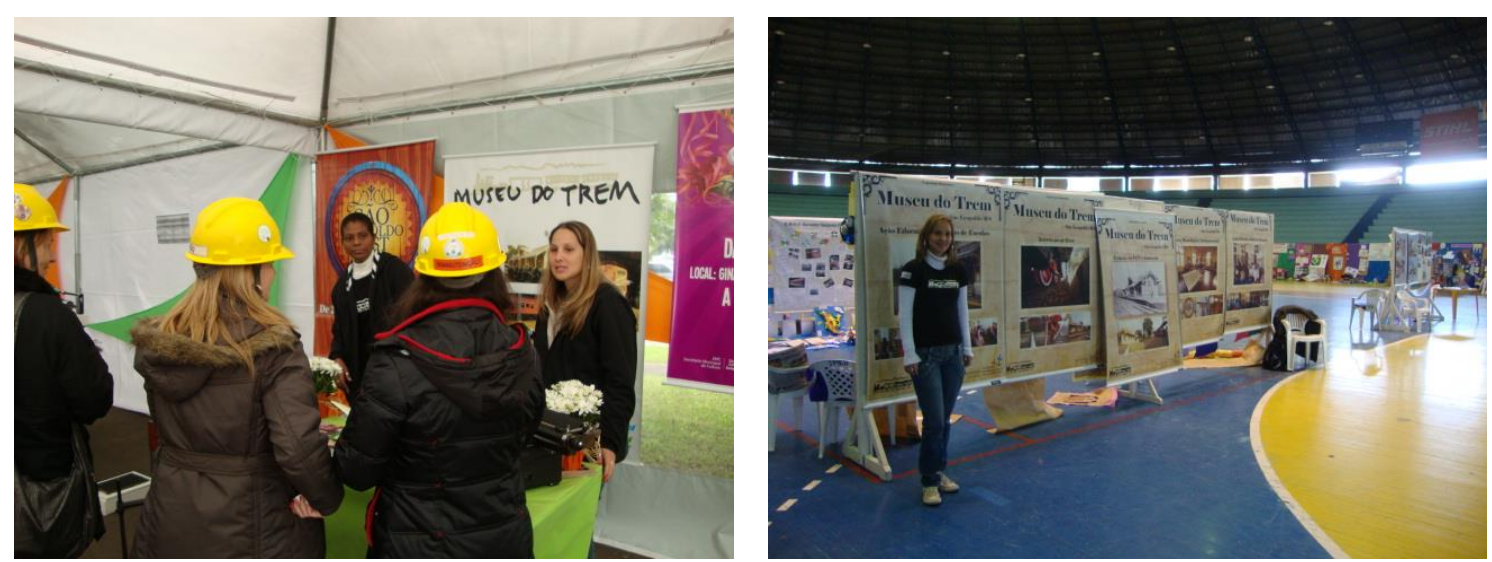

Fig. 182 e 183 - Participação do Museu do Trem na Feira na Empresa Gerdau (Esteio). Ano: 2010, e participação na Feira do Congresso de Educação (São Leopoldo). Data: 16.10.2010.

Fonte: arquivo digital da autora.

\subsection{EXPERIMENTANDO UM MUSEU}

\subsubsection{O trabalho coletivo no educativo}

O Museu do Trem instituiu um Programa de Ação Educativa, a fim de fomentar a compreensão do museu, em sua função social, como lugar de saber que oferece às escolas condições de ampliar as relações de troca e produção de novos saberes - saberes estes integrados com as disciplinas curriculares.

Na concepção de "museu para todos", o Programa de Ação Educativa estrutura a concepção do espaço museológico como ambiente de ensino/ aprendizagem, envolvendo, desse modo, as diversas áreas do conhecimento, com o propósito de ampliar as relações entre a educação e a cultura. Essa percepção ainda acrescenta a oportunidade de lazer e fortalece a manifestação das identidades da comunidade local, assim como a percepção crítica e reflexiva da contemporaneidade, na promoção da dignidade humana.

Os itens relacionados ao Programa de Ação Educativa são: atendimento de escolares; programa de visitação para terceira idade; Museu Inclusivo; Oficina de Patrimônio para crianças; encontro de formação de professores; oficinas de conservação de peças em metal; oficinas de ferromodelismo; Roda de Memória; Semana de Museus; curso de formação de mediadores e o Projeto de Férias de inverno e verão.

O Programa de Ação Educativa também envolveu a equipe do Museu através de capacitações e formações continuadas. A equipe participou do processo como peça-chave no exercício da prática museológica, do ponto de vista de museu como espaço de construção de saberes (BEMVENUTI, 2008) - relacionados à pesquisa histórica, a partir do tema do Museu, porém, prioritariamente saberes construídos a partir da participação. 
As atividades de estudo, capacitação e formação continuada estiveram em constante movimento, articulando outros setores. Os encontros com objetivo de nutrir (MARTINS, 1992) a equipe, também impulsionava a participação da mesma como protagonista. A metodologia, pautada nos Instrumentos Metodológicos ${ }^{108}$, utilizou o registro escrito como meio para observação, reflexão, planejamento, avaliação e replanejamento. A prática sistematizada dos registros escritos foi determinada pelos objetivos:

- registrar as atividades desenvolvidas, a fim de capturar informações sobre a memória da instituição museal;

- registrar as atividades a partir de um ponto de vista do observador, evidenciando especificidades do integrante inserido em um determinado setor do museu;

- estimular a prática da escrita como reflexão individual;

- socializar questões específicas de atividades desenvolvidas, a fim de provocar identificação entre os pares;

- reconhecer, na prática desenvolvida, questões referentes à museologia;

- fortalecer o grupo, a partir desta metodologia de prática, registro, reflexão e replanejamento;

- desafiar o grupo a experimentar-se, individual e coletivamente, como centro das escolhas e atitudes que formaria uma prática ativa no museu;

- criar instrumentos de avaliação para a gestão;

- ampliar canais de comunicação com a direção;

- estimular a pesquisa de temas a serem estudados, pesquisados e propostos para abordagem com o público;

Um extenso material escrito decorreu dos registros dessa prática. Dentre eles, é possível identificar relatos dos Cursos de Verão, de atividades externas, participação em cursos, Semana de Museu, relatos de Rodas de Memória, da confecção de materiais, planejamentos, observações de prática de $\operatorname{colegas}^{109}$, reflexões, relatos da recepção de escolas e grupos diversos e de reuniões administrativo-pedagógicas. Também se identifica registro de projetos de curso e de oficinas.

\footnotetext{
108 Instrumentos Metodológicos I e II, escritos por Madalena Freire, Mirian Celeste Martins, Juliana Davini e Fátima Camargo, foram explorados no Capítulo 3 desta dissertação.

109 As observações das práticas dos colegas foram sistematizadas a partir de P.O (Pontos de Observação), fundamentados na experiência da autora com Mirian Celeste Martins e Madalena Freire.
} 
Os registros realizados retroalimentaram as reflexões e a aquisição de conhecimento por parte da equipe. Ao longo dos quatro anos de gestão, a utilização desse instrumento metodológico nas práticas da equipe garantiu o amadurecimento e inúmeros desdobramentos na prática museológica.

Também foi desenvolvido formulário de registro dos finais de semana, no qual as anotações eram sistematizadas por padrão, obedecendo a outra lógica.

Tanto os registros sistematizados de modo escrito, quanto os instrumentos de avaliação, sugerem novo problemas para pesquisa acadêmica que poderão ser aprofundadas futuramente.

\title{
5.3.2 Atendimento ao público
}

Não basta que os museus estejam abertos a todos: é preciso possibilitar o acesso aos bens culturais, ampliar a experimentação do campo museológico, envolvendo o processo curatorial, a participação do público e a ressignificação cultural do próprio museu (CURY, 2014).

Segundo Jesús Martin-Barbero, a recepção não é somente uma etapa do processo de comunicação. Nesse sentido, o autor chama a atenção para a confusão epistemológica:

\begin{abstract}
Estaríamos confundindo, permanentemente, a significação da mensagem com o sentido do processo e o das práticas de comunicação, como também reduzindo o sentido dessas práticas na vida das pessoas ao significado que veicula a mensagem. Seria entender todo o processo com base nesse significado, no qual se encontram as intenções do emissor e suas expectativas quanto ao receptor que o espera. (BARBERO, 2009:40)
\end{abstract}

$\mathrm{Na}$ identificação dos objetos, dos textos e das interações que o público poderia fazer com o acervo na exposição de longa duração do Museu do Trem, foi possível compreender o complexo universo de elementos em um mesmo espaço e verificar como alguns deles reforçam a tipologia do museu temático, essencialmente histórico, que, de alguma maneira, reforça o que Ulpiano de Bezerra Meneses chama de vinculação com os fatos memoráveis da história.

Segundo a tipologia museológica acima discutida, concebe-se correntemente o museu histórico como aquele que opera com objetos históricos. Se, contudo, é a dimensão do conhecimento que sobe à tona, é preciso retificar e dizer, como vimos, que o museu histórico deve operar 
com problemas históricos, isto é, problemas que dizem respeito à dinâmica na vida das sociedades (MENESES, 1993:20).

A exposição, ao ser concebida, demonstra a necessidade de discutir a permanência da temática e a exposição de um discurso que enaltece o objeto histórico, ou seja, a exposição oferece ao público relíquias para serem admiradas, ao invés de "articular enunciados sobre certos problemas humanos, desenvolvidos com o suporte das coisas materiais", como afirma Meneses (1993:37).

Com efeito, o artefato neutro, asséptico é ilusão, pelas múltiplas malhas de mediações internos e externos que o envolvem, no museu, desde os processos, sistemas e motivos de seleção (na coleta, nas diversificadas utilizações), passando pelos classificações, arranjos, combinações e disposições que tecem o exposição, até o caldo de cultura, as expectativas e valores dos visitantes e os referenciais dos meios de comunicação de massa, a doxa e os critérios epistemológicos na moda, sem esquecer aqueles dos instituições que atuam na área, etc. etc (MENESES, 1993:20).

Ao observar a visita de escolas, é possível verificar a metodologia desenvolvida. Seguindo um roteiro planejado, estagiários organizam as crianças sentadas no chão, em um círculo, e se apresentam, fazendo as combinações de como ver a exposição. São utilizados recursos pedagógicos desenvolvidos pelo Museu, entre eles as palavras ${ }^{110}$ impressas em folhas coloridas e plastificadas.

110 Recurso Pedagógico que destaca as seguintes palavras: MUSEU, PRESERVAÇÃO, TREM, HIGIENIZAÇÃO, CONSERVAÇÃO, MAC GINITY, CONCESSÃO, MEMÓRIA, HISTÓRIA, PRESERVAÇÃO. 


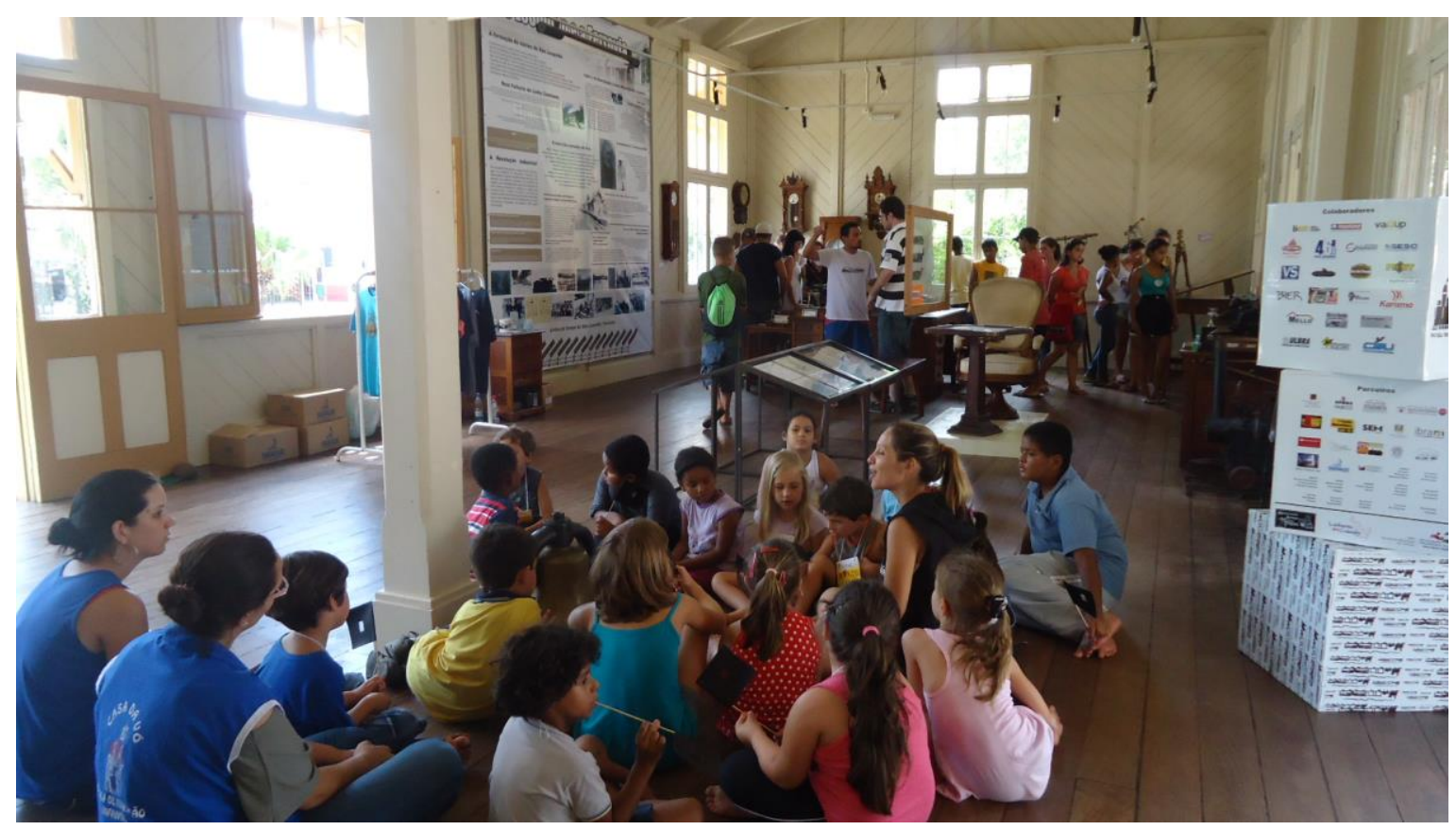

Figura 184 - Visita de escolares na exposição de longa duração. Ano: 2011. Fonte: arquivo digital da autora.
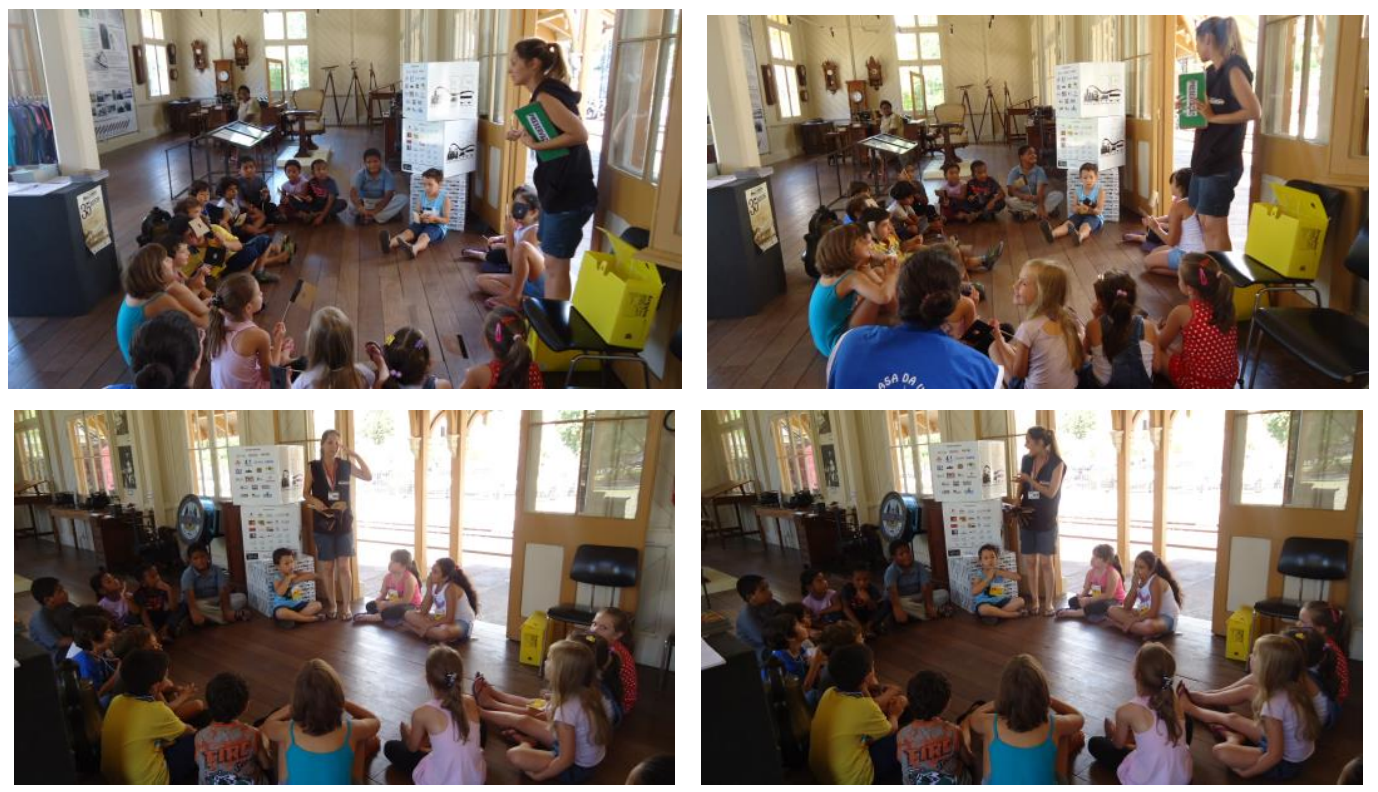

Figuras 185, 186, 187 e 188 - Visita de escolares e recepção da equipe do Setor Educativo em atividade com uso de recursos pedagógicos. Ano: 2011. Fonte: arquivo digital da autora. 

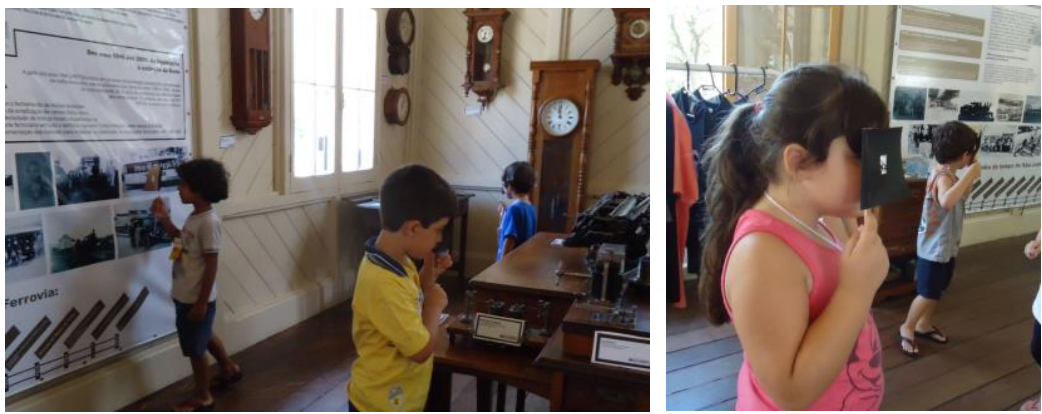

Figuras 189 e 190 - Crianças em atividade na exposição com material confeccionado pelo Setor Educativo. Ano: 2011. Fonte: arquivo digital da autora.
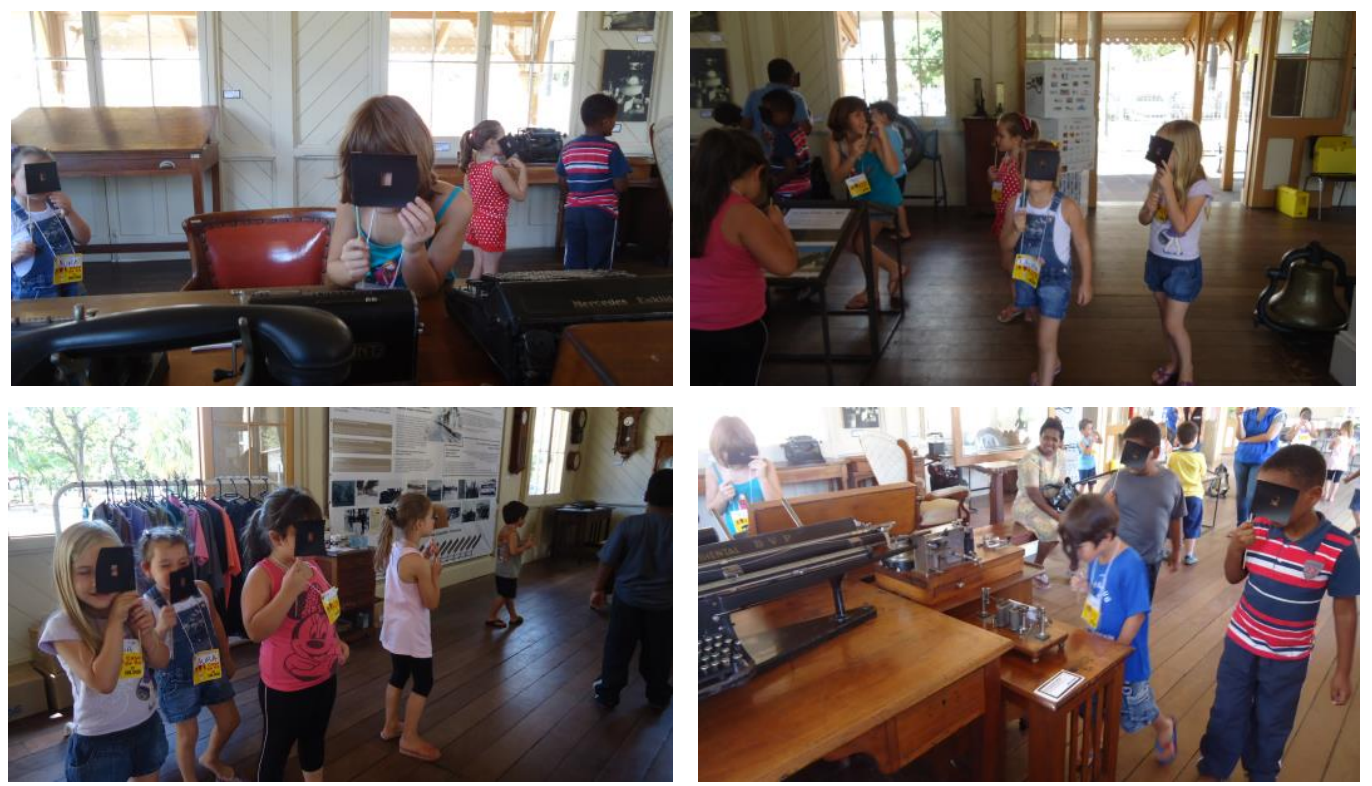

Figuras 191, 192, 193 e 194 - Crianças em atividade de exploração da exposição utilizando recursos pedagógico. Ano: 2011.

Fonte: arquivo digital da autora

Compreender "o museu para todos" exige pensar a perspectiva do público e em como acolher diferentes interesses e necessidades do público no Museu. É preciso ampliar horários e oferecer diferentes narrativas fundamentadas nos fatos históricos, mas também é preciso planejar a recepção de grupos com outras necessidades. O Museu do Trem, através do Projeto Museu Inclusivo, coordenado pela educadora Cláudia KochJonhstone ${ }^{111}$, capacitou estagiários para atendimento de grupos com sindrômicos, com surdos e com cegos ${ }^{112}$.

111 A educadora responsável pelo Projeto Museu Inclusivo é alfabetizadora de surdo.

112 Como referencial para atividades, também foi utilizada a pesquisa de Amanda Tojal, no MAC USP. 

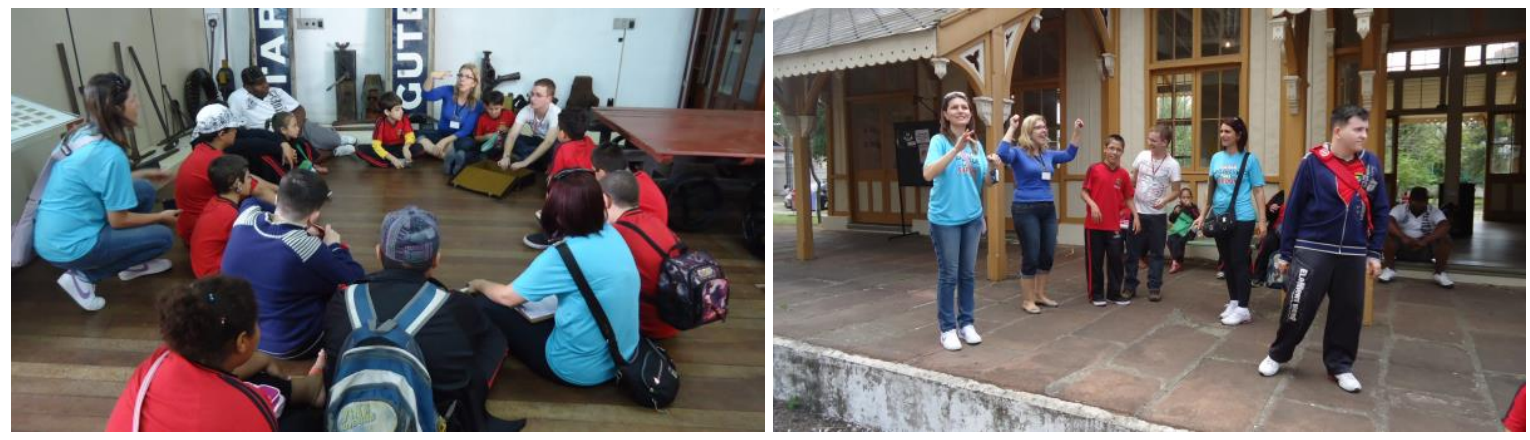

Figuras 195 e 196 - Atividade com crianças surdas e sindrômicas, da Escola Cruz Vermelha, de São Leopoldo. A esquerda no interior do Armazém, à direita, na plataforma. Ano: 2011.

Fonte: arquivo digital da autora
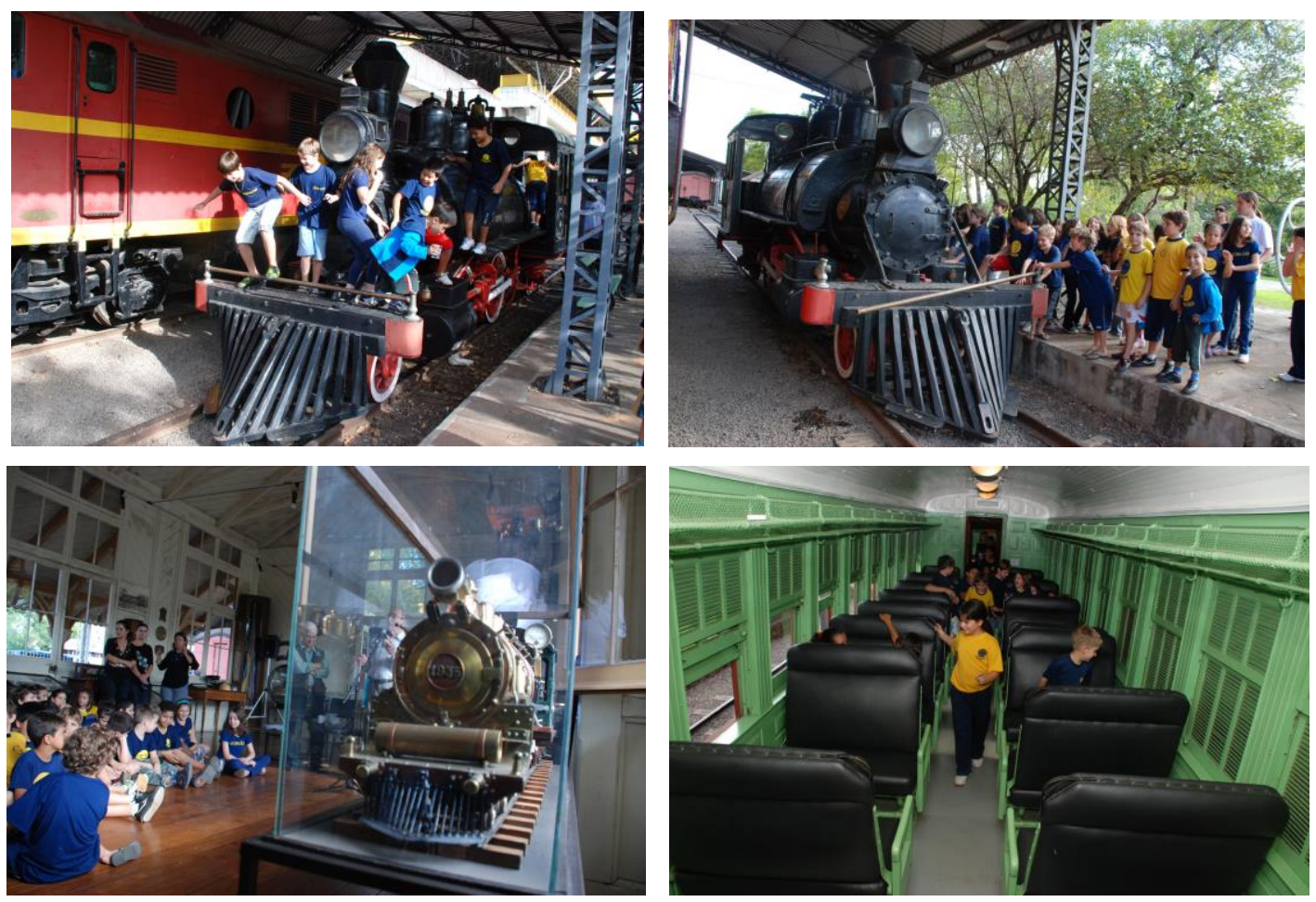

Figuras 197, 198, 199 e 200 - Crianças da Escola Municipal Gusmão Maria Brito, de São Leopoldo, em atividade educativa com momentos de caminhada no pátio, conversa na antiga Estação e visitação no interior dos carros de passageiros. Data: 30 abr 2009. Fotógrafo: Thiago.

Fonte: arquivo Jornal Vale dos Sinos.

Segundo Chagas (2002), as relações estabelecidas no espaço museológico podem reforçar a compreensão de um trabalho paternalista com o patrimônio cultural, confirmando ainda a existência de procedimentos autoritários. Para o museólogo:

...o patrimônio nacional (ou da Pátria) é então apresentado como um dado inquestionável, como em ente natural, despolitizado e possuidor de essência sagrada. Apenas alguns patrícios eleitos saberiam dizer e identificar o que é o patrimônio cultural e nacional (CHAGAS, 2002:19).

Este ponto provoca pensar o modo como é realizada a aproximação com o museu, a forma como os indivíduos se apropriam das informações oferecidas, enfatizando as questões de reconhecimento do objeto museológico como documento. Destaca que um 
objeto não nasce documento, e sim torna-se a partir de sua utilização, adquirindo, então, uma função representacional.

\begin{abstract}
...um documento só se constitui no momento que lanço o meu olhar interrogativo sobre a coisa e pergunto o seu nome, de que matéria-prima é constituída, quando e onde foi feita, qual seu autor [...] o importante é compreender que uma coisa ou objeto só se transforma em bem cultural quando alguém (indivíduo ou coletivo) por ato de vontade afirma, descreve e garante a sua passagem simbólica para uma nova condição. A constituição do bem cultural implica um processo de atribuição voluntária e significados e valores (CHAGAS, 2002:24).
\end{abstract}

Chagas nos remete à participação do visitante, menciona o exercício investigativo diante do objeto, de maneira a gerarmos, a partir de então um movimento de comunicação vinculado ao objeto, principalmente com relação à existência do museu e de suas coleções a partir do olhar do público.
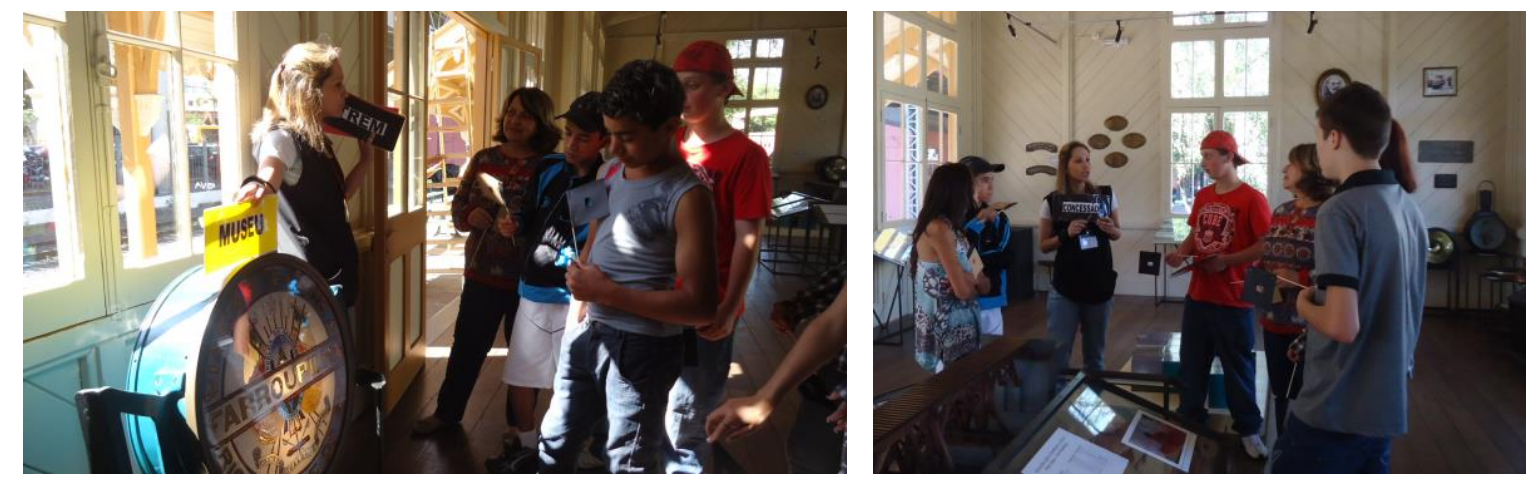

Figura 201 e 202 - Recepção de jovens com atividade e uso de material pedagógico. Data: 25.11.2011. Fonte: arquivo digital da autora.
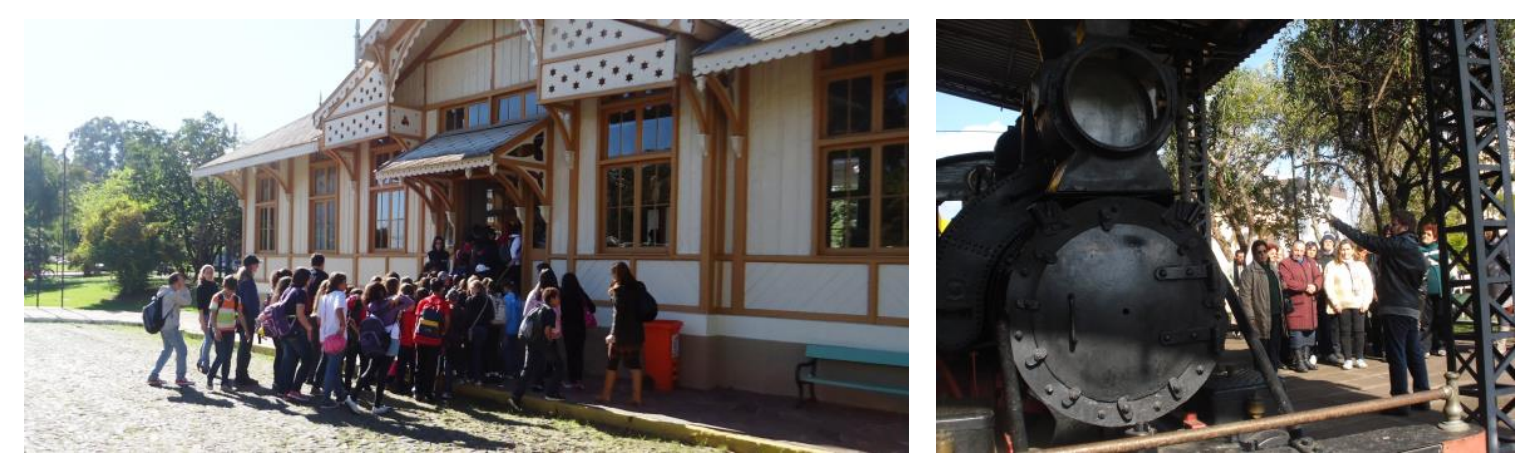

Figuras 203 e 204 - Visita de escolares (esquerda) e recepção de Grupo de 3ª Idade (direita). Ano: 2012. Fonte: arquivo digital da autora.

A práxis comunicacional exige um pensar sobre o todo do museu; exige compreender museu como atividade meio e atividade fim (CURY, 2005), responsável pela comunicação de uma herança cultural. E comunica "tanto mais for um lugar de emaravilhamento, de encontro e de reflexão, de criatividade e de aprendizagem, deixando assim de se desenharem como meros repositórios" (SEMEDO, 2013:53). 
O Museu do Trem planeja a recepção dos diferentes grupos com atenção aos diversos aspectos que envolvem desde o agendamento.

Para muitos, o museu ainda reserva o ranço de um lugar de coisas velhas, sem funcionalidade, com cheiro de mofo, porém, diferente disto, o museu é cheio de possibilidades que apenas poderão ser reveladas no encontro significativo com o objeto e com o que ele representa, cabendo a educação a descoberta do patrimônio aproximando gerações.

O Programa de Ação Educativa do Museu do Trem investe em qualificar a relação com os escolares, com os pesquisadores, com as famílias leopoldenses e com os turistas, ofertando atividades convidando o visitante a aventurar-se como aprendiz.

Para que o encontro entre gerações ocorra, é preciso amorosidade. Hoje temos ciência que o vínculo afetivo é uma porta para a aprendizagem, assim, fica o convite para netos e avós, pais, mães e filhos, professores e alunos, curiosos e amigos, experimentarem no Museu um novo olhar sobre o objeto histórico exposto, compreendendo nossa coleção como patrimônio a ser desvelado (BEMVENUTI, 2009:04).

Conforme artigo publicado ${ }^{113}$ pela diretora, a visita ao Museu pode ser definida como uma aventura. Durante a recepção do público o Museu do Trem realiza e experimenta, junto com os visitantes, o momento do encontro com tudo aquilo para o qual se preparou. É na recepção do público que a equipe coloca em prática os conceitos e as práticas estudas, planejadas e (re)planejadas e desfruta da vivência.

\subsubsection{Na relação com outros museus da cidade}

A Secretaria Municipal de Cultura, através do Museu do Trem, encabeça uma aproximação entre os museus da cidade. Inicialmente com a identificação e localização de cada um. Entre os museus identificados foram incluídos museus públicos e privados de diferentes tipologias: museu histórico, museu comunitário, museu universitário, museu escolar, além acervos salvaguardados por instituições religiosas e ponto de memória.

Em parceria, o Museu do Trem organiza quatro edições da Semana de Museus de São Leopoldo dentro da programação da Semana Nacional de Museus. Cada instituição responsável pelas suas atividades, sendo o Museu do Trem propositor de mesas redondas e painéis incluindo diferentes museus e também museus de outras cidades, a fim de apresentarem pesquisas e relatos de experiência.

113 Publicação local no Jornal Vale dos Sinos. 

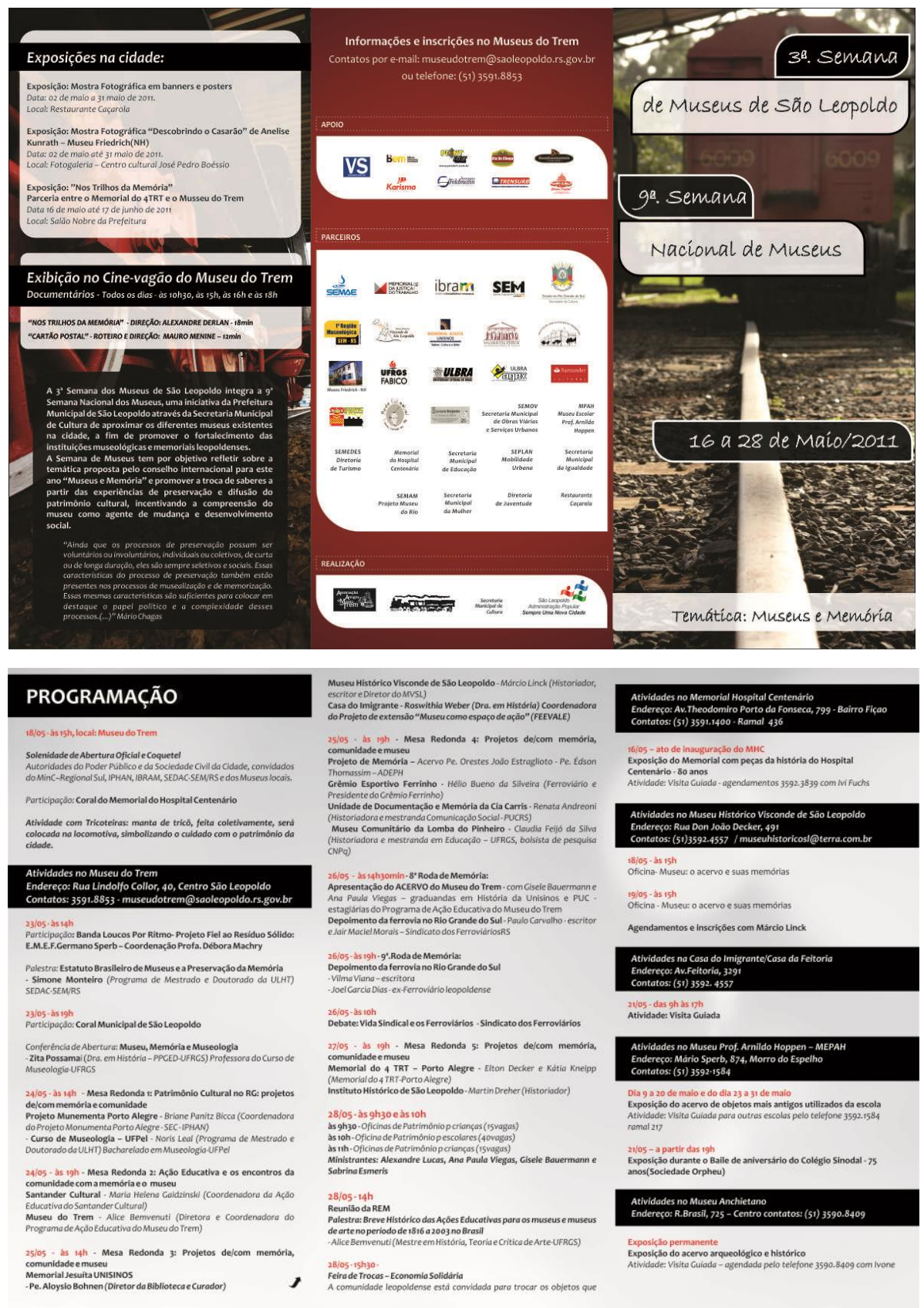

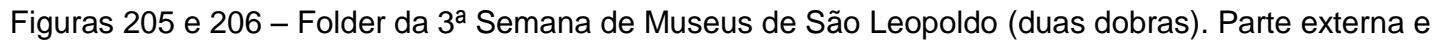
interna. Ano: 2011.

Fonte: arquivo digital da autora.

Em especial, com relação aproximação entre os museus da cidade, foi identificada reunião-almoço, realizada em 17 de junho de 2011 na Sociedade Orpheu, após a

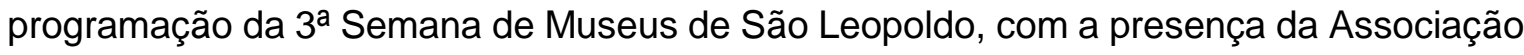
de Amigos do Museus do Trem (AAMT). Entre os Museus presentes, localizou-se representantes das seguintes instituições: Museu Escolar Prof.Arnildo Hoppen (Colégio Sinodal), Memorial do Hospital Centenário, Museu de Arqueologia (Instituto Anchietano de Pesquisa), Memorial Jesuíta - Acervo de Obras Raras e Especiais (UNISINOS), Museu Histórico Visconde São Leopoldo, Projeto do Memorial Pe.Orestes. Também identificada presença de parceiros institucionais, empresas e o Programa de Pós-Graduação de 
História (UNISINOS), além da presença da equipe do Museu do Trem e de membros da Secretaria Municipal de Cultura. Outros museus identificados na programação da Semana de Museus não se fizeram presentes na reunião-almoço.

Conforme Relatório da 3롤 Semana, a iniciativa a reunião tinha como objetivo inicial avaliar a Semana e ampliar a participação dos museus, assim como fortalecer vínculos e discutir a possibilidade da criação de um sistema municipal de museus. A avaliação do evento resulta em uma programação mais qualificada e diversificada da $4^{\text {a }}$ Semana de Museus de São Leopoldo, em 2012. Quanto a discussão de um Sistema Municipal de Museus, não houve avanços. 


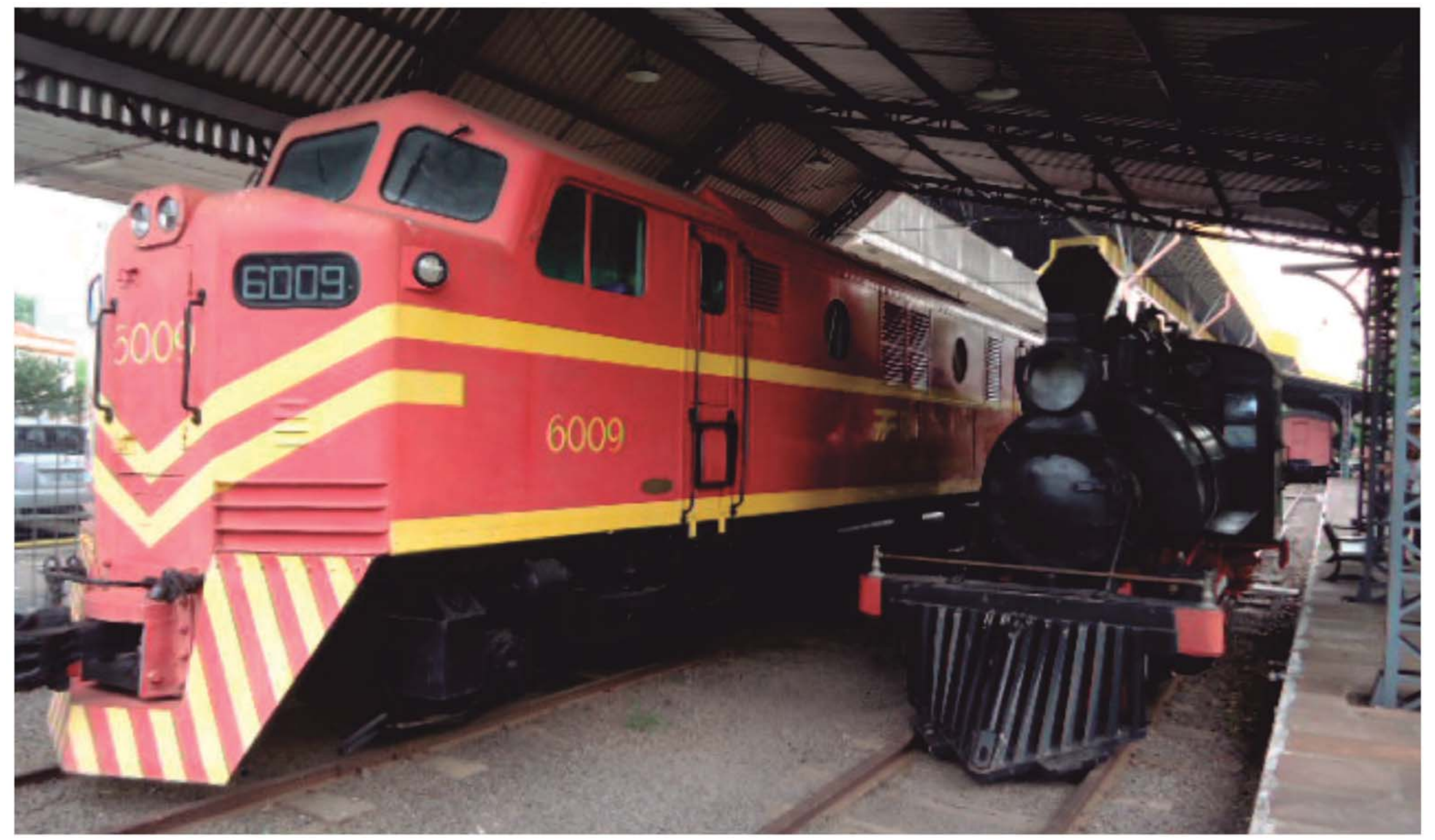

Capítulo 6

GESTÃO DE MUSEU, COMUNICAÇÃO E PÚBLICO 
Breve relato histórico da ferrovia, aspectos relacionados ao patrimônio industrial ferroviário e sua preservação (Capitulo 1); relato histórico e dos processos museológicos e panorama dos museus ferroviários brasileiros (Capitulo 2); relato histórico do Museu do Trem de São Leopoldo (Capítulo 3); dados empíricos da realidade gaúcha, através de um minucioso detalhamento das ações desdobradas na gestão do Museu do Trem e no campo comunicacional (Capítulos 4 e 5), são arcabouço do capítulo a seguir que realiza uma abordagem reflexiva sobre gestão e museus ferroviários. 


\subsection{ABORDAGEM REFLEXIVA}

Dados apresentados até o momento, nesta dissertação, possibilitam que retornemos às inquietações que deram origem à pesquisa, apresentadas na Introdução:

1. Em que medida a gestão no museu garante e impulsiona a relação entre museu/política/comunicação/público?

2. Em que medida a gestão de museu compreende a aproximação entre público-objetomuseu e proporciona uma experiência para o público?

3. Em que medida os princípios da comunicação museológica e da educação permitem desenvolver uma gestão de qualidade?

As questões elencadas movimentam o pensar sobre vários aspectos em diversas direções, mas aqui destaca-se três pontos disparadores.

- museu/política/comunicação/público (concepção).

- público-objeto-museu e a experiência do público (comunicação).

- princípios da comunicação e da educação e implicações da gestão (execução).

Os tópicos apontados como disparadores serão abordados não com a pretensão de esgotar o tema, mas conduzir a uma reflexão acerca dos aspectos relacionados a gestão de museu, processos comunicacionais e objeto ferroviário musealizado.

Em primeiro lugar, sobre a relação implícita e explicita entre museu/política/ comunicação/público sugerindo a composição de parte de um todo, como um sistema imbricado de ações integradas e relacionadas, fundamental para a existência da instituição, que por sua vez "se trata de um estabelecimento que tem um propósito a longo prazo" (SEMEDO, 2005:309), necessitando deste modo identificar a serviço do quê, para quê, e, para quem?

Entre as ações elencadas na prática do Museu do Trem é possível identificar aquelas que possuem essa preocupação. Neste caso, e não menos importante, refletir se o que se está realizando neste cenário que abrange o museu, numa ação reprodutora ou criadora. E, com clareza de os propósitos, a missão e os objetivos dessa instituição.

Estabelecer uma missão pressupõe avaliar potencial institucional e o mercado vigente. Tarefas que ao envolver a equipe do museu avançam em direção a harmonia necessária a própria natureza do museu.

La falta de armonia entre la misión y las furzas del mercado puede dar lugar a um grande número de problemas y roces que no podrán ser mitigados. El tono y la cultura del museo puede sufrir um profundo 
desequilíbrio que acarree uma serie de consecuencias destrutivas (AMES, 1998:39).

Conforme sugerem os autores, a missão de uma instituição deve ser a informação primeira a encabeçar, no topo do desenho, os itens de um planejamento ou de uma estrutura organizacional sistematizada. Do mesmo modo, diferentes autores afirmam ser a missão o ponto estratégico para definir os passos de um planejamento ou mesmo de um plano diretor. Certamente a missão cabe o motivo pelo qual toda equipe trabalha. Mas importante destacar os tempos que não são desencadeados em uma sequência lógica estrutural, mas desenrolam-se nos desdobramentos simultâneos e sobrepostos, impulsionados e estimulados pelo exercício da prática, resultado da reflexão cotidiana. Os tempos reais, que ora aponto, desenham uma forma não mais sequencial, nem mesmo linear, mas sim com ritmos dissonantes e movimentos impulsionados por descargas de ideias e ou de afetos gerados pelo bem-estar de realizar algo que seja reconhecido por outrem, ou mesmo, por fazer sentido a tarefa realizada.

Pensar o museu como "organismo público" (HORTA, 2002) requer a participação de muitos fatores e elementos ao qual determina um fazer complexos e, nesse, o fato museal (GUARNIERI, 2010), fenômeno museológico e processos de musealização. Deste modo torna-se possível identificar preocupações que abrangem os seguintes tópicos apresentados por Bruno:

a) Alargamento do campo essencial/fato museal: referenciais culturais, territórios e sociedade: Novos conceitos e metodologias de pesquisa e de trabalho técnico; Distinção entre as "escolas" de pensamento museológico; Gestão compartilhada e colaborativa.

b) Protagonismo do campo de interlocução museológica - fenômeno museológico: Interdisciplinaridade e compartilhamento de responsabilidade; Participação "comunitária"; Inserção de novos tipos de profissionais. Enfrentamento no campo de projeção - processo de musealização: Identificação dos capitais cultural, social e econômico; Ampliação e diversidade da reverberação institucional (BRUNO, 2014:104).

Na preocupação de pensar a si próprio, como espaço público disponível para e de todos, o museu tem na comunicação o meio pelo qual pode proporcional diferentes experiências. Por outro lado, para comunicar, o museu precisa garantir segurança e condições técnicas para que o objeto seja exposto.

Neste sentido "a instituição museu não é um produto pronto, acabado. É resultado das ações humanas que o estão construindo ou reconstruindo a cada momento; portanto, é resultado da prática social (SANTOS, 2002:19).

Em segundo lugar, a aproximação entre público-objeto-museu e a experiência se dá pela especificidade na relação entre o Homem e o Objeto em um determinado cenário, 
de uma instituição, um museu. A experiência fruto da relação aberta (GUARNIERI, 2010) entre Homem e Objeto, permite ao homem conhecer e reconhecer a si próprio "nos e através dos artefatos que ele criou e nos e através dos objetos da natureza, aos quais ele deu valor pela atribuição de significado" (GUARNIERI, 2010:183).

Para Cury, significado este que está intrinsecamente relacionado a ordem do sensível. O Homem valoriza e acolhe o que dá sentido à vida. E o museu é um dos lugares que reserva para guardar e organizar em coleção de objetos. O museu abriga o objeto musealizado e a experiência, sendo a experiência resultado do encontro e, portanto, repleta de sentido a respeito de si próprio e do mundo que se vive.

A musealização está estreitamente ligada à preservação: musealizamos porque damos valor à poesia que está nas coisas e as preservamos porque queremos guarda-las - as coisas que detém a poesia que valorizamos como referência. Assim, tanto a musealização quanto a preservação são atitudes compromissadas com o interrogar (CURY, 2005:31).

A experiência no museu pressupõe o encontro mediados pela exposição, onde estão os objetos e a poesia que se refere Cury. O objeto material carregado de sentido informa e afeta.

[...] a exposição é a ponta do iceberg que é o processo de musealização, é a parte que visualmente se manifesta para o público e a grande possibilidade da experiência poética por meio do patrimônio cultural. É ainda, a grande chance dos museus de se apresentarem para a sociedade e afirmarem a sua missão institucional (CURY, 2005: 35).

O público, fundamental para pensar a exposição, tem no potencial do encontro no museu a singularidade relativa as características do patrimônio em questão: industrial ferroviário. E com ele, deste modo, uma segunda experiência.

Experiências mediadas pela exposição num conjunto com o cenário estruturado a partir de um planejamento que exige dos diferentes setores a compreensão de trabalhar para o mesmo propósito. A citar no caso em estudo, desde a reorganização da expografia e dos espaços físicos, a disponibilização do acesso aos carros de passageiros, as condições de saúde, de limpeza e de manutenção para uso local, além dos materiais gráficos para convidar o público a visitar/estar no Museu, os materiais de apoio e os educativos que participam em diferentes espaços e situações, compondo um campo comunicacional.

Essa perspectiva, para alguns museus representa desviar os museus de sua função, o que é equivocado, porém não só no Brasil há uma carência de atenção para 
essa questão. Para Alice Semedo, os museus portugueses também necessitam investir nesse aspecto.

Ao sector ainda falta um trabalho de animação dos espaços mais intenso e generalizado, considerando como fator essencial de captação e fidelização de públicos; a publicação de materiais informativos de qualidade; programas educacionais inclusivos; a investigação generalizada quer sobre as colecções, quer sobre todas as outras funções do museu (SEMEDO, 2004: 26).

Ulpiano Bezerra de Meneses aponta para a importância dá experiência nos museus e do sentido vivo e inteligível que esta possui ao compreender as implicações que agrega quando reconhece que o lugar das interpretações está carregado de associações e deslocamentos. O museu ao imobilizar e oferecer em exposição um objeto, possibilita ao público condições de realizar experimentar e interpretar. Para o autor, "sempre provisória e incompleta, destinada a ser refeita", a interpretação é fruto da experiência que designa ao museu lugar diferente daquele de "repositório e dispensador de paradigmas visuais" (MENESES, 1994).

[...] o museu é essencialmente uma forma institucionalizada de transformar objetos em documentos. Bastaria para tanto a intenção (ou ação) designativa? Não. A imobilização dá valor de uso (a reclusão em vitrinas) é um passo significativo. Assim também, não bastaram a manifestação volitiva e a inserção física num museu, para que o mictório de Duchamp tivesse transfigurada a sua natureza original. Esta inserção define um quadro dialógico de motivações, expectativas e as respectivas estratégias. Por isso, ela implica em deslocamentos e associações que escapam ao acaso e que só o museu pode oferecer poderosamente (MENESES, 1994: 31).

O museu deve ser pensado tanto na relação com o público externo (visitantes e parceiros), como do público interno (gestores/equipe técnica/funcionários/voluntários). Diferentes autores mencionam o fazer experimental das organizações administrativas como resultado de solução das dificuldades, assim como aqueles relativos aos processos museológicos. A experiência do Museu do Trem não foi diferente.

Dificuldade e adaptações pertinentes a solução de problemas, envolvendo as necessidades técnicas, torna esse um "fazer museu nesse contexto globalizado é deveras experimental" (CURY, 2014:65).

Em terceiro lugar, com relação as implicações resultantes das escolhas pertinentes a gestão, em especial quando dá importância dos processos comunicacionais, os museus são palco de inúmeras dificuldades e polêmicas (BRUNO, 1997b; CURY, 2005), como por exemplo: àqueles referentes ao mercado e ao marketing cultural; a natureza administrativa e os recursos públicos; a inserção das novas tecnologias e a experiência corporal e 
temporal; colecionismo em sociedade de consumo, além de questões relacionadas a formação técnica e das prioridades em tempos de diversidade. "Os museus chegaram até este século como os grandes repositórios de coleções ecléticas, como centros de saber e, evidentemente, como locais privilegiados e sacralizados" (BRUNO, 1997a:35).

Para existir, são necessárias articulações interdisciplinares e multiprofissionais para o funcionamento do todo. Sendo ainda um alvo vulnerável aos impactos políticoeconômicos externos (BRUNO, 2014), sendo instituições de natureza pública ou privada.

Os museus públicos parecem enfrentar, de modo geral, um descompasso entre as responsabilidades que sobrecaem sobre gestores que talvez nem tenham desejado assumir a função, tendo assumido como indicação política, por cotas negociadas ainda no período das campanhas. Nesse descompasso percebe-se que, assim como no caso apontado por Drucker (apresentado na próxima seção deste capítulo), que a qualificação técnica não solucionaria totalmente os problemas. É preciso que a mantenedora, a autarquia, o órgão ao qual o museu faz parte, tenha incluído em seu programa de trabalho [programa de governo] o que se pretende com o museu.

Quais os meios e métodos de trabalho escolhidos pelo gestor? O gestor opera na cadeia de serviços onde estão os processos e práticas museográficas, importando cada vez mais averiguar quais são os serviços desejados e necessários (MELO, 2007) considerando ser o museu aquele que conserva e que também comunica (CURY, 2005).

Sobre a experiência do sujeito no museu "além da leitura, o público tem reservado para si o trabalho criativo de intepretação, ressignificação e reformulação da mensagem museológica, quando agrega valor a ela e a faz circular em seu meio" (CURY, 2014:62).

Atrair visitantes amplia para uso de ferramentas do marketing, campo que ainda poderia discutir no caso em estudo. A partir delas, as contradições pertinentes a conservar e expor.

Perseguir a perpetuação de um objeto significa colocá-lo em condições ideais de conservação, isolado numa reserva técnica. No entanto, um museu só atinge a sua finalidade social inquestionável por meio da comunicação do patrimônio cultural musealizado, via exposições essencialmente (CURY, 2009:110).

O gestor necessita considerar essa contradição como uma dificuldade pertinente, a fim de realizar seu propósito, cabendo a ele definir os meios para solucionar. Neste 
sentido, se faz necessário retornar ao fato de o museu ser um espaço público ${ }^{114}$ para o público. O público de museu é formado pelo Homem que preocupado com a própria existência acumula objetos, cuida, pesquisa e comunica sobre.

Os museus que se focalizam no público, em todos os seus aspectos operacionais, têm maior potencial para ganhar popularidade e novos visitantes. Comunicar com o público não é um processo de um só sentido, O museu com sucesso será interativo, não se limitando (MORK, 2009:110).

O público de museu é formado por um contexto plural, onde encontram-se atravessados distintos interesses e motivações, independentes das variáveis relacionadas a de onde vem, por que chegou até ali e o que vai fazer a partir deste contato, seja ele o responsável pelas ações técnicas de quem recolhe e guarda o objeto, seja ele um visitante curioso simplesmente. Pensar em que condições o público é recebido, torna-se essencial para oferecer um encontro no museu passível de manter o desejo do visitante em retornar ao local. Neste caso, cabe ao gestor a clareza e a compreensão do público com parte do museu.

Outro aspecto importante é quanto a imagem que o museu constrói de si e como ele é visto pelo público. Nem sempre interessado na exposição, o público também procura o Museu do Trem para descansar a sombra, ler em meio ao verde, namorar, jogar vôlei com os filhos, passear com animais, fazer pic-nic, ouvir música, esperar o tempo passar, sendo este também um encontro possível. Todo encontro produz uma reação. A instituição não deve desconsiderar nenhuma das opções como parte do conjunto. Assim, destaca Mork:

Do ponto de vista do visitante geral os "produtos" do museu nessas condições são principalmente as galerias, as exposições especiais e as outras partes do museu abertas ao público. Mas para outros visitantes isto também significa serviços de investigação, as áreas de serviço e os locais de encontro para amigos e famílias, como o restaurante ou o café do museu. Todas estas áreas têm que ter a satisfação do visitante porque se o museu não for atractivo, não ganhará e manterá popularidade, mesmo que ofereça admissão gratuita e gaste fortunas e publicidade (MORK, 2004:177).

A situação se complexifica e os desafios elencados por Bruno identificando necessidade e resultados na gestão de museu, onde a formação acadêmica tem papel fundamental, merecem destaque:

\footnotetext{
114 Aqui refere-se ao espaço utilizado em situações públicas e não privadas. Não se faz referência neste aspecto a natureza da administração pública ou privada.
} 
Refinar as metodologias de trabalho de salvaguarda e comunicação, a partir do exercício profissional cotidiano; Implementar procedimentos sistemáticos de planejamento e avaliação com vistas à prestação de contas à sociedade; Desdobrar as potencialidades de acesso aos processos de musealização, ampliando os espaços de ação e desdobrando os conteúdos; Especializar os olhares profissionais a partir do ensino acadêmico (BRUNO, 2006:18).

Considerando o caso em estudo, fica clara a ação inter-relacionada entre gestão, comunicação e educação, a partir do referencial patrimônio industrial ferroviário. Cada vez mais se reconhece o papel fundamental da aproximação entre esses os fazeres e as práticas dentro do museu, ampliando o conceito de herança a patrimônio cultural musealizado. Assim, a experiência no Museu do Trem de São Leopoldo, ao envolver funcionários e estagiários, tanto contratados, quanto voluntários, possibilitou a compreensão de uma concepção de museu para além de um depósito de relíquias.

\subsection{GESTIONANDO}

Inicia-se a seção apresentando um problema descrito por Peter Drucker sobre as dificuldades na gestão de um museu específico, no caso um Museu Universitário ${ }^{115}$ nos EUA.

O Museu de Arte da Universidade, que durante quase meio século teve como diretora a Sra. Kirkhoff, ex-aluna da Universidade, cresceu e se tornou referência em diversos aspectos, prioritariamente nas questões de uso do museu pela comunidade acadêmica e pela realização de seminários e publicações. O sucessor, outro ex-aluno, não teve a mesma sorte. Tendo permanecido por apenas três anos, assumindo o cargo por indicação unânime do Conselho Universitário devido suas qualidades profissionais.

No momento de posse, anuncia que "consideraba el museo 'un recurso principal de la comunidad' y que pretendía 'proporcionar pleno acceso a la comunidad académica, así como al público, a los enormes recursos artísticos y académicos" e assim o fez. Diferentemente da Sra. Kirkhoff, promoveu exposições a partir do interesse geral, implantando nova política de exposição do acervo. Dedicou-se a aproximar escolas de ensino fundamental da região e popularizou o Museu, tendo como resultado uma crescente e agitada movimentação. O Conselho, nada satisfeito com o barulho no Campus, que rompia a tranquilidade no qual estavam acostumados, realizaram uma pesquisa com os alunos da Universidade, que manifestaram sua opinião afirmando que

${ }^{115}$ Fato ocorrido nos EUA, no Museu de Arte da Universidade, em 1974. 
"el museo se había convertido em um lugar demasiado ruidoso y 'sensacionalista' como para que los alumnos pudieran disfrutar de las clases y tener la oportunidade de aprender." A gota d'água para o insucesso foi a exposição de arte islâmica e o discurso de abertura, quando um convidado da embaixada atacou publicamente Israel e a política norteamericana de apoio a Israel. O Conselho, em caráter de emergência, nomeia um comitê de consulta encarregado de aprovar os próximos programas de exposição do Museu. Insatisfeito, o diretor do Museu dá uma declaração pública atacando a Universidade de elitista e classista, se demitido seis meses após. Coube então ao mesmo Conselho fazer nova indicação para solucionar a questão. $\mathrm{Na}$ busca de alternativas, discutiram qual o perfil adequado para a tarefa, quando um dos membros destaca: "No téneis un problema de personalidade, tenéis um problema de gestión. Como universidad, no os habéis responsabilizado de la misión, de la dirección ni de los objetivos de vuestro museo", provando a reflexão, segue dizendo: "No sirve de nada hablar acerca de quién tiene que realizar atividades de gestión hasta que quede claro qué es lo que se tiene que gestionar y para quê.". Diante desta exposição, o Reitor se dá conta e interrompe o debate, retomando apenas após ter elaborado questões norteadoras para um novo debate entre os membros do Conselho, para só após fazer a indicação de um nome para a função de diretor. Entre elas:

\begin{abstract}
¿Cuáles son los posibles objetivos del museo de la universidad [del tren]? ¿Quiénes son o deberían ser sus clientes?

¿Cuáles de estos objetivos son compatibles y pueden ser atendidos simultaneamente? ¿Cuáles se excluyen mutuamente o, como mínimo, puedem interponer-se em el caminho de los demás?

¿Qué consecuencias para la estrutura del museo, la cualificación del diretor y su relación com la universidad se derivan de los objetivos anteriormente mencionados? (DRUCKER, 1977)
\end{abstract}

O caso apresentado por Peter Drucker, originalmente em 1977 ${ }^{116}$, detalha observações importantes e ao final do artigo enfatiza as questões destacadas pelo Reitor. Encerra assim com outras duas perguntas: “¿Que solución daria usted a estas preguntas? ¿Son las preguntas correctas?"

Sendo este um museu de arte, universitário, que compreende que a definição da missão da instituição, e seus respectivos objetivos, orienta a gestão e as decisões subsequentes. Enfatiza ser necessário ter clareza da natureza do museu, de suas potencialidades a partir do acervo que salvaguarda, e dos interesses dos órgãos ao qual está vinculado, além de compreender sua função específica e públicos.

\footnotetext{
${ }^{116}$ E reapresentado no livro "Museum Managent", organizado por Kevin Moore, e publicado em 1994, em Londres e Nova York, tendo sido traduzido para o espanhol em 1998.
} 
O exemplo apresenta um problema recorrente as instituições museológicas, quando muitas carecem compreender sua função e sua existência. Apenas a partir desta clareza será possível gerir de maneira a crescer e obter êxito. "Qué es lo que se tiene que gestionar y para quê" (DRUCKER, 1998:181) são aspectos aparentemente destituídos de maior grandeza, mas que são fundamentais para dar o passo: gerir/gestionar.

Sobre gestão, a definição apresentada por André Desvallées e François Mairesse, nos Conceitos-Chave de Museologia:

\begin{abstract}
A gestão museológica, ou administração de museus, é definida, atualmente, como a ação de conduzir as tarefas administrativas do museu ou, de forma mais geral, o conjunto de atividades que não estão diretamente ligadas às especificidades do museu (preservação, pesquisa e comunicação). Nesse sentido, a gestão museológica compreende essencialmente as tarefas ligadas aos aspectos financeiros (contabilidade, controle de gestão, finanças) e jurídicos do museu, à segurança e manutenção da instituição, à organização da equipe de profissionais do museu, ao marketing, mas também aos processos estratégicos e de planejamento gerais das atividades do museu (DESVALLÉS e MAIRESSE, 2013:49).
\end{abstract}

Diante da provocação de Drucker cabe pensar aspectos sobre a gestão de um museu que salvaguarda o patrimônio industrial ferroviário. As questões abaixo apontam para itens fundamentais na gestão de museus: as prioridades.

- Quais são as prioridades do museu ferroviário?

- São as mesmas prioridades de quando fundado?

- Quais as prioridades da instituição para garantir sua função social?

- Quem determina as prioridades?

- Qual a prioridade da gestão para o período vigente?

- O que é prioridade para o público do museu ferroviário?

- Qual público é prioridade para este museu?

- Quais serviços são prioridade para o museu cumprir o papel desejado?

Sendo ainda importante abordar o cenário externo e nele o mercado, destaca-se:

- Quais são as prioridades da Prefeitura Municipal (desta cidade) neste governo?

- Quando o museu ferroviário é prioridade para a cidade?

- Em que aspectos o museu é prioridade para as autarquias (IPHAN, IBRAM, IPHAE)?

- Quais são as prioridades dos parceiros institucionais?

- O que é prioridade ao se estabelecer parcerias institucionais?

As interrogações elencadas a partir da prioridade, servem para provocar a reflexão sobre questões pertinentes a gestão, sem a intensão de alcançar respostas fechadas, 
visto que para cada contexto, situação e ou programa, projeto, as respostas podem surpreender aparentando contraditórias. Neste caso, definir prioridades também não se trata de excluir este ou aquele setor, mas deixar estabelecer, entre as partes envolvidas, a ordem para a realização, a partir do que é possível fazer em num prazo determinado, envolvendo um setor específico por vez.

Priorizar objetivos desencadeia acertar quais as ações devem ser realizadas em primeiro lugar, dando condições a melhor definição de um planejamento, organizado para a executar as metas em etapas. Ou seja: iniciar, desenvolver e concluir uma tarefa, um objetivo, um propósito para um fim.

Elencar prioridades requer envolvimento, comprometimento, reflexão com ponderações. Prioridades possuem prazo de validade, pois prioridade não é prioridade para sempre. Neste caso, exigindo serem revisadas e redefinidas periodicamente. Para isso o norte: a missão do museu.

Priorizar algo em detrimento a outro, não diz respeito ao esquecimento e ao abandono. Mas entender, por exemplo, que quando o museu não é prioridade da administração pública, deve buscar compreender que lugar ocupa, aceitando ou não. Isso tornará mais profícuas as tomadas de decisão.

Cabe ainda as interrogações: Os museus ferroviários são prioridade para quem? Quando eles são prioridade? Quais as vantagens e desvantagem de estar entre as prioridades? Aspectos que precisam ser amplamente debatidos pelo museu.

Por um lado, as influências exercidas pelo mercado sobre a instituição museu, por outro, a especificidade o museu ferroviário, que como a ferrovia, perde espaço e neste caso, precisa dar-se conta de seu lugar entre as prioridades. Não se trata de estabelecer um lugar fixo entre as prioritários, ou fora delas, mas a partir dos aspectos políticos, econômicos e sociais, estabelecer objetivos e planos de ação viáveis. Podendo aqui a comparação de o fixo ${ }^{117}$ ser tratado como falta de movimento e de vida, geralmente relativas ao abandono, por isso, é possível e necessário, experimentar diferentes lugares e movimentos, em diferentes situações e prioridades estabelecidas.

O museu como uma organização em muitos aspectos assemelhasse as organizações empresariais e, deste modo, como todas as organizações, é orientado pelos objetivos. Para Willliam M. Sukel, os museus movimentam valores consideráveis na economia do país, desde os gastos com a conservação, seguro e quantidade de

\footnotetext{
117 Entendido como algo estabelecido e sedimentado pelo tempo.
} 
funcionários, apesar de no caso norte-americano tratado por Drucker estes estarem em menor número dos parques de bombeiros, hospitais e escolas, sendo similares a organizações como orquestras sinfônicas e companhias de ballet, "cumplen su misión de manera calada y sin intervenir em los asuntos ajenos" (SUKEL, 1998:391).

Deste modo, segundo Sukel, identifica-se entre museus e empresas, pontos em comum e pontos que os diferenciam. Com relação ao que possuem em comum, o autor aponta que aos museus se tem confiado uma das metas mais importantes da sociedade: "la conservación y presentación ante el público de creaciones contemporáneas e históricas de las artes y las ciências, así como la generación de nuevos conocimientos para sus visitantes" (SUKEL, 1998:391); os museus realizam seus objetivos a partir de estruturas que requerem colaboradores para que suas atividades sejam realizadas, referindo-se ao fato do trabalho ser distribuído em departamentos distintos com pessoas e coordenações, sendo o diretor encarregado "de la planificación, el control y otras funciones."(SUKEL, 1998:392). O museu, assim como as empresas, necessita dos especialistas funcionais, que no caso específico são os conservadores, museólogos, historiadores, educadores e comunicadores.

Quanto ao que diferencia museu de empresa, Sukel aponta o fato de o museu possuir um objetivo como empresa, porém um objetivo que não é um benefício econômico. E que apesar disto, "los objetivos del museo puedem parecer intangibles, pero son muy reales." (1998:392). Por sua vez, o autor elenca itens que envolvem os fatores econômicos presentes na estrutura dos museus, entre eles: o número de visitantes; o número de visitantes que socorrem o museu; o número de exposições; o número de estudantes e profissionais que fazem uso do museu para pesquisa; o número de novo sócios (das que possuem associação de amigos ou natureza comunitária); número de voluntários que colaboram; seleção de pessoal e reconhecimento dos profissionais e da sociedade. E, embora esses possam ser número já identificados pelos museus, para Sukel caberia ao museu se deter a uma investigação exaustiva do que isso representa enquanto aspecto econômico, destacando o crescimento com os custos desde as restaurações, os seguros, aquisição de acervo, a ampliação dos horários de abertura e a expansão da oferta dos serviços, honorários administrativos, de seguranças, aumento de salário ${ }^{118}$, etc. no sentido de que quando mais usa, mas giram os recursos econômicos.

Puede que los museos no sean empresas, pero puedem ser gestionados com eficácia, como sucede com las comisarías de policía, los hospitales, las universidades y otras instituiciones, incluso aunque tengan otros

\footnotetext{
$118 \mathrm{O}$ autor destaca que os salários não são atrativos como nas funções equivalentes desempenhadas em empresas, o que gera problemas com os recursos humanos.
} 
critérios distintos al de obtener benefícios económicos (SUKEL, 1998:393).

Ainda que hajam semelhanças entre empresas e museus, Sukel aponta para aspecto que determina como exclusivo, relacionado a composição da estrutura organizacional que engloba profissionais, estudantes e voluntários como parte da mesma equipe. Com relação a função de diretor, alguns "no tienen el deseo de implicarse em la mundana tarea de administrar el museo" (SUKEL, 1998:393), preferindo as atividades restritas a pesquisa do acervo.

La misión del diretor - ya sea um experto em arte, um científico, um administrador, um funcionário, um membro destacado del conselho de gobierno, uno de los benefactores, um factótum de los poderosos, o uma combinación de todo ello - tiene que ser definida cuidadosamente por el consejo de gobierno, el personal y el próprio director (SUKEL, 1998:393).

Sobre desdobramentos da missão do museu e as escolhas da gestão destaca-se a qualidade da experiência no museu. Os investimentos para alcançar o público externo podem desencadear uma procura para o qual o museu ainda não está preparado, aspecto inicialmente não considerado no caso apresentado por Peter Drucker, sendo do mesmo modo, um dos problemas identificado no caso do Museu do Trem em São Leopoldo.

O público quando chega ao museu, pode não saber exatamente o que vai encontrar em exposição, porém, impulsionado por um estímulo, chega cheio de expectativas e vontades. E para isso será imprescindível uma equipe capacitada para a recepção dos diferentes públicos, com pena de provocar frustrações que desdobradas implicam em possível afastamento do público.

Neste sentido retoma-se aspectos relacionado anteriormente ao uso da Qualidade na gestão, considerando ser esta a ferramenta eleita pelo Museu do Trem no período. Segundo a pesquisadora Isabel Margarida Melo, os primeiros autores a salientar a importância dos princípios da Gestão de Qualidade para os museus foram: Peter Amar, em 1990, seguido por Middleeton, ainda em 1990, e sete anos mais tarde Michael Fopp.

Ames propõe 38 indicadores de performance para os museus, subdivididos em seis categorias: 1) Acesso; 2) Finanças e infraestrutura; 3) Angariação de fundos; 4) Recursos Humanos; 5) Marketing; 6) Exposições, coleções e educação.

Outros também exploraram a teoria com relação aos museus e a Qualidade, mas cabe ressaltar a síntese de Melo sobre a análise apresentada por Carol Browsher, quando 
investiga os impactos nos museus que adotaram a Qualidade ${ }^{119}$. Segundo Browsher (apud MELO, 2007), a implementação de um sistema de Qualidade apresenta pontos não compatíveis com as características qualitativas dos museus. Elenca: falta de clareza e sentido nos objetivos; complexidade da estrutura de gestão, considerando que os museus em geral não possuem autonomia financeira e institucional; poucos recursos financeiros e humanos.

Diferentemente, Antônio Ramos Pires refere-se a Qualidade não quanto ao uso de normas e métodos de gestão, conceituando como "medidas organizacionais capazes de assegurar que os resultados desejados" (PIRES, 2006:81-82) sejam alcançados na qualidade dos produtos e serviços; na garantia da qualidade no controle dos processos; e, na gestão de qualidade através de medidas organizacionais (2006).

A gestão da qualidade é o subsistema da gestão geral que assegura que a qualidade dos produtos é conseguida de forma consciente, coerente e eficaz. Ao nível das competências internas, as organizações, na maioria dos casos, não possuem meios para apoiar a concepção dos produtos/serviços, o que constitui uma deficiência vital, desde logo para a sobrevivência (PIRES, 2006:83).

O caso do Museu do Trem encontra ressonância nos pontos apresentados por Pires, e também pode-se afirmar que ao experimentar ferramentas da Qualidade experimentou os cinco motores da mudança (FEIGENBAUM apud PIRES, 2006), em especial nas alternativas frente a comunicação e público.

Entre os tópicos, o autor considera: mudanças comportamentais significativas; qualidade como meta; flexibilidade (uso da rede externa de capacidade e rede interna de competência); criação de novas necessidades; e aspectos econômicos (quantificação das atividades).

A quantificação das atividades, quer em termos de número das realizações, quer em termos dos respectivos recursos consumidos continua a ter interesse para justificar a existência e a relevância dos serviços dos museus. Contudo, deve ser salientado que algumas vantagens, talvez as mais importantes não possam ser com facilidade traduzidas em termos econômicos e ou quantitativos (PIRES, 2006:93).

Quantificar os resultados em museu abrange apenas parte dos aspectos alcançados, considerando que através da exposição, das atividades educativas, dos materiais comunicacionais estão movimentos de interpretação, aprendizagem, reflexão do sujeito, além da aquisição e promoção do conhecimento.

\footnotetext{
119 Pesquisa realizada na região de Leiscester.
} 
Ainda sobre a questão inicial: em que medida os princípios da comunicação museológica e da educação permitem desenvolver uma gestão de qualidade? É possível constata-se que a experiência no Museu do Trem abrange os itens elencados por Bruno e apresentados anteriormente, como: alargamento do campo essencial; protagonismo do campo de interlocução museológica; enfrentamento no campo de projeção, a partir das questões específicas do patrimônio industrial ferroviário que serão abordadas na próxima seção. Neste ponto, a avaliação museológica deve ser utilizada. No museu leopoldense os instrumentos de avaliação e de observações do público foram propulsores de reflexões e tomadas de decisões. A constatação de algo que não estava funcionando ou produzindo efetivos resultados permitiu localizar aspectos com maior fragilidade. Tratava-se a dificuldade ou a fragilidade como processo num contexto específico, sendo que no exercício da avaliação se impulsionava novas ações a fim de obter um resultado favorável. Com certeza esse exercício que envolve a equipe mobilizou não só questões relacionadas ao operacional.

É preciso desejar estar num museu (ou em qualquer lugar onde se esteja) para que as tarefas desenvolvidas não adquiram uma sobrecarga relaciona ao trabalho repetitivo e mecânico. O desejo de querer estar no museu. Não se trata aqui de adoração ou de manutenção de um lugar de fetichização (CURY, 2006b; MENESES, 1994; RODRIGUES, 2010), pelo contrário. Compreender o lugar à medida em que se participa dos processos por ele oferecidos permite significar o lugar como desafio e experiência possível, diferentemente de um espaço de depósito em exposição. O momento em que há uma sinergia.

Ainda sobre o caso leopoldense, percebe-se uma aceleração desdobrada por adesão da equipe, quando reestruturada e integrada nos processos museológicos. Assim como observa-se dados de valoração quando o processo de pensar e gestionar o museu agregou plenamente a equipe. Ou seja, o estar junto ao processo de criação de uma gestão resultou inúmeros aspectos positivos, independente do grau de dificuldade.

\subsection{MUSEUS FERROVIÁRIOS EM QUESTÃO}

Ferrovia é patrimônio cultural em qualquer cidade, em qualquer país. A ferrovia representa a modernidade resultante da Revolução Industrial e com ela as mudanças de paradigmas de uma sociedade na relação com um mundo moderno. Waldisa Russio Camargo Guarnieri ao discutir aspectos do museu de indústria em São Paulo, aponta para questões relacionadas contraditórias das invenções modernas em benefício da espécie humana. 
O que compete saber é se resulta HUMANO o esforço do cientista, do tecnólogo ou do artista; se são dignas e HUMANAS suas condições de produção; se a LIBERDADE indispensável a qualquer criação lhes é, ou não, concedida. Enfim, importante é saber se o USO da INVENÇÃO ARTíSTICA ou CIENTÍFICA tem, ou não propósitos e resultados em benefício da ESPÉCIE HUMANA. Curiosamente, desta aparência de contradição entre Ciência e Humanidade, (que só se torna real na medida em que manipulada pelos centros de poder), é que surgiram as grandes cogitações, das quais resultou uma consciência nova bastante crítica. Por outro lado, embora tenham envolvido desde as primitivas relações de trabalho (escravagismo, almas da gleba, etc) o fato de os nossos sistemas de produção nem sempre gerarem melhores condições de vida para uma sociedade que se vai cada vez mais caracterizando como sociedade de massa, auxiliaram o estabelecimento de uma consciência nova e de um novo e rigoroso debate sobre as próprias relações produtivas (GUARNIERI, 1980:103).

Compreendendo a ferrovia como um dos lugares onde as invenções modernas eram colocadas em prática com diferentes usos da mão de obra, encontramos desde operários, artífices, caldeiros, maquinistas, foguistas, tucos ${ }^{120}$. Muitas eram as atividades profissionais, sendo que o conhecimento técnico era oferecido pela própria ferrovia que ao formar seu funcionário, já encaixava na atividade laboral. Porém merece nossa atenção denominações adoradas decorrentes de atividades anteriormente realizadas no sistema escravagista, como por exemplo, o responsável pela turma de homem que realizada consertos na via permanente $^{121}$. Chamado de Feitor ${ }^{122}$ de Linha, ele supervisionava as tarefas.

O cenário da ferrovia ao ser descortinado oferece inúmeras informações relacionadas ao patrimônio. José de Souza Martins ${ }^{123}$, desenvolveu pesquisa sobre aspectos da ferrovia e da modernidade em São Paulo, elencando o uso da própria ferrovia como elemento visível do moderno: locomotiva, vagão, vapor e a imagem do atravessar distâncias, alterando o espaço e a imagem do cenário em dimensões cinematográficas (MARTINS, 2004). Do mesmo modo utilizado para controle dos tempos, dos caminhos, das aproximações, impondo ritmos dos tempos modernos.

A ferrovia anunciava e realizava o novo, ao mesmo tempo em que nele inseria 0 velho e tradicional. Era como se descosturasse a trama das velhas relações sem destruí-las inteiramente, recosturando-as no sistema de significados e funções do primado do capital e de suas reproduções ampliadas. Não atuava apenas no âmbito da economia, mas também no

\footnotetext{
120 Expressão utilizada para chamar os homens que assentavam trilhos e que pelo uso da força em suas marretas era possível ouvir as batidas de longe.

121 Na Via Permanente estão as atividades operárias.

122 Feitor era o homem que cuidava do trabalho escravo.

123 Professor aposentado da FFLCH-USP.
} 
do reajustamento e refuncionalização das relações sociais, dos valores, das concepções (MARTINS, 2004:12).

O tema bastante complexo oferece dados históricos sob diferentes áreas dos conhecimentos relativos a engenharia mecânica, estradas e geografia, expansão econômica e comércio local, comércio internacional, tecnologia moderna, vida doméstica, relações de trabalho, apenas para destacar alguns.

A ferrovia anunciava e realizava o novo, ao mesmo tempo em que nele inseria o velho e tradicional. Era como se descosturasse a trama das velhas relações sem destruí-las inteiramente, recosturando-as no sistema de significados e funções do primado do capital e de suas reproduções ampliadas. Não atuava apenas no âmbito da economia, mas também no do reajustamento e refuncionalização das relações sociais, dos valores, das concepções (MARTINS, 2004:12).

Cabe destacar também os estremos sociológicos apontados por Martins no uso da arquitetura pela São Paulo Railway na Estação da Luz e na Vila de Paranapiacaba,

(...) o desenho da Vila foi inspirado na concepção do panótipo. Isto é, na interiorização subjetiva do agente da vigilância. Cada trabalhador e cada morador carregavam dento de si o capaz do seu trabalho, mas o capataz da vida pessoal e família. Sua construção e seu funcionamento foram presididos pela ideia de que a disciplina do trabalho moderno dependia da interiorização dos temores, sobretudo o temor de ser visto fazer. A Estação da Luz porque expressava outra dimensão do medo, já não mais o medo do trabalhador em relação a figura invisível dos patrões e de quem manda. Mas agora o medo que tem quem manda em relação a quem trabalha e é mandado. Neste caso, concretamente, o telefone secreto da estação desde quando construída, mas acionado unicamente em 1924, por ocasião da Revolução e da tomada da estação pelos revoltosos (MARTINS, 2004:12).

A reutilização de edificações industriais para uso cultural não é novidade no Brasil. Existem exemplos importantes de projetos arquitetônicos assinados por Lina Bo Bardi e por Marcelo Ferraz, apenas para citar alguns. O uso do patrimônio edificado industrial teve um marco polêmico importante que possibilita disparar debates sobre a reutilização. Diz respeito ao caso clássico parisiense do Hotel e da Estação Ferroviária del Quoi d’Orsay, obra de Victor Laloux, datado de 1898 e 1900, destinado a ser demolido na década de 1970. Segundo Civera, uma das primeiras intervenções em edifícios industriais com certa polêmica (2003), grifo edifício industrial ferroviário. O projeto para sua reabilitação foi definido em 1982, sendo que havia sido declarado monumento nacional já em 1978.

También observamos que estos edifícios industriales de esta forma reutilizados puede servir, em e unas ocasiones más que em otras, para regenerar barrios deprimidos, pero no debemos nunca olvidar que estos edifícios mantienen uma memoria, que responden a unas características detreminadas y específicas de la é poca em que surgieron y que son 
nuestro patrimônio más próximo y por ello el de mayor dificultad valoración (CIVERA, 2003:61).

Para Matos e Sampaio, o patrimônio industrial desempenha papel fundamental na renovação da museologia, observando que

\begin{abstract}
se a constituição de suas coleções, a musealização de espaços industriais constituem um exercício de diálogo inter comunidades, interdisciplinar, então nada melhor do que avaliar os riscos e as potencialidades deste novos projetos e reclamar o seu lugar no desenvolvimento educacional, cultural, científico e tecnológico nesse novo milênio (MATOS e SAMPAIO, 2014:108).
\end{abstract}

A musealização do patrimônio industrial ferroviário é um tema convidativo a ser explorado em pesquisa acadêmica, assim como convida a pensar singularidades relativas unicamente a ele. São questões que abrangem subjetividades, mas também os conflitos e as contradições da modernidade. A exemplo das estações paulistas, pode-se dimensionar a complexidade do universo na qual a ferrovia está inserida e que permanecerá no museu após a musealização. A complexidade está por nela representar as escolhas de um tempo e de uma sociedade, neste caso se fará presente como parte da práxis museográfica em questão.

Os museus do trem, ou museus ferroviários, são inaugurados no Brasil em diferentes circunstâncias. O movimento em prol da preservação do patrimônio material surge no momento que se percebe que o patrimônio obsoleto está sendo vendido, transformado em sucata, derretido para reutilização, além de realocação por interesses diversos como decoração de órgãos, departamentos e/ou residências, conforme aprofundado em capítulo anterior.

Em meio aos movimentos de preservação, o sentimento de nostalgia. Manter a memória após algum período de investimento, o museu também sofre com o abandono e a falta de políticas públicas que garantam sua função na preservação, conservação e salvaguarda do acervo industrial ferroviário. Segundo Custódio,

Os museus ferroviários surgiram no Mundo para dar respostas à reunião de colecções de material circulante e outros aspectos dos sistemas ferroviários, do ponto de vista técnico, social e industrial. Nasceram pela força de engenheiros técnicos e operários ferroviários. Um ponto de vista temporal e conceptual, estes museus são contemporâneos e parceiros dos museus industriais, embora filiados no campo doutrinal do patrimônio industrial. Aliás, só tardiamente é que se entendeu que o campo conceptual do patrimônio ferroviário continha em si o gérmen de uma potencial autonomia (CUSTÓDIO, 2010:3-4). 
Os museus apresentam além de seu tema, o próprio país. Cabe neste caso, também pensar que no contexto brasileiro, a organização administrativa institucional dos museus abrange modelos dos diferentes períodos históricos, para Maria Cristina Oliveira Bruno "os distintos processos de colonização, estão na base de afirmação, proliferação e diversidade" (2006:09) dos modelos institucionais que vem desde o século XIX. Já os museus contemporâneos, coincidem em muitos aspectos como resultado

do humanismo do renascimento, do iluminismo do século XVIII e da democracia do século XX. Com a origem vinculada aos traços culturais que herdamos da antiguidade, as instituições museológicas têm também, raízes identificadas com os perfis das galerias, dos antiquários e dos gabinetes de curiosidade do renascimento(...) (BRUNO, 2006:8).

Para Bruno os museus cumprem importante papel na "visibilidade de nossa alma" ao "explicar como somos". E enfatiza que "as instituições museológicas podem colaborar com a difícil tarefa de explicar o Brasil" (1997a). Segundo a museóloga, os museus são dotados de uma engrenagem e uma articulação interdisciplinar e multiprofissional que tem avançado nas últimas década na discussão referente aos princípios (2006), porém as dificuldades para a implementação das tarefas referentes a salvaguarda (conservação, documentação) e a comunicação (exposição, educação e ação cultural) da herança patrimonial dizem respeito ao fato de os museus serem vulneráveis as oscilações políticas e aos impactos político-econômicos (BRUNO, 1997a; BRUNO, 2006), conforme também constatamos no caso em questão nessa pesquisa.

Para Inmaculada Aguilar Civera, há um aspecto específico a ser considerado, diz respeito a arquitetura industrial e aos valores da arquitetura como fonte de memória.

Todavia me llama atención que en actual processo de documentación, catalogacion y conservación de esta arquitectura industrial se hable de uma intención estética secundaria, de unos involuntários aspectos formales.?? Qué código estético devemos planteamos? El del sistema compositivo renascimiento barroco el de los decimonónica, los neohistoricismo, el ecleticismo, el modernismo...etc.?? Qué característica, qué valores tiene la arquitectura industrial? (CIVERA, 2003:44).

Em 2010, em Ultrecht, foi inaugurada a exposição "Royal Class. Regal Journeys", do Museu Nacional Ferroviário ${ }^{124}$, na Holanda, que segundo Jorge Custódio, foi um marco

\footnotetext{
124 O Museu Ferroviário em Utrecht, Het Spoorwegmuseum, foi criado em 1927 para preservar equipamentos históricos das ferrovias nacionais holandesas. Em 1954, o museu foi instalado permanentemente na Estação Maliebaan, em Utrecht. Foi realizada uma renovação no final do século XX, com a adição de novas instalações modernizadas. Em 2002, o prédio foi totalmente remodelado para ser mais acessível ao público geral, com mostras interativas que atraíram centenas de milhares de visitantes.
} 
referencial para os museus ferroviários internacionais, assim como a Carta de Rigo, de 2005, de Portugal.

A exposição "Royal Class. Regal Journeys"125, realizada por The Spoorwegmuseum na Estação de Maliebaan, concebeu uma exposição relevante ao concentrar "nas gares do museu holandês composições, carruagens e coleções históricas referentes ao modo como os monarcas europeus usaram os caminhos de ferro, enquanto afirmação do exercício do poder régio, impondo as famílias reais" (CUSTÓDIO, 2010:01) um modo de viajar.

O Museu Nacional Ferroviário holandês, apresenta investimentos ${ }^{126}$ que surpreendem em restauro de material rodante e de terminais do caminho de ferro, visto que o transporte ferroviário conduz desde a realeja as classes trabalhadoras, além de ser ainda hoje nos países de primeiro mundo, um transporte eficiente e importante na mobilidade do cidadão.

A exposição "Royal Class. Regal Journeys" contou com o empréstimo do comboio real português ${ }^{127}$ e representou, ao deslocar peças de material rodante de proporções e características avolumadas - que exigem grande investimento - fato determinante no campo da museologia, da investigação histórica e científica. Os investimentos deste país realizado em restauro, seguro, transporte e montagem reapresenta "problema do patrimônio ferroviário, num novo paradigma cultural" (CUSTÓDIO, 2010:03), como também

[...] reforça o papel das comunidades ferroviárias na construção dos bens culturais comuns e na afirmação do significado histórico da memória europeia e internacional colectiva e do papel dos caminhos de ferro amanhã, em função dos desafios ambientais e sociais que se antevê (CUSTÓDIO, 2010:05).

A Carta de Riga foi criada para orientar as decisões na preservação do patrimônio industrial ferroviário de Portugal e "é uma declaração de princípios que orienta a conservação, o restauro, a manutenção, a reparação e a utilização do Equipamento Histórico Ferroviário, que é intervencionado" (Carta..., 2005). Diferentemente e em outro contexto, cabe comparar com a Carta de Santa Maria, Rio Grande do Sul, encabeçada pela Associação de Amigos do Museu do Trem $^{128}$, que solicita atenção básica para o patrimônio industrial ferroviário, como pedido de ajuda. (Carta..., 2010)

\footnotetext{
125 Realizada no período entre 14 de abril e 05 de setembro de 2010.

${ }^{126}$ Em 2002, desenvolvem projeto de renovação do museu sob a direção de Paul M. L. van Vlijmen.

127 Locomotiva D. Luís I e respectivo tender (1862), salão D. Maria Pia (1858) e Salão do Príncipe (1877).

128 Museu este que ainda não foi constituído por falta de apoio do setor público governamental.
} 
No caso estrangeiro, fica nítida a importância do patrimônio industrial ferroviário para Portugal ao produzirem um documento que elenca doze artigos que orientam para melhor entender porque preservar e como fazê-lo a partir dos mecanismos de reparação, restauro, conservação, além do fato de tratarem o termo com as iniciais maiúsculas: Patrimônio Ferroviário, mas cabe destacar que apesar de ter sido escrita apenas dois anos após a Carta de Nizhny Tagil, pela Assembleia Geral do TICCIH, a mesma ainda não teve o devido reconhecimento.

Para Custódio,

Independentemente de sua gestão, este patrimônio, entendido como uma herança ferroviária cultural, envolve uma capacidade de perpetuação da vida ao material circulante, por via de conceitos de gestão dos sistemas ferroviários preservados ou da sua exploração nas redes nacionais de caminhos de ferro. Estes factos conferem aos museus um carácter de "museus em movimento" (CUSTÓDIO, 2010:05).

Em 2005, foi criado em Portugal, pelo Decreto-Lei $n^{0} 38 / 2005^{129}$, o Museu Nacional Ferroviário ${ }^{130}$ no Entroncamento, como um museu polinucleado que agrega 19 linhas com núcleos ${ }^{131}$ distribuídos pelo país. O caso português apresenta uma estrutura administrativa que interliga coleções, mantendo a mesma característica do patrimônio preservado, neste caso específico, incluindo a ligação entre as estações.

A arquitetura industrial, regida pelos princípios de produção, onde podemos inserir a arquitetura do patrimônio industrial ferroviário, torna-se obsoleta à medida que se moderniza com a tecnologia de transporte. Essa modernização de tecnologia inclui aparelhamentos e estruturas, deixando vagos numerosos edifícios que se tornam suscetíveis a reutilização (MENDES, 2013).

Independendo do modo como são adaptadas as antigas estruturas, sejam centros culturais para finalidades diversas, ou museus e centros de memória, que segundo Mendes, evocam nas novas atividades, o passado e a história das atividades outrora exercidas. Este aproveitamento desempenha importante papel nas localidades onde está inserido.

\footnotetext{
129 Tendo sido inaugurado apenas em 2015.

130 O acervo museológico da FMNF é constituído por cerca de 36000 objetos, muitos com peso e volumetria consideráveis, os quais se inserem nas seguintes categorias: Material Circulante; Equipamentos de Via e Catenária; Equipamento de Oficina; Equipamentos de Comunicação, Informação e Sinalização; Equipamentos de Estação, Escritório, Tarifários e Bilhética; Proteção e Segurança; Equipamentos de Restauração; Equipamento Têxtil; Equipamento de Saúde e Espólio Documental.

131 Entroncamento: núcleo central, com coleções nos museus: Museu Ferroviário de Arco de baúlhe, Museu Ferroviário de Bragança, Museu Ferroviário de Chaves, Museu Ferroviário de Estremoz, Museu Ferroviário de Lagos, Museu Ferroviário de Macinhata do Vouga, Museu Ferroviário de Santarém e Museu Ferroviário de Valença.
} 


\begin{abstract}
Além de poderem contribuir para fomentar o desenvolvimento econômico, social e cultural dessas regiões - com destaque para o contributo que podem e devem dar ao turismo cultural -, são ainda factores de identidade das próprias comunidades que, por essa via, se sentem reconhecidas e recordadas, ao mesmo tempo que verificam não terem sido esquecidos a memória e o legado transmitido pelos seus antepassados (MENDES, 2013:3-4).
\end{abstract}

Importante aqui retomar o uso de edifícios ferroviários para outras atividades. As transformações são as mais diversas, desde setores e órgão públicos, posto de polícia, Shopping Center, lojas e restaurantes, setores administrativos como o PROCON e atendimentos a saúde do trabalhador, ponto de encontro de associações e escritórios das concessionárias da Rede até o uso em atividades culturais como oficinas de arte, pinacotecas e galerias de arte, espaços culturais diversos, museus e memoriais, entre outros.

Em recentes exemplos de transformação de edifícios ferroviários, verificase que a intervenção nesses bens culturais, reconhecidos ou não por lei, padecem, contraditoriamente, da falta de fundamentos culturais, mesmo quando o novo uso está vinculado a atividades culturais (KUHL, 2012).

No Brasil, a atividade do PRESERVE/PRESERFE importante na recuperação de estações, rotundas entre outros para abrigar os Centros de Preservação da História Ferroviária (CPHF) e os Núcleos Históricos Ferroviários (NHF). Projetados em edifícios em desuso que adaptados, respeitando critérios de restauro (MORAIS, 2015 entrevista) sofreram intervenções para melhor transformação e reutilização do local. Haviam duas vertentes de pensamento com relação ao modo como o restauro deveria intervir. Segundo o arquiteto Sérgio Morais, um grupo acreditava que, como no caso de São Leopoldo, houve descaracterização que desfigurou o prédio original.

Evidencia-se ainda poucas discussões sobre a patrimonialização e a musealização do patrimônio industrial ferroviário no estado do Rio Grande do Sul. Considerando a ocupação da malha ferroviária no território brasileiro, com destacado desenvolvimento na primeira metade do século XX na Região Sul do país, assusta verificar que o boa parte dos bens patrimoniais ferroviários ainda não estejam vinculado a processos museológicos, como o caso da cidade de Santa Maria, onde o acervo está resguardado pela Associação de Amigos do Museu, criada em 2003, porém o Museu Ferroviário na cidade ainda não foi fundado oficialmente. Ou mesmo, no exemplo do patrimônio acumulado pelo ferroviário Hélio Bueno da Silveira, no Grêmio Esportivo Ferrinho, em Porto Alegre, que aguarda atenção do poder público para constituir uma coleção. O que se vê, é que mesmo diante da importância histórica e do contexto econômico favorável, a preservação do patrimônio industrial ferroviário, assim como, a preservação do patrimônio industrial do setor elétrico (CURY e YAGUI, 2015), pouco tem sido alvo dos investimentos dos muses municipais. 
Considerando que o patrimônio industrial é também resultado do acumulo de objeto que se tornam obsoletos em nossa sociedade. A proximidade entre os tempos a partir da invenção da ferramenta industrial, seu uso, superação e substituição por outra mais potente e moderna ferramenta, até o descarte e o abandono da mesma. É intensa a produção de 'ferramentas", objetos em potencial para a musealização, que em um circuito poderão se transformar em testemunhos, ou seja, integrar uma coleção museológica dado sua importância histórica.

Segundo Waldisa Russio Camargo Guarnieri, existe um desprezo, uma indiferença com o que chama de fato industrial e seu respectivo processo (1980), do mesmo modo, se repete o modus operandi sobre objetos musealizadas relacionados a essa natureza.

Particularmente no Brasil se adquiriu verdadeira fobia às atividades que exigem empenho predominantemente manual. País que se formou mediante feitorias e criação do latifúndio (as capitanias e as sesmarias) em que o escravo era tudo, o operário, o músico, o artífice, o artesão... até o 'esgoto 132', todas as atividades que tivessem sido num dia por ele desenvolvidas (ou elas assemelhadas) passaram a ter conotação pejorativa (...) Essa visão de uma aristocracia rural que, por vezes, renega suas próprias raízes, vai se constituindo em comportamento condicionado e condicionante, na média em que, perdido o "status" de "senhores", para sobreviver, são, posteriormente levadas a buscar ocupações em aparentes múnus públicus de que possam auferir ganhos. Toda a Administração pública vai se tornando uma imensa sinecura. Para a área de educação se dirigem os 'filhos de família'133, que irão impregná-la de todos os "pre-conceitos" de uma sociedade patriarcal e agrária que se estava a extinguir. (GUARNIERI, 1980:105).

Memória e esquecimento num mesmo lugar. Considerando o caso do Museu do Trem de São Leopoldo, localizado em um Sítio Histórico, tendo parte da exposição acolhida pela antiga Estação ${ }^{134}$, e um Armazém de cargas restaurado. O ambiente, conforme apresentado no Capítulo 3 e 5, dispõem no pátio locomotivas, carros de passageiro, vagões, carro restaurante, trole, entre outros, oferecendo uma experiência com o objeto em uma exposição distribuída dentro das edificações, pelo pátio em locais cobertos e outros não. A ocupação de grandes espaços físicos é característica do patrimônio industrial ferroviário, assim como a reutilização de antigos prédios o que confere potencial turístico. Sendo a memória individual resultado do convívio com o patrimônio ferroviário como elemento formador de identidade (RODRIGUES DA SILVA, 2014b).

\footnotetext{
132 Citação de Guarnieri sobre artigo de Lúcio Costa publicado sob título de "Muita construção, algumas arquiteturas e um milagre", publicado no Correio da Manhã em 15 jun.1951.

${ }^{133}$ Menciona análise de Sérgio Buarque de Holanda

${ }^{134}$ Reconstruída pelo PRESERVE.
} 
E neste sentido pensar o patrimônio industrial ferroviário na perspectiva de museu ferroviário. Mário Chagas discorre das relações entre a memória como expressão da verdade pura e do supremo bem. O que se está apontando é para o patrimônio e seu valor como testemunho e objeto. O museólogo e poeta Mário Chagas considera a discussão a partir da questão e destaca-se a seguir:

Passou a ser praxe de elogio institucional a afirmação de que o museu
"x" ou "y" é um lugar (ou casa) de memória; como a memória tivesse
valor em si mesma e fosse a expressão da verdade pura e do supremo
bem; como se o esquecimento fosse o mal ou um vírus criminoso que
devesse ser combatido, deletado, destruído (...) talvez fosse adequado
para melhor compreendê-los numa perspectiva crítica, aceitar a
obviedade: os museus são lugares de memória e de esquecimento, assim
como são lugares de poder, de combate, de conflito, de litígio, de silêncio
e de resistência; em certos casos, podem até mesmo ser não-lugares.
Toda tentativa de reduzir os museus a um único aspecto, corre o risco de
não dar conta da complexidade do panorama museal no mundo
contemporâneo (CHAGAS, 2011:12).

O patrimônio cultural brasileiro tem uma complexa representação de significados (RODRIGUES DA SILVA, 2014a) de modo que não se pode reduzir a memória presente no imaginário a uma única questão ou verdade. Diante desta área, no qual Museu do Trem de São Leopoldo é um exemplar, cabe interrogar sobre a carga simbólica do prédio, em especial quando em eminência de sofrer intervenções estruturais com restauros ou reconstruções para a então reutilização. Para Peixoto estão imbricadas atitudes de ruptura e continuidade, sendo que "elas implicam, muitas vezes, os vocabulários de tendência, a individualidade das expressões dos arquitetos, a relação conceitual que estes mantêm com o objeto construído, seu contexto e história." (PEIXOTO, 2005: 95).

A memória dos indivíduos que se constrói a partir da relação com os elementos do complexo ferroviário ocorre de maneira efetiva em muitas cidades e núcleos rurais e urbanos brasileiros em que esteve presente(...) (RODRIGUES DA SILVA, 2014).

A produção acadêmica com relação ao patrimônio industrial ferroviário ainda se sobrepõe ao campo da arquitetura. São arquitetos que contribuem com nossa relação no campo da Museologia. No caso das estações ferroviárias portuguesas, Ana Tereza Martins Hagatong nos apresenta estudo comparando a linguagem e ou materiais utilizados nas estações, segundo a autora:

[...] pode se verificar que a estação ferroviária é um tipo de edifício que tem crescido e desenvolvido de acordo com a sua necessidade e que varia no tipo de estrutura urbana que se insere, de modo a responder aos fluxos, ao tipo de passageiros e ao tipo de rede e viagens que integra (HAGATONG, 2014:107). 
Verifica que, no caso português, a concepção da estação não é destacada por ser rotineira. Para Hagatong, existe há procura de uma linguagem singular em consonância a arquitetura própria do país (2014). O museu ferroviário pode ser visto também nesse contexto que preservam o passado na sua forma externa, como aqueles relacionados ao patrimônio industrial que "correspondem a características tipológicas vinculadas à natureza de seus acervos e ao perfil do repertório patrimonial que está sob sua responsabilidade" (BRUNO, 2014:100).

Neste sentido é que o patrimônio do setor elétrico deva ser entendido na sua transversalidade e, assim, outros modelos de museus são vislumbrados, associados ou não ao museu tradicional ou clássico, o que denominamos simplesmente museu à modelagem institucional que decorre da formação de um acervo abrigado em uma edificação, para nos referir a sua mínima formulação (CURY e YAGUI, 2015:111).

O interesse no patrimônio industrial ferroviário pode ser visível nas iniciativas de criação dos museus ferroviários ${ }^{135}$ com concepção de museu e organização administrativa a partir de diferentes modelos.

Tendo em comum a preservação do patrimônio industrial ferroviário, os museus ferroviários nascem em um contexto árido pelas disputas provenientes tanto da economia e do crescimento urbano, por sua vez, proveniente das cidades contempladas na malha ferroviária, como das escolhas políticas que definem como melhor opção o desmonte e extinção da RFFSA, produzindo sucessivos descontentamentos, desnorteando uma parte da população, prioritariamente dos trabalhadores e suas respectivas famílias.

A trajetória dos museus ferroviários no Brasil encontra eco nos fatos históricos relativos ao sistema de transporte, porém é inegável que, os museus da referida tipologia, abrangendo diferentes iniciativas através de diferentes organizações administrativas, tem impulsionado alternativas para os processos museais. Segundo Bruno:

esforços, de origem e natureza distinta, têm demonstrado a existência de
inúmeros heróis anônimos, que permeiam a história dos museus, são
responsáveis pela constatação da relevante função social que estas
instituições podem desempenhar em um país em desenvolvimento e,
sobretudo, deve ser ressaltado que, em uma sociedade de consumo,
como aquela em que vivemos, os museus se constituem em um
segmento de mercado importante, seja enquanto consumidores de uma
imensa série de produtos, equipamentos e serviços, seja enquanto
criadores de estímulos para o turismo cultural (BRUNO, 1997a:41).

Bruno enfatiza o processo e a abrangência das ações que possibilitam o museu existir de fato. Chama de "heróis anônimos" aqueles que tanto dedicaram suas vidas para

135 Conforme apresentado no Capítulo 2 desta dissertação. 
a existência da instituição, mesmo que esteja inserida em uma sociedade de consumo e para tanto é preciso atualizar a instituição museológica para essa e outras disputas.

Semedo apresenta panorama de mudanças operadas no cenário museológico português elencando diversos fatores entre eles os problemas enfrentados e a importância das atividades educativas, a saber:

Ao setor ainda falta um trabalho de animação dos espaços mais intenso e generalizado, considerando como fator essencial de captação e fidelização de públicos; a publicação de materiais informativos de qualidade; programas educacionais inclusivos; a investigação generalizada quer sobre as colecções, quer sobre todas as outras funções (SEMEDO, 2004:26).

Ainda sobre aspectos da comunicação, o investimento em produzir matérias gráficos oferece ao Museu uma série de aspectos positivos, não apenas de divulgação, motivo pelo qual foram confeccionados, mas também pelo fato de tornarem-se documentos dos eventos realizados e da própria a instituição.

Também encontramos alguns museus ferroviários organizados a partir do turismo cultural, oferecendo ao público a viagem de "maria fumaça" e a experiência nesse meio de transporte com tecnologia do início do século XIX.

Nos resultados é possível identificar a realização museológica, que segundo Maria Cristina Bruno, "demonstram muito mais um confronto entre realidade e utopia" (BRUNO, 2006:05). Tendo, segundo a pesquisadora, por um lado, os processos museológicos com procedimentos técnicos-científicos entrelaçados as expectativas e desejos de um fazer museal inclusivo e democrático e, por outro, a prática museológica realizada como sobrevivência em contextos subordinados a apoios políticos-empresariais que determinam essa ou aquela prioridade, reiterando características elitistas e excludentes (BRUNO, 2006).

Os museus têm assumido o desafio de trabalhar a partir dos mais diferentes acervos, para distintos segmentos das sociedades, em todas as regiões do mundo, procurando explicitar as características da nossa condição humana. Apesar dos reiterados questionamentos, crises de identidades e confrontos institucionais, os museus sobrevivem a estes impactos e ainda ocupam um lugar na formação das novas gerações, na equação que os governos estabelecem entre cultura e desenvolvimento, no cotidiano das pequenas comunidades, na programação cultural dos mais diferentes segmentos sociais dos grandes centros urbanos e representam um item importante na indústria do turismo (BRUNO, 2006:09).

O caso do Museu do Trem de São Leopoldo, apresentado nessa pesquisa, não é diferente. São inúmeros elementos elencados que exemplificam os esforços de sobrevivência e a convivência com as duas dimensões museológicas apresentadas por Bruno - a sonhada e a real. 


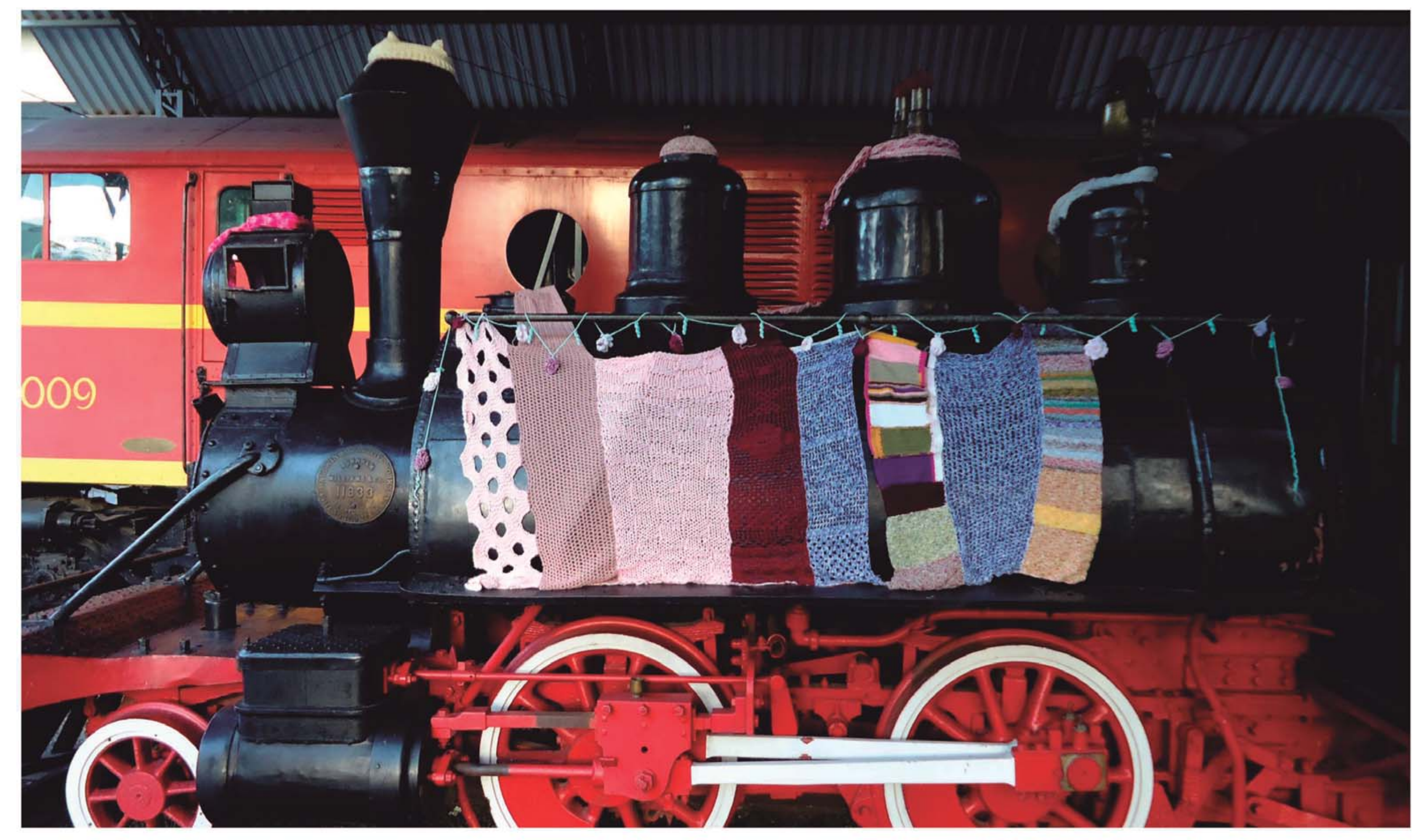


Não é somente almoçar, mas preparar-se para o almoço e/ou preparar o almoço. São inúmeros os fatores que ocorrem entre a ideia inicial e o término da experiência, mas a consumação se dará com a harmonia entre o processo e o fim, o antes do almoço e o fato em si.

A totalidade da experiência é a integração do meio processual com o resultado (CURY, 2005:44)

Encerra-se aqui o almoço. E, com ele, o corpo se manterá nutrido por longo tempo.

A experiência impulsiona movimentos que se desdobram em pesquisa. Os inícios são muitos e simultâneos. Identificar uma única origem para esta pesquisa seria reduzir a experiência.

Neste caso, aponta-se questões iniciais diante de uma ausência de dados organizados e de registros sistematizados sobre a trajetória histórica do Museu do Trem de São Leopoldo. Não parecia haver sentido e nem se fazer possível a compreensão de como gerir um museu sem saber das práticas anteriores realizadas.

Acolhe-se então a inquietação e essa dá voz à dissertação de mestrado.

Apesar de ser exatamente a inquietação o impulso para a pesquisa e a busca de respostas, são os aspectos desencadeados pelo processo da pesquisa que ganham força e se destacam.

Primeiro. Relacionado às descobertas relativas aos processos museográficos nos diferentes períodos da história dos museus ferroviários. No decorrer da pesquisa, a compreensão teórica da prática específica da gestão de museus. Aqui são cunhadas novas interrogações relacionadas às possibilidades de gestionar uma instituição museal e, para tanto, necessário inteirar-se dos contextos nos quais o museu está inserido.

Segundo. Relacionado ao contexto histórico do país. A trajetória da ferrovia brasileira, que possui testemunhos com informações fragmentadas e desconexas, muitas vezes obscuras e incompletas, revelam o cenário como uma estratégia política. Neste sentido, não é precipitado discutir a repetição de um mesmo modelo estrutural, fruto das escolhas regidas pelos interesses imediatos (PAULA, 2004) que ocorrem nas instituições museais ferroviárias. O desmonte da ferrovia e o tratamento dado aos museus ferroviários brasileiros deixam transparecer uma intenção originada na mesma estratégia de não oferecer a informação completa aos envolvidos. Fica evidente que debates decorrentes do estudo, da pesquisa, das inúmeras interpretações evocadas frente ao acervo salvaguardado configuram-se como um perigo aos olhos de alguns interesses específicos. Neste sentido, museu e ferrovia são alvo de desconsideração, desmobilização e 
abandono, por sua vez correntes de interesse na manutenção de um poder e de um saber restrito e exclusivo. De certo modo, incompatível com as ações que viabilizam o museu ferroviário como lugar vivo, com reconhecimento das potencialidades museológicas da tipologia e como um modo para conhecer o Brasil.

A Museologia e o museu têm uma importância central no contexto de reconstrução das nações, na busca de um mundo livre e equitativo. Para tanto, torna-se necessária a formulação de novas diretrizes, à luz dos conhecimentos historicamente acumulados (SANTOS, 2002:21).

Exige-se cada vez mais da museologia a análise dos processos, gerando a redefinição das concepções museais e, consequentemente, a revisão das práticas profissionais do campo.

\begin{abstract}
O museu parece estar fadado a contribuir para a emergência de um interesse comum no âmago do espaço público; ele exerce, de fato, uma hegemonia em termos de coleções, assim como de reflexão coletiva a propósito do patrimônio, do ponto de vista tanto da filiação e identidade, quanto da experiência relativamente à alteridade. Em particular, a nova cultura museal nutre uma reflexão sobre a memória, seu trabalho, suas ambivalências e seus paradoxos, até mesmo sobre os recursos que ela oferece em face da abjeção histórica (POULOT, 2013:12).
\end{abstract}

Os escassos registros da trajetória institucional com dados dos processos museológicos desenvolvidos no campo da gestão, comunicação e público de museus não são privilégio da tipologia, nem do caso em questão. A organização para isso é exigente e demanda tempo, além de onerar um custo real na previsão orçamentária. Porém, entendendo-se esse fazer de identificação de uma prática cotidiana, e o registro do mesmo, como parte de um processo e, por consequência, reveladora de escolhas e concepções, dá-se importância para o detalhamento das fontes organizadas para essa pesquisa. Além do que, estão carregadas de subjetividade quanto ao lugar de cada integrante da equipe do Museu do Trem no período dos quatro anos aqui destacados. Neste sentido, a opção é uma escolha metodológica: incluir os dados pesquisados juntamente com informações visuais, a partir de um corpus documental, pois "compete ao museu reafirmar e fazer visível sempre o seu sentido político, agregando sentido político às suas coleções" (CURY, 2005:314). Ao sistematizar informações dos museus ferroviários no território nacional, apresentam-se novas interrogações:

- Os museus criados e que permanecem abertos o estão por incentivo da comunidade (ferroviária ou local) ou por incentivo do poder público (municipal, estadual ou federal)?

- Entre os diversos interesses (turismo, cultura, economia e política), quais as concepções de museus que estão relacionadas à sua origem?

- De que modo, os museus denominados espaços culturais, oferecem o encontro com acervo material? 
Terceiro. É possível pensar que o Brasil desconhece o Brasil? Isso é tão presente no modo como a história é alvo de apagamentos e torna-se pouco conhecida. Caberia uma análise aprofundada sobre nosso país e nossa cultura, as influências e as decorrências, porém de antemão é possível identificar discursos do cotidiano se ocupam com lamentações, intrigas e disputas com relação aos fatos, antes mesmo de compreender que se trata de resultados de uma ação estratégica de enfraquecimento de um povo. Como, por exemplo, quando observada a construção de uma estrada nova pelo estado brasileiro e nela ficam evidentes: falta de condições de segurança, de oferta de melhores serviços, de projeção futura, de qualidade - falta essa revelada inclusive no uso de material de segunda linha. Espanta-se quando, ao contrário disso, são observadas a construção de estrada com condições reais de servir às necessidades com conforto, segurança, adequação e estratégia logística em prol da nação e revelar, portanto, cuidados com a vida e o Pais como um todo.

Aprofundando leituras sobre a criação e as transformações da estrada de ferro no Brasil, é possível tecer ainda diversas considerações a respeito de como o país não planejou um sistema eficiente de transporte para passageiros e, por outro lado, como interesses privados solucionaram dificuldades com a criação de condições básicas para que a economia cresça. Caberia uma análise aprofundada das condições encontradas e do modo como os interesses impulsionam os fatos que se aproximam, de algum modo, a estrutura ideológica de como se pensa a preservação do patrimônio brasileiro. Neste caso, constata-se a falta de uma política abrangente para a tipologia dos museus ferroviários.

Apesar de no processo desta pesquisa ter sido reunidos inúmeros documentos relativos à trajetória histórica do PRESERVE, caberia maior dedicação na comparação de dados e averiguação de outras fonte, a fim de ampliar a investigação sobre a museologia brasileira nas ações desdobradas nos centros de preservação da história ferroviária, assim como compreender peculiaridades de cada estado na organização do acervo e nos envolvidos, tanto anterior à inauguração do centro ou núcleo, como nos destinos posteriores, até os dias atuais. Destaca-se: não é possível concluir aqui a reflexão com relação aos motivos que determinaram, por exemplo, a escolha de estações e quais os bens patrimoniais seriam privilegiados no programa PRESERVE, pois se sabe que, além das denúncias sobre a depredação do patrimônio, também estão implicadas importantes questões de concepção do desenvolvimento do País, tanto de ordem política como, prioritariamente, questões econômicas. Portanto, para abordar esse tópico, será necessária nova investigação, pautada no resgate de aspectos históricos, coletando dados nas diferentes cidades e estados, assim como nos diferentes setores envolvidos no 
processo, pois a falta de informações referentes ao processo de institucionalização dos museus ferroviários, evidencia lacunas, inclusive, da história do País.

Quarto. O cruzamento das fontes consultadas teve como intenção apresentar o cenário com informações indicativas dos museus ferroviários nos seus diferentes contextos e abordagens. Listagem que informa e indica, porém não conclui no que tange aos acervos ferroviários. Aqui não foi investigada a metodologia utilizada no levantamento de dados de cada fonte, nem, tampouco, aprofundados dados relacionados à proteção, entre IPHAN e Prefeituras Municipais, destinação dos acervos das instituições fechadas ou extintas, como o caso do Centro de Preservação da História Ferroviária do Ceará, organizado pelo PRESERVE. Outro universo não explorado no recorte desta dissertação são os museus de diversas tipologias que ocupam estações e edificações ferroviárias. Conforme o Cadastro de Museus do IBRAM, existem 63 instituições museológicas em edificações ferroviárias, dentre os quais não foi verificado quais apresentam acervo ferroviário e/ou denominação vinculada ao patrimônio referido. Campo fértil para novas investigações.

Quinto. A dificuldade da pesquisadora de distanciar-se da prática e torná-la objeto de reflexão e análise foi persistente. Não se trata de uma dificuldade simplesmente, mas fruto das escolhas metodológicas. Neste caso, estando a metodologia empregada no processo de gestão, quando a participação da equipe era estimulada pela valorização das relações estabelecidas através de uma prática, próximas do pensar museu como processo de construção de conhecimento também vivido pela pesquisadora durante a pesquisa.

Sexto: o volume de museus ferroviários e o volume de questões que podem ser aprofundadas, sobretudo sobre os aspectos da gestão, na subárea da comunicação. Campo vasto e fértil em potencial para futuras pesquisa é convidativo.

Por último: a sobremesa.

[...] uma fonte infinita de conhecimento e crescimento pessoal. Ressalto que não quis ser "objetiva" almejando uma neutralidade absoluta que apagasse as marcas de minha implicação no meu objeto de estudo. Estive, todo o tempo, imersa no processo, na totalidade; tem sido, realmente, um encontro de ação, pensamento, desejo, prazer, paixão e sonho (SANTOS, 2002:18). 


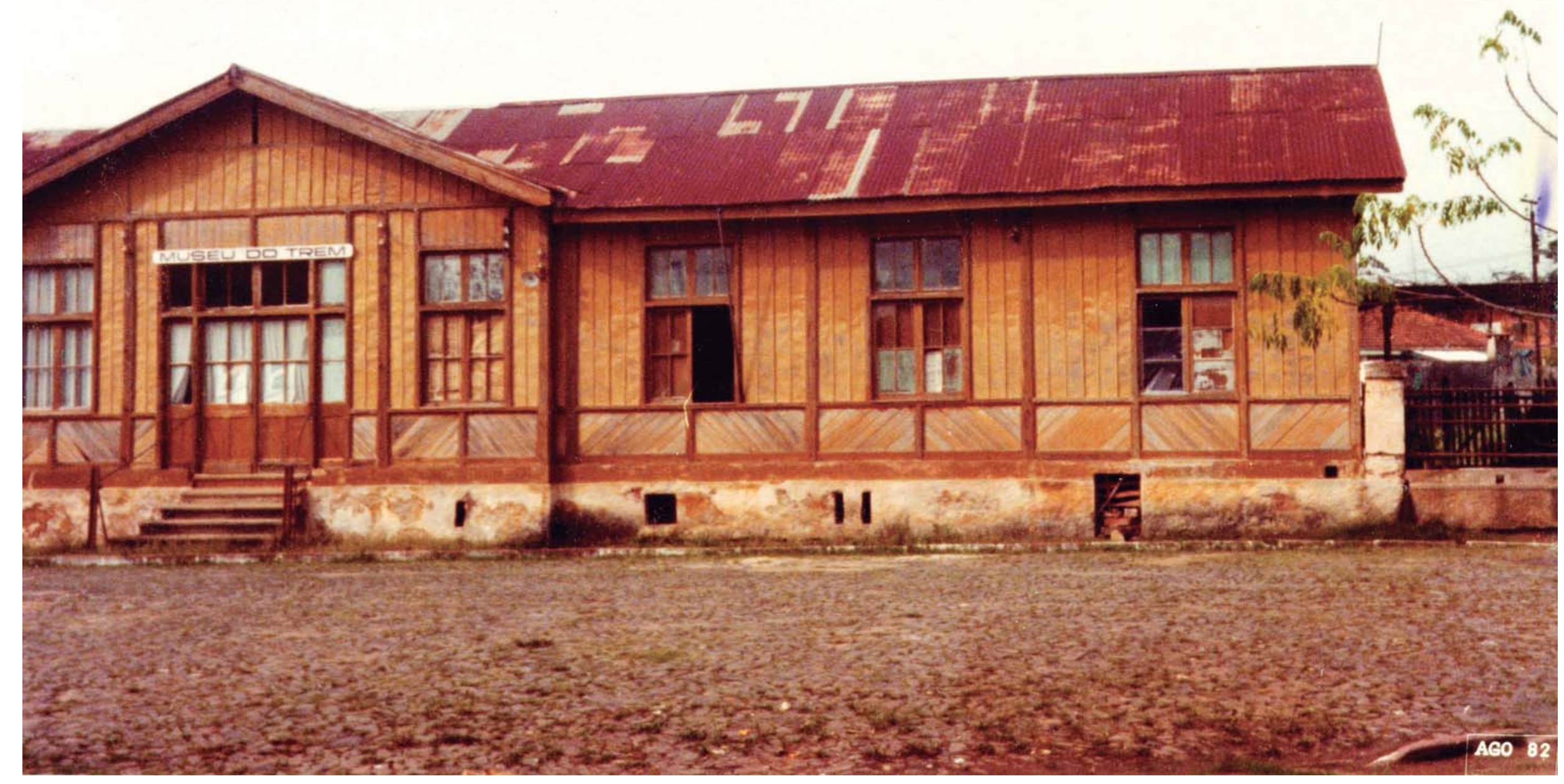

REFERÊNCIAS 


\section{REFERÊNCIAS}

AAKER, DA. Construindo marcas fortes. Porto Alegre: Bookman, 2007. In: MOORE, K. La Gestión del Museo. Gijón: Ediciones Trea: 1998. p. 175-182.

ABREU, Bebel. Expografia Brasileira Contemporânea: Rio São Francisco Navegado por Ronaldo Fraga. São Paulo, 2014. 186 p. Dissertação (mestrado em Arquitetura) Universidade de São Paulo.

ALMEIDA, Cícero. Plano Museológico - Marco de Regulação da Gestão Museal no Brasil. In: Gestão Museológica: questões teóricas e práticas/Seminário Internacional sobre Gestão Museológica realizado pelo Museu Nacional do Conjunto Cultural da República: organizador Wagner Barja. Brasília: Câmara dos Deputados, Edições Câmara, 2013. p.2732.

AMES, Peter J. Conjugar La Misión com el Mercado: um problema para la gestión moderna de los museos. In: In: MOORE, K. La Gestión del Museo. Gijón: Ediciones Trea: 1998. p. 35-46.

ANDREATTA, Margarida Davina. Arqueologia Histórica Industrial: um patrimônio em São Paulo. Diário Oficial do Estado - Suplemento. V.113, no18. [25 jan.2003]

BARBOSA, Malvina. Um Século das Estradas de Ferro Brasileiras - 105 anos de história - 1854 - 1959. Rio de Janeiro: Letra Capital Editora, 2010.

BEMVENUTI, Alice. Espaços, tempos, ações e ambiente - lugares de aprendizagem. In: 2008. p.189- 208. (Org.) O Lúdico na Prática Pedagógica. Curitiba-Canoas: IBPEX-Ulbra,

Estudos de Público: reflexões sobre a gestão no Museu do Trem. In:

III Encontro Paulista Questões Indígenas e Museus / IV Seminário Museus, Identidades e Patrimônio Cultural. 2014, Tupã. Resumos. São Paulo: USP, 2014. p.62-64.

. 35 anos - Museu do Trem (parte 1). Jornal Vale dos Sinos, São Leopoldo, no 10.296, 11 jun. 2012a. Seção Opinião, p. 08.

. 35 anos - Museu do Trem (parte 2). Jornal Vale dos Sinos, São Leopoldo, no $\overline{10.297,} 12$ jun. 2012b. Seção Opinião, p. 11.

.35 anos - Museu do Trem (parte 3).Jornal Vale dos Sinos, São Leopoldo, no 10.298, 13 jun. 2012c. Seção Opinião, p. 11.

. 35 anos - Museu do Trem (parte 4). Jornal Vale dos Sinos, São Leopoldo, no $\overline{10.299,14}$ jun. 2012d. Seção Opinião, p. 11.

. 35 anos - Museu do Trem (parte 5). Jornal Vale dos Sinos, São Leopoldo, no 10.300, 15 jun. 2012e. Seção Opinião, p. 11. 
O encontro amoroso entre gerações. Jornal Vale dos Sinos, São Leopoldo, no 9.352, 06 maio 2009. Seção Opinião, p.04.

. Vila dos Ferroviários, Rua Diretor Augusto Pestana em Porto Alegre. Revista Memória em Rede. v.6, no11, Jul/Dez. UFPel, 2014. p. 191-200. Disponível em: https://periodicos.ufpel.edu.br/ojs2/index.php/Memoria/article/view/9427

BORDENAVE, Juan E. Díaz. O que é Comunicação. São Paulo: Editora Brasiliense, 1987.

BRUNO, M. C. O. Museus hoje para o amanhã, 1997a. Cadernos de Sociomuseologia, 10) p. 35-42. Disponível em: http://revistas.ulusofona.pt/index.php/cadernosociomuseologia/article/view/299 Acesso em: 01 Mai. 2016.

Museologia e Museus: como implantar as novas tendências, 1997b. Cadernos de Sociomuseologia, 10) p. 07-11. Disponível em: Disponível em: <http://revistas.ulusofona.pt/index.php/cadernosociomuseologia/article/view/296/205>. Acesso em: 01 mai. 2016.

. Museologia e Museus: os inevitáveis caminhos entrelaçados, 2006. Cadernos de Sociomuseologia, 25) p. 05-20. Disponível em: file://C:/Users/User/Downloads/4191-1418-1-10-20090620\%20(1).pdf Acesso em: 01 mai.2016

Processos Museológicos: os caminhos para a gestão dos museus. In: Marilia Xavier Cury. (Org.). Fronteiras Regionais e perspectivas Nacionais - Seminário Interdisciplinar em Museologia. 1ed.Blumenau: Fundação Herman Hering, 2014, v. 1, p. 100-105.

.(Coord.). Waldisa Rússio Camargo Guarnieri: textos e contextos de uma trajetória profissional. São Paulo: Pinacoteca do Estado, 2010. v. 1.

BUZELIN, José Emilio de Castro. R.F.F.S.A. - Rede Ferroviária Federal Sociedade anônima - Histórico de Formação. Almanaque da RFFSA, Vol. 1. Cap.1. Postado em 02 dez.2009. Disponível em http://almanaquedarffsa.blogspot.com.br/search?updated$\min =2009-01-01$ T00:00:00-02:00\&updated-max=2010-01-01T00:00:00-02:00\&maxresults $=8$ Acesso em: 04 dez. 2013.

R.F.F.S.A. - Fases Administrativas: fase III - de 1976 a 1996. Almanaque da RFFSA, Vol. V. Cap.22. Postado em 21 jan. 2010. Disponível em http://almanaquedarffsa.blogspot.com.br/2010/01/rffsa-volume-v-capitulo-22.html Acesso em: 04 dez. 2013.

CÂNDIDO D., Manuelina M. Gestão de Museus, Diagnóstico Museológico e Planejamento: um desafio contemporâneo. Porto Alegre: Medianiz, 2013.

CARTA DE NIZHNY TAGIL. TICCIH: 2003.

CARTA DE RIGO. Portugal: 2005. 
CARTA DE SANTA MARIA. Brasil: 2010.

CARVALHO, Alexandre de J.F.. Gestão de Museus: o caso do Museu Nacional de Arqueologia. Lisboa: 2015. 97 p. (Dissertação de Mestrado em Museologia) - Universidade Nova de Lisboa. Disponível em https://run.unl.pt/bitstream/10362/17242/1/FINAL\%20Relat\%C3\%B3rio\%20de\%20Est\%C 3\%A1gio_MNA_Alexandre_Carvallho.pdf Acesso em 04 jan. 2016

CAVALCANTI NETO, José Rodrigues; CARNEIRO, Fernanda; GIANNECCHINI, Ana Clara. Avanços e desafios na preservação do patrimônio ferroviário pelo Instituto do Patrimônio Histórico e Artístico Nacional. In: Colóquio Latino Americano sobre Recuperação e Preservação do Patrimônio Industrial, 2011. Anais. Disponível em: http://portal.iphan.gov.br/uploads/ckfinder/arquivos/VI_coloquio_t6_avancos_desafios.pdf Acesso em 17 jan. 2016

CAZELLI, Sibele; COIMBRA, Carlos Alberto Quadros. Pesquisas Educacionais em Museus: Desafios colocados por diferentes audiências. 1ํㅡorkshop Internacional de Pesquisa em Educação em Museus, São Paulo: dez. 2012. Anais (CD-Rom)

CHAGAS, Mário. Museus, memórias e movimentos sociais. Cadernos de Sóciomuseologia, 41. 2011. p. 05-15. Disponível em: http://revistas.ulusofona.pt/index.php/cadernosociomuseologia/article/view/2654 Acesso em: 15 jan.2015.

CHIAVENATO, Idalberto. Introdução à Teoria Geral da Administração. São Paulo: McGraw-Hill do Brasil, 1977.

Teoria Geral da Administração. Vol.1. 5 ed. São Paulo: Makron Books,1997.

CHOAY, F. Alegoria do Patrimônio. São Paulo: UNESP, 1999.

CIVERA, Inmaculada Aguilar. Patrimônio Industrial. Aproveitamento Cultural e Reutilização. In: ARECES, Miguel A.A. (coord.) Esructuras y Paisajes Industriales Proyectos socioculturales y turismo cultural. Coleção Los Ojos de la Memoria, 3. Gijón: 2003. p. 41-61.

CÓDIGO DE ÉTICA PROFISSIONAL DO ICOM. 2004.

COMISSÃO DE PATRIMÔNIO CULTURAL. Guia de Museus Brasileiros. São Paulo: EDUSP: Imprensa Oficinal do Estado, 2000.

CURY, M. X. A importância das coisas: Museologia e museus no mundo contemporâneo. In: SIMON, Samuel (Org.). Um século de conhecimento: arte, filosofia, ciência e tecnologia no século XX. Brasília: Ed. UnB, 2011. p. 1015-1047.

2005.

Exposição: concepção, montagem e avaliação. São Paulo: Annablume, 
Museologia e Conhecimento, Conhecimento Museológico - uma perspectiva dentre muitas. In: Museologia \& Interdisciplinaridade. Revista do Programa de PósGraduação em Ciências da Informação. Vol.III. n⒌ Brasília: Ed. UnB, 2014. p. 55-73.

. Museu e Museologia: Interfaces e Perspectivas/Museu de Astronomia e Ciências Afins - Org. Marcus Granato, Claudia Penha dos Santos e Maria Lúcia de N.M.Loureiro. Rio de Janeiro: MAST, 2009.p.25-41.

Museu em transformação. Revista Museu, mai.2009. Disponível em http://www.revistamuseu.com.br/18demaio/artigos.asp?id=32846 Acesso em 20 jan. 2015.

. Revisão Museológica e Museográfica do Museu Histórico de São Francisco. Diagnóstico. São Francisco do Sul: abr.2006a. 49p.

Revisão Museológica e Museográfica do Museu Histórico de São Francisco. Documento Preliminar de Conceituação Museológica. São Francisco do Sul: ago.2006b. $18 p$.

. Revisão Museológica e Museográfica do Museu Histórico de São Francisco. Projeto Museológico Institucional. São Francisco do Sul: set.2006c. 52p.

. Síntese teórica. São Paulo: 2013. Anotações de aula na Disciplina: Museologia: Princípios Teórico-Metodológicos [05.08.2013]. Programa de Pós-Graduação Interunidades em Museologia - Universidade de São Paulo. $13 \mathrm{fl}$.

CURY, M.X.; YAGUI, M.M.P. A musealização do setor elétrico em São Paulo: construção de perspectivas para as usinas hidrelétricas. Revista Labor \& Engenho, Campinas [SP] Brasil, v.9, n.1, p.104-134, jan./mar. 2015. URL: http://www.conpadre.org/

CUSTÓDIO, Jorge. A Exposição "Royal Class. Regal Journeys" no Museu de Utrecht e a mudança de paradigma do patrimônio ferroviário. Portugal: Entroncamento, 25 mai 2010.

DAVIES, Stuart. Plano Diretor. Tradução Maria Luiza Pacheco Fernandes. São Paulo: Editora da Universidade de São Paulo, Fundação Vitae, 2001. (Série Museologia, 1)

DESVALLÉS, André; MAIRESSE, François (Ed.). Conceitos-chave de museologia. Tradução Bruno Brulon, Marília Xavier Cury. São Paulo: Comitê Brasileiro do Conselho Internacional de Museus, Conselho Internacional de Museus, Pinacoteca do Estado de São Paulo, Secretaria de Estado da Cultura, 2013.

DIAMOND, J. Practical Evaluation Guide - Tools for Museum \& Other Informal Educational Setting. Oxford: Altamira Press, 1999.

DRUCKER, Peter. El museo universitário de arte: definición de su propósito y misión. In: MOORE, K. La Gestión del Museo. Gijón: Ediciones Trea: 1998. p. 175-182.

Prática da Administração de Empresas. Trad. Carlos A. Malferrari. São Paulo: Pioneira Thomson, 2002. 
EDSON, Gary. Gestão do Museu. In: Como Gerir um Museu: Manual Prático. ICOM, 2004. p.145-165.

FINGER, Anna Eliza. Vila dos Ferroviários no Brasil - Os casos de Paranapiacaba em São Paulo e da Vila Belga no Rio Grande do Sul. Brasília: 2009. Dissertação (mestrado em Arquitetura e Urbanismo) - Universidade de Brasília.

FRANCISCO, Júlio C.B., MORIGI, Valdir J. O olhar do Outro: a gestão de museus e a sustentabilidade. (Museologia \& Internacionalidade) v.II, no 03 mar/jun 2013

FRANCO-AVELLANEDA, Manuel. Ensamblar Museus de Ciências e Tecnologias: compreensões educativas a partir de Três estudos de Caso. Florianópolis: 2013. 300 p. Tese (doutorado em Educação Científica e Tecnológica) - Universidade Federal de Santa Catarina.

FREIRE, M.; DAVINI, J.; CAMARGO, F.; MARINS, M.C.. Observações - Registro Reflexão. Instrumentos Metodológicos I. São Paulo: Espaço Pedagógico, 1995. 64 p. Série Seminários.

Avaliação e Planejamento A prática educativa em questão. Instrumentos Metodológicos II. São Paulo: Espaço Pedagógico, 1997. 87 p. Série Seminários.

Grupo - Individuo, saber e parceria - malhas do conhecimento. São Paulo: Espaço Pedagógico, 1993. 59 p. Série Seminários.

GUARNIERI, Waldisa Rússio Camargo. Museologia e identidade. Cadernos Museológicos. Rio de Janeiro. n.3: p. 39-46, out.1990.

. Um Museu de Industria em São Paulo. 1980. Escola de Sociologia e Política de São Paulo, São Paulo. (Tese de Doutorado)

Museu, museologia, museólogos e formação. Revista de Museologia. São Paulo, Instituto de Museologia de São Paulo/FESP, v.1, n.1: 7-11, 1989.

A elaboração de princípios teóricos-metodológicos e as abordagens sociopolíticas e culturais. In: BRUNO, M.C.O., Waldisa Russio Camargo Guarnieri: textos e contextos de uma trajetória profissional. Volume 1. São Paulo: Pinacoteca do Estado de São Paulo, 2010. p. 179-210.

HAGATON, Ana Tereza Martins. Patrimônio Industrial Ferroviário - Uma arquitetura em risco. Revista Arquitectura Lusiana, no 51. P. 101-115. URL: http://repositorio.ulusiada.pt/bitstream/11067/1614/1/ral_5_8.pdf Acesso em 16 mar. 2015.

HEINEN, Nivia Terezinha. Introdução ao Estudo das Ferrovias no Rio Grande do Sul: 1874-1905. Porto Alegre, 1981. 66 p. Monografia (especialização em História) Universidade Federal do Rio Grande do Sul.

HORTA,M.L.P., Gestão dos museus e do patrimônio cultural. Revista Ciências\&Letras. Porto Alegre, 31, jun. 2002. p. 33-52. 
HUYER, André. A Ferrovia do Riacho: Um caminho para a urbanização da Zona Sul de Porto Alegre. Porto Alegre, 2010. 241 p. Dissertação (mestrado em Arquitetura) Universidade Federal do Rio Grande do Sul.

INSTITUTO BRASILEIRO DE MUSEUS. Política Nacional de Museus. Brasília, 2003.

INSTITUTO BRASILEIRO DE MUSEUS. Guia dos Museus Brasileiros. Brasília, 2011.

INSTITUTO DO PATRIMÔNIO HISTÓRICO E ARTÍSTICO DO ESTADO. Parecer Técnico IPHAE no 23. Definição de entorno: Sitio Histórico Museu do Trem, São Leopoldo. 28 mar.2002. $10 \mathrm{fl}$

ISO 9000. Sistemas de gestão da qualidade - Fundamentos e Vocabulários. Rio de Janeiro: Associação Brasileira de Normas Técnicas, dezembro, 2005.

ISO 9001. Sistemas de gestão da qualidade - Requisitos. Rio de Janeiro: Associação Brasileira de Normas Técnicas, dezembro, 2000.

JENKINS, G. Quality control. Lancaster, UK. University of Lancaster, 1971.

JURAN, J.M.; GRYNA, F. Controle de qualidade handbock. São Paulo: Mackron, 1991. v.1.

KUHL, Beatriz. A expansão ferroviária em São Paulo (Brasil) e problemas para a preservação de seu patrimônio. In: TST Transportes, Serviços y Telecomunicaciones, v. 23,p. 166-197, 2012.

Patrimônio Industrial: algumas questões em aberto. Revista eletrônica da Universidade São Judas Tadeu - Arquitetura e Urbanismo, n..3, primeiro semestre 2010. Rio de Janeiro. p.23-27.

LIMA, Diana Farjalla Correia. Museologia-Museu e Patrimônio, Patrimonializaçao e Musealização: ambiência de comunhão. Boletim do Museu Paraense Emilio Goeldi. Ciências Humanas. V.7, n.1, p. 31-50, jan-abr, 2012.

LOPES, Luis Filipe Gomes. Museu Nacional Ferroviário. Um Museu Industrial? Lisboa, 2012. 188 p. Dissertação (mestrado em Museologia) - Universidade Nova de Lisboa.

LOPES, Maria Margaret. O Brasil descobre a pesquisa científica: os museus e as ciências naturais no século XIX. São Paulo: Aderaldo \& Rochschild; Brasília: Editora UNB, 2009.

LORD, Gail; LORD, Barry. Manual de Gestión de museos. (Título original: Manual of Museum Managent.) Barcelona: Ariel Arte e Patrimônio, 2010.

MASON, Timothy. Gestão Museológica: Desafios e Práticas. São Paulo: Editora da Universidade de São Paulo British Council: Fundação Vitae, 2004. (Série Museologia, 7) 
MARANDINO, Martha. (2005) Museus de Ciências com Espaços de Educação. In: FIGUEIREDO, Betânia Gonçalves; VIDAL, Diana Gonçalves. (org.) Museus: dos Gabinetes de Curiosidades à Museologia Moderna. Belo Horizonte, p. 165-176.

MARTINS, José de Souza. A ferrovia e a modernidade em São Paulo: a gestação do ser dividido. Revista da USP, n 63. p, 6-15. Set/nov 2004.

MARTINS, M.C. Sensível-olhar-pensante. São Paulo: Espaço Pedagógico,1992.

MARTÍN-BARBERO, Jesús. Dos meios às mediações: comunicação, cultura e hegemonia. Tradução de Ronald Polito e Sergio Alcides. Rio de Janeiro: Editora UFRJ, 1997.

MATOS, Ana Cardoso de. SAMPAIO, Maria da Luz. Patrimônio Industrial e Museologia em Portugal. FALTA LOCAL: Museologia \& Interdisciplinaridade. Vol.II, nํ5, maio/junho, 2014. (95-112)

MELO, Isabel. Museus e Qualidade - Intersecções e divergências. Cadernos de Sóciomuseologia. 32, jun. 2007. p. 91-144. Disponível em: <http://revistas.ulusofona.pt/index.php/cadernosociomuseologia/article/view/494/397>. Acesso em: 01 Jun. 2016.

MENDES, José Amado. O patrimônio industrial na museologia contemporânea: o caso português. Lisboa: Museus dos Lanifícios de Covilhã, 2012. p. 89-104. (Revista on line do Museu dos Lanifícios de Covilhã)

MENESES, Ulpiano Bezerra de. A problemática da identidade cultural nos museus: objetivo (de ação) a objeto (de conhecimento). Anais do Museu Paulista. Nova Série n 1, 1993. p. 207-309.

. Do teatro da memória ao laboratório da História: a exposição museológica e o conhecimento histórico. Anais do Museu Paulista. São Paulo. N.Ser.v.2, jan-dez. 1994. p.9-42

MIDDLETON, Victor. La irresistible atracción de la demanda. In: MOORE, K. La Gestión del Museo. Gijón: Ediciones Trea: 1998. p. 373-382.

MOEHLECKE, Germano O. Estrada de Ferro - contribuição para a história da primeira ferrovia do Rio Grande do Sul. São Leopoldo: Impressão e Acabamento Rottemund, 2004. $285 \mathrm{p}$.

MOORE, Kevin (Ed.). La Gestión del Museo. Gijón: Ediciones Trea: 1998. Título original: Museum Management.

MORK, Paal. Marketing. In: Como Gerir um Museu: Manual Prático. ICOM, 2004. p.175191. 
OLIVEIRA, Ana Laura Ferrer. Novos Usos para o Patrimônio Industrial: O Caso da Cordoaria Nacional. Lisboa, dez. 2012. 139 p. Dissertação (Mestrado em Arquitetura) Universidade Técnica de Lisboa.

OLIVEIRA, Eduardo Romero de. Museus Ferroviários do Estado de São Paulo (Brasil): as políticas de conservação e o estado atual do patrimônio ferroviário brasileiro. TST Transportes, Servicios e Telecomunicações, v. 19, dez 2010. p.190-204.

O centenário da Ferrovia Brasileira (1954): Ensaio sobre a elaboração da memória ferroviária no Brasil. 2013. Revista Espaço \& Geografia (UnB), Vol.16, n 12. p. 675-717.

Patrimônio Ferroviário do Estado de São Paulo: as condições de preservação e uso dos bens culturais. 2010. Revista Patrimônio e Cultura Material. Projeto História (PUCSP), v.40, p. 179-203.

Patrimônio Ferroviário no Rio Grande do Sul: inventário das estações. 1874-1959. Porto Alegre: IPHAE, 2002. 284p.

PAULA, Dilma Andrade de. Fim da Linha: a extinção de ramais da Estrada de Ferro Leopoldina, 1955-1974. Niterói, 2000. 346 p. Tese (doutorado em História) - Universidade Federal Fluminense.

PEIXOTO, E.R.. Um ponto de vista acerca do Patrimônio Industrial. Pós. Ver. Programa Pós-Grad. Arquit Urban. FAUSP, São Paulo, n.17, jun, 2005. p. 88-101. URL: http://revistas.usp.br/posfau/article/viewFile/43402/47024 Acesso em: 21 jan 2016.

PIRES, Antônio João Pinto. O Museu Ferroviário Nacional e Polinucleado - Um museu em construção. Lisboa, 2004. 172 p. Dissertação (mestrado em Museologia) Universidade Lusófona de Humanidades e Tecnologia.

PIRES, Antônio Ramos. Gestão da Qualidade em Museus. Lisboa: ULHT, 2006. p. 81103. (Cadernos de Sociomuseologia, 25) Disponível em: $<$ http://revistas.ulusofona.pt/index.php/cadernosociomuseologia/article/view/425/330>. Acesso em: 01 Jun. 2015.

POULOT, Dominique. Uma história do patrimônio no Ocidente. Tradução Guilherme João de Freitas Teixeira. São Paulo: Estação Liberdade, 2009.

PREFEITURA MUNICIPAL DE SÃO LEOPOLDO. URL: www.saoleopoldo.rs.gov.br Acesso em: 14 jan.2015.

PREFEITURA MUNICIPAL DE SÃO LEOPOLDO. Relatório Leitura Técnica. Processo de Revisão do Plano Diretor Participativo de São Leopoldo. Secretaria de Planejamento/SEPLAN. (Coord. Geral e Revisão de Conteúdo: Isabella da Costa Albrecht). São Leopoldo: 2006. $78 \mathrm{fl}$.

PROCHNOW, Lucas Neves. O Iphan e o patrimônio ferroviário: a memória ferroviária como instrumento de preservação. 2014. 177 f. Dissertação (Mestrado Profissional em Preservação do Patrimônio Cultural) - IPHAN, Rio de Janeiro, 2014. 
- Memória ferroviária. In: REZENDE, Maria Beatriz; GRIECO, Bettina; TEIXEIRA, Luciano; THOMPSON, Analucia (Orgs.). Dicionário IPHAN de Patrimônio Cultural. 1. ed. Rio de Janeiro, Brasília: IPHAN/DAF/Copedoc, 2015. (verbete).

RODRIGUES, Marly. Patrimônio industrial, entre o fetiche e a memória. Revista eletrônica da Universidade São Judas Tadeu - Arquitetura e Urbanismo, VI (3), p.3140, 2010. Disponível em http://www.usjt.br/arq.urb/ . Acesso em: 22 abr. 2016.

RODRIGUES DE SILVA, André Ronaldo. Patrimônio Industrial, Memória e Identidade Social: "Quem" são as Rotundas Ferroviárias? In: 3o. Congresso Internacional Interdisciplinar em Sociais e Humanidades (CONINTER3), 2014, Salvador - Bahia. Anais CONINTER3, 2014a. v. 16. p. 355-367.

Patrimônio Ferroviário Brasileiro: Da inclusão à exclusão de uma paisagem cultural. In: 3ํㅡㄹ Colóquio Ibero-americano Paisagem Cultural, Patrimônio e Projeto, 2014, Belo Horizonte - MG. Anais. Belo Horizonte - MG: IEDS/MACPS/IPHAN, 2014b. v. único.

SANTOS, M.C. Entrevista ao Prof. Mário de Souza Chagas. Cadernos de Sociomuseologia, América do Norte, 18, Jun. 2009. Disponível em: $<$ http://revistas.ulusofona.pt/index.php/cadernosociomuseologia/article/view/360/269>. Acesso em: 19 Jun. 2016.

Os Museus e a Busca de Novos Horizontes. III Fórum de Profissionais de Reservas Técnicas de Museus, 18 a 22 nov. 2002. Anais. Salvador: COFEM, COREM.

SANTOS, Suzenalson da Silva. Os Kanindé no Ceará. O Museu indígena como uma experiência em museologia social. In: III ENCONTRO PAULISTA QUESTÕES INDÍGENAS E MUSEUS / IV SEMINÁRIO MUSEUS, IDENTIDADES E PATRIMÔNIO CULTURAL. 2014, Tupã. Resumos. São Paulo: USP, 2014. p. 60-61.

SANTOS, Welber. O Complexo Ferroviário de São João Del - Rei entre a ABPF, o PRESERVE e o IPHAN. Pesquisa Acadêmica, 21 p. URL: http://portal.iphan.gov.br/portal/baixaFcdAnexo.do?id=3006 Acesso em: 12 dez. 2013.

SCHOENMAKER, Letícia Lopes Borges. Apontamentos sobre o acervo do Museu da Companhia Paulista de Jundiaí. Jundiaí: Revista Cidade, Patrimônio e Memória/Prefeitura Municipal de Jundiaí - Secretaria de Cultura. Edição 000 - Maio 2016. p. 80-83.

SEMEDO, Alice. Estratégias Museológicas e Consensos Gerais. In: BRITO, Mário A.N.P.de., CUNARRO,José M. H.(org). Museus do Eixo Atlântico. 2004 p. 5-32.

Políticas de gestão de coleções. Revista da Faculdades de Letras Ciências e Técnicas do Patrimônio. Porto: 2005, série volume IV. p. 305-322.

Formação em Museologia: círculos e outras geometrias. Anais do Museu Paulista. São Paulo: V.21. p. 49-62. jan-jun.2013.

SILVA, Ayrton Camargo e. A implantação e o desenvolvimento dos trens de passageiros no Brasil. Revista da ANTP - Ano 36, 2014, 2ำ quadrimestre. p. 83-94. 
SISTEMA ESTADUAL DE MUSEUS DO RS. Guia de Museus do Rio Grande do Sul. Porto Alegre, 2013.

SUKEL, William M. Los Museos como organizaciones. In: MOORE, K. La Gestión del Museo. Gijón: Ediciones Trea: 1998. p. 391-394.

WOLTON, Dominique. Pensar a Comunicação. Brasília: Fundação Universidade de Brasília, 2004.

VERGARA, Luiz Guilherme. Curadorias educativas a consciência do olhar: percepção imaginativa perspectivas fenomenológica aplicadas à experiência estética. In: CONGRESSO NACIONAL DE PESQUISADORES EM ARTES PLÁSTICAS. v.3. São Paulo, out./1996. Anais 96. São Paulo, Associação Nacional de Pesquisadores em Artes Plásticas, 1996. p.240-247.

VICTOR, Isabel. A qualidade em museus problemática a esclarecer. 2006. p. 21-32 Cadernos de Sociomuseologia. no25 ano http://recil.grupolusofona.pt/bitstream/handle/10437/3979/A\%20QUALIDADE\%20EM\%20 MUSEUS.pdf?sequence=1 Acesso em 22 abr 2016.

VICTOR, I.. PARTE V - OS MUSEUS E A QUALIDADE. Cadernos de Sociomuseologia, América do Norte, 23, Jun. 2009. Disponível em: <http://revistas.ulusofona.pt/index.php/cadernosociomuseologia/article/view/403/310>. Acesso em: 01 Jun. 2016.

VIEIRA, Flávio. Os Caminhos ferroviários Brasileiros. In: I Centenário das Ferrovias. Diversos Autores. Rio de Janeiro: Serviço Gráfico do IBGE, 1954. p. 77-175.

YAGUI, Mirian Midori Peres. Museu e patrimônio industrial: um estudo sobre a musealização do setor elétrico no estado de São Paulo. São Paulo, 2014. 171 p. Dissertação (Mestrado em Museologia) - Universidade de São Paulo.

\section{FONTES DOCUMENTAIS}

\section{Audiovisual}

AULER, Marioni. Marioni Auler: depoimento [17 nov. 2011]. Entrevistadora: A. Bemvenuti, Câmera: L. Moreira. São Leopoldo: CPHFRS-Museu do Trem de São Leopoldo, 2011. 1 DVD. (20'01") son. color. Entrevista concedida na coleta de informações da história do Museu do Trem de São Leopoldo - 35 anos.

CALEGARI, João Edacir. João Edacir Calegari. depoimento [11 nov. 2011]. Entrevistadora: K.Kerpen, Câmera: L. Moreira. São Leopoldo: CPHFRS-Museu do Trem de São Leopoldo, 2011. 1 DVD. (24'56") son. color. Entrevista concedida na coleta de informações da história do Museu do Trem de São Leopoldo - 35 anos. 
CAVEDON, Ubirajara Sperb. Ubirajara Sperb Cavedon. depoimento [17 nov. 2011]. Entrevistadora: A. Bemvenuti, Câmera: L. Moreira. São Leopoldo: CPHFRS-Museu do Trem de São Leopoldo, 2011. 1 DVD. (20'12") son. color. Entrevista concedida na coleta de informações da história do Museu do Trem de São Leopoldo - 35 anos.

FERNANDES, Isabel Cristina Flores. Isabel Cristina Flores Fernandes. depoimento [17 nov. 2011]. Entrevistadora: A. Bemvenuti, Câmera: L. Moreira. São Leopoldo: CPHFRSMuseu do Trem de São Leopoldo, 2011. 1 DVD. (20'01') son. color. Entrevista concedida na coleta de informações da história do Museu do Trem de São Leopoldo - 35 anos.

GARCIA, Joel. Joel Garcia. depoimento [27 out. 2011]. Entrevistadora: A. Bemvenuti, Câmera: L. Moreira. São Leopoldo: CPHFRS-Museu do Trem de São Leopoldo, 2011. 1 DVD. (47'25") son. color. Entrevista concedida na coleta de informações da história do Museu do Trem de São Leopoldo - 35 anos.

GUEDES, Andréa. Andrea Guedes. São Leopoldo: 09 nov. 2011. depoimento [17 nov. 2011]. Entrevistadora: K.Kerpen, Câmera: L. Moreira. São Leopoldo: CPHFRS-Museu do Trem de São Leopoldo, 2011. 1 DVD. (09'33") son. color. Entrevista concedida na coleta de informações da história do Museu do Trem de São Leopoldo - 35 anos.

KLUMB, Eliane. Eliane Klumb depoimento [08 nov. 2011]. Entrevistadora: A. Bemvenuti, e, K.Kerpen. Câmera: L. Moreira. São Leopoldo: CPHFRS-Museu do Trem de São Leopoldo, 2011. 1 DVD. (16'31') son. color. Entrevista concedida na coleta de informações da história do Museu do Trem de São Leopoldo - 35 anos.

LINCK, Márcio. Marcio Linck. depoimento [01 nov. 2011]. Entrevistadora: A. Bemvenuti, Câmera: L. Moreira. São Leopoldo: CPHFRS-Museu do Trem de São Leopoldo, 2011. 1 DVD. (29'45") son. color. Entrevista concedida na coleta de informações da história do Museu do Trem de São Leopoldo - 35 anos.

LUZ, Roberto Albuquerque Guedes da. Roberto Albuquerque Guedes da Luz. depoimento [27 out. 2011]. Entrevistadora: A. Bemvenuti, Câmera: L. Moreira. São Leopoldo: CPHFRS-Museu do Trem de São Leopoldo, 2011. 1 DVD. (24'25') son. color. Entrevista concedida na coleta de informações da história do Museu do Trem de São Leopoldo - 35 anos.

MALLO, Alejandro. Alejandro Mallo. depoimento [09 nov. 2011]. Entrevistadora: A. Bemvenuti, Câmera: L. Moreira. São Leopoldo: CPHFRS-Museu do Trem de São Leopoldo, 2011. 1 DVD. (31'11') son. color. Entrevista concedida na coleta de informações da história do Museu do Trem de São Leopoldo - 35 anos.

MARTINS, Daniel. Daniel Martins. São Leopoldo: depoimento [17 nov. 2011]. Entrevistadora: A. Bemvenuti, K.Kerpen Câmera: L. Moreira. São Leopoldo: CPHFRSMuseu do Trem de São Leopoldo, 2011. 1 DVD. (35'30') son. color. Entrevista concedida na coleta de informações da história do Museu do Trem de São Leopoldo - 35 anos.

MOEHLECKE, Germano. palestra [26 mai. 2009]. Áudio: A. Bemvenuti. São Leopoldo: CPHFRS-Museu do Trem de São Leopoldo, 2009. (50'44") Celular. 1ª Semana de Museus em São Leopoldo e 7ª̂Semana Nacional dos Museus. 
Germano Moelhecke. depoimento [14 nov. 2011]. Entrevistadora: A. Bemvenuti, e K.Kerpen; Câmera: L. Moreira. São Leopoldo: CPHFRS-Museu do Trem de São Leopoldo, 2011a. 1 DVD. (44'07') son. color. Entrevista concedida na coleta de informações da história do Museu do Trem de São Leopoldo - 35 anos.

Germano Moelhecke. depoimento [dez. 2011]. Entrevistadora: A. Bemvenuti, Câmeras: R. Tosca e L. Moreira. São Leopoldo: CPHFRS-Museu do Trem de São Leopoldo, 2011b. 1 DVD. (35'22") son. color. Entrevista concedida na coleta de informações da história do Museu do Trem de São Leopoldo - 35 anos.

PRIETO, Henrique da Costa. Henrique da Costa Prieto. depoimento [08 nov. 2011]. Entrevistadora: K;Kerpen, Câmera: L. Moreira. São Leopoldo: CPHFRS-Museu do Trem de São Leopoldo, 2011. 1 DVD. (23'09") son. color. Entrevista concedida na coleta de informações da história do Museu do Trem de São Leopoldo - 35 anos.

RAMOS, Eloisa Helena Capovilla da Luz. Eloisa Helena Capovilla da Luz Ramos depoimento [10 nov. 2011]. Entrevistadora: A. Bemvenuti, Câmera: L. Moreira. São Leopoldo: CPHFRS-Museu do Trem de São Leopoldo, 2011. 1 DVD. (01:04'29') son. color. Entrevista concedida na coleta de informações da história do Museu do Trem de São Leopoldo - 35 anos.

ROESSLER, Maria Luiza. Maria Luiza Roessler. depoimento [31 out. 2011]. Entrevistadora: A. Bemvenuti, Câmera: L. Moreira. São Leopoldo: CPHFRS-Museu do Trem de São Leopoldo, 2011. 1 DVD. (20'01") son. color. Entrevista concedida na coleta de informações da história do Museu do Trem de São Leopoldo - 35 anos.

SILVEIRA, Hélio Bueno. Hélio Bueno da Silveira. depoimento [10 nov. 2011]. Entrevistadora:, Câmera: L. Moreira. São Leopoldo: CPHFRS-Museu do Trem de São Leopoldo, 2011. 1 DVD. (28'01') son. color. Entrevista concedida na coleta de informações da história do Museu do Trem de São Leopoldo - 35 anos.

SOUTO, Daniel Lenna. Daniel Lenna Souto: depoimento [27 nov. 2011]. Entrevistadora: A. Bemvenuti, Câmera: L. Moreira. São Leopoldo: CPHFRS-Museu do Trem de São Leopoldo, 2011. 1 DVD. (21'47') son. color. Entrevista concedida na coleta de informações da história do Museu do Trem de São Leopoldo - 35 anos.

\section{Documentos}

ASSOCIAÇÃO AMIGOS MUSEU DO TREM. Estatuto. São Leopoldo, 2010. 10fl

ASSOCIAÇÃO AMIGOS MUSEU DO TREM. Relatório Biênio 2011-2012. São Leopoldo, 2012.

CARRAZONI, Maria Eliza. Diretrizes para a instalação do centro de preservação da história ferroviária. Datilografado. 03 nov.1981 (2 fl)

INSTITUTO DO PATRIMÔNIO HISTÓRICO E ARTÍSTICO DO ESTADO. Parecer Técnico IPHAE no 23. Definição de entorno: Sitio Histórico Museu do Trem, São Leopoldo. 28 mar.2002. $10 \mathrm{fl}$ 
LADEIRA, Stella. Faisquinha: a unidade elétrica que trabalhou no suburbio. Rio de Janeiro: RFFSA/CPHFRJ, 1989, 11 p.

LADEIRA, Stella. Maria Fumaça: a locomotiva do tempo do Vovô. Rio de Janeiro: RFFSA/CPHFRJ, 1985, $13 \mathrm{p}$.

MINISTÉRIO DOS TRANSPORTES. Escritório de Inventariança da Extinta Rede Ferroviária Federal S.A. Inventário Museu do Trem 2008. Porto Alegre: 12 dez.2008. $59 \mathrm{fl}$

MINISTÉRIO DOS TRANSPORTES. Gibi da Mangueira. (Texto: Paulo Jesuan Guimarães Ulbrich, Desenhos: Gerson Luiz Cordeiro). Porto Alegre: RFFSA/SR-6/SENAI, s/d. 24 p.

MINISTÉRIO DOS TRANSPORTES. Programa de Preservação do Patrimônio Histórico do Ministério dos Transportes. PRESERVE, 1989.

MINISTÉRIO DOS TRANSPORTES. Documento no1 - 1980/1982. Brasília: PRESERVE/RFFSA/Ministério dos Transportes, 1982. 36fl.

MUSEU DO TREM DE SÃO LEOPOLDO. Livro de Tombamento. Aberto por Maria Thereza Kahl Fonseca. PRESERVE/Rede Ferroviária Federal S.A./Ministério dos Transportes. $18 \mathrm{dez} .1984 .44 \mathrm{fl}$

MUSEU DO TREM DE SÃO LEOPOLDO. Livro de Tombamento. Aberto por Clarissa Oliveira de Carvalho. PRESERVE/Rede Ferroviária Federal S.A./Ministério dos Transportes. 24 ago.1985. $03 \mathrm{fl}$

MUSEU DO TREM DE SÃO LEOPOLDO. Livro de Tombamento. Aberto por Clarissa Oliveira de Carvalho. PRESERVE/Rede Ferroviária Federal S.A./Ministério dos Transportes. 03 set. $1988.126 \mathrm{fl}$

MUSEU DO TREM DE SÃO LEOPOLDO. Relatório de Gestão 2009-2012. São Leopoldo, 2012a. $44 \mathrm{fl}$

MUSEU DO TREM DE SÃO LEOPOLDO. Relatório de Transição. São Leopoldo, 2012b. $32 \mathrm{fl}$

PREFEITURA MUNICIPAL DE SÃO LEOPOLDO. Relatório Leitura Técnica. Processo de Revisão do Plano Diretor Participativo de São Leopoldo. Secretaria de Planejamento/SEPLAN. (Coord. Geral e Revisão de Conteúdo: Isabella da Costa Albrecht). São Leopoldo: 2006. $78 \mathrm{fl}$.

PREFEITURA MUNICIPAL DE SÃO LEOPOLDO. Memorial Descritivo (Prédio da Estação; Depósito; Cobertura para Vagões) . dez.1997.7fl

PRESERFE. Museu como instrumento de educação. Museu do Trem do Engenho de Dentro/CPHFRJ/PRESERFE/RFFSA. Museóloga Responsável: Maria Stella de Paula Ladeira. Rio de Janeiro: out 1992. $22 \mathrm{fl}$ 
PRESERFE. Manual para funcionamento dos Centros de Preservação e Núcleos Históricos Ferroviários. PRESERFE/RFFSA. Execução: Telma Lasmar. Rio de Janeiro: 1991. $28 \mathrm{fl}$

PRESERVE. Projeto de Oficinas de Férias. Museu do Trem do Engenho de Dentro/CPHFRJ/PRESERVE/Ministério dos Transportes. Museóloga Responsável: Maria Stella de Paula Ladeira. Rio de Janeiro: $\mathrm{s} / \mathrm{d}$. $7 \mathrm{fl}$

PRESERVE. Plano de visitas orientadas para monitores. Museu do Trem do Engenho de Dentro/CPHFRJ/PRESERVE/Ministério dos Transportes. Museóloga Responsável: Maria Stella de Paula Ladeira. Rio de Janeiro: 1987. $17 \mathrm{fl}$

PRESERVE. Projeto Educativo "Vamos Conhecer o Museu do Trem". Museu do Trem do Engenho de Dentro/CPHFRJ/PRESERVE/Ministério dos Transportes. Museóloga Responsável: Maria Stella de Paula Ladeira. Rio de Janeiro: out 1987. 23 fl

PRESERVE. Projeto do Setor Educativo. Museu do Trem do Engenho de Dentro/CPHFRJ/PRESERVE/Ministério dos Transportes. Responsável: Maria Stella de Paula Ladeira, Supervisão: Maria Elisa Carrazzoni. Rio de Janeiro: s/d. $6 \mathrm{fl}$

PROGRAMA DE PRESERVAÇÃO DO PATRIMÔNIO HISTÓRICO DO MINISTÉRIO DOS TRANSPORTES. Centro de Preservação da História da Ferrovia no Rio Grande do Sul - Museu do Trem, São Leopoldo. (Pesquisa de Ana Cristina Oliveira Alves. Texto de Elaine T. Sardi Ayestarán). PRESERVE/RFFSA, 1985. 115 p. 158 ilustrações. Catálogo.

PROGRAMA DE PRESERVAÇÃO DO PATRIMÔNIO HISTÓRICO DO MINISTÉRIO DOS TRANSPORTES - PRESERVE. Museu do Trem. (Apresentação Maria Elisa Carrazzoni). Recife: RFFSA, 1982. 36 p. Catálogo.

REDE FERROVIÁRIA FEDERAL S.A. Superintendência de Patrimônio. Gerência de Preservação do Patrimônio Histórico Ferroviário (PRESERFE) Manual de Preservação de Edificações Ferroviárias Antigas. (Apresentação Cláudio Terêncio Marques Bacalhau). Rio de Janeiro: RFFSA, 1991. 78 p.

PREFEITURA MUNICIPAL DE SÃO LEOPOLDO. Memorial Descritivo (Prédio da Estação; Depósito; Cobertura para Vagões) . dez.1997.7fl

REPUBLICA FEDERATIVA DO BRASIL. Certidão. Oficio do Registro de Imóveis. 18 set.1990. $2 \mathrm{fl}$

\section{Periódicos}

LONGHIL, Raquel. O Museu do Trem é para todos. Revista Rua Grande, São Leopoldo, 06 set. 1985, p. 08.

JORNAL VALE DOS SINOS. Museu do Trem. Encarte especial. 26 fev.1885. p.07.

REVISTA RUA GRANDE. A centenária estação ferroviária transforma-se hoje no Museu do Trem. Ano XII. № 595. 26 nov.1976. São Leopoldo. p.8-11. 


\section{Entrevistas}

AULER, Marioni. Marioni Auler: depoimento [06 mai. 2015]. Entrevistadora: A. Bemvenuti, Áudio: G. Riboriski. Porto Alegre: Grêmio Esportivo Ferrinho. (38'22") Celular. Entrevista concedida para Disciplina Fotografia Documental, pesquisa trajetória de vida do ferroviário Hélio Bueno da Silveira.

PINTO, Bartolomeu Homem d'El-Rei. Bartolomeu Homem d'El-Rei Pinto: depoimento [27 ago. 2015]. Entrevistadora: A. Bemvenuti. Rio de Janeiro. (43'31") Celular. Entrevista concedida na coleta de informações da história do PRESERVE e do Museu do Trem de São Leopoldo - para dissertação de Mestrado (Museologia Universidade de São Paulo).

LASMAR, Telma. Telma Lasmar: depoimento [28 ago. 2015]. Entrevistadora: A. Bemvenuti, Áudio: A. Bemvenuti. Rio de Janeiro. (1:10'47") Celular. Entrevista concedida na coleta de informações da história do PRESERVE e do Museu do Trem de São Leopoldo - para dissertação de Mestrado (Museologia Universidade de São Paulo).

MONASCHECI, Manoel. Manoel Monascheci: depoimento por e-mail [23 mar. 2016 e 04 abr. 2016]. Entrevistadora: A. Bemvenuti. São Leopoldo/Juiz de Fora. Entrevista concedida na coleta de informações da história do PRESERVE e do Museu do Trem de São Leopoldo - para dissertação de Mestrado (Museologia Universidade de São Paulo).

MORAIS, Sérgio Santos. Sérgio Santos Morais: depoimento [28 ago. 2015]. Entrevistadora: A. Bemvenuti, Áudio: A. Bemvenuti. Rio de Janeiro. (1:10'47") Celular. Entrevista concedida na coleta de informações da história do PRESERVE e do Museu do Trem de São Leopoldo - para dissertação de Mestrado (Museologia Universidade de São Paulo).

SILVEIRA, Hélio Bueno da. Hélio Bueno da Silveira: depoimento [06 mai. 2015]. Entrevistadora: A. Bemvenuti, Áudio: G. Riboriski. Porto Alegre: Grêmio Esportivo Ferrinho. (?') Celular. Entrevista concedida para Disciplina Fotografia Documental, pesquisa trajetória de vida do ferroviário Hélio Bueno da Silveira. 


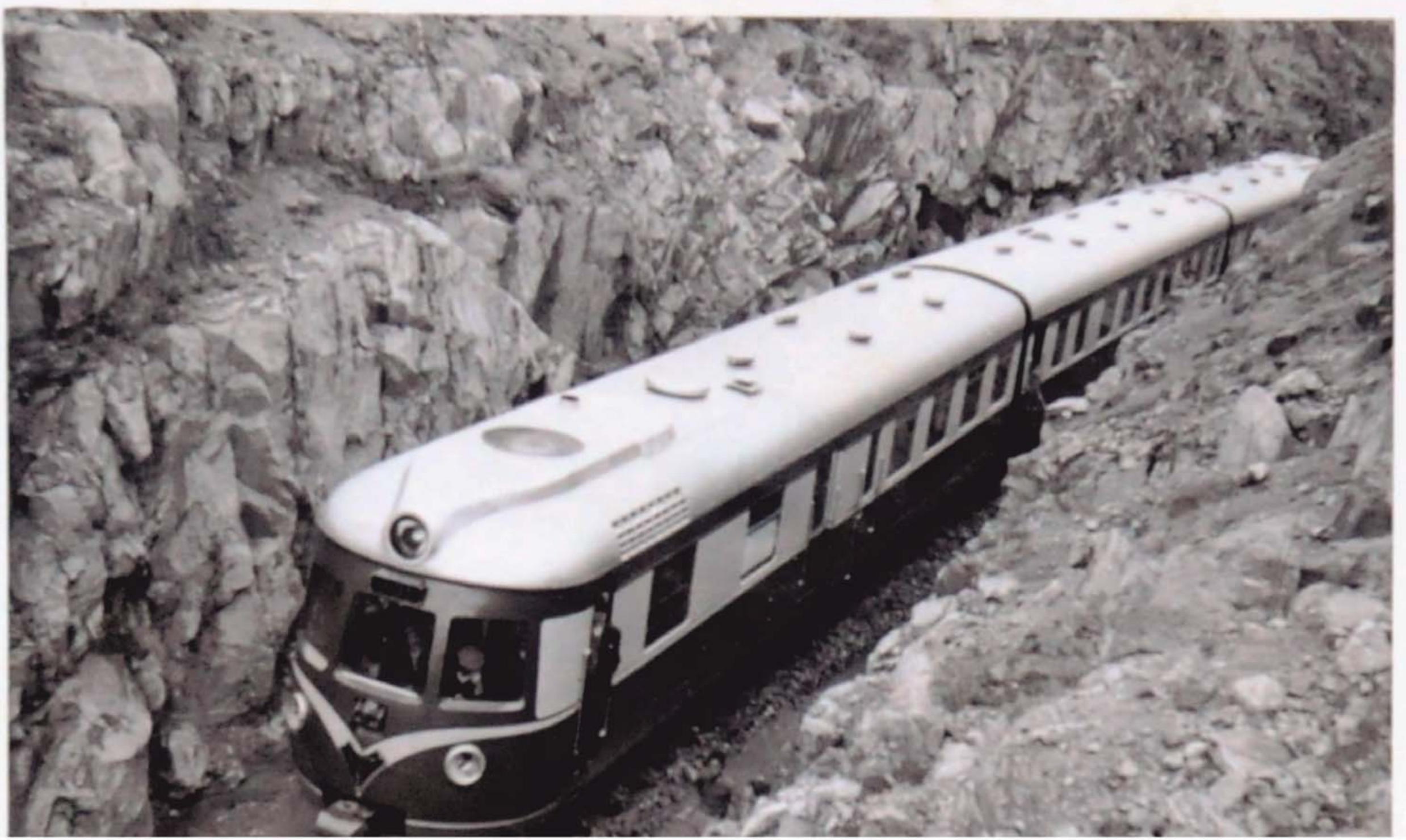

APÊNDICES

ANEXOS 


\section{APÊNDICE - CORPUS DOCUMENTAL REFERENTE AO MUSEU DO TREM DE SÃO LEOPOLDO \\ LISTAGEM DE DOCUMENTOS - PERÍODO DE 2009 A 2012}

GESTÃO

\section{Quadro 1 - Documentos Administrativos}

\begin{tabular}{|c|c|c|c|}
\hline Classificação & Descrição & Período & Características \\
\hline \multirow{5}{*}{ Diagnóstico } & Diagnóstico Preliminar & Jan. a mar.2009 & 02 folhas \\
\hline & Anotações de cinco funcionários (através de fichas com roteiro) & 2009 & 13 folhas \\
\hline & Diagnóstico - sistematização em reunião - ata & 12 ago.2009 & 04 folhas \\
\hline & Diagnóstico sistematizado da Estação para Projeto de Restauro (Arquiteta Simone Pretto Ruschel) & Jun.2010 & 12 folhas \\
\hline & Revisão do diagnóstico para fins da escrita do Plano Museológico & Jan.2011 & Não especificado \\
\hline \multirow{12}{*}{$\begin{array}{l}\text { Planejamento (do } \\
\text { programa, dos } \\
\text { projetos e } \\
\text { apresentação } \\
\text { Institucional) }\end{array}$} & Organizando possibilidades (roteiro de ideias) (Alice Bemvenuti) & Fev.2009 & 04 folhas \\
\hline & Plano Diretor (incompleto) & Mar.2009 & 05 folhas \\
\hline & Proposta Inicial para debate - Diretoria de Patrimônio (Alice Bemvenuti) & Mar.2009 & 06 folhas \\
\hline & Plano Estratégico para quatro anos & 2009 & 10 folhas \\
\hline & Programa de Ação Educativa - Institucional & 2010 & 08 folhas \\
\hline & Lista ações e planejando o ano de 2011 & 2011 & 03 folhas \\
\hline & Programa e Projetos - Institucional & 2011 & 07 folhas \\
\hline & Museu para Todos - Institucional & Abril 2011 & 11 folhas \\
\hline & Museu Inclusivo - projeto (Claudia Rosana Koch) & 01.04 .2011 & 04 folhas \\
\hline & Proposta Gestão (atualização do Plano Diretor 2009) & 2011 & 07 folhas \\
\hline & Planejamento Estratégico para 2012 & 2012 & 14 folhas \\
\hline & Calendário/agenda & $\begin{array}{l}2009,2010, \\
2011,2012\end{array}$ & Diversos \\
\hline
\end{tabular}




\begin{tabular}{|c|c|c|c|}
\hline Classificação & Descrição & Período & Características \\
\hline \multirow{19}{*}{$\begin{array}{l}\text { Estudo de } \\
\text { necessidades }\end{array}$} & Estudo para banheiros novos - com estudo arquitetônico & 2009 & 03 folhas \\
\hline & Estudo preliminar para Projeto Expográfico & 2009 & 03 folhas \\
\hline & $\begin{array}{l}\text { Estudo de necessidades - calhas e telhado } \\
\text { Contemplado com recurso da Prefeitura Municipal de São Leopoldo }\end{array}$ & 2009 & 02 folhas \\
\hline & E-mail para arquiteta com estrutura para Programa de Necessidades (Caroline Teixeira) & 09.12 .2009 & 02 folhas \\
\hline & Estudo para Programa de Necessidades Básicas (Caroline Teixeira e Simone Ruschel) & 05.01 .2010 & 07 folhas \\
\hline & $\begin{array}{l}\text { Estudo Expográfico para o todo o Sitio Histórico integrado com a Estação São Leopoldo TRENSURB } \\
\text { (Arquiteto Marcelo Ferraz) }\end{array}$ & 2009 & Não localizado \\
\hline & Estudo para Restauro da Estação (Arquiteta Simone Ruschel) & 2010 & 12 folhas \\
\hline & Estudo de Necessidades Básicas - preparando para Edital (Caroline Teixeira e Simone Ruschel) & 05.01 .2010 & 07 folhas \\
\hline & Estudo para Projeto Básico Expografia & Nov.2010 & 03 folhas \\
\hline & $\begin{array}{l}\text { Anotações para concorrer ao Edital Prêmio Darcy Ribeiro com Programa de Ação Educativa do } \\
\text { Museu do Trem }\end{array}$ & $\begin{array}{l}2010 \\
2011\end{array}$ & Incompleto \\
\hline & Projeto para Revitalização do Museu do Trem - Inscrito no Edital de Modernização de Museu - IBRAM. & 2010 & Não localizado \\
\hline & E-mail ao Secretário de Cultura com necessidades e urgências & 18 abr.2011 & 01 folha \\
\hline & Manutenção geral - pintura & 2011 & $\begin{array}{l}\text { Contemplado com recurso } \\
\text { da Prefeitura Mun. de SL }\end{array}$ \\
\hline & Estudo Projeto Catálogo (impresso) Museu do Trem - inscrito no FAC RS (não contemplado). & 2011 & Não localizado \\
\hline & $\begin{array}{l}\text { Projeto para Sistema Municipal de Museus - inscrito Edital de Microprojetos do IBRAM (não } \\
\text { contemplado). }\end{array}$ & 2011 & 18 folhas \\
\hline & $\begin{array}{l}\text { Estudo Projeto construção espaço para Reserva Técnica, Acessibilidade e Restauro Estação } \\
\text { (Arquitetos responsáveis Daniel Martins e Fernanda Basso) }\end{array}$ & 26.10.2011 & $\begin{array}{c}07 \text { folhas, planilha } \\
\text { orçamentária e planta } \\
\text { baixa }\end{array}$ \\
\hline & $\begin{array}{l}\text { Estudo Projeto para Manutenção e Climatização Armazém (Arquitetos Daniel Martins e Fernanda } \\
\text { Basso) }\end{array}$ & 26.10 .2011 & $\begin{array}{l}02 \text { folhas, planilha orça- } \\
\text { mentária e planta baixa }\end{array}$ \\
\hline & $\begin{array}{l}\text { Proposta Acessibilidade, Restauro e Climatização - inscrito no Edital Modernização de Museus do } \\
\text { IBRAM e SICONV № 065991/2011 (não contemplado). }\end{array}$ & 2011 & 07 folhas \\
\hline & $\begin{array}{l}\text { Proposta de Ampliação Sanitário, Apoio e depósito - inscrito no SICONVI №062121/2011 (anunciado } \\
\text { em Porto Alegre, pela Ministra da Cultura Srªna de Holanda o recurso para demanda espontânea } \\
\text { do Museu do Trem) }\end{array}$ & 2011 & 08 folhas \\
\hline
\end{tabular}




\begin{tabular}{|c|c|c|c|}
\hline Classificação & Descrição & Período & Características \\
\hline \multirow{5}{*}{$\begin{array}{l}\text { Power Point } \\
\text { (apresentações } \\
\text { diversas) }\end{array}$} & Museu do Trem (Institucional) & 2010 & \\
\hline & Museu do Trem (Institucional) & Nov. 2011 & 41 lâminas \\
\hline & Programa de Ação Educativa (Institucional) & 2011 & 35 lâminas \\
\hline & Museu do Trem - Projetos (Institucional) & Nov. 2011 & 29 lâminas \\
\hline & $\begin{array}{l}\text { A educação como eixo da gestão e da relação com a cidade: experiência no Museu do Trem, São } \\
\text { Leopoldo (Alice Bemvenuti). } \\
\text { Encontro de Educação e Patrimônio Cultural, UFRGS, Porto Alegre }\end{array}$ & 03 e 04 nov.2011 & 49 lâminas \\
\hline \multirow{5}{*}{$\begin{array}{l}\text { Organograma e } \\
\text { estrutura } \\
\text { organizacional e } \\
\text { funcional }\end{array}$} & Diretoria de Patrimônio & 2009 & 01 folha \\
\hline & Diretoria de Museu & 2011 & 01 folha \\
\hline & Equipe do Museu do Trem & 2011 & 01 folha \\
\hline & Estrutura Organizacional & 2011 & 01 folha \\
\hline & Estrutura em Setores e Áreas (Estudo para Regimento Interno) & 2012 & 01 folha \\
\hline \multirow{3}{*}{$\begin{array}{l}\text { Elaboração do } \\
\text { Regimento Interno }\end{array}$} & Estudo do desenho da estrutura (resultado de atividade coletiva) & 2012 & 28 folhas agrupadas \\
\hline & $\begin{array}{l}\text { Textos produzidos para os diferentes setores e áreas com finalidade de elaborar o Regimento Interno } \\
\text { (resultado de atividade coletiva) }\end{array}$ & 2012 & 24 folhas agrupadas \\
\hline & Escrita Preliminar do Regimento Interno (resultado de atividade coletiva) & 2012 & 08 folhas \\
\hline \multirow{9}{*}{$\begin{array}{l}\text { Convênios e } \\
\text { Termos de } \\
\text { Cooperação }\end{array}$} & IPHAN - Higienização, Registro e Acondicionamento do Acervo Fotográfico do Museu do Trem. & $2008 / 2009$ & Não localizado \\
\hline & $\begin{array}{l}\text { Memorial 4ํ TRT (Tribunal Regional do Trabalho) Porto Alegre. Integração Cultural - Exposição } \\
\text { Itinerante e doação de computadores e impressora }\end{array}$ & 2009 & 03 folhas \\
\hline & SEDAC-IPHAE - Termo de Cooperação Técnica Inventário Bem Cultural Imóvel & 2009 & 04 folhas \\
\hline & Município de Portão - Integração Cultural - Exposição Itinerante e Oficina de Conservação em Metal & $\begin{array}{l}2009 \text { a } 2012 \\
(4 \text { anos })\end{array}$ & 03 folhas \\
\hline & $\begin{array}{l}\text { Município de Salvador do Sul } \\
\text { Exposição Itinerante }\end{array}$ & 2009 & Não especificado \\
\hline & $\begin{array}{l}\text { Município de Maratá } \\
\text { Exposição Itinerante }\end{array}$ & 2009 & Não especificado \\
\hline & $\begin{array}{l}\text { TRENSURB - Cessão de Uso da Sala da TRENSURB com entrada pela Av.Mauá para uso do } \\
\text { Museu do Trem - duração um ano (renovável) }\end{array}$ & $21.08 .2009-$ & 03 folhas \\
\hline & UNISINOS - Cooperação Científica (estudo não finalizado) & $2011 / 2012$ & Incompleto \\
\hline & IBRAM - Prêmio do edital MICROPROJETOS intitulado: Projeto Aplicabilidade do processo de conservação & $2011 / 2012$ & 19 folhas \\
\hline Ata & Diversas atas administrativas do período & $2009-2012$ & Diversas \\
\hline
\end{tabular}




\begin{tabular}{|c|c|c|c|}
\hline Classificação & Descrição & Período & Características \\
\hline Informativo & Comunicação interna através de informativo eletrônico & $2009,2010,2011$ & Diversos \\
\hline \multirow{12}{*}{$\begin{array}{l}\text { Relatórios gerais e } \\
\text { específicos }\end{array}$} & Relatório de atividades & 2009 & 07 folhas \\
\hline & Relatório de atividades & 2010 & Não especificado \\
\hline & Relatório Público oficinas de Patrimônio Verão 2011 & 25.02 .2011 & 01 folha \\
\hline & Relatório das Semanas de Museus -3 edições & $2009-2011$ & 19 folhas \\
\hline & Relatório de atividades & 2011 & 03 folhas \\
\hline & Relatório de atividades & 2012 & 07 folhas \\
\hline & Relatório da $3^{\text {a }}$ Semana de Museus & 2011 & - \\
\hline & $\begin{array}{l}\text { Espelho de Visualização, valorização e potencialização das Políticas Públicas em São Leopoldo - } \\
\text { Secretaria de Planejamento }\end{array}$ & 2011 & - \\
\hline & Síntese de participações da equipe em atividades externas & $2009-2012$ & Diversos \\
\hline & Relatório atividade do Prêmio Edital MICROPROJETO & nov e dez 2012 & 28 folhas (inacabado) \\
\hline & Relatório de Gestão com planilhas & $2009-2012$ & 44 folhas \\
\hline & Relatório de Transição & Jan 2013 & 32 folhas \\
\hline \multirow{4}{*}{ AAMT } & Estatuto & 24.08.2010 & 10 folhas \\
\hline & Termo de adesão de Estágio Voluntário & 2010 & 02 folhas \\
\hline & Reunião Almoço & 17.06.2011 & 02 folhas \\
\hline & Prestação de contas Gestão & $2010-2012$ & 06 folhas \\
\hline
\end{tabular}




\begin{tabular}{|c|c|c|c|}
\hline Classificação & Descrição & Período & Características \\
\hline \multirow{21}{*}{$\begin{array}{l}\text { Relatório e } \\
\text { anotações equipe }\end{array}$} & \multirow{3}{*}{ Rotina diária } & 2009 & Não especificado \\
\hline & & 2010 & Não especificado \\
\hline & & 2011 & Não especificado \\
\hline & \multirow{18}{*}{ Final de semana } & $1^{\circ}$ semestre 2009 & Não especificado \\
\hline & & $2^{\circ}$ semestre 2009 & Não especificado \\
\hline & & $1^{\circ}$ semestre 2010 & Não especificado \\
\hline & & $2^{\circ}$ semestre 2010 & Não especificado \\
\hline & & 2011 novembro & 02 itens \\
\hline & & 2011 dezembro & 02 itens \\
\hline & & 2012 janeiro & Não localizado \\
\hline & & 2012 fevereiro & 09 itens \\
\hline & & 2012 março & 20 itens \\
\hline & & 2012 abril & 24 itens \\
\hline & & 2012 maio & 14 itens \\
\hline & & 2012 junho & 17 itens \\
\hline & & 2012 julho & 13 itens \\
\hline & & 2012 agosto & 11 itens \\
\hline & & 2012 setembro & 14 itens \\
\hline & & 2012 outubro & 10 itens \\
\hline & & 2012 novembro & 09 itens \\
\hline & & 2012 dezembro & 05 itens \\
\hline
\end{tabular}

Elaborado pela autora. 
Quadro 2 - Documentos iconográficos - diagnóstico e verificação

\begin{tabular}{|c|c|c|c|}
\hline Classificação & Descrição & Período & Quantidade \\
\hline \multirow{10}{*}{$\begin{array}{l}\text { Fotografia Digital - Arquivo Digital } \\
\text { Utilizado na coleta de informações } \\
\text { no diagnóstico e registros } \\
\text { posteriores para fins de } \\
\text { documentar condições do acervo e } \\
\text { do Sítio Histórico de modo geral }\end{array}$} & Primeiro contato - visão geral & 10 fev.2009 (Fotografia Alice Bemvenuti) & $\begin{array}{l}65 \text { imagens } \\
\text { Tamanho } 134 \text { KB (cada) }\end{array}$ \\
\hline & Vandalismo - Vagões e carros de passageiro & $\begin{array}{l}12 \text { mar. } 2009 \\
\text { (Fotografia Alice Bemvenuti) }\end{array}$ & $\begin{array}{l}15 \text { imagens } \\
\text { Tamanho } 1,48 \mathrm{~KB} \text { (cada) }\end{array}$ \\
\hline & Estação - Panorama geral & 30 mar.2009 (Fotografia Rogério Tosca) & $\begin{array}{l}01 \text { imagem } \\
\text { Tamanho } 49 \mathrm{~KB}\end{array}$ \\
\hline & Estação & 19 maio 2009 (Fotografia Rogério Tosca) & $\begin{array}{l}05 \text { imagens } \\
\text { Tamanho } 1 \mathrm{~KB} \text { (cada) }\end{array}$ \\
\hline & Telhado interno & 07 jan.2010 & $\begin{array}{l}03 \text { imagens } \\
\text { Tamanho 2,16 MB jpg (cada) }\end{array}$ \\
\hline & Estação & 07 jan.2010 & $\begin{array}{l}12 \text { imagens } \\
\text { Tamanho 2,2 KB jpg (cada) }\end{array}$ \\
\hline & Vagões e Carros de Passageiro & 07 jan.2010 & $\begin{array}{l}17 \text { imagens } \\
\text { Tamanho 2,2 KG jpg (cada) }\end{array}$ \\
\hline & Negativos de Vidro & $\begin{array}{l}04.06 .2009 \\
\text { (Fotografia Alice Bemvenuti) }\end{array}$ & $\begin{array}{l}03 \text { imagens } \\
\text { Tamanho } 1,7 \mathrm{~KB} \text { jpg }\end{array}$ \\
\hline & $\begin{array}{l}\text { Fachada Plataforma, Fachada Praça, lateral, telhado, } \\
\text { detalhes de ornamentos, espaço interno }\end{array}$ & $\begin{array}{l}\text { Jun.2010 } \\
\text { (Fotografia Simone Pretto Ruschel) }\end{array}$ & $\begin{array}{l}15 \text { imagens impressas } \\
\text { (agrupadas em três folhas em } \\
\text { pdf, dentro do Projeto de } \\
\text { Restauro) }\end{array}$ \\
\hline & $\begin{array}{l}\text { Registro fotográfico e escrito para fins de } \\
\text { planejamento de novo banheiro }\end{array}$ & 2009 & Não especificado \\
\hline
\end{tabular}

Elaborado pela autora. 
Quadro 3 - Pesquisa de opinião - público externo

\begin{tabular}{|c|c|c|c|}
\hline Classificação & Descrição/objetivo & Período & $\begin{array}{l}\text { Questionários } \\
\text { respondidos }\end{array}$ \\
\hline \multirow{3}{*}{$\begin{array}{l}\text { Registro do } \\
\text { público infantil }\end{array}$} & \multirow{3}{*}{$\begin{array}{l}\text { Avaliação após atividades desenvolvidas } \\
\text { pela equipe em visitas, oficinas, etc. }\end{array}$} & 2011 julho & 32 \\
\hline & & 2012 outubro & $30+13$ \\
\hline & & 2012 novembro & 05 \\
\hline \multirow{33}{*}{$\begin{array}{l}\text { Registro do } \\
\text { público adulto }\end{array}$} & \multirow{31}{*}{$\begin{array}{l}\text { Professores de escola } \\
\text { Público espontâneo }\end{array}$} & 2010 julho & 04 \\
\hline & & 2010 agosto & 18 \\
\hline & & 2010 setembro & 13 \\
\hline & & 2010 outubro & 13 \\
\hline & & 2010 novembro & 18 \\
\hline & & 2010 dezembro & 01 \\
\hline & & 2010 sem mês & 02 \\
\hline & & 2011 janeiro & Não localizado \\
\hline & & 2011 fevereiro & Não localizado \\
\hline & & 2011 março & 01 \\
\hline & & 2011 abril & Não localizado \\
\hline & & 2011 maio & 01 \\
\hline & & 2011 junho & 12 \\
\hline & & 2011 julho & 10 \\
\hline & & 2011 agosto & 06 \\
\hline & & 2011 setembro & 10 \\
\hline & & 2011 outubro & 07 \\
\hline & & 2011 novembro & 11 \\
\hline & & 2011 dezembro & 03 \\
\hline & & 2012 janeiro & 02 \\
\hline & & 2012 fevereiro & 02 \\
\hline & & 2012 março & 02 \\
\hline & & 2012 abril & 08 \\
\hline & & 2012 maio & 10 \\
\hline & & 2012 junho & 28 \\
\hline & & 2012 julho & 07 \\
\hline & & 2012 agosto & 14 \\
\hline & & 2012 setembro & 22 \\
\hline & & 2012 outubro & 23 \\
\hline & & 2012 novembro & 41 \\
\hline & & 2012 dezembro & 03 \\
\hline & Projeto com funcionário da empresa (Sthil) & 2011 & 28 \\
\hline & E-mails diversos & Jan a abril 2011 & 20 \\
\hline
\end{tabular}

Elaborado pela autora. 
Quadro 4 - Gestão/Comunicação (avaliação - público interno)

\begin{tabular}{|c|c|c|c|c|}
\hline Classificação & Descrição/Objetivo & Período & Período & $\begin{array}{l}\text { Questionários } \\
\text { respondidos }\end{array}$ \\
\hline \multirow{12}{*}{$\begin{array}{l}\text { Registro da equipe } \\
\text { (funcionários e estagiários). } \\
\text { Avaliações diversas sobre } \\
\text { expectativas, processos e } \\
\text { atividades desenvolvidas. }\end{array}$} & \multirow{3}{*}{$\begin{array}{l}\text { Diagnóstico } \\
\text { (expectativas) }\end{array}$} & Início do período da Gestão no Museu & 10.02 .2009 & 06 \\
\hline & & Novos na equipe & Ago a dez 2011 & 03 \\
\hline & & Novos na equipe & Ago. 2012 & 06 \\
\hline & \multirow{4}{*}{$\begin{array}{l}\text { Do processo (incluindo do processo } \\
\text { e autoavaliação junto) } \\
\text { (atividades específicas) }\end{array}$} & 1으 Curso de Formação de Verão & Jan. 2011 & 06 \\
\hline & & $2^{\circ}$ Curso de Formação de Verão & Jan. 2012 & $09+07$ \\
\hline & & Tarefas e Responsabilidades & Abr. 2010 & 09 \\
\hline & & Avaliação de 2010 e planejamento de 2011 & $2010 / 2011$ & 09 \\
\hline & \multirow{2}{*}{$\begin{array}{l}\text { Somativa (incluindo somativa e } \\
\text { autoavaliação junto) } \\
\text { (fechamento anual ou de período) }\end{array}$} & $\begin{array}{l}\text { 3a Semana de Museus de São Leopoldo/9a } \\
\text { Semana Nacional de Museus }\end{array}$ & Mai. 2011 & 08 \\
\hline & & Avaliação de 2011 e planejamento de 2012 & $2011 / 2012$ & 09 \\
\hline & \multirow{3}{*}{ Autoavaliação } & Período de estágio - Programa Jovem Aprendiz & 2012 & 01 \\
\hline & & Avaliação período semestral do estagiário & Ao longo de 2012 & 07 \\
\hline & & Término do período de estágio (diversos) & 2012 & 04 \\
\hline
\end{tabular}

Elaborado pela autora. 


\section{COMUNICAÇÃO}

\section{Quadro 5 - Material comunicacional}

\begin{tabular}{|c|c|c|c|}
\hline Classificação & Descrição & Característica & Período \\
\hline \multirow{13}{*}{ Evento } & Plano de distribuição de cartazes e folders - $3^{\text {a }}$ Sem de Museu de SL/9âsem de Nacional de Museus & 26 folhas & 2011 \\
\hline & Folder - 1ª Semana de Museus de SL & Impresso & 2009 \\
\hline & Cartaz e folder - 2a Semana de Museus de SL & Impresso & 2010 \\
\hline & Cartaz e folder - 3a Semana de Museus de SL & Impresso & 2011 \\
\hline & Cartaz e folder - 4a Semana de Museus de SL & Impresso & 2012 \\
\hline & Flyers e mosquitinhos diversos de Oficinas, atividades em geral & Impresso & 2009 a 2012 \\
\hline & Flyer Feira de Natal & Impresso & 2011,2012 \\
\hline & $\begin{array}{l}\text { Banner, Cartaz, folder e marcado de página } \\
35 \text { anos - aniversário do Museu do Trem }\end{array}$ & $\begin{array}{l}\text { Impressos em diversos materiais } \\
\text { Banner } 110 \times 70 \mathrm{~cm}\end{array}$ & 2011 \\
\hline & Gasebos adesivado com Projeto de Verão no Museu & Gasebo adesivado & 2011 \\
\hline & Banner Dia do Maquinista & Banner & 2012 \\
\hline & Banner para divulgação na rua da Feria de Trocas, Brique e Encontro de Carros Antigos & Banner $450 \times 90 \mathrm{~cm}$ & 2012 \\
\hline & Cartazes Feria de Trocas, Brique e Encontro de Carros Antigos no Museu & $\begin{array}{l}\text { Impressos e informativo } \\
\text { eletrônico }\end{array}$ & 2012 \\
\hline & Placas de numeração das Bancas na Feira de Troca e Brique & Impresso em PVC & 2012 \\
\hline \multirow{3}{*}{ Exposição } & Texto de parede com imagens & Lona adesivada & 2011 \\
\hline & Divulgação da marca dos apoiadores & Cubos de papel adesivado & 2011 \\
\hline & $\begin{array}{l}\text { Exposição itinerante (subtítulos: Programa de Ação Educativa, Recepção de Escolas, Roda de } \\
\text { Memória, Acervo Tridimensional, Acervo ao Ar Livre, Acervo Fotográfico) }\end{array}$ & Banners & 2010 \\
\hline
\end{tabular}




\begin{tabular}{|c|c|c|c|}
\hline Classificação & Descrição & Característica & Período \\
\hline \multirow{7}{*}{ Institucional } & Logomarca & Criação Augusto Bier & 2009 \\
\hline & Banner Institucional & Banner & 2009 \\
\hline & Uniforme & Casaco, camiseta, colete & 2009 a 2012 \\
\hline & Folder & Impresso & $2009 / 2010$ \\
\hline & Banner AAMT & Banner & 2011 \\
\hline & Painel informativo adesivado nos vidros da Guarita & Adesivo em vidro & 2011 \\
\hline & Spot para Rádio (André - Rádio ) & Áudio & 2011 \\
\hline Educativo & Caderneta de anotações (duas edições) & Impresso & $2009 / 2010$ \\
\hline \multirow{2}{*}{ Sinalização } & Placas de sinalização interna - redondas & $\begin{array}{l}\text { Metal adesivado - tamanho } \\
\quad 60 \times 60 \mathrm{~cm}\end{array}$ & 2012 \\
\hline & Placas de sinalização externa (trânsito) indicando o Museu & Metal pintado & 2011 \\
\hline Outros & \multicolumn{3}{|c|}{$\begin{array}{l}\text { Souvenires: canecas, canetas, camisetas, quebra-cabeças, agendas, bloco de notas, imã de geladeira, artesanato temático com o acervo: apoio de } \\
\text { notebook, nécessaire de pano. }\end{array}$} \\
\hline
\end{tabular}

Elaborado pela autora. 
Quadro 6 - Materiais diversos, de apoio, de uso didático, atividades lúdicas.

\begin{tabular}{|c|c|c|c|}
\hline Classificação & Tipo/grupo/linguagem & Descrição & Período \\
\hline \multirow{14}{*}{$\begin{array}{l}\text { Recursos e materiais } \\
\text { diversos elaborados } \\
\text { pela equipe em } \\
\text { atividades de } \\
\text { formação com fins } \\
\text { didáticos }\end{array}$} & \multirow{6}{*}{ Recursos didáticos } & $\begin{array}{l}\text { Varal de História (em processo - inacabado). } \\
\text { (material para ser montar varal com imagens, entre elas: colagens com informações históricas, } \\
\text { palavras, datas, desenhos de Karina Kerpen, etc.) }\end{array}$ & 2011 \\
\hline & & $\begin{array}{l}\text { Pranchas com reproduções de obras de arte com o tema cadeira: Van Gogh, Lia Menna } \\
\text { Barreto, Alex Flemming, Man Ray, (tamanho } 42,5 \mathrm{~cm} \times 30 \mathrm{~cm} \text {, plastificada) }\end{array}$ & 2011 \\
\hline & & $\begin{array}{l}\text { Palavras: MUSEU, PATRIMÔNIO, ACERVO, TREM, MAC GINITY, CONCESSÃO, CUIDAR, } \\
\text { PRESERVAÇÃO, RESTAURAÇÃO, HISTÓRIA e MEMÓRIA. Tamanho } 30 \mathrm{~cm} \times 14,5 \mathrm{~cm} \text {, } \\
\text { plastificadas, } 11 \text { fls. }\end{array}$ & 2011 \\
\hline & & $\begin{array}{l}\text { Janelinhas para olhar através - como uma moldura para dar foco ao olhar } \\
\text { (confeccionado de papelão preto preso em palito longo) }\end{array}$ & 2011 \\
\hline & & $\begin{array}{l}\text { Jogo de associação de palavras (palavras relacionadas com deslocamento): } 116 \text { palavras } \\
\text { (impressão em fonte preta, colado sobre papel colorido e plastificado) }\end{array}$ & 2011 \\
\hline & & $\begin{array}{l}\text { Jogo de associação de palavras (palavras relacionadas as coisas que não se deslocam, } \\
\text { portanto estão fixas): } 67 \text { palavras (impressão em fonte preta, colado sobre papel colorido e } \\
\text { plastificado) }\end{array}$ & 2011 \\
\hline & \multirow{2}{*}{ Outras atividades } & Organize a exposição - folha com imagens do acervo & 2011 \\
\hline & & Cuidando do objeto - com perguntas para associar e refletir & 2011 \\
\hline & \multirow{2}{*}{ Distribuído para o público } & Caderneta - impressão em 2009 & 2009 \\
\hline & & Caderneta - impressão em 2010 & 2010 \\
\hline & \multirow{3}{*}{$\begin{array}{l}\text { Disponível para o público na } \\
\text { Estação - junto à exposição }\end{array}$} & Caderninho sinaleira (com espiral) & 2012 \\
\hline & & Quebra-cabeça gigante (madeira) & 2010 \\
\hline & & $\begin{array}{l}\text { Cuidando do Acervo: Caderno gigante, tema Máquina Fotográfica (folhas plastificadas em } \\
\text { espiral) }\end{array}$ & 2011 \\
\hline & $\begin{array}{l}\text { Áudio: Música: "O que é meu é teu } \\
\text { também" - Criação coletiva da } \\
\text { equipe e Arranjo de Vinicius Rafael } \\
\text { da Luz }\end{array}$ & $\begin{array}{l}\text { gravada em estúdio } \\
\text { voz e violão: Vinicius Rafael da Luz duração: } 1226^{\prime \prime} \\
\text { letra impressa para cantar com crianças }\end{array}$ & 2011 \\
\hline
\end{tabular}




\begin{tabular}{|c|c|c|c|}
\hline Classificação & Tipo/grupo/linguagem & Descrição & Período \\
\hline \multirow{8}{*}{$\begin{array}{l}\text { Recursos utilizados } \\
\text { pelo Educativo } \\
\text { (materiais não } \\
\text { desenvolvidos pela } \\
\text { equipe, porem } \\
\text { utilizados nas } \\
\text { atividades de } \\
\text { recepção de público) }\end{array}$} & Áudio & Apito e sino do trem em movimento - Duração: $1^{`}$ & $\mathrm{~s} / \mathrm{d}$ \\
\hline & \multirow{5}{*}{ Objetos diversos } & Malas de diferentes tamanhos com objetos (a escolher conforme objetivo e público) & $2011 / 12$ \\
\hline & & Avental colorido com bolsos & $2011 / 12$ \\
\hline & & Acessórios cênicos e figurinos & 2012 \\
\hline & & Lanterna & 2012 \\
\hline & & Lupas (lente de aumento) & $2011 / 12$ \\
\hline & Impressos & $\begin{array}{l}\text { 1. Livro "Beleléu'. Patricio Dugnani. São Paulo: Editora Paulinas. } \\
\text { 2. Livro "Aventuras da Memória". Patrícia Engel Secco Ed.Boa Companhia - } 2008 \\
\text { 3. Livro "O Ventre da Maria Fumaça".Vilma Viana. Porto Alegre: Ed.CORAG - 2011(2 ed) }\end{array}$ & $2011 / 12$ \\
\hline & Materiais para oficinas & $\begin{array}{l}\text { Lápis de desenho, canetinhas, giz de cera, lápis de cor, Papéis de diferentes texturas e cores, } \\
\text { EVA colorido, tesoura, cola, cola quente, materiais alternativos (canudinhos, tampinhas) }\end{array}$ & $2011 / 12$ \\
\hline
\end{tabular}

Elaborado pela autora. 


\section{Quadro 7 - Discursos proferidos pela direção do Museu e protocolo dos cerimoniais de eventos comemorativos} (Secretaria de Comunicação)

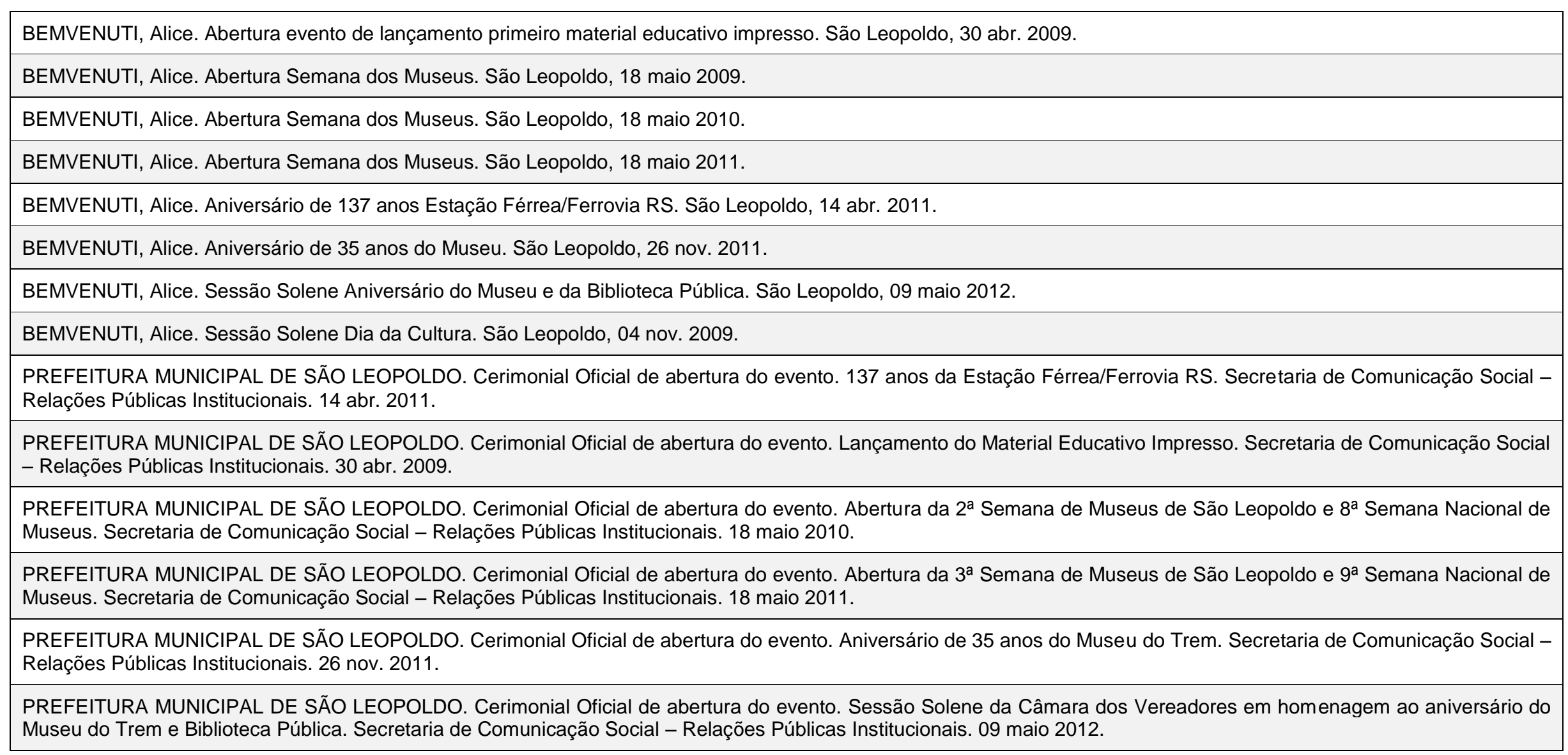

Elaborado pela autora. 


\section{Quadro 8 - Artigos publicados em jornal e revista}

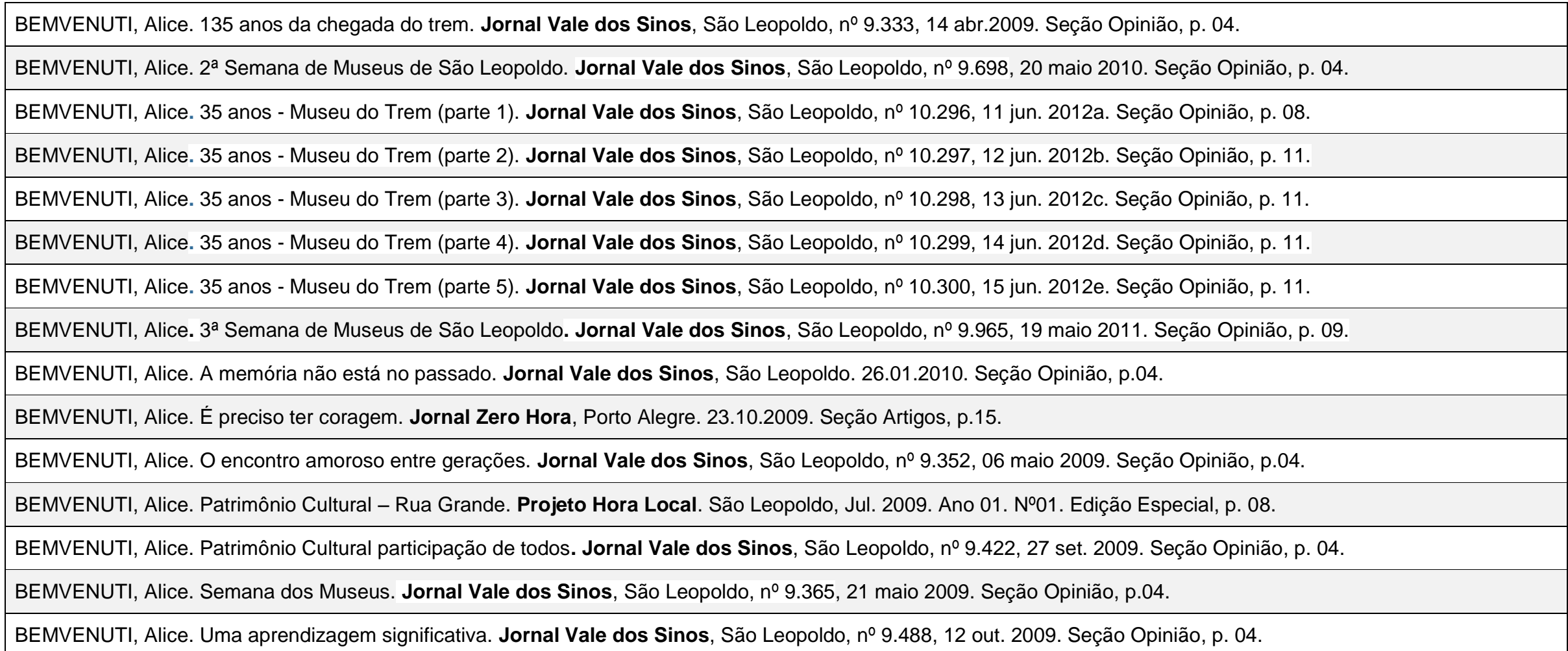

Elaborado pela autora. 
Quadro 9 - Exposição, Reserva Técnica, Documentação (atividades de organização, conservação e afins)

\begin{tabular}{|l|l|l|l|}
\hline \multirow{4}{*}{ Classificação } & \multicolumn{1}{|c|}{ Descrição } & \multicolumn{1}{|c|}{ Característica } \\
\hline \multirow{5}{*}{ Relatório } & Descrição condições e necessidades - negativos de vidro & 04.06 .2009 \\
\cline { 2 - 4 } & Relatório IPHAN (fotografias) & Dez. 2009 \\
\cline { 2 - 4 } & Relatório da Oficina de Conservação de Metal & $2009-2010$ \\
\cline { 2 - 4 } & Relatório atividade de listagem de objetos e higienização - Memorial Hospital Centenário & $2010 / 2011$ & 03 folhas \\
\cline { 2 - 4 } & Relatório Oficina de Metal & Dez. 2010 folhas & 11 folhas \\
\cline { 2 - 4 } & Levantamento de objetos em exposição & 2011 \\
\cline { 2 - 4 } & Diagnósticos de peças com avarias (Daniela Schmitt) & 07 folhas & 2012 \\
\hline
\end{tabular}

Elaborado pela autora 


\section{SETOR EDUCATIVO}

\section{Quadro 10 - Produção escrita da equipe}

\begin{tabular}{|c|c|c|c|c|}
\hline Classificação & Descrição & Período & $\begin{array}{l}\text { Quantidade } \\
\text { de itens }\end{array}$ & Soma \\
\hline \multirow{8}{*}{$\begin{array}{l}\text { CAPACITAÇÃO } \\
\text { (anotações dos } \\
\text { estudos, relatórios, } \\
\text { registros das } \\
\text { atividades) }\end{array}$} & 1 Curso (de formação) de Verão & 2011 & 10 & \multirow{8}{*}{67 itens } \\
\hline & 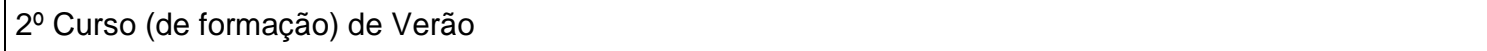 & 2012 & 08 & \\
\hline & 3ํㅡ Curso (de formação) com Workshop & 2012 & 11 & \\
\hline & Atividades externas (palestra, cursos, etc) & $2009-2012$ & 11 & \\
\hline & Atividades externas (reuniões diversas) & $2009-2012$ & 08 & \\
\hline & Semana de Museus (MT) & $2009-2012$ & 08 & \\
\hline & Roda de Memória (MT) & $2009-2012$ & 08 & \\
\hline & Feedback dos textos (coordenação $p$ estagiários) & $2009-2012$ & 03 & \\
\hline \multirow{5}{*}{$\begin{array}{l}\text { PRÁTICA } \\
\text { (anotações } \\
\text { reflexivas da prática } \\
\text { e exercícios de } \\
\text { planejamento) }\end{array}$} & Planejando oficinas, projetos e atividade com o grupo & $2009-2012$ & 05 & \multirow{5}{*}{37 itens } \\
\hline & Planejamento individual & $2011 / 12$ & 03 & \\
\hline & Ponto de Observação & $2010 / 11$ & 06 & \\
\hline & Relatos de recepção de grupos (mediação) & $2011 / 12$ & 13 & \\
\hline & Atividades internas (reuniões Administrativas - Pedagógicas) & 2010-2012 & 10 & \\
\hline \multirow{5}{*}{$\begin{array}{l}\text { APOSTILA } \\
\text { (textos para estudo } \\
\text { da equipe e } \\
\text { organização de } \\
\text { apostilas com } \\
\text { subsídios para } \\
\text { capacitação) }\end{array}$} & Apostila para $1^{\circ}$ Curso (de formação) & 2011 & \multicolumn{2}{|c|}{42 folhas } \\
\hline & $\begin{array}{l}\text { Caderno de Textos e subsídios teóricos (Apostila para } 2^{\circ} \text { Curso de Verão de Formação agrupando } \\
\text { diferentes textos e referencias) }\end{array}$ & 2012 & \multicolumn{2}{|c|}{59 folhas (encadernado) } \\
\hline & $\begin{array}{l}\text { Caderno de Estudos (Apostila para } 3^{\circ} \text { Curso de Formação no Museu do Trem apresenta programa do } \\
\text { curso, cronograma e diferentes textos e referencias) }\end{array}$ & 2012 & \multicolumn{2}{|c|}{$\begin{array}{l}50 \text { páginas } \\
\text { (encadernado) }\end{array}$} \\
\hline & $\begin{array}{l}\text { Diário de Bordo - Programa de Ação Educativa (encadernação com folhas propositivas, folhas ilustradas, } \\
\text { espaços específicos para anotações) }\end{array}$ & 2012 & \multicolumn{2}{|c|}{98 folhas (encadernado) } \\
\hline & Ponto de Observação - impresso & 2012 & \multicolumn{2}{|c|}{01 folha } \\
\hline
\end{tabular}




\begin{tabular}{|c|c|c|c|}
\hline Classificação & Descrição & Período & Quantidade de itens \\
\hline \multirow{6}{*}{$\begin{array}{l}\text { TEXTOS inéditos } \\
\text { (Subsídio para o } \\
\text { Educativo) }\end{array}$} & Título "Acessibilidade" Autora: Claudia Koch-Johnstone & 2012 & 01 folha (não publicado) \\
\hline & Título: "Entendendo que aprendizagem se alcança com o Down" Autora: Claudia Koch-Johnstone & & 01 folha (não publicado) \\
\hline & Título: "Entendendo que aprendizagem se alcança com o Deficiente Intelectual" Autora: Claudia Koch-Johnstone & & 01 folha (não publicado) \\
\hline & Título: Mediando Sindrômicos" Autora: Claudia Koch-Johnstone & & 01 folha (não publicado) \\
\hline & Título: "Orientações para Mediação em Museus" Autora: Alice Bemvenuti & & (inacabado) \\
\hline & $\begin{array}{l}\text { Roteiro de Mediação: estrutura textual para nutri a fala dos estagiários e educadores em atividades com } \\
\text { roteiros planejados (Alice Bemvenuti) }\end{array}$ & & (inacabado) \\
\hline \multirow{10}{*}{$\begin{array}{l}\text { Apresentação de } \\
\text { trabalhos } \\
\text { acadêmicos, relatos } \\
\text { de experiência, } \\
\text { comunicações, } \\
\text { lâminas em Power } \\
\text { Pont e artigos. }\end{array}$} & $\begin{array}{l}\text { Ana Maria Merlotti } \\
\text { 1a Semana de Museus de São Leopoldo - Museu do Trem (São Leopoldo/RS) }\end{array}$ & 2009 & Apresentação oral \\
\hline & $\begin{array}{l}\text { Ana Paula Viegas e Gisele Bauermann } \\
2^{\text {a }} \text { Semana de Museus de São Leopoldo - Museu do Trem (São Leopoldo/RS) }\end{array}$ & 2010 & Apresentação oral \\
\hline & 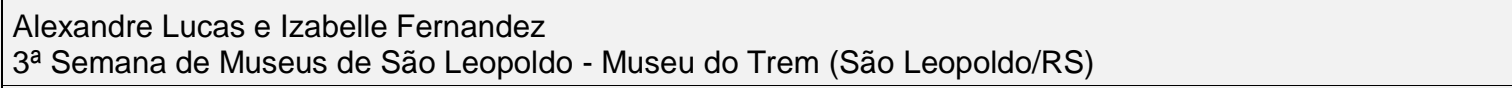 & 2011 & Apresentação oral \\
\hline & $\begin{array}{l}\text { Lorran Pizzato e Yuri Rapkiewicz } \\
\text { 4a Semana de Museus de São Leopoldo - Museu do Trem (São Leopoldo/RS) }\end{array}$ & 2012 & Apresentação oral \\
\hline & $\begin{array}{l}\text { Lorran Pizzato, Yuri Rapkiewicz e Alice Bemvenuti } \\
\text { 1ㅇ Salão Científico - Museu de Antropologia do RS (MARS) - Santander Cultural (Porto Alegre/RS) }\end{array}$ & 2012 & Apresentação oral \\
\hline & $\begin{array}{l}\text { Alice Bemvenuti } \\
\text { Encontro de Educação e Patrimônio (UFRGS) (Porto Alegre/RS) }\end{array}$ & 2011 & Apresentação oral \\
\hline & $\begin{array}{l}\text { Alice Bemvenuti } \\
\text { 4ํㅜoórum Nacional de Museus - IBRAM (Petrópolis/RJ) }\end{array}$ & 2012 & Apresentação oral \\
\hline & $\begin{array}{l}\text { Alice Bemvenuti e Claudia Rosana Koch-Johnstone } \\
\text { Apresentação do Programa de Gestão 2009-2012 do Museu do Trem (São Leopoldo/RS) }\end{array}$ & 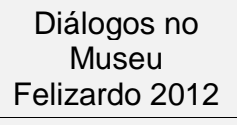 & Apresentação oral \\
\hline & $\begin{array}{l}\text { Alice Bemvenuti e Claudia Rosana Koch-Johnstone } \\
\text { Seminário UNISINOS/4a Semana de Museus de São Leopoldo (São Leopoldo/RS) }\end{array}$ & 2012 & Apresentação oral \\
\hline & $\begin{array}{l}\text { Trabalhos acadêmicos (graduação) apresentado para o próprio curso/aulas } \\
\text { Ana Paula Pinto Viegas (História - PUC RS). } \\
\text { Alexandre Luccas (Pedagogia - UNISINOS). } \\
\text { Yuri Rapkiewicz (Antropologia - UFRGS) }\end{array}$ & 2011 e 2012 & Apresentação oral \\
\hline
\end{tabular}

Elaborado pela autora. 


\section{DOCUMENTOS MANUSCRITOS}

\section{Quadro 11 - Anotações do processo, anotações diversas e sobrepostas de Alice Bemvenuti}

\begin{tabular}{|c|c|c|c|}
\hline Identificação & Descrição & Período & Tamanho documento \\
\hline \multirow{11}{*}{$\begin{array}{l}\text { Capacitação, } \\
\text { estudo e } \\
\text { formação }\end{array}$} & $\begin{array}{l}\text { Anotações da abertura, agenda 21, mesas, reuniões e pensamento de Jose Marti (II Reunião Publica } \\
\text { Mundial de Cultura - Fórum Social Mundial - Teatro Jose Pedro Boéssio - São Leopoldo) }\end{array}$ & 26 Jan. 2010 & $\begin{array}{l}10 \text { folhas (Caderno Agenda do } \\
\text { Professor ULBRA de 2004) }\end{array}$ \\
\hline & $\begin{array}{l}\text { Anotações das falas de Mario Chagas, Maria Célia dos Santos e elaboração dos textos dos cinco eixos } \\
\text { no grupo de trabalho GT -Pré-Conferência Nacional de Museus (Rio de Janeiro) }\end{array}$ & 26 Fev.2010 & $\begin{array}{l}34 \text { folhas (Caderno Agenda do } \\
\text { Professor ULBRA de 2004) }\end{array}$ \\
\hline & $\begin{array}{l}\text { Anotações da Plenária Geral de Abertura e aprovação do Regimento Interno, Conferência Magna com } \\
\text { Antonio Pinto Ribeiro, Painel Integrado (II Conferência Nacional de Cultura - Brasília DF) }\end{array}$ & $\begin{array}{l}11 \text { a } 14 \\
\text { Mar.2010 }\end{array}$ & $\begin{array}{l}52 \text { folhas (Caderno Agenda do } \\
\text { Professor ULBRA de 2004) }\end{array}$ \\
\hline & $\begin{array}{l}\text { Encontro no Museu de Arte do Rio Grande do Sul (MARGS) (palestrantes Simone Monteiro e Mário } \\
\text { Chagas) - organização Sistema Estadual de Museus (SEM RS) }\end{array}$ & 22 Jun. 2010 & $\begin{array}{l}09 \text { folhas (Bloco } 2^{\circ} \text { Fórum de } \\
\text { Museus de SC) }\end{array}$ \\
\hline & $\begin{array}{l}\text { Anotações sobre Conferência de abertura - Benoit de L’Estoile, palestrantes: Guilherme Vergara, } \\
\text { Maria Helena Gaidzinski, José Rufino (Colóquio Arte Contemporânea e Museus - Santander Cultural - } \\
\text { Porto Alegre) }\end{array}$ & 24 Ago. 2010 & 06 folhas \\
\hline & $\begin{array}{l}\text { Seminário de Formação da Secretaria Municipal de Cultura (palestrantes André Mustoff (Secretaria de } \\
\text { Governo - São Leopoldo), Margarete Moraes (MinC-Regional Sul), Glauber Piva (MinC - ANCINE), } \\
\text { Pedro Vasconcellos (SMC-São Leopoldo) }\end{array}$ & $\begin{array}{l}27 \text { e } 28 \\
\text { Jan.2011 }\end{array}$ & 18 folhas \\
\hline & $\begin{array}{l}\text { Curso História de São Leopoldo - Republicana - pelos Caminhos da Rua Grande (palestrante } \\
\text { Profa.Dra.Marluza Harres) }\end{array}$ & 2011 & 07 folhas \\
\hline & $\begin{array}{l}\text { Anotações palestra Estatuto de Museus e Preservação da Memória com Simone Monteiro (SEM RS - } \\
\text { SEDAC) ( } 9^{\underline{a}} \text { Semana Nacional de Museus e } 3^{\text {a }} \text { Semana de Museus de São Leopoldo) }\end{array}$ & 23 Mai. 2011 & 03 folhas \\
\hline & $\begin{array}{l}\text { Palestra de Abertura: Museu, Memória e Museologia, com Profa.Dra.Zita Possamai (UFRGS) (9a } \\
\text { Semana Nacional de Museus e } 3^{a} \text { Semana de Museus de São Leopoldo) }\end{array}$ & 23 Mai 2011 & 03 folhas \\
\hline & $\begin{array}{l}\text { Encontro de Educação e Patrimônio (palestras diversas) organização: Secretaria de Patrimônio da } \\
\text { Universidade Federal do Rio Grande do Sul (UFRGS). Local: FABICO }\end{array}$ & $\begin{array}{l}03 \text { e } 04 \text { Nov. } \\
2011\end{array}$ & $\begin{array}{l}27 \text { folhas (Bloco } 2^{\circ} \text { Fórum de } \\
\text { Museus de SC) }\end{array}$ \\
\hline & $\begin{array}{l}\text { Mario Chagas (Encontro dos Museus Universitários da UFRGS - local: Museu da UFRGS - Porto } \\
\text { Alegre) }\end{array}$ & 04 Out. 2012 & 06 folhas \\
\hline
\end{tabular}




\begin{tabular}{|c|c|c|c|}
\hline Identificação & Descrição & Período & Tamanho documento \\
\hline \multirow{4}{*}{ Planejando } & $\begin{array}{l}\text { Registrando ideias (souvenires, loja, turismo, infraestrutura, programação, marketing, equipe, agenda, } \\
\text { uniforme, publicações, relações institucionais, educativo, associação de amigos, manutenção, tarefas) }\end{array}$ & $\begin{array}{l}1 \text { ㅇs semestre } \\
2009\end{array}$ & 10 folhas \\
\hline & Anotações pensando ficha de estudo para o educativo & $S / d$ & 01 folha \\
\hline & Anotações diversas & 2011 & 06 folhas \\
\hline & Estudo do Plano Museológico & 2011 & 10 folhas \\
\hline \multirow{11}{*}{ Reuniões } & Reunião com equipe do educativo do Museu do Trem & 30 jul. 2009 & 01 folhas \\
\hline & Reunião com diretores e Secretário de Cultura & $\begin{array}{l}1 \text { o semestre } \\
2009\end{array}$ & 11 folhas \\
\hline & Reunião 1 Região Museológica SEM RS e diversos & 23 Mar.2010 & $\begin{array}{l}01 \text { folha (Bloco de anotações } \\
\text { capa Cultura Diversidade } \\
\text { Cidadania e Desenvolvimento) }\end{array}$ \\
\hline & Reunião com SMC pauta SICONV & 24 Mar. 2010 & $\begin{array}{l}02 \text { folhas (Bloco de anotações } \\
\text { capa Cultura Diversidade } \\
\text { Cidadania e Desenvolvimento) }\end{array}$ \\
\hline & Anotações Projeto Coletivo & Mar 2010 & $\begin{array}{l}08 \text { folhas (Bloco de anotações } \\
\text { capa Cultura Diversidade } \\
\text { Cidadania e Desenvolvimento) }\end{array}$ \\
\hline & Reunião com João Winkler (Ferromodelista e Membro da ABPF) & 04 Ago. 2010 & $\begin{array}{l}03 \text { folhas (Bloco 2Fórum de } \\
\text { Museus de SC) }\end{array}$ \\
\hline & $\begin{array}{l}\text { Reunião com equipe do educativo do Museu do Trem (ouvindo grupo sobre P.O. - Ponto de } \\
\text { Observação) }\end{array}$ & Nov. 2010 & 04 folhas \\
\hline & $\begin{array}{l}\text { Reunião com equipe do educativo do Museu do Trem (ouvindo grupo com metodologia de escrita e } \\
\text { reflexão com Ponto de Observação - P.O.) }\end{array}$ & 15 Dez 2010 & 03 folhas \\
\hline & Reunião de planejamento cronograma e oficinas com equipe do educativo do Museu do Trem & Jan. 2011 & 08 folhas \\
\hline & Reunião Diretoria SMC com Secretário de Planejamento & Jan. 2011 & 01 folha \\
\hline & Reunião Pedagógica e Planejamento das Oficinas de Patrimônio & Jan. 2011 & 04 folhas \\
\hline
\end{tabular}




\begin{tabular}{|c|c|c|c|}
\hline Identificação & Descrição & Período & Tamanho documento \\
\hline \multirow{5}{*}{ Reuniões } & Reunião Diretoria SMC (cronograma ano) & 03 Fev. 2011 & 01 folha \\
\hline & Reuniões diversas (Pontão, SESC, Secretaria da Mulher) & Nov. 2011 & 06 folhas \\
\hline & Anotações p concorrer a Edital, prioridades e escrita Regimento & $\begin{array}{c}2^{\circ} \text { semestre } \\
2011\end{array}$ & 05 folhas \\
\hline & $\begin{array}{l}\text { Tópicos reunião (guarda municipal, Aldeia SESC, lixo, oficinas para crianças, geladeira, exposição, } \\
\text { falecimento ferroviário Vitor Ferreira, horários verão, etc) Não esquecer: Plano Museológico. }\end{array}$ & $\begin{array}{l}2^{\circ} \text { semestre } \\
2012\end{array}$ & 03 folhas \\
\hline & $\begin{array}{l}\text { Anotações de reuniões administrativas com SMC, no Museu, com parceiros, planejamento, } \\
\text { cronograma, rotina e manutenção, estudos, Associação, diversos (Caderno espiral - capa dura - } \\
\text { ilustração Sweet Jolie - Tilibra) }\end{array}$ & 2009 a 2012 & 146 folhas \\
\hline & Organização das pastas para o arquivo & 2012 & 06 folhas \\
\hline & Reunião diretoria AAMT & 04 Ago. 2012 & 03 folhas \\
\hline Pesquisa & $\begin{array}{l}\text { Anotações entrevistas com Profa. Dra. Eloisa Capovilla da Luz Ramos (UNISINOS), Germano } \\
\text { Moehleche (Museu do Trem), Marioni Auler (RFFSA). }\end{array}$ & 2011 & $\begin{array}{l}13 \text { folhas (Bloco 2Fórum de } \\
\text { Museus de Santa Catarina) }\end{array}$ \\
\hline \multirow{2}{*}{ Educativo } & Anotações - Conversando sobre mediação & 24 Ago.2012 & 05 folhas \\
\hline & Anotações diversas & $2009 / 2010$ & 09 folhas \\
\hline
\end{tabular}

Elaborado pela autora.

\section{Observações}

1. O Corpus Documental reúne documentos diversos do período entre 2009 e 2012, do Museu do Trem de São Leopoldo, que incluem anotações e documentos pessoais da pesquisadora; anotações do processo e documentos do processo institucional do referido período.

2. Corpus Documental está apresentado por subgrupos: Gestão, Acervo, Comunicação, Setor Educativo e Documentos Manuscritos.

3. Não foram incluídos nessa organização aqueles referentes a entrevistas gravadas com ferroviários e ex-funcionários com objetivo de pesquisa histórica institucional; as reportagens do período de 2009 a 2012; as planilhas elencando a clipagem (apresentadas na seção Referencial, subtítulo Fonte).

4. Também não foram apresentados os documentos relativos ao arquivo fotográfico digital produzido no mesmo período e as planilhas de fluxo de visitantes. 
PREFEITURA MUNICIPAL DE SÃO LEOPOLDO SECRETARIA MUNICIPAL DE CULTURA Gestão 2009-2012

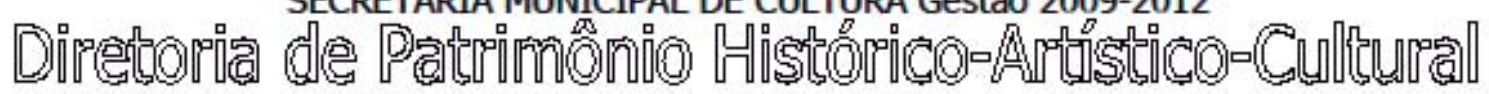

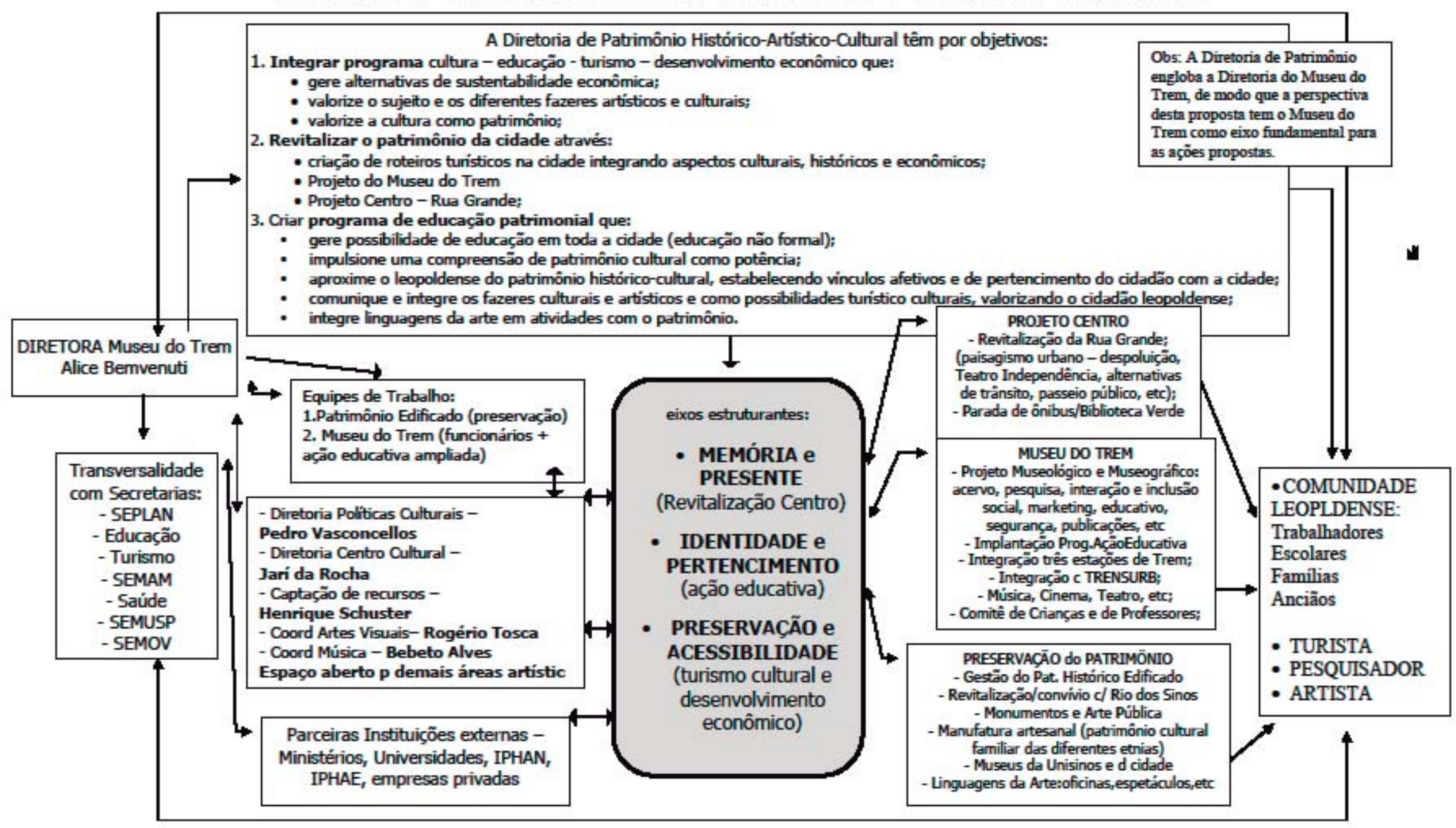


PREFEITURA MUNICIPAL DE SÃO LEOPOLDO

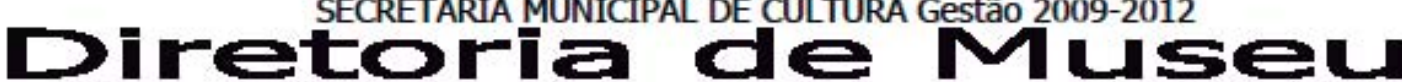

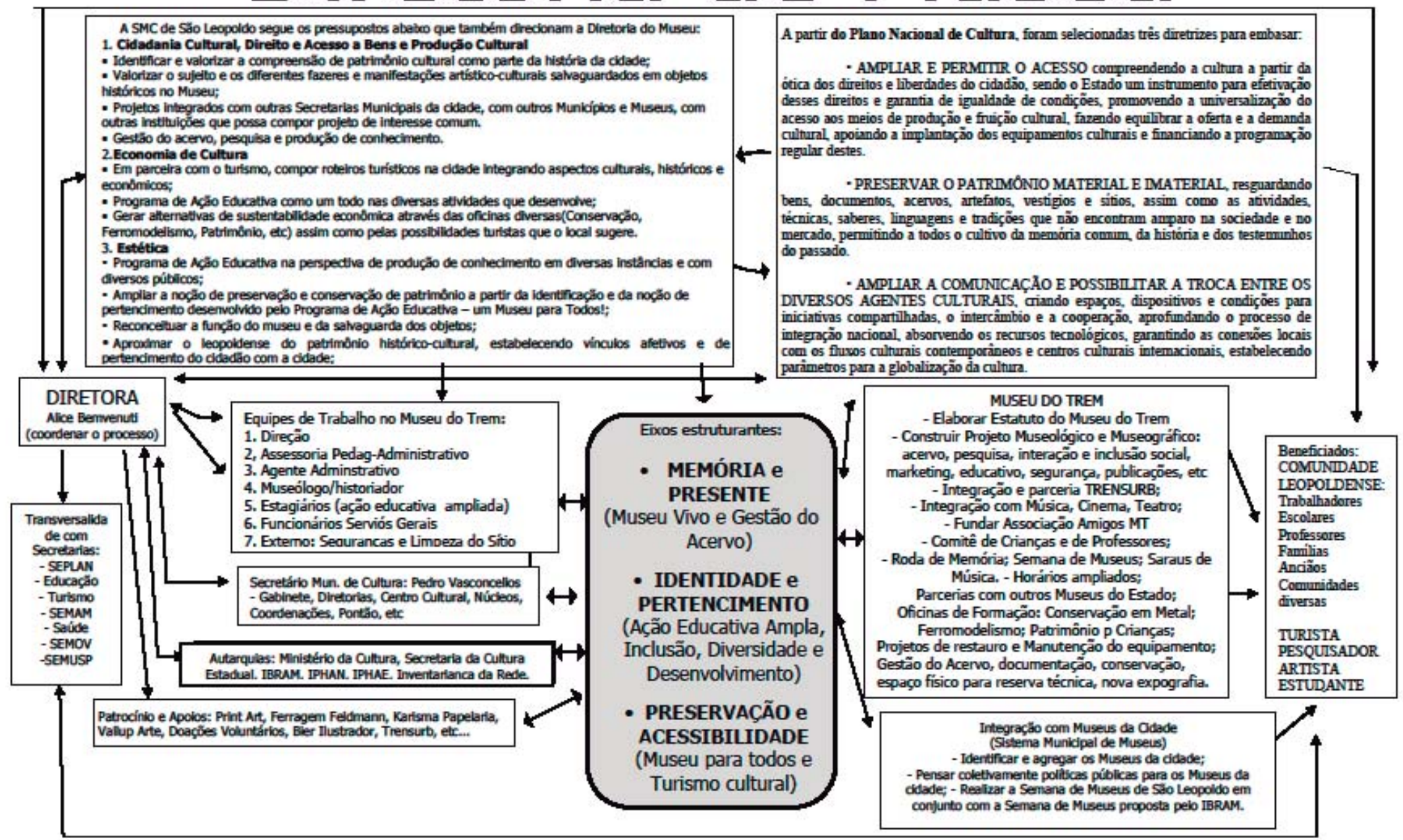


A formação do núcleo de São Leopoldo

A história de Săo Leopoldo inicia como a história das

demais localidades da região sul do Brasil. A Coroa Portuguesa

inha como preocupaçăo estabelecer no sul do pais um ponto de apoio

criadores de gado como uma estratégia politico militar de expansấo em direçấo à região do Prata.

Uutro sistema de ocupaçáo de territorio tor implantado de forma complementar ao primeiro: pequenos lotes ocupaçăo e defesa do território.

\section{Real Feitoria do Linho Cânhamo

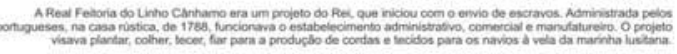

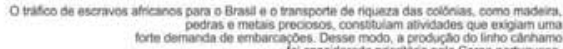

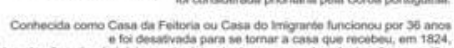

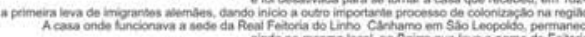

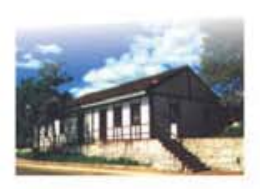

1824: a vila denominada Colônia Alemã de São Leopoldo

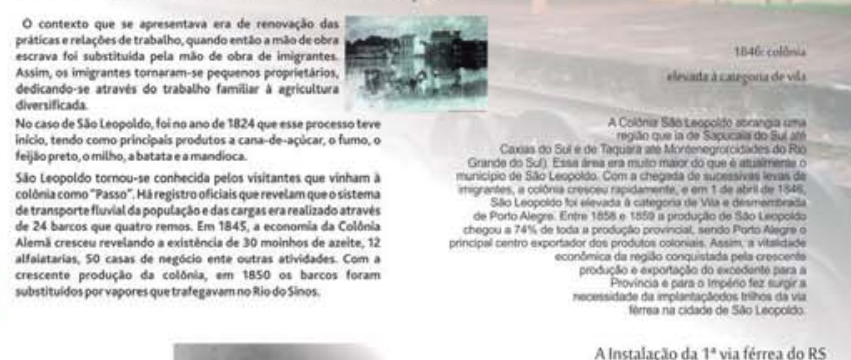

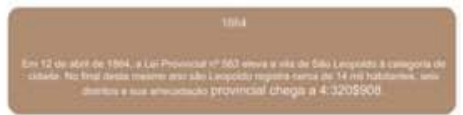

ARevolução Industrial

Em um quadro mais amplo, no século XVIII e XIX teve lugar na Inglaterra a Revoluçāo Industrial que desencadeou intensas transformaçoes técnicas que trabalho e as sociedades pelas quais as inovaçes, tais como teares mecanicos e maquina a vapor eram disseminadas. Essas inovaçoes tecnológicas meios mais eficientes de locomocăo para que exigis mercadorias chegassem nos destinos onde seriam consumidas.

\section{5}
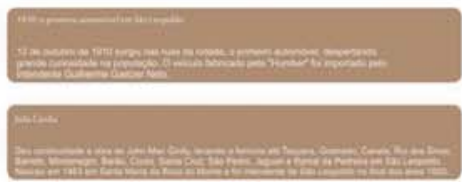

O início das estradas de ferro

Neste contexto, o engenheiro inglês George Stephenson elaborou a primeira locomotiva, chamada "Locomotion" em 1825, dando inicio ao periodo das ferrovias. Na metade do século XIX as estradas de ferro e os trens ja stavam espalhados por continentes como Europa e Améric. No Brasil, o gaúcho Irineu Evangelista de Souza, mais
tarde denominado Barăo de Mauá, que no ano de 1852 recebeu do Governo Imperial a concessăo para construir e explora a linha férrea instalada no Rio de Janeiro, inaugurada em 1854 . Vinte anos depois foi inaugurada em Săo Leopoldo o primeiro trecho da ferrovia do Rio Grande do Sul.
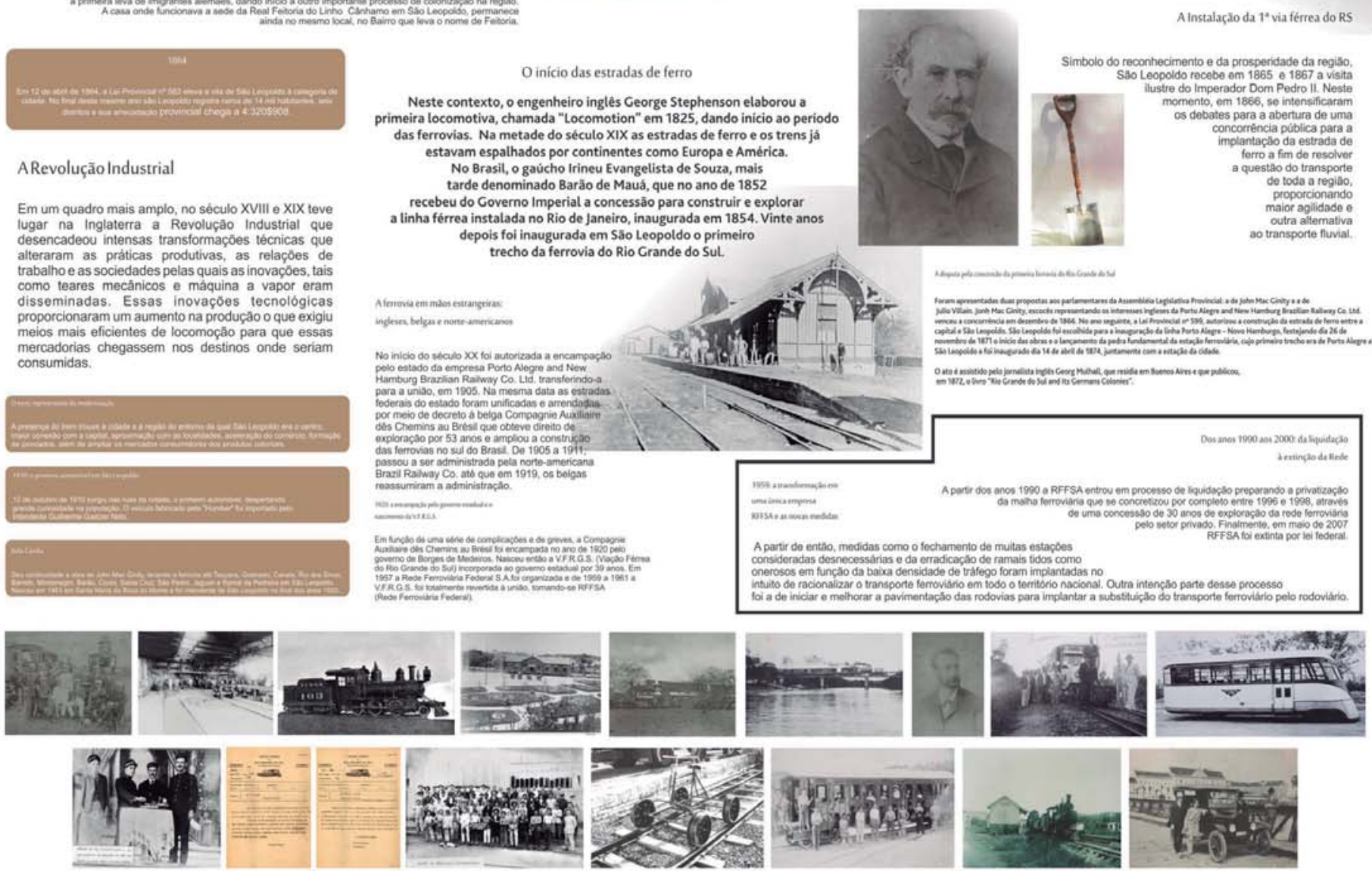

Linha do tempo de São Leopoldo / Ferrovia:

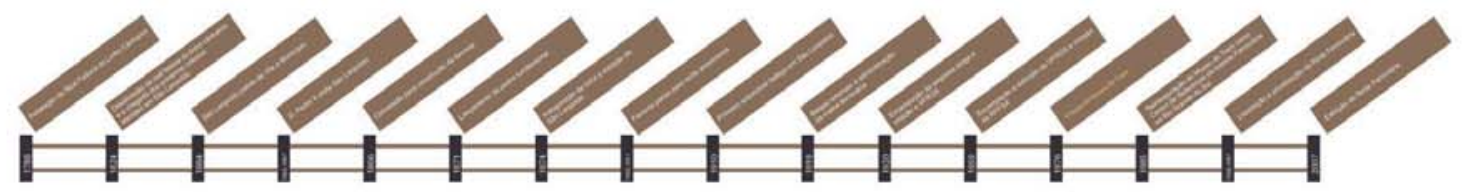

Fonte: PRINT Art Impressões - São Leopoldo. 